R.S. Gilbert The Australian Loan Council in Federal Fiscal Adjustments 1890-1965 
This book was published by ANU Press between 1965-1991. This republication is part of the digitisation project being carried out by Scholarly Information Services/Library and ANU Press.

This project aims to make past scholarly works published by The Australian National University available to a global audience under its open-access policy. 
The Australian

Loan Council 


\section{The Australian Loan Council in Federal Fiscal}

Adjustments, 1890-1965

\section{R. S. Gilbert}


First published in Australia 1973

Printed in Australia for the

Australian National University Press, Canberra

North, South, and Central America:

International Scholarly Book Services, Inc.,

Portland, Oregon

Southeast Asia:

Angus \& Robertson (S.E. Asia) Pty Ltd, Singapore

Japan: United Publishers Services Ltd, Tokyo

(C) R. S. Gilbert 1973

This book is copyright. Apart from any fair dealing for the purposes of private study, research, criticism, or

review, as permitted under the Copyright Act,

no part may be reproduced by any process without written

permission. Inquiries should be made to the publisher.

ISBN 0708102409

Library of Congress Catalog Card no. 73-78728 


\section{Preface}

As the title indicates, this book analyses the purpose and the functions of the Loan Council in the financial relations between the central, or Commonwealth Government and six State Governments of the Australian federation. I have endeavoured to shed new light on the intentions that the Australian people, and the Founders who represented them, had for the federal system. The work is an exercise in at least three disciplines-constitutional law, economics, and politics. Such a task required good counsel.

I am indebted to a number of people. Of these, I owe most to Mr Peter Bailey, Dr Alan Barnard and Professor G. Sawer who made many valuable comments at successive or at critical stages of the work. To the other persons whose views were sought, I express my deepest appreciation. Some are mentioned in the footnote references. The others include Sir Leslie Melville, Professors N. G. Butlin, R. F. Henderson, R. L. Mathews, J. A. La Nauze, P. H. Partridge, J. H. B. Tew and L. R. Zines, Drs G. M. Neutze and D. I. Wright, and Messrs Colin Clark, H. P. Brown, R. Jay, R. G. Opie and D. K. Stout.

The actual writing of the book was handicapped by the need to regard the task largely as a spare time enterprise. I am aware of some of its deficiencics. As it stands, the undertaking was only practicable because I was given the opportunity to devote two and a half years to it full time. That was made possible by the grant of leave of absence from duty in the Prime Minister's Department to accept a generous scholarship from the Commonwealth Public Service Board; by fellowships in the Department of Economic History of the Research School of Social Sciences, Australian National University, for which I owe much to Professor N. G. Butlin; and by assistance from the Houblon-Norman Fund; and from the Institute of Commonwealth Studies, the Committee for Advanced Studies and the John Webb Medley Endowment Fund, all of the University of Oxford.

The staffs of the Australian National Library, the Menzies Library of the Australian National University, the Institute of Commonwealth Studies and the Rhodes House Library, Oxford, were ever willing to assist in finding source material and I wish to thank them for their fine services. 
To the many typists who gave their time and goodwill I am sincerely grateful. I owe much in this respect to Mrs. A. Guenot, who typed the final draft.

The views expressed in this book are my own and I have acknowledged in the footnotes the sources of information and of many of my judgments. Published material has been used almost entirely and a balanced evaluation has been attempted on that basis. I have not changed the basic assessment as presented in my Adelaide masters and Oxford doctoral theses, in which it was essential to incorporate the virtues of dispassionate judgment as well as thorough research and analysis.

It has been convenient and wise to conclude at about 1965, when Sir Robert Menzies retired as Prime Minister. The span of seventy-five years that is analysed up to that time has enabled much to be done and the main ideas to be developed as far as I, then a Commonwealth public servant, felt free to take them.

Australian National University,

\section{Canberra}

December 1971 


\section{Contents}

Preface $v$

Abbreviations $x i$

1 Contour of Australian Federal Finance 1

2 Constitutional Foundations of the Council 10

3 Proposals for a Loan Council and Major Fiscal Developments, 1900 to 191031

4 The Origins of the Voluntary Loan Council, 1910 to 192345

5 Monetary Policy in the 1920s 56

6 The Ferment of Commonwealth and State Financial Relations, 1923 to 192769

7 Framing the Financial Agreement of 192785

8 The Cessation of Overseas Lending in 1929101

9 The Failure of Expansionary Policies in the Depression, 1929-31 126

10 The Premiers' Plan, 1931 141

11 The Struggle for Revenue, 1932-1942 153

12 Allocation of the Loan Program, 1929 to the War 174

13 Overseas Borrowing, 1932 to the War 187

14 Realignments of Power over Economic Policy, 1932 to the War 195

15 Borrowing and the Bond Rate in the 1930s 211

16 Post-war Effective Demand 228

17 The Consequences of Uniform Taxation 245

18 Governmental Borrowing Abroad since 1941268

19 The Post-war Bond Rate 284

20 Reflections 309

Bibliography 318

Index 329 


\section{Tables}

2.1 Names of delegates to convention debates mentioned in the text 15

4.1 Meeting dates of the Loan Council, 1923-29 54

5.1 Australian cash and conversion loans by the Commonwealth, 1918-30 59

5.2 Governments' Australian borrowing and debt operations, 1918-19 to 1929-30 60

5.3 Financial operations of financial institutions, 1921-29 65

6.1 Special (later Commission) grants and road grants 1910 to 193074

7.1 Payments to the States by the Commonwealth per capita, 1923-39 93

7.2 Commonwealth payments to or for the States, 1926-39 94

7.3 Accumulated sinking funds of the State governments, 1922 and 192799

8.1 Balance of payments, 1918-19 to 1929-30 105

8.2 British and Dutch new issues, foreign lending, 1925-34 110

8.3 London market quotations of comparable dominion securities, 1929-32 111

8.4 Budget deficits, net loan expenditure and change in debt of all governments, $1928-29$ to 1932-33 119

8.5 Components of gross domestic product, 1930-31 to $1932-33$ at $1928-29$ prices 120

8.6 Meeting dates of Loan Council, 1929-1966 124

10.1 Governments' overdraft and treasury bill finance, 1929-35 142

11.1 Commonwealth's assistance to States and direct taxation per head, 1901-2 to 1938-39 168

11.2 Financial Agreement-loan allocations to States, 1932-33 to $1966-67169$

11.3 Gentlemen's Agreement-loan allocations, 1936-37 to $1966-67170$

11.4 Financial Agreement-index of loan allocations to States per capita, 1932-33 to 1965-66 171

11.5 Gentlemen's Agreement-index of loan allocation per capita, 1936-37 to 1965-66 172

11.6 Gentlemen's and Financial Agreements -index of total loans per capita, 1936-37 to $1965-66173$

12.1 Allocation of the loan program, May 1935178

12.2 Shares of actual loan raisings allocated to the States, 1934-35 and 1935-36 179 
12.3 Local and semi-governmental authorities new money loan raisings, $1930-31$ to $1937-38183$

12.4 Total Loan Council allocations per capita, 1936-37 to $1940-41184$

13.1 London refunding and conversion of overseas issues, 1932-36 190

13.2 Balance of payments and overseas borrowing, 1928-99 to $1939-40193$

15.1 Effective yields on new issues and open market sales of long-term bonds, 1935.39 218

15.2 Commonwealth loan programs, 1932-33 to $1938-39223$

16.1 Financing the loan program, 1951-52 to 1964-65 230

16.2 Measures of the importance of Loan Council's total program, 1932-33 to $1964-65234$

17.1 Commonwealth tax reimbursement and supplementary grants, 1952-53 252

17.2 Tax reimbursement and financial assistance grants, $1944-45$ to $1962-63257$

17.3 Commonwealth payments to or for the States, 1938-39 to $1964-65258$

17.4 Indcx of the tax-paying capacity of the States, 1914-15 to 1941-42; and index of personal income per capita, 1948-49 to 1965-66 262

17.5 Index of Commonwealth payments to or for the States per capita, 1951-52 to 1965-66 263

17.6 Inequalities among the States, 1964264

18.1 Commonwealth and State governments' interest payable abroad, 1930 to 1965271

18.2 Pattern of new loan raisings, 1951-52 to 1965-66 275

18.3 Overseas loans, 1951-52 to 1965-66 277

18.4 Government and private income payable abroad, 1949 to 1965279

18.5 Commonwealth new cash borrowing overseas, $1950-51$ to $1965-66282$

18.6 Effective interest costs to Commonwealth of loans in Australia and overseas, $1950-51$ to $1964-65283$

19.1 Commonwealth new issues-difference in yields to lender, $1950-51$ to $1965-66289$

19.2 Economic indicators, 1928-31 and 1950-53 292

19.3 New capital raising by Australian listed companies, 1952-53 to $1965-66298$

19.4 Government long-term security yields in Australia, 1926 to 1971307 


\section{Figures}

Fig. 1 Security yields, London and Australia, 1935 to 1939213

Fig. 2 Government security yields, Australia, 1926 to 1953286

Fig. 3 Short-term and long-term new issues interest rates, Australia, 1951 to 1966288

Figures drawn by Hans Gunther of the Cartographic Office, Department of Human Geography, A.N.U. 


\section{Abbreviations}

A.I.B.R. Australian Insurance and Banking Record A.I.P.S. Australian Institute of Political Science A.L.J. Australian Law Journal

C.B.C.S. Commonwealth Bureau of Census and Statistics

CSIRO Commonwealth Scientific and Industrial Research Organisation

C.F.B. Commonwealth Finance Bulletin

C.L.R. Commonwealth Law Reports

C.P.D. Commonwealth Parliamentary Debates

C.P.P. Commonwealth Parliamentary Papers

I.B.R.D. International Bank for Reconstruction and Development

I.M.F. International Monetary Fund

N.S.W.P.D. New South Wales Parliamentary Debates Q.P.D. Queensland Parliamentary Debates

R.C.M.B. Report of the Royal Commission to Inquire into the Monetary and Banking Systems of Australia

R.I.I.A. Royal Institute of International Affairs

S.M.H. Sydney Morning Herald

T.P.P. Tasmanian Parliamentary Papers

V.P.P. Victorian Parliamentary Papers

\section{Note}

The Australian government's financial year begins on $1 \mathrm{July}$ and ends the following 30 June 


\section{Contours of Australian Federal Finance}

Many countries in recent years have encountered problems in the distribution of power and of financial responsibility between central and regional governments. Australians were brought face to face with these difficulties in the decade of the 1890 s when a federal system was created out of six colonies on an island continent of three million square miles occupied by three million people. Widely separated around the relatively fertile circumference and throughout the habitable parts of the interior, in an area approximately the size of the United States, the Australian people had none the less a number of common characteristics. They were largely of British stock, spoke the same language and were egalitarian in outlook and in their form of government. The franchise had for long been accorded to all men and was being extended to women, and there was no property qualification attached to nomination for parliament. By the $1890 \mathrm{~s}$ the industry of the people, their willingness to allow governments to borrow abroad to finance development works, especially communications, and their good fortune in finding mineral wealth, particularly gold, enabled them to enjoy one of the highest standards of living in the world.

These characteristics were important influences on the shape of the Constitution fashioned by the Founders of the new Commonwealth of Australia. Three fundamental beliefs about economic life on the continent underlay negotiations in the $1890 \mathrm{~s}$ that produced those parts of the Constitution that are relevant to this book. The first was that the individuality or rights, including financial independence, of the federating colonies should be preserved. With a central or federal government merely a prospect until 1900 and with colonial governments very much in the public mind as providers of services, particularly of transport, water and communications--vital in a rather harsh and lonely environment - this was an understandable and reasonable attitude. The Founders were therefore careful to frame a Constitution that acted by way of a gift of powers from the States to the Commonwealth that at the same time ensured that the States had equal access to finance for their development. 
The second belief was that in the course of the first generation after federation, each State's development would reach a point where the average wealth and income of each citizen would be about the same. They expected that access to loanable funds and the same rate of taxation would yield to governments the same average loans and the same average tax revenue per head. Thus the egalitarian instincts of the people would be satisfied. On this major assumption about income and wealth rested the hopes that, for example, each State would eventually be able to provide for its people an equal standard of those government services that required heavy capital expenditure so that a fair deal by governments would be accorded to all Australians. The concept of fairness or justice was not a vague, abstract principle; the fairness and the fitness of government action were expressly written into the Constitution itself. The third major assumption of the Constitution was that the 'laws of supply and demand' governed economic life and activity; there was no comprehension that the Commonwealth might engage in the general management of the Australian economy to achieve economic stability and therefore no provision of comprehensive powers to enable it to do so.

It was not surprising that the generations who participated in the framing of the Constitution by voting for or against it and the generation that followed in the first quarter of the twentieth century should have held so dearly to the concepts of 'State rights' and the 'sovereign States'. The people believed that they had provided in the Constitution for 'independent States' to evolve within a decade or two after 1900. Clever constitutional lawyers may have seen ways ultimately to achieve indirectly a unitary system of government but that was not the way the mass of voters saw it and, in a system where constitutional amendment was by referendum, what the mass of the people thought was to be important and will continue to be so.

'Sovereign States' required independent sources of revenue. There was a moral principal involved: that the government that spends public money should have the responsibility for raising it. Here lay, and still lies, the basic problem. ${ }^{1}$ The shape of the difficulties to come and, indeed, those under discussion, are by no means new. Try as they might, the Founders could not create immediately a system of Commonwealth-State financial relations in which the member governments would be independent of each other for their finance. None the less, they fondly hoped that the Constitution would enable such a co-ordinate system to be established when the people were ready for it, 'in the distant future' as one delegate put it. The term 'co-ordinate' is a simple way of expressing in one word

1 The Founders referred to its implications as 'the lion in the path of federation'. The fear that inhibited the Colonies was the possible loss of functions or powers to the new Commonwealth with the result that its surplus would be devoted to specific areas of expenditure. 
the theory of independence that the Founders strove to apply. It is a recurring idea throughout the subsequent analysis, and it therefore needs to be well understood at the beginning. Sir Kenneth Wheare expressed the concept clearly. "What is necessary for the federal principle is not merely that the general government, like the regional governments, should operate directly upon the people, but, further, that each government should be limited to its own sphere and, within that sphere, should be independent of the other.'2

The financial problem arose from the simple fact that, by handing over to the new Commonwealth the exclusive right to raise what had been the colonies' main source of income-customs and excise revenue-the new States were faced with very large budget deficits to meet the cost of the services they continued to provide. The Founders considered that ultimately a co-ordinate financial system could be arranged by the Commonwealth taking over some of the States' debts and interest liability, so that the interest would be nearly equal to the States' deficits at federation.

In the end the Constitution enabled the Commonwealth, if it wished, to take over the States' debt existing in 1900, but was rather inconclusive in that there was no provision about new or joint borrowing. This was because the Founders, representing the will of the people, could not bring themselves to oblige the States to pass the sole borrowing power and the responsibility for the debt to the Commonwealth. It was none the less intuitively understood to be the heart of the arrangement to be negotiated in the future when the people were ready for it and when it was politically expedient to arrange it.

Until the debt was taken over, the compensation to the States for 'guarantee' as delegates to the Conventions put it) was settled by a payment of three-quarters of the customs revenue for ten years (the 'Braddon clause' of s.87), and by what was believed to be the guarantee of the Commonwealth's surplus revenue, inexact though this would be. The Commonwealth also received the power to assist the States by making grants to them if it wished. ${ }^{3}$ While much was thus left to the future, the Founders thought they could see ahead to a co-ordinate system of financial relations, its keystone being s.105, which enabled the Commonwealth to take over State debts.

The history of Commonwealth, or Federal, and State financial relations since the formation of the Commonwealth is one of debate and adjustment as successive generations grappled with the impediments to a system of co-ordinate finance that the Founders thought time would solve. This book is about one of those adjustments, the Financial Agreement of 1927

2 K. C. Wheare, Federal Government (4th ed., London, 1963), 14.

3 The Founders were not particularly troubled about the allocation of the financial assistance between States because they were certain that, within ten to twenty-five years, the wealth and personal income per head, or the taxable capacity, of the different States would be equal and that payments could be equitably made by equal per capita payments. 
and the Loan Council it created. Having itself the force of constitutional law, and writing the Council into the Constitution as a supra-parliamentary body, the Agreement was generally regarded at the time as the final, permanent adjustment of federal finance and close to the system envisaged by the Founders.

The Financial Agreement had two parts. One was to transfer all the States' debts and part of the interest and repayment burden to the Commonwealth so that most of the Commonwealth's payment to or for the States would be related to the debt. It was a device to achieve a co-ordinate system by the transfer to the Commonwealth of not so much a State power over a service as a State responsibility-that to the holders of their public debt. It was hoped to sever the tie between the Commonwealth and the States' finances with a minimum loss of State functions by an agreement mutually understood by all governments and approved by the people through the processes of constitutional amendment. There can be little doubt that in principle, but not in detail, the mass of the people understood the intention of this adjustment to fiscal relations. They had voted for an amendment of 5.105 in 1910 to enable the Commonwealth to take over all of the States' debts and not just those in existence at federation, and in 1928 they voted overwhelmingly on the same theme to allow the insertion of $5.105 \mathrm{~A}$, which so broadened the debts power that agreements could be made by the Commonwealth with the States about the debts of the States and were enforceable upon the parties. These amendments were demonstrations by the people of the long-held belief that there should be a co-ordinate system and they were highly significant because of the fewness of amendments to enlarge the Commonwealth's powers. The amendments of the debt power in the first twenty-eight years of federation accounted for no less than half of all major constitutional amendments in the first seven decades of the federation. ${ }^{4}$

But the first part of the Agreement was about dead-weight debt and it was supplemented by a second part, a living institution that would manage the amortisation of the old debt and arrange new borrowing. The belief in co-ordinate federalism was relaxed to allow an explicit organ of co-operative federalism to be created in the Loan Council. But it was so balanced that the States between them had a majority of the voting power; and the narrow yet important responsibilities of the Council were clearly defined. The implicit assumption upon which the Loan Council was based, statutorily established as it was on the eve of the depression

4 It is highly significant in the author's view that the other two major amendments were only of a welfare kind-the transfer to the Commonwealth of the social services power and of the power over Aborigines, the neediest, most depressed social group in the community. There is a consistency about the voting for amendments: it has been for a co-ordinate system and for action by the strong federal government to help the weak. It has been, in essence, a vote for marginal, supplementary action by the Commonwealth on the broad basis of a co-ordinate system of federal finance. 
of the 1930s, was that there was no need for general economic management by the Commonwealth to maintain economic stability in the federation. Therefore, without any understanding of the implications for Keynesian economic policies, the Loan Council was empowered to make decisions binding upon all member governments, affecting with varying degrees of significance the following areas of general economic policy: first, monetary policy in that the Council decides the long-term bond rate and other interest rates paid by governments with the exception of the rate on defence loans; second, in Commonwealth and State fiscal and development policies, the Council decides how much shall be borrowed and how the loan program shall be allocated between member governments but not how it will be spent; and third, balance of payments policy is affected in that the Council decides the amount and terms of foreign borrowing by governments.

The Council therefore became a monetary and fiscal authority and its decisions could not be gainsaid by the Commonwealth or any other member government; when the Lang Labor government tried to do this in 1932, the High Court made it clear that responsibilities incurred under the Agreement and decisions of the Loan Council were enforceable by the Commonwealth, as the Council's agent, against each State member; the States had the same right in relation to the Commonwealth. It therefore followed that if one member, especially the Commonwealth, wished to influence or change a decision of the Loan Council, it could do so only by the persuasion of argument and negotiation with the other members.

If the keystone in the Constitution for the adjustment in the 1927 Agreement was s.105, its foundation stone was the belief in a fairly quick growth towards equal taxable capacity throughout the country. But by 1924 it was accepted at the highest academic and government levels that no progress was being made along the road to equality. The revelation was too late to stop the inbuilt momentum of the nation towards the financial adjustment by the transfer of debt and the creation of the Loan Council to manage new borrowing. The weakness in the foundations was naturally not widely understood because taxable capacity is a technical term and the implications of differences as between the States were to take many years to work out and to be accepted by the people. The important thing at the time of the 1927 Agreement was the general understanding that payments under it were nearly 80 per cent of all payments and grants from the Commonwealth to the States in 1927-28. The adjustment to federal financial relations in the Financial Agreement was thus great enough to be regarded by the parties as the final, permanent adjustment, and very close to being the co-ordinate system envisaged by the Founders.

The erosion of the foundations of the co-ordinate fiscal system had begun before the Financial Agreement with the realisation at the policy 
level that inequalities would continue. Further erosion followed soon after the Agreement when the depression of the 1930s increased the dependence of the States upon the Commonwealth's assistance. Grants were made for a variety of purposes in the 1930s, including relief of unemployment and for States' general revenue and works purposes. The proportion of payments under the Financial Agreement to all payments made to the States steadily fell in the 1930s to just over one-half of the 80 per cent it had been in 1927, when the Agreement was drafted.

The growth in the Commonwealth grants to the States was accompanied by a major effort by the States to achieve financial independence of the Commonwealth. The States' attempt to achieve independence is probably best measured by the increase in their direct taxation rates compared with the Commonwealth's. By the end of the 1920s the States' average per capita rate of direct taxation was more than double the Commonwealth's, and at the outbreak of World War II it was three and a quarter times as great. Therefore the States' dependence on grants was not without a remarkable effort to achieve a high degree of independence of the Commonwealth by relatively severe direct taxation.

The Commonwealth legislated to become the sole income taxing authority in 1942 when it introduced uniform taxation and this had farreaching effects in many directions, including the Financial Agreement. The action of the Commonwealth was upheld by the High Court in 1942 and again in 1957. Between 1938-39 and 1964-65, all payments to the States grew nearly twenty-five times, but payments under the Agreement less than doubled. The share of the Agreement payments in the total of payments to or for the States fell from 45 per cent in 1938-39 to about 3 per cent in 1964-65. The relative importance of the Grants Commission likewise diminished and it was further diminished in 1959 when the Commonwealth's large general revenue grants changed from being about the same per capita to being relatively much more to the smaller States -so much so that South Australia discontinued seeking special (Commission) grants in 1959. Western Australia followed suit in 1968-69 and Tasmania remained as the only 'claimant' State.

The advent of Uniform Taxation transformed federal financial relations. The guarantees to the States for the first ten years of federation under the Braddon clause of s.87 and after 1927 by the Financial Agreement under s.105A, were replaced in principle and in effect by negotiations for capital and revenue grants under the financial assistance power in 5.96 of the Constitution. But it was achieved by judicial decision and not by the full weight of the vote of the people that had characterised the 1927 arrangements.

The Loan Council's importance did not wane as did the fiscal adjustment in the 1927 Agreement. Throughout the period from its inception to the mid-1960s, the Council's role varied in importance depending upon 
whether its specific powers over parts of general economic policy were equally or even more important than other policy measures. The Council was at the centre of what general or national policy formation there was in the 1920s and over most of the 1930s but the ends it served differed as between the two decades, and within each decade, except for two important purposes-it was always an instrument of co-operative federalism and it negotiated with what were then unfettered central and private banks. An example of how quickly its role could change occurred in 1931; up to the end of 1930 the Council was heavily involved in decisions about the level of aggregate demand and in co-ordinating Commonwealth and State deficit finance and overseas payments. Early in 1931 the Council accepted that wider policy measures than its narrow powers permitted were required and the initiative in federal economic policy formation passed to the Premiers' Conference, wherein all powers and policies not vested in the Council could be examined and decided upon. It was notable that the main depression policies fashioned by governments in 1931 were called the Premiers' Plan-it was not a Loan Council operation.

In the period of the Lyons governments between 1932 and 1939, the Council played a highly significant part in negotiations with the independent central bank. The Council was clearly instrumental in weaning power over policy away from the bank and in assisting the Commonwealth and the States to maintain economic growth from the bottom of the depression until the outbreak of the war, despite recurring balance of payments crises. Strong Premiers and an able Prime Minister joined in the Loan Council to decide the size of the works program, aligned themselves with those forces, mainly the private banks, that supported steady growth and economic stability; the achievement of a Keynesian policy in 1938 was a fitting end to an extremely difficult decade in the management of the Australian economy. It is perhaps necessary to add that the political survival of governments depended upon getting out of the depression and the policies pursued were therefore simply explained; it was the tactics used and the judgments made that revealed political skill of a high order. The Loan Council was an indispensable instrument of its members' talents.

In the post-war years the much greater sophistication in the management of the economy and the growing complexity of the Australian monetary system reduced the Council's role in policy formation relative to earlier decades. The greater financial resources of the Commonwealth as a result of Uniform Taxation, and the deficiency of loanable funds in the longterm bond market in an economy constantly under strain from the persistently high rate of immigration, enabled the Commonwealth to exercise a much greater infuence, often a deciding influence, on the size of the loan program and the terms of borrowing. However, the Council, meaning in this context the States, co-operated closely with the Commonwealth 
in the measures taken to extend the influence of the Commonwealth and its instrument, the central bank, over the burgeoning capital and money markets. The Council was again an organ of co-operation and it remained firmly embedded in the constitutional framework as a decision-making, politically oriented monetary and fiscal institution.

But the long-term survival of the Loan Council cannot be taken for granted. The wording of the Financial Agreement makes it uncertain whether the Council will definitely continue to fulfil some or all of its functions after 1980, that is fifty-three years after the Agreement began to operate in 1927. This question will be resolved in the light of the political and economic circumstances in the federation in 1980. It may be resolved by unanimous agreement of the seven governments and parliaments that are the parties to the Agreement or it may be resolved by an appeal to the High Court for a decision. It is not possible for the author to engage in prognostication about the events at that time $\mathrm{e}^{5}$ This book therefore sets down the origins, the purposes and some of the effects and achievements of the Loan Council in general economic policy formation, and of the 1927 Agreement in fiscal adjustments, between the time that federation became a vital practical possibility in 1890 to the mid-1960s, when Sir Robert Menzies's term as Prime Minister was voluntarily ended. ${ }^{6}$

If any lessons emerge from the new light shed on federal financial relations, the most salutary would seem to be that adjustments in financial relations have been relatively easily and painlessly made by the Commonwealth's assumption of part of the States' debt responsibilities. This course of action was readily accepted by the people, being in accord with their view of the kind of co-operative federalism that they wanted. The acid test was the willingness of the people to accept the voluntary Loan Council, and then the statutory Council, and their strong vote for appropriate amendments of the Constitution to that end. But it is equally salutary that, since the Loan Council was created, the people have expected the Commonwealth to exercise a much greater, conscious responsibility for general balance of payments policy, monetary policy and fiscal policy. It so happened that, in 1927, the Loan Council was given the power over a major part of each of these areas of general economic policy. On the one hand, the Council has shown ability to co-operate with the Common-

5 See G. Sawer, 'The Commonwealth and the States' in Current Affairs Bulletin, 11 January 1971, 60-1 for interesting speculation, not about the Loan Council, but about the general course of Commonwealth and State financial relations in the future- We are likely to muddle along as at present with occasional changes in detail . ..

6 In the year $1889-90$, the political groundswell to federation became an irresistible force because of the defence motive-strength would come from unity. Sir Henry Parkes made his famous speech on defence at Tenterfield, N.S.W., on 24 October 1889 and at the Melbourne Conference on 6 February 1890 he responded to mention of the lion in the path' with his clarion call to unity. 'The crimson thread of kinship runs through us all. J. Quick and R. R. Garran, The Annotated Constitution of the Australian Commonwealth (Sydney, 1901), 118-19. 
wealth in the exercise of the few vital powers that it had. The history of the relations between the parties reveals that co-operation depended upon the Commonwealth acting out the role of the great negotiator from a position of financial strength; and co-operation in a crisis, such as in 1931-32 and 1951-52, required something as binding as the Financial Agreement to achieve adequate co-ordination. On the other hand, there is little thus far in federal history to indicate that the return to the States of the powers vested in the Loan Council in the 1927 Agreement would result in certain and adequate co-operation between all the States and the Commonwealth in the exercise of general economic policy.

It would therefore seem that one possible course for the future which emerges from the history of federal financial relations is that the adjustment of financial relations between the Commonwealth and the States should be made as painlessly as possible by a transfer of State debt responsibilities to overcome the non-fulfilment of the assumption in the Constitution, and the 1927 Financial Agreement, that the average income and wealth of the citizens of each State would become equal; and in making fiscal adjustments, the Commonwealth should not be deprived of the powers it needs, including an obligation upon the States to co-operate as and when required, to fulfil the Commonwealth's responsibility for balance of payments, monetary and other fiscal policies. For only the Commonwealth can achieve the national objectives of equality in the standard of government services, and steady economic growth at a high level of employment in economic crises originating at home and abroad.

But the achievement of these objectives would leave at least one other problem that the 1927 Agreement and the Loan Council did not solve. That is that, because of the effects of continuing unequal taxable capacity and of Uniform Taxation, the States would still depend on the Commonwealth for finance. The States remained, therefore, in what was regarded in the past as the individious position of spending large sums of revenue that they did not have the responsibility to raise. That is a matter of fundamental principle that the history of Australian federal finance has shown requires a political solution. Perhaps it too needs what the Founders sensed about the use of the debt adjustment-a long gestation period for a satisfactory, balanced solution to emerge that is acceptable to the people in all States. Regrettably, the way ahead in the 1970s is not anything like as clear as the concept of the debt adjustment was to the Founders. 


\section{Constitutional Foundations of the Council}

The Founders of the Australian federation were always confident that 'some day' an institution like the Loan Council would be established. They foresaw a twofold development. First, a transfer of the States' public debt to the Commonwealth with the Commonwealth assuming liability for the interest upon part or all of the debt. That was to be a means to achieving a co-ordinate system of finance, meaning simply that the Commonwealth and the States would be independent of each other for their revenue. Understandably, the independent Colonies sought this financial independence for themselves in the new federal structure. The second expectation was related closely to the first: the Founders believed that the arrangement to transfer State debt would include Commonwealth borrowing on behalf of the States by the issue of one Commonwealth security to achieve lower interest and other costs. This borrowing by the Commonwealth for the States could only be achieved in council with them, as the States would be responsible for the expenditure of the loans and for their repayment.

The Founders allowed for these developments as best they could when framing the Constitution, but the finance problem was complex. After five formal conventions they could do no more than leave the way open for the evolution of a co-ordinate system. ${ }^{1}$ This they did in s.105, which empowered the Commonwealth to take over the States' debts; in the meantime, they provided in $\mathrm{s.87}$ for short-term revenue guarantees to all of the States by the return of three-quarters of the customs and excise revenue to them; and the Constitution gave the Commonwealth a general grants power in s.96 which enabled it to give financial assistance to a particular State at any time as the need arose. The hopes of the Founders

1 The five formal Conventions and meetings were the Sydney Convention, 2 March to 9 April 1891; Adelaide Convention, 22 March to 5 May 1897; Sydney Convention, 2 to 24 September 1897; Melbourne Convention, 20 January to 17 March 1898; and a Premiers' Conference, 29 January to 2 February 1899. 
were to be fulfilled in part when the Loan Council was created and the States' debt transferred by the Financial Agreement of 1927; that this did not result in a co-ordinate system with financial independence for the States is now evident. This chapter reviews the Founders' general thinking about the fiscal settlement, both to understand why the fiscal part of the Constitution took the form it did and to establish the firm basis for later chapters on why the Founders' expectations were not to be fulfilled after 1927 .

\section{No simple fiscal arrangement for the federation}

From the first Federal Convention in 1891, free traders and protectionists agreed that the tariff barriers between Colonies should come down to make way for a uniform external tariff administered by the Commonwealth. The achievement of free trade between the States was one of the great objectives of the federal movement, but simultaneously it raised a fiscal, or tax and revenue problem for the States and, less so, for the Commonwealth. The Commonwealth would start with a very large surplus derived from the tariff and the States would start with large deficits because they no longer received the tariff revenue. For practical purposes, the fiscal issue at the Conventions was how to provide in the Constitution for the transfer of the Commonwealth's surplus to the States to bridge their deficits. It was admitted without exception that such a transfer should be made. The Commonwealth was given the largest powers to raise revenue but as Alfred Deakin put it, "we do that subject to what we admit to be practically a debt from the Commonwealth to the several states'. ${ }^{2}$ There is, therefore, no novelty in the current problem of financial relations between the Commonwealth and the States-it was present at the conception of the federation.

It was a problem not only of the total amount of the transfer to the States but also of its allocation between them. Estimates, freely used at the Conventions because they were the best available, showed the probable early expenditure by the Commonwealth to be $£ 300,000$ on new services and $£ 1,250,000$ on services taken over from the States, totalling $£ 1,550,000{ }^{3}$ The revenue of the Commonwealth from customs and excise duties was impossible to predict until the new tariff structure was decided and tested for its effect on buyers of imported goods. Even if a tariff schedule had

2 Official Record of the Debates of the Australasian Federal Convention, Third Session, Melbourne, 1898 (Government Printer, Melbourne, 1898), 1060. Hereafter Convention Debates, Melbourne and similarly for other Conventions.)

3 Proceedings of the Australasian Federal Convention (with Papers Ordered to be Printed), Adelaide Convention, 1897 (Government Printer, Adelaide, 1897), paper no 13. Unless otherwise noted, figures used are those prepared jointly by the Government Statisticians of the colonies of Victoria, South Australia, Western Australia and Tasmania for the Convention in Adelaide in March 1897, and ordered to be printed by the Convention. They relate to the years $1893-5$ and are not only suitable for the purpose but they were the reliable, raw material of the Adelaide and succeeding Conventions. 
been prescribed by the Conventions and appended to the Constitution, this figure would have remained a matter of guesswork. However, the loss to the States as a result of handing over the customs and excise revenue could be estimated, the average annual figure for 1893-5 being over $£ 6,625,000$. Deducting from this the $£ 1,250,000$ that it cost the States to provide the services and functions handed over to the Commonwealth left the net figure for their expected deficits in the early years after federation at $£ 5,375,000 .{ }^{4}$ This was about one-fifth of their total revenue; low as taxation rates at that time were by modern standards-an average of $£ 2.05$ per capita from customs and excise duties and $£ 0.575$ per capita from direct taxation-it was simply impracticable for the States to treble direct taxation rates, or greatly to increase charges on business undertakings to make up their deficits. ${ }^{5}$ It was obvious, therefore, that unless an alternative could be found, the Commonwealth's new uniform tariff or other taxation would have to be high enough to enable it to return to the States nearly $£ 5 \frac{1}{2} \mathrm{~m}$.

One alternative solution to the problem appeared to be the use by the Commonwealth of its surplus revenue to pay part or all of the interest on the States' public debt; for just prior to federation, the total interest on the Colonies' public debt about equalled their customs and excise revenue. It was also a long-held and cherished expectation of federation that if the scheme to take over State debts included an arrangement for the Commonwealth to borrow on behalf of the States, using one instead of six competing State securities, there would be a significant reduction in borrowing costs in London, where 86 per cent of the national debt had been raised. ${ }^{6}$ More fundamentally, the attraction of transferring the debts or part of the debts was that it created a co-ordinate system of federal finance. If the Commonwealth assumed constitutional responsibility for the debts and the payment of interest and the sinking fund, the tie between the Commonwealth and the States would be cut-the former would not be a tax-raising machine for the latter. It was believed that there would be resources of taxable capacity for the States to draw upon as their needs grew, and that they could, in particular, move more deeply into direct taxation. ${ }^{7}$ In principle, but not for immediate purposes, all

4 Ibid., paper no. 12.

5 T. A. Coghlan, A Statistical Account of the Seven Colonies of Australasia 1899-1900 (Government Printer, Sydney, 1900), 744. In 1899-1900, the States' total revenue from all sources including business undertakings was $£ 26.685 \mathrm{~m}$. of which 26.5 per cent, or $£ 7.07 \mathrm{~m}$., was raised from import and excise duties, 8.5 per cent was raised from direct taxation and 37 per cent from business undertakings, excluding posts and telegraphs.

6 Convention Debates, Sydney, 1891, 841, and subsequent Debates. As carly as 1884, the idea of a single borrower for all of the States was advanced seriously; see A. W. Martin, "Economic Influences in the "New Federation Movement"' in J. J. Eastwood and F. B. Smith (eds.), Historical Studies-Selected Articles (Melbourne, 1964), 220-2.

${ }^{7}$ Quick and Garran, Annotated Constitution, 828: 'it can hardly be doubted that one result of Federation will, sooner or later, be that provincial taxation will be increasingly resorted to for provincial purposes'; and Barton, Convention Debates, Mel- 
of these possibilities were provided for in the Constitution, to be given practical effect at some future date.

A number of obstacles stood in the way of creating at the outset a practical or definite co-ordinate system. The hard facts were that the States' net loss was only three-quarters of the customs revenue and, overall, the States would gain from the Commonwealth if all State debt interest were paid. An alternative was for the Commonwealth to pay the interest on an equal amount of debt per capita which, in total, would bridge the gap. But this would have resulted in unequal treatment of the States: if the Commonwealth paid the interest on $£ 40$ per head of debt in the States, which was the most that it could, ${ }^{8}$ Victoria and Western Australia would have paid no interest; but Victoria would have made a relatively great overall gain compared with Western Australia and some other States because Victoria's debt interest almost equalled her customs and excise revenue and her budgetary position therefore improved by the amount of administrative costs handed over to the Commonwealth, whereas Western Australia, which had received more tariff revenue than interest paid on debt, would have suffered a net loss of about one-third of revenue (on the basis of 1895 statistics); and New South Wales, Queensland and Tasmania had smaller disadvantageous gaps. South Australia, on the other hand, would have gained handsomely because her revenue from tariffs and excise was less than her debt interest.

Nor did a convenient solution suggest itself if, instead of considering the net revenue the States would give up under the old colonial tariffs, calculations were based upon estimates of how much each State would contribute under the new uniform tariff, relating that contribution to debt interest. While there could be only guesses about the revenue received under a new tariff, those of $\mathrm{F}$. W. Holder acquired considerable respect; he estimated that if $£ 40$ per head of the States' debts were taken over at the current rate of interest of 4 per cent, the Commonwealth would pay the States $£ 1 \cdot 6$ per head of the population. Under any reasonable new tariff, the people of New South Wales would contribute perhaps £2 per head and Western Australia a much larger sum for many years to come. The other States would benefit. ${ }^{9}$ The transfer from New South Wales to other States, excluding Western Australia, would be about $£ \frac{1}{2} \mathrm{~m}$.,

bourne, 1898,2423 , 'If there is not a taxable margin . . then, in the past, the population of Australia must have been screwed down pretty close to their taxable capacity. Now, I do not think that any of us hold that belief. Certainly I do not'. Coghlan also believed that this would follow because the customs revenue would fall with the uniform tariff and growing import replacement as the manufacturing sector developed. Seven Colonies 1899-1900, 822.

8 The State with the lowest per capita interest limited the Commonwealth to that amount as the upper limit of its payment. Victoria's interest was about $£ 40$ per head throughout the $1890 \mathrm{~s}$ and, in the middle of the decade, Western Australia's was also.

${ }^{9}$ Contention Debates, Sydney, 1897, $76-7$ (F. W. Holder, Treasurer and South Australian Delegate to the Conventions). 
or over 5 per cent of the State's revenues. This again showed the difficulties in the very attractive, but deceptively simple per capita system of distribution as long as income per head and therefore taxable capacity differed between States.

The only certain method of equitably distributing the federal surplus in the period before, as it was hoped, the people would be making equal tax payments per capita was on the basis of what the States contributed, without relating it to debt interest. But even this basis would not bridge State deficits exactly, because contributions would be different under the new tariff compared with the old. This system would also require the continuation of the border customs houses to ensure that the duties paid on goods which crossed State borders after being landed were credited to the consuming State; this 'book-keeping' system was both contrary to the fundamental principle of free trade between the States and an administrative nightmare.

The statistics confirmed problems which were evident from the first Federation Conference of $1890 .{ }^{10}$ Try as they might, delegates could not find a way to create a federal financial settlement which would enable the Commonwealth and the States to be financially independent of each other in the foreseeable future. What did they do? 11 They could only include in the Constitution powers which would, they believed, enable a co-ordinate system to evolve. The basis for that co-ordinate system was in $\mathrm{s.105;}$ as a protective measure there was the short-term ten-year guarantee in s.87 and the grants power in s.96 which enabled the Commonwealth to assist with any fiscal problems which might arise at any time in the future.

\section{Concepts of a co-ordinate financial system-a Loan Council?}

The Convention Debates were fertile in producing ideas. Some proposals were far-sighted but not immediately practicable. At the 1891 Convention, it was proposed that the Commonwealth take over all State debts, the States to remain liable only for the interest over a fixed per capita sum which the Commonwealth would pay. ${ }^{12}$ Deakin was much taken with this at the time, and at the Sydney Convention of 1897 he developed

10 It is, perhaps, not surprising that the Government Statisticians of New South Wales and Victoria should have each issued pamphlets, printed in Victoria's case by the Government Printer, and that each Premier not only accused the other's statistician of exaggeration and wrong reasoning, but that neither document was regarded as 'official' by the respective Premiers. Convention Debates, Melbourne, 1898, 1618.

11 In the ensuing assessment of their ideas, the names of delegates and their States will be used freely; some delegates were to be most powerful influences after federation and it is useful to know where they stood at the Conventions. Of the twenty delegates mentioned in this chapter, all but Dibbs and Frascr were Fathers of the Constitution in Professor La Nauze's judgment-see his 'Who Were the Fathers?', Historical Studies, vol. 13, October 1968, 345 .

12 Convention Debates, Sydney, 1891, 837 (Bray). 
Table 2.1

Names of delegates to convention debates mentioned in the text

$\begin{array}{lll}\text { Barton } & \text { The Hon. Edmund, Q.C., M.L.C. } & \text { New South Wales } \\ \text { Braddon } & \text { The Rt Hon. Sir Edward Nicholas Coventry, } & \\ & \text { P.C., K.M.M.G., M.H.A. } & \text { Tasmania } \\ \text { Bray } & \text { Sir John Cox, K.C.M.G., M.H.A. } & \text { South Australia } \\ \text { Deakin } & \text { The Hon. Alfred, M.L.A. } & \text { Victoria } \\ \text { Dibbs } & \text { George Richard } & \text { New South Wales } \\ \text { Dickson } & \text { J.R. } & \text { Queensland } \\ \text { Downer } & \text { The Hon. Sir John William, Q.C., K.C.M.G., M.H.A. } & \text { South Australia } \\ \text { Forrest } & \text { The Rt Hon. Sir John, P.C., K.C.M.G., M.L.A. } & \text { Western Australia } \\ \text { Fraser } & \text { The Hon. Simon, M.L.C. } & \text { Victoria } \\ \text { Glynn } & \text { P.M. } & \text { South Australia } \\ \text { Griffith } & \text { The Hon. Sir Samuel Walker, K.C.M.G., Q.C., M.L.A. } & \text { Queensland } \\ \text { Henry } & \text { The Hon. John, M.H.A. } & \text { Tasmania } \\ \text { Higgins } & \text { Henry Bourne, M.L.A. } & \text { Victoria } \\ \text { Holder } & \text { The Hon. Frederick William, M.H.A. } & \text { South Australia } \\ \text { Kingston } & \text { The Rt Hon. Charles Cameron, P.C., Q.C., M.H.A. } & \text { South Australia } \\ \text { Lyne } & \text { William John, M.L.A. } & \text { New South Wales } \\ \text { McMillan } & \text { William, M.L.A. } & \text { New South Wales } \\ \text { Parkes } & \text { The Hon. Sir Henry, G.C.M.G., M.L.A. } & \text { New South Wales } \\ \text { Reid } & \text { The Rt Hon. George Houston, P.C., M.L.A. } & \text { New South Wales } \\ \text { Turner } & \text { The Rt Hon. Sir George, P.C., K.C.M.G., M.L.A. } & \text { Victoria } \\ \text { Wise } & \text { B.R. } & \text { New South Wales } \\ & & \end{array}$

Delegates by States

New South Wales

Victoria

South Australia

Western Australia

Tasmania

Queensland
Barton, Dibbs, Lyne, McMillan, Parkes, Reid, Wise Deakin, Fraser, Higgins, Turner

Bray, Downer, Glynn, Holder, Kingston

Forrest

Braddon, Henry

Dickson, Griffith

the proposal further. He suggested a system of federal financial relations which he believed would be as close to co-ordinate as the political situation would allow. He proposed that the Commonwealth should give a fixed sum on the assumption of part of the States' debts, to avoid financial embarrassment to the State governments and be free to give an additional sum if the Commonwealth could afford it from what he foresaw would be an unpredictable but rising revenue from customs and internal excise receipts derived from a growing and increasingly wealthy population. He wanted the Commonwealth to be able to spend the additional sum either directly on specific State projects without going through the State governments, or by handing sums over to the States. ${ }^{13}$ Deakin concluded: 'By the means I suggest you cut the connection between state and federal finance, subject always to the power of the federal parliament at any

13 Lyne was so incensed by this part of Deakin's proposal that he interjected successively three times that it 'would mean the destruction of the States', no doubt fearing that a condition of assistance might be the handing over of some State functions. Convention Debates, Sydney, 1897, 56. 
time, on being moved by its constituents, to make any grants to the state parliaments, and, if they are of the opinion of the Hon. Member, $\mathrm{Mr}$ Lyne, to follow the course which he desires. ${ }^{14}$

Holder suggested a growing payment to the States instead of the fixed basic sum. It was to increase with the population and by the different amount per head each State was paying to the Commonwealth under the uniform tariff at the end of an initial book-keeping period. There was no basic conflict: Deakin and others assumed that taxable capacity would soon be equal in all States and therefore an equal per capita payment by the Commonwealth up to a certain sum to pay interest would be just. Holder was concerned not only with the problem of growth but with the interim period when taxable capacity would not be equal. ${ }^{15}$

Then there was a far-sighted suggestion by Kingston that the process of handing over the debt should mean only that the Commonwealth would pay the interest to bondholders, either directly or through State treasuries, but that the States retain the debt in their names to avoid many difficulties, not the least of which was a massive conversion operation. ${ }^{16}$

The basic reason why these ideas were not acted upon was that the people were not ready for a major transfer of State debt liabilities. ${ }^{17}$ Their untimely character was recognised as early as the first Convention in Sydney in 1891. Sir Samuel Griffith, who had the chief hand in drafting the 1891 Bill for a Constitution Act, ${ }^{18}$ said of the financial problem that 'some day' the difficulty would be found to be so great that the federal Parliament and State Parliaments would have to come together and make provision for transferring to the Commonwealth, on a fair basis, such obligations of the States as would absorb all the federal surplus. ${ }^{19}$ New South Wales's delegates spoke vigorously in support of Griffith's view that the solution of the financial problem was a matter for the distant future. They alleged that, were the Commonwealth obliged to take over State debts immediately, it would then undertake their new borrowing, which might conceivably lead to the public works policies of the States being discussed in the Commonwealth Parliament. An immediate, compulsory

14 Ibid.; see also 50 .

15 Ibid., 79-82.

16 Convention Debates, Melbourne, 1898, 1585.

17 When the time did come, the Financial Agreement of 1927 incorporated most of these ideas but not exactly as suggested at the Conventions. See chap. 7.

18 Alfred Deakin, The Federal Story (2nd ed., Melbourne, 1964), 47-8.

19 Quick and Garran, Annotated Constitution, 132. Griffith's committee had great difficulty in finding an alternative, but eventually it drafted a flexible but, essentially, a stopgap proposal which, although a temporary expedient, became the basis for the final form of the Constitution. The 1891 Convention proposed that the revenue be returned according to contribution until the uniform tariff was imposed and on that basis thereafter until the Commonwealth otherwise provided; Convention Debates, Sydney, 1891, 529-30, 802-35, 959-60. As will be seen later, s.87 gave a guarantee for ten years by the end of which it was expected that taxable capacity in the States would be the same. 
assumption of State debts was therefore regarded as a 'bombshell'. ${ }^{20}$ In Melbourne in 1898, Forrest declared: 'The question is too complicated, and the time would be inopportune'.21 Basically, the Conventions were unable to cope constructively with the question of institutional machinery, such as the Loan Council, to arrange future borrowing-except to hear intermittently that the Commonwealth should borrow on behalf of the States. It was expected to be a matter which the Commonwealth would negotiate with the States after federation; ${ }^{22}$ it was also expected that ideas expressed at the Conventions would 'be considered very carefully'. ${ }^{23}$

\section{A long-term solution: section 105}

When it came to the matter of writing a constitutional clause which, it was hoped, would prepare the way for the eventual transfer of States' debts as the step to financial independence for the Commonwealth and the States, the debates were keen and the view that the people would not be ready for that course of action for a very long time prevailed but slowly amongst delegates. There were several reasons for this. Delegates who favoured a high tariff both to protect industries and to enable the Commonwealth to pay defined guarantees to the States sought such a guarantee by having debts taken over and interest paid by the Commonwealth immediately after federation. New South Wales delegates had to work hard to win converts to the view that, at federation, the debt should not be taken over immediately. The gradual change was a fascinating process. A second reason for the slow evolution of firm opinions and changes of view by some delegates was that the issue as a whole was most complex. Facets only came to light slowly from convention to convention and the integrity of some delegates was such that, until they had as many of the facts and arguments as possible before them, they seemed not to make up their minds. In the final voting, personal decisions appear to have been more important than conforming to any collective view of a State delegation.

It is tedious and unrewarding to record all the details of the tortuous debate to the final vote on what became s.105. The general outcome in s.105 was that the Commonwealth was not given the mandatory power, 'compulsorily' as delegates constantly expressed it, to take over the debts of the States; the actual wording agreed was 'may take over' instead of 'shall take over' the debts. ${ }^{24}$ Nor was winning the consent of the States

20 Convention Debates, Sydney, 1891, 840 (McMillan). See also Dibbs, ibid., 840 and 842-4, and McMillan again at Adelaide, 1897, 883-4. Except in time of war, the question of Commonwealth intervention in the States' works programs has always been taken most seriously by the States, which have retained the power over these matters.

21 Convention Debates, Melbourne, 1898, 1553.

22 Ibid., 1552 (McMillan) and 1560-4 and 1612-13 (Reid).

23 Ibid., 1579 (Holder).

24 Section 105 The Parliament may take over from the States their public debts [as 
made necessary; it was omitted. As there would be an indefinite delay before debts were transferred, the guarantee of revenue had to be provided for elsewhere so that in s.105 the States were required to indemnify, or to pay to, the Commonwealth the principal of debt redeemed on their behalf, and to indemnify the Commonwealth for the interest paid on their behalf, if the Commonwealth's surplus revenue was inadequate to pay the interest. Section 105 refers to 'the States' and requires collective action, not a piecemeal State by State approach. Only the debts at federation could be taken over and there was no mention of future borrowing.

Some of the discussion on s.105 had long-term significance. In the debates on obtaining the consent of the States it was argued that consent should be obtained before any part of the debt was taken over because of the sheer size of the matter. ${ }^{25}$ The New South Wales delegates argued persuasively in reply that it was not necessary to provide for the consent of the States in 5.105 because the terms and conditions on which the Commonwealth arranged conversions would have to be decided in any event in consultation with the States, as their contracts would be changed and they would pay the interest. ${ }^{26}$ It was also understood that not only conversions but new borrowing would be dealt with by the Commonwealth as 'the great negotiator' with the States after federation. ${ }^{27}$ The concept of 'the great negotiator' became influential especially among the South Australians, who accepted and then argued that it was necessary to leave much to the Commonwealth in the ultimate financial settlement.

While the obligation to obtain the consent of the States was excluded from the Constitution, the practical realism of the statements by Kingston, Holder, Barton, McMillan and others was such that consultation has invariably been the mode of action adopted in financial relations and it was the method adopted in the preparation of the 1927 Financial Agreement by which State debts were transferred.

Much more time was devoted at the Conventions to the question whether it should be mandatory for the Commonwealth to take over State debts at federation. The debates over 'compulsion' tell a story of considerable

existing at the establishment of the Commonwealth], or a proportion thereof according to the respective numbers of their people as shown by the latest statistics of the Commonwealth, and may convert, renew, or consolidate such debts, or any part thereof; and the States shall indemnify the Commonwealth in respect of the debts taken over, and thereafter the interest payable in respect of the debts shall be deducted and retained from the portions of the surplus revenue of the Commonwealth payable to the several States, or if such surplus is insufficient, or if there is no surplus, then the deficiency or the whole amount shall be paid by the several States. (Phrase in brackets deleted by Commonwealth Act No. 3, 1910, s.2.)

25 Convention Debates, Adelaide, 1897, 1091.2 (Kingston); see also Sydney, 1897, 85 (Holder).

26 Ibid., Adelaide, 1093 (Barton); Melbourne, 1898, 1551 (McMillan).

27 Ibid., Adelaide, 883 (McMillan). 
confusion. The ultimately successful argument was that nothing practical could be gained from a massive conversion before maturity as bondholders would not convert except at the same or a higher rate of interest. The only way an advantage might be gained would be if the Commonwealth were left free to convert as bonds fell due. Compulsion was also feared because an unwise Treasurer might convert at a loss, presumably by choosing the wrong time or forcing a massive operation through on disadvantageous terms. ${ }^{28}$ There was no certainty that the bondholder would have immediate confidence in the Commonwealth but, instead, he might wait and see how the federation worked before making up his mind about the risk of lending to the Commonwealth. ${ }^{29}$

Hopes that an early massive conversion of the debt into the name of the Commonwealth, which would assume liability for some or all of the interest and provide protectionist States with a guarantee, lost intellectual conviction as a practical course and an alternative had to be found. It was not an easy victory and Holder, in exasperation, expostulated at the last Convention that he had to repeat the argument 'over and over again before you can get the truth in' ${ }^{30} \mathrm{He}$ was arguing robustly against compulsion-it endangered cheaper borrowing, the only financial argument of any weight he had found used in the press and in the Conventions to support federation.

There will be commercial dividends, dividends of finance, dividends of sentiment-all these things will accrue-but the only one cash dividend which federation can pay, the only one cash argument we can use to our constituents in recommending them to adopt federation will be the profit arising from any possible conversion of our loans. ${ }^{31}$

He was referring to the long-held hope that, ultimately, borrowing by the Commonwealth for the States would eliminate competition between the States for London loans and reduce borrowing costs.

The outcome of the debates on s.105 obliged delegates to turn their minds to means of guaranteeing revenue to the States other than by the transfer of debt and interest obligations from the States to the Commonwealth.

\section{A short-term imperative: section 87}

In the search for a guaranteed transfer of the Commonwealth's revenue to the States other than by the Commonwealth's assumption of liability for interest on some or all State debt immediately after federation, the basic question was how the aggregate amount of the guaranteed grants 
would be determined. The representatives of the smaller States sought guarantees as high as possible, and the representatives of New South Wales sought lower guarantees, in the form of limitations on Commonwealth expenditure in order to keep at a low level the revenue and the tariff by which it was raised. New South Wales also sought to limit the guaranteed return so that it did not exceed the amount paid in the year prior to the uniform tariff. ${ }^{32}$

Holder was the first to mention the ultimate course of the debates and the actual wording of the Constitution. He said that the smaller States could not make ends meet by imposing other forms of taxation if the customs and excise revenue were not to be returned to them. 'While we would like from the point of view of the Federal Treasurer to leave him free, we cannot from the point of view of the States.' It was not possible to rely upon the Commonwealth Treasurer while there was no hope of a small State having large representation in the House of Representatives, and the Senate was too weak to insist on and obtain with certainty payments by the Commonwealth to the States. Holder sought a guaranteed payment because the Commonwealth might suddenly be called upon to spend all of its revenue for defence purposes, leaving it without a surplus. Objecting to the provisions in the current draft of the Constitution limiting the amount of the Commonwealth's expenditure, he proposed instead that the Commonwealth should return to the States not less than 70 per cent of the customs and excise revenue (and not less than the mean of the aggregate returned to the States in the two years before the uniform tariff came into operation). ${ }^{33}$ This proposal for a percentage of the customs and excise revenue contained the germ of the guarantee finally inserted in the Constitution.

It appears that by the Sydney Convention of 1897 there had emerged an appreciation of the general form the wording of the Constitution would have to take. Like Holder at Adelaide, other leading personalities, including Barton, Downer and Forrest, had begun to see the way ahead-the eventual acceptance of the clause requiring payment to the States of some proportion of the customs revenue.

At the last Convention in Melbourne in 1898 the matter of the guaranteed aggregate was settled after long debate and several recommittals of resolutions to the Convention. Braddon of Tasmania proposed the 'Braddon clause' whereby the Commonwealth returned three-quarters of the customs and excise revenue to the States, and it was passed by the Convention without the ten-year provision, which was to come at a secret Premiers' Conference in 1899. New South Wales delegates, Reid and Barton, supported Braddon's resolution but endeavoured to have the 
application of the clause limited to the first five years of the uniform tariff, Barton being again most anxious that there should not be an absolute tie between the finances of the Commonwealth and the States. ${ }^{34}$ Holder spoke ably in an endeavour to compromise but favoured the simplicity of the Braddon clause without the five-year limitation; ${ }^{35}$ this view prevailed to the end at the Conventions even though it was believed that the smaller States had an additional, fundamental assurance-it was that the Commonwealth could not live and prosper unless it maintained the solvency of all the States; federal political parties would not wish to lose seats in disaffected States. Delegates were reminded that the Australian people were at one and the same time citizens of the States and of the Commonwealth. ${ }^{36}$ These were persuasive arguments which Holder and others used to make s.87 acceptable with or without a time limit on its life. ${ }^{37}$

The draft constitution agreed at the Melbourne Convention was submitted to the people at a referendum in 1898. Queensland and Western Australia stood out and awaited the results of the remaining four colonies. Three were decisively in favour of the bill; New South Wales rejected it narrowly. To the supporters of federation it meant that New South Wales electors had to be mollified, particularly as to how long guarantees should continue, and a meeting of Premiers was called to negotiate suitable changes. An election was imminent in New South Wales and the conference was therefore delayed until the election had revealed more clearly the wishes of the people of that State, including whether they wanted Reid to be Premier. ${ }^{38}$ Reid was re-elected with a smaller majority and met the other Premiers, including J. R. Dickson of Queensland, at a Premiers' Conference in Melbourne behind closed doors from 29 January to 2 February 1899.

At the meeting, 'The financial question proved the hardest of all to solve, and nearly caused a breakup of the Conference'. ${ }^{39}$ All present were prepared to let the idea of the Braddon clause go, but no better answer could be found. A report was issued and its words might be quoted in full because it brought together in a few words the part of the Convention Debates that dealt with short-term guarantees.

The Premiers have given full consideration to the objections which have been urged against this clause, and have also considered other proposals which have been suggested for the purpose of giving some

34 Ibid., Melbourne, 1898, 2378, 2422, 2427 and 2430-1; Quick and Garran, Annotated Constitution, 199.

35 Convention Debates, Melbourne, 1898, 2424-5.

36 Ibid., 1595, 1600-1.

37 Ibid., Sydney, 1897, 75 (Holder); 53, 56 (Deakin).

38 Quick and Garran, Annotated Constitution, 213.

39 Ibid., 219. 
security to the States that a reasonable amount of the revenue collected in the States shall be returned to them, while, if possible, avoiding excessive burdens of taxation, a prolonged system of book-keeping, uncertainty as to the amount of the surplus to be divided, and uncertainty as to the method of distributing the surplus amongst the States.

The Premiers consider that all the other proposals are open to more serious objections than those which have been raised against the clause as it appears in the Bill; but with a view of meeting the objections as far as possible, consistently with the safety of the States, the Premiers are of opinion that the operation of the clause should not continue after a period of ten years if the Parliament then desires to repeal or alter it; and that, in addition, power should be granted to the Parliament to deal with any exceptional circumstance which may from time to time arise in the financial position of any of the States.

To give effect to these decisions, the Premiers limited the return of threefourths of customs and excise revenue to 'A period of ten years after the establishment of the Commonwealth, and thereafter until the Parliament otherwise provides'; and added a new clause, s.96, empowering the Parliament to grant financial assistance to any State on such terms and conditions as the Parliament provides. ${ }^{40}$

The quite fateful ten-year limitation on the mandatory application of the Braddon clause, after which the Commonwealth was no longer obliged to return the three-quarters of the customs and excise revenue, removed what was regarded at the time as 'one of the chief objections to the section, namely, its want of elasticity'. In the early years of federation the clause was not expected to cause much inconvenience, but in the unknown future it could seriously hamper federal finance, even though the Constitution does not explicitly require that any revenue should be raised by customs and excise, but that three-quarters of whatever was raised in the first ten years should be returned to the States. It fixed an arbitrary and unalterable proportion that might have been an insurmountable barrier to the Commonwealth in the event of an emergency requiring greater Commonwealth outlays relative to the States. Nor was there an eternal principle in the three-to-one proportion which was based on fortuitous financial conditions at the time. The loss of constitutional protection for the guarantee in $\mathbf{s . 8 7}$ after ten years did, of course, enhance the power of the Commonwealth. ${ }^{41}$

Once the debts and the Braddon clauses were agreed to, it became necessary to make it explicit that the Commonwealth should not in any sense be held to pay both three-quarters of the customs revenue and the interest on State debts taken over. Section 87 was amended so that three-

40 Ibid. The debates on s.96 are considered in some detail below.

41 Ibid., 826. 
quarters of the customs and excise revenue shall be returned to the States 'or applied in accordance with this Constitution in the payment of interest on State debts taken over by the Commonwealth'.

The words added to 5.87 did not give the States a definite guaranteed return after the first ten years because 5.105 provided that the States would have to indemnify the Commonwealth from their own resources if the interest it paid was greater than the Commonwealth's surplus revenue plus the three-quarters of the customs revenue. It may be helpful to mention again that the Commonwealth was neither under an obligation to have surplus revenue nor was it obliged to pay three-quarters of the customs revenue, or any revenue, to the States after the first ten years.

\section{The allocation of the guaranteed revenue between the States}

In addition to the important general problem of determining the aggregate of the guarantee, there was the subtler problem of evolving a formula for its allocation between the States. Agreement was reached with surprising ease because delegates made the basic assumption that within a reasonable period after federation the taxable capacity of the States would be the same. The equal per capita grants of revenue would then be an equitable and not a redistributive return of revenue to the States.

The evidence for this permeates the Debates, and it seems never to have been doubted. Deakin probably expressed the view of the majority when he said that, with the exception of Western Australia, consumption of dutiable goods per head would probably be the same throughout Australia within five or ten years. ${ }^{42}$ Holder was more cautious, but believed it would be less than twenty-five years. ${ }^{43}$ The general idea was incorporated in an early version of what was to become s.94 of the Constitution.

After the expiration of five years from the imposition of uniform duties of Customs each State shall be deemed to contribute to the revenue an equal sum per head of its population and all surplus revenue over the expenditure of the Commonwealth shall be distributed month by month among the several States in proportion to the numbers of their people. ${ }^{44}$

It was also explicit in early attempts at an allocation formula that when uniform duties were imposed there should be one year of 'bookkeeping' at State borders to ascertain how much each State contributed

42 Convention Debates, Sydney, 1897, 52.

43 Ibid., 80. . . a gradual approximation of all the divergent colonies to the mean point. It must be so'. Walker, a New South Wales delegate, suggested twenty-five years
in an interjection.

44 Ibid., Adelaide, 1897, 1070. The Constitution ultimately guaranteed the States the surplus revenue of the Commonwealth, a matter which will be considered again. It was a second guarantee of relatively minor importance compared with the guarantee of
three-quarters of the tariff revenue. 
to customs and excise, and then a four-year period of gradual scaling up or down to equal per capita payments of surplus revenue to each State. This formula for a gradual change by sliding scale to a per capita basis was subsequently found to be unacceptable. ${ }^{45}$ It was, however, used in 8.95 of the Constitution to permit special consideration to be given to Western Australia during the first five years after the imposition of the uniform tariff.

Griffith, at the 1891 Convention, and New South Wales delegates at all Conventions were persuasive in arguing that a distribution formula prescribed in the Constitution for the long period after the early formative years would lead to a 'considerable convulsion in our federation'. They considered that definite proposals should not be made about an unpredictable customs revenue and Commonwealth surpluses. ${ }^{46}$ South Australian delegates came to agree with the New South Wales view on the matter, Holder and Downer being particularly powerful supporters. They probably expressed the final sentiments of the Conventions when they took up New South Wales's theme that there was no alternative but to trust the Commonwealth, ${ }^{47}$ presumably to allocate an equal amount per capita if that was deemed to be the fairest method when the time came. The tangible expressions of the idea of trusting the Commonwealth are in sections 93 and 94, which provide for the period after the mandatory five-year bookkeeping period. It was left open to the Parliament to distribute all surplus revenue 'on such basis as it deems fair'.

The significance of equal per capita payments before equal taxable capacity was attained was not lost upon delegates, especially those from New South Wales, which would lose to the less wealthy States. The Premier of New South Wales made the point that, while it was impossible to estimate the outcome of a uniform tariff, it seemed to him that equal per capita payments might result in a transfer to the other States of half a million pounds by his State and $£ 300,000$ by Western Australia. He said that he could only take constitutional proposals to his colony if it were to 'lose a few hundred thousand pounds upon this matter during this intervening period'.48 The Convention delegates expected that such

45 Quick and Garran, Annotated Constitution, 861. A sliding scale to equal per capita allocation was struck out of early drafts of s.93, which finally prescribed the book-keeping system at State borders as the aid to deciding allocation for five years after the uniform tariff was imposed and 'thereafter until the Parliament otherwise provides'.

46 Convention Debates, Sydney, 1897, 203-4 (Barton) and also 41-2 (McMillan) and 140-2 (Reid).

47 Ibid., 80 (Holder) and 106 where Downer said 'this financial difficulty, which seemed to be the stumbling block in our way, may be said almost to be removed, because we are all beginning more and more to understand that to trust the Commonwealth when established is the only possible method which can be adopted, and that there can be no scientific basis on which the contribution can be established and continued'. See also 53, 56 (Deakin).

48 Ibid., Adelaide, 1897, 899-907 (Reid); see also McMillan, 878-84. 
transfers would be temporary; they framed the Constitution on the assumption that all States were equally well endowed for their economic development, and that wealth and income per head and therefore taxable capacity would soon be the same everywhere.

\section{The financial assistance power: section 96}

The uncertainty about the length of time that would elapse before the taxable capacity of the States became equal made it necessary to have a section enabling the Commonwealth to grant financial assistance to States discriminately.

The insertion of s.96 at the 1899 Premiers' Conference was regarded at the time as being as important as the ten-year limitation upon the Braddon clause of s.87. It was not a new concept, having been suggested by Deakin in connection with his proposal for co-ordinate finance and it was the subject of a motion by Henry, a representative of Tasmania, at the Convention in Melbourne. He had moved that the 'Parliament may, upon such terms and conditions and in such a manner as it thinks fit, render financial aid to any State' ${ }^{49}$ In principle, the motion was to become s.96. Some significant comments were made on it in the debates of 1898 .

Henry argued that it was generally recognised that there was a necessity for the Commonwealth to have power to step in and give aid to a State that became financially embarrassed. It was regarded as being crucial during the first five years when the States might pass through a trying time. Such a clause was essential to get some States into the federation, no doubt including his own Tasmania, and Western Australia, which was mentioned.

Forrest regarded it as a principle which had long-term significance as well. Concluding the debate on the motion he said prophetically: 'There may be great public works which are altogether beyond the means of a State itself, but which are very necessary in the interests of Australia.'50 Other delegates were like-minded in that they regarded the first five years as 'plain sailing' and looked ahead to the 'more distant future'. ${ }^{51}$ The reservation that terms and conditions could be prescribed by the Commonwealth was regarded as essential to avoid extravagance by a State and to protect the Commonwealth's credit. ${ }^{52}$

The persuasive arguments used against the motion at the Melbourne Convention of 1898 were that it was indefinite, that it left the impression that the States were likely to become insolvent, that it made the other financial clauses look inept, and that it was implied in the nature of the federation. Quick and Garran considered that at the secret Premiers'

49 Ibid., Melbourne, 1898, 1100.

50 Ibid., 1122 .

51 Ibid., 1105 (Fraser and Wise); Sydney, 1897, 81 (Holder).

62 Ibid., Melbourne, 1898, 1104 (Forrest). 
Conference of 1899 , s.96 was inserted partly as a compensation to the smaller States for the limitation of the Braddon clause to ten years, but chiefly to meet any difficulties which might arise in the first few years of the uniform tariff as a result of the unyielding requirements of the distribution clause, and to remove any necessity for an excessive tariff. ${ }^{53}$ Garran was in a singularly advantageous position to know, as he shared with Coghlan the role of adviser to Reid who, alone, represented New South Wales. ${ }^{54}$ There was also present an important element of com. promise. ${ }^{55}$

Deakin's account of this fateful Premiers' Conference suggests that Reid's lack of personal conviction about what was the best constitutional framework made him malleable in his advisers' hands. ${ }^{50}$ One senses from Deakin's account that Reid, alone, was unable to cope with the personal power and determination of Turner and Kingston particularly, and with the willingness of J. R. Dickson, Premier of Queensland, to accord with whatever his fellow Premiers might agree, provided Queensland could be subdivided and new States would have equal representation.

In fact, the outcome of the Braddon clause is an echo of McMillan's, Barton's and Reid's oft repeated requests on behalf of New South Wales for a limitation on the guarantee in the Constitution and the consummation of pleas, by them and Holder particularly, that they would trust the Commonwealth to work out the best financial solution in the light of future experience. The insertion of s.96 is in one sense added evidence which Deakin failed to mention. Also, on the surface, the New South Wales proposal that the guarantee of three-quarters of the customs revenue should be removed was not accepted. None the less, in the context of history, its limitation to but ten years was a major concession to New South Wales, and Deakin's view that 'Reid's one and only achievement was in securing the permanent capital for New South Wales' needs to be qualified accordingly. ${ }^{57}$

Writing close to the events, Deakin seemed to lose, for once, his remarkable sense of historical perspective. In fact, as a result of the Conference, seven amendments were made to the Bill, six at the instance of New South Wales and one emanating from Queensland. ${ }^{58}$ One effect was that at the 1899 referendum, New South Wales decisively voted for the Bill and all other States gave their approval simultaneously, except Western

53 Quick and Garran, Annotated Constitution, 869.

54 Deakin, The Federal Story, 101-2.

55 Commonwealth Grants Commission, First Report, 1934 (Canberra, 1934), par. 26 and S. R. Davis, 'A Vital Constitutional Compromise', University of Western Australia Annual Law Review, vol. 1, no. 1, December, 1948, 28.

56 Deakin, The Federal Story, 101-2.

57 Ibid.

58 Quick and Garran, Annotated Constitution, 220. 
Australia which was slowly won round to acceptance one year later in July $1900 .^{59}$

\section{The fiscal system for the first decade}

The Constitution as accepted by the people in 1900 may be briefly summarised as to its main intentions at that time for revenue and loan arrangements in Commonwealth and State financial relations.

The fiscal problem arising directly from the tariff was dealt with in the Constitution in three stages. The first was that uniform duties of customs were to be imposed within two years after the establishment of the Commonwealth (s.88). This period was governed by the bookkeeping system whereby each State was credited with all Commonwealth revenue collected therein and debited with the Commonwealth's expenditure on the State's departments transferred to it; and the other expenditure of the Commonwealth was debited to each State in proportion to its population. The Commonwealth was required to pay each State, month by month, the balance, if any (s.89). The first period ended on 8 October 1901, when uniform duties became payable. Once imposed, the power of the Commonwealth to exact duties of customs and excise and to grant bounties on the production and export of goods became exclusive (s.90), and trade, commerce and intercourse among the States became 'absolutely free' (s.92).

The second period extended for five years following the imposition of uniform customs duties (until 8 October 1906) during which the same book-keeping system and revenue arrangement was in operation: but the interest of those States whose import trade was largely not direct from foreign countries but through some internal distributing centre, such as Melbourne or Sydney, was protected by the provision that, where imported goods passed into other States for consumption, the duty should be taken to have been collected in, and be credited to, the consuming State (s.93). In effect, the book-keeping system arranged the finances of the States in the same manner as they were before federation except that they were affected by the uniform tariff.

The third stage was reached at the end of this period of five years. Thereafter the book-keeping system was to endure as long as the Parliament pleased (s.93); and by s.94 'the Parliament may provide on such basis as it deems fair for the monthly payment to the several States of all surplus revenue of the Commonwealth', a section which is not limited by the words 'subject to the Constitution'.

The Constitution, thus far considered, guaranteed to the States the definite right to the 'balance' of revenue over expenditure in the first and second periods, and ultimately the 'surplus revenue'; it determined the

59 Ibid., 225 and 250. 
basis of distribution until the end of the second period and thereafter while the book-keeping system continued, but the amounts depended entirely upon the voluntary restraint of the Commonwealth on its expenditure and therefore afforded no guarantee against financial loss and deficits in the States.

The definite guarantee was provided by $\mathrm{s.} 87$ under which not more than one-quarter of the customs and excise revenue would be applied annually by the Commonwealth towards its expenditure during a period of ten years after the establishment of the Commonwealth and thereafter until the Parliament otherwise provides. Thus, the certainty of the guaranteed aggregate ended with the tenth year of federation, after which surplus revenue 'may' be returned to the States (s.94). In practice, the Commonwealth continued the book-keeping system until the ten-year guarantee provisions in s.87 expired and the Surplus Revenue Act took its place in 1910.

The possibility of exceptional circumstances in any State in these early years was met by s.96, under which, during a period of ten years after the establishment of the Commonwealth and thereafter until the Parliament otherwise provides, the Parliament may grant financial assistance to any State on such terms and conditions as the Parliament thinks fit.

The special conditions of Western Australia were met by s.95, whereby during the first five years after the imposition of uniform duties, that State might impose duties of customs and excise on goods produced in other States not exceeding the duties in force in Western Australia at the date of the imposition of the uniform duties and diminishing by a sliding scale until at the end of the five years they disappeared altogether. After the tenth year the States had no guarantees at all.

\section{Prospects after 1910}

There was a definite expectation by all States that surplus revenue was secured to them and would be returned. There was no discussion of the nature and effect of appropriations to trust funds to enable the Commonwealth to avoid a surplus. What was expected to be the permanent or final solution to the States' deficits, by the taking over of their debts, was left to the Commonwealth to arrange in the role of 'the great negotiator'. It was hoped that a co-ordinate system of finance would emerge. In the interim, "The course adopted was to make temporary provision in the Constitution and to leave the ultimate adjustment to the Commonwealth Parliament when the course of years had furnished the necessary experience'. ${ }^{60}$ Sir Robert Garran, when Solicitor-General, echoed these words in evidence before the Royal Commission on the Constitution in 1927-28,61

$60 \mathrm{~W}$. Harrison Moore, The Constitution of the Commonwealth of Australia (2nd ed., Melbourne, 1910), 531.

61 Royal Commission on the Constitution of the Commonwealth, 1927-28, Minutes of Evidence (Government Printer, Canberra, 1927) 73. 
and the independent Grants Commission, in its First Report in 1934, agreed that 'a good deal was left by the framers to be adjusted as experience suggested'. ${ }^{62}$

It is essential to be aware that there were weaknesses in the temporary and the longer-term provisions of the Constitution, which would give rise to controversy. First, s.87 obliged the Commonwealth for at least ten years to raise customs and excise revenue for a specific purpose; this in itself was bad in principle. Second, the first weakness was intensified by the obligation to pay at least three-quarters of the tariff revenue to the States. This intertwined, or tied, most of the Commonwealth's revenue raising policy to the needs of the States and their policies; it injected a serious complication into the federal relationships and the New South Wales delegation had been sound, in principle, in opposing it. In other words, the ten-year limitation on the transfer of three-quarters of the customs revenue to the States was a major triumph of principle in public finance in the federation. Thirdly, the provision for a permanent solution in s.105, enabling the Commonwealth to take over State debts, and the Commonwealth's power under s.87 or s.96 to pay interest on part or all of the debt, provided a means whereby the Commonwealth, taking over a State responsibility (their public debt), could cut the tie between its tariff or other revenue raising policy and payments to the States. The Commonwealth, in effect, could pay part or all of the debt interest and the States would, in principle, be obliged thenceforth to fend for themselves. The weakness of s.105 and the hopes held for it as the basis for developing a co-ordinate system of federal finance was that it rested on the assumption that taxable capacity would become equal in the States so that equal per capita payments of interest on debt taken over would be a just and fair way to meet the loss of tariff revenue by the States. ${ }^{63}$

A fourth and quite fundamental weakness of the permanent as well as the temporary financial provisions was that they assumed that, in the federation, the maintenance of national economic stability would not be made more difficult if the States had complete autonomy in their revenue and loan policies. In fact, apart from Deakin's flashes of foresight and brief comments by Forrest and McMillan, there was no vision of the role of the Commonwealth in future economic policy. Between the Conventions of 1891 and 1897 a severe economic depression spread throughout the colonies. The fact of the depression was accepted, no parliament being charged with the task of corrective action because the causes of change in the state of the economy were not sufficiently well understood. 'Con-

62 Commonwealth Grants Commission, First Report 1934, par, 28.

63 The theme of this interpretation of the Debates is in accord with but extends that of Giblin, one of the few who have written about the system of federal financial relations envisaged by the Founders. Giblin's interpretation does not give due weight to the meaning and implications of s.105. See L. F. Giblin, 'Financial Aspects of the Constitution' in A.I.P.S. (eds.) Federation in Australia (Melbourne, 1949), 91; and chap. 6. 
sequently, although the Founders had first-hand experience of the effects of an economic depression, no conscious effort was devoted to the powers needed to obtain and maintain a stable economy or to divide economic powers between the Commonwealth and the States.' ${ }^{\prime 4}$ One incidental purpose of what follows will be to assess whether the flexibility in the Constitution and the creation of the Loan Council, which was always an implication of s.105, have enabled the Commonwealth to control the general level of economic activity satisfactorily.

But economic policy, while important, is not the whole gambit of government. The Founders were aware that other great and more demanding crises could be expected and they expressed repeatedly and explicitly their belief that the Commonwealth would, when meeting the demands upon it, maintain the existence, the integrity and the solvency of each State. The strength of their conviction was that the people would be citizens of both the Commonwealth and the States. This was taken to be sufficient reason in itself for trusting the Commonwealth to conduct its relations with the States in a just, or 'fair', and reasonable manner.

64 Report from the Joint Committee on Constitutional Review 1959 (Camberra, 1959), par. 1022. 


\section{Proposals for a Loan \\ Council and Major Fiscal \\ Developments, 1900 to 1910}

There is a naivety about the Founders' belief that the new Commonwealth would have few needs for revenue and could therefore be magnanimous in financial relations with the States. Within a few years of federation, the Commonwealth's functions and, therefore, its need for revenue began to grow as the federal political parties met the demands of the electorate. State leaders soon had deep misgivings and there was an inevitable clash between them and the Commonwealth's representatives. None the less, the Commonwealth fulfilled the role of 'the great negotiator', although it did so with increasing financial constraint in its proposals to the States. This constraint grew as the States rejected the Commonwealth's repeated proposals for a Loan Council and the creation of what it believed would be a co-ordinate fiscal system by a transfer of State debts. An alternative, temporary, but none the less co-ordinate arrangement was negotiated in the form of equal per capita grants to the States. This agreement was not achieved easily. The first decade is littered with a tangle of frustrated proposals and counterproposals, yet there was an element of drama present as each side tried to fashion thinking about the course of the inevitable changes when the guarantee of revenue expired in 1910: it was a watershed of ideas-after 1910, the tempo slackened until 1923.

\section{The tensions of the first decade}

In spite of the confusing debate of the first decade, certain trends emerged which give events a definite sense of direction. The most significant determinant was the constitutional power of the Commonwealth to decide unilaterally, if it wished, the amount and conditions of payments to the States after 1910; a second was the influence of Deakin and those who supported him; a third, the political influence of the rising Labor Party, which was determined to use the Commonwealth's social services power 
to have a national pensions scheme. It was against these rocks that the waves of State hopes were dashed. The States found the Commonwealth to be a strong child and they could not stop it growing.

Deakin's position, and therefore his influence, was central in this first decade, particularly towards the end of it. He was Prime Minister for nearly six of the seven and a half years after September 1903. His three ministries brought down the five budgets up to that of 1909 and met the Premiers at five of the last six meetings before the Braddon clause expired. For half of the twenty months that Deakin was not Prime Minister, Labor was in office, for four months in 1904 under J. C. Watson and for six months in 1909 under A. Fisher. ${ }^{1}$ There was mutual support or at least a good understanding between Deakin and the Labor leaders, an important matter throughout, but particularly in 1909 when negotiations with the States were most significant. ${ }^{2}$

Deakin went to the people as Prime Minister at the elections of 1903 and 1906 and was re-elected. His electoral successes were a confirmation of the accuracy with which he gauged popular feeling and it was on this, and his ability to sense how far he need go in bargaining with the States to reconcile the clash between their demands and those of the growing Commonwealth, that his influence on relations with the States was founded. The future of the States as Deakin saw it has not always been fully understood. For example, the States were undoubtedly troubled from the beginning of federation by the power of the Commonwealth. The Commonwealth's decision in 1902 not to impose traditional revenue raising duties on kerosene and tea demonstrated 'to the astounded politicians of the States the flimsy foundations on which they were resting'. 3 They had other problems besides a possible fall in revenue. The drought between 1895 and 1902 reduced the total sheep population by nearly one-half and Queensland lost two-thirds. In this context, Deakin made his remarkable and picturesque prediction in April 1902 in the London Morning Post about the States being 'legally free, but financially bound to the chariot wheels of the central Government. Their need will be its opportunity. The less populous will first succumb; those smitten by drought or similar misfortunes will follow; and, finally, even the greatest and most prosperous will, however reluctantly, be brought to heel'.4 These were long-term musings as it will be seen that, in the short term of the first decade,

1 Reid was Prime Minister for the remaining ten months in 1904-5. Watson (Bland, N.S.W.) and Fisher (Wide Bay, Queensland) were members of the First Parliament, Fisher as Deputy Leader of the Labor Party under Watson.

2 G. Sawer, Australian Federal Politics and Law 1901-1929 (Melbourne, 1956), 40, 64-6, 77.

3 Alfred Deakin quoted in J. A. La Nauze (ed.), Federated Australia-Selections from Letters to the Morning Post 1900-1910 by Alfred Deakin (Melbourne, 1968), 96. Lettex written I April 1902.

4 Ibid. 
Deakin was much more determined to achieve, as far as practicable, a co-ordinate system of federal finance than to take over State functions.

Between June 1905 and November 1908, Deakin as Prime Minister and Forrest and Lyne, his Treasurers, became opposed to the payment to the States of three-quarters of the tariff revenue and all the surplus revenue, an attitude shared by Labor, which also became increasingly restive at the paying over of large surpluses to the States while the Government postponed social services and public works on the plea of poverty'.5 The States drew no comfort from the brief period of the Reid ministry in 1904-5 either. For instance, they must have felt their inferior position very keenly at the first discussions of the financial problem between a Prime Minister and Premiers in February 1905. Reid attended the meeting with Turner, who was Treasurer. The latter was sympathetic to the States, ${ }^{6}$ yet he warned them that the Commonwealth would be assuming greater responsibilities which would require increased financial resources. He referred to age pensions, the trans-continental railway, the loss of perhaps $£ 700,000$ customs revenue if home-produced sugar replaced imported sugar, the need to start a navy, and the cost of the Commonwealth's share of locks on the River Murray. Turner said that he expected strong opposition in the Federal Parliament to proposals which were not in the interests of the Commonwealth as well as the States. ${ }^{7}$

The States' poor negotiating position was not altogether hopeless. They could resist proposals which required their full co-operation and this they did successfully. They could also arrange conferences to which Commonwealth Ministers were invited and, by publicity, stir up the strong traditional feelings the people had for the States. In this way they could hope, and it was only a hope, to obtain a better deal from the Commonwealth than they would if they accepted a plan without protest or without making their views known. The result was that between April 1903 and August 1909 nine conferences were convened by State Ministers at which, inter alia, they discussed schemes for settlement of their financial situation, and Commonwealth Ministers were invited to take part in all but the first.

Throughout the decade, the proposals and counterproposals between the Commonwealth and the States were grounded in the dilemmas of the Conventions. The Commonwealth stood for a scheme to settle the financial problem on the basis of s.105, which enabled it to take over the States' debts; the States stood for a change of s.87 so that the payment of threequarters of the customs revenue would go on indefinitely. The States were happy to continue being dependent and to make the Commonwealth

5 Sawer, Politics 1901-1929, 50.

6 Ibid., 49-50, 74.

7 TP.P., 1905, vol. LIII, 'Conference of Commonwealth and State Ministers, Hobart, 6-17 February, 1905', 2 et seq. See also Deakin on this theme, C.P.P., 1906, vol. II, 'Conference of Ministers, Sydney, 5-16 April, 1906', 96-7. 
their tax-raising machine; the Commonwealth wanted to cut the tie between the tariff revenue and payments to the States and have as near a co-ordinate system as the circumstances would permit. The States feared that if their debts were handed over, they would lose control of their vote-winning loan expenditure policy, and that the Commonwealth's proposals would give them only a fixed sum or much less than the threequarters of the tariff revenue, which would oblige them to exact additional unpopular direct taxation. On the other hand, the Commonwealth feared that the States' proposal would oblige it to levy income tax to finance its growing responsibilities and second, on principle, the Commonwealth believed that it should not have to frame its tariff policy knowing that three-quarters of the revenue would be used for a particular purpose, namely, payments to the States.

The manoeuvring and the air of unreality in the early conferences is explained mainly by the fact that the day of reckoning would be the year 1910, when the ten-year guarantee ended; the note of urgency in the conferences arose in part at least from the wish of each side to influence public opinion so that its proposals for constitutional amendment would prevail-for amendments were inherent in the proposals of the Commonwealth and the States.

\section{The frustration of proposals for a Loan Council}

The two sides did not settle into their positions immediately. Early in 1903, the Commonwealth replied to a Victorian request to take over a State loan due in 1904 that the Constitution did not allow separate bargains and that all States must be dealt with together and on common principles. ${ }^{8}$ A meeting of Premiers in April 1903, without the Commonwealth, listened with interest to the Victorian Premier's proposal that the Commonwealth take over State debts and the interest burden in a manner that would commit a large proportion of the customs revenue and also prevent the Commonwealth committing itself to large expenditure which would deplete the surplus revenue available to the States. ${ }^{9}$

When State Treasurers met federal ministers at a conference in February 1904, Deakin did not attend but Turner (Treasurer) and Forrest submitted a Commonwealth memorandum which elaborated on the Victorian proposal. The Commonwealth's plan was that: the whole of the debts should be dealt with and, at the next election, the Constitution should be appropriately amended; all new loans for the States after 1 January 1905 should be raised by the Commonwealth; the indemnity to the Commonwealth should be the right to use the surplus revenue which it had under the Constitution, and the right to reccive the States' gross

8 C.P.P., 1903, vol. II, $941-4$ (letter from Turner, Treasurer).

9 Harrison Moore, Constitution, 538. The Victorian Premier was W. H. Irvine. 
railway revenue, but to take only enough to make up any deficiency; the States would fix their annual loan requirements, but the Commonwealth would have discretion as to the time of borrowing to avoid clashing. There were other provisions to safeguard the Commonwealth. ${ }^{10}$ The proposal did not give the States a constitutional guarantee after 1910 and they responded with a unanimous resolution that the provision of threefourths of the customs and excise revenue should be prolonged indefinitely by an appropriate amendment of 5.87 and that this should precede the taking over of the debts. The States seemed willing to allow the Commonwealth power to cut borrowing by a State but the States' decisions on this and other matters included dissenting minutes which revealed disunity. For example, there was division about whether the Commonwealth could borrow more cheaply than the States. ${ }^{11}$ Discussion of the Treasurers' proposals and counterproposals was subsequently raised to the level of the heads of governments and remained at Prime Minister and Premier level for the remainder of the decade without a substantial change in the States' position.

On the other hand, the Commonwealth's plans evolved and developed slowly; a further step was taken at the Conference following the one which has just been reviewed, when the first proposal for a Loan Council as part of a financial settlement was put to the Premiers by Reid and Turner. The original idea had come from William Knox, M.H.R., a Freetrader from Victoria, who had proposed to Parliament a Council of Finance of the Commonwealth of Australia to manage the public debts of the States and Commonwealth. Composed of representatives to be appointed by the Commonwealth and by the States, it would have undertaken the flotation of new loans authorised by the Commonwealth or State Parliaments, issued Commonwealth stock to replace State debentures when possible and undertaken other relevant incidental work. An amendment of the Constitution would have been necessary. It appeared to Knox 'that some office or authority possessing the confidence of both Commonwealth and States should be constituted', ${ }^{12}$ since the States would not be prepared to leave the matter to the Commonwealth alone. Both were to have equal representation on the Council through representatives appointed by the respective Parliaments, with an impartial chairman, the Chief Justice being suggested. Speaking in Parliament on his proposal, Knox was original and illuminating on the nature of the Council:

it must possess specific executive authority, and it will be necessary to endow it with originating powers in respect of future loans... I repeat

10 V.P.P., 1904, vol. II, 'Treasurers' Conference, Melbourne, 5-12 February, 1904', 135. 11 Ibid., 159-60.

12 T.P.P., 1905, vol. LIII, 'Conference of Commonwealth and State Ministers, Hobart, 6-17 February 1905', Appendix C, 1-4. 
that the authority must primarily be of an advisory character. Consequently, it will be necessary for the Commonwealth and the States to indicate what powers they wish to transfer to their representatives. As the Council gains the confidence of the people it will naturally acquire larger powers. ${ }^{13}$

Turner put the Commonwealth's views to the meeting without enthusiasm and the States did not respond to them. The discussion of the Conference was mainly devoted to the extension of the period of the guarantee of the three-quarters of the customs and excise revenue. An extension of twenty years appeared to be agreed upon at the Conference, but in the subsequent correspondence between the Prime Minister and the Premiers, New South Wales and Queensland stood out for the return of three-quarters of the customs revenue indefinitely. ${ }^{14}$ It was a further example of disunity between the States.

In its tentative proposals prior to and at the next Premiers' Conference, the Commonwealth's scheme evolved to another stage. It proposed that the passing over of three-fourths of the customs revenue to the States should be replaced by the fixing of a definite sum for a definite period based upon receipts from customs during past years. ${ }^{15}$ Deakin and Forrest subsequently persisted with the concept of a fixed payment and coupled it to their plan to take over all State debts, which they hoped would lead to less expensive borrowing and hence lower payments to the States. In effect, by 1906 Deakin's ministry was pursuing the policy he had conceived in principle at the Sydney Convention-a fixed or a calculable grant to the States at the handing over of the States' debts; as yet, the plan did not allow for growth but ideas about machinery to cope with new borrowing had been advanced in Knox's Finance Council. Deakin and Forrest tried to pass legislation for a referendum enabling all State debts to be taken over and to allow special duties for the Commonwealth's use alone, the revenue to be used in the first instance mainly to provide old age pensions, to counter the growing power of the Labor Party.16 Parliament rejected both bills after arrangements for the Premiers' Conference in October 1906 had been completed; in the case of the debts bill on the day before the Conference ended, and then it was by but one vote of the Senate. Nothing, therefore, came of the Conference, the States demanding yet again the advantageous amendment of s.87.17 However, the closeness of the voting in Parliament on the debts bill encouraged

13 C.P.D., 3 November 1904, 6490.

14 Conference, Hobart, Appendix $P$ and the proceedings, and D. I. Wright, Commonwealth and States 1901-10. A study of the executive and administrative relations of the seven governments of Australia in the first decade of the federal system (Ph.D. thesis, A.N.U., 1968), 366.

15 C.P.P., 1906, vol. II, 'Conference of Ministers, Sydney, 5-16 April 1906', iv, v, 96-7, $131-5$ (Deakin).

16 Sawer, Politics 1901-1929, 49-50.

17 V.P.P., 1906, vol. II, 'Interstate Conference, Melbourne, 8-12 October 1906', 147. 
Commonwealth leaders to pursue plans incorporating the transfer of State debts, but not immediately. A Conference in May 1907 also went over almost the same ground as the preceding Conference and the outcome was much the same. ${ }^{18}$

The climax to development of the Commonwealth's thinking on the basis of s.105 was the comprehensive scheme involving the transfer of the States' debts and the creation of a Loan Council that was proposed to the Premiers' Conference in April-May 1908. Deakin regarded the scheme as separating in a definite predictable way the Commonwealth's finance from the States', ${ }^{19}$ and it would have been a co-ordinate system for the federation had the States co-operated and had the necessary constitutional amendments been passed. Under the scheme, all State debt would have been handed over to the Commonwealth so that bondholders had the security of the Commonwealth's revenue to look to for interest and redemption; the payment of the customs and excise revenue to the States would be replaced by a fixed payment of $£ 6 \mathrm{~m}$., which was almost the same as the interest on the States' debts in 1900. An allowance for growth was made by additional assistance, beginning at the end of five years, which would be paid over thirty years, so that the annual grant would grow gradually from $£ 6 \mathrm{~m}$. to $£ 8.75 \mathrm{~m}$. That was the States' interest bill on their debts in 1908. In return, it was proposed that the States would not only hand over their debt but also submit to a Finance Council, which would not prevent borrowing but would replace State loans with the 'superior' borrowing power of the Commonwealth to achieve, it was hoped, less expensive loans; the Council would ensure that the States were consulted. The other main parts of the plan advanced by Deakin and Lyne (who had succeeded Forrest as Treasurer) were sinking fund arrangements; an obligation upon the States to pay to the Commonwealth the interest it paid on their debts; and apologetically, yet with real foresight, the Commonwealth proposed that it be given the power, on the certificate of the Council of Finance, to impose a special tax in a State which failed to pay interest due. This replaced Turner's proposal of 1905 that the whole of the States' railway revenue should pass through the Commonwealth Treasury. ${ }^{20}$ The Commonwealth was reasonably sensitive in its presentation of the plan-it appreciated that the States fear the Commonwealth will encroach on their legitimate functions and dictate to them how much they should borrow and, perhaps, even criticize their loan expenditure'. 21

The States rejected the proposal for a number of reasons, the main ones

18 C.P.P., 1907-8, vol. III, 'Premiers' Conference, Brisbane, May 1907', v, 200, 239-45. Forrest attended as acting Prime Minister in the absence of Deakin who was at an Imperial Conference.

19 C.P.P., 1908, vol. II, 'Interstate Conference, Melbourne, April-May 1908', 93-4.

20 It was felt to be a remote contingency yet it was just this problem of non-payment that the New South Wales government precipitated in 1932.

21 C.P.P., 1908, vol. II, 'Interstate Conference, Melbourne, April-May 1908', Appendix A, 
being that the $£ 6 \mathrm{~m}$. was much less than the $£ 7 \cdot 85 \mathrm{~m}$. that they had received in 1906-7 and the larger sum they expected in 1907-8, and they wanted to remain the sole judges of their loan raisings. ${ }^{22}$

This reaction by the States to a proposal which was fundamentally in accord with ss.87 and 105 must have hardened even more the Commonwealth's attitude to them and, indeed, its response fulfilled their worst possible fears. It pressed on with the Surplus Revenue Act of June 1908 which, designed to obtain additional revenue for pensions and other new policies, had the far more fundamental effect of eliminating the Commonwealth's surplus revenue from which advances to the States could be made under s.94. The Commonwealth could appropriate revenue under $\mathbf{s . 8 1}$ to meet obligations not yet incurred. Changing the common understanding of relations between the Commonwealth and the States, the Act must have been an unnerving backdrop to the Conference whose meetings its introduction into Parliament preceded, and its passage succeeded.

\section{The end of surplus revenue}

The attitude of the States was not the only reason for the Act. The obligatory terms of ss.89 and 93 ended on 8 October 1906, five years after the imposition of the uniform tariff. The Commonwealth continued to conform strictly to them but the book-keeping clauses had hampered considerably the financial arrangements of the Commonwealth. The strict system of crediting revenue, debiting actual expenditure and paying monthly balances to the States meant that whatever its financial obligations for the coming month or the coming year might be, the Treasury had to be emptied of cash at the end of each month. There was also the problem of allocating revenue and expenditure which could not be attributed specifically to any State, examples being interest earned on money in London and freight charges. ${ }^{23}$

The Surplus Revenue Act enabled detailed adjustments to be made to debits and credits in respect of awkward items. It also provided that when a federal trust account was created and money appropriated to it, it should be regarded as spent and not available for distribution to the States. Thenceforth the States were to receive only three-quarters of the customs and excise revenue, to be allocated according to the results revealed by the book-keeping system at State borders, which was to be continued

264-70. It was ironic that Lyne's outburst against Deakin's proposal in 1897 should be followed ten years later by Lyne enunciating an even more comprehensive scheme for a Deakin government. By then there was a bandwaggon of schemes-Lyne acknowledged those of Knox and of Robert Harper, M.H.R.; and King O'Malley, M.H.R., had one in print; see Conference, Appendixes $\mathrm{A}$ and $\mathrm{E}$.

22 C.P.P., 1908, vol. II, 'Interstate Conference, Melbourne, April-May 1908', vii and viii (resolutions).

23 C.P.D., 31 March 1908, 9847 et seq. 
under the Act until 30 June 1910, when the Braddon clause, in effect, expired.

Up to mid-1908, all but one of the States had received more than threequarters of the customs and excise revenue attributable to them-New South Wales, 86 per cent; Victoria, 83 per cent; Queensland, 75 per cent; South Australia, 86 per cent; Western Australia, 88.5 per cent; and Tasmania, 80 per cent. The amount paid to the States out of the one-fourth retainable by the Commonwealth was $£ 6,059,089$ above the minimum of $£ 51,717,522$ required by 5.87 .

The Surplus Revenue Act was challenged in the High Court by the States. The constitutional background was briefly this: s.94 provides that 'After five years from the imposition of uniform duties of customs, the Parliament may provide, on such basis as it deems fair, for the monthly payment to the several States of all surplus revenue of the Commonwealth'. In 1900, Quick and Garran asserted dogmatically that the whole surplus must be distributed monthly among the States'. ${ }^{24}$ However, by 1927, Sir Robert Garran's view was that it

is another point as to whether there is any legal right on the part of the States to a return of the surplus. Personally, I have very grave doubts whether section 94 does give any such right to the States . . . the framers were particularly careful not to say that anything should happen except during the preliminary periods. Every clause up to 93 says, 'The Commonwealth shall', but, after that, they say 'The Commonwealth may'. ${ }^{25}$

The view that it seems to be permissive only is probably correct. ${ }^{26}$

The High Court held that the sums appropriated by certain legislation but not spent was expenditure within the meaning of 5.89 and could not form part of the 'surplus revenue' under s.94.27 The effect was that the Commonwealth was able to ensure that there was no surplus revenue. In the mood of the Commonwealth in 1908, the States could have no doubts that after the guaranteed aggregate provided in 5.87 expired in 1910, the States would become dependent upon s.96 for grants from the Commonwealth. Legally, the States were thenceforth 'financially bound to the chariot wheels' of the Commonwealth until they so increased their revenue by their own efforts that they became independent of the Commonwealth's assistance; or they came to an arrangement under 5.105 whereby they transferred their debts and the liability for some or all interest on them to the Commonwealth.

24 Annotated Constitution, 865.

25 Royal Commission on the Constitution, 1927-28, Minutes of Evidence, 73.

26 W. Anstey Wynes, Legislative, Executive and Judicial Powers in Australia (3rd ed., Adelaide, 1962), 473.

27 New South Wales v. The Commonwealth (1908), 7 C.L.R., 179. 


\section{The financial settlement of 1910}

When Fisher became Prime Minister in November 1908 by an amicable arrangement with Deakin, neither Deakin, Forrest nor other senior ministers in Deakin's government was offered a portfolio, but Deakin continued as a power in effect, simply by giving Fisher's government discriminating support in what little it did. ${ }^{28}$ When Fisher met the Premiers at a Conference in March 1909, he resisted all attempts to reveal his hand about a financial settlement. The Premiers heard only his emphasis upon heavy Commonwealth expenditure in the near future. ${ }^{29} \mathrm{He}$ mentioned the power of the Commonwealth to act unilaterally, and responded to the Premiers several weeks after the Conference with counterproposals which were harsher on the States than any previous scheme by Deakin and his ministers. ${ }^{30}$

Within a few months, Deakin was pushed to the fore again. He became Prime Minister and one reason why he accepted office was undoubtedly to consolidate as best he could the Commonwealth's position according to his own conception of Commonwealth and State financial relations. ${ }^{31}$ The Deakin ministry faced three hurdles in arranging a financial settlement: an agreement with the States; then, Parliament's approval of a plan; and, finally, acceptance by the people at a referendum of any change of the Constitution which might be necessary. Each of these steps can be considered in turn. It was to be a significant aspect of the settlement that while there were no proposals for a Loan Council, s.105 was amended and this was the first significant amendment of the Constitution.

Meeting with the Premiers was essential for political reasons; the Commonwealth was expected to continue in the role of 'the great negotiator' ${ }^{32}$ Hence the States' proposal that a conference be held in August 1909 was accepted. The sitting was in complete secrecy, understandable procedure as the States were the convenors, they provided the presiding ministers and secrecy was the only means they had to save face after demanding for so long the return of more than they would get. Deakin could promise nothing permanent because the arrangement would undoubtedly be debated at the elections that would be held before the

28 Sawer, Politics 1901-1929, 62-5. The period out of office gave Deakin time for reflection, which he needed. J. A. La Nauze, Alfred Deakin, a Biography (2 vols, Melbourne, $1965)$, vol. $1,56$.

29 C.P.P., 1909, vol. II, paper no. 48.

30 Labor's proposals would have guaranteed, not a proportion of the Customs revenue, but a fixed sum of $£ 5 \mathrm{~m}$. with an additional $£_{4}^{1} \mathrm{~m}$. to Western Australia on a diminishing scale; the distribution of the $\$ 5 \mathrm{~m}$. would be on a population basis and the Commonwealth would endeavour to supplement it as in the past. Fisher also noted that the States' proposals did not include handing over State debts. Harrison Moore, Constitution, 545-6.

31 Sawer, Politics 1901-1929, 76; La Nauze, Deakin, 572, 574, 592 et seq.

32 Deakin's Fusion Party included Joseph Cook and various Tariff Reform groups, who believed that the States should be fully consulted. Sawer, Politics 1901-1929, 72. 
end of the ten-year guarantee. These elections would also determine which party would be in power to legislate. However, Reid wrote an open letter to the Premiers pointing the way-it was in substance the equal per capita plan often pressed at the Conventions. ${ }^{33}$

Piecing together the proceedings of the Conference reveals that there was virtually no discussion of a Loan Council to manage future borrowing, or the taking over of State debts. ${ }^{34}$ It seems that a good deal hung on Forrest's proposals in the Budget Speech, made the day before the Conference began, that the Commonwealth would meet a budget deficit in 1909-10 by a short-term loan-this would have been the start of Commonwealth borrowing. The States feared this, as Commonwealth competition for loans might result in higher interest rates and, as the heavier borrowers, the States would probably suffer. Hence the States were under pressure either to reduce their demands upon the Commonwealth or to suggest to the Commonwealth ways by which it could reduce its other expenditure. Careful combing of the federal Budget revealed no way to reduce it and the reduction of the payment to the States looked to be the only course open. There were other influences which induced agreement. It suited the Commonwealth to terminate the obligation in $\mathrm{s} .87$ before 31 December 1910 if possible; this concession gave the States their only material bargaining power. Also, all governments at the Conference were non-Labor and all had an incentive to reach agreement in case the return of Labor, particularly to the Commonwealth, resulted in a harsher policy for the States.

The arrangement finally made with the Premiers followed the simple per capita distribution ideas of the Conventions, again with special provision for. Western Australia and with New South Wales making the greatest per capita sacrifice. The decision referred the debts question, the management of future loans and the transferred properties question to an investigating committee of the Commonwealth and the States. This was 'to fulfil the intention of the Constitution'; in fact it merely shelved these acute problems and the States succeeded in escaping that part of the Commonwealth bargain. To free the Commonwealth from levying customs and excise duties of which a fixed proportion would be given

33 C.P.P., 1909, vol. II, 'Premiers' Conference (Melbourne) 1909', 1-4; and 'Report of the Interstate Conference', $x i$, for Reid's letter. Reid's influence lay in the confession in his letter that he was more responsible than any man for the termination of the Braddon clause'. He stated that he had never wished to allow the States less than a fair share of customs and excise revenue but he made it clear that what the States now had to fear was that the future would be determined by the unilateral will of the Federal Parliament, unless they compromised. He suggested to the Premiers a per capita payment which would grow with the population and possibly revenue; that it should be a fair share of revenue and that there should be no other point of contact between the Commonwealth and the States.

34 D. I. Wright, 'The Politics of Federal Finance: the First Decade', Historical Studies, vol. 13, no. 52, April 1969; C.P.D., 12 August 1909, 2413-17. 
to the States, and to assure the States of a rising and fairly definite annual income, the Commonwealth undertook to pay $£ 1.25$ per head of the population from 1 July 1910, six months earlier than the Constitution provided. This was proposed as a permanent provision, to be written into the Constitution by amendment. It would cost the Commonwealth $£ 5.67 \mathrm{~m}$. in $1910-11$ compared with $£ 8.49 \mathrm{~m}$., or $£ 1.96$ per capita, in $1909-10$ under the guarantee in the Braddon clause. This was not all gain to the Commonwealth as, by 1910 , the Commonwealth was relieving the States of expenditure, for example pensions. In view of the large contribution to the customs revenue per head made by Western Australia, the Commonwealth undertook to make an annual grant of $£ 250,000$ diminishing at the rate $£ 10,000$ a year to which the other States were to contribute half, on a per capita basis. The States undertook to provide up to $£ 600,000$ to assist the Commonwealth in its pensions policy, the pension-paying States of New South Wales, Victoria, and Queensland paying more than the others. ${ }^{35}$ The effect of the agreement and rising Commonwealth revenues made Commonwealth loans unnecessary. The proposals had then to go before Parliament.

In the Commonwealth Parliament the Labor Party was not strongly opposed to this arrangement, provided it was not incorporated in the Constitution. Hence the Constitution Alteration (Finance) Bill 1909 met spirited Labor opposition in which a number of Deakin's party joined and the government pushed the bill through committee in the House of Representatives by a majority of one. There was also opposition because there was no agreement between the Commonwealth and States for joint borrowing arrangements. However, the Constitution Alteration (State Debts) Bill, which was designed to give the Commonwealth power to take over, as well, the State debts incurred since federation, passed without opposition.

The referendum on the two constitutional changes was held at the same time as the April 1910 election, which was fought out between the Labor Party and Deakin's weakening Fusion Party. In his policy speech, Fisher had supported a grant to the States on a per capita basis but opposed putting it in the Constitution. Labor won decisively in the House with forty-one seats to thirty-one, with three Independents. The swing was also reflected in the Senate results-Labor won all eighteen vacant seats and gained a majority of twenty-two to fourteen held by the Fusion.

The referendum on the State debts alteration clause giving the Commonwealth the power to take over all debts, and not just those incurred to 1900, was carried. The results were 715,053 to 586,271 in favour, and all States except New South Wales approved it. The country, therefore,

35 C.P.P., 1909, vol. II, 'Report of the Interstate Conference', Agreement on Commonwealth and State Finance. 
decisively favoured a scheme on the basis of s.105 to relieve the States of some of their financial burden. The attempt to write the per capita payment of $£ 1.25$ into the Constitution failed, but this did not indicate that Deakin was out of touch-to the contrary, it was defeated by a majority of only 25,000 out of 1,400,000 votes and was approved in three States. In view of the strong swing to Labor this was a close result, as it had been on the bill in the House of Representatives.

The new Labor government embodied the 1909 agreement with the States in the Surplus Revenue Act 1910, whereby the Parliament itself imposed on the Commonwealth the obligation to make these payments for ten years under the financial assistance power in s.96. In fact, it continued to do so, whatever the political complexion of governments until the Financial Agreement of 1927. The legislation in 1910 closed, until after World War II, effective discussion of general revenue grants to all of the States, and co-ordinated peacetime borrowing and debt management.

The experience of the first decade of federal financial relations revealed some notable features.

The Commonwealth fulfilled the role of 'the great negotiator' in financial relations with the States in the first decade. Believing taxable capacity was the same, or in the case of Western Australia, eventually would become the same, a measure of justice and a high degree of co-ordinate federal finance seemed to have been achieved. This, Deakin and other influential Founders had hoped for, but as it had not been written into the Constitution in 1910, it depended upon the Commonwealth's exercise of the financial assistance power under s.96 for its continuity. Deakin and his ministries were not concerned to tie the States financially to the 'chariot wheels' of the Commonwealth; they were, in intention and accomplishment, intent upon creating a co-ordinate financial system for the federation and they were a force in the opposite direction to greater Commonwealth control of State responsibilities.

In the relatively important second half of the decade, Deakin's influence was clearly very significant. He and his followers were influenced by, as well as having the co-operation of, the rising Labor Party in restraining the States' determined efforts to extend permanently the guarantee in s.87 beyond 1910. They were aided by the disunity of the States and by High Court decisions. The Commonwealth not only escaped from the restrictions on federal finance created by the Braddon clause; its freedom of manoeuvre was enhanced from 1908 when s.94, the surplus revenue clause, became ineffectual to the States. In the circumstances it remained as an advantage to the States that the Constitution left the way open for a permanent solution to financial relations by handing over their public debt, with the Commonwealth assisting the States by paying part or all of the interest. The referendum of 1910 revealed that the people were probably sympathetic to a permanent solution by an adjustment of debt 
arrangements which would provide financial assistance to replace the Braddon clause. But the time was not yet ripe-it was to be an issue which would be solved only after a long period, when the people were ready for it, as some Founders had foreseen. This meant, in effect, that the people would eventually come to accept and to trust the Commonwealth as an experienced member of a co-operative institution or Council that would manage new loans and old debts. That would be a part of the adjustment of the outstanding fiscal problem in a permanent manner. 


\section{The Origins of the Voluntary Loan Council, 1910-23}

The decision to establish a Loan Council on a voluntary basis was first and foremost a political one, but underlying this there was the persistent long-term economic influence, the belief that co-ordinated borrowing would reduce its cost. That, in itself, had always had political implications. New political conditions for its inception steadily developed from 1919 and reached their climax suddenly in 1923. At a Premiers' Conference in May and June of that year, the Commonwealth's proposal that a Council be established on an informal basis was accepted by the States; its function was defined and from that time onwards it was to grow with the tests of experience.

It is perhaps helpful to emphasise that, at the beginning, the Council was not induced by overseas borrowing conditions, as borrowing in London was already well co-ordinated long before the war, orderly procedures being followed there to prevent competition between Australian governments. ${ }^{1}$ Nor was it related to the transfer of debt, or to the question of guarantees to the States to replace the $£ 1.25$ per capita grant; these matters were kept quite separate in the early 1920s. None the less, it was the forerunner of what became the statutory Council and the Financial Agreement of 1927, which incorporated adjustments to achieve the objectives of the Founders.

The reasons why the voluntary Council was established may be separated for analytical purposes but they interacted one upon the other to make the Council acceptable. The important, and one of the unimportant, influences may be conveniently considered under the following general

1 C.P.P., 1923 and 1923-24, vol. II, 'Conference of Commonwealth and State Ministers, May-June 1923', 396-9. 'While London business is controlled . . . the borrowings in Australia are subject to no real control at all.' This co-ordination in London is discussed in chap. 8 . 
headings; the role of the States prior to 1923-that was relatively insignificant; the growth of the Commonwealth's fiscal and borroving power; the powerful forces of economic growth and the pressure they applied to keep interest rates high; and finally, the vital political conditions.

\section{No initiatives from the States}

There was little fruitful discussion of Commonwealth and State financial relations and of co-ordinated peacetime borrowing between the time Fisher assumed office in 1910 and 1923. Under the Fisher Labor government of 1910-13, there was no discussion of these matters with the Premiers. Proceedings at a Premiers' Conference in April 1914. revealed such disunity amongst the States on the basic question whether the State debt might be tranferred to the Commonwealth that even very tentative proposals made by Forrest, non-Labor federal Treasurer, were referred to a Treasurers' conference to avoid the issue. ${ }^{2}$ A small amount of co-ordinated Commonwealth and State borrowing was arranged in November 1914, when Fisher was Prime Minister again, as part of wartime finance. Thereafter, first the Labor Party and subsequently the Nationalist Party, which included a number of former Labor members and senators, were in power until 1922 under W. M. Hughes as Prime Minister, and neither was moved to reopen the issue. ${ }^{3}$

It cannot be said that what little co-ordinated wartime borrowing that occurred was either comprehensive or a catalyst for wider action in peacetime. At the most, it was a precedent which may have influenced later thinking. The decision to co-ordinate in 1914 arose from the problems of war finance which the Commonwealth faced soon after hostilities began. Consultations with the States in November 1914 led to an agreement, into which all but Queensland entered, that the Commonwealth would advance them $£ 18 \mathrm{~m}$. at $£ 1 \frac{1}{2} \mathrm{~m}$. a month, in London and in Australia as needed, pending the raising of that sum for the States by a Commonwealth loan from the British government. ${ }^{4}$ One condition was that the States would not themselves raise new cash loans during the year. Queensland borrowed little and entered into the spirit if not the letter of the arrangement. One important result of the Conference was that the States accepted that

2 C.P.P., 1914, vol. 11, Inter-state Conference, Melbourne, March-April 1914, 75-7, $169,181$.

3 Hughes (West Sydney, 1900-17, Bendigo, 1917-22, North Sydney from 1923) was a Labor member of the First Parliament and changed from Labor to Nationalist Prime Minister in 1916-17. The views of Hughes and Labor and ex-Labor members about relations with the States probably remained the same as they had held in 1910 regarding the referendum at that election. See chap. 3 and L. F. Fitzhardinge, William Morris Hughes, a Political Biography (Sydney, 1964), 244.

$4 £ 8.94 \mathrm{~m}$. borrowed in 1916 and $£ 8 \mathrm{~m}$. in 1917. Commonwealth Auditor-General's Report, $1921-22,47$. 
not only would very considerable bank credit be required, but that the Commonwealth would have to borrow heavily in London and in Australia. ${ }^{5}$

\section{The Commonwealth exercises its fiscal powers}

The record of Commonwealth borrowing before 1915 had peculiarities. Up to 1911 the Commonwealth had met its public works expenditure out of revenue. In that year, the Labor government issued securities at $3 \frac{1}{2}$ per cent which were deposited with the large quantity of gold held by the Treasury, principally on behalf of the Australian Notes Account. Money was therefore raised not from the public but from within the monetary authorities themselves. The loans, or credit, were used to initiate the transcontinental railway, the Australian Capital Territory, and to redeem, as it fell due, $£ 5.93 \mathrm{~m}$. of London debt passed to the Commonwealth at the beginning of 1911 when it took over from the South Australian government the administration and liabilities of the Port AugustaOodnadatta railway and the Northern Territory. ${ }^{6}$

After the November 1914 arrangement with the States, the Commonwealth borrowed at home and in London. A net $492.48 \mathrm{~m}$. was borrowed from the British government for war purposes and, to relieve anxiety about this large commitment, the two governments drew up an agreement in 1920-21 whereby payments including interest should be made to the British government half-yearly, the debt to be liquidated in about 35 years. ${ }^{7}$

The origin and amounts of the remainder of the Commonwealth's public debt which was raised in Australia were to have considerable significance. The Commonwealth first began to borrow directly from the Australian public in 1915, for war purposes. By June 1923, the Commonwealth's debt for civil works and other non-war purposes, including amounts due on the pre-war debts, was but $\$ 31.55 \mathrm{~m}$. in Australia and overseas whereas total war debt was $£ 326.96 \mathrm{~m}$. The significance of the war debt was that much of the Australian-held portion, $£ 232.29 \mathrm{~m}$. at its peak in June 1921, was short-dated and fell due in the 1920s. When combined with the demand for funds to finance the general, rapid economic development which was occurring at the time, the large conversions of the war debt from 1923 onwards were to be a significant cause of the creation of the voluntary Loan Council. The basic effect was strong competition, and fear of further strong competition, for the available savings and high interest rates.

5 C.P.D., 3 December 1914, 1340 (Fisher in the first wartime Budget Speech); C.P.P., 1923 and 1923-24, vol. II, 'Conference of Commonwealth and State Ministers, May-June $1923 ', 46$.

6 Commonwealth Year Book, no. 15, 660 .

7 Commonwealth Auditor-General's Report, 1920-21, 38. Mr. O. E. Niemeyer, Deputy Controller of the Imperial Treasury, and J. R. Collins, Secretary of the Commonwealth Treasury, acted on behalf of the respective governments. 
The war was also a catalyst of further Commonwealth taxes and this was a significant cause of the growth in the Commonwealth's power. It also led to competition for taxation fields and strained relations with the States in the 1920s. Up to the end of the financial year 1909-10 the Commonwealth levied only customs and excise. One of the early acts of the Fisher Labor government was to impose land tax in 1910-11 to finance public works and, it was hoped, to break up large estates to release land for immigrants. After the outbreak of World War I, the Commonwealth gradually imposed direct and indirect taxation in a number of fields - in 1914-15, succession duties were introduced in addition to those concurrently imposed by the States; the Commonwealth's first income tax was levied in 1915-16; entertainment taxation was raised for the first time by the Commonwealth in 1916-17; a wartime profits tax was levied in 1917-18 and did not cease until the early 1920s; and war postage made a late start in 1918-19. After the war, the Commonwealth remained in the field of direct taxation because of its continuing commitments. Debt charges, which before had been insignificant, absorbed about one-third of Commonwealth tax revenue in 1919-20 and war pensions and other rehabilitation costs required relatively heavy expenditure. The effect of these developments, particularly direct taxation by the Commonwealth, was to hinder the States in their efforts to achieve independence of the Commonwealth for part of their revenue; it was more difficult for them to raise their taxation rates once the Commonwealth began cropping the field.

The strength of the Commonwealth was further enhanced in this period by the High Court's decision in the Engineers' Case of 1920. Prior to this case, the doctrine of implied immunity of both Commonwealth and State instrumentalities from interference by another legislature or government had prevailed. The judgment made it clear that the extent of the Commonwealth's powers was to be ascertained by construction of the Constitution according to ordinary rules of interpretation and there should be no preliminary presumption in favour of the preservation of State powers. ${ }^{8}$

The practical effect of this decision was to expand greatly the potential scope of Commonwealth power, because the Constitution operates by way of gift of power to the Commonwealth, not to the States, and the decision requires that powers so granted should be given the fullest amplitude of meaning possible before one can begin to speak of the powers left to the States. ${ }^{9}$

One of its most significant effects was to be that the revenue needs of

8 J. G. Latham, 'Interpretation of the Constitution' in R. Else-Mitchell (ed.), Essays on the Australian Constitution, (Sydney, 1952), 33; Engineers' Case (1920), 28 C.L.R. 145.

OSawer, Politics 1901-1929, 217. 
the States could be met not only by resolving the outstanding problem of transferring State debts, but also by using the grants power in 5.96 for specific purposes such as roads and development projects, as Deakin and Forrest had foreseen.

Between 1910 and 1923, therefore, the Commonwealth grew stronger relative to the States as it began exercising its loan and revenue raising powers to achieve national objectives under its defence, immigration and other powers. This growing status was further enhanced by judicial decision.

\section{Economic and financial origins}

The decision to have a voluntary Council to co-ordinate government borrowing was undoubtedly influenced by economic and financial conditions. Interest rates were much higher after the war than they had been during or before it and the pressure on them stemmed from the high level of private and government demand for capital. This in turn had several causes. Rapid economic development occurred as the tariff wall rose and as the post-war immigration program got under way and the Commonwealth honoured its promises to settle Australian and British ex-servicemen on the land. Innovation, particularly electricity and transportation, and the determination of Australia to industrialise were also important causes of investment and therefore demand for capital. ${ }^{10}$

At least one of these major dynamic elements in Australia's economic growth was present before the war. In 1909, the Commonwealth and the States embarked upon a considerable immigration program and by 1911-13 the annual rate of population increase was well over 3 per cent. This was interrupted by the war but before hostilities ceased it was agreed at Imperial Conferences to arrange assisted migration from Britain to Australia in the post-war years with both British and Australian governments contributing. ${ }^{11}$ W. M. Hughes, whose government was responsible for Australia's part, expressed the national objective in characteristic language.

What are the facts of immigration? For they involve the beginning and ending of our national salvation. If we cannot create conditions

10 N. G. Butlin, 'Some Structural Features of Australian Capital Formation 1861 to 1938-39', Economic Record, vol. XXXV, no. 72, December 1959, 413-14: 'In the course of the 'twenties decade, industrial fixed assets more than doubled, greatly widening the scope of employment and the range of Australian industrial production. The content of the industrial sector changed a great deal.' See also C. Forster, Industrial Development in Australia 1920-1930 (Canberra, 1964), 5 et seq.

11 F. A. Bland, 'Development and Migration' in Persia Campbell, R. C. Mills, and G. V. Portus (eds.), Studies in Australian Affairs (Sydney, 1930), 54. See also Brinley Thomas, Migration and Economic Growth (Cambridge, 1954), 208. Immigration was a central feature of the Fisher Labor government's policy in 1910 in the simple belief that Australia must 'populate or perish'. Fitzhardinge, Hughes, 244. 
which, of themselves, will ensure an influx of the right kind of population-the kind which will enable us to hold as well as to develop this country-we are undone. All our talk concerning the vastness of our heritage will have proved unavailing. Owing to the distribution of power as between the Commonwealth and the States the Commonwealth authorities have very little land outside of the Northern Territory, which they can offer to settlers. Consequently, there must be co-operation with the States. The Commonwealth has done its part in this business; it has created an organisation which is capable of bringing out immigrants at the rate of 100,000 a year. This great machine is ready .. . All of us are agreed that it is of no use to call more people in to our cities. There is no need to do that . . . The States, of course, have control of the lands, and the Commonwealth tells the States that if they cannot continue to find room, we cannot go on with immigration. ${ }^{12}$

The States arranged land settlement on an agreed basis with the British government, which provided financial assistance, and the population increase reached a peak of $2 \cdot 29$ per cent in 1922 and fell below 2 per cent in but one year between 1920 and 1927 inclusive.

The State governments sought large sums of loan money as in the past and capital markets in Australia and the United Kingdom were approached even before borrowing for war purposes ceased. In the post-war decade there was a sustained increase of the order of one quarter in the average annual rate of governments' capital expenditure at constant prices when compared with the previous comparable peacetime period, 1910 -11 to $1915-16$. The rise was from $£ 29 \mathrm{~m}$. to $£ 36 \mathrm{~m}$. per annum; and in 1923-24 it was, at current prices, about double pre-war yearly rates of outlay. The movements in private capital expenditure were also very large after the war. Gross private capital formation at constant prices increased by one-fifth over the previous year in 1919-20 and by one-third in 1921-22, while the annual rate of growth was about 15 per cent between 1918-19 and the end of 1923-24, or a rise of 87 per cent over the period. At current prices, public investment rose at an even faster rate, doubling over the same period. ${ }^{13}$

Not all of the finance for this capital expenditure was raised on the open market, but the movements in expenditure indicated that there was heavy demand for the available savings at the time; for example, between June 1919 and June 1925, the States' Australian-held debt doubled. The pressure on Australian sources of funds was accentuated by two other developments. First, the State governments' heavy borrowing

12 C.P.D., 23 November 1921, 13107.

13 N. G. Butlin, Australian Domestic Product, Investment and Foreign Borrowing 1861 $1938 / 39$ (Cambridge, 1962), 19, 25, 34, 461-5; C.F.B., no. 30, table 61. 
on the Australian market in the four years up to June 1922 raised their net Australian-held debt by $\$ 88.7 \mathrm{~m}$. and this was nearly 72 per cent of their total borrowing at home and abroad over the period. The change to the Australian loan market from the London, which had been going on since federation, had accelerated, and the Australian-held share of all State debt rose nearly 10 per cent to 43 per cent between June 1918 and June 1922. Greater demands were therefore made on Australian savings relative to pre-war years. Second, the due dates of Australian-held short-dated war loans loaded the years up to 1930 with Commonwealth conversions or redemptions. The amounts for 1921, 1926, 1928 and 1929 were insignificant, being about $£ 2 \mathrm{~m}$. a year; but the big conversions in $1923,1924,1925$ and 1927 alone amounted to $£ 227 \cdot 4 \mathrm{~m} .{ }^{14}$

A contemporary analysis concluded that in the early months of 1923-24 'the competition of the Governments to obtain money has become to an excessive degree the dominating factor in the Australian money market'. ${ }^{15}$ In their efforts to raise loans, the States offered high interest rates and tried to attract subscriptions by making the interest tax free. In mid-1923, when the first large war loan conversion of $£ 38 \frac{1}{4} \mathrm{~m}$. was in progress, the Commonwealth Treasurer commented that some holders of loans to be converted thought, quite understandably, that the Commonwealth terms would be unattractive. ${ }^{10}$

The high interest rates paid by governments were significantly above the ceiling of about 4.5 per cent which the community had been accustomed to for the twenty years before the war. ${ }^{17}$ From 1920 until early in 1925, the effective rate paid by the Commonwealth on new issues was over 6 per cent, except for a temporary dip to 5.07 per cent in April 1923 and a rapid subsequent rise to 5.47 per cent; the decline below 6 per cent was brief. There was confirmative evidence. The average monthly yields on New South Wales and Commonwealth government securities with more than six months before maturity rose to over 6 per cent in May 1920 and did not fall appreciably below that level until early in 1925, with the exception of the period of a few months before and four months after the inauguration of the voluntary Loan Council in May 1923. Yields were close to or over 7 per cent throughout 1921.

While these economic and financial forces were undoubtedly significant, the vital creative influences to have co-ordinated borrowing were political. They were the advent of the Country Party and, in 1923, the replacement of Hughes as Prime Minister by S. M. Bruce, an ex-serviceman and a barrister who had been elected in 1917 as member for Flinders (Victoria).

14 C.F.B., no. $12,17$.

15 A.I.B.R. (1923), 878.

16 Ibid., 513, which quoted the Treasurer's memorandum to Premiers' Conference, MayJune $1923,397$.

17 D. McL. Lamberton, Security Prices and Yields $1875-1955$ (Sydney Stock Exchange Research and Statistical Bureau, Sydney, 1960). 


\section{The political origins}

The political impetus for co-ordinated borrowing developed at the federal level. It sprang from the emerging Country Party which, following the elections of 1919, became a small but increasingly powerful entity in the federal Parliament. Its platform included consolidation of federal and State public loans and joint borrowing for the future, in the belief that this would reduce the costs of borrowing, and the reorganisation of Commonwealth and State functions to prevent wasteful overlapping. These policies were two of a number intended to reduce rural costs. ${ }^{18}$ The Country Party was, in effect, grappling with the effects of the significant changes in government finance which the war had caused.

The pressure from the Country Party was not an isolated phenomenon. From the beginning of the 1920s, there was constant strong criticism in Australia of the heavy governmental borrowing and public works programs. The criticism took several forms, one being that the annual earnings of public utilities on which loans had been spent were less than the annual interest bill on the debt incurred; another was that the loss which this difference implied, and which had to be met by the taxpayer, was due to inefficiency. ${ }^{19}$ These views were complementary to those of the Country Party in that a reduction of borrowing costs would increase the profitability of or reduce the losses on public utilities.

It was undoubtedly also vital that the elections of 1922 should have resulted in such diminution of Hughes's power that he resigned as Prime Minister in February 1923 and made way for Bruce. Bruce had a relatively quiet but none the less powerful personality and had been Treasurer under Hughes in the last year of the previous Parliament. Bruce reached an agreement to assume the leadership with Dr Earle Page, ${ }^{20}$ leader of the Country Party, which had won thirteen seats at the 1922 elections and which held the balance of power between Labor and all other parties. Page became Treasurer in the coalition of the Nationalist and Country Parties and he was then in a position to give rein to his own party's policy to co-ordinate borrowing and to reduce the bond rate and the amount of government borrowing. Bruce and Page chose to exploit the Commonwealth's more powerful position by proposing a Loan Council to the States.

The willingness of the States to participate in the voluntary Council had a number of causes. The Council was to be advisory and without executive power. That was fundamental. Then the Commonwealth undertook to leave the local market free for State loans, the Common-

18 Sawer, Politics 1901-1929, 183-4. The Country Party won ten seats at the 1919 elections.

19 See A.I.B.R. (1920), 462 and (1922), 411 inter alia.

20 Earle Page, surgeon, Member for Cowper, N.S.W. from 1919 and elected leader of the Country Party in 1921. 
wealth relying upon revenue and overseas loans for its works finance. With the exception of $£ 2 \mathrm{~m}$. borrowed for the Federal Capital Commission, all new cash loans raised in Australia for non-war purposes between 1924 and June 1929 were for the States' loan programs; 21 the Commonwealth's debt for works and other non-war purposes maturing in Australia fell from $£ 26 \mathrm{~m}$. in 1920 to $£ 23.8 \mathrm{~m}$. in 1929 , whereas Commonwealth overseas non-war debt rose from $£ 3.2 \mathrm{~m}$. to $£ 66 \mathrm{~m}$. in the same period. ${ }^{22}$ In the local market, the Commonwealth was content to restrict itself to arranging satisfactory conversions of its Australian-held war debt. It was also undoubtedly significant that the Commonwealth had already taken steps to assist the States with finance for the immigration program by offering to raise on their behalf London loans on which it would pay one-third of the interest for the first five years of the loans. New South Wales, Victoria and Western Australia had, by the time the Premiers' Conference began in 1923, accepted the offer and this co-operation was an aid to experiments in co-ordination of Australian borrowing. ${ }^{23}$

Agreement to have a voluntary Loan Council was made easier in 1923 because all States but one had non-Labor governments through which commercial, industrial and Country Party objectives could be expressed. The Labor member of the May 1923 Premiers' Conference, E. G. Theodore, ${ }^{24}$ Premier of Queensland, was competent in financial matters and understood the implications of the Commonwealth's proposals. His only comments in the published Conference Report were that he agreed with other Premiers who believed that no advantage would be derived from attempting to co-ordinate London loans. ${ }^{25}$

\section{Representation and procedures at Loan Council meetings}

From its inception, the voluntary Council met at regular intervals. There was invariably a pre-Budget meeting in May or June and another during the period December to February. When London lending ceased temporarily in 1925, a number of meetings was called to deal with the situation. In 1927, more meetings than usual were held while the Financial Agreement was being worked out, and in 1929 the financial crisis was responsible for more frequent meetings. The voluntary Council became the statutory Council at the January 1929 meeting, but all decisions from

21 C.P.D., 14 June 1928, 6146-7, and 6 October 1927, 314-15.

22 C.F.B., no. 22, table 59.

23 Conference, May-June 1923, 403. The Commonwealth undertook to borrow $£ 2 \mathrm{~m}$. a year for each State for the three years 1923-24 to 1925-26. Victoria asked for £3m. in the first year and the total was $119 \mathrm{~m}$.

24 Theodore was born in Adelaide in 1884, was Treasurer of Queensland at 31 and Premier when aged 35 to 41 . He subsequently became a federal member.

25 Conference, May-June 1923, 398-9; the public discussion took up but these two pages of the Conference Report. The rest of the proceedings were in camera. F. Eggleston, Reflections of an Australian Liberal (Melbourne, 1953), 286-7. 
Table 4.1

Meting dates of the Loan Council, 1923-29

\begin{tabular}{|c|c|c|c|c|c|c|}
\hline Number & Date & Number & Date & Number & \multicolumn{2}{|c|}{ Date } \\
\hline 1 & May 1923 & 7 & Aug. 1925 & 14 & Dec. & 1927 \\
\hline 2 & Feb. 1924 & 8 & Dec. 1925 & 15 & June & 1928 \\
\hline 3 & June, July 1924 & 9 & May 1926 & 16 & Jan. & 1929 \\
\hline 4 & Feb. 1925 & 10 & Feb. 1927 & 17 & May & 1929 \\
\hline 5 & June 1925 & 11 & May 1927 & 18 & Aug. & 1929 \\
\hline \multirow[t]{2}{*}{6} & July 1925 & 12 & June, July 1927 & 19 & Nov. & 1929 \\
\hline & & 13 & Oct. 1927 & 20 & Dec. & 1929 \\
\hline
\end{tabular}

30 June 1927 were then deemed to have been taken under the 1927 Financial Agreement (Part II).

In principle, there was probably very little difference between the meetings of the voluntary Loan Council and the statutory Council. Issues and emphasis change but, in substance, there are certain common characteristics of all Loan Council meetings. In the era of the voluntary Council, the Commonwealth government was the only government which always had a separate Minister as Treasurer. Page, sometimes accompanied by the Prime Minister as at the May 1923 and the June-July 1927 meetings, represented the Commonwealth as its Treasurer, and was regarded as Chairman of the Council. However, when the Premiers' Conference resolved itself into a Loan Council meeting, it is probable that sometimes Bruce was Chairman, or remained present. Except when the Prime Minister was in the chair, Page presided over what was largely a meeting of Premiers during the life of the voluntary Council as, from 1924 to 1929, it was the rule for a Premier to be State Treasurer also in all States except New South Wales and Victoria, and in those two States he was Treasurer in three and four years respectively.

The tone of the Council is set by the basic fact that it is a meeting of representatives of executives. The respect and courtesies due to persons at this political level govern the way proceedings unfold. As in the Premiers' Conferences, States' views on each new item will be heard in the order of their size - New South Wales first, then Victoria and so on down to Tasmania. Each representative is heard in silence and with close attention. Advisers and committees appointed by the Council to report to it receive like consideration.

The Council's business is concerned with the state of the loan markets at home and abroad and the Council meets in secret because it deals with money market matters and it does not want to disturb the local and overseas markets for its securities with reports and rumours of details of its intentions. The discussion can be technical. Under the protection of secrecy, it is usually to the point because there are no representatives 
of the press or members of the public present to make it necessary to colour, or to be circumspect about what is said. Each government's views, supported by whatever confidential information representatives are empowered to present, can be evaluated alongside those presented by others. In reaching decisions, not only the needs of a State but the power of individual personalities, their experience at Council meetings and the relative importance and degree of development of their States are all influential on the outcome.

The Council is constantly aware of the political implications of its decisions. There is mutual understanding between members about political reactions and it can be expected to influence decisions taken, enabling members to report back to their executives, parliaments and people in a manner, and with substance, which minimises any loss of face in the event of unfavourable decisions. An example is a fall in a State's share, or the absolute amount of a State's share, of the program. It was as a part of these political purposes that the voluntary Council reached unanimous decisions and that compromise rather than the counting of votes has since been the modus operandi as often as possible. 
The voluntary Loan Council was intended to play a central role in monetary policy. The primary purpose of the Council was to regulate the several governments' impact on the Australian capital market, particularly their influence on the bond rate. How far the voluntary Council was successful in achieving the objectives of a lower interest rate and more restrained government borrowing is amenable to analysis but first, a background sketch of the institutional setting at the time.

\section{The financial background of the 1920 s}

The banking and currency structure was almost devoid of governmental control except that there was one unit of currency. Neither the responsible Commonwealth ministers nor the central bank had the power or the knowledge to exercise a central banking function and none was regarded as necessary. ${ }^{1}$ Apart from the note issuing function, the central bank was no more than a trading bank. The Australian pound and the English pound were regarded as identical and could be exchanged freely; Australian banks held sterling in London and allowed these London funds to fluctuate to keep the value of the two pounds virtually the same. There was no control by the Commonwealth government or by the central bank of the country's gold or foreign exchange reserves and exchange rate; no control of the cash basis and hence the lending policies of the trading banks; and bank and bond interest rates were left to the free forces of the market until the Loan Council was created to endeavour to lower the bond rate. The influence of the central bank on the economy was expected to be by means of variations in the note issue. ${ }^{2}$ The central bank held the accounts of South Australia, Tasmania, Western Australia 
and Queensland as well as the Commonwealth by 1920 , but that was an administrative device. ${ }^{3}$

The power of the private banking system extended deeply into government policy formation in the form of an advisory function and the underwriting of loans. From 1924 onwards the Commonwealth government used the services of both the central and trading banks for underwriting purposes, although the central bank managed the issues. In 1924 the banks assumed an obligation to take such amounts of a proposed $£ 10.3 \mathrm{~m}$. loan as were not applied for by the public. A charge of $£ 0.5$ per cent was made; the banks refused $£ 1$ per cent to undertake additional functions, mainly issuing, inscribing and recording issues. The rate of $£ 0.5$ charged for the service of supplying the balance of cash not subscribed by the public was continued beyond 1928 and underwriting was to be shared by all the banks in proportion to their deposits. In fact, only once in the 1920 s were the underwriters required to make up part of a loan; that was $£ 10 \mathrm{~m}$. of the $£ 36 \mathrm{~m}$. war loan conversion in 1927.4

There can be no doubt that the underwriting function of the banks included advice to governments, including the Commonwealth. Thus, in the weeks preceding a new issue, the financial press would ask whether the federal Treasurer had consulted the banks about the terms and timing of borrowing which would be acceptable to investors, ${ }^{5}$ and it was reported consistently that the terms have been fixed after close consultation with the banks and with leading financial authorities'. ${ }^{6}$ The advisers were confident of their ability to predict the amount which could be raised on the Australian market by floating large new issues, as distinct from counter sales at State treasuries. ${ }^{7}$ As only one loan required the exercise of the underwriting function in the 1920s, the estimates of the amounts which could be raised appear to have been accurate. The advising relationship between the Loan Council and the private banks was continued until the early 1930s, and it was a critically important part of the institutional structure. It meant that the private trading banks were an integral part of the monetary authorities.

It was usually agreed that the rate of interest on the prospective loan would be the same as or close to the rate paid on the last loan, and the current yield on government bonds. ${ }^{8}$ Another indicator of the rate to

3 R. Gollan, The Commonwealth Bank of Australia-Origins and Early History (Canberra, 1968), 149.

4 C.P.D., 6 June 1928, 5573-4; Giblin, Central Bank, 52-3, 177-8.

5 Argus, Melbourne, 28 May 1925, 8; 9 July 1925, 8.

6 A.I.B.R. (1927), 872, quoting from a statement by the Treasurer; see also Argus, 6 October 1927, 15; C.P.D., 6 October 1927, 314; A.I.B.R. (1925), 188, which quotes a statement by the Chairman of the Associated Banks of Victoria, 'The terms were arranged in consultation with the Associated Banks, which are giving the loan wholehearted support'.

7 C.P.D., 13 August 1925, 1393.4 (Budget Speech).

8 Argus, 1 November 1926, 19; A.I.B.R. (1927), 271. 
offer was the response to the rate of interest on sales over the counter. The movement of exports, seasonal conditions, and national and international issues could affect optimism on the local market, and the Council tried to time its issues to avoid making them while the market was in a disturbed state. ${ }^{9}$ Bad timing of a loan could lead to either under-subscription or the need to offer more expensive terms and conditions. Increases of more than a small fraction of 1 per cent in the interest rate were avoided as much as possible because subscribers to previous, cheaper issues would suffer capital loss if they sold before maturity. If rates of interest rose steadily, the number of bond holders with a sense of grievance would increase, with obvious political implications. ${ }^{10}$

In the late 1920s there were references to the fact that 'long term loans, where attempted, have met with little favour from Australian investors, and interminable loans .. . have fallen into disfavour' ${ }^{11}$ To meet the needs of the variety of investors in government issues in the 1920s, issues which matured in five, ten and fifteen years were floated. Not only did this meet the needs of different kinds of investors; it also spread maturities, which was to the advantage of institutional holders and the issuing government, as it diversified the redemption and conversion dates. However, the issuing government had to meet the cost of more frequent conversions of shorter loans.

\section{Reducing the amount of government borrowing}

It proved to be easier for the Loan Council to reduce the amount of government borrowing in Australia than to lower the bond rate.

All war loans raised in Australia up to February 1918 were at 4.5 per cent, the ceiling which yields had reached in the two pre-war decades, but in February 1918 the rate rose to 5 per cent. The subsequent rise to over 6 per cent, together with the fact that large sums were raised by governments in the three years from 1918-19 (tables 5.1 and 5.2) indicates that the Australian market was under pressure as loans for governments' civil purposes replaced war loans. By the fourth post-war year, 1921-22, and again in 1922-23, governments were borrowing less. None the less, in these two years the State governments borrowed annually more in Australia than in any of the five comparable years up to the outbreak of the war. Between 1910-11 and 1914-15, the States' net borrowing in Australia had averaged about $£ 7 \cdot 4 \mathrm{~m}$. a year; in 1921-22 and $1922-23$ the net borrowing by the States at constant prices was close to $£ 1 \mathrm{~lm}$. in each year. The Commonwealth reduced its debt in these last two years but after allowing for that, the net change in total government borrowing was, at constant

11 A.I.B.R. (1923), 415, 705 inter alia; (1925), 971; (1927), 849, 872 inter alia. 


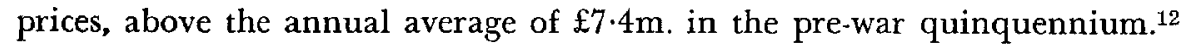
Even though the trend of net government borrowing was downwards by the time Bruce and Page mooted the voluntary Loan Council, the annual amount borrowed remained higher than at any time for at least two decades.

The demand by governments was further relaxed in 1923-24, the first year of operation of the voluntary Council, when redemptions of war

Table 5.1

A ustralian cash and conversion loans by the Commonwealth government for all purposes, 1918-30

\begin{tabular}{|c|c|c|c|c|c|}
\hline $\begin{array}{l}\text { Date loan } \\
\text { opened }\end{array}$ & $\begin{array}{c}\text { Amount } \\
\text { fm. }\end{array}$ & $\begin{array}{l}\text { Term of } \\
\text { loan years }\end{array}$ & $\begin{array}{l}\text { Issue } \\
\text { price }\end{array}$ & $\begin{array}{c}\text { Rate of } \\
\text { interest } \\
\%\end{array}$ & $\begin{array}{c}\text { Effective rate to } \\
\text { investor (longest term) } \\
\%\end{array}$ \\
\hline 18. 2.18 & 36.29 & $9 \frac{8}{4}$ & 100 & 4.50 & 4.50 \\
\hline 18. 2.18 & 6.65 & $9 \frac{3}{4}$ & 100 & 5.00 & 5.00 \\
\hline 9.8 .18 & 44.07 & 5 & 100 & 5.00 & 5.00 \\
\hline 1. 8.19 & 25.02 & 8 & 100 & 5.00 & 5.00 \\
\hline 7. 7.20 & 26.61 & $10 \frac{1}{2}$ & 100 & 6.00 & 6.00 \\
\hline 22. 7.21 & 10.09 & $8 \frac{1}{2}$ & 96 & 6.00 & 6.66 \\
\hline 11. 4.29 & 8.07 & 25 & 99 & 5.00 & 5.07 \\
\hline 29.6 .23 & 21.50 & 5 & 98 & 5.00 & 5.47 \\
\hline 4. 2.24 & 16.99 & various & & 6.00 & 6.00 or over \\
\hline 8. 9.24 & 10.4 & $5 \frac{1}{2}-10 \frac{1}{2}$ & $98 \frac{1}{2}$ & 6.00 & 6.20 or over \\
\hline 24. 2.25 & 4.9 & $5-10$ & 99 & 6.00 & 6.14 \\
\hline 22.7 .25 & 67.37 & $6-16$ & 100 & 5.50 & 5.50 \\
\hline 8.12 .25 & 6.24 & $6-16$ & 100 & 5.25 & 5.25 \\
\hline 1.11 .26 & 31.56 & $6-16$ & 100 & 5.25 & 5.25 \\
\hline 20. 4.27 & 3.39 & $5 \frac{1}{2}-15 \frac{1}{2}$ & 100 & 5.25 & 5.25 \\
\hline 6.10 .27 & 36.16 & $5-15$ & $98 \frac{1}{2}$ & 5.25 & 5.40 \\
\hline 7. 6.28 & 22.42 & $7-14$ & $98 \frac{1}{2}$ & 5.25 & 5.41 \\
\hline 22. 2.29 & 7.64 & 10 & 100 & 5.25 & 5.25 \\
\hline 1. 5.29 & 1.40 & 10 & 100 & 5.25 & 5.25 \\
\hline 7.11 .29 & 10.00 & 5 & 98 & 5.25 & 5.73 \\
\hline 3. 2.30 & 48.22 & 7 & 100 & 6.00 & 6.00 \\
\hline
\end{tabular}

Sources: CP.P., 1932-34, vol.II, The Budget 1933-34, 110-15; Commonwealth AuditorGeneral Annual Reports, 1923-30; A.IB.R.; the table includes most of the loans arranged.

debt totalling nearly $£ 10 \mathrm{~m}$. Offset what were mainly new issues by the States of $£ 13 \mathrm{~m}$., making the net demand by governments for new cash just over $£ 3 \mathrm{~m}$. This was consciously achieved as, from the inaugural meeting, it was an article of policy that the voluntary Council would avoid competing as far as practicable for money which would otherwise find

12 Net borrowing from table 5.2 and C.F.B., no. 9, table 35. Deflating indexes are from Butlin, Gross Domestic Product, table 268. In general, prices roughly doubled between 1910-11 and 1918-19 but were about the same in 1918-19 and 1928-29. 
productive outlets through private enterprise and local and semi-governmental authorities. ${ }^{13}$ 'As far as possible we ought to allow that money to be spent upon development within our own State. ${ }^{14}$ Another practical step taken in 1923-24 was that it was agreed at the February 1924 Loan Council meeting that States would remain off the market until a war (gratuity) loan of $£ 19 \frac{1}{2} \mathrm{~m}$. was redeemed or converted. Although there was

Table 5.2

Governments' Australian borrowing and debt operations 1918.19 to 1929-30

\begin{tabular}{|c|c|c|c|c|c|c|}
\hline \multirow{3}{*}{$\begin{array}{l}\text { Year } \\
\text { ended } \\
30 \text { June }\end{array}$} & \multirow{2}{*}{\multicolumn{3}{|c|}{$\begin{array}{l}\text { Commonwealth and States } \\
\text { annual net change } \\
\text { Australian-held debt ( }(\mathrm{mm} .)\end{array}$}} & \multicolumn{2}{|c|}{$\begin{array}{l}\text { National debt sinking } \\
\text { fund }\end{array}$} & \multirow{3}{*}{$\begin{array}{l}\text { Highest effec- } \\
\text { tive rate paid } \\
\text { on new Common- } \\
\text { wealth loans } \\
\text { (6) }\end{array}$} \\
\hline & & & & \multirow{2}{*}{$\begin{array}{c}\text { Redemp- } \\
\text { tions } \\
\text { (£m.) } \\
(4)\end{array}$} & \multirow{2}{*}{$\begin{array}{c}\text { Balance on } \\
\text { 30 June } \\
\text { (£m.) } \\
(5)\end{array}$} & \\
\hline & $\begin{array}{l}\text { War } \\
(1)\end{array}$ & $\begin{array}{c}\text { Non-war } \\
\text { (2) }\end{array}$ & $\begin{array}{l}\text { Total } \\
(3)\end{array}$ & & & \\
\hline $1918-19$ & 36.0 & 6.9 & 42.9 & - & - & 5.00 \\
\hline $1919-20$ & 37.4 & 24.4 & 61.8 & - & - & 5.00 \\
\hline $1920-21$ & 0.8 & 35.4 & 36.2 & - & - & 6.10 \\
\hline $1921-22$ & -0.7 & 17.1 & 16.4 & - & - & 6.66 \\
\hline $1922-23$ & -5.0 & 18.5 & 13.5 & - & - & 5.47 \\
\hline 1923-24 & -9.7 & 13.0 & 3.3 & 3.0 & 2.1 & 6.18 \\
\hline $1924-25$ & -3.8 & 14.1 & 10.3 & 2.3 & 4.2 & 6.20 \\
\hline $1925-26$ & -0.4 & 10.6 & 10.2 & 5.1 & 3.2 & 5.50 (July) \\
\hline $1926-27$ & -8.8 & 21.6 & 17.8 & 6.4 & 1.3 & 5.25 \\
\hline $1927-28$ & -4.7 & 1.8 & -2.9 & 4.5 & 1.0 & 5.41 \\
\hline 1928-29 & -2.6 & 9.7 & 7.1 & 5.0 & 0.7 & 5.25 \\
\hline $1929-30$ & -3.9 & 10.1 & 6.2 & 5.1 & 0.6 & 6.00 \\
\hline
\end{tabular}

Sources: (1)-(3) C.F.B., no. 30, table 61.

(4) and (5) ibid., no. 18, table 22 and no. 22, table 35.

(6) table 5.1 .

some State competition in that year, the net effect of the Loan Council's decision, to which all States including New South Wales were parties, was a 'rest' for the Australian market in 1923-24.15

The effect of the principle that the Council would accept what the market lent after private investment and, presumably, local and semigovernment needs had been met was that, between 1923-24 and 1929-30, net Commonwealth and State borrowing rose to the high, early post-war levels only in $1926-27$, when net borrowing was $\$ 17.8 \mathrm{~m}$. and the amount was comparable with the loans in the last two pre-Loan Council years. However, this high figure was followed by a net diminution of debt, a return of cash of nearly $£ 3 \mathrm{~m}$. by governments to the public in 1927-28,

13 Conference, May-June 1923, 398; A.I.B.R. (1927), 453.

14 N.S.W.P.D., 22 December 1926, 94 (J. T. Lang, Premier).

15 A.I.B.R. (1924), 96, 138; Argus, 4 February 1924, 6. 
a year in which some difficulty was experienced in arranging a $£ 36 \mathrm{~m}$. war loan conversion. In fact, the annual average of net borrowing between 1923-24 and $1929-30$ was $f 7.4 \mathrm{~m}$. ( $\mathrm{It}$ is almost the same if $1929-30$, the first depression year, is omitted.) At constant prices, this was: only onehalf the annual average in the pre-war quinquennium; about one-half the lowest annual net borrowing program between the end of the war and the inauguration of the voluntary Council; and only one-quarter of the average annual net loan program for all government purposes from 1918-19 to 1922-23 (inclusive).

The voluntary Loan Council succeeded in reducing the demand by member governments for loans from the Australian capital market. While the trend of this demand was already downwards when the Council came into being, it fell further in a decisive manner from the voluntary Council's first year of operation. The successive rates of interest offered on Commonwealth and State loans were therefore fixed at a level that ensured that this fall in demand occurred almost immediately.

\section{Lowering the bond rate in the 1920 s}

A lower bond rate was not achieved so quickly. It was not until July 1925 that a rate lower than 6 per cent was paid on governments' new issues, over two years after the Council's first meeting. By December 1925 , over two and half years after, the Council was able to raise a loan at 5.25 per cent. What kept the rate of interest high for so long after the inauguration of the voluntary Council?

Without presuming to know with certainty what causes the rate of interest to be what it is, some probable influences on the Australian rate from the later war years onwards can be identified.

First, between March 1919 and July 1920, the Melbourne wholesale price index rose 60 per cent and probably encouraged a rise in yields in 1920. Between August 1919 and August 1920, the effective rate paid by the Commonwealth on new issues in Australia rose from 5 per cent to $6 \cdot 10$ per cent.

Secondly, by mid-1921, the wholesale price index had fallen back to its 1919 level, but there was, instead, another shock to the economy; imports for the financial year $1920-21$ were almost $£ 200 \mathrm{~m}$. or half as much again as the previous year's, and to help pay for them, the trading banks' ratio of advances to deposits rose by a fifth, and advances also rose by a fifth. ${ }^{16}$ There was an incentive to keep interest rates up to restrain the demand for imports.

Thirdly, there was the rising level of private investment in the early 1920s. The relaxation of pressure by governments was offset by growing pressure from the private sector wishing to raise capital.

16 R.C.M.B., 326-7. 
But these influences in themselves are not complete proof with which to answer the question why the bond rate continued at over 6 per cent until 1925. This is particularly so because gross domestic capital formation was almost stable from 1923-24 onward, ${ }^{17}$ and there was another factor in the situation that might be expected to exert a downward influence on the Australian bond rate from the beginning of 1923. That was the fall in the new issues rate paid by the Australian governments in London to about 5 per cent by the end of 1922. Government loans in London had cost at least 6 per cent between August 1919 and August 1922 and the Australian rate had, over this period, risen to the same level. But when, from the end of 1922, the British rate on Australia's London borrowing fell, the Australian rate remained at over 6 per cent except for a brief period of about six months between February and September 1923.

A plausible explanation of what transpired is that member governments of the Loan Council and their financial advisers probably fixed on 5 per cent as the long-term bond rate which they considered to be the appropriate rate for governments, as first class borrowers, to pay in Australia, and they aimed to achieve that, or a rate as close as possible to it. They found, however, that this would not be practical until after a big proportion of the war loans had been converted. That occurred when the $\$ 67 \mathrm{~m}$. conversion in July 1925 was out of the way. After that, there was an equally large conversion in 1927-28 but no more until 1930.

The Commonwealth's experience with the first war loan conversion and with the States in 1923 showed early how difficult it would be to reduce the bond rate. In April 1923 the Commonwealth opened the conversion of $138.7 \mathrm{~m}$. at a nominal rate of 5 per cent but an issue price of 99 over 25 years with a bonus of $£ 1$. The effective rate was 5.07 per cent on a war loan which had been raised in 1918 at 5.25 per cent. In effect, an attempt was made to follow the London rate down to 5 per cent. The response to the conversion was so poor that a number of changes of policy were made before the loan expired in mid-September, in order to complete the conversion and redemption of the $₫ 38.7 \mathrm{~m}$. When only $£ 17.25 \mathrm{~m}$. was converted at 5.07 per cent, the Commonwealth realised that it had a serious liquidity problem on its hands. At the end of June, options were given to bondholders to convert to five-year securities, instead of twenty-five years, at 5.47 per cent and this option was open to those who had converted to twenty-five year bonds at 5.07 per cent; about $£ 9 \mathrm{~m}$. was reconverted to the higher rate. Other options made available were (a) Peace Savings Certificates up to a limit of $£ 2,000$ at 5 per cent with which a pass book was issued to enable holders to withdraw certain sums, for example, $£ 100$ on demand and $£ 100$ to $£ 200$ at three days

17 Butlin, Gross Domestic Product, 34. 
notice; and (b) the issue of treasury bills at 5 per cent payable to bearer in one year. Ultimately the loan was met by $£ 23.5 \mathrm{~m}$. of conversions (only a little over $£ \mathrm{~lm}$. being taken out in Peace Certificates and treasury bills); $£ 8.7 \mathrm{~m}$. was subscribed in cash by new bondholders; and the balance was found from the National Debt Sinking Fund, and the Commonwealth's revenue and trust funds.

This harrowing start to the Bruce-Page government's financial policy was attributed in part to the fact that there had been over 243,000 subscribers to the 1918 loan, which was more than twice as many as had subscribed to any other war loan. More important, the Commonwealth's problems were compounded by competition by the States for loan funds throughout 1923. The States not only offered a comparable or higher interest rate, they also added the attraction of freedom from Commonwealth and State taxation on the interest, whereas the Commonwealth's firm policy was to tax interest. The inaugural meeting of the voluntary Loan Council resolved that no more tax-free loans should be issued from the beginning of 1924, and while carried out to the letter by the States, it intensified the competition for funds throughout the rest of 1923, during which the opportunity to raise tax-free State loans remained. The result was a rapid rise in interest rates, yields touching 6 per cent on traded Commonwealth securities in November 1923 and Queensland floated a loan at that rate in January $1924 .^{18}$

The effect upon the Loan Council was salutary. It appreciated that member governments had let the situation get out of hand in 1923 and that the uncertain legal position relating to taxation of interest on loans might be tested in the High Court if allowed to continue. The decision could have gone against the States' interests and they were therefore under pressure to co-operate. At the February 1924 Council meeting it was agreed that the Commonwealth should help Queensland and Western Australia to remain off the loan market up to mid-1924 by making temporary loans to them from its relatively abundant revenue, so that the Australian market might be left as free as possible for the Commonwealth's $\$ 19.5 \mathrm{~m}$. war gratuity conversion loan at 6 per cent. It also became evident to the States that the end of tax-free issues made it attractive to let the Commonwealth borrow on their behalf in the Australian market not only to avoid bidding up the interest rate but to be able to intimate as an answer to the constant criticism of the level of government borrowing, that it was the Commonwealth which was borrowing, not the States. At a Loan Council meeting in July 1924 it was agreed that the Commonwealth should begin some, but not all, borrowing in Australia for the States in 1924-25.19

18 C.P.D., 29 June 1923, 544 and 26 July 1923, 1660; A.I.B.R. (1923), 415, 705, 807, 871, 956, (1924), 1; Lamberton, Security Prices 1875-1955.

19 A.I.B.R. (1924), 199, 629, 916; C.P.D., 29 June 1923, 544 and 26 July 1923, 1660. 
It took some time for these significant decisions to affect the bond rate. The turning point was the year 1925, which began with a February loan at 6.14 per cent, then the $£ 67 \mathrm{~m}$. conversion in July at 5.5 per cent, followed by the small December loan of $£ 6.24 \mathrm{~m}$. at 5.25 per cent; the rate of 5.25 per cent was to be the long-term rate at which all future loans would be aimed and, in this, the Loan Council was largely successful. This explanation of what occurred in 1925 can be supported with additional evidence.

Open market operations were consciously used to reduce the bond rate in 1925-26. By purchasing more government securities from 1925 onwards the government and private financial institutions supported the market by absorbing the private sales of bonds between loans and ensured that a portion of the supply of loanable funds would be available for new Commonwealth issues and for conversions. The Federal Treasurer said in the 1926 Budget Speech that the Commonwealth had operated in the market using the National Debt Sinking Fund, ${ }^{20}$ and Giblin commented that the central bank began open market operations secretly in January $1926 .{ }^{21}$

Statistical evidence lends weight to their assertions. Between 1925-26 and 1928-29, the central bank increased its holdings of securities by $£ 22 \mathrm{~m}$. compared with $14 \mathrm{~m}$. in the preceding three years; and the private trading banks increased theirs by $£ 11.3 \mathrm{~m}$. compared with $£ 2.9 \mathrm{~m}$. in the earlier period. All banks increased their advances and securities to deposits ratio in the second half of the decade (table 5.3). There was, incidentally, no clear and definite relationship between cash and London funds on the one hand and security holdings and advantages on the other, either immediately or with a time lag.22

The details of the operations of the National Debt Sinking Fund show that they were significant. Created in 1923 to provide funds largely for redemption of Commonwealth issues, it grew quickly and between 1923-24 and 1928-29 Commonwealth redemptions of over $£ 26 \mathrm{~m}$. were made from its resources. The Commonwealth's net reduction of war debt over the period 1923-24 to $1928-29$ was $£ 32 \cdot 6 \mathrm{~m}$., only $£ 8 \mathrm{~m}$. more than Sinking Fund redemptions. While the annual average of Sinking Fund redemptions was nearly $£ 4.5 \mathrm{~m}$., the amounts redeemed in 1923-24 and 1924-25 were some-

20 C.P.D., 8 July $1926,3939$.

21 Giblin, Central Bank, 28-9. The bank had also taken up some of the 1923 war loan conversion.

22 R. S. Gilbert, The Australian Loan Council 1923-29 (M.A. thesis, Adelaide University, 1957), chap. 4; $R$. Wilson had found that bank credit in the form of advances had, between 1900 and 1930, 'Some tendency to vary with the excess of deposits over advances with a lag of from one to two years' and that current advances had a close inverse correlation with the current excess of deposits over advances. 'Australian Monetary Policy Reviewed', Economic Record, vol. VII, no. 13, November 1931, 210. His work was directed to identifying a long-term trend. 
Table 5.3

Financial operations of financial institutions, 1921-29

\begin{tabular}{|c|c|c|c|c|c|c|}
\hline \multirow{3}{*}{ Year } & \multicolumn{6}{|c|}{ All cheque paying banks (incl. the central bank) } \\
\hline & \multicolumn{3}{|c|}{$\begin{array}{l}\text { Changes in holdings of government } \\
\text { and municipal securities } \\
\text { (fm.) }\end{array}$} & \multicolumn{3}{|c|}{$\begin{array}{l}\text { Percentage of advances plus } \\
\text { investments to total } \\
\text { deposits } \\
\end{array}$} \\
\hline & Central Bank & Other & Total & Central bank & Other & Total \\
\hline $1922-23$ & 2.7 & 0.1 & 2.8 & 73.1 & 84.5 & 81.9 \\
\hline 1923-24 & 2.0 & -4.0 & -2.0 & 75.6 & 87.6 & 85.0 \\
\hline $1924-25$ & -0.7 & 1.8 & 1.1 & 71.5 & 84.0 & 81.3 \\
\hline $1925-26$ & 3.5 & 4.1 & 7.6 & 75.3 & 87.0 & 84.5 \\
\hline $1926-27$ & 10.6 & -2.1 & 8.5 & 96.0 & 93.0 & 93.6 \\
\hline $1927-28$ & 4.2 & 8.8 & 18.0 & 105.3 & 91.4 & 94.1 \\
\hline $1928-29$ & 3.7 & 0.5 & 4.2 & 101.9 & 96.7 & 97.1 \\
\hline
\end{tabular}

Source: C.F.B., no. 22, tables $69,71$.

\begin{tabular}{|c|c|c|c|c|c|c|c|c|c|}
\hline & \multicolumn{9}{|c|}{ Commonwealth securities held by central bank (incl. savings bank) } \\
\hline & 1921 & 1922 & 1923 & 1924 & 1925 & 1926 & 1927 & 1928 & 1929 \\
\hline \multirow{2}{*}{ Annual change ( $\mathrm{fm}$} & & -0.13 & 0.36 & -1.38 & 0.01 & 0.13 & 0.41 & & \\
\hline & \multicolumn{9}{|c|}{ Government and municipal securities held by life insurance companies } \\
\hline Annual change ( $\mathrm{fm}$. & .) 4.0 & 1.2 & 2.8 & 3.3 & 2.5 & 4.9 & 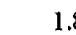 & 3.0 & 5.4 \\
\hline
\end{tabular}

Sources: Life insurance companies from C.F.B., no. 17, table 95 and no. 22, table 98. Central bank's holdings from Summary of Balance Sheets, Commonwealth Bank of Australia, 31 December 1912 to 31 December 1927, frontispiece. The statistics cannot be taken beyond 1927, because the central bank and savings bank were divided in 1927, and there was a change in the accounts which hid these transactions.

what less, being $£ 3 \mathrm{~m}$. and $£ 2 \cdot 3 \mathrm{~m}$. respectively; and accumulations in unused balances were $£ 4.2 \mathrm{~m}$. by $1924-25$ and were higher in that year than in any subsequent year, falling within a few years to about $f 1 \mathrm{~m}$. per annum (table 5.3). The full use of the Sinking Fund was therefore delayed until 1925-26, as part of what appears to have been a concerted plan to withhold support from the bond market until the July 1925 conversion of the $£ 67 \mathrm{~m}$. war loan, which had originally been raised at $£ 4.5$ and 5 per cent.

Insurance companies may also have played a part in getting the bond rate down. In 1920, their holdings of government and municipal securities amounted to $£ 41 \mathrm{~m}$. and by 1929 they had risen to $£ 71 \mathrm{~m}$., representing an average increase of $£ 3.3 \mathrm{~m}$. per annum (table 5.3 ). The annual increases are fairly uneven, and although the increase of $£ 4.9 \mathrm{~m}$. in 1926 is high and coincides with the commencement of greater annual net holdings 
by the banks, it may have been fortuitous. ${ }^{23}$ On the other hand, this action of the insurance companies could have been part of a concerted policy of the Loan Council and its advisers, as both banks and insurance companies were interested in converting their war bonds at as high an interest rate as possible. In view of the Loan Council's intention to reduce the interest rate, they stood to make capital gains if obliged to sell the conversions (at the higher rate) before maturity but after the bond rate had fallen again. If these institutions, therefore, were not only income conscious but also capital cautious investors, their advice may well have been that the rate ought to be reduced to its minimum after the 1925 war loan conversion. Advice of this kind would naturally express the wishes of all income conscious investors who desired to convert at as high a rate as possible, and the Council must have appreciated that all bondholders would be encouraged to convert if the fall in interest was delayed until conversions were largely out of the way.

Once the Council had reduced the rate to 5.25 per cent by its decision of December 1925, the nominal rate on all new issues was kept at 5.25 per cent, and the effective rate to lenders at or below 5.40 per cent until the onset of the Depression nearly four years later; the effective rate to lenders of a Commonwealth issue in November 1929 then rose to $5 \cdot 7$ per cent.

The evidence suggests that from the first year of the Council's formation, its policy was to keep the demand for money down to the residual which remained after the private sector had raised its capital and to strike a rate of interest which would encourage holders of war loans to convert. The treatment to holders of war loans at 4.5 and 5 per cent was generous, as all major conversions of war loans except two were completed before the rate of interest fell to its minimum of 5.25 per cent in 1925. It is also probable that from 1923 to 1925 the Loan Council was finding its feet and was obliged not to change the status quo on the bond rate quickly but to pay some attention to the advice of the private financial advisers, even if it was to the advisers' advantage in so far as the rate was kept high. It is also possible that the Loan Council was being tested before 1925 compared with the later 1920s when the banks took up more securities knowing, by then, that government borrowing, including New South Wales, was well disciplined and would not embarrass them with excessive issues and the danger of further rises in the rate of interest.

The deviation from the 5.25 per cent on Commonwealth issues was precipitated by the New South Wales government's decision in early 1927-28, almost immediately after the drafts of the Financial Agreement

23 When war loans of $117 \mathrm{~m}$. were converted at 6 per cent in 1923-24, one comment was that about $£ 6 \mathrm{~m}$. was held by the banks and a large amount by insurance companies, indicating their considerable interest in these issues. A.I.B.R. (1924), 96-7. 
were discussed by the Premiers, to raise the rate on its new issue above the agreed level to 5.5 per cent. That probably raised the Commonwealth's effective rate from 5.25 to 5.40 per cent for over a year. ${ }^{24}$ It obliged the Commonwealth to lower the issue price of the October 1927 war loan conversion of $\$ 36 \mathrm{~m}$. to $98 \frac{1}{2}$ at 5.25 per cent $(5.40$ per cent effective rate to lenders), and the market did not recover until after the loan of June 1928. This recovery was aided by the net return of nearly $£ 3 m$. cash by governments to the public in 1927-28. The circumstances of the action by New South Wales are simply told: When J. T. Lang was elected as Labor Premier of New South Wales in 1925, he withdrew his government from formal membership of the voluntary Loan Council but he none the less tacitly conformed to the Council's interest rate policy. But Lang, it will be seen, also opposed the creation of the statutory Loan Council in 1927 and that led him to show his independence by raising the rate offered on his State's loan above 5.25 per cent.

\section{The voluntary Council and general economic development}

It has been noted that in the 1920 s there was a considerable expansion of manufacturing industry, assisted by the rising tariff wall and in response to the high rate of population increase and innovation. Unemployment remained a fairly constant proportion of the workforce.

This economic expansion was influenced by the Loan Council's policy, as the lowering of the bond rate in 1925 was an added inducement to invest in capital with a long working life, particularly the building construction sector. More importantly, there was the considerable overseas capital inflow to governments. Between 1924-25 and 1929-30, public works expenditure, financed from net loan raising in Australia and abroad, averaged $£ 40 \mathrm{~m}$. a year. ${ }^{25}$ This large loan program was essential to sustain the private sector, particularly when it flagged in the last half of the decade. ${ }^{26}$ The instability of the situation was that foreign borrowing could cease unexpectedly. That occurred almost as soon as the early meetings of the statutory Loan Council began in January 1929 and is examined in chap. 8 in the context of the fundamental disequilibrium that had then set in. There was also a weakness in the voluntary Loan Council's policy to keep government borrowing in Australia down and to borrow only the amounts available after the private sector had satisfied its capital requirements; this was that it assumed that private investment would expand fast enough to keep the economy growing. From 1925-26, that did not occur and while on the surface there seemed to be good reason for

24 Argus, 6 October 1927, 16; C.P.D., 22 November 1927, 1682 and 14 December 1927, 3181.

25 C.F.B.--for example, no. 22, table 21.

26 Butlin, Gross Domestic Product, table 269 and 'Capital Formation 1861 to 1938/39', 413-14. 
additional government expenditure of a pump priming nature, fundamental disequilibrium was already present and would have made this course difficult to pursue for very long.

The voluntary Loan Council was a product of the pre-Keynesian era of a minimum amount of governmental control of the economy, and in accord with the views of the Founders of the Constitution about the role of governments in the federation. The success of the voluntary Council in achieving the objective of the Founders that government borrowing should be co-ordinated to reduce the interest cost, if only on Australian loans, contributed to the Council's general acceptance and it was an essential prelude to the Financial Agreement of 1927 in which the Council was put on a statutory basis. Co-ordinated borrowing was, however, only one half of the Founders' hopes; they were also concerned about a transfer of State debt to achieve the financial independence of the States and the Commonwealth. In the 1920 s that part of the problem of federal finance reached a state of ferment. 
The Founders had been concerned to find a means of achieving the independence of the States and the Commonwealth in raising revenue. To achieve this, they allowed for the loss of independence in respect of the States' debt management in $\mathbf{5 . 1 0 5}$ but they did not provide for the Loan Council explicitly. The voluntary Council's success between 1923 and 1927 demonstrated quickly, clearly and pragmatically that new borrowing and conversions could be co-ordinated and, de facto, it filled that gap in the constitutional framework.

The ease with which the voluntary Loan Council was established contrasted remarkably with the difficulty in reaching a settlement to transfer State debts to the Commonwealth. The Financial Agreement of 1927 was achieved only after a great deal of preliminary bargaining between the Commonwealth and the States during which alternatives to handing over the States' debts to the control of a statutory Loan Council were thoroughly explored. The impetus for the new initiatives came in the first instance from the Country Party but Bruce echoed its proposals. The coalition found itself under conflicting pressures - on the one hand, to end the $£ 1.25$ per capita system whereby one government raised revenue which other governments spent without being accountable to taxpayers, and to reduce the costs of, and therefore taxation by, the Commonwealth; on the other hand, to meet claims for assistance to all States for specific purposes and for assistance to the less wealthy States for general revenue purposes. For example, Bruce promised special assistance to Western Australia at the same time as he criticised the existing system of the Commonwealth's per capita grants to the States in his 1925 election speech for the Nationalist Party. ${ }^{1}$

1 Sawer, Politics 1901-1929, 257. 
The Commonweath was able to satisfy the demands to reduce taxation and to increase payments to the States, thus getting, to some extent, the best of both worlds, because it inherited in the 1920s the high direct taxation rates of the war years. As the war expenditure diminished, the peak of $£ 4$ per head of direct federal taxation in 1921-22 fell to £2.4 per head in 1928-29, customs and excise rates remaining fairly stable at about $£ 9$ per head because of the higher protection, inter alia. However, the electorate did not achieve what it had hoped for because, as the vital needs of the Commonwealth fell, those of the States grew and their average taxation rate rose from $£ 3.254$ per head to $£ 5.067$ per head over the same period. ${ }^{2}$ One reason for the rising State rates was that the main responsibility for development expenditure had rested with the States from the inception of the federation. Even allowing for the earnings of revenue producing works, debt charges proved a serious burden on the States, particularly the smaller States. In the decade between 1920-21 and 1929-30, interest on the States' debts steadily rose from 25 per cent to 30 per cent of their expenditure from revenue, including business undertakings.

The pressure to end the $£ 1.25$ per capita payments posed deeper problems than reducing federal taxation, increasing special grants to the less wealthy States and making specific purpose grants to all of the States. Determined attempts were made to divide taxation fields between the Commonwealth and the States so that the Commonwealth would not need to continue the $£ 1.25$ per capita payment but these were not successful. The frustration of this endeavour was one of a number of reasons why an alternative course was followed in the form of the 1927 Financial Agreement which, inter alia, established the statutory Loan Council.

A sketch of the main fiscal, judicial and political developments is essential to appreciate why the Financial Agreement was entered into and whether it was to be successful in achieving its objectives, immediately and in the long period. The fiscal and economic problems were influenced, it will be seen, by overseas as well as by local developments.

\section{More financial assistance to the States}

In 1923, the same year as the inauguration of the voluntary Loan Council, the Commonwealth introduced grants to the States on a $£$ for $£$ basis to assist with main roads. The roads grants were made on the 'twofifths area, three-fifths population' formula which slanted them to assist Western Australia, South Australia and Queensland. ${ }^{3}$ In 1924 the first and only step towards railway unification before 1949 was taken to standardise the rail link between New South Wales and Queensland.

2 Commonwealth Grants Commission, Third Report, Appendixes 34-7.

3 Main Roads Development Act, 1923; the allocation formula defined in the Federal Aid Roads Act, 1926, was used from 1923. 
The Commonwealth contributed a third of the cost. ${ }^{4}$ These grants benefited the rural sector which the Country Party was forcefully representing, but they were undoubtedly an aid to greater efficiency in the economy.

The States, particularly those with high taxable capacity, did not accept these moves by the Commonwealth without protest. The Commonwealth had the power under the Constitution to legislate on railways but not directly so in respect of roads, and in 1926 Victoria challenged the Federal Aid Roads Act 1926 (which succeeded the Main Roads Development Act 1923). Victoria argued that (a) the terms and conditions referred to in s.96 should relate either to financial aspects or to circumstances otherwise placed within Commonwealth competence; this did not include roads, which were a State responsibility; (b) that unless all States either accepted or rejected the grants they would contravene s.99 which states that in a revenue matter the Commonwealth shall not give preference to one State over another; and (c) that the Act related to roads and not to financial assistance to the States. The High Court's decision was that the Act is a valid enactment. It is plainly warranted by the provisions of sec.96 of the Constitution, and not affected by those of sec.99 or any other provisions of the Constitution, so that exposition is unnecessary'. ${ }^{5}$

The Court's brief, unanimous statement on a matter of such substance 'makes it stand out like a beacon light in constitutional history'. ${ }^{6}$ The implications of this decision in 1926 were explicitly stated over thirty years later by Dixon CJ. ${ }^{7}$ The Court's decision meant that the power conferred by s.96 authorised the following:

(1) the Commonwealth can bind the State to apply financial assistance specifically to an object which the Commonwealth has defined;

(2) the Commonwealth can prescribe an object outside its powers;

(3) payments can be left to the discretion of the Commonwealth Minister;

(4) the Commonwealth can provide assistance to an object for which the State is also to contribute funds.

In the 1920s the significance of the decision was not fully understood but, in fact, this and revenue grants to the smaller States on a variable basis were the beginnings of great changes.

The end of the belief in equal taxable capacity

In 1924 the belief in development towards equal taxable capacity was shown by Giblin to be completely unsound. Giblin's statistics of taxable

4 Grafton to South Brisbane Railway Act, 1924.

5 Roads Case (1926), 38 C.L.R. 406.

6 R. G. Menzies, 'The Challenge to Federalism', Melbourne University Law Review, vol. 3, 1961-2, 11 .

7 Victoria v. The Commonwealth (1957), 99 C.L.R. 605-6. 
capacity (subsequently presented in the Case for Tasmania by the Premier and Treasurer, J. A. Lyons, in 1926) revealed that from 1914-15 until 1923-24, New South Wales had maintained a comparatively high and steady position; Victoria had moved upward relatively from a rather low to a very high figure and there was a similar, less consistent and less spectacular movement in South Australia. There was a marked decline in the relative taxable capacity of Western Australia and Queensland throughout the greater part of the period. Tasmania maintained a consistently low relative position, about 60 per cent of the average for all States with no decisive trend either up or down. Giblin therefore argued that it was to the advantage of poorer States which were, in some cases, taxing their citizens more severely than the wealthier States, to preserve the status quo. As the Founders had realised, uniform Commonwealth taxation resulted in higher taxation per capita in the wealthier States but equal per capita grants to the States and uniform Commonwealth services resulted in a redistribution of income from the wealthier to the poorer States. 8 Only the wealthier States could be expected to want to change the current practices and resist the use of $\mathbf{s . 9 6}$ by the Commonwealth. This explains, partly at least, Victoria's challenge in the Roads Case.

There were at least three legitimate grounds, Giblin (and others before him) argued, on which smaller States could seek financial assistance, under s.96, to redress the effects of federation and federal financial policy. ${ }^{9}$ The longest standing of these was that the tariff protected the existing industries in the larger, more developed States and made competition by industrialists in the smaller States impracticable, especially after the 1914-18 wartime expansion in manufacturing industry. There was a steady flow of population, especially from Tasmania, to the eastern industrial areas. The protests of the smaller States increased with the rise in tariffs from 1921. Western Australia secured in 1924 an inquiry by the Tariff Board into the effect of protection on the State's industry and finance, and the Board reported in 1925 that it supported the State's claims regarding the tariff's adverse effect; it recommended measures to prevent the dumping of eastern Australian goods in Western Australia and an expert investigation into the State's financial position.

The second cause was the Navigation Act, proclaimed in 1921 after a gestation period of a decade. It was primarily intended to promote the growth of an Australian mercantile marine and it provoked the smaller States to complain bitterly that it meant higher freight charges on goods

81. F. Giblin, 'Federation and Finance', Economic Record, vol. II, no. 3, November 1926; and Giblin's pamphlet published in 1924 called The Taxable Capacity of Australian States, referred to by Giblin in his article and by H. P. Brown, 'Giblin and the Grants Commission', in D. B. Copland (ed.), Giblin-the Scholar and the Man (Melbourne, 1960), 50 et seq; table 17.4.

9 R. J. May, Federation and Financial Inequalities in Australia (M.Ec. thesis, Sydney University, 1964), 10-16. 
purchased from the eastern States with the charges accruing to the exporting States and increasing their taxable capacity relative to the smaller States. Activity was intense in Tasmania and it gave rise to a Royal Commission on the Navigation Act, which reported in 1924 and 1925; amendments were made to the Act in 1925 and 1926 which met some of the States' demands.

The third object of complaint against the Commonwealth's policies was the Conciliation and Arbitration Act which resulted in federal wage awards higher than comparative State awards in the smaller States. The effect was that smaller States had to pay the higher federal awards and State awards rose to match the federal judgments resulting in higher costs again to these States, and imposing a burden they could ill afford to carry.

A fourth factor of considerable importance was that the $£ 1.25$ per capita grant had remained constant while prices had almost doubled between 1910 and 1923. The smaller States were less able to bear the fall in the real value of the per capita payments.

The effect of the persistent pressure from the States for assistance and of the successful impact of Giblin's work on trends in taxable capacity can be seen in table 6.1. From 1924-25 onwards a complete change took place in the Commonwealth's policy. The grants to Western Australia and Tasmania became both bigger and more flexible, depending upon the Commonwealth's view of their position, after consultation on an ad hoc basis with the States concerned. ${ }^{10}$ Although it was not understood at the time, this change of policy sounded the knell of the Founders' expectation of a co-ordinate system of federal finance. Their most pessimistic forecast had been that, within twenty years of federation, taxable capacity would be the same in the States; in fact, soon after the end of that period, State and federal political parties alike could no longer proceed without redressing, in part at least, the inequalities between the States. The originally rigid, or diminishing, general revenue grants to Tasmania and Western Australia became flexible or variable grants and were the forerunner of what was to become assistance to the claimant States as recommended by the Grants Commission. Until the Grants Commission period, which began in 1933, that assistance will be called 'special (later Commission) grants'.

The Commonwealth was aware of the inconsistencies in making specific purpose (roads) grants to all States and special (later Commission) grants to the less wealthy while trying to find ways to do away with the $£ 1.25$ per capita assistance. Page argued by way of apology that some control was exercised over specific purpose and special (later Commission) grants: the Commonwealth's specific purpose grants were made on the condition that

10 R. J. May, 'The Commonwealth Grants Commission', Public Administration, vol. XXI, no. 3, September 1962, 233. 


\section{Table 6.1}

Special (later Commission) grants and roads grants, 1910 to 1930 $\left(£^{\prime} 000\right)$

\begin{tabular}{|c|c|c|c|c|c|}
\hline Year & $\begin{array}{c}\text { South } \\
\text { Australia }\end{array}$ & $\begin{array}{c}\text { Western } \\
\text { Australia }\end{array}$ & Tasmania & Total & $\begin{array}{l}\text { Roads } \\
\text { grants }\end{array}$ \\
\hline $1910-11$ & & 250 & & 250 & \\
\hline $1911-12$ & & 240 & & 240 & \\
\hline $1912-13$ & & 230 & 95 & 325 & \\
\hline $1913-14$ & & 220 & 90 & 310 & \\
\hline $1914-15$ & & 210 & 90 & 300 & \\
\hline $1915-16$ & & 200 & 90 & 290 & \\
\hline $1916-17$ & & 190 & 90 & 280 & \\
\hline $1917-18$ & & 180 & 90 & 270 & \\
\hline $1918-19$ & & 170 & 90 & 260 & \\
\hline $1919-20$ & & 160 & 90 & 250 & \\
\hline $1920-21$ & & 150 & 90 & 240 & \\
\hline 1921.22 & & 140 & 85 & 225 & \\
\hline $1922-23$ & & 130 & 85 & 215 & \\
\hline $1923-24$ & & 120 & 85 & 205 & 132 \\
\hline $1924-25$ & & 110 & 146 & 256 & 519 \\
\hline $1925-26$ & & 450 & 68 & 518 & 719 \\
\hline $1926-27$ & & 300 & 378 & 678 & 964 \\
\hline $1927-28$ & & 300 & 378 & 678 & 1,598 \\
\hline $1928-29$ & & 300 & 220 & 520 & 2,043 \\
\hline $1929-30$ & 360 & 300 & 250 & 910 & 3,093 \\
\hline
\end{tabular}

Source: Commonwealth Payments to or for The States (Government Printer, Canberra, 1962), tables 2 and 13.

Note: Western Australia began to receive this grant first, followed by Tasmania in 1912-13. South Australia did not qualify until 1929-30. All three became the original claimant States in 1933 .

the States contributed $£$ for $£$ and the Commonwealth supervised the expenditure in a general manner, and this reduced the danger of irresponsibility; ${ }^{11}$ further, the special (later Commission) grants to Tasmania and Western Australia were only made after thorough investigation of the States' position, which was a responsible way to dispose of the Commonwealth's funds, and the grants could be reduced in later years if an unacceptable degree of inefficiency crept into a State's administration. ${ }^{12}$ The argument and counter-argument, and the special inquiries, did not settlè the matter.

The pressure on the Commonwealth to reduce costs and taxation induced a thorough reconsideration of the $\$ 1.25$ per capita payment. Bruce and Page raised the matter first at the 1923 Premiers' Conference at which the voluntary Loan Council was created. The main principle, which was given a good deal of publicity, was that it was wrong for the Commonwealth to 
be raising large sums to hand over to the States: governments should be accountable to their electorates both for raising their revenue and for its expenditure. Implied in the argument was a strong, widespread desire to see a co-ordinate system of federal finance. To achieve this by allocating direct taxation fields so that the Commonwealth had some and the States had the remainder immediately raised a sharp political issue. The Commonwealth and the States each wanted to retain the least unpopular taxation fields and leave the most unpopular to the other. As there was not going to be quick, if any, headway in readjusting taxation, the proposal for a voluntary Loan Council was accepted as one way of showing progress in reducing costs almost from the moment the Bruce-Page coalition took office.

Page had started from the position at the 1922 elections that the Commonwealth should give up gradually the imposition of direct taxation and leave it to the States. ${ }^{13}$ This was watered down for the May 1923 Premiers' Conference when Bruce and Page submitted a scheme to terminate the £1.25 per capita arrangement and to simplify the taxation system by the cessation of Commonwealth taxes upon all persons earning $£ 2,000$ a year or less and granting an exemption of $£ 2,000$ to all other persons. ${ }^{14}$ The States rejected this proposal, one reason being that most of the electorate was in the group which would be subject to State taxation only, and the scheme was therefore politically favourable only to the Commonwealth. The States would forgo the advantage of being able to tax companies and higher personal incomes which were lucrative and relatively constant and predictable groups in their political alignments.

The States therefore proposed instead Page's scheme for the complete retirement of the Commonwealth from the income tax field. On that condition, the States were willing to forgo the per capita grants and to contribute to the Commonwealth Treasury sums to cover any Commonwealth loss under the proposals. (In a general sense, this was the reverse of what became, after 1942, the Uniform Tax arrangement.) The Commonwealth rejected their proposal because its existing and possible future responsibilities, especially in the spheres of defence and development, were such that it could not rely on customs and excise duties as its main revenue source..$^{15}$ Also, protectionists were a powerful force in all federal parties and they considered that effective protection would reduce imports and hence revenue from customs duties. ${ }^{16}$

13 Sawer, Politics 1901-1929, 222-3; Ulrich Ellis, A History of the Australian Country Party (Melbourne, 1963), 88.

14 The sources of the main points of the proposals at Premiers' Conferences up to the end of 1926 are the Commonwealth Year Book, no. 19, 1926, 361; the N.S.W. Official Year Book, 1925-6, 284-5; Sawer, Politics 1901-1929, 271.

15 This fundamentally important point was subsequently stressed by the Commonwealth Grants Commission. See Third Report (1936), para. 21.

16 Sawer, Politics 1901-1929, 274. In fact, in the 1920s, the tariff revenue rose with the population as the average rate per head remained fairly constant. 
The rejection of the States' proposal was accompanied by an amended Commonwealth proposal that it should vacate the personal income tax field but retain the right to impose company tax up to a limit of $2 \mathrm{~s}$. $6 \mathrm{~d}$. in the £; per capita payments to the States would cease and there would be no interest payments on transferred properties. These proposals were much more favourably received, four States agreeing in principle, but New South Wales dissented and Tasmania, notably a small State, was not represented. The decision was taken without exact knowledge of the value of the taxation field to be vacated by the Commonwealth, which was the key information, and practical consideration of the scheme was deferred for a year.

In June 1924 and also in 1926, the revenue and per capita arrangements were considered again but agreement could not be reached. Between 1923 and 1927, Premiers' Conferences on the revenue and per capita grants aspect of federal financial relations were for Page 'a long process of negotiation, bluff and counter-bluff, which reached no issue, but during which he and his critics had to alter their ideas'.17

What they came to understand was that it was impracticable for the Commonwealth to depend largely, if not entirely, upon customs and excise revenue; more importantly, the basic issue in the rearrangement of taxation was the requirement of $\mathrm{s.51(ii)}$ of the Constitution that the Commonwealth's taxation must be uniform. This meant that the Commonwealth could not tax States with a lower taxable capacity more lightly than those with a higher capacity. It has, in practice, always been well-nigh impossible for the Commonwealth to vacate a sufficient area of the tax field, with a consequent reduction of grants to the States, and leave to States with a low taxable capacity, particularly Tasmania, an adequate tax field to crop to replace the grants, without the less wealthy States being obliged to charge taxation rates that would be unacceptable to their electorates, both federal and State. Because the Constitution requires a uniform cut in rates, a unanimous decision of all governments is necessary for such a drastic step and in the 1920s it was not forthcoming; without it, action was politically impracticable. The achievement of the unanimous co-operation of the less wealthy States was, of course, made more unlikely still by the understanding the Premiers and their advisers acquired from 1924 onwards of the implications of continued, wide disparities in the taxable capacity of the States: that confirmed the dependence of the less wealthy States upon the redistributive effect of Commonwealth grants.

By 1926, Page and Bruce were in an awkward position in the face of the pressure to reduce taxation and the unwillingness of the States to co-operate unanimously on taxation proposals. They faced opposition not only from the States but also at the federal level. In Parliament, which would have a powerful influence on any course chosen, there were three 
groups which opposed the Commonwealth's withdrawal from the direct taxation fields. ${ }^{18}$ On the government side there were supporters of State interests who were no doubt aware that the rising State taxes would have to rise faster still, especially in the smaller States, if the Commonwealth withdrew from a part of the tax field and withheld the £1.25 per capita payment. The Labor Party favoured continuing the per capita payments until a general review of the Constitution had been carried out; Labor was concerned to expand the power of the Commonwealth. The protectionists in all parties hoped that the rising tariff would reduce imports and tariff revenue and believed that the Commonwealth should not therefore become too dependent on customs revenue.

In the face of this stiff opposition, why did the Commonwealth leaders press so hard in 1926 for a readjustment of taxation and the cessation of the $£ 1.25$ per capita payments?

Local conditions were clearly important. There was unremitting criticism of inefficiency by governments and the bad principle in the $£ 1.25$ per capita payment as well as of the high rate of borrowing and the inefficient use of loans. ${ }^{19}$ The criticism was tempered very occasionally by an appreciation of two important facts: firstly, that works often took a long period to attain full productivity and hence revenue earning capacity; and secondly, the benefit to the community was not measured only by the government revenue earned, but also by the gains in the form of employment created and receipts accruing to ancillary industries. ${ }^{20}$ The critical comments were far stronger and more frequent than words of understanding. The federal elections late in 1925 had therefore been fought on promises by the coalition parties to continue their efforts to improve Commonwealth and State financial relations.

The logical outcome of this undertaking was another Premiers' Conference in May 1926, at which the Commonwealth proposed that in return for abolishing per capita payments, the Commonwealth should vacate the fields of land tax, estate duties and entertainment tax, and should reduce federal income tax rates. Predictably, the Premiers rejected the proposals unanimously because it was doubtful whether some, if not all, of the States would have been able to derive sufficient revenue to replace per capita grants, and much more importantly, the direct taxes which the Commonwealth proposed to abandon were once again politically unpopular, and any existing State government would have run the greatest risk of losing office if it had tried to impose, in addition to land, estate and entertainment taxes, the income taxes which the loss of per capita grants made necessary.

18 Unless otherwise noted, the Parliamentary debate on the 1926-8 proposals on financial relations is based upon Professor Sawer's account in ibid., 271-3.

19 A.I.B.R. (1925), 92, 175-6; (1926), 259, 1102; Argus, 9 July 1924.

20 A.I.B.R. (1920), 704; (1926), 1102. 
No coercing the States into a taxation agreement

Earle Page followed this May Conference with a proposal which gave rise to accusations that the Commonwealth was coercing the States to do its will. In June he introduced in the Commonwealth Parliament the States Grants Bill, in substance was ultimatum to the States; it proposed that the per capita payments should be forthwith terminated in order to put pressure on the States to negotiate a settlement like that proposed in May-politically satisfactory to the Commonwealth, but disastrous for the States. The principle on which the Treasurer took his stand was in opposition to 'the vicious principle' of one authority raising taxation for another to spend. ${ }^{21}$ Cabinet's decision appears to have been based on the view that it would not be in the best interest of Australia to leave the States at the mercy of any chance majority that might control the Commonwealth Parliament. ${ }^{22}$ Bruce certainly made much of it at the time. ${ }^{23}$ The government found that Labor and some of its own supporters were strongly opposed to the Commonwealth adopting a stand-and-deliver attitude to the States. Being in a cleft stick between the opposition from the States and in Parliament on the one hand and, on the other, the strong support for a change from the electorate, the government could be looked upon as merely testing the strength of the parliamentary opposition to coercion. The government could also point to its Bill as an attempt to get something done. In any event, the Commonwealth leaders responded to the criticism by letting the matter stand over until March 1927, when the Prime Minister, S. M. Bruce, announced a more conciliatory policy. The offending bill was amended to provide that the per capita payments to the States should continue on a monthly basis in 1927-28, but in the meantime the States would be called to a Premiers' Conference to consider a scheme which would relate the abolition of the per capita payments to the taking over of the State debts ${ }^{24}$ -as prescribed by the Constitution but steadfastly avoided by the States since the Conferences of the first decade, unless s. 87 was extended.

\section{The alternative-a transfer of debts and a statutory Council}

In the year that followed Page's coercive Bill of June 1926, the Commonwealth clearly gave deep consideration to federal financial relations. Besides the chastening in Parliament, there were other reasons for the decision to introduce the transfer of the debt into discussions with the Premiers. The importance of these is difficult to assess in order of priority and no attempt will be made to do that.

Opposition to coercion. The task of literally forcing through Parliament a scheme to readjust taxation that was totally unacceptable to the States,

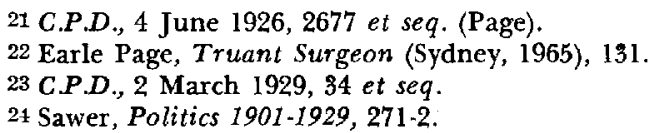


particularly the less wealthy States, was formidable. It probably would not have succeeded and it was out of character with the role of the Commonwealth as the negotiator of schemes with the States.

The Founders' intention in s.105, the 'debts' clause. It was relatively easy to turn to a scheme to transfer State debts and make a payment to the States specifically to help them meet the interest. The electorate was ready to accept it, as the roads and the special (later Commission) grants legislation had revealed. Such a settlement would involve co-ordinated borrowing, and the precedent had been created for that by the practices of the voluntary Loan Council.

Criticism in London of Australian loan policy. In 1922, 1924, 1926 and 1928, Australian governments borrowed heavily in London and the available evidence indicates that in the last three of these years, governments borrowed between 22 and 31 per cent of all types of London new issues to overseas borrowers; and between 45 and 63 per cent of all overseas government issues. Between 1923 and 1929, Australian governments borrowed in London over a quarter of total government issues, and about a seventh of total new issues to all comers. ${ }^{25}$ It is most likely that these high proportions were about the same in 1922, and by 1926 they provoked criticism. One of the early adverse comments was probably made by J. M. Keynes, ${ }^{26}$ and it was elaborated in October 1926 in a booklet called Australian Finance, written by Sydney Russell Cooke, a London stockbroker, and E. H. Davenport. Published just before, and dedicated to, the Imperial Conference of Prime Ministers, its tone was bound to sow seeds of doubt about Australia's financial position; a quotation will illustrate:

In the whole British Empire there is no more voracious borrower than the Australian Commonwealth. Loan follows loan with disconcerting frequency. It may be a loan to pay off maturing loans, or a loan to pay the interest on existing loans, or a loan to repay temporary loans from bankers...

No Dominion takes such full advantage of these unique opportunities of raising cash as the Australian Commonwealth. But is the system safe? Are trustees in this country justified in continuing to hand over a large proportion of the nation's savings to such reticent and pertinacious borrowers? It is, in fact, high time to ask the question--Is Australian finance sound? ${ }^{27}$

25 These estimates give orders of magnitude and are derived from C.F.B., no. 24, table 60, for Australian governments' borrowing in London; and from R.I.I.A., International Investment, 157, for British lending to overseas borrowers.

26 Argus, 9 October 1926, 30. Writing in 1932, Keynes said: 'I believe that Australia has heavily over-borrowed in the past. I have often advised her securities to be avoided ... '. E. O. G. Shann and D. B. Copland (eds.), The Australian Price Structure 1932 (a book of documents) (Sydney, 1933), 84.

27 Sydney Russell Cooke and E. H. Davenport, Australian Finance, Dedicated to the 
They went on to allege that London loans were devoted to purposes bound to run at a loss, or which were damaging to firms in which British investors were directly interested; that States had failed to make proper provision for debt redemption and had not made a serious attempt to reduce their heavy indebtedness to the United Kingdom. They urged 'public opinion' in the United Kingdom 'to compel Australian Governments to satisfy the accepted code of financial ethics when they borrow money in London'. Statistics were used wildly to suggest that Australia was borrowing more than it could afford. The Australian Prime Minister, S. M. Bruce, and the High Commissioner, Sir Joseph Cook, made immediate, considered replies. They showed that the pamphlet bristled with inaccuracies, and questioned its ethics, since its issue coincided with the Prime Minister's arrival for the Imperial Conference. They emphasised that Australia was a British country concerned with Empire unity and was working by agreement with the United Kingdom government to settle British emigrants in Australia. They argued that Australia had always met her obligations, that the security of the loans was safe in the hands of British people able and very willing to meet their contract with the lenders, ${ }^{28}$ and that while the lender was entitled to be convinced that his securities were safeguarded, he was not entitled to attempt to dictate the borrower's policy. ${ }^{29}$

As a direct result of the criticism by Cooke and Davenport, the Australian Prime Minister posed at the Imperial Conference the question of four independent businessmen being sent from the United Kingdom to Australia to investigate the full position. It was subsequently arranged at the request of the Australian government that the personnel of the Mission should be nominated by the British government, and should proceed to Australia with the following terms of reference:

To confer with the Commonwealth and State Governments, with the Development and Migration Commission and the leaders of industry and commerce in Australia on the development of Australian resources and on any other matters of mutual economic interest to Great Britain and the Commonwealth, which may tend to the promotion of trade between the two countries and the increase of settlement in Australia. ${ }^{30}$

One effect of the criticism of borrowing in London must have been the incentive it gave the Commonwealth and State governments to make the voluntary Loan Council a more formal or statutory institution. Such a

Imperial Conference 1926 (London, 1926), 3, 4, 8 inter alia. The pamphlet has 24 pages. Criticism was also made by a British M.P., Sir Gratton Doyle, A.I.B.R. (1926), 835, and The Economist, 6 November 1926, 625 .

28 A.I.B.R. (1926), 835, which quoted a statement made on 13th October 1926 in London. 29 A.I.B.R. (1926), 1021-2; The Times, 17 November 1926.

30 C.P.P., 1929, vol. II, 'Report of the British Economic Mission'. 
statutory Council would be better able to take what might be regarded in London (and elsewhere) as responsible decisions about governments' borrowing and sinking fund arrangements. Even a statutory Council would, however, have had the greatest difficulty in meeting the many criticisms in London about the dominant position of Australia in governmental borrowing on that market. To cut the amount of borrowing overseas raised acute policy issues discussed in chap. 8. The substance of the difficulties was that, in the fundamental economic disequilibrium and administrative situation of the decade, the Australian governments were not able to pursue policies which would enable them to reduce borrowing. The incentive to put the Loan Council on a statutory basis was therefore even greater if it might induce a more sympathetic reaction to Australian governmental borrowing in London.

The success of the voluntary Loan Council. The transfer of attention to s.105 was made much simpler by the success of the voluntary Council which, by 1926, had achieved a great deal besides getting the bond rate down to 5.25 per cent. These other achievements speak for themselves and were to become principles and practices of the statutory Loan Council. The strong criticism by the press of government borrowing was directed mainly at the States, which were responsible for almost all public works and development projects. The States reacted by allowing the Commonwealth to begin floating Australian loans on their behalf in September 1924, using Commonwealth securities. The Council also reviewed loan programs, suggested reductions, and unanimously agreed about the allocation of loan programs. $^{31}$ In mid-1925, on the recommendation of the London advisers, the New York market was tapped and the Commonwealth issued its own securities for a loan it raised on behalf of the States. ${ }^{32}$ In $1925-26$ and in 1926-27, prior to the Financial Agreement, States made payments to the Commonwealth's National Debt Sinking Fund in respect of this loan. ${ }^{33}$ In December 1926, following Cooke and Davenport's criticism, the Commonwealth managed State loans as well as its own issues in London ${ }^{34}$ and State issues were consciously made to test that market prior to larger Commonwealth issues. ${ }^{35}$ This co-operation enabled the States, including New South Wales up to June 1925, to leave the impression that only the Commonwealth was borrowing in Australia and New York. The Commonwealth was able to say that it did not borrow for itself in Australia. All governments could point to the voluntary Council as a third party or authority

31 A.I.B.R. (1924), 629, 916; C.P.D., 25 June 1925, 448 et seq.; C.P.P. 1926-28, vol. V, 'Conference of Commonwealth and State Ministers, June-July 1927', 12-13.

32 A.I.B.R. (1925), 803; C.P.D., 8 July 1926, 3940-1 (Page, Budget Speech). R. S. Gilbert, 'London Financial Intermediaries and Australian Overseas Borrowing 1900-1929', Australian Economic History Review, vol. XI, no. 1, March 1970, 39.

33 National Debt Commission, 23rd Annual Report, table 10.

34 N.S.W.P.D., 22 December 1926, 98 (T.R. Bavin, former Premier).

35 Argus, 11 February 1927, 12. 
where the amount of borrowing was decided and sometimes cut. For example, it was highlighted in the 1926 Budget Speech that the Commonwealth would leave all of the proceeds of loans issued by prospectus on the Australian market to the States and that only Commonwealth securities would be used. It was in accord with these attitudes that the States should continue quietly raising money over the counter provided no prospectus was issued..$^{36}$ Other significant decisions demonstrated the close co-ordination and co-operation in the voluntary Council. At its first meeting it was agreed to abolish tax-free loans which involved the very great task of converting, as it fell due, all Commonwealth war debt and State debt from tax-free to taxable securities. That was achieved. ${ }^{37}$ It was conscious policy to limit overseas loans to the amount necessary to cover the interest owing in London and some minor additional purchases in London. However, works in Australia were regarded as being financed by the transmission to Australia of money raised in London. ${ }^{38}$ In fact, the net increase in all Commonwealth and State overseas debt between 1920 and 1927 was $£ 157.8 \mathrm{~m}$. and interest paid overseas was almost the same, $£ 161.5 \mathrm{~m} .{ }^{39}$ The States appear to have agreed to inform each other of the loan programs of local government and semi-government authorities and by mid-1926 co-ordination in Australia included the understanding that every maturing loan was to be converted in the domicile of the original loan, presumably because each State was anxious to keep as much capital within its borders as possible. ${ }^{40}$ Combined with the success achieved in monetary policy, the policies of the voluntary Loan Council were powerful encouragement to look again at schemes based upon s.105.

Weaknesses of the voluntary arrangement. It was basic that the voluntary Council was in no sense compulsory, and the absence of a representative of the New South Wales Labor government while Lang was Premier between June 1925 and October 1927 bore witness to this. Although Lang abided by the voluntary Council's interest rate policy until a formal, statutory arrangement was proposed in June 1927, his departure from that policy showed that disunity could completely upset the Council's monetary policy. It was attractive, therefore, to contemplate a binding statutory arrangement while the basis of the voluntary Council was so fragile.

Insecurity of the States. It was as much an incentive in 1927 as it was in the Convention Debates and the first decade to write a guarantee of a

36 C.P.D., 8 July 1926, 3940-1. See also A.I.B.R. (1924), 916 and (1925), 169; C.P.D., 31 July 1924, 2727 (Budget Speech), 25 June 1925, 449; Argus, 26 February 1925, 10 , 7 July 1925; Age, 7 July 1925.

37 Page, Truant Surgeon, 127-8; C.P.D., 29 June 1923, 545 and 26 July 1923, 1661-2.

38 N.S.W.P.D., 22 December 1926, 96 (Bavin); E. O. G. Shann and D. B. Copland (eds.), The Crisis in Australian Finance (a book of documents) (Sydney, 1931), 14 (Loan Council press statement); A.I.B.R. (1924), 629.

39 C.F.B., no. 22, 32-3.

40 Page, Truant Surgeon, 127-8 and C.P.D., 8 July 1926 (Page, Budget Speech). 
return of revenue into the Constitution; until that was done, the assistance depended upon the unilateral action of the Commonwealth government.

It is perhaps useful to summarise the complex negotiations between 1923 and 1927. The four-year life of the voluntary Loan Council was a period of ferment in Commonwealth and State financial relations dominated by the search for means to repair the cracks that were appearing in the structure of existing per capita arrangement for grants to the States. The debate was about matters of principle in administration, politics and economics. The main objective was still to create, as far as practicable, a co-ordinate system of public finance in the federation. To this end, a way was sought to avoid one government raising revenue for another to spend without some kind of control being exercised on the expenditure. A degree of control was achieved over roads and special (later Commission) grants, and these policies were accepted because, as will be seen when the Financial Agreement itself is analysed, they required only small sums. Much greater amounts were paid in the $\$ 1.25$ per capita grants and finding an alternative to these was politically imperative but difficult. A readjustment of taxation proved impossible to achieve without coercion and that method could not be used; such an arrangement would have been easy to achieve if the Founders' hopes of equal taxable capacity between the States had been realised or if the Commonwealth was not obliged by the Constitution to tax uniformly in all States.

The fact that the Commonwealth could not offset unequal taxable capacity with compensating but unequal taxation rates obliged all governments to look for an alternative. This was to be the preparation of an agreement whereby State debts were transferred to the Commonwealth; a payment was made to the States for a specific purpose, to help meet the interest on their debt, in lieu of the $£ 1.25$ per capita grant; and new borrowing was co-ordinated. The incentives to reach such an agreement were numerous-there was strong pressure from the Australian electorate, which had always favoured this course; the insecurity of the States while the per capita assistance from the Commonwealth depended upon the views of the federal party in power; the success of the voluntary Loan Council in coordinating borrowing and stabilising the Australian bond rate; the weaknesses of the voluntary Council, particularly the ability of one government to upset the members' agreed policy; and the push given to introducing a statutory Loan Council by strong criticism of Australian governmental borrowing in London, although there was no certainty that a statutory Council could avoid the adverse effects of that criticism and still the equally strong criticism at home.

This is not a complete list; the balance of incentives and disadvantages and the full implications of the 1927 Agreement for federal finance can only be fully appreciated after the contents of the Agreement are under- 
The Australian Loan Council

stood. However, it is reasonable to conclude that, while the voluntary Council was being experimented with, the alternatives to a scheme based on s.105 were fully explored and only when these proved futile was a scheme involving a transfer of State debts, a specific purpose payment to the States and co-ordinated borrowing evolved. 
The Financial Agreement was first discussed with Premiers at a Conference in June 1927 and signed by the Premiers on 12 December 1927. The main opposition to the Financial Agreement came from Lang, both as Premier of New South Wales (up to October 1927) and subsequently when out of office. The federal Labor Party also expressed opposition but some of its members supported it; in the event, Lang's arguments and his persistent presentation of them towered above all others and were not always answered. The manoeuvring will be considered in the order in which events occurred-first the Premiers' Conferences, then Parliamentary discussion and finally the referendum.

Lang's position between July and October 1927 is difficult to determine. The discussion of the draft Financial Agreement was almost entirely in camera, but the Conference decision of 22 July 1927 stated that all participants, including Lang, had approved in principle the draft agreement and would refer it back to their law officers for drafting alterations before governments endorsed it. ${ }^{1}$ Yet, at the same time, Lang's government authorised the local loan at 5.5 per cent, a higher rate of interest than the $5 \cdot 25$ per cent agreed to by the Council and complied with by Lang since 1925 .

Lang stated his criticism of the statutory co-ordination of borrowing during the June 1927 discussion of the Financial Agreement, and subsequently in the New South Wales Parliament. He said that New South Wales needed to borrow freely because individual State loans would be smaller and therefore cheaper and more easily raised than larger loans by

1 Argus, 20 June 1927, 15; Round Table, December 1927, 184; C.P.P., 1926-8, vol. V, 'Conference of Commonwealth and State Ministers, June-July 1927', 33 and 65. Three years later, Bavin, the N.S.W. Premier who had signed the Agreement but who was then in opposition, asserted forcefully, but with a hint of ambiguity, that Lang expressed his concurrence with the Agreement and brought it back to New South Wales with him, leaving it with the State Crown Solicitor for examination. N.S.W.P.D., 3 December 1930, 154. 
the Commonwealth. Nor did New South Wales want to let other States voice an opinion on its total borrowing program, and hence its economic development, at Loan Council discussions, as it would interfere with the sovereign power of the New South Wales people to determine the rate of development of their own State. The Premier of Western Australia, P. Collier, agreed with Lang on these points. Lang also argued that by leaving out co-ordination of local and semi-governmental loans, the Loan Council's activities were 'farcical'. Lang especially feared the possibility of eventual control of semi-governmental borrowing by the Council. ${ }^{2}$

It was reported that Collier withdrew his opposition after long argument in which he was persuaded that the statutory Council would have no more authority than the informal Loan Council. ${ }^{3}$ Lang's and Collier's objections need to be weighed against the incentives to join in the Agreement, but they were met in part by altering the allocation formula so that it took the form which was incorporated in the final Agreement, and by providing that the States' practice of raising temporary loans within their own territory for State development be continued, as the Commonwealth's first draft did not permit temporary borrowing; ${ }^{4}$ but the effective costs, but not the amounts, of bank overdrafts and other borrowing for temporary purposes were made subject to maximum limits decided by the Loan Council, if it so desired. Also, responding to pressure from the financial advisers in London, Lang succeded in having the provision made for a State to borrow overseas, using its own securities, with the unanimous approval of the Council. ${ }^{5}$

Only Lang of the five Labor Premiers who negotiated the Agreement looked so deeply at its implications that he probably became irrevocably opposed to it. No answer was given to Lang's deeper objections about the loss of independence and the costs of borrowing.

Of the signatories to the Agreement in December 1927, four represented State Labor governments, including Collier and J. A. Lyons, Premier of Tasmania, whose States received special (later Commission) grants. Collier had not been easily persuaded and the fiscal advantages the Agreement offered his State, together with the belief that the statutory Council would operate in the co-operative way that the voluntary Council had, can only have had a positive influence upon him. In the event, the four State Labor governments took a position which was contrary to the policy of the majority of the federal parliamentary Labor Party.

The judgment of what was practicable by those responsible for the

2 Argus, 17 June 1927, 15-16; N.S.W.P.D., 80 May 1928, 1084 et seq.; C.P.P., 1926-8, vol. V, 'Conference of Commonwealth and State Ministers, June-July 1927', 16 et seq.

3 Argus, 20 June 1927, 15.

4 Conference, June-July 1927, 3-8, for the first draft of the plan and 53-63 for the final draft agreed to on 22 July 1927. The incentives to join in the Agreement are considered fully later in this chapter.

5 Gilbert, 'London Financial Intermediaries'. 
Commonwealth's policy was proved sound by the voting in and out of Parliament. After the Premiers had drawn up the Agreement, it was submitted to the federal Parliament. Alternative proposals, one being to postpone the Financial Agreement Bill until after a comprehensive reform of the Constitution, were debated, but the voting revealed that the statutory Loan Council was supported by large sections of all parties. Labor opponents of the Agreement wanted per capita payments continued because they kept out rigidities in Commonwealth and State financial relations, which the Financial Agreement would introduce, and which would make it more difficult to alter the distribution of power between the Commonwealth and the States by constitutional reform. Some government members, especially from the smaller States, feared that the new Agreement placed too much potential power over State financial policy in the Commonwealth's hands. ${ }^{6}$

When the proposed amendment of the Constitution by the insertion of s.105A was put to the people to enable legislation on the Financial Agreement to be validated, it was carried by overwhelming majorities. The voting was 2,237,391 in favour and 773,852 against, with all States voting in favour. This could have been anticipated to a large extent from the disinterested debate in all Parliaments except New South Wales, and from the weight of political opinion for the voluntary Council.

\section{The essentials of the Agreement}

When the Agreement was made in 1927, some of its provisions were outside the powers of the Commonwealth, and possibly of the States, and as matters stood, there would be doubts about the ability of either the Commonwealth or the State Parliaments to bind their successors to observance of the Agreement. The Agreement provided, therefore, that the Commonwealth should submit to Parliament and to the electors an amendment of the constitution, s.105A, and that the provisions of the Agreement would not come into force unless the amendment of the constitution was made. $^{7}$

Temporary provisions applied from 30 June 1927 for up to two years by when s.105A had to be submitted to the people at a referendum and, if accepted, the Agreement had then to be validated by the Commonwealth. The amendment was agreed to by all Parliaments, accepted by the electors of each State in November 1928, and the Financial Agreement became effective when the Commonwealth's Financial Agreement Validation Act 1929 received Royal Assent on 18 March 1929. All action taken under the temporary provisions was then deemed, as far as practicable, to have been taken under the permanent provisions. 
The recitals of the Agreement state specifically that its intention was the adjustment of Commonwealth and State financial relations' with 'permanent effect'. It is notable that is was not merely an adjustment but 'the' adjustment. It was to be achieved by the three main parts of the Agreement.

Part I provided for the establishment of the Australian Loan Council and transferred to it, as its primary purpose, the power to decide the rate of interest and other costs on all types of Commonwealth and State loan operations, excepting defence loans and the use of public moneys for any purpose. The Commonwealth became the borrowing authority for the Council. In conjunction with the power to decide the rates of interest on and conditions of government borrowing, the Agreement conferred upon the Council the power to determine, each financial year, the amount to be sought at the agreed interest rate. ${ }^{8}$ The loan program comprised all loans for one year or longer requiring the issue of a security, which included a receipt, for non-temporary or long-term civil purposes, namely public works and revenue deficits. In essence, the Commonwealth would take up the loans offered at the Council's chosen interest rate.

The allocation of the loan program was to be by unanimous decision, otherwise the formula in the Agreement, based upon members' loan expenditure over the preceding five years, would be used. As this formula was inexactly defined and agreement about its precise meaning could not be easily reached, it was in itself an incentive to unanimity. The only other decision requiring full assent was that to allow a State to borrow overseas using its own securities. Otherwise all decisions required a majority vote only. As the Commonwealth's representative, who became chairman, had two votes and a casting vote, the Commonwealth, with the assistance of two States, for example those in 1927 receiving special (later Commission) grants, could achieve a majority vote on a voting matter. The allocation of a disproportionate share of voting to the Commonwealth may be explained by its greater responsibilities. It was responsible for debt administration including legislation, new loans, conversions and redemptions. The Commonwealth assumed liability to the bondholders for the large State debts and new borrowing. The Commonwealth's responsibility for large defence loans and for the co-ordination of Loan Council policy with other monetary and economic policy makes additional voting power for the Commonwealth very significant to it.

As Part II contained the temporary provisions, the second main part

8 Bruce explained it thus: 'The terms to be paid, and the conditions to be accepted, are the only executive determinations at which the Loan Council would arrive . . . A first-class borrower, such as Australia, should not pay, say, more than 5 per cent interest. The Council automatically determines how much money can be borrowed and tests the market. [If the market will not provide all the loan money required] . . . without paying terms that would not be justified in the case of a first-class borrower . . . it then decides how the lesser amount available should be allocated.' Conference, June-July 1927, 12-13. 
of the Agreement was Part III, headed PERMANENT PROVISIONS, by which the Commonwealth took over all State debts at 30 June 1927 , $£ 669.5 \mathrm{~m}$. at face value and equal to seven-eighths of the gross national product at the time; the Commonwealth undertook for a term of 58 years to contribute to both current interest and sinking funds to provide for redemption of this debt. In addition, the Commonwealth undertook to contribute for 53 years to the Sinking Fund for the redemption of each new loan since 30 June 1927. It is submitted by the author that while the Agreement remains as it is, this Part continues for 53 years after the most recent new loan; this is the basis of the conception of permanency. The Loan Council shall remain in existence for the same period. ${ }^{9}$

The view that the Loan Council will go on interminably is open to doubt on the grounds that the submission of loan programs to the Loan Council shall continue only so long as Part III is in force (sub-clauses 3(8), $5(1)$ and 6(1) and not just part thereof. ${ }^{10}$ As two arrangements in Part III, the fixed payment towards the interest on States' debt and the Sinking Fund provisions for pre-1927 debt, lapse in 1985, not all of Part III will then be in force; and the arrangements for amortising the first new loan after 30 June 1927 also lapse 53 years later, in 1980. This raises constitutional and political questions of fundamental importance for the future.

The third main part provided (in Part IV) for the alteration of the Constitution by the insertion of $5.105 \mathrm{~A}$, the transference of certain properties used by the Commonwealth since federation from the States to the Commonwealth and the indemnifying of the Commonwealth by the States for all liabilities taken over subject, of course, to the Commonwealth making its contributions.

The States secured, therefore, a return to the financial position under s.87, a constitutional guarantee of payments from the Commonwealth, but the Commonwealth's payments to the Sinking Fund go on until 53 years after the latest loan incurred since 1,927, and the amount of the payments bears no relationship to the customs or other Commonwealth revenue. Also, during the life of the Agreement the general intention of s.105 would be fulfilled: governmental borrowing would be in the name and with the backing of the Commonwealth's resources. At the same time, the Commonwealth assumed liability for the principal and interest payments on all governmental debt, the principal being provided for in a statutory sinking fund, the Commonwealth's National Debt Sinking Fund administered by

9 E. F. Mitchell, What Every Australian Ought to Know (Melbourne, 1931), 70, who refers to the period as 'possibly a new definition of "eternity".' Sir Edward Mitchell, K.C.M.G., K.C., born 1855, for many years the recognised leader of the Victorian Bar.

$10 \mathrm{~K}$. H. Bailey in G. V. Portus (ed.), Studies in The Australian Constitution (Sydney, 1933), 38. The Report of the Royal Commission on the Constitution, 197, hints at 58 years. G. Sawer, Cases on the Constitution of the Commonwealth of Australia (3rd ed., Sydney, 1964), says: 'The Loan Council's monopoly of loan-raising power will expire in 1985 but the Council itself will not ... ' 
the National Debt Commission which uses the Commonwealth as its agent. The States would indemnify the Commonwealth for their share of all interest paid and debt redeemed on their behalf; the remainder, provided by the Commonwealth, would grow with the States' debt, and these payments on behalf of the States superseded the surplus revenue mentioned in s.105. The Agreement, notably, did not give the Council any power over the expenditure of loan moneys.

However, s.105A went much further than s.105. It not only empowered the Commonwealth to make agreements with the States on matters referred to in s.105; in addition, it empowered agreement with respect to the borrowing of new loans by the State and Commonwealth. It also empowered the Commonwealth Parliament to make laws to validate the Financial Agreement already made, to 'make laws for the carrying out by the parties thereto of any such agreement', and declared that every such agreement, and any variation agreed to by all participating governments, 'shall be binding upon the Commonwealth and the States parties thereto, notwithstanding anything in this Constitution or the Constitution of the several States or in any law of the Parliament of the Commonwealth or of any State'. This extraordinary provision established the Loan Council as a supraparliamentary institution. Section 105A did not refer to or validate the Financial Agreement of 1927 directly; hence the powers it gave permitted variations of that Agreement or the making of fresh agreements by the parties thereto without a referendum to the people. ${ }^{11}$

Perhaps it should be emphasised that s. 105A only empowered agreements relating to the debts of the States, and nothing else; and that it authorised the Commonwealth Parliament to legislate on the subject, but that Parliament could provide for State or autonomous administrative instruments' as it does with respect to the National Debt Commission. Both of these circumstances limit the sphere of the Council's statutory power to influence general economic policy. However, it could voluntarily assist the Commonwealth in general economic policy.

The amendment was a rare occurrence in the Australian federation. Up to 1967 there had been four, of which two were minor. The other one of importance was the acceptance in 1946 of s.5l(xxiiiA) of the Constitution, empowering the Commonwealth to legislate on certain social services. One of the two minor amendments changed s.105 in 1910 to empower the Commonwealth to take over all State debts, not just those existing at federation. The debt sections had therefore figured in half of the constitutional changes which had occurred up to 1967.

\section{Other general powers of the Loan Council}

When the Financial Agreement was validated by the Commonwealth in 
1929, the Loan Council was formally established as a supraparliamentary authority to exercise the powers which the agreement conferred upon it. Sovereignty in the sense of decision-making power over economic policy was thenceforth divided between the Council, the States and the Commonwealth. The Agreement was made at the end of the era of pre-Keynesian economics in which the Constitution itself was framed. It was hoped that it solved the outstanding fiscal and monetary problems in the federation in a co-ordinate system of federal-State financial relations, but there was already reason to be uneasy about whether a co-ordinate system was viable, and this issue is considered again later in this chapter.

The implicit assumption in the Agreement, made as it was on the eve of the great depression of the 1930s, was that there was no need for general economic management by the Commonwealth to maintain economic stability in the federation. Balanced budgets, and belief in the equilibrating power of the rate of interest in the capital market, were the dominant principles of policy. Hence, without any consciousness of the implications in terms of Keynesian and post-Keynesian economic policy, the Loan Council was added to the institutions usually comprising the monetary and fiscal authorities and empowered directly to make binding decisions affecting with varying degrees of significance, the following areas of policy:

(1) balance of payments, in that the Council decides the amount and terms of foreign borrowing by governments;

(2) monetary policy, in that the Council makes decisions about the longterm bond rate and a wide range of other interest rates to be paid by governments, the only important exception being the rate on loans for defence purposes;

(3) State fiscal policy, because the Financial Agreement imposes upon the States severe sinking fund penalty payments if they are obliged to finance revenue deficits with long-term loans; and

(4) development policy (which, in principle, is part of fiscal policy) in that the Council decides the allocation of the loan program, which affects regional development.

The Council's powers in these areas of policy are limited in that they are shared with the Commonwealth or the States who have power to act in other parts of the same area. For example, the Commonwealth has, in balance of payments policy, the power over exports and imports; it has the power over the issue of the currency and banking in monetary policy; and it may, as may the States, spend loan money and revenue in whatever directions of development they wish within the limits imposed by the Constitution. The powers transferred from the Commonwealth and the States, and the remaining obligations of the Commonwealth and the States are examined throughout the rest of this book, but in the concluding chapter particularly, to see whether or not the powers directly conferred on the Council are, in the context of constitutional interpretation before 
and since the Financial Agreement, a constitutional restriction or otherwise upon the Commonwealth to maintain economic stability.

\section{Hopes for a co-ordinate financial system}

The main problems of financial relations between the Commonwealth and the States have been shown to arise from the wide differences in taxable capacity between the States. To deal with the situation, the Commonwealth began in 1924-25 to take flexible action in the form of roads grants to all States and variable, special (later Commission) grants to two of the poorer States.

The Financial Agreement was superimposed on this new trend of policy in Commonwealth and State financial relations, and it was purported to be the permanent adjustment of federal finance. What was the basis for the belief that a co-ordinate system had been achieved or that it was largely so?

The general effect of the Financial Agreement can be briefly summarised in two parts-the fixed payment and the Commonwealth's Sinking Fund contributions. The fixed payment of $\$ 7.585 \mathrm{~m}$. for 58 years (until 1985) is provided explicitly to meet the interest payable by the States to the Commonwealth. It is a matter of some interest that the fixed payment was 23 per cent of the interest on State debts at 30 June 1927, amounting to $£ 32.89 \mathrm{~m}$, and only one-sixth of the customs and excise revenue of $£ 43.55 \mathrm{~m}$. in 1926-27. The payment was the same as the $£ 1.25$ per capita in 1926-27. The Sinking Fund contribution is in two parts: first, on the debt existing at 30 June 1927, the Commonwealth pays 0.125 per cent and the States 0.25 per cent to the National Debt Sinking Fund for 58 years; and second, on debt incurred after that date, except to finance revenue deficits which the States must pay off at penal rates, the Commonwealth and the States each contribute 0.25 per cent to the Sinking Fund for 53 years after each loan. These contributions are not accumulated but applied to redeeming, purchasing and cancelling securities. What was the effect of these contributions on the States' finances?

One significant general observation is that they were made for a specific purpose and there was not only control of them, but there was no way in which the States could use them inefficiently. They met the developing criteria of the 1920s as to the form grants, if any, should take.

The fixed payment is based upon population distribution in 1926-27 and will become less favourable to a State the greater is its population increase relative to other States. Except for this qualification, it is a benefit in the same way as the automatic adjustment accompanying uniform Commonwealth taxation and equal per capita payments aids States with relatively low taxable capacity. Another main advantage of the grant was that it would go on for 58 years, the States being assured of its payment by statute with the force of constitutional law. 
The payments by the Commonwealth to the Sinking Fund to pay off existing debt at 30 June 1927 were a different matter. The payments are equal per cent of debt per State and are in proportion, therefore, to the amount of debt per head taken over from each State. States with a high debt per head in 1927 stood to gain from the Commonwealth relative to others with a low debt per head. The per capita public debt of the States at 30 June 1927 was New South Wales, $£ 101 \cdot 8$; Victoria, $£ 86 \cdot 6$; Queensland, $£ 121.9$; South Australia, £153.2; Western Australia, £180.0; and Tasmania, $£ 115 \cdot 0.12$ Clearly the four less wealthy States stood to gain relative to New South Wales and Victoria.

The Sinking Fund payments on debt taken over succeeded, in their timing, the roads grants, which favoured States with large areas, and the special (later Commission) grants. Between 1923-24 and 1926-27, the period of greater and more flexible grants before the Financial Agreement, Tasmania and Western Australia, the two States receiving special (later Commission) grants received more per head than the others, but they and South Australia and Queensland all improved their position relative to New South Wales and Victoria from the roads grants. In 1927-28 and 1928-29, South Australia and Western Australia noticeably improved their relative positions as a result of payments under the Agreement. This was due to the Commonwealth's payments to the Sinking Fund on their current debt. In 1929-30, when it became the recipient of a special (later Commission) grant, South Australia began to receive more per head from the Commonwealth than Queensland (table 7.1).

Commonwealth payments to the Sinking Fund to amortise new debt depend for their effect on the relative rate of increase per head of new loans, and at the time of the Agreement of 1927 they were an unknown

Table 7.1

Payments to the States by the Commonwealth per capita, 1923-24 to 1938-39 (f)

\begin{tabular}{cccccccc}
\hline Year & N.S.W. & Vic. & Qld. & S.A. & W.A. & Tas. & $\begin{array}{c}\text { Average of } \\
\text { six States }\end{array}$ \\
\hline $1923-24$ & 1.23 & 1.24 & 1.25 & 1.25 & 1.57 & 1.62 & 1.28 \\
$1926-27$ & 1.46 & 1.45 & 1.71 & 1.66 & 2.00 & 3.43 & 1.68 \\
$1927-28$ & 1.55 & 1.53 & 1.83 & 1.83 & 3.09 & 3.53 & 1.78 \\
$1928-29$ & 1.53 & 1.53 & 1.81 & 1.84 & 3.01 & 2.80 & 1.74 \\
$1929-30$ & 1.53 & 1.52 & 1.80 & 2.48 & 2.94 & 2.89 & 1.79 \\
$1938-39$ & 2.20 & 2.30 & 2.70 & 5.70 & 6.10 & 4.70 & 2.90 \\
\hline
\end{tabular}

Source: Commonwealth Grants Commission, Third Report (1936), 221; Seventh Report (1940), 151, for 1938-39.

12 Commonwealth Grants Commission, Third Report (1936), Appendix 45. 
in the situation. The average annual net loan expenditure per head of the States in the five years up to the Financial Agreement was New South Wales, £4.28; Victoria, £5.09; Queensland £4.47; South Australia, £9.85; Western Australia, £10.81; Tasmania, £2.78 and the average of the six States, $£ 5 \cdot 4 .{ }^{13}$ The trend, and therefore the Commonwealth's amortisation payments, could be expected to favour two of the less wealthy States, South Australia and Western Australia.

This covers all payments by the Commonwealth to the States up to 1929 and it contributes to an understanding of why the Financial Agreement was regarded as the adjustment of Commonwealth and State financial relations. Table 7.2 lists the Commonwealth's payments to and for the States from 1926-27, when the last of the $\$ 1.25$ per capita grants was paid, with the Financial Agreement payments shown in place of the per capita grants after 1926-27; included are roads and special (later Commission) grants; and all other payments made in later years.

Before the Financial Agreement, the $£ 1.25$ per capita payments were 82.2 per cent of all grants by the Commonwealth to the States. Payments under the Financial Agreement to the States were expected to be greater than the per capita payments and in the first year were in fact over 10 per cent greater. Moreover, even though roads grants were rising and

Table 7.2

Commonwealth payments to or for the States, 1926-27 to 1938-39 (f'000)

\begin{tabular}{|c|c|c|c|c|c|}
\hline Year & $\begin{array}{c}\text { Special } \\
\text { (Commission or } \\
\text { pre-Commission) } \\
\text { grants } \\
\text { (1) }\end{array}$ & $\begin{array}{c}\text { Road } \\
\text { grants } \\
(2) \\
\end{array}$ & $\begin{array}{c}\text { L1.25 per } \\
\text { capita and } \\
\text { Financial } \\
\text { Agreement } \\
\text { payments* } \\
(3)\end{array}$ & $\begin{array}{c}\text { Total† } \\
(4) \\
\end{array}$ & $\begin{array}{c}\text { Per capita and } \\
\text { Agreement } \\
\text { grants as } \\
\text { percentage } \\
\text { of the total* } \\
\text { (3) as \% (4) }\end{array}$ \\
\hline $1926-27$ & 678 & 964 & 7,583 & 9,227 & 82.2 \\
\hline 1927.28 & 678 & 1,598 & 8,408 & 10,684 & 78.7 \\
\hline $1928-29$ & 520 & 2,043 & 8,517 & 11,080 & 76.9 \\
\hline $1929-30$ & 910 & 3,093 & 8,579 & 12,582 & 68.2 \\
\hline 1934-35 & 2,400 & 2,410 & 8,916 & 21,079 & 42.3 \\
\hline $1938-39$ & 2,020 & 4,287 & 9,063 & 20,287 & 44.7 \\
\hline
\end{tabular}

* Per capita payment in 1926-27.

†In 1934-35 and 1938-39, other grants are included in the total.

Sources: (1) (2) and (3) Commonwealth Payments to or for the States 1963.64 (Canberra, 1964), tables 8, 10, 19.

(4) Other grants from Grants Commission Sixth Report, appendix 23 and Twentieth Report, appendix 17 adjusted to allow for actual payments to the States for roads.

13 C.F.B., no. 22, table 47. 
special (later Commission) grants were flexible and tending to move upwards, the proportionate importance of Financial Agreement payments in all Commonwealth payments to the States was maintained, in the first two years, near that of the $£ 1.25$ per capita payments in 1926-27, or about 80 per cent.

Notably, the large payments under the Agreement were generally in accordance with the concept of automatic transfers being made from the wealthier to the poorer States. Also, all the grants received by the States,

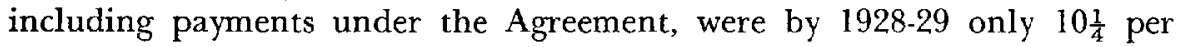
cent of all the States' revenue excluding grants but including public utilities, and in their revenue raising policies the States' direct taxation per head was $£ 5.067$ or more than twice the Commonwealth's direct taxation rate of $£ 2.400$ per head. The States had made a remarkable effort to achieve independence of the Commonwealth's revenues compared with the first decade. The belief that the fiscal arrangement in the Financial Agreement was a final and permanent adjustment was therefore understandable and very plausible. It was also in accord with the Founders' view of what should be done to achieve, as far as practicable, co-ordinate federal finance, although the Loan Council had not been foreseen by them.

This system lasted only a few years. Under the impact of the depression, the proportion of Financial Agreement payments in all grants to the States fell as the Commonwealth assisted the States from revenue and loan funds to ease unemployment and hardship. The proportion of Agreement payments in Commonwealth assistance reached a low of $42 \cdot 3$ per cent in 1934-35 and rose slightly in the late $1930 \mathrm{~s}$, but it did not pass one-half before the introduction of Uniform Tax completely transformed the situation (table 7.2). It was to fall far lower when Uniform Taxation began in 1942. But in late 1927 when the Agreement was signed, these possibilities were not in sight, and it was reasonable to regard the settlement as being the kind of permanent system the Founders had provided for in the Constitution, with but marginal adjustments to assist States with development finance and to offset the effects of differing taxable capacities. None the less, the continuation of unequal taxable capacity was a deep-seated reason for uneasiness about the future of relations between the Commonwealth and the States.

\section{Were the States coerced?}

The Financial Agreement was a profound change which, it has often been alleged without much reasoning, the Commonwealth forced upon the States by using its strong constitutional and financial position. ${ }^{14}$ It has been

14 'Having under the Constitution the dominant financial power, the Commonwealth has taken advantage of its position to compel the States to agree to common action upon some of the most pressing problems of public finance in Australia.' Round Table, December 1927, 187; and 'Commonwealth pressure was unremitting; and there is probably little doubt that the States were brought to the Financial Agreement "at the point 
shown that while the Commonwealth had the power to act threateningly or without the consent of the States, Parliament rejected such a modus operandi to readjust taxation. There is strong evidence that the attempt at coercion ended in 1926 with the taxation proposals; the States were persuaded to join in the Agreement by the considerable advantages which it gave to them in addition to the incentives which induced all governments, including Lang's, to go to the conference table.

First, there was an appeal to the States through their budgets. The Commonwealth's per capita payments to the States in $1926-27$ were 6.8 per cent of their total revenue, including works and services, and 27 per cent of the amount of taxation raised. Per capita payments were, therefore, a significant proportion of total State revenue. In the 1927 discussions of the expected Commonwealth payments for the States to the National Debt Sinking Fund and the fixed payment for interest, it was shown on generally accepted assumptions about increases in borrowing as against increases in population, that for at least a decade, and as it turned out for the full period between 1927 and Uniform Tax in 1942, the Commonwealth annually would pay more to and for each of the States than it would have if the $\$ 1.25$ per capita payments had continued. The States, knowing this, had an incentive to prefer the Financial Agreement to the per capita payments. ${ }^{15}$ In Page's view, it was decisive, particularly in Victoria. ${ }^{16}$ The incentive was the greater because the States were frequently in deficit in the 1920s despite the prosperity of the period. Total official deficits of each State exceeded total surpluses between 1920-21 and 1926-27; in aggregate there was over $£ 7 \mathrm{~m}$. in deficits compared with about a quarter of a million pounds in surpluses; and apart from 1924-25, when two States had deficits, in all other years at least three States were in deficit at the same time and in 1921-22 there were five.17 There can be no doubt about the budgetary difficulties, although allowance needs to be made for payments from revenue to reserves and trust funds which could conceivably make the actual expenditure on goods and services less and the deficits smaller, or even turn some into surpluses. To measure these transfers, and to make other adjustments according to the Grants Commission's practice which places the published budget results on a comparable basis, would be too complex a task for the purpose served. The net effects would probably show that the States had an even greater need for grants, judging by the results of the Grants Commission's calculations for the 1930s, when

of a gun"'. S. R. Davis, 'A Unique Federal Institution', University of Western Australia Annual Law Review, vol. II, no. 2, December 1952, 362; James A. Maxwell, Commonwealth-State Financial Relations in Australia (Melbourne, 1967), 65.

15 C.P.D., 14 December 1927, 3180; New South Wales Year Book, 1928-29, 178.

16 Truant Surgeon, 131.

17 Commonwealth Grants Commission, Fifth Report (1938), 173. 
there was, for most of the States, an increase in adjusted as compared with published deficits. ${ }^{18}$

Secondly, the ploy of referring to the Loan Council as the loan raising authority to divert attention from the States' loan raising when there was heavy criticism of borrowing and works expenditure was, by the Agreement, cemented firmly into the Constitution. The States retained complete sovereignty over their works expenditure and the political advantages which were derived from providing public works. They got the best of both worlds in the matter.

Thirdly, although the Commonwealth took over great responsibilities from the States, they retained a majority of the votes in deciding the costs and the amount of borrowing. The Commonwealth was able to exercise some influence indirectly by means of its power to make or withdraw grants under s.96. However, on balance, the States achieved more freedom of action under the Agreement-only two depended upon special (later Commission) grants after it, whereas previously all six were in the insecure position of receiving the relatively larger $£ 1.25$ per capita grants at the Commonwealth's discretion.

Fourthly, the Commonwealth assumed liability for new State debt and $1670 \mathrm{~m}$. of existing State debt, and undertook to meet the interest and redemptions as and when required. This was no light matter. It was in the States' interest to bind the Commonwealth to pay commitments as they fell due; it was in the Commonwealth's interest to bind the States to make their steady Sinking Fund contributions and to indemnify the Commonwealth against all liabilities incurred on their behalf.

In addition to commonly held reasons for a statutory agreement, or reasons which were in the States' own interests, the Commonwealth had reasons of its own for proposing the draft Agreement in 1927 which were undoubtedly significant.19

It is the Commonwealth's responsibility in the federation to ensure foreign exchange equilibrium. If the currency depreciates, the reputation of the Commonwealth government of the day is compromised. In the $1920 \mathrm{~s}$, the percentage of Commonwealth and State governments' interest payments abroad to Australian exports (f.o.b.) rose from 10 per cent in $1920-21$ to about 20 per cent in 1928-29.20 Although no specific emergency was anticipated by the governments, many critics both at home and abroad were uneasy about the growth of interest and the heavy borrowing to pay for it and, by implication, about the balance of payments or 'the nation's credit'. The issue received serious attention, before the Agreement was

18 Ibid. (1933), 84; (1934), 57; (1935), 99; (1936), 73; (1937), 66.

19 C.P.D., 14 December 1927, 3178 et seq., Bruce in Second Reading on the Financial Agreement Bill.

20 C.F.B., no. 24, tables 58-60, and I. W. McLean, 'The Australian Balance of Payments on Current Account 1901 to I964-65', Australian Economic Papers, vol. VII, no. 10, June $1968,84$. 
signed, by E.C. Dyason who made calculations in an attempt to estimate the validity of the criticism. ${ }^{21}$

Dyason's work led him to the important conclusion that there seemed to be no reasonable doubt that the nation was wealthy enough, in terms of the national income, to sustain the burden of the national debt in 1927 with comparative ease. He did not show by cost/benefit analysis whether it was profitable to have incurred the debt project by project ${ }^{22}$ (even assuming that in a decade when at least 4 per cent of the total workforce was unemployed, the employment and income effects of the public works expenditure can be ignored). ${ }^{23}$ Using the early attempts to measure real income per head, Dyason considered that its growth was not rapid enough to make it certain that the large expenditure of loan money on development produced satisfactory returns in production. Professor R. C. Mills reached much the same conclusion later. ${ }^{24}$ One omission from this analysis was the matter of the rapid growth of fixed interest payments abroad and their high and growing proportion of export receipts, upon which they would make heavy demands if lending ceased. Professor E. O. G. Shann took up this vital question and warned that the depression of the $1890 \mathrm{~s}$ could repeat itself unless the country put its house in order and took steps to guard against the effects of drought and falling wheat and wool prices. ${ }^{25}$ On balance, Shann and the other economists, together with the London critics, lent weight in 1927 to the Commonwealth's view that, as Australia might need overseas all the goodwill it could muster, a statutory Loan Council might help to that end. It is reasonable to believe that the States shared this view.

Another purpose of the Commonwealth was to comply with the political pressure it was under to attach conditions to, or make checks upon, grants to the States. Under the Surplus Revenue Act, the per capita payments were an example of one government raising revenue for others to spend. Under the Agreement the payments made after 1926-27 were related specifically to interest on the debt and to its amortisation. The fixed grant under the Agreement, legally if not in practice, would be paid back to the Commonwealth to help meet interest on debt taken over, and Sinking Fund payments would be made to the National Debt Sinking Fund, and not a State government. The growth in payments would be determined by the Loan Council's decisions about the rate of new borrowing. This was a clear-cut transformation from the situation in which unconditional

21 'The Australian Public Debt', Economic Record, vol. III, no. 5, November 1927, 161. 22 Sir Lennon Raws, 'Australian Loan Expenditure', Economic Record, vol. IV, no. 7 , November 1928, 209.

23 M. Keating, 'Australian Work Force and Employment, 1910-11 to 1960-61', Australian Economic History Review, vol. VII, no. 2, September 1967, 164-8.

24 'Australian Loan Policy' in Campbell, Mills and Portus (eds.), Studies in Australian Affairs, 110 and 114 et seq.

25 The Boom of 1890-and Now (2nd ed., Sydney, 1927). 
£l.25 per capita general revenue grants were made to the States at the Commonwealth's discretion.

From one aspect, the Agreement was not to the Commonwealth's political advantage in the short period. Bruce asserted with some justification that 'No Commonwealth Government would make an arrangement with the States involving it in heavier payments than it was under an obligation to make unless it sincerely believed that some fundamental principle impelled it to that course'. ${ }^{26}$ In his elaboration of the Commonwealth's motives, the Prime Minister stated reasons in addition to those already considered: ' . . the necessity of the reduction of Australia's debt, the provision of sinking funds for all its past indebtedness, the assurance of sinking funds for future indebtedness, and the co-ordination and mobilization of Australia's credit'. In London, lenders had insisted, through the underwriting firm of Nivison and Co., that the New South Wales government should provide adequate sinking funds. ${ }^{27}$ The enforceable Sinking Fund provisions in the Agreement were useful in themselves but they were also part of the strategy to maintain goodwill in London. The differences between the States' own pre-1927 sinking fund provisions, especially New South Wales's as compared with the others' accumulated funds, are shown in the composition of the $\$ 19.85 \mathrm{~m}$. taken over from the States by the Commonwealth under the Financial Agreement (table 7.3).

Table 7.3

Accumulated sinking funds of the State governments, 1922 and 1927 (£m.)

\begin{tabular}{rrrrrrrrr}
\hline & & N.S.W. & Vic. & Qld. & S.A. & W.A. & Tas. & Total \\
\hline \multirow{2}{*}{ 30 June } & 1922 & 0.498 & 2.754 & 0.458 & 1.263 & 8.370 & 1.118 & 14.463 \\
& 1927 & 0.565 & 5.592 & 1.721 & 1.744 & 8.909 & 1.320 & 19.851
\end{tabular}

Annual sinking fund commitments under Financial Agreement

$\begin{array}{llllllll}1927 & 0.585 & 0.342 & 0.255 & 0.212 & 0.153 & 0.056 & 1.603\end{array}$

Source: C.P.P., 1926-28, vol. III, The Budget 1928-29, p. 119.

In summary, the expediencies, advantages and incentives to have an Agreement were: the success of the voluntary Loan Council, which was established in response to strong political pressure to co-ordinate borrowing to reduce costs of government, made a statutory Loan Council a practical proposition; the strong political pressure to change the principles of one government raising taxation to make grants to another without conditions or control made an adjustment based upon a transfer of State 
debts the only way out once there was deadlock over proposals to replace the $\$ 1.25$ per capita payment by a readjustment of taxation; there was the need for a formal statutory arrangement, binding upon all governments, whereby their respective contributions to the National Debt Sinking Fund for States' debt service would be assured; the Commonwealth needed to be assured that, on its assumption of the huge responsibility for the States' debt, it had a formally established Council in which to consult and to negotiate and which could co-ordinate, if and when necessary, with the central bank in arranging the foreign exchange required to pay the considerable debt service abroad; there was the commonly held hope that a statutory Loan Council and Sinking Fund arrangements would help to maintain the flow of London lending; the experience of the voluntary Council had revealed that disunity was possible on that fragile basis and a binding arrangement gave an assurance of co-operation; the Commonwealth's generosity in payments under the Agreement was the States' financial gain of a windfall character at a time of publicised State deficits; there was the distinct political advantage to the States of transferring loan and debt decisions to the Loan Council and to the Commonwealth as its agent, with the States at the same time retaining control of works expenditure; and the large, $£ 1.25$ per capita payments to the States were removed from the realm of political prejudice and decision in the Commonwealth Parliament and given the permanence of a constitutional guarantee.

The case for the Agreement had a number of attractive features for the States as well as for the Commonwealth and together they must have been persuasive in the setting of the late 1920s. It is not necessary to entertain the suggestion that the Commonwealth applied pressure upon the States; that ended with the discussion of adjustments of taxation in 1926. It is more realistic to accept that there was, by 1927 , an inbuilt momentum in the nation, dating back to the nineteenth century, that the fiscal problems of the federation should be adjusted and settled by arrangements to meet part of the States' debt interest and capital repayments from the Commonwealth's revenue. 


\section{8 \\ The Cessation of Overseas Lending in 1929}

In January 1929, two months before the Financial Agreement was validated by the Commonwealth Parliament, the Commonwealth raised a cash loan of $18 \mathrm{~m}$. for works in London. Thenceforth long-term London and New York lending to the Loan Council virtually ceased until after World War II. ${ }^{1}$ The statutory Council was born to endure crisis immediately.

The end of the heavy flow of net lending occurred despite the transformation of the voluntary Council into a statutory arrangement and despite the well-established co-ordination of Australian governmental borrowing in London. Why New York lending ended is relatively easily explained but the cessation in London requires some understanding of the co-ordinating mechanism in London, of the British monetary authorities' control of lending and of their view of the Australian situation in 1929 and 1930. London provides the main interest because New York only became a significant source of loans from 1925-26 when the Commonwealth borrowed there on behalf of itself and four States. Although 40 per cent of governments' net overseas borrowing from 1925-26 to 1927-28 inclusive was from New York, it was only 8 per cent of the total debt incurred abroad. ${ }^{2}$ London was the traditional source of funds and the centre of Australian hopes for loans in the downturn to the depression in 1929 and 1930.

The importance of the cessation of lending is well known: it was a major reason for the initial severity of Australia's downturn to economic depression in the early 1930s. But it was not the primary cause and the

1 R.C.M.B., para. 114. The difference between the $f 8 \mathrm{~m}$. cash loan and the $12.1 \mathrm{~m}$. net increase in debt in 1928-29 is made up of redemptions, mainly by use of the Sinking Fund. But there were short-term loans for six months on the security of Commonwealth debentures and treasury bills between September 1929 and April 1931; the British public and the Australian trading banks took $\$ 11.5 \mathrm{~m}$. of these. They were not renewed but were paid off and the securities held by the central bank. The Westminster Bank held another £5m. of treasury bills for over three years after April 1931 to cover an overdraft. This was not a long-term loan in the traditional sense. R.C.M.B., paras. 127-32.

2 C.F.B., no. 24, tables 58-60; before 1925-26 there had been two small State loans, one of $£ 100,000$ by Tasmania and one of $£ 4.54 \mathrm{~m}$. in $1921-22$ by Queensland. 
analysis of the cessation of overseas borrowing would not be balanced without a brief review of the fundamental disequilibrium in the Australian economy as early as the mid-1920s. Significant lessons for the future emerge from this analysis of the turning point in overseas lending.

\section{Fundamental disequilibrium in the 1920 s}

Bruce, like Deakin, Fisher and Hughes before him, regarded peopling the Australian continent as his first objective. 'Australia's greatest problem is that of population, and our future will be seriously endangered unless we bring about a rapid increase in the number of our people.'3 By 1929 there had been two decades of rapid population increase interrupted by five years of war and post-war adjustment. Bruce and the State governments had, in no uncertain manner, experienced and accepted the limitations of the Australian capital market. They saw that in order to allow the private sector to grow and do its part in providing work and an attractive standard of living for immigrants, the governments would have to keep out of the Australian capital market as a competitor for funds. The only course left to governments was to borrow abroad: they did and two-thirds of capital inflow in the 1920s was on government account (table 8.1 ) to pay the interest on governments' overseas debt. ${ }^{4}$ The governments, to that extent, were not a drain on foreign exchange reserves; export receipts and private capital inflow then covered the net payment of other items in the invisible account and payments for imported capital equipment, consumption goods, materials and parts that grew with the economy and were required to maintain employment and the standard of living. In mid-1927, Bruce confessed that the alternative course, self-sufficiency in capital and, by implication, foreign exchange, was politically and economically impracticable. Perhaps he personally appreciated that alternatives could be thrust upon the country by overseas events but even he could not have conceived the severity of what might occur. Had he done so, he might have taken steps to prepare for it, principally by cutting the immigration program and by further protecting Australian producers to bring about much more import substitution. In fact, he was to make a determined and politically costly attempt to change the arbitration system to keep wage costs down to improve the competitive position of Australian manufacturers.

Professor Shann had been correct in drawing an analogy between the 1880 s and the 1920s. As Professor N. G. Butlin later showed, in the $1880 \mathrm{~s}$ fundamental disequilibrium had set in well before export income and overseas lending to Australia fell in the early 1890s. 'In essence an eventual depression was inherent in the manner and conditions of growth within

3 'The Financial and Economic Position of Australia', The Joseph Fisher Leciure in Commerce, University of Adelaide (1927), 12, 14.

4 Ibid., 15 inter alia; Shann and Copland (eds.), The Crisis, 14. 
Australia.' ${ }^{5}$ The problem was that the growth up to the late 1880 s 'led to an unstable situation which could not long survive while the economy remained oriented along these lines'. This orientation was concentration of investment in the pastoral, housing and communications sectors to improve productive capacity and living conditions; the investment was financed partly by considerable overseas capital inflow but it was not accompanied by an adequate increase in export earnings to pay for the growth in imports which accompanied the rising population and the improvement in income per head. Also stagnation or a falling rate of economic growth was beginning to diminish the profitability of investment by the late 1880 s and was a signal that overseas capital inflow would possibly be discouraged within a few years.

Serious fundamental disequilibrium began to appear again in the Australian economy in 1925-26. The gross national product at constant prices had then ceased to grow. Unlike the decades up to 1890 , the resumption of capital inflow before World War I and in the 1920s was largely for government activities. There was an increase in land settlement for migrants and ex-servicemen, but the large proportion of the public investment was directed to make up deficiencies, some long-standing, in public utilities and services in towns and cities. Electricity, gas, sewerage, electric railways and roads for the novel motor vehicle were examples of the impact of innovations. There was, to a considerable extent, a delayed improvement in amenities, particularly in urban areas. ${ }^{6}$ These developments required imports of capital goods and the rising aggregate personal income which occurred led also to an increasing demand for imported consumption goods.

The major characteristic of the disequilibrium which developed was that, as the economy grew under the influence of immigration, innovations and the protective tariff, the increase in imports of goods and payments for overseas services was not matched by an adequate growth of export receipts and it became essential to have continuous, growing overseas borrowing. This gave rise to a fundamental balance of payments problem. There was some import substitution but the private sector did not supply an adequate volume of goods and services usually imported. In other words, the tariff and the movements of relative costs and prices did not encourage expenditure on home produced goods and services in place of imports to an adequate degree.

Direct investment of foreign, especially British firms, in the early $1920 \mathrm{~s}$ gave an initial stimulus to the necessary new technology. Employment

5 N. G. Butlin, Investment in Australian Economic Development 1861-1900 (Cambridge, 1964), chap. VI, particularly pp. 414 et seq.; and chap. 6, 'Some Perspectives of Australian Economic Development 1890-1965' in C. Forster (ed.), Australian Economic Development in the Twentieth Century (London, 1970).

6 See Butlin's account of this in Forster (ed.), Australian Development. 
and investment, for a time, rose very quickly until skill limitations and the emergence of excess capacity in many areas emerged to plague most of these new enterprises until the second world war. ${ }^{7}$

Of the short-term influences, two were notable. The terms of trade changed very little between 1925-26 and 1928-29 inclusive but the import price index fell by about 10 per cent over this period and the Australian nominal weekly wage rose by 7 per cent. ${ }^{8}$ These movements lessened the protective effect of the tariff and therefore contributed to the excess capacity and balance of payments disequilibrium. From 1925-26, the balance of payments on current account was persistently and heavily in deficit (table 8.1).

The voluntary Loan Council was heavily involved in these difficulties and early in its life it made a fundamental decision on Australian governments' overseas borrowing that helped to fill two-thirds of the gap in the balance of payments on current account throughout the 1920s. Table 8.1 shows the annual borrowing operations of Australian governments at home and overseas between 1918-19 and 1929-30. The amounts and the dates of the bigger war loan conversions in Australia are as they appeared to the Commonwealth Treasurer in his 1923 Budget.

There was a definite pattern to these operations. Australian governments' net overseas borrowing was high in one year and low in the next and the high level of overseas borrowing occurred in those years when there was a major domestic war loan conversion. It is possible that the difficulties experienced in the Australian capital market with war loan conversions in 1923 and alternate years made the overseas borrowing in those same years convenient. Had it not suited the member governments of the Loan Council, the pattern could have been changed; instead it seems to have been encouraged. Even so, it cannot be said that the war loan conversions in Australia definitely caused the alternating pattern of overseas loans because the overseas borrowing had achieved that characteristic prior to the start of the war loan conversions. The element of coincidence was present but probably not the whole explanation.

The voluntary Loan Council discussed the size and the purposes of overseas borrowing early in its life. At its July 1924 meeting, all but two members committed their governments to borrow only that amount required in 1924-25 to meet 'payments'; the exceptions were Victoria which agreed only to raise up to $£ 2.175 \mathrm{~m}$. more than required for 'payments' overseas, and South Australia which agreed to raise no more than $£ 0.6 \mathrm{~m}$. for other purposes. Another explicit objective of the Council was

7 Ibid.

8 Roland Wilson, Capital Imports and the Terms of Trade (Melbourne, 1931), 89, 98. S. Bambrick, 'Indexes of Average Prices of Australian Imports from the United Kingdom 1919-20 to 1927-28', Australian Economic Papers, vol. 6, no. 9, December 1967, 253. 


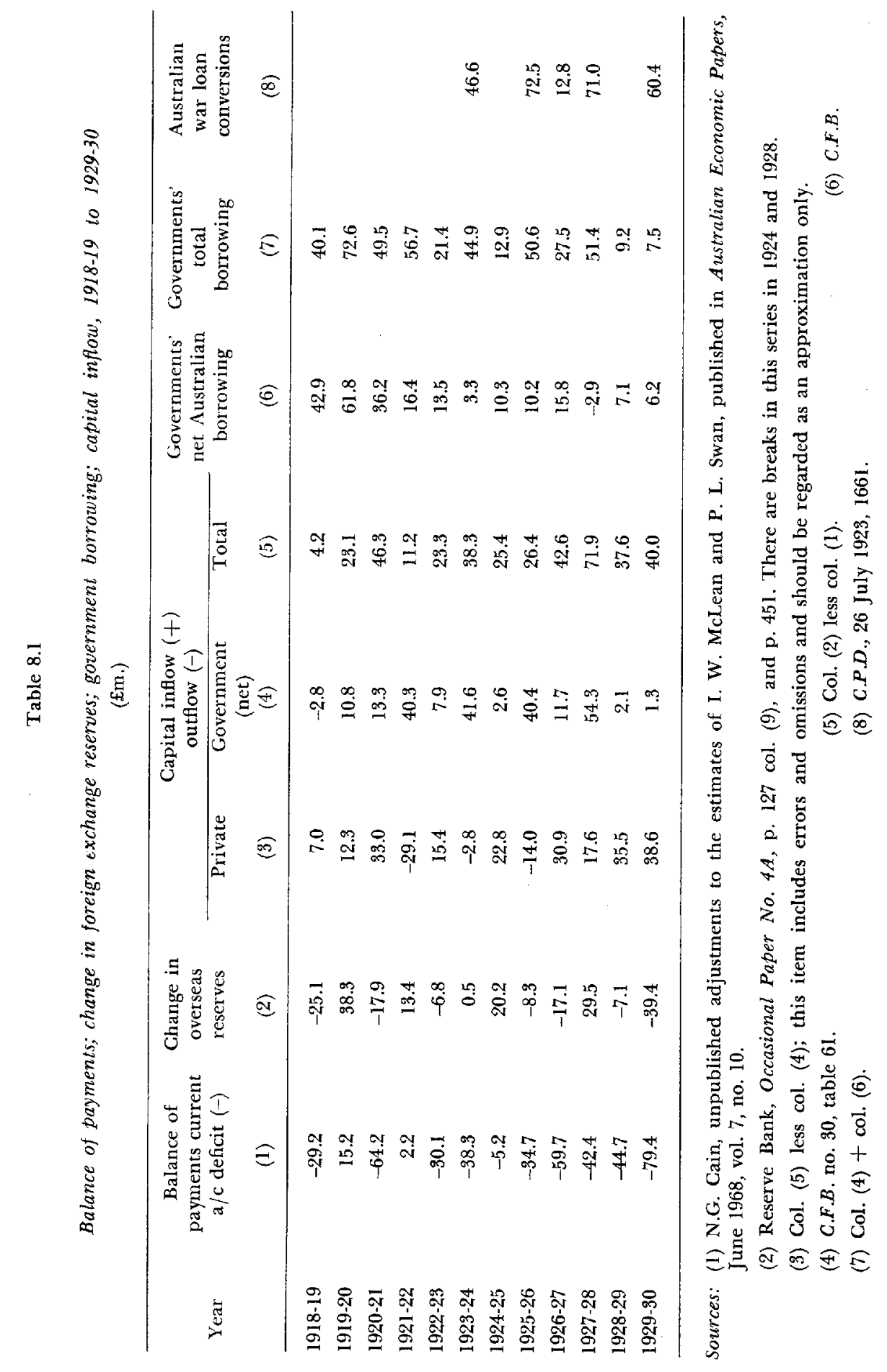


to avoid approaching the banks for foreign exchange. The 'payments' were interest on overseas debt and redemptions of unconverted debts and, it has been noted, the net increase in overseas debt almost exactly equalled interest payments in the 1920s. ${ }^{9}$ As the net loan expenditure of the Commonwealth and the States was also almost exactly equal to their net increase in Australian plus overseas debt, the size of the Australian governments' works programs seemed to be in large part, but not totally, determined by the amount of overseas debt interest. In effect, the difficulty of raising loans in Australia in the 1920 s meant that dependence upon overseas sources for about 55 per cent of loan funds became mechanical with all the repercussions for the economy if a mechanical fault occurred.

At the end of August 1924 the Council intimated that governments were unwilling, and it can be taken to mean unable, to obtain adequate sterling exchange from the banks to finance their overseas debt interest. ${ }^{10}$ In a most real sense, this was the financial mechanism of disequilibrium in the Australian financial system. Had Australia not needed such a high level of imports or had it earned enough from exports to have idle London funds in the hands of the banks, they in turn would have been able to let the governments have their requirements of foreign exchange to pay debt interest. Theoretically the Loan Council and the Premiers' Conferences, with this as an objective, could have arranged that taxation in the 1920s was adequate to leave a surplus, that is provide funds, for the purchase of the surplus sterling from the Australian banks to pay their overseas interest. The overseas debt service would not have risen as rapidly as it did in the $1920 \mathrm{~s}$ - from $£ 15.4 \mathrm{~m}$. to $£ 27.6 \mathrm{~m}$. annually-and the depressing effect of the higher taxation upon employment and imports would have been offset by the expansion of advances by the banks, which would have had greater liquidity. Instead of maintaining taxation rates or even raising them, one great debate of the 1920s was how to reduce them, with the Commonwealth accomplishing that purpose progressively throughout the decade. One other major obstacle to this theoretical course was that, had taxation or revenue been raised, as many hoped it would be from 'productive works', it could have been difficult to make it serve the dual purpose of paying for overseas interest and being regarded as finance for the works program as well. The traditional belief that finance for works should be by loan money was a barrier to the large-scale use of revenue to pay for works.

The Loan Council's practical difficulty in the 1920s, therefore, was that governments could not earn exchange like ordinary exporters and to buy it would have imposed great strains upon the exchange rate and, ultimately, the level of imports and therefore employment. In fact, what

9 A.I.B.R. (1924), 629; for this and the ensuing relationships see C.F.B. statistics.

10 A.I.B.R. (1924), 629. 
was to happen in 1930-31 would have occurred earlier but on a smaller scale. Governments borrowed while they could and the situation was worsened inexorably under the snowballing effect of each additional loan adding to the annual interest burden.

\section{The fall in foreign loans}

It has been noted that between 1921-22 and 1928-29, Australian governments' net borrowing overseas had the remarkable symmetry of being very high one year and negligibly small the next. It averaged over $£ 44 \mathrm{~m}$. annually in 1921-22, 1923-24, 1925-26 and 1927-28; and only $£ 7.4 \mathrm{~m}$. annually in the alternate years. It was consistent with this sequence that net borrowing in 1928-29 was only $£ 2 \cdot 1 \mathrm{~m}$. It was also consistent that governments expected to raise about $£ 45 \mathrm{~m}$. in $1929-30$, but they were disappointed because the symmetry, or the pattern, had by then ended. This observation is about the trend or symmetry of, and not about the right to, loans which, of course, Australian governments did not have. The pattern goes a long way towards explaining why it was not until August 1929 that the pinch was felt and the works program for 1929-30 was then cut by one-fifth.11

The mechanism of London borrowing partly explains the alternations. The specific circumstances that prompted loans were: governments either had an overdraft with their London banks which they wished to pay off by raising a long-term loan; or they were short of Australian loan money for works purposes in Australia and finance was sought in London. The States legislated a long period ahead of their need for cash in order to be free to raise a loan when they needed it without revealing their intention to other States in parliamentary debate. Overdrafts in London gave them flexibility in the timing of loans and, as a rule, the overdraft rate was lower than the bond rate and the governments thus made a saving. ${ }^{12}$

The overdraft limits in the 1920s were quite considerable, in New South Wales's case between $£ 6 \mathrm{~m}$. and $£ 7 \mathrm{~m}$, and overdrafts would continue for as long as seven or eight months. This time lag is one reason for London borrowing being high in one year and low in the next, a characteristic also of the later decades of the nineteenth century; the full implications remain obscure. ${ }^{13}$ New South Wales, Victoria and Western Australia used the London and Westminster Bank and in 1928-29 and in 1929-30 their combined interest payable in London totalled $£ 24 \mathrm{~m}$. This, together with any loans for redemption which fell due and could not be converted,

11 A.I.B.R. (1929), 644.

12 Gilbert, 'Loan Council 1923-29', chap. V.

13 Ibid., and Butlin, Australian Economic Development, 388. For example, one effect was to make private capital inflow fall drastically when governments' foreign borrowing rose and vice versa. Both private and government borrowing abroad would show smaller fluctuations if the short-term overdrafts in London banks were taken to be long-term government borrowing in the years when long-term government loans appeared to be low. Table 8.1 provides estimates of the capital inflow in the $1920 \mathrm{~s}$. 
measured the governmental liability to that London bank, an institution completely beyond their control. The Commonwealth, South Australia and Tasmania used the Commonwealth (central) Bank and their combined interest due in London in 1928-29 and $1929-30$ totalled $£ 20 \mathrm{~m}$. ${ }^{14}$ They were in what might be expected to have been more sympathetic hands, their own central bank. Queensland used the Bank of England and its interest due totalled nearly $£ 6 \mathrm{~m}$. over the two years, but its traditional relationship with the Bank required it to pay interest as it fell due. Even so, any difficulty which Queensland experienced in obtaining foreign exchange would involve the British central bank directly. The measure of the impact of the cessation of lending to governments in 1929-30 was therefore interest due of $£ 50 \mathrm{~m}$.

Australia's foreign exchange and gold reserves, including short-term investments, were about $£ 100 \mathrm{~m}$. throughout 1928.29 and $\$ 97.7 \mathrm{~m}$. in the June quarter, but from the September quarter of 1929, or the first quarter of 1929-30, these reserves fell sharply as they were drawn upon to meet the gap left by the fall in export prices and income, and the cessation of lending. By the end of the December quarter of 1929, the reserves had fallen to $£ 60 \mathrm{~m}$., a pace of change which heralded a serious crisis. Excepting the banks and the federal cabinet, the seriousness of the situation was not widely understood at the time; certainly, the aggregate amount of the reserves was not known to the authorities, or to the banks which held them, and no figures were published. ${ }^{15}$ Furthermore, the fall in export prices in 1929-30 was not an unusual occurrence, the Australian banks being ready and indeed accustomed to meet fluctuations of that kind. Furthermore, it would seem that private capital inflow in 1929-30 rose far more than the pattern of previous years would suggest and that helped to cushion the effect of the cessation of lending to the Loan Council and the fall in export income. ${ }^{16}$ The awakening to the situation was therefore governed a good deal by the slowly dawning realisation that overseas borrowing by the Loan Council would not recommence.

There were two phases in the period between early 1929 and late 1930, by when it was accepted that there would be no more new borrowing abroad by governments. In the first period which ended about March 1930 , the Council chose not to compete with other dominion borrowers in

14 C.F.B., no. 22, table 62; C. B. Schedvin, Australia and the Great Depression (Sydney, $1970), 131$.

15 Giblin, Central Bank, 67 inter alia; and S. J. Butlin, A. R. Hall and R. C. White, A ustralian Banking and Monetary Statistics $1817-1945$ published by Reserve Bank as Occasional Paper No. 4A, 451.

16 Table 8.1; Butlin, Australian Domestic Product, table 26; and helpful suggestions by Dr A. R. Hall and Dr N. Cain of the Australian National University. Table 8.1 shows that in 1929-30, net government borrowing overseas was $£ 1.3 \mathrm{~m}$. and net private capital inflow was about $139 \mathrm{~m}$.; this reversed the trends, as the symmetry of the 1920 s indicated that in that year private inflow would normally have been low or negative and the government borrowing as high as the private inflow. 
London by offering a higher rate of interest than it had paid and they were paying. In the second phase, the evidence indicates that when the Council really wanted to raise a London loan, presumably at any price, the British authorities informally advised the Commonwealth, as agent of the Council, that loans were not available until Australia fulfilled what were, in effect, impossible conditions in the short term.

\section{Restraint by the Loan Council-1929 to early 1930}

Australian governments were not cut off altogether from access to the London market when the main stream of new cash loans ended in 1929. There were conversions of a $£ 12.4 \mathrm{~m}$. Queensland loan at 5.18 per cent in May 1929; and a Queensland conversion loan of $£ 3.8 \mathrm{~m}$. was floated in April 1930, at an effective rate of $6 \cdot 1$ per cent. The rate in April was nearly one percentage point higher than that demanded by lenders a year earlier: gradually, Australia had come to be regarded as a greater risk, since rates to comparable countries like New Zealand and South Africa had remained unchanged at just over 5 per cent. The higher rate was not acceptable to Australian governments and E. G. Theodore, the Chairman of the Loan Council and Commonwealth Treasurer, reported that "The London market had not been, and is not now, accessible to us . . at the interest rates which any decent or reputable nation would agree to pay'.17 The Commonwealth (central) Bank said the same thing in its December half-yearly report in 1929. 'During the last half of 1929 no Government loans have been raised overseas. The usual channels of overseas supply of loan moneys have been unavailable to Australia, at any rate on terms acceptable to Australian borrowers.'

The Loan Council believed that to offer more than the customary rate of interest (up to 5.5 per cent) would worsen the loss of confidence which had occurred, and thus make certain an expected or feared diminution of subscriptions to any new loans which might be floated. There were persistent hopes of new London lending in the Loan Council and by ministers of all governments until the December quarter of $1930 .{ }^{18}$ Restraint was exercised only in the London market; in New York conditions were entirely different and can be explained briefly. American lending began to slow down in 1928 and Australian borrowing received a check for several reasons. As a newcomer to the New York capital market, Australia did not have the traditional ties there that it had in London. It is also possible that New York was influenced by the views of London funancial intermediaries. Australian governments were diverted to New York in 1925 and subsequent years by the London broking firm of Nivison and Co., which had co-ordinated all the Australian governments' borrowing in

17 A.I.B.R. (1930), 261.

18 See below, later chapters, and N.S.W.P.D., 10 September 1929, 2250 (Stevens's Budget Speech). 
London. ${ }^{19}$ In addition, there were powerful American conditions which brought Australian borrowing in New York to an end in 1929. American overseas lending began to fall when the internal American investment boom developed towards the end of 1928. As the prices of American equities rose rapidly, American investors turned their attention to the opportunities for capital gains; 'they ceased to be interested in fixedinterest-bearing securities, either American or foreign'. ${ }^{20}$ The annual rate of United States capital exports in the second half of 1929 was down to one-quarter of the annual rate in 1928 and remained very low after the New York stock exchange collapsed in October 1929. A recovery in foreign lending, mainly direct company investment, in the first half of 1930 was brief, as the United States position deteriorated further when creditor countries, especially France, did not renew short-term credits made in the 1920s. ${ }^{21}$ 'In Great Britain no such decline in the volume of new issues occurred until 1931.'22

Statistical estimates, imperfect though they are, indicate that the United Kingdom's new foreign issues excluding conversions in 1929 and in 1930 were nearly $£ 100 \mathrm{~m}$. a year-not significantly lower than the annual average of the preceding four years. The ability of the United Kingdom to lend for two more years after loans to Australian governments ceased was matched by the Netherlands as table 8.2 shows. No matter which of the two sets of estimates is used for the United Kingdom, new issues overseas (by both countries) were higher in 1930 than in 1929. The United Kingdom's current surplus was uncomfortably low, at $£ 27 \mathrm{~m}$. in 1930 , but as it

Table 8.2

British and Dutch new issues, foreign lending, 1925-34

\begin{tabular}{lccccccc}
\hline & \multicolumn{7}{c}{ Year } \\
\cline { 2 - 7 } Country & $\begin{array}{c}1925-28 \\
\text { (yearly av.) }\end{array}$ & 1929 & 1930 & 1931 & 1932 & 1933 & 1934 \\
\hline $\begin{array}{c}\text { United Kingdom (Im.) } \\
\text { Midland Bank's est. }\end{array}$ & 120 & 94 & 109 & 46 & 29 & 38 & 43 \\
$\begin{array}{c}\text { R.I.I.A.'s estimate* } \\
\text { Netherlands (guilders m.) }\end{array}$ & 93 & 96 & 98 & 41 & 37 & 83 & 63 \\
\hline
\end{tabular}

* Based on the work of Sir Robert Kindersley and the estimates of the authors of the book for R.I.I.A.

$\dagger 1927-28$ average.

Source: R.I.I.A., International Investment, 282-3 and 338.

19 Gilbert, 'London Financial Intermediaries'.

20 R.I.I.A., The Problem of International Investment (London, 1937), 284.

21 Ibid., and United Nations, International Capital Movements During the Inter-war Period (New York, 1949), 36-7.

22 R.I.I.A., International Investment, 284. 
was supplemented by sales of $£ 40 \mathrm{~m}$. of older investments, the new issues went on unabated. ${ }^{23}$

The deterioration in Australia's standing as a borrower relative to other like borrowers can be seen clearly from London market quotations of comparable securities (table 8.3). With all the knowledge of hindsight it can now be said that the Loan Council erred in not recognising that Australia's goodwill was being irretrievably lost as time passed: loans in the name of the Commonwealth or the States at the going rate in 1929

Table 8.3

London market quotations of comparable dominion securities, 1929-32

\begin{tabular}{|c|c|c|c|c|c|c|}
\hline \multirow{3}{*}{$\begin{array}{l}\text { Date } \\
\text { 15. } 1.29\end{array}$} & \multicolumn{3}{|c|}{ Prices quoted on comparable securities } & \multirow{2}{*}{\multicolumn{2}{|c|}{$\begin{array}{l}\text { Yield on } \\
\text { Australian } \\
\text { securities } \\
\text { purchased in }\end{array}$}} & \multirow{3}{*}{$\frac{\%}{5.47}$} \\
\hline & \multirow{2}{*}{$\begin{array}{c}\begin{array}{c}\text { Australia } \\
5 \% \\
1945-75\end{array} \\
98.25\end{array}$} & \multirow{2}{*}{$\begin{array}{c}\text { New Zealand } \\
5 \% \\
1946 \\
102.75\end{array}$} & \multirow{2}{*}{$\begin{array}{c}\text { South Africa } \\
5 \% \\
1945-75 \\
103.50\end{array}$} & & & \\
\hline & & & & Nov. & 1929 & \\
\hline 15. 4.29 & 97.00 & 101.25 & 101.25 & Dec. & 1929 & 5.55 \\
\hline 15. 6.29 & 96.25 & 102.25 & 101.25 & Jan. & 1930 & 5.85 \\
\hline 14. 9.29 & 93.00 & 98.50 & 98.75 & March & 1930 & 6.00 \\
\hline 14.12 .29 & 91.25 & 99.25 & 99,25 & Jan. & 1931 & 6.86 \\
\hline 15. 1.30 & 89.75 & 100.50 & 99.75 & Feb. & 1931 & 7.27 \\
\hline 15. 3.30 & 89.25 & 100.25 & 98.75 & July & 1931 & 6.54 \\
\hline 10. 6.30 & 86.25 & 100.75 & 99.25 & Sept. & 1931 & 7.11 \\
\hline & & & & June & 1932 & 5.51 \\
\hline
\end{tabular}

Source: Commonwealth Treasury and Shann and Copland (eds.), The Crisis, 157-8.

would have added invaluable amounts to London funds, especially in the second half of that year.

\section{No more long-term loans in London}

It is possible to assess many of the reasons for the loss of goodwill in London, a process which had no room for sentiment or deeper ties. Economic criteria overrode the memories of loyalties which only a decade before had led no less than 5 per cent of Australia's population to volunteer to fight beside Britain with the allies in the first world war and in which 1 per cent of the Australian population was killed.

Some of the economic influences have been meritioned in preceding chapters and can now be brought together with others. By 1929, a delicate stage had been reached in Australian borrowing experience. In March the Financial Agreement had been validated and the Loan Council formally established to authorise borrowing by the Commonwealth on behalf of

23 Ibid., 139-40, and A. E. Kahn, Great Britain in the World Economy (New York, 1946), 161. The United Kingdom's current account surplus of $£ 27 \mathrm{~m}$. in 1930 may be compared with an average of nearly $£ 70 \mathrm{~m}$. in the preceding five years. 
the States. One purpose of this replacement of the old voluntary Loan Council by a statutory Council had been to create goodwill in the London capital market. It was reasonable for the Council to expect that the Agreement would take time to have the desired effect. In the event, other influences were to be far more significant.

The traditional brokers to Australian government flotations, Nivison and Co., were probably neutral in the situation. The importance of Nivison and Co. was that it had exercised control of underwriting loans to Australian governments since the nineteenth century. It decided the timing, the underwriting, the priorities as between governments and it voiced persuasive views on the amount and the terms of loans. It was accustomed to having a variety of State issues to pass on to investors and this continued after the voluntary Loan Council began operating. When the Financial Agreement was negotiated in 1927, the financial advisers expressed the wish to have a clause inserted that permitted a State to continue issuing its own securities. ${ }^{24}$ Clause $4(2)$ provided for this, but with the limitation that a State could only issue its own stock if it had the unanimous approval of the Loan Council. Thus the statutory Council, using the Commonwealth as its agent, replaced the old, informal arrangements between the firm and the States. There could be time absorbing delays in obtaining Council approval of State issues, and the firm could be overloaded with the one Commonwealth stock. None the less, it could hardly have influenced the firm to create the situation which developed: persistent selling of Australian stocks and the relative deterioration of their prices. Nivisons could have had a variety of Australian government securities to issue had it wanted them.

Other features of Australian experience which, at first sight, might have justified the uncertainty about its prospects were in fact not as serious as they seemed. A high proportion of Australia's public debt-52 per cent in 1930-was held abroad. This might have been regarded as a source of potential risk: a risk of default if government revenues fell and interest could not be paid even if foreign exchange was available. But both South Africa (63 per cent) and New Zealand ( 57 per cent) were as heavily committed to overseas lenders and their ability to borrow at the usual interest rates in 1930 was unimpaired. ${ }^{25}$ Australia's external debt per capita was also high, at $£ 122$, also creating a risk of default in depression if income per head, and therefore taxable capacity, fell (assuming the availability of foreign exchange). Again, the Australian figure was exceeded by Canada's (£127) and New Zealand's (£128). ${ }^{26}$ Neither was the concern about Australia characteristic of a generally more cautious attitude by British investors

24 N.S.W.P.D., 22 May 1928, 839 (B. S. B. Stevens, Assistant Colonial Treasurer); Gilbert, 'London Financial Intermediaries'.

25 R.I.I.A., International Invesiment, 225.

26 Ibid., 223. 
in the late 1920 s since, between 1926 and 1928 , $355 \mathrm{~m}$. was lent to Brazil and $120 \mathrm{~m}$. to the Argentine where, admittedly, the United Kingdom already had large investments. ${ }^{27}$ Nor, at that time, had Australia given any grounds whatever on which British fear of a breach of contractcertainly fatal to further loans to a country-could have been based. The earliest serious proposal for repudiation was by a committee of the political and industrial wings of the New South Wales Labor movement in August 1930. Lang's proposals came even later, in February 1931.28 In other words, the question of repudiation was raised seriously eighteen months after the slump in confidence in London. Minor, London inspired, rumours in early 1990 were effectively answered by the Prime Minister, Scullin, to the effect that Australia would meet its obligations. ${ }^{29}$

Against these advantageous or relatively neutral influences there were several basic causes of uneasiness about Australia. Fundamentally, the balance of payments was known to be in persistent large deficit on current account. Officially, policy had been rationalised in but a fragmentary manner; the Australian governments borrowed to develop the country for settlers who would produce exports and enable debt service to be paid from the proceeds. The success of the policy depended upon quick rural development and high but steady exported commodity prices; ${ }^{30}$ in fact, the policy failed and there developed instead fundamental disequilibrium in the balance of payments. Australians had been their own worst enemies in publicising so heavily throughout the 1920 s their criticism of 'unproductive' development, meaning works from which there was no adequate return of interest or foreign exchange. The Australian and the British belief that Australian governments had increased their expenditure too much is supported by statistical evidence. The share of all Australian governments, including local and semi-governmental authorities, in total gross domestic capital formation rose from about 44 per cent to 53 per cent over the 1920 s. But it was due entirely to a rise in local and semi-governmental authorities, which doubled their share at the expense of the share of private investment. ${ }^{31}$

The high proportion of Australian governments' borrowing in the total of all kinds of London new issues for foreigners led to serious public criticism in 1926 by Cooke and Davenport, by J. M. Keynes and others. To quell this, Bruce, the Prime Minister, at the Imperial Conference in 1926, invited the British authorities to send an investigating mission to Australia. When the British Economic Mission arrived in 1928, it knew

27 Ibid., 147.

28 Argus, 22, 27, and 28 August 1930, 7-8; C.P.P., 1929-81, vol. II, 'Conference of Commonwealth and State Ministers, February 1931', 41.

29 Shann and Copland (eds.), The Crisis, 10-12.

30 R.I.I.A., Survey of British Commonwealth Affairs, vol. II (London, 1940), by W. K. Hancock, 178.

31 Butlin, Atustralian Domestic Product, 17. 
that the governments' $1927-28$ net borrowing program in London was very high-in fact, $£ 36 \mathrm{~m}$. This was one-quarter of London new issues abroad and over three-fifths of all new issues to overseas governments. ${ }^{32}$ It made the views of Cooke and Davenport and others about the amounts borrowed all too realistic. Although these matters were given serious consideration by some Australian economists, they were an isolated minority (chap. 7). For example, Dyason's calculations were barely recognised in passing by the Mission, which paid lip service to his work, ${ }^{33}$ and then devoted itself to condemning government development policies and to making gloomy predictions more in accord with Shann's views. Its report, in January 1929, is courteously worded but almost the only development schemes which it praised were the Development and Migration Commission and the CSIRO. Otherwise,

it cannot be read as other than a very severe indictment of our attempts to develop Australia by protection, the Navigation Act, subsidies and bounties, by the expenditure of borrowed money, and by schemes of closer settlement ... The Report undoubtedly preached some return to the policy of laissez-faire on the part of the Australian Governments. ${ }^{34}$

After quoting examples of projects which were uneconomic, the Report recommended a curtailment of borrowing and deflation. ${ }^{35}$ The Mission was aware that the Financial Agreement would soon be validated but it none the less concluded that 'our knowledge of the London money market enables us to say with confidence that the sooner that final step is taken the better it will be for Australian credit'. There was no promise of more lending in these words; rather they implied imminent difficulties.

The London press reaction to the Mission's Report was that it was favourable to Australia's financial position, but against a continuance of unrestricted borrowing and uneconomic development. ${ }^{36}$ The discretion of the four members of the Mission may be measured in part by the fact that nowhere in the United Kingdom subsequently did they say anything in their public statements that was derogatory to Australia; rather, they constantly expressed faith in the country's future. ${ }^{37}$ None the less, the value of Australian stocks on the London market fell throughout 1929 relative to New Zealand's and South Africa's. The Mission was an example of Australia literally inviting trouble.

32 R.I.I.A., International Investment, 157; C.F.B., no. 24, table 60.

33 Report, C.P.P., 1929, vol. II, paras. 30 and 45.

34 L. G. Melville, 'Report of the British Economic Mission', Australian Quarterly, no. 1, March 1929, 100-1.

35 Report of the British Economic Mission (Canberra, 1929), paras. 26, 29, 30. The Report is also in C.P.P., 1929, vol. II.

36 The Times, 10 January 1929, 11; 11 January 1929, 11; 28 March 1929, 9.

37 The Times, 8 March 1929, 18 (Hirst); 12 April 1929, 9 (Clarke); 7 November 1929 (Duckham and Clarke). All were knighted. 
The Report of the Mission, following the criticism of Cooke and Davenport and others, could only have alerted the United Kingdom authorities to Australia's problems. The Mission had expressed a view that was to be echoed in no uncertain manner by the Bank of England and its representative, Sir Otto Niemeyer, over a year later.

The Loan Council did not turn to the British monetary authorities for assistance before 1930. Up to the end of 1929 the overseas reserves were supplemented by an overdraft with the London and Westminster Bank $(£ 8.63 \mathrm{~m}$.) and by the issue of $£ 10 \mathrm{~m}$. of treasury bills in London. In addition, there was an overdraft of $£ 4.5 \mathrm{~m}$. with the Commonwealth (central) Bank; a total short-term debt of $£ 23 \cdot 1 \mathrm{~m} .{ }^{38}$ However, the reluctance of the Council to go to the market for long-term loans made the two banks holding overdrafts feel insecure. The Bank of England had communicated its anxiety as early as October $1929 .{ }^{39}$ The treasury bill issues were floated on the Westminster Bank's initiative and were made in two lots, one of $£ 5 \mathrm{~m}$. at 6.55 per cent in August and another $15 \mathrm{~m}$. at 5.375 per cent in November, before and after the New York stock exchange crashed in October. This fall in the cost nourished hopes that there would soon be a diversion of international capital to safer securities such as Australia's. ${ }^{40}$

The first official overture to the British for help was an initiative by the Commonwealth. It asked the British Treasury to postpone the $£ 2.77 \mathrm{~m}$. due at the end of the first quarter of 1930 on the Commonwealth's war debt with the British government; the Commonwealth was referred to the Bank of England which replied that no finance could be made available until it knew the Australian position better. The $£ 2.77 \mathrm{~m}$. was paid from foreign exchange reserves. The Bank asked whether 'a visitor would be welcome' to make an inquiry. On the advice of the Commonwealth (central) Bank Board the Commonwealth invited a mission in May 1930,41 yet another example of inviting trouble. Sir Otto Niemeyer, Senior Adviser and later Director of the Bank of England, and two others, duly arrived in July. This meant that until the visitors had reported, the Australian authorities could receive no help from their British counterparts. In the meantime, the reserves were in danger of running out quickly, quarter by quarter. W. S. Robinson recounts that he made personal representations secretly on behalf of Theodore and Scullin, Treasurer and Prime Minister, to the Chancellor of the Exchequer and to several directors of the Bank of England, including Sir Ernest Harvey who was acting as Governor in Montagu Norman's absence at the time. Robinson sought what he held to be absolutely essential: 'Either a deferment of payment of interest in

38 C.F.B., no. 24, table 61; Commonwealth Treasury.

39 Giblin, Central Bank, 74.

40 N.S.W.P.D., 10 December 1929, 2250 (Stevens, Premier and Colonial Treasurer).

41 C.P.D., 14 November 1930, 387-8, statement by J. E. Fenton, Acting Prime Minister; Giblin, Central Bank, 74. 
London or temporary assistance from financial institutions. ${ }^{42}$ Robinson regarded Harvey highly but bitterly records that he found him "bound hand a foot by the rules, regulations, traditions and policy of the Bank, plus probably the advice of the Treasury': Australia was to 'pay to the last shilling'. Giblin concluded that 'Australia had now become the bad boy of the British Commonwealth and it was fitting that an example should be made'. ${ }^{3}$

This record of the attitude of the British monetary authorities suggests that even if the Loan Council had wished to raise a long-term loan through Nivison's at any price in 1930 or later, it would not have been possible. There was at the time subtle but definite control by the British authorities over foreign issues in London to support the pound when the demand for sterling became excessive. It took the form of informal personal 'requests' by the Treasury and the Bank of England to broking and other firms arranging loans, as the authorities had no legislative power to back their policies after November 1919. It became customary for issuers to obtain the Bank's permission and the Stock Exchange forbade dealings in shares when permission had not been granted. The last period of relative freedom terminated late in 1929 when the world liquidity crisis started in earnest. ${ }^{44}$ The source of the Bank of England's power over issuing houses and joint stock banks was that it was the lender of last resort; issuing houses and banks could be refused this accommodation at the discretion of the Bank. It was also in their interests to keep on good terms with the monetary authorities so that they might be favourably considered in connection with any business the Treasury and Bank might allot. The control was 'quantitative in that it may discriminate, as was done in the case of overseas issues, between different classes of borrowers, and different types of transactions' ${ }^{\prime 4}$ Control was exercised in such a manner that no direct unequivocal evidence of it can exist: there is no archival record of it in London. ${ }^{46}$

The Loan Council and Australian ministers experienced the technique at first hand. For example, when Niemeyer met them in 1930 he said that

42 W. S. Robinson, If I Remember Rightly (Melbourne, 1967), 146-7.

43 Giblin, Central Bank, 84.

44 The Banker, July 1930,11, anonymous article entitled 'Foreign Loans'; Kahn, Great Britain, 161; R.I.I.A., International Investment, 164, 254. 'Since the war both the Bank of England and the Treasury have exercised a general scrutiny of Dominion and colonial governments, and very flagrant over borrowing has been prevented'; John Atkin, 'Official Regulation of British Overseas Investment, 1914-1931', Economic History Review, 2nd series, vol. XXIII, no. 2, August 1970, 331.

45 R.I.I.A., International Investment, 77. The first public appeal to the London capital market to refrain from floating new issues, as distinct from personal requests, was made by the Chancellor of the Exchequer in June 1932, just prior to and in preparation for the $£ 2,085 \mathrm{~m}$. war loan conversion operation. Ibid., 78-81 and A.I.B.R. (1932), 851 .

46 Atkin, 'Regulation of British Investment', 331. The author is indebted to Professor Ian Drummond for information that confirms Atkin's observation. 
he was expressing 'his own views for which he took the responsibility'. These were that 'Australian credit is at a low ebb' in Australia and abroad; and that 'By a series of accidents, chiefly the liberality of lenders and accidental high prices for Australian exports', Australia had avoided deflation. He intimated without promises of renewed lending that budgets should be balanced. ${ }^{47}$ None the less, he must have been expressing the United Kingdom authorities' view.

Another example of the British control of lending was the reception given the Prime Minister, J. H. Scullin, in November 1930 in London. He was left in no doubt that a precondition of any flotation was that budgets should be balanced. Until then, there were hopes in Australia that lending might be resumed. In fact, the explicit criteria which the British laid down in 1930 were as Robinson declared, impossible to achieve and were unlikely to be met by Australian governments for several years. Though Scullin might feel 'the door was not quite closed', 48 the difficulties were immediately insurmountable. The Loan Council took up what shortterm treasury bill finance it could and was thenceforth subjected to unremitting pressure from lenders to repay it and interest on long-term debt 'to the last shilling'.

\section{The impact on the gross national product}

When the governments' overseas borrowing is combined with local loans in the 1920s, the average net annual increase for non-war purposes was nearly $£ 40 \mathrm{~m}$. It was well over this level in $1927-28$ ( $\$ 54.7 \mathrm{~m}$.) but it fell to $114.8 \mathrm{~m}$. in 1928-29; and when the imminent depression began to be felt in 1929-30, net long-term borrowing at home and abroad for works was only $£ 5.6 \mathrm{~m}$., despite an Australian cash loan of $£ 12 \mathrm{~m}$. in June 1930 . Thenceforth, until November 1932, no long-term loans could be raised in Australia. ${ }^{49}$ In effect, therefore, the Loan Council experienced a period of three and a half years, 1929-30, 1930-31, 1931-32 and most of the first half of 1932-33, when the sources of money for loan expenditure and budget deficits were over-the-counter sales, the use of trust and other funds, and overdrafts or short-term loans from London and Australian banks.

Counter sales were but a few million annually $y^{50}$ and there was an obvious limit to the amount which could be drawn from trust funds and other government sources, particularly as the net increase in debt to which the Council had been accustomed was $£ 40 \mathrm{~m}$. per annum. The primary source of money became therefore loans for temporary purposes from the banks.

Official figures of the loan program in the period up to 1931-32 are

47 Shann and Copland (eds.), The Crisis, 20-1, 28-9.

48 Ibid., 63-5.

49 Giblin, Central Bank, 64, 83, 151-2, 174; C.F.B., no. 31, table 61.

50 C.P.P., 1934-35, vol. II, The Budget, 113 and 115. In 1931-32 counter sales and conversions were together equal to $£ 1.76 \mathrm{~m}$. In $1933-34$, counter sales were $£ 2.55 . \mathrm{m}$. 
not available, the Council's program being recorded only from 1932.33 onwards. ${ }^{51}$ Using other official statistics, however, a general picture of the loan arrangements for budget deficits and loan expenditure up to the end of 1932-33 has been constructed in table 8.4. The small changes that occurred in the war debt have been included to show the full strain of debt commitments upon governments. These were relieved by the 1931 Moratorium after which budget deficits were lessened by the cessation of large interest and small amortisation commitments on war debt held in London. The Moratorium was an international arrangement that did not favour Australia particularly but benefited debtor countries generally.

In 1928-29, deficits and net loan expenditure were financed largely by short-term loans totalling about $£ 36 \mathrm{~m}$. for which no Commonwealth securities were issued. That was the overall cash deficit on loan and revenue accounts for the year (col. 9). In 1929-30 the same sources were used again for about $£ 32 \mathrm{~m}$., but their limit was probably exceeded, for in the next year, 1930-31, about $115 \mathrm{~m}$. appears to have been repaid. Therefore, during the three years of the downturn to the bottom of the depression, the financial years 1929-32, budget deficits $(£ 56.9 \mathrm{~m}$.) and net loan expenditure $(£ 54 \cdot 1 \mathrm{~m}$.) totalled about $£ 111 \mathrm{~m}$. and this expenditure was financed largely by short-term bank loans of $£ 87 \mathrm{~m}$. for which securities were issued (col. 5). The difference of $£ 24 \mathrm{~m}$. in this three-year period between expenditure and short-term loans from banks on the security of treasury bills and debentures would be accounted for by the increase in long-term debt of $£ 7.4 \mathrm{~m}$. for which Commonwealth securities were issued and by the use of about $£ 17 \mathrm{~m}$. of public moneys which did not require the issue of (Commonwealth) securities and therefore Loan Council approval.

The ability of the Australian government in 1928-29 and 1929-30 to command the use of funds other than through long-term borrowing by the Loan Council was surprisingly great. Even so, the fall in normal long-term loans in 1929-30 was accompanied by a decline of over a quarter in export income in the same year and those two factors, combined with pessimistic statements of government and Loan Council representatives, so reduced the expected rate of profit in industry that gross private investment fell by a third in the same year. ${ }^{52}$ Using statistics compiled with the assistance of Bryan Haig, it is possible to make some observations about the movements in employment and the gross domestic product at 1928-29 prices as the multiplier took effect in the downturn (table 8.5).

51 C.P.D., 15 August 1963, 231-2.

52 Butlin, Australian Domestic Product, for the gross national product, private investment and government capital formation; Dr N. Cain's unpublished estimates of export income and imports; and Mr Bryan Haig, A.N.U., for other information; regarding the effect of the multiplier, information is not available to improve upon the direct calculation of the marginal propensity to consume home produced goods and services and the multiplier by Colin Clark and J. G. Crawford, The National Income of Australia (Sydney and London, 1938), 100-1. 
The Cessation of Overseas Lending

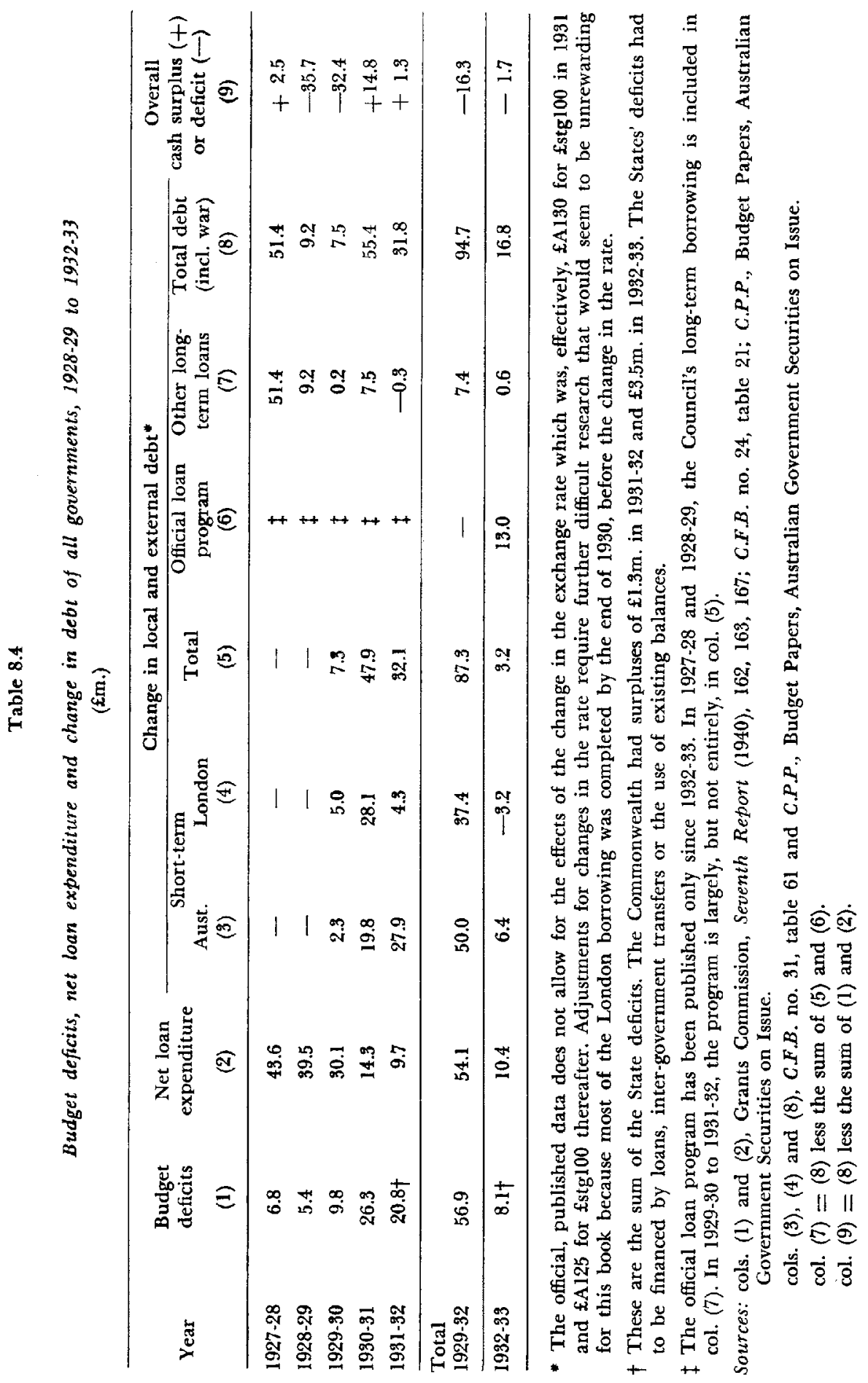


In 1929-30, there were compensating movements in the determinants of the gross domestic product which at $1928-29$ prices remained stable: that is, there was in that year no multiplier effect on the gross domestic product. Exports of goods and services and private and government construction and investment together fell $£ 50.3 \mathrm{~m}$. in 1929.30 but this was offset almost exactly by a rise in non-farm stocks and the omissions and discrepancy item. If we assume that this item was largely private consumption and some government consumption, then it is likely that private savings and government reserves were run down in this, the first year of depression, and had a cushioning effect. The rise of 3.6 per cent in unemployment appears to have been exactly offset by the increased productivity of the more efficient workforce retained in employment. As the effects of the depression grew, the less efficient were no doubt dismissed first.

In 1930-31, the gross domestic product fell by $8 \cdot 1$ per cent and employment fell by 7 per cent. It was in this year that the multiplier took effect as the economy plunged into depression. If it is assumed that there was no autonomous change in personal consumption expenditure (including an appropriate proportion of the discrepancy item allotted to it), then the other determinants of the gross national product at 1928-29 prices changed relative to the preceding year as in table $8.5 \mathrm{col} .1$.

In 1931-32, there were negligible changes in the gross domestic product $(-£ 4.6 \mathrm{~m}$.$) and the non-consumption determinants of it (-£4m.). Employ-$ ment fell a little ( 1.5 per cent), but the negligible change in production was probably attributable to productivity per person employed rising again.

In 1932-33, recovery began, coinciding with new loan flotations in Australia from November 1932 and seems to have been caused mainly by an upward movement in stocks investment and exports, but not export prices.

Table 8.5

Changes in components of gross domestic product, 1930-31 to 1932-33 at 1928-29 prices

(£m.)

\begin{tabular}{lcrr}
\hline & $1930-31$ & $1931-32$ & $1932-33$ \\
\hline $\begin{array}{l}\text { Government } \\
\text { Capital: Commonwealth and States }\end{array} \quad-18.0$ & & +2.7 \\
$\quad \begin{array}{l}\text { Current expenditure } \\
\quad\end{array}$ & -1.5 & -6.4 & +2.3 \\
Private fixed investment & -17.9 & -5.3 & +5.9 \\
Exports of goods and services & +32.7 & +17.4 & +10.6 \\
Non-farm stocks & -23.4 & +0.3 & +22.5 \\
Omissions and discrepancy & -3.0 & -6.0 & -2.0 \\
\hline Net change & -34.6 & -10.0 & +42.0 \\
Gross domestic product & -69.8 & -4.6 & +47.3 \\
\hline
\end{tabular}

Source: Bryan Haig, unpublished research. 
During the downturn, imports at constant prices remained high until consumption fell; then imports fell to about half their pre-depression levels and the author has estimated that a long-term downward movement in the average propensity to import began. The early sustained demand for imports helped to drain the foreign exchange reserves quickly. The main downward movements of consumption and imports occurred in 1930-31, the second year of low export income, suggesting that primary producers particularly, but others as well, were able to and, in fact, waited a year before cutting their consumption. Exports of goods and services moved in a remarkable manner. Between 1928-29 and 1932-33, the current value of exports of goods and services fell by over one-quarter but, at constant prices, they rose by over a quarter, even though the workforce in the rural industries remained fairly constant. The considerable increase in rural production was directed to offsetting the fall in rural incomes due to the adverse movement in the terms of trade. This adverse movement resulted in a loss of real national income, that is, the 'terms of trade effect', of about 6 per cent of gross national product per annum from 1929-30 to 1932-33. The community shared this particular loss, farmers more so than other groups because their relative income fell furthest.

The most significant social effect was on the workforce: an estimated fall of 12.1 per cent in the overall level of employment resulting in $19 \cdot 7$ per cent of the workforce being unemployed in 1931-32.53 Was so much hardship necessary? Could there have been some cushioning of the effects of the fall in foreign exchange reserves which resulted from the cessation of lending and the fall in export prices to 40 per cent of their 1928 level by August 1931? The short answer to this question is that the fundamental disequilibrium into which the economy had moved made a major and a painful readjustment necessary.

When the fall in reserves began in late 1929, all but two of the major policies pursued were suggested to the Commonwealth government by Sir Robert Gibson, chairman of the central bank Board. These were (1) to bring gold under the control of the bank so that it could be used to meet interest and other essential foreign commitments; (2) to reduce the national income; (3) to restrict and ration foreign exchange issued by banks to customers; (4) to increase temporarily duties on luxuries; and (5) quantitative restrictions on imports. A sixth method, depreciation of the exchange rate, was mentioned but not recommended..$^{54}$ In fact, all six methods were used together with (7), a cut of 10 per cent in money wages; some were introduced late, but Giblin measured their effects (excepting wage reductions but including depreciation by 25 per cent) and concluded that the fall in income and employment which accompanied these

53 M. Keating, 'Australian Work Force and Employment, 1910-11 to 1960-61', 158.

54 Letter dated 9 November 1929 in Shann and Copland (eds.), The Crisis, 1-3; Giblin, Central Bank, 70-1. 
measures was the only practical course at the time in view of the institutional setting. ${ }^{55}$ The structure of imports was such that the demand for them was highly inelastic: nearly four-fifths were capital equipment and goods requiring further processing, of which one-half were the hard core of simply transformed materials and equipment needed to keep public utilities and the manufacturing sector functioning, , $^{56}$ and the fall in employment could only have been less if far more drastic quantitative restrictions on imports than were politically acceptable, and extraordinary cuts in consumption, probably by rationing and accompanying price control to prevent inflation, had been introduced. In other words, the economy required wartime controls from 1930 onwards for some years.

In the long period, the economy benefited from some of the measures which were taken. It had become necessary to reduce the average propensity to import, since Australia could no longer depend on overseas loans as it had in the 1920s. Depreciation and wage reductions lowered Australian costs and prices relative to imported goods and, together with the tariff, improved the competitive position of Australian manufacturers, and helped to solve the balance of payments problem in a permanent manner. This was seen to be 'the fundamental thing that had to be done' by the Labor Prime Minister by mid-1931.57 Between 1928-29 and the end of the 1930s the average propensity to import fell from about 18 per cent to about 15 per cent of the gross national product; 58 this was no mean achievement.

Notwithstanding that the short-term borrowing from the banks was in fact appropriate pump priming and could be regarded as long-term because the treasury bills were not redeemed until some years later, the circumstances from 1929 to the end of 1932 represented a tremendous transformation from the 1920s when normal long-term loans financed long-term capital works expenditure, and budget deficits were to be subject to penalty sinking fund rates, if paid for from long-term loans. It is hardly possible to conceive a more uncharacteristic and difficult start upon the Loan Council's statutory life.

\section{Some lessons of 1929 and 1930}

In the light of the United Kingdom's economic position and lending policy in 1929 and 1930, the loans could have gone on at a reduced rate if there had been wholehearted co-operation by the monetary authorities, issuing bank, broker and underwriters. This is not a new conclusion; when addressing the Premiers in February 1931, the Prime Minister said of the decline in borrowing: "This reduction should have taken place

55 Ibid., 81 .

56 R. S. Gilbert, 'Structural Trends in Australian Imports', Economic Record, vol. XXXV, no. 70, April 1959, 130-2.

57 C.P.P., 1929-31, vol. II, 'Conference of Commonwealth and State Ministers, 25 May 1931 ', 11 .

58 Author's estimate. 
over a period of years. If, for example, overseas loans had been reduced gradually over a period of five years we should now be able to face with less grave misgivings the task that confronts us' ${ }^{59}$ It is salutary to add that, in Britain's circumstances in 1931, Australia would have been lucky to have obtained loans after 1930 .

Another lesson learned too late was that the Loan Council should have been willing to pay a rate much higher than usual. The decision not to pay higher interest rates was taken because, inter alia, loans were expected and there was no awareness of the crisis ahead. Even so, it is not possible to be sure that more British loans would have been forthcoming to Australian governments. This conclusion has been reached with all the benefits of hindsight and it should not be taken as criticism of policy at the time but as an example of the dependence of any monetary authority on adequate information and on personal judgments.

Finally, Australia committed itself to too high a rate of foreign borrowing from two markets. Borrowing might therefore be spread over a number of markets and in the absence of an international lending authority that can act as lender of last resort to governments in the event of a world liquidity crisis, borrowing should not be a dangerously high proportion of foreign exchange earnings. What is the danger level depends in part upon the probability of a diminution of foreign exchange receipts from exports and borrowing, and in part upon the proportion of imports which are essential to maintain employment in the manufacturing sector and in government business undertakings. The less elastic the demand for imports to maintain employment, the more important it is to maintain a reliable flow of foreign exchange receipts. If there is no alternative to a flow of volatile, borrowed exchange, then a sudden cessation of that inflow leaves the alternatives of the use of reserves, deflation, a reduction of relative costs and prices or controls on imports, or a mixture of these policies in the short run; and consideration of exchange depreciation as a long-term measure.

Between 1929 and 1932, all of these policies were tried and the Loan Council was perforce at the centre of governmental decision-making for reasons considered in the ensuing analysis of its role in the downturn to depression.

59 J. H. Scullin, 'Conference of Commonwealth and State Ministers, February 1931', 6, in C.P.P., 1929-31, vol. II. 
Table 8.6

A ustralian Loan Council as constituted under the Financial Agreement

Meetings

\begin{tabular}{|c|c|c|c|c|c|}
\hline No. & Place & Date & No. & Place & Date \\
\hline & & 1929 & & & 1942 \\
\hline 1 & Canberra & 10 January & 53 & Canberra & 3 February \\
\hline 2 & Canberra & 27 to 30 May & 54 & Melbourne & 11 August \\
\hline 3 & Sydney & 6 August & & & 1943 \\
\hline 4 & Melbourne & 11 November & 55 & Melbourne & $15 \mathrm{July}$ \\
\hline \multirow[t]{2}{*}{5} & Canberra & 9 December & & & 1944 \\
\hline & & 1930 & 56 & Canberra & 26 and 27 January \\
\hline 6 & Canberra & 7 February & 57 & Canberra & 24 August \\
\hline 7 & Canberra & 19 and 21 February & & & 1945 \\
\hline 8 & Canberra & 10 and 11 June & 58 & Canberra & 22 August \\
\hline 9 & Canberra & 5 and 6 August & & & 1946 \\
\hline 10 & Melbourne & 21 August & 59 & Canberra & 23 January \\
\hline \multirow[t]{2}{*}{11} & Canberra & 11 November & 60 & Canberra & 21 August \\
\hline & & 1931 & & & 1947 \\
\hline 12 & Melbourne & 13 and 14 January & 61 & Canberra & 20 August \\
\hline 13 & Canberra & 7 February & & & 1948 \\
\hline 14 & Melbourne & 25 and 26 February & 62 & Canberra & 24 August \\
\hline 15 & Melbourne & 23 to 26 April & & & 1949 \\
\hline 16 & Melbourne & $\begin{array}{l}22 \text { and } 23 \text { May, and } \\
10 \text { June }\end{array}$ & 63 & Canberra & $\begin{array}{l}17 \text { August } \\
1950\end{array}$ \\
\hline 17 & Melbourne & 5 to 14 August & 64 & Canberra & 6 and 7 September \\
\hline \multirow[t]{2}{*}{18} & Melbourne & 4 to 12 September & & & 1951 \\
\hline & & 1932 & 65 & Canberra & 18 June \\
\hline 19 & Melbourne & 28 January to 5 February & 66 & Canberra & 16 and 17 August \\
\hline 20 & Melbourne & 20 April & 67 & Canberra & 7 December \\
\hline 21 & Canberra & 28 June to 1 July & & & 1952 \\
\hline 22 & Sydney & 8 July & 68 & Canberra & 1 to 3 May \\
\hline 23 & Melbourne & $\begin{array}{l}27 \text { to } 29 \text { October } \\
1933\end{array}$ & $\begin{array}{l}69 \\
70\end{array}$ & $\begin{array}{l}\text { Canberra } \\
\text { Canberra }\end{array}$ & $\begin{array}{l}7 \text { to } 9 \text { July } \\
17 \text { and } 18 \text { October }\end{array}$ \\
\hline 24 & Melbourne & 1 to 4 February & & & 1953 \\
\hline 25 & Melbourne & 15 and 16 May & 71 & Canberra & 18 and 19 May \\
\hline 26 & Melbourne & 6 to 14 June & & & 1954 \\
\hline 27 & Melbourne & $\begin{array}{l}3 \text { to } 6 \text { November } \\
1934\end{array}$ & 72 & Canberra & $\begin{array}{l}29 \text { and } 30 \text { June } \\
1955\end{array}$ \\
\hline 28 & Melbourne & 23 to 28 February & 73 & Canberra & 21 to 23 June \\
\hline 29 & Melbourne & 18 to 21 June & & & 1956 \\
\hline \multirow[t]{2}{*}{30} & Canberra & 29 and 30 October & 74 & Canberra & 1 February \\
\hline & & 1935 & 75 & Canberra & 26 to 28 June \\
\hline 31 & Canberra & 27 to $31 \mathrm{May}$ & 76 & Canberra & 14 November \\
\hline \multirow[t]{2}{*}{32} & Melbourne & 6 to 8 November & & & 1957 \\
\hline & & 1936 & 77 & Canberra & 23 and 24 May \\
\hline 33 & Canberra & 3 and 4 February & & & 1958 \\
\hline 34 & Canberra & 18 and 19 May & 78 & Canberra & 13 February \\
\hline 35 & Adelaide & 28 August & 79 & Canberra & 4 and 5 June \\
\hline \multirow[t]{2}{*}{36} & Melbourne & 5 to 7 November & & & 1959 \\
\hline & & 1937 & 80 & Canberra & 23 and 24 June \\
\hline 37 & Melbourne & 4 February & & & 1960 \\
\hline 38 & Melbourne & 15 and 16 April & 81 & Canberra & 12 February \\
\hline 39 & Canberra & 15 and 16 July & 82 & Canberra & 23 and 24 June \\
\hline
\end{tabular}


The Cessation of Overseas Lending

Table 8.6 (continued)

Australian Loan Council as constituted under the Financial Agreement Meetings

\begin{tabular}{|c|c|c|c|c|c|}
\hline No. & Place & Date & No. & Place & Date \\
\hline & & 1938 & & & 1961 \\
\hline 40 & Melbourne & 21 and 22 April & 83 & Canberra & 9 February \\
\hline 41 & Canberra & $\begin{array}{l}21 \text { October } \\
1939\end{array}$ & 84 & Canberra & $\begin{array}{l}14 \text { and } 15 \text { June } \\
.1962\end{array}$ \\
\hline 42 & Canberra & 31 March & 85 & Canberra & 15 and 16 February \\
\hline 43 & Canberra & 20 to 22 June & 86 & Canberra & 27 and 28 June \\
\hline \multirow[t]{2}{*}{44} & Canberra & 9 and 10 November & & & 1963 \\
\hline & & 1940 & 87 & Canberra & 14 February \\
\hline $\begin{array}{l}45 \\
46\end{array}$ & $\begin{array}{l}\text { Melbourne } \\
\text { Canberra }\end{array}$ & $\begin{array}{l}19 \text { January } \\
27 \text { and } 28 \mathrm{May}\end{array}$ & 88 & Canberra & $\begin{array}{l}17 \text { and } 18 \text { June } \\
1964\end{array}$ \\
\hline 47 & Canberra & 12 and 13 August & 89 & Canberra & 2 July \\
\hline \multirow[t]{2}{*}{48} & Canberra & 18 November & & & 1965 \\
\hline & & 1941 & 90 & Canberra & 1 and 2 June \\
\hline 49 & Canberra & 31 January and 1 February & & & 1966 \\
\hline 50 & Canberra & 15 April & 91 & Canberra & 16 and 17 June \\
\hline 51 & Canberra & 8 and 9 August & & & \\
\hline 52 & Canberra & 19 and 20 December & & & \\
\hline
\end{tabular}




\section{The Failure of \\ Expansionary Policies in the Depression, 1929-31}

The powers of the Loan Council gave it decision-making authority over two areas of policy which, in the economic crisis, were central to the management of the economy. They were overseas borrowing including the payment of overseas interest; and securing local finance for member governments to spend to create work and income for the unemployed whose numbers grew apace in 1930 . In a federal system with the central government experiencing its first serious economic depression without the legislative power to exercise control of the economy, a power struggle to manage the national economy developed. In this and the next chapter, the Loan Council will emerge as temporarily exercising a central, controlling influence until it was appreciated that its limited constitutional powers obliged it to hand this function over to the Premiers' Conference and to the Commonwealth where the main constitutional powers rested-over money, the banks, their gold and the foreign exchange, the tariff, expenditure on works, the rural sector and, to a lesser extent, over wages.

The years of the downturn included the life of the Labor government which was elected in October 1929, with all the goodwill of a landslide victory, and which went out, disintegrated and powerless, in December 1931. The degree of support for Labor at the 1929 elections can be measured in part by the fact that former Prime Minister Bruce and four ministers lost their seats. The Labor Party governed with purpose and a good sense of direction until about July or August 1930 when the coincidence of at least three major events led to a turning point and the government lost control of the situation. The subsequent disintegration of the Party did not enable it to recover.

The year of good management, 1929-30

Although the Loan Council cut the loan program by a fifth in August 
1929, there was no sense of looming economic crisis before the October elections at which speakers assumed that economic recovery would soon begin. The victory for Labor in the House of Representatives was a hollow one as there was no simultaneous Senate election and the government was faced from the start with a strong, hostile Senate majority. Labor did not bring about a double dissolution. This was the first and probably the most serious error in its strategy, since the worsening of the economic situation was paralleled by diminishing Labor chances of electoral success. ${ }^{1}$

The new Prime Minister, J. H. Scullin, a member since 1910, first for Corangamite and then Yarra, Victoria, had forged his way to the leadership in the 1920s. Theodore became deputy leader and Treasurer. They were the leaders of Labor's centre party. J. E. Fenton and Lyons were on the right wing; Anstey led the left. ${ }^{2}$ Scullin was to prove an outstanding chairman and conciliator; Theodore was a gifted financier able to conceive constructive policy in the most challenging circumstances and willing to take advice. ${ }^{3}$

Scullin and Theodore soon showed their ability. When in October 1929 the Governor of the Bank of England, Montagu Norman, reported to Sir Robert Gibson, Chairman of the central bank's Board, that British exporters were complaining that they could not be paid in sterling, Gibson wrote to Scullin suggesting legislation to bring gold under the control of the central bank to prevent gold being bought and shipped abroad by private persons to pay London debts. It was needed to assist in paying overseas debt interest. ${ }^{*}$ The advice was acted upon and Australia formally left the gold standard on 17 December. ${ }^{5}$ The control did not extend to London funds held in sterling, the central control of which was not politically feasible and about which all but two of the banks refused at this time to give any information. The bill had to be fought through point by point in each House: 'The protracted debates illustrate both the tension of political feeling and the effects of the combination of acute fear for the future with very imperfect understanding of the issues at stake' ${ }^{6}$

1 G. Sawer, Australian Federal Politics and Law 1929-1949 (Melbourne, 1963), 2, 3, 5, 9. Sce J. R. Robertson, 'Scullin as Prime Minister: Seven Critical Decisions' in R. Cooksey (ed.), The Great Depression in Australia (Canberra, 1970), for an analysis of the difficulty of bringing about a double dissolution.

2 J. E. Fenton, born 4 February 1864, member for Maribyrnong, Victoria, 1910-34; F. E. Anstey, born in London, 18 August 1865, M.L.A. Victoria, 1902-10, member for Bourke, Victoria, from 1910; J. A. Lyons, member for Wilmot, Tasmania, formerly Premier of Tasmania. Scullin was 53 and Theodore 45 years of age when they took office.

3 Bruce McFarlane, Professor Irvine's Economics in Australian Labor History (Canberra, 1966), 19 et seq. shows that Irvine, formerly Professor of Economics at Sydney, influenced Theodore.

4 Giblin, Central Bank, 70-1; Schedvin, Depression, 123.

5 Commonwealth Bank Act, no. 31 of 1929.

6 Giblin, Central Bank, 67. Giblin states that 'nominal' information on the amount of 
The year 1929 therefore closed on a note of deepening gloom. The Loan Council was not yet at the centre of policy-making and its main action had been to cut demand parallel with, but not by the same amount as, the fall in loans at home and abroad. Other decisions showed that the Council was grappling with the situation: the rate on a conversion loan in the third quarter was 5.73 per cent, significantly higher than the 5.25 per cent that had previously been the norm. This reflected rising liquidity preference, and the Council, through the States, took steps to avoid clashing and competitive interest rates between Commonwealth and local and semigovernmental loans. ${ }^{7}$ In November, the Commonwealth made the first of many increases in the tariff and began to restrict some imports to protect industry, to increase employment, and to improve the balance of payments; these policies were practical by means of parliamentary tactics that avoided debate in the hostile Senate throughout almost all of Labor's term in office. $^{8}$

Two Loan Council meetings in February 1930 followed the pessimistic half-yearly report of the central bank issued in January. The Loan Council publicly endorsed statements which had been made by the Prime Minister and the Treasurer that Australia would promptly meet all overseas debt obligations; it agreed that the current loan program should be cut further and there was a forewarning of further 'drastic reductions'. ${ }^{9}$ The effect the bank's report and the Council's statement must have had upon the expected rate of profit and hence investment is obvious. The stream of like announcements explain in part the fall in private investment which occurred in 1929-30.

Reports from the central and private banks on the loan market indicated sagging confidence and $£ 10 \mathrm{~m}$. of Sinking Fund money was used to redeem local and overseas debt and help support bond prices; it steadied the market for the current cash loan and war loan conversion at 6 per cent. ${ }^{10}$ To lessen tension, B. S. B. Stevens, non-Labor Treasurer of New South Wales, declared publicly that he had not known politics to enter into Loan Council discussions since its inception in 1923, nor had he known any member attempt to review the public works program of another State.11 Personalities and the issue of allocating the diminishing loan program were beginning to haunt the scene.

London funds was not made known to the Commonwealth government until December 1931, after the crisis was over. See p. 70.

7 A.I.B.R. (1929), 932. The Melbourne Metropolitan Board of Works was reported as not floating a planned public issue. However, it raised money privately. See also p. 1022 and $A g e, 10$ December 1929, 9 .

8 Sawer, Politics 1929-1949, 28; R.C.M.B., p. 49.

9 Shann and Copland (eds.), The Crisis, 10-12.

10 S.M.H., 7 February 1930, 11; Argus, 20 February 1930, 9.

11 S.M.H., 7 February 1930, 11. 
The most important monetary development in February was the start of close liaison by Theodore and two State Treasurers with the banks, which were co-ordinated by the central bank, to mobilise gold and to arrange payment of interest due in London. ${ }^{12}$ The three governments that banked with the London and Westminster Bank had overdrafts aggregating $\$ 10-11 \mathrm{~m}$. and the trading banks agreed to find $\$ 2.95 \mathrm{~m}$. to reduce them. This was the small start of what became the very significant Mobilization Agreement later in the year. The liaison with the banks at this time was essential because although they had lost control of gold, they retained it over the foreign currency reserves, or London funds. The question was whether the banks would accept treasury bills (a) for foreign exchange to meet governments' overseas debt obligations, mainly interest, and (b) for deficit finance of expenditure in Australia as governments' revenue fell with the national income. This was potentially embarrassing because deficits were regarded as bad economics and long-term loans (for more than a year) to meet deficits were subject to the penalty clauses of the Financial Agreement. As yet the loans from the banks were well within the one-year time span and therefore 'temporary', concerning which the Agreement provided in subclauses $5(9)$ and $6(7)$ that there should be no control by the Loan Council of the amount borrowed. In other words, governments were accustomed and permitted to obtain temporary overdrafts. The new element was that foreign exchange was now scarce, revenues were falling and it was obvious that overdraft limits might be exceeded for longer than usual. The banks were to be successful in insisting at the end of 1930 that loans under subclauses $5(9)$ and $6(7)$ of the Financial Agreement should be on the security of treasury bills issued by the Commonwealth on the Loan Council's authority. The banks received a security which might be discounted at the central bank and the Loan Council received long-term loans on the security of short-term treasury bills. Both sides gained. This matter will be considered again.

Between the February and June 1930 meetings of the Loan Council the decision was taken to invite representatives of the Bank of England to Australia. Until their arrival in July there was a period of hesitancy in Loan Council matters; some steps had been taken to ensure overseas interest was paid and there were hopes that Niemeyer's party would bring news of new London loans; in fact the Council contemplated with considerable presumption 'that, when conditions become favourable, further issues should be made to assist in meeting some of the arrears of borrowing of the last two years' ${ }^{13}$ The illusion that there could be 'arrears' of loans in overseas markets was self-deception on any criterion of relations between lender and borrower. The optimism was based partly on the view held by some that the collapse of the New York stock market in the December

12 Ibid.; C.P.D., 1 May 1930, 1341; Giblin, Central Bank, 69; A.I.B.R. (1930), 175, 178. 13 Shann and Copland (eds.), The Crisis, 12-13. 
quarter of 1929 would lead to the diversion of overseas capital to a safer class of security. Australian government securities might then be sought at a rate of interest the Loan Council considered it could pay. ${ }^{14}$ There was another reason for confidence in June-a local $£ 10 \mathrm{~m}$. 6 per cent new issue at par yielded $112.44 \mathrm{~m}$. It was to be the last loan in Australia until November 1932. However, a realistic balance was struck by the Council's announcement that the total of Commonwealth and State governments' deficits in $1929-30$ would probably be $£ 9 \mathrm{~m}$., with worse to follow on current trends, and that although it was not the function of the Council even to suggest the form of policy, it urged cuts in government expenditure, and balanced budgets because of the serious effect deficits would have on Australian credit abroad. ${ }^{15}$ This announcement revealed that the Council, and Scullin and Theodore at its head, had a thorough grasp of the constitutional relationship between the Council, the Commonwealth, and the States. The Labor leaders were to show this on several later occasions.

On the eve of Niemeyer's arrival, there occurred the first of three developments of fundamental importance which cost the government the control that it had of the situation. It arose from the character and person of Theodore, Chairman of the Loan Council. A Queensland government Royal Commission found him guilty of 'fraud and dishonesty' in respect of allegations that, when he was Premier, he was involved in the sale to the Queensland government of a mine in which he had an interest. Scullin, at Theodore's request, relieved him of his ministry next day, and took over the Treasury on the assumption that Theodore would quickly clear himself. ${ }^{16}$ Political manoeuvring ensured that this was not to be, and over six months were to elapse before Theodore returned to the Ministry and nearly a year passed before he was cleared. Instead of continuing in the positions of Treasurer and Chairman of the Loan Council where he could have been most effective, he became a backbencher, and was distrusted by the right wing of his own Party and, of course, by all interests and persons within and outside Parliament who were opposed to Labor, and any form of government deficit finance, however mild.

The second major development occurred in the same month that Theodore resigned. Niemeyer's party arrived and he and Professor Gregory, who accompanied him, began echoing, without mentioning their names, the views of Cooke and Davenport and the British Economic Mission in statements which received wide publicity. They communicated their views skilfully in a diplomatic tone. At a meeting with the Premiers and the Loan Council in August 1930, Niemeyer condemned the current budget deficits, advocated further reductions in costs to help primary producers,

14 N.S.W.P.D., 10 December 1929, 2250 (Stevens, Budget Speech).

15 Shann and Copland (eds.), The Crisis, 34-6; Giblin, Central Bank, 74.

16 Sawer, Politics 1901-1929, 259-60 and Politics 1929-1949, 6, for a review of Theodore's problems, beginning when elected to Dalley in 1927. 
and suggested cuts in government expenditure all round to eliminate deficits and to reduce the mounting short-term (treasury bill) debt at home and in London. Regarding the prospects of further London loans Niemeyer made skilful, indirect references:

There is a general desire to assist a Dominion . . But the fundamental question is the extent to which Australia herself will make it possible for the present picture to change. Australia must reassure the world as to the direction in which she is going, financially and economically, and no one else can do that for her. ${ }^{17}$

Hopes that the Loan Council had about London borrowing were further dashed. Giblin records that more important was the realignment of attitudes which Niemeyer started by the tone of his address at this turning point. In Giblin's words, 'There is a remarkable absence in Sir Otto's address of any mention even of possible ways of softening the harshness of the necessary adjustment ... It was unfortunate that the Bank Board allied itself so strongly to this political judgment, as it helped to postpone agreement on a working compromise until the middle of 1931'18 One immediate effect of Niemeyer's words was to provoke the first serious proposals for repudiation of overseas debt interest from New South Wales industrial groups which Gregory then debated publicly, increasing the growing bitterness towards the visitors. ${ }^{19}$ The Niemeyer party was a strongly divisive influence by August.

The third major event to weaken the government's control occurred a few days after Niemeyer's address to the leaders of all governments. Scullin and two other Ministers left Australia for five months to attend the Imperial and Economic Conference on the Statute of Westminster, to look into the question of London loans and to carry through the appointment of Sir Isaac Isaacs as the first Australian-born Governor-General. The abdication of leadership at a critical time in effect transferred power to the banks, a shift which was made greater when, just prior to his departure, Scullin, not alone but against the views of some his Ministers, reappointed Gibson chairman of the central bank Board for a term of seven years from August 1930. This decision of a Cabinet meeting which was not fully attended was influenced in part by a desire not to upset London talks about a loan of sterling and probably by the wish to avoid an unsettling change of management at the central bank at the time of Scullin's departure and Theodore's transfer to the back benches. ${ }^{20}$

17 Argus, 6 August 1930, 7; Shann and Copland (eds.), The Crisis, 27-8.

18 Giblin, Central Bank, 84; Niemeyer's address, Argus, 19 and 27 August 1930, 7; 8. Giblin saw Australia as the 'bad boy of the British Commonwealth' in this general context.

19 Argus, 28 August 1930, 7.

20 C.P.D., 29 April 1931, 1369; Giblin, Central Bank, 100, mistakenly puts the time of Gibson's reappointment as May 1931. 
Early in 1930-31, therefore, at the point of time when the economy dipped down sharply as the multiplier took effect, the government leaders' firm hands were effectively taken from the wheel, the central bank's power was consciously left intact, and Niemeyer's melancholy messages sent disintegrating waves throughout the land. Combined with the initial mistake of not seeking a double dissolution these decisions and events precipitated political crises and, for some months, thrust the Loan Council into the seat of power with the banks.

\section{The crises of $1930-31$}

In the absence of Scullin, Fenton became Acting Prime Minister and Lyons was Acting Treasurer. They represented the Commonwealth at the conferences with Niemeyer, Scullin being ill and about to go abroad.

A legacy from the period of relatively good management was the Mobilization Agreement, undoubtedly drawn up with Niemeyer's strong approval at the August conference. This simply committed the banks to supply approximately $£ 36 \mathrm{~m}$. of foreign exchange annually to the Commonwealth and State governments and their authorities to pay overseas interest and services; the main difficulty about it was that the banks were not bound by legislation to meet the obligation. The Loan Council announced that it would 'support the Banks in their endeavours to control the market for overseas exchange', and appealed to private persons dealing in foreign exchange to do so through the banking system. The banks weathered the subsequent difficulties, and this method of meeting governmental commitments abroad lasted until wartime exchange control superseded it in 1939. It was one of the most effective measures consciously taken in monetary policy in the depression. ${ }^{21}$

As the number of unemployed increased rapidly in the second half of 1930 and the leadership of Theodore and Scullin temporarily disappeared, the federal Labor Party split into three main groups over the economic policy to pursue. ${ }^{22} \mathrm{~A}$ right wing group, led by Lyons, favoured financial orthodoxy, mainly controlled deflation and wage and pension reductions in proportion to the fall in price levels, and no change in debt interest and redemption contracts. A centre group, led by Scullin and Theodore, was flexible and began with views somewhat the same as the more conservative group, but favouring greater use of bank credit to maintain employment; at no time did they advocate repudiation of debt contracts. The left wing was a heterogeneous group of radicals who began to voice their views at Caucus meetings late in October 1930, particularly after Lang became Premier again at elections in that month. They sought credit expansion and changes in debt contracts. For example, on 4 November,

21 Giblin, Central Bank, 69-70, 85, and Shann and Copland (eds.), The Crisis, 14-15. 22 Sawer, Politics 1929-1949, 5. 
a motion by Anstey (Minister for Health) was carried calling for legislation compelling holders of $£ 27 \mathrm{~m}$. of internally held securities maturing in December to retain them for a further year, interest to be paid as usual. These moves were stopped by Scullin's threat to resign, in cables which passed between himself and Fenton and Lyons, and on 30 November Lyons made an orthodox statement in accord with Scullin's wishes regarding the terms of conversions if bondholders of the $£ 27 \mathrm{~m}$. chose to convert. ${ }^{23}$

A further sign of disintegration was that Theodore (centre) had begun to criticise openly the action of Lyons (right wing) in allowing Niemeyer into the recent Loan Council and Premiers' meetings. It is a moot point whether, as a guest of the Commonwealth, Niemeyer could have been kept out of the Loan Council's meeting by the Commonwealth's unilateral decision, or whether the Council could have voted to admit him. On the same day as Theodore made his statement, Niemeyer felt obliged to make one too, in an attempt to make his true position clear. By then he and Theodore were achieving nothing constructive but it is reasonable to reflect a little upon what Theodore might have achieved had Niemeyer been used for backroom advice and Theodore had retained the reins. It was reported in his attack on Lyons that 'Speaking of the relations between the Ministry and the banking institutions, $\mathrm{Mr}$ Theodore said that it might be necessary to precipitate a crisis so that the Ministry could dictate to the private banks, and force the release of credits' ${ }^{24}$ It is possible that Gibson might have come to an arrangement with a Theodore untainted, Scullin at home to help manage the crisis, and Niemeyer used for unpublicised advice on the British view. Instead, Gibson and representatives of the banks assumed the role of thinkers and strong managers in a situation which, with the advent of Lang as a member of the Loan Council, deteriorated very rapidly. ${ }^{25}$ Niemeyer's visit was a further example of Australia inviting trouble from an overseas delegation.

Lang soon showed that his mind had not changed since the debates on the Financial Agreement. At a Loan Council meeting in November 1930 he provocatively moved to terminate the Financial Agreement because the Loan Council had failed to provide adequate loans. He wanted his State to raise its own loans. Other Premiers opposed this and Sir Edward Mitchell spent considerable energy in useful articles for the press, explaining why, under the Financial Agreement and s.105A, a State could not do as New South Wales wished without the consent of all Commonwealth and State Parliaments. ${ }^{20}$ Lang's concern sprang from the reluctance of the Sydney banks to renew treasury bills, let alone provide additional finance.

23 Shann and Copland (eds.), The Crisis, 61-7.

24 Argus, 28 October 1930, 7.

25 Warren Denning, Caucus Crisis (Sydney, 1937), 93.

26 Argus, 12 November 1930, 7; 31 October 1930, 8; 10 November 1930. 
He constructively suggested to Lyons that banks not lending to governments be persuaded to do so to spread the load. ${ }^{27}$

The Council and the central bank were aware of the problem which was, basically, that the temporary overdrafts were becoming loans for more than a year, or long-term, to finance deficits. All were also aware that under the existing banking legislation, the central bank and private banks had the deciding and controlling voice on the money supply and the finance for government deficits. Their power stemmed from the accepted belief that the Parliament did not have any practical understanding of monetary policy and should have no control over it. The banks' traditions were the unwritten law for practical policy unless an exceptional, respected figure were to emerge in the Commonwealth to transform the situation with amending legislation. This was not even remotely possible with Scullin and Theodore hors de combat and a non-Labor Senate. Another example of the power of the central bank was that, at meetings between a Loan Council subcommittee and the banks in November, Gibson was chairman, not the responsible Minister. ${ }^{28}$ The important thing to note is that the leadership of bank representatives at meetings of the monetary authorities was simply in continuity with the accepted relationships of the 1920s. Gibson was then an acceptable, independent chairman, but to modern eyes, it was extraordinary. The private banks were soon to reveal their great traditional power in still another direction when, in January 1931, the general manager of the bank of New South Wales (A. C. Davidson) forced devaluation of the exchange rate to $£$ A1 30 for £stg100.29

The private banks as lenders had the legal right to seek the best possible security before making temporary or other loans, which they feared might be dishonoured or be made worthless by inflationary finance. Most importantly, only they knew accurately the level of the foreign exchange reserves and therefore the level of imports the economy should have. Through Gibson, their position was presented to the Loan Council thus:

Owing to the practical unification of the finances of the Australian Governments through the creation of the Loan Council and the control of borrowing, it has become necessary, especially on account of the very difficult financial position, that all borrowing by Governments, whether through public loans, Treasury bills or overdrafts, should be treated by the Loan Council under the general heading of borrowing, and dealt with by the Loan Council.30

This they regarded as part of the arrangement arising from the conferences with Niemeyer of which there were a number, with Commonwealth and State ministers present, subsequent to the August meeting.

27 Shann and Copland (eds.), The Crisis, 81 .

28 Ibid., 83.

29 Giblin, Central Bank, 77-9.

30 Shann and Copland (eds.), The Crisis, 83. 
There was no recognition of the statutory provision that the Loan Council is to decide only the costs of borrowing for temporary purposes, and that power over the amount of temporary loans reposed with the individual governments. Instead, the private banks exercised their right to play safe; what they asked for was a new principle to replace clauses $5(9)$ and $6(7)$ concerning temporary borrowing, or overdrafts, and in effect they achieved what amounted to a constitutional amendment without any of the legislative processes! 'Without the slightest desire to dictate the policy of governments' the banks, through Gibson, nevertheless laid down new principles for the governments' short-term borrowing arrangements. These the Council accepted in December 1930. The main points were that the overdraft requirements of all governments should be approved by the Loan Council and presented to the central bank, as the representative of all banks, in the form of a request to discount treasury bills to a stated amount. The bank was in no sense obliged to accept them. The trading banks took such amounts of treasury bills as suited their portfolios. ${ }^{31}$ Bank overdrafts without the security of treasury bills continued on a small scale, but the agreement was substantially kept. ${ }^{32}$

It put the Council at the centre of national, that is Commonwealth and States', economic policy because its obligations under the Financial Agreement coupled with the new arrangement for temporary borrowing obliged the Council to meet to discuss the level of government deficits and hence their expenditure and the level of effective demand. The Financial Agreement was, in that most significant sense, a unifying force in federal economic policy formation. However, it was not unification, as stated by Gibson, because the need for so-called temporary loans on a large scale only lasted while foreign exchange reserves were low, the domestic loan market was unresponsive and, most important, budget deficits continued. Once the crisis was over, the federal-State discussions no longer occupied the centre of the stage, and State taxing policies and public works expenditure resumed their fundamental roles in State politics, relegating Loan Council discussions to the less significant place they occupied in the 1920s.

In the circumstances, the whole handling of the matter by the private banks was not only safe for them but very skilful. The weakness lay with the Commonwealth government and its handling of the central bank and monetary policy at a time of grave fiscal difficulties.

By the end of 1930 the central bank had advanced $130 \mathrm{~m}$. and, allied with the private banks, it had shown its strong determination to halt credit because of its fear of inflation. This fear was never satisfactorily

31 Giblin, Central Bank, 86. Early, there was no definite basis of allocation to the trading banks, but a rough guide later followed by the central bank was the amount of deposits held with it: R.C.M.B., paras. 125-6.

32 Giblin, Central Bank, 151. Giblin considered that Gibson was primarily responsible for the policy (p. 56). 
explained ${ }^{33}$ but it was probably both a fear of too high demand causing a worsening balance of payments, and the fear of runaway inflation which central European countries had experienced in the 1920s. The bank Board was therefore making political judgments about the limit to deficit finance, but it made it clear to the acting Treasurer (Lyons) that it was open to the Parliament to relieve the Board of its responsibility for controlling the currency, but while this responsibility remained with the Board it must exercise its best judgment and act accordingly. ${ }^{34}$ This was bluff, as the Senate was expected to block such legislation, as, in fact, it did later.

\section{The Council's role in plans for controlled expansion}

Scullin returned to Australia on 7 January 1931, and three weeks later he reappointed Theodore Treasurer, but they were unable to regain the control of the situation they had exercised up to the end of 1929-30. Theodore was reinstated with the consent of a Caucus majority, because no steps had been taken by January to follow up the Commission's report by either civil or criminal proceedings. In July 1931 the Queensland non-Labor government brought a civil action against Theodore and others, that put in issue the Mungana allegations, and Theodore was completely vindicated on all counts. However, by then the question of Theodore's character was no longer of major importance as the political advantages had been derived from challenging his integrity. Theodore had been a backbencher for six months and when he was reinstated on 29 January 1931 it worsened the widespread series of splits and defections in the Labor Party throughout Australia. Lyons and Fenton resigned from Cabinet in protest, on the grounds that Theodore should have been cleared of the charges first. ${ }^{35}$ In the interregnum of three weeks between Scullin's return and Theodore's reappointment, Gibson's letter to the Loan Council regarding the principles of treasury bill finance was released to the press by Lang. ${ }^{36}$ This and Theodore's reinstatement helped to worsen the feverish controversy and Giblin considered that, from the beginning of 1931, it became increasingly difficult to make an objective judgment on any question of financing the needs of Governments. The propaganda of the extreme inflationists and the activities of the Lang Government had frightened the community'. ${ }^{37}$

As a result of the decision on treasury bill finance, Lang absented himself from all meetings of the Loan Council in 1931 until May, for which he had created a precedent in the 1920s. In 1931, however, he was no longer

33 Ibid., 154, 188; E. O. G. Shann and D. B. Copland (eds.), The Battle of the Plans (a book of documents) (Sydney, 1931), 46; see also chap. 15.

34 Giblin, Central Bank, 88, letter dated 16 December 1930.

35 Sawer, Politics 1929-1949, 7.

36 S.M.H., 19, 21 January 1931, 12.

37 Giblin, Central Bank, 89; P. R. Hart, 'Lyons: Labor Minister-Leader of the U.A.P.' in Cooksey (ed.), The Great Depression, passim. 
concerned with a voluntary arrangement but was confronted with the Financial Agreement, the full weight of which he was ultimately to experience.

Although Scullin had just returned, he and others had come to appreciate the Council's limitations. They had recognised that budget deficits would continue for several years and the Council accepted in mid-January the need for urgent, wider action than was possible under the Financial Agreement. The Council unanimously recommended that policy formation be elevated to the level of an early Premiers' Conference to lay down a three-year plan aiming at the adjustment of public finance and general monetary conditions; and that, in the meantime, an expert officials' committee consisting of Gibson as chairman and an official of each government, except New South Wales which refused to participate, be appointed to investigate the position and prepare information for consideration by the Conference. ${ }^{38}$ It is probable that Lang's refusal to participate in Loan Council discussions at any level was a further incentive to move policy formation to the Premiers' Conference.

The Premiers on 6 February 1930 began an eventful and significant Conference during which the Loan Council met briefly. Theodore, fresh back as Treasurer but still under a cloud, proposed a strikingly modern policy of moderate reflation, ideas for which he undoubtedly absorbed from Professor Irvine. By the time he spoke, there had been a 30 per cent devaluation and wages and prices had fallen over 20 per cent, the wage reduction including a 10 per cent cut by the Arbitration Court. Starting with the comment that a great deal of credit was made available for war finance in 1914-18, he said that credit could be made available to the trading banks by the central bank for advances to industry to absorb the unemployed; the expansion should proceed until prices returned to their pre-depression level, which would not be inflationary or devalue the currency; he hoped the policy would expand the national income by $£ 100 \mathrm{~m}$; he advocated a reduction of the bond rate to start a general downward movement in interest rates to assist governments and the primary producer and as a means to 'bring about equality of sacrifice'; to avoid capital outflow, drastic exchange control might be necessary, and he regarded this step as a means of restoring confidence in London, presumably by stopping the fall in London funds and enabling London commitments to be met-that would enable loans to be raised to settle more of the short-term debt there. ${ }^{39}$ Theodore's proposal was a nearKeynesian solution with one significant weakness-there was no mention of further quantitative restrictions on imports (or other measures) to correct

38 S.M.H., 15 January 1931, 7. There were reports of a quarrel between Scullin and Lyons at this time.

39 C.P.P., 1929-31, vol. II, Conference 6-13 February 1931, 32-6. This was the plan that made Theodore a household word for two generations. 
the balance of payments. Without full knowledge of the level of London funds, and in the light of measures already taken or forced upon the government, this was understandable, but the weakness remained. To a man the Premiers, including Lang, consented, provided the banks agreed'The banking institutions are the responsible authorities in the financial world of Australia today'. ${ }^{40}$

An extraordinary incident occurred at this meeting. Scullin made it clear on the first day that officials were not to make themselves responsible for expressions of opinion as to the policies to adopt and Gibson, chairman of the officials committee, had ruled the same. Their report, signed by all members, consisted of a useful summary of the facts of the financial and economic position, and it had incorporated information from three economists. Simultaneously, the Under-Treasurers of Victoria, Tasmania, Western Australia and Queensland (all public servants), having signed the first report, prepared and signed a second report which was a comprehensive plan for financial reconstruction along narrowly deflationary lines and seriously alarmist in tone; it said, for example, that "The persistent refusal of even one Government to balance its Budget would pile up new credits on which the banking system, moved by the pressure for advances when prices began to rise, could not fail to set up an inflationary boom'. ${ }^{41}$ The report of the four Under-Treasurers was not received, but it was circulated for information. On the surface, it was a gross travesty of proper official action; but it is not clear whether it had the approval of the Premiers of the officials concerned-for example, Barnes (Queensland) and McPhee (Tasmania) had agreed to Theodore's reflation plan provided the banks concurred.

On Monday, 9 February, after a weekend during which he met his Cabinet in Sydney to discuss the two sets of proposals, Lang spontaneously sprang his own plan which had the support of his Cabinet and crystallised the left wing's views by calling for abandonment of the gold standard (which had already been done), compulsory reduction of the interest rate on internal public loans to 3 per cent; and suspension of interest payments on overseas debt, as a weapon to compel overseas bondholders to accept a lower rate of interest. ${ }^{42}$ Among the influences upon Lang, not the least must have been the deflationary minority report of the four officials. Its damage was therefore serious in a situation already critically disturbed by deep disunity. The Loan Council had an unfortunate precedent in this outcome of its request for a report.

The Premiers' Conference directed Theodore to negotiate an $\$ 18 \mathrm{~m}$.

40 Ibid., 50, words of Hill, South Australian Labor Premier and Treasurer; other Premiers at p. 52 and Lang, 'it will be alright', p. 54.

41 Giblin, Central Bank, 90-1; Shann and Copland (eds.), The Crisis, 146-58, 165. The economists mentioned were Professors Brigden, Hytten and Shann.

42 Conference, 9 February 1931, 41; Sawer, Politics 1929-1949, 6. 
loan from the banks. The central bank rejected it, its resolution being: Subject to adequate and equitable reductions in all wages, salaries and allowances, pensions, social benefits of all kinds, interest and other factors which affect the cost of living, the Commonwealth Bank Board will actively cooperate with trading banks and the Governments of Australia in sustaining industry and restoring employment. ${ }^{43}$

The trading banks likewise rejected the plan because it was 'not on sound banking or economic lines'; no other reason such as the level of imports and the state of London funds was given. ${ }^{14}$ The Premiers had been conciliatory, having undertaken, as part of their proposal, to reduce public service salaries and increase taxation.

The Loan Council and Premiers' Conference met late in February 1930 to discuss the banks' replies. The Commonwealth, Victoria and South Australia supported a proposal for Commonwealth legislation to authorise a fiduciary note issue of $£ 18 \mathrm{~m}$. and the other three States opposed it, although at the previous meeting they had agreed that the banks be asked for $118 \mathrm{~m}$. New South Wales was not represented, Lang being busy propounding his own plan and rousing great public opposition in the process. ${ }^{45}$ This division between the Premiers was an important lesson because it revealed, in a crisis, the inadequacy of the Premiers' Conference as a national economic policy forming institution. Neither it nor the Loan Council had the constitutional power nor the necessary unity. In effect, the Commonwealth was left isolated to proceed alone. This it tried to do.

When Parliament reassembled in March, a motion of no confidence resulted in two ex-Ministers, Lyons and Anstey, and four Labor members siding with the opposition and automatically dismissing themselves from the Labor Party. The Lang Labor group, numbering six New South Wales federal members and senators, also defected. In State Labor Parties similar defections occurred, and extra-parliamentary groups initiated the coalition of all those who opposed the Scullin-Theodore and Lang policies. ${ }^{46}$ The weakening Scullin government proceeded with legislation to increase the note issue; later there was an additional, comprehensive set of Acts to give the government effective control of monetary policy, including foreign exchange, but all the legislation was doomed to failure in the Senate; the banks' view on the management of general economic policy, trimmed to the strong political wind, prevailed. However, the attempted legislation was important because it signified two things to posterity. First, the course banking policy should take; and second, the ever present possibility of

43 Shann and Copland (eds.), The Crisis, 182-3; Giblin, Central Bank, 92-3 (letter, 13 February, Gibson to Theodore).

44 Shann and Copland (eds.), The Crisis, 185 (letter, 24 February, Tranter to Theodore). 45 S.M.H., 14 February, 13 and 17 February 1931, 9, which refer to public meetings in town halls in many places.

46 Sawer, Politics 1929-1949, 6. 
disunity in the Premiers' Conference, and the possibility of disunity in, and the narrow powers of, the Loan Council, made it essential for the Commonwealth to act alone within the limits of its constitutional powers in maintaining internal and external economic balance. Thus, with a favourable majority in the Senate, the Labor government of 1931 could have amended the Commonwealth Bank Act to enable the issue of more currency and credit by way of advances to governments and industry. ${ }^{47}$ Just how far the Labor Party would have gone once it was convinced that the foreign exchange reserves were dangerously low is a fascinating topic for speculation. It is a question whether the people would have accepted planning on a war economy basis.

There seems to be little doubt that as early as March 1931 the reserves were down to the absolute minimum. Overtures had revealed that no temporary assistance could be obtained from the Bank of England; the government introduced legislation to do away with the gold base for the note issue, but this was also rejected by the Senate after Gibson had been called to the bar and had given extraordinarily equivocating information. Anticipating events a little, the outcome of the matter of the gold base for the currency was that in June 1931, after the Premiers' Plan, parliamentary authority was obtained and $£ 5 \mathrm{~m}$. of gold was shipped abroad. ${ }^{48}$

The Labor government, the Loan Council and the Premiers were obliged thenceforth to conform to the policies laid down by central and private banks with which the Senate was in full accord. Scullin and Theodore stood as best they could on principle which proved sound in the long period but which was not practicable in the overwhelming circumstances of the day. They were obliged to retreat from position to position until the Premiers' Plan of June 1931 when they compromised with the forces arrayed against them.

47 Ibid., 6, 20-2; Giblin, Central Bank, 95; Norman Cowper, 'The Financial Agreement' in Portus (ed.), Studies, 128, was one of the few observers who appreciated the subtleties of this.

48 See Sawer, Politics 1929-1949, 15-16, and Giblin, Central Bank, 99, for penetrating accounts of this episode; and C.P.D., 6 May 1931, 1615. 
By the end of the first quarter of 1931 it had become clear to Scullin and Theodore that neither the Loan Council nor the Premiers' Conference had the necessary power or unity to manage the nation's general economic policy in the crisis. But they were unable to legislate to gain control of the foreign exchange reserves and monetary or banking policy which they considered the Commonwealth needed in order to exercise adequate control of the situation.

Unable to take effective action in Parliament, they compromised by taking policy formation back to the Premiers' Conference and evolving the Premiers' Plan in mid-1931. The Loan Council's role in the Plan was small but specific-it had formally to approve the conversions of the whole of the Australian-held national debt to a rate of interest 22.5 per cent less than it had been. After the Plan was agreed to, the Council continued what was to become, in the decade of the 1930s, regular bargaining with the central bank for temporary finance and over the size and the terms and conditions of public loans in Australia. By the time Labor was swept from office at the end of 1931, the Council had returned to the formal relationship with governments and the banks which had existed in the 1920s. None the less, the depression had created a political groundswell for change and later chapters will reveal that things could not long be the same again.

\section{The Premiers' Plan of June 1931}

There were several significant events in the months before the Premiers' Plan which were in the nature of preliminaries.

Theodore, in his tussle with the banks, showed again his thorough grasp of the Constitution and the Financial Agreement, and his anticipation of modern arrangements for managing monetary policy. In April 1931, Gibson, on behalf of the Bank Board, had informed Theodore as Chairman of the Loan Council of the Board's decision that a point was being reached beyond which it would be impossible to make further advances on the security of treasury bills; the bank set limits of $£ 25 \mathrm{~m}$. in 
Australia and just over $£ 25 \mathrm{~m}$. in London. Gibson sent copies of his letter to the five States which had accounts with the central bank, thus assuming the function of providing a secretariat for the Loan Council on the occasion of one of its most important pieces of correspondence. The amount of treasury bill and overdraft finance was as in table 10.1.

Table 10.1

Governments' overdraft and treasury bill finance, $1929-35$ (£m.)

\begin{tabular}{|c|c|c|c|c|c|c|c|}
\hline \multirow{2}{*}{\multicolumn{2}{|c|}{ Date }} & \multicolumn{2}{|c|}{$\begin{array}{c}\text { Amount issued } \\
\text { (progressive total) }\end{array}$} & \multirow{2}{*}{\multicolumn{2}{|c|}{ Date }} & \multicolumn{2}{|c|}{$\begin{array}{c}\text { Amount issued } \\
\text { (progressive total) }\end{array}$} \\
\hline & & $\begin{array}{c}\text { Aust. } \\
\dot{f}\end{array}$ & $\begin{array}{l}\text { London } \\
\text { Estg }\end{array}$ & & & $\begin{array}{c}\text { Aust. } \\
£\end{array}$ & $\begin{array}{l}\text { London } \\
\text { fstg }\end{array}$ \\
\hline June & 1929 & 1.5 & - & June & 1931 & 20.6 & 38.1 \\
\hline Dec. & 1929 & 2.5 & 23.1 & June & 1932 & 45.0 & 37.3 \\
\hline June & 1930 & 2.3 & 34.1 & March & 1933 & 51.8 & 34.4 \\
\hline Dec. & 1930 & 9.0 & 38.1 & June & 1934 & 48.5 & 33.6 \\
\hline 2 Apr. & 1931 & 13.4 & 38.1 & June & 1935 & 45.1 & 33.6 \\
\hline
\end{tabular}

Sources: Shann and Copland (eds.), The Battle of the Plans, 44-7; and Commonwealth Auditor-General, Annual Reports; C.F.B.

Theodore replied in characteristic terms to the Bank Board.

The board now intimates to the Government that it will not provide financial accommodation to the Commonwealth or the State Governments beyond a point which will be reached in a week or two. The attitude of the board throughout the recent negotiations, and as disclosed in the letter now referred to, can only be regarded by the Commonwealth Government as an attempt on the part of the bank to arrogate to itself a supremacy over the Government in the determination of the financial policy of the Commonwealth, a supremacy which, I am sure, was never contemplated by the framers of the Australian Constitution, and has never been sanctioned by the Australian people.

In financial matters, as in all other aspects of public policy, the Government is responsible to the electorate, and not to the banks, and this responsibility cannot be renounced by the Government except at the risk of grave danger to the democratic principles of the nation. The control of the public purse has heretofore always been regarded as an essential prerogative of the people, a prerogative which is exercised not by the banking institution, but by the people's representatives in Parliament. The Government will not be a party to any attempt by the bank board, or any other authority, to subvert this principle. ${ }^{1}$ 
Theodore made it clear that further accommodation from the bank was essential for contractual and other obligations, and as a result of his pressure, and the Premiers' Plan, the short-term debt of the governments rose by the end of June to nearly $£ 59 \mathrm{~m}$. or by about $£ 7 \mathrm{~m}$. above the level of early April. There was to be a further issue of $£ 25 \mathrm{~m}$. of treasury bills in 1931-32, and in practice a large proportion of the reflationary treasury bill finance sought was ultimately gained but in an atmosphere which discouraged expansion in private investment and therefore of the economy generally-as Labor had intended. None the less, 'the banks, especially the Commonwealth Bank, can by no means escape Mr Theodore's soft impeachment that they attempted to dictate the financial policy of the Australian Governments'. ${ }^{2}$

At a Loan Council meeting late in April it was accepted that all governments would end 1930-31 with deficits and that they would aggregate at least $£ 25 \mathrm{~m}$; a committee of three Premiers was appointed to look into the question of economies with power to co-opt the services of economists. Professors Giblin (Acting Commonwealth Statistician), Copland (Chairman), Melville and Shann were asked to form a working committee with the Under-Treasurers from all States except New South Wales, which did not participate. ${ }^{3}$

Meanwhile, the groups which had been forming a coalition to oppose the Scullin-Theodore and Lang policies were gathering important adherents. In April and May 1931, these moves came to a successful head when J. G. Latham, Leader of the Nationalist Party in the Opposition and subsequently Chief Justice, resigned his leadership and joined Lyons and his followers in a new party-the United Australia Party (U.A.P.)under Lyons's leadership. Hence, by May 1931, the Scullin-Theodore A.L.P. had but thirty-five members in Parliament and as there were the same number in all the other non-Labor parties and the Independents, the balance of power rested with the Lang Labor group of five. ${ }^{4}$

The point had been reached where the Commonwealth government was faced with the problem of default at home and abroad; it had been humiliated in Parliament and defeated by the central bank; it had been rent by division; the community was frightened; the time was ripe to compromise. One other important move helped set the stage for compromise. On the day the Loan Council met and received the report of the subcommittee, A. C. Davidson, General Manager of the Bank of New South Wales, spoke in favour of a general reduction in interest rates; the banks' liquidity position had substantially improved and his object was to encourage the transfer of rising and extensive fixed deposits into more active current accounts, simultaneously generating an expansion of private

2 Cowper, 'The Financial Agreement', 143.

3 Shann and Copland (eds.), Battle of the Plans, 72; S.M.H., 25 and 27 April 1931.

4 Sawer, Politics 1929-1949, 7. 
investment and trade. ${ }^{5}$ Davidson had lent his support to the conversion of all the Australian-held debt to a lower rate of interest.

The report submitted to the Loan Council by the subcommittee dealt mostly with fiscal policy and how to achieve balanced budgets, and Scullin and Theodore persuaded the Council to refer it to a Premiers' Conference because the proposals were outside the Council's jurisdiction, and no doubt because Lang would not participate in a meeting of the Council, but would attend a Premiers' Conference. ${ }^{6}$ From 25 May to 11 June, during which the Loan Council met formally only on the 10th, what became known as the Premiers' Plan was drawn up. The Loan Council was to be the servant as well as, to some extent, the creator of this Conference, which drew up the nation's general economic policy.

The Premiers' Plan was designed to share the burden of sacrifice involved in the falling national income and to unite the country in a plan which would balance budgets; it was supposed, paradoxically, that it would generate recovery. It was not expected to balance budgets immediately and in the meantime, now that the banks' policies had been accepted, deficits would be met by further treasury bill finance. To these ends, the following measures were agreed:

(a) A reduction of 20 per cent in all adjustable Government expenditure including wages, salaries and pensions.

(b) Conversion of the internal debts of the Governments on the basis of a 22.5 per cent reduction of interest.

(c) Additional taxation to be levied.

(d) A reduction of all bank rates of interest and relief in respect of private mortgages. ${ }^{7}$

Of these measures (b), the reduction of the rate of interest on Australian held debt, affected the Loan Council directly.

\section{The conversion of the national debt held in Australia}

The internal debt conversion was a novel as well as a difficult undertaking. There were numerous conferences of subcommittees with representatives of the central bank, the trading banks, the stock exchange, the life insurance societies and other financial institutions; and the federal Opposition leaders, Lyons, Latham and Senator Pearce, were invited to hear the proposals and took part in the discussion of the major issuewhether the conversion should be compulsory or voluntary. The Opposition members were influential in the decision to make it a voluntary scheme without any open threat of equivalent taxation on bonds which

5 Shann and Copland (eds.), Battle of the Plans, 70 (22 May).

6 S.M.H., 25 May 1931, 9.

7 Shann and Copland (eds.), Battle of the Plans, 127-8. Table 10.I shows that between June 1931 and June 1932, treasury bill finance increased $£ 23.6 \mathrm{~m}$. 
were not converted; the conversion was made automatic unless dissent was filed within a fixed period.

It was left to Parliament to devise what to do with bondholders who did not convert. The total of debt was $£ 558 \mathrm{~m}$. and only 3 per cent of holders failed to convert. The Premiers and then Parliament agreed that certain cases of genuine hardship, mainly people whose entire savings were held in short-dated issues and who were dependent upon repayment on the due date, should be met from the National Debt Sinking Fund; the rest were to be compelled to convert, otherwise they would be favoured relative to the vast majority which converted. ${ }^{8}$

The general conversion was to a 4 per cent nominal rate on 10 issues of new stock with varying maturity dates between 7 and 30 years, but there were some at lower rates. ${ }^{9}$ The importance of the sweeping reduction in interest rates was many-sided. It was fundamental that it provided the concession to governments 'which alone made possible a resolute adoption of the plan',10 and it was expected to encourage expansion of investment and trade. In modern eyes the steps taken in the Premiers' Plan were in fact, deflationary. The Plan was expansionary only in the narrow sense that it might improve expectations and encourage some long-term private investment in which the interest rate was an important item of cost, namely most of building construction and the small proportion of equipment which was long-lived. Under the illusions of the time, however, there was a general belief in the effectiveness of the rate of interest as a significant equilibrator of the economy.

In addition to the effect on investment, there were other political and budgetary reasons for the decision to cut the interest rate. The interest and Sinking Fund commitment of the seven governments in 1929-30 was $£ 63.6 \mathrm{~m}$. out of total revenue of nearly $£ 200 \mathrm{~m}$., excluding roads and special (later Commission) grants from the Commonwealth, or 32 per cent. In 1930-31 it was expected to be nearly 35 per cent because the devaluation of the exchange rate meant more Australian currency was required to pay the same amount of interest on overseas debt; and the estimate for 1931-32 was 37 per cent. In South Australia it was 38 per cent in 1929-30 and was expected to grow in a year or so to 45 per cent. The strain of the interest and Sinking Fund burden on the budgets was very great, and a cut of 22.5 per cent was a shrewdly chosen figure which would give the governments relief and be a reasonable proposition to put to the bondholders and Parliament. The relief was about 7.5 per cent of expenditure from revenue which would help to reduce budget deficits. The report of the Loan Council committee had estimated that from $£ 11 \mathrm{~m}$. in 1929-30, 105 .

8 C.P.P., 1929-31, vol. II, Conference 1-4 September 1931, 9, 13; Giblin, Central Bank,

9 Debt Conversion Agreement Act 1931 and Commonwealth Debt Conversion Act 1931. 10 Giblin, Central Bank, 116. 
the deficits would grow under policies prior to the Premiers' Plan to $£ 31 \mathrm{~m}$. in 1930-31 (when the Conference was held) and they were expected to be nearly $£ 40 \mathrm{~m}$. in 1931-32. The Treasurers bore the brunt of explaining these deficits, and their support, as members of the Loan Council, for the cut in the contracted bond rate as well as other costs must have been more easily obtained than that of other Ministers. It was hoped that the Premiers' Plan would, overall, reduce deficits to about one-third in 1931-32, ${ }^{11}$

The concept of equality of sacrifice in bearing the loss of income had become important politically and the report of the Premiers' Conference referred to the Premiers' Plan as combining all possible remedies to achieve that end. The most seriously affected section was the farmers. The export price index had fallen by 40 per cent between 1928-29 and 1930-31 and farmers' share of the national income fell from 13.3 per cent in 1928-29 to 5.4 per cent in 1930-31. A cut in all interest rates was expected to reduce their costs, especially of overdrafts. From the point of view of political justice, receivers of interest and rent (other than dividends and dwelling rent) had increased their share from 4.7 per cent to 6 per cent, and as a political group their position was hard to defend, except on the important basis of the law of contract. Their real income rose almost proportionately with the fall in prices of about 20 per cent between 1929 and 1931; also, this income was not normally subject to reduction by changing economic conditions as was that of wage and salary earners, farmers and dividend receivers, the latter's share falling steadily from $2 \cdot 6$ per cent to 1.8 per cent in $1932-33 .^{12}$

More important than changes in shares were changes in absolute levels. In January 1931, the Commonwealth Court of Arbitration, after a protracted hearing and a comprehensive survey of the economy, awarded a 10 per cent cut in all railway wages from 1 February 1931. That judgment was followed in other federal and State awards, and together with an additional automatic adjustment downwards as a result of a 10 per cent fall in prices, the total reduction in average money wage rates was 20 per cent of the level in $1929 .^{13}$ Although the share of wages and salaries in the national income rose from 58.6 per cent in $1928-29$ to $64 \cdot 1$ per cent in 1930-31, mainly because farm income fell proportionately more than wage rates, it was not such a notable trend as the downward movement in money wages. Hence the political views of dividend receivers, wage and salary earners and farmers were not sympathetic to rentiers in a period of crushing adversity.

Equally important was the belief that the rate of interest would not

11 Shann and Copland (eds.), Battle of the Plans, 77, 104, 135.

12 H. P. Brown, 'Composition of Personal Income', Economic Record, vol. XXV, no. 48, June 1949, 35.

13 Commonwealth Year Book, 1935, 914; Shann and Copland (eds.), The Crisis, 102. 
be raised again during the period of low wages, low export income and stagnant business. If there is added the several governments' concern to keep expenditure down and the Commonwealth's anxiety to avoid the political backwash from bondholders suffering capital loss in the event of a rise in yields, the conversion operation established the firm basis for a period of cheap money until the start of large-scale war finance.

\section{Some technicalities of treasury bill finance, 1929-35}

There were unusual Sinking Fund aspects of the decision in December 1930 to finance budget deficits by Commonwealth treasury bills which were referred to by Theodore in the budget speech of July 1931.

During the period of rehabilitation of the finances . . . the statutory sinking fund contribution of 10s. per cent per annum will be paid. When we have returned to budgetary equilibrium it will be decided whether the loans covering deficits will be repaid from future surpluses, or whether the annual sinking fund contributions will be substantially increased so as to extinguish the debt within the period of, say, nine or ten years. ${ }^{14}$

There was no published Loan Council decision defining this policy, but there appears to have been 'an informal understanding between the Loan Council and the National Debt Commission' about the Sinking Fund payments. ${ }^{15}$ The policy was essentially a compromise; as long as the governments viewed the treasury bill finance of deficits as temporary, and took no step to fund the treasury bills with long-term loans which would be subject to penalty rates, they undoubtedly felt free to make their own Sinking Fund arrangements outside the formal provisions of the Financial Agreement. But as time passed, the member governments of the Loan Council became disturbed about the legality of the arrangements. Apparently there were suggestions of illegality when P. C. Spender, A. W. Fadden and R. G. Casey were each non-Labor Treasurers and Lyons and later R. G. Menzies as Prime Minister, were chairing the Loan Council during the $1930 \mathrm{~s}$, but the issue was pushed to one side whenever it arose. For example, in April 1938, the Treasurer of Tasmania raised the matter at a Loan Council meeting on advice from his State Auditor-General that treasury bills for budget deficits should carry the higher 4 per cent rate of Sinking Fund payment; however, it seems that the Premier intimated that he did not wish to press the matter. ${ }^{16}$ The Auditor-General reported that the Loan Council had arranged that the bills outstanding were those discounted for works purposes, that there was a tacit agreement between the

14 C.P.D., 9-10 July 1931, 3739.

15 Giblin, Central Bank, 157.

16 H. V. Evatt, Commonwealth Attorney-General, C.P.P., 30 November 1944, 2522.7; T.P.P., vol. CXIX, 1938, paper no. 18, 'Financial Statement for 1938-39 by the Treasurer of Tasmania'. 
Commonwealth and the States to avoid the payment of the 4 per cent Sinking Fund on revenue deficits under the Financial Agreement, and that the Loan Council had connived in the arrangement up to 1934-35.17

In 1935-36 and subsequently, the Loan Council complied with the request of the central bank Board and included in the loan programs the anticipated deficits of all governments, and allocated a portion of loan flotations for that purpose; the National Debt Commission, which had not previously enforced the payment of the 4 per cent sinking fund contribution, demanded such a contribution, which was paid accordingly.

The publicised pressure exerted by the Tasmanian Auditor-General concerning deficit finance prior to 1935-36 roused the concern of the National Debt Commission, which in 1944 sought legal advice from four leading counsel; they expressed the general view that a 4 per cent Sinking Fund payment should have been made by the governments incurring the deficits, instead of $£ 0.25$ per cent each by the Commonwealth and the State. There was a suggestion that counsel may have agreed that the f0.5 per cent should be regarded as a completely legal payment ${ }^{18}$-although apparently not enough. More importantly, the switch of the treasury bill finance to 'works' instead of being for 'budget deficits' appears to have been legally unacceptable.

The implications of the legal opinion were considerable. At $£ 0.25$ per cent the States had paid $£ 1.36 \mathrm{~m}$. whereas it would have been $£ 21.76 \mathrm{~m}$. or about $£ 2 \mathrm{~m}$. a year if they had paid 4 per cent. The difference represented a very great imposition on the States, even though in 1944 their reserves had been swollen by wartime economies, and the issue which arose in that year was how much of the outstanding $\$ 53 \mathrm{~m}$. of bills held in Australia could be redeemed immediately, and how much should be paid off gradually by Sinking Fund arrangements. The claimant States alleged that they were experiencing the usual financial weakness and Victoria resisted a large immediate redemption with the result that, in 1944, the Loan Council decided to redeem $£ 7 \mathrm{~m}$. only, and amend the Financial Agreement by the insertion of clause 12(11) to provide special treatment for the remaining $£ 46 \mathrm{~m}$. of bills; of these $£ 3 \mathrm{~m}$. were redeemed by the National Debt Commission, that being the approximate amount of Commonwealth and State Sinking Fund contributions of $£ 0.5$ per cent together with accumulations at 4.5 per cent. No further contributions to the Sinking Fund were to be made in respect of the $£ 3 \mathrm{~m}$., even though they were cancelled securities. The remaining $£ 43 \mathrm{~m}$. of bills was converted to debentures in new provisions that in no way vitiated the seventeen-year obligation in respect of later deficits funded. The details are set out in the 1944 amendment of

17 T.P.P., vol. CXXVII, 1942-43, 'Annual Report of the Auditor-General of Tasmania, $1941-42,3$.

18 C.P.D., 17 November 1944, 1896, and 30 November 1944, 2524 (Prime Minister); W. J. Campbell, Australian State Public Finance (Sydney, 1954), 175-6. 
the Financial Agreement and show the disproportionate allocation of the loan program in the early 1930s in favour of New South Wales. Victoria's very small proportion may, in part, explain the State's reluctance to have more than $£ 7 \mathrm{~m}$. met from reserves.

The elaborate treatment given to the short-term debt held in Australia poses a question-why was not the London-held short-term debt treated in a similar manner? In fact, it was not until 1956-57 that the London bills and debentures issued in the downturn of the depression in 1929-31 were converted to Australian long-term securities.

It would seem that pressure on the Loan Council to do something about the Australian-held debt emanated from the central bank as well as from the Tasmanian Auditor-General. The bank became concerned from 1942 onwards about the surpluses of revenue that the States were able to accumulate under wartime conditions. In correspondence with the Treasurer in 1943 and 1944, the bank pointed out that the accumulated surpluses 'would free them from any control by the Loan Council in the post-war period and was likely to result in a riot of spending which would be in direct conflict with the monetary policy on which the Government and Bank were agreed'. ${ }^{19}$ Proposals put to the Treasurer by the bank were considered by the Council throughout 1943 and 1944, including proposed amendments to the Agreement. The net result was, as has been noted, a reduction of only $£ 7 \mathrm{~m}$. in the cash reserves of the States. The bank's bargaining position in this protracted controversy was that it had constantly renewed the bills at low interest rates and it could choose not to renew them. It was notable that the reduction of liquidity in the hands of the States appeared to be the main issue rather than the legality of the treasury bill arrangements; had legality been taken as seriously, the London-held debt would have been considered simultaneously. A further possible reason for restricting the matter to the Australian-held portion was that it was smaller and was more likely to be acceptable to the Loan Council than the larger sum of Australian plus London bills.

The London-held treasury bills reached a maximum of 5 stg $38 \mathrm{~m}$. in 1930 and gradually fell to $f s t g 23 \mathrm{~m}$. in 1955, mainly as a result of small, fairly regular redemptions; in mid-1944 the amount that would have had to be considered by the Council was $£$ stg $25 \cdot 8 \mathrm{~m}$. This debt had been incurred to obtain sterling to meet governmental liabilities, mainly interest in London; the British public, the London and Westminster Bank and the central bank had provided the exchange, including gold from the Note Issue Reserve in 1931. As time passed, the central bank met the privately held bills and debentures from its reserves and retained the securities. ${ }^{20}$ It would seem to be a measure of the psychological problem created in the mind of

19 Giblin, Central Bank, 311.

20 R.C.M.B., 54 et seq.; successive Treasury issues in C.P.P. of 'Government Securities on Issue', table headed Australian Short-term Securities, London and Australia. 
the Australian public concerning London finance in the depression that it was deemed desirable to renew these bills quarterly, in some cases for twenty-five years, until they were replaced by longer-term securities issued in Australia and held by the central bank in return for the service rendered so long before.

\section{The Loan Council in the second half of 1931 -the anti-climax}

The Loan Council's policy in the remainder of 1931 can be summarised briefly, the main point being that it was a period of relative anti-climax after the events up to the Premiers' Plan.

After the February Conference at which Lang had proposed suspension of overseas interest payments, his government logically refused in March 1931 to pay the Commonwealth the equivalent of interest payable to the Westminster Bank. The Commonwealth, being liable to the bondholders, arranged payments on the due date without entering into public controversy with New South Wales. The people were not left in ignorance of these technicalities of the Financial Agreement with their considerable political overtones, as there was some newspaper comment with Sir Edward Mitchell to the fore again; it was generally appreciated that the Commonwealth, not the State, was directly responsible to bondholders. ${ }^{21}$ Lang was allowed to get away with delaying payments; Scullin and Theodore appear to have played the incident down.

In July 1931, Lang sought assistance of $£ 0.5 \mathrm{~m}$. in July, £2m. in August and $f 1 \mathrm{~m}$. in September, as he had been refused overdrafts by two private banks unless he presented Commonwealth treasury bills. Scullin circulated the request to the members of the Loan Council who reacted unfavourably, mainly because New South Wales was persisting in its refusal to pay interest. On 23 July, Lang was informed accordingly, and on $28 \mathrm{July}$, he undertook to pay interest and cut his government's expenditure, as agreed in the Premiers' Plan, and received in reply an assurance of the $10.5 \mathrm{~m}$. for July. ${ }^{22}$ Lang attended a Council meeting in mid-August, the incentive being more treasury bill finance. The passage of a salaries reduction bill by the New South Wales Parliament in the first few days of this Council meeting resulted in formal approval of Lang's $£ 0.5 \mathrm{~m}$. by the Council, and then by the central bank by letter. ${ }^{23}$

A committee was appointed at this meeting to examine government accounts and submit a monthly statement on progress towards the target deficits, and to prepare a statement of requirements, presumably meaning proposed shares in deficit finance. ${ }^{24}$ By the end of 1931, only the Labor governments in the Commonwealth, Victoria and South Australia had

21 C.P.D., 20 March 1931, 749 (Theodore); S.M.H., 30-31 March, 1 April 1931.

22 S.M.H., 23 June 1931, 21; 29 July 1931.

23 Argus, 8 August 1931, 19; 10 August 1931, 7.

24 Argus, 11 August 1931, 7. 
kept to the Plan, and of the non-Labor governments, Western Australia lagged most per head, closely followed by Queensland and much less so by Tasmania. New South Wales, the only Labor government to lag, did so less per head than Western Australia, but its size, together with 'the instinctive belief that $\mathrm{Mr}$ Lang had no real intention of reducing his deficit', kept attention on New South Wales. ${ }^{25}$ A second secretariat was created to investigate and report on projects proposed for development and was a forerunner of the wartime National Works Council and the wartime and post-war Co-ordinator-General of Works. ${ }^{26}$ Its purpose was to assist in convincing the central bank, in the continued bargaining which ensued, that certain expenditures were necessary. Every effort was made to please the bank, judging by newspaper reports, ${ }^{27}$ and Giblin summed it up thus: "There was a long continued haggling between the Loan Council and the Bank which resulted in very moderate sums being put at the disposal of Governments for special and defined purposes, including the restoration of State Funds which had been drawn upon to meet Treasury needs before the Premiers' Plan. ${ }^{28}$

An example of this bargaining occurred at the next Loan Council meeting and was characteristic of many meetings to follow. The Council tried to reach agreement with the central bank Board about the amount of treasury bill finance governments could expect as the 'loan program' for 1931-32. The Premiers' secretariat committee proposed $118 \mathrm{~m}$. and the Board replied with a limit of $£ 15 \mathrm{~m}$., which became the subject of bargaining reported in the press daily between 8 and 12 September; ${ }^{29}$ after waiting the whole of the 12th for the bank Board's decision, the Council was informed by letter from Gibson that the representatives of the banks have decided to make certain representations to their various boards for the provision of some measure of financial assistance embraced under the requests submitted'. ${ }^{30}$

The Loan Council disbanded and waited. Scullin received a long letter from Gibson on 17 September which was presented to Parliament. The amount provided was $£ 16.5 \mathrm{~m}$., made up of $£ 8.5 \mathrm{~m}$. for existing works, $£ 5 \mathrm{~m}$. for new works for six months and $£ 3 \mathrm{~m}$. for necessitous wheat farmers. The report of the development works secretariat was reviewed and drawn upon by the banks in Gibson's letter to lecture the governments on adhering to the letter and the spirit of the Premiers' Plan. ${ }^{31}$ This was the last Loan Council meeting under a federal Labor government before the war but the

25 Giblin, Central Bank, 123-4.

26 S.M.H., 12 August 1931, 12.

27 S.M.H., 14 and 15 August 1931, 13; Argus, 15 August 1931, 21.

28 Giblin, Central Bank, 125.

29 See Argus and S.M.H. on 8, 9, 10, 11 and 12 September.

30 S.M.H. and Argus, 14 September 1931, 9 and 7 respectively.

31 S.M.H. and Argus, 18 September 1931, 9, 10. 
bargaining with the banking system was to continue until well into the 1930s.

The Labor Party was so badly split that it could not recover electoral confidence before the end of the decade. It was not until 1936 that the Lang Labor members and the Scullin A.L.P. members of the federal Parliament achieved unity, by when the depression had run its course. ${ }^{32}$ The non-Labor parties were re-elected with overwhelming majorities in 1932 and 1934 under Lyons's leadership. The policy speech upon which Lyons's government was returned to power in 1932 revealed clearly the national concern to return to the conditions upon which the Financial Agreement was based-balanced budgets; foreign exchange reserves and credit policy largely in the hands of the private banks; interest rates on governmental borrowing decided by the Loan Council in consultation with, but basically at the direction of the banks, speaking through the central bank; and all except the budgets to remain independent of ministerial and parliamentary control in the belief that governments could not be trusted with monetary policy and foreign exchange reserves, as it would lead to inflation.

None the less, the events of 1930 and 1931 had shaken thinking at all levels in the community to its foundations. Within a few years, there were realignments; the Loan Council was involved in negotiations that shifted much more power over general monetary policy from the traditional holders to the central government and its authorities. But the realignment of power occured as well in the area of revenue raising and payments by the Commonwealth to the States. 
Non-Labor governments held office from 1932 until the eve of Uniform Taxation in 1942. Lyons was Prime Minister until he died in 1939 and he participated in the main changes that occurred. From its very first days in office, Lyons's government was heavily involved in financial relations with the States. The Loan Council and the Financial Agreement were important in these events, particularly the Garnishee Case, but they were by no means the whole of them as the Grants Commission was established in 1933 and there was a flowering of other s.96 grants for specific purposes in the second half of the 1930s. The increasing financial assistance to the States eroded the effectiveness of the Financial Agreement as the basis of a co-ordinate financial system for the federation. The overall effect of all the changes that occurred in respect of revenue arrangements in the 1930s was a further strengthening of the Commonwealth's position relative to both the States and the Loan Council.

\section{The Garnishee Case, 1932}

The Loan Council met in January 1932, and the important matter of the New South Wales default on payment of interest due was brought to a head by Lang. He was probably influenced, inter alia, by the change of federal government (Lyons was in his first month of office) and by the latest expressed attitude of the central bank Board. In that month, Gibson had informed Lyons that the central bank's policy remained unchanged following the change of government. 'It is needless to point out that my Board cannot control the situation, except by refusing to provide national finance . . Needless to say my Board dislikes the position which it is compelled to take up in connexion with these matters, but it cannot evade its responsibilities as custodian of the monetary system of the financial fabric of the country.' 1 Lang was influenced as well by the very high level of

1 C.P.P., 1932-34, vol. IV, 'Conference of Commonwealth and State Ministers, 28 January to 5 February 1932', Report, Appendix B. letter dated 13 January 1932; and Argus, 1 February 1932, 8. 
unemployment in his State. He informed the Council that he was unable to meet in full overseas interest obligations due in London, amounting to $£ 958,763$ and he asked for $£ 0.5 \mathrm{~m}$. from the central bank. The Loan Council was not prepared to sanction the application being made. ${ }^{2}$

Although the bonds in question came within the scope of the Financial Agreement,

there had been no express new agreement between the bond-holders and the Commonwealth, so that the only legal liability as a matter of contract was that of the original borrower-the State of New South Wales. It was accordingly open to argument that if the Commonwealth now paid the amount due, it would be doing so without any legal obligation and could not recover from New South Wales. Partly for this technical reason, and partly on the view that the people of New South Wales should be exposed to the shock of being classed as defaulters, Lyons and Bruce (the latter of whom played a prominent part throughout these affairs) did not pay on the due date, but waited until legislation could be passed which put the Commonwealth's legal duty to pay beyond doubt. ${ }^{3}$

The Financial Agreement (Commonwealth Liability) Act no.2 of 1932 (assented to 12 March 1932) settled the doubts as to the construction of the Financial Agreement of 1927, by which the Commonwealth took over liability for the debts of the States, by asserting that the Commonwealth was directly liable to holders of State securities and might be sued by holders. It was a step in the process of compelling New South Wales to discharge its obligations under the Financial Agreements, but the Act had permanent effect.

Simultaneously, the Commonwealth Parliament passed the Financial Agreements Enforcement Acts 1932, containing provisions of an unprecedented kind, designed to secure the payment of the amount due by a defaulting State, in this case, New South Wales. The Financial Agreements Enforcement Acts (nos 1, 2, 3, and 4) of 1932 established a procedure by which a State in default might be compelled to pay.

The State of New South Wales brought an action in the High Court against the Commonwealth and others, claiming a declaration that the Acts were ultra vires the Commonwealth and were invalid. The political manoeuvring in this episode was extremely involved and has been described by Professor Sawer; it was mainly between the Commonwealth non-Labor government and the State, although the challenge in the High Court had the support of the Victorian Labor and the Tasmanian non-Labor governments, neither of which approved debt repudiation, but both of which 
feared the threat to State 'sovereignty' which the Enforcement Acts involved. ${ }^{4}$

In March 1932 the scope and meaning of s.105A fell for determination by the High Court. The Court considered Act no.1 above. In effect, s.5 of the Enforcement Act required the Auditor-General to certify to the Treasurer the amount by which a State was in default to the Commonwealth under or by virtue of the Financial Agreements, and provided that after the publication by the Treasurer of the certificate in the Gazette, the Attorney-General may apply to the High Court for a declaration that the whole or part of the amount is due and payable and unpaid by the State. The declaration was to be enforced as a judgment and shall in addition to any other remedies for enforcing such judgement by law provided operate as a charge upon all the revenues of the State'.

The section then provided that a resolution may be passed by both Houses of Parliament, bringing into operation ss.7-13 of the Act in relation to revenues of the State which are specified in the resolution. Thereupon those sections would, to the extent of the amount so declared by the Court, apply in relation to the State. The effect of ss.7-13 was to create an involuntary assignment of the specified revenues of the State to the Commonwealth during a period commencing at a date fixed by proclamation and ended by a proclamation when the State's debt to the Commonwealth was paid. The revenue became payable to the Treasurer of the Commonwealth; payment to the Treasurer by a person liable to the State operated as a discharge of his liability to the State; the Commonwealth could sue persons liable to the State in respect of any of the specified revenue; no moneys owing to the State in respect of the specified revenues could be paid to the State and such a payment if made should not operate in discharge of the liability; it was made an offence for a Minister or other officer of a State to receive or permit to be received any such moneys or to give an indemnity in respect of any such payment. The Commonwealth was required to refund to the State any amount received in excess of the State's liabilities to the Commonwealth. The revenues of the State concerned were to be taken as including moneys held to its account by banks.

Section 6 of the Act provided for emergency 'receivership'. In the event of urgency and in order to protect the interests of the Commonwealth before the determination by the High Court, both Houses of Parliament were authorised, if the Auditor-General gave a certificate setting out the amount of a State's default, to approve the certificate and to resolve that certain provisions of the Act should apply to a specified State on the condition that the Commonwealth applied to the Court for a declaration within two months of the resolution. The Court, not the Auditor-General, had the power to determine whether a State was liable. The section also 
provided that a State could apply to the Court for a declaration that all or part of the money was not due. The States had three days in which to serve notice on the Commonwealth.

The Act therefore prescribed two methods of securing the receipt by the Commonwealth of the moneys due by a defaulting State.

The main ground of the States' attack was that execution of judgments could not issue against State governments, as the satisfaction of their financial obligations required an Appropriation Act of the State Parliament; this had been asserted with emphasis two years before in the A.R.U. Case. ${ }^{5}$ It was argued that $5.105 \mathrm{~A}$ did not increase the power of the Commonwealth in this respect, and in particular s.105A(3), giving the Commonwealth Parliament power to make laws for the carrying out by the parties of their agreement, was not an authorisation of laws for the enforcement of the agreement in case of breach. It was also contended that if $5.105 \mathrm{~A}$ conferred a power of enforcement, it could not be exercised discriminately in favour of the Commonwealth against the States.

The High Court (Gavan Duffy CJ. and Evatt J. dissenting) held that Part II (Enforcement Against State Revenue) of the Financial Agreements Enforcement Act 1932 was valid. ${ }^{6}$

Rich and Dixon JJ., in a joint judgment, considered that ss.5 and 7-13 of the Enforcement Act which related to action after the judgment of the Court were within the power conferred upon Parliament by s.105A(3) that 'The Parliament may make laws for the carrying out by the parties thereto of any such agreement' and that they were also within the power derived by the Parliament from the operation of certain other sections of the Constitution. Section $105 \mathrm{~A}(5)$, relating to the binding nature of an agreement with respect to State debts according to s.105A, made such an agreement obligatory upon the Commonwealth and the States, placed its operation and efficacy beyond the control of any law of any of the seven Parliaments, and prevented any constitutional principle or provision operating to defeat or diminish or condition the obligatory force of the agreement. The Commonwealth Parliament could enable the High Court to pronounce a judgment that is unconditional, and could enact laws for the enforcement of that judgment against the State. A Commonwealth law which provided the alternative to voluntary performance by the parties and compelled involuntary satisfaction was properly described as a law for the carrying out by the parties thereto of the Agreement. The provisions of s. 6 of the legislation enabling Commonwealth action before the determination of a

${ }^{5}$ (1930) 44 C.L.R. 319. The decision contains dicta suggesting that, although judgments may be obtained against States under federal laws, protection of State autonomy requires limitation on the possibility of carrying such judgments into execution. G. Sawer (ed.), Federalism (Melbourne, 1952), 265.

6 New South Wales v. Commonwealth (no. 1) (1932) 46 C.L.R., 155; 6 A.L.J., 38-42; 4 Austn Digest, 155; Garnishee Cases nos. 2 and 3 (1932) 46 C.L.R., 235, 246. 
State's liability by the Court were held to be valid and, strong as this provision was, it was regarded in the conditions which prevailed at the time of the judgment as reasonably necessary to ensure payment of a liability if and when judicially established.

McTiernan J. referred to the imperious character of the language employed' in s.105A(5) which states that an agreement on State debts according to s.105A shall be binding upon the Commonwealth and the States parties thereto notwithstanding anything contained in the laws or Constitutions of the States or the Commonwealth'. This, he said,

in my opinion, renders certain the paramount force of any Financial Agreement to which the sub-section applies. It restrains the Commonwealth and every State, which is a party to such an agreement, from contravening the Agreement and raises the obligations, which the Agreement fastens on the parties, to the level of an obligation arising out of the Constitution itself.

He held s.6 to be valid and said that the Financial Agreement was not a mere political engagement but was a contract of strict legal obligation and that a breach of the Agreement gave rise to a justiciable matter. ${ }^{7}$

An application to the High Court on behalf of the State of New South Wales to appeal to the Privy Council was refused by a majority but the reasons for the application included a statement of the importance to the State of the Court's decision in the Garnishee Case ${ }^{8}$ It deprived the defaulting State of the power to appropriate, control and expend its own revenues while default continued; it enabled the Commonwealth to appropriate revenues of a defaulting State contrary to the will of the Parliament of the State when it defaulted; it impaired the officers of the defaulting State in discharging the powers and functions imposed on them by the legislation of the State during the period of default; it enabled the Commonwealth to destroy the capacity of officials lawfully appointed by the State whilst default continued; and it enabled the Commonwealth to deprive the defaulting State of the power to discharge its functions, including its exclusive functions, during the period of default.

That was but one side of the matter. Section 105A, particularly subsection (5) operates to restrain the power of the Commonwealth no less than that of the States, for an agreement relating to State debts, once made,

is part of the organic law of the Commonwealth. It can only be varied or rescinded by the parties thereto. Nothing in the Constitution or in the Constitution of the States can affect it or prevent its operation. It creates rights and duties as between the Commonwealth and States upon

7 (1932) 46 C.L.R., 228. The minority judgment of Evatt J. was of significance. See also Sawer, Politics 1929-1949, 64.

8 (1932) 46 C.L.R., 235. 
and in respect of which the judicial power of the Commonwealth can be exerted. ${ }^{\vartheta}$ If a Commonwealth Act contains provisions inconsistent with a term of an agreement made in pursuance of s.105A of the Constitution, the Commonwealth Act is necessarily invalid.10

But there are differences between the relative positions of the parties. Any one or all of the States can enforce the Agreement against the Commonwealth, or against any other State, through the Courts. The Loan Council is not dependent upon the Commonwealth to provide remedies in the event of the Commonwealth's failure to fulfil the conditions of the Agreement or the Council's decisions under the Agreement. However, apart from appropriate Commonwealth legislation like the Garnishee Acts, to assist the cause of a State, the States would only be able to obtain declarations, not garnishee or charging orders on taxes, bank accounts and the like. The Garnishee Case also revealed that in exceptional circumstances relating to the States' debts, the States are dependent upon the Commonwealth to provide the extraordinary remedy of acting for itself, or on behalf of the States or the Loan Council, before a decision of the High Court and on the Commonwealth's presumption of a breach of the Agreement, subject to the State's right to apply to the Court to seek redress. In the use of its power the Commonwealth cannot circumvent the Courts. ${ }^{11}$

The Garnishee Case established that s.105A altered the original position of the Commonwealth and the States in relation to agreements with respect to State debts in three respects. (1) It vested the Commonwealth with legislative power to create temporary extra-judicial remedies to be exercised prior to the ordinary judicial powers of enforcement. (2) The States do not have this right, but retain the right to seek redress through the Courts. (3) The Commonwealth can accept public moneys of a defaulting State and enforce action to obtain same in the absence of State Appropriation Acts in order to meet a defaulting State's obligations under the Financial Agreement. The effects of this upon a State have been listed above. ${ }^{12}$

It has been suggested by Norman Cowper that if a State refused to obey the decision of the High Court in a matter pertaining to an agreement under s.105A, and either a Governor retained the State government in office or the same government was re-elected to power, there would be three possibilities: (a) the breaking up of the federation; (b) civil war; or (c) that some other person not commanding a majority in the State Parliament should be called upon to govern. ${ }^{13}$

9 Starke J. (1932) 46 C.L.R., 186; see also McTiernan J., 228, Evatt J., 202.

10 Latham CJ., Bank Nationalisation Case (1948) 76 C.L.R., 244.

11 Rich and Dixon JJ. (1932) 46 C.L.R., 181-2 and Starke J., 190-1; S. R. Davis, 'A Unique Federal Institution', 2 University of Western Australia Annual Law Review, December, 1952, 389-90.

12 Davis, 'A Unique Federal Institution', 389-90.

13 Cowper, 'The Financial Agreement', 141. 
The effect of (c) would be to prevent the people of the State from having the government they desired, and the three possibilities could only be put into practice if the Governor in the exercise of his duties or the Commonwealth in the exercise of its powers were willing to go that far.

The climax to the Garnishee Case came in May 1932. By 13 May, the

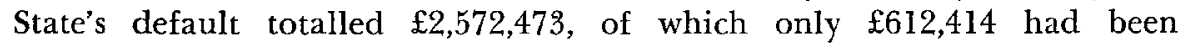
recovered by garnishee action by the Commonwealth, throwing some doubt upon the efficiency of the method. The Lang government was that day dismissed from office by the State Governor after Lang caused a circular to be issued to State public servants requiring them to pursue a procedure in the handling of public moneys in conflict with the method required by the federal government's legislation. ${ }^{14}$

Section 105A, then, writes into the Constitution any financial agreement made under it, and sets the provisions of an agreement not only beyond the reach of all Parliaments except when they are unanimous about a change, but beyond the reach of the processes provided for constitutional amendment by s.128. Presumably, deletion or a change of $5.105 \mathrm{~A}(5)$ by the processes under $\mathrm{s} .128$ would be possible, altering the conditions upon which an agreement may be made. ${ }^{15}$

The provisions of s.128, inter alia, enable one House of Parliament in conjunction with the necessary majority of voters in four States only, provided they happened also to be the majority of persons voting, to alter the Constitution against the wishes of the remaining two States. Sir Edward Mitchell asserted that 'any party to the Agreement . . . could successfully oppose any one or more of the other six parties taking steps under section 128 or otherwise, to alter the provisions of section $105 \mathrm{~A}^{\prime} .^{16}$ The basis for Mitchell's view would seem to be that an agreement under s.105A shall be binding on all parties 'notwithstanding anything contained in this Constitution or the Constitution of the several States'. The answer to Mitchell's contention was provided by the reviewer of his book who said, rightly it is submitted, that it is not reasonable to contend that an amendment duly made to the Constitution can so operate as to limit the legal power to make future amendments while s.128 stands. He also found it still more difficult to understand how a mere agreement made under a constitutional power can react upon and limit the organic law itself; the Commonwealth and the States by mere agreement cannot impose restrictions upon the constituted means of amending the Constitution..$^{17}$

14 Sawer, Politics 1929-1949, 52; H. V. Evatt, The King and His Dominion Governors (London, 1936), chap. XIX.

$15 \mathrm{~K}$. H. Bailey, 'The Working of the Constitution Since Federation' in Portus (ed.), Studies, 48; A. P. Canaway, 'Section 105A of the Commonwealth Constitution', 12 A.L.J. 1939, 325-7; and Wynes, Powers, 698.

16 Mitchell, What Every Australian Ought to Know, 23. See also his Supplement to What Every Australian Ought to Know (Melbourne, 1933), 11.

17 R.G.M., 5 A.L.J. 1932, 358. It is not hard to guess who R.G.M. may be. 
If by the processes of s.128 the people voted for the abolition of State Parliaments, the Financial Agreement would become unworkable because, inter alia, there would no longer be a State Premier to appoint to the Loan Council nor State machinery for independently raising funds within the State and appropriating them to satisfy its liabilities to the Commonwealth as incurred under the Financial Agreement. The abolition of State Parliaments and the repeal of s.105A are bound up together..$^{18}$

While s.105A(5) seems to contemplate executive action as sufficient for making, varying and rescinding agreements, it has been suggested that both the Commonwealth and State Parliaments could legislate to prescribe the methods by which their will as 'parties' is to be expressed. This would relate to matters concerned with the management of existing debt and incurring new debt, and has nothing to do with the expenditure of loans, which must still be authorised by Appropriation Acts of the several parliaments. In fact, the terms of s.105A would not seem to authorise an agreement giving the Loan Council authority to specify the purposes on which loan money is to be spent. ${ }^{19}$

The power conferred by s.105A was tested in relation to banking matters in Melbourne Corporation v. The Commonwealth. Latham CJ. and Williams $\mathrm{J}$. said, in effect, that the Loan Council but not the Commonwealth can regulate a State's banking arrangements, and then only the effective rate of interest consistent with clause 5(9) of the Financial Agreement, which provides that a State may borrow money by way of overdraft, 'subject to maximum limits (if any) decided upon by the Loan Council from time to time for interest, brokerage, discount, and other charges' ${ }^{20}$ In the Bank Nationalization Case, it was argued that both the above clause of the Agreement and clause 6(7), which contains similar provisions regarding Commonwealth borrowing by way of overdraft, conferred upon the States and the Commonwealth the right to borrow on overdraft, and destruction of the banking system as it existed at the time when the Financial Agreement was made was invalid in view of s.105A. Only two judges accepted this view, the majority concurring in the view that the Financial Agreement did not import continuance of the banking system in its existing form. In the words of Dixon J.

If the clause confers upon the States any constitutional right, as against the Commonwealth, to borrow by way of overdraft, I should put it no higher than a right to seek an overdraft from whatever banking institutions are from time to time provided or permitted by law and are conducting banking business. ${ }^{21}$

18 A. P. Canaway, 'Section 105A of the Conmonwealth Constitution', 12 A.L.J. 1939, 325-7.

19 Sawer, Cases, 54.

20 (1947) 74 C.L.R., $63-4,101$.

21 Bank of New South Wales v. Commonwealth (1948) 76 C.L.R., 1, 339 (H.C.); (1949) 79 C.L.R., 497 (P.C.). 
The Garnishee Case of 1932 was a many-sided political and constitutional event of considerable historical significance. By constitutional interpretation, the Commonwealth's financial position was strengthened and the decision cut across the intention of the Constitution to establish States' autonomy over their revenues. In principle, however, Uniform Tax under s.96 is more important but it came ten years later. In the context of the depression, the Commonwealth's action against New South Wales greatly strengthened the Commonwealth's position in the eyes of the public; it resulted in the departure of a controversial member of the Loan Council after at least two years of bitter division in the Loan Council and Premiers' Conferences; and it meant at the same time that the proponents of orthodox policy (balanced budgets, no political influence on central banking policy to obtain extended credit for public works purposes) had become completely dominant. It was an outcome which helped greatly to smooth Lyons's path early in his long term in office.

\section{The Grants Commission complements the Loan Council}

The Commonwealth's success in the Garnishee Case of 1932 was followed in 1933 by the legislation which formally established the Commonwealth Grants Commission. Lyons had foreshadowed 'some definite plan' in his Budget Speech in September 1932.22

The creation of the Grants Commission owed much to Giblin, whose influence on fundamental policy in federal finance in the 1920s has already been considered. In 1926, he also recommended an independent advisory body to make proposals to the Commonwealth Parliament 'with powers and duties corresponding roughly to those of the Tariff Board', which is essentially an independent advisory authority. ${ }^{23}$ Giblin's proposal received support, with some minor amendments, from a wide variety of persons in the smaller States' public services and the academic, political professional and business spheres. ${ }^{24}$ It was the height of the era of federal authorities made independent of the governments which created them and which were, none the less, empowered to recommend policy or to influence the government's policies directly. The central bank's power was another very significant example.

The Report of the Royal Commission on the Finances of South Australia as Affected by Federation in 1929 concluded that although South Australia was the third State to seek special (later Commission) grants, there was no body of principles for the determination of the amount of such payments. It suggested that 'This duty should be delegated to a small body of men,

22 C.P.D., 1 September 1932, 105.

23 L. F. Giblin, 'Federation and Finance', Economic Record, vol. II, no. 3, November $1926,158$.

24 R. J. May, Federation and Financial Inequalities in Australia (M.Ec. thesis, University of Sydney, 1964), 103-4. 
specially qualified for the purpose, who would be able from time to time to inform the Commonwealth and the States authoritatively of the interactions of their policies and financial proposals' ${ }^{25}$

South Australia joined Tasmania in becoming a strong advocate of an independent authority as the depression deepened and the unemployment in South Australia became the worst in the Commonwealth. There was, as might be expected, a sympathetic reaction from Scullin; in 1931, he amended the terms of reference of an inquiry by the Commonwealth Parliament's Joint Committee of Public Accounts so that it might establish a basis for a common approach to the small States' claims. Although this was a step forward in achieving uniformity of principles, it did not go as far as establishing an independent advisory authority outside the Parliament, which would develop a body of doctrine. ${ }^{26}$

Up to 1930, there had been a series of ad hoc arrangements based on both the Commonwealth's and the States' view that the marginal adjustments in special (later Commission) grants should be made for 'disabilities' suffered by smaller States as a result of federation and the Commonwealth's policies, particularly the tariff, the Navigation Act and the federal wage awards of the Arbitration Court. By 1930, Giblin had formed the view that differences in income per head were due to other factors as well, including wide variations in natural resources and population; he argued that, altogether, they made a 'needs' basis the appropriate one for special grants. First, he constructively criticised the several governments' attitude by applying studies of the cost of the tariff to Tasmania to show that, among other things, an adverse effect on population growth in Tasmania was one important consequence of the Commonwealth's tariff because it developed industry in and attracted population to eastern States, and that this could neither be measured in money terms nor offset by special (later Commission) grants. Secondly, he argued that it was impossible to separate disabilities arising from federation from natural disabilities in respect of resources and geography, and that both are equally relevant in assessing the needs of the States for grants of this kind.

There is no question of remedying the disabilities of the State. For the most part they must continue to be borne. It is a question only of supplying the urgent necessities of the State Treasury, and the amount may be ascertained with due precautions from an examination of the Treasury position.

He suggested precautions, or the conditions, of special (later Commission) grants to a State in his appendix to The Case for Tasmania 1930.

(1) It should be taxing its people with considerably greater severity than the Australian average. (2) It should not be attempting social provision 
on a more generous scale than the average. (3) Its costs of administration should be below average. (4) It should for some years at least have shown moderation and caution in loan expenditure. ${ }^{27}$

He recommended a part-time board of three with a permanent secretary and it was a logical ending to the mounting pressure from the three smaller States and the general acceptance of Giblin's principles by leaders in the community when, in 1933, Lyons, the former Premier of Tasmania, appointed the Grants Commission with Giblin as a member and a structure such as Giblin had suggested. ${ }^{28}$ Impartiality and independence from political and departmental influence was aided by having the Commission attached to the Prime Minister's Department, not the Treasury; by having it report to the Governor-General, not to the Prime Minister; and by its secretariat being located in Melbourne, the capital of a non-claimant State, not Canberra. More than anything, the impartiality and the industry of the Commission were to advance its reputation.

The basic sociological and political propensity at the back of it, which has shown no sign of changing, was the national preference for Australiawide uniformity of treatment by governments. ${ }^{29}$ This was explicitly defined in the Third Report of the Commission.

Special grants are justified when a State through financial stress from any cause, is unable efficiently to discharge its functions as a member of the Federation and should be determined by the amount of help necessary to make it possible for that State, by reasonable effort, to function at a standard not appreciably below that of other States.

This purpose made the task of successive federal political parties easier as they sought to win Senate and House of Representatives seats in the smaller States.

Giblin persuaded the Commission to accept his basic approach, and the conditions of grants as finally adopted in the Third Report (1936) were much as he had developed in 1930 . The fiscal need of a claimant State was its budget deficit, not the needs of its individual citizens, and the Commission thus avoided the subtleties of assessing the welfare gains and losses of different sections of the community. The practical details were that the claimant States' budget results were compared on a per capita basis with the average of the three non-claimant States. The deficits of the claimant States were each corrected for differences in accounting procedure; they were adjusted by the amounts by which their taxation collections exceeded the non-claimant States' average severity; and they were adjusted by the

27 H. P. Brown, 'Giblin and the Grants Commission' in Copland (ed.), Giblin, 52-3.

28 C.P.D., 19 May 1933, 1570 (Lyons).

29 S. J. Butlin, 'The Problems of Federal Finance', Economic Record, vol. XXX, no. 54, May $1954,18$. 
amount which claimant States' expenditure on social services and administration fell below the non-claimants' average. The first approximation to the grant was the excess of the adjusted deficits of each of the three claimant States over the non-claimants' average. The grant was finally assessed after broad allowances had been made for other items of revenue and expenditure within each claimant State's control and for the degree of culpability for losses on loan expenditure. 'Finally a small deduction was made so that the claimant State would be in a slightly worse position than the nonclaimant States.' 30

The Commission developed an interesting but independent relationship to the Loan Council. The Council decided the amount of long-term loans for civil purposes but had no power over the direction in which they are spent. The work of the Grants Commission in the 1930s had, on the other hand, an important direct bearing on States' policy because special (Commission) grants constituted in the 1930s a significant source of claimant States' revenue and the Commission's methods induced States to adopt certain standards of expenditure and revenue raising for particular items, and to give consideration to the Commission's past critiques and potential reactions when formulating policies. ${ }^{31}$ It is difficult to assess the actual extent of the Commission's influence on claimant States' fiscal policy, but there is clear evidence that some is exerted. In its Fifth Report (1938) South Australia was criticised for its failure to collect outstanding public debts, Western Australia for continuing unproductive loan expenditure and Tasmania for the unsatisfactory way in which its railways system had been administered. As a result, the Commission in its final assessment reduced each State's grant marginally below the initial calculation. In the same Report the Commission noted that a reorganisation of Tasmania's local government system seemed to be urgent. ${ }^{32}$

Corrective action by the States led the Commission to make an appropriate adjustment but where no action was taken the Commission summarised its position thus:

While it is not our province to interfere with State policy, we deem it our duty to point out that a claimant State cannot reasonably expect to invest in unproductive works or enterprises and to get all the resulting losses made up in the form of special grants. ${ }^{33}$

The operations of the Grants Commission were clearly salutary to the

30 Brown in Copland (ed.), Giblin, 54-5; see also W. Prest 'Federalism in Australia: the Role of the Commonwealth Grants Commission', Journal of Commonwealth Political Studies, vol. V, 1967, 10.

31 R. J. May, 'The Commonwealth Grants Commission', Public Administration, vol. XXI, no. 3, September 1963, 246.

32 Fifth Report (1938), 81. South Australia's grant was reduced by $£ 10,000$, Western Australia's by $£ 9,000$ and Tasmania's by $£ 7,000$.

33 Seventh Report (1940), 63. 
three claimant States and it effectively assumed an important complementary role to that of the Loan Council.

In addition to the Grants Commission, the Commonwealth's other policies in the depression also affected the importance of the Loan Council and the adjustment to federal finance in the Financial Agreement. Before the formal appointment of the Commission in 1933, the Commonwealth had assisted States with grants under s.96, and some under s.94, for unemployment relief, for farmers' assistance and for works for the unemployed. There was a strong political development of confidence in the Commonwealth as the source of assistance to the States, and the outcome was that, from 1934-35 onwards, there was a flowering of other specific purposes grants under s.96. These, together with roads and special (Commission) grants resulted in the permanent diminution in the share of Agreement payments in the total of payments by the Commonwealth (table 7.2), and the variety of the grants provided a small but fascinating precedent for the grants made in later decades.

These important developments in the 1930s were seriously discussed at federal conferences just as, between 1920 and 1926, there had been frequent conferences between Commonwealth and State Ministers concerning the question of the Commonwealth vacating part of the direct tax field. Having introduced the Grants Commission in 1933, Lyons's governments looked to the States for arguments to refute the general developments in the use of 5.96 grants to adjust inequalities between the States in Australia's federal financial structure.

The best exposition of the status and of the dilemmas of the States in the 1930 s was probably given in 1934 by R. G. Menzies, then Acting Premier of Victoria, at a meeting of Commonwealth and State Ministers on constitutional matters. ${ }^{34}$ In a sentence, the question was whether the States' deficiencies could be met by reducing their responsibilities, or increasing their resources by some rearrangement of taxation under existing or rearranged powers. The States' taxable capacity continued to be unequal and there was therefore no change in the basic taxation position between the 1920s and the 1930s; nor was the necessary unanimity between the States forthcoming to achieve a political solution (chap. 6).

In fact, the Grants Commission found convincing evidence that a change of the Constitution would not help materially and it regarded a transfer of powers and functions as a political issue which, while helpful, was probably impracticable. ${ }^{35}$ The Grants Commission concluded that to return to the conditions before World War I was impossible: 'an Australian government entirely dependent on customs and excise would be in a very

34 C.P.P., 1934-37, vol. II, 'Conference of Commonwealth and State Ministers on Constitutional Matters, 16-28 February 1934', 17-24. Lyons had a complete grasp of the situation, ibid., Conference of Ministers, 26-28 August 1936, 8-9.

35 Third Report (1936), paras. 58-62. 
precarious position, and that any nice adjustment of taxing powers to responsibilities is, in practice, impossible' ${ }^{36}$ It added that unpredictable change was inevitable and this was a weakness of federation, particularly where there were considerable differences in taxable capacity, because it rendered it impossible to apply the principle of co-ordinate, financial responsibility necessary to sound politics. ${ }^{37}$ The use of what Menzies had described in 1934 as the 'power of purchase', already operating in such policies as roads grants and the Grants Commission, thenceforth gained momentum and in the decade of the 1930s grants as a proportion of States' revenue, excluding grants, nearly doubled (table 7.2).

\section{Grants under s.96 and loan allocations}

Despite the variety of grants later in the 1930s, the actual amount per head of population reached its peak in 1934-35 as a result of assistance to the States during the depression, and declined slightly until the advent of Uniform Tax in 1942-43. Thus the average payment per capita was $\$ 1.74$ in $1928-29, £ 3 \cdot 2$ in $1934-35, £ 2 \cdot 9$ in $1938-39$ and down to $£ 2 \cdot 6$ in $1941-42$, after which it moved up rapidly to $£ 6.3$ in the first year of Uniform Tax (1942-43) and was half as much again two years later. ${ }^{38}$

Within the very small changes in the average grant per capita which occurred prior to Uniform Tax (1942) there was only a small marginal amount in favour of Victoria relative to New South Wales. Between 1928-29 and 1934-35, the two States received the same amount per capita from the grants but the Financial Agreement loan allocations to New South Wales between 1932-33 and 1934-35 averaged $£ 3.4$ per head per annum to New South Wales as against $£ 1.4$ to Victoria. For the next three years Victoria acquired an advantage of $£ 0.2$ in its grants of about $£ 2.2$ per capita, but New South Wales averaged £1 per head more from the loan program under the Financial Agreement alone (table 11.2 on a per capita basis).

In the period between 1936-37 to 1941-42, for which there are official figures of the total Loan Council allocations-that is under the Financial Agreement and to semi-government and local government authorities under the Gentlemen's Agreement-Victoria, at best, was again $£ 0.2$ per capita per annum better off from grants than New South Wales in three years and advantaged less so or not at all in the other three. The average per capita grant received by Victoria was $£ 2 \cdot 2$. Out of loans, New South Wales averaged $£ 3.45$ per capita and Victoria $£ 1.65$ or $£ 1.8$ less. This gap was fairly uniform from year to year. There were, therefore, no general compensations for Victoria from s.96 grants in the 1930s to offset its smaller relative share of loans (tables 11.2 and 11.3 on a per capita basis).

36 Ibid., para. 21.

37 Ibid., para. 23.

38 Commonwealth Grants Commission, Seventh Report (1940), Appendixes 18 and 19; and subsequent Reports. 
Of the other States, South Australia fared relatively badly from loan allocations; but between 1931-32 and 1936-37 South Australia received more per capita from the grants than any other State (except Western Australia in one year). Compared with the other two smaller claimant States, however, South Australia received about the same in grants-between $£ 5.2$ and $£ 6.7$ per head per annum. As South Australia's bigger grants were recommended largely by the Grants Commission, as were those to Western Australia and Tasmania, the small compensation of slightly bigger grants to South Australia did not offset the advantages the other two claimant States enjoyed from loan allocations. In the later 1930 s and early 1940 s grants to Western Australia and Tasmania were about equal per capita to South Australia's, and the difference in treatment was again in the bigger allocation of loans to Tasmania and Western Australia.

The s.96 grants for all purposes, including those on the recommendation of the Grants Commission, did little more than maintain uniformity with respect to revenue expenditure and the standards of public and social services as between States. The differences in allocations of finance for basic development were therefore largely in the sharing of loans, including loans for local and semi-governmental authorities. The larger share of loans to claimant States increased their debt interest payments. The effect on their budgets was nullified by the special (Commission) grants, breaking what would otherwise have been a vicious circle of increasing debt interest and relatively slow growing revenue.

Further erosion of hopes for a co-ordinate financial system stem from s.96 grants

The States' dependence on grants was not without a further remarkable effort in the 1930s to achieve a high degree of independence of the Commonwealth, by relatively severe direct taxation. By the end of the 1920s the States' average rate more than doubled the Commonwealth's, but at the outbreak of World War II it was three and a quarter times as great as the Commonwealth's (table 11.1). Nevertheless, payments to the States under the Financial Agreement fell from over 82 per cent of all assistance to the States in 1926-27 to about 45 per cent in 1938-39 (table 7.2). The slow rate of increase in, and the inflexibility of, the payments to the States under the Agreement were serious and chronic weaknesses in it, and other specific purpose and general revenue grants under s.96 had therefore to be made to meet the States' needs in the period up to the introduction of Uniform Tax in 1942.

The 1930s had revealed that in times of great economic strain and for a variety of purposes under normal conditions, the States would accept unequal per capita grants from the Commonwealth; they had recognised the Commonwealth's strength: it had to tax uniformly in all States and had access to all forms of direct and indirect taxation including exclusive control 
Table 11.1

Commonwealth's assistance to States as proportion of States' other revenues; and direct taxation per head by the Commonwealth and the States, 1901-2 to $1938-39$

\begin{tabular}{|c|c|c|c|c|c|}
\hline Year & $\begin{array}{c}\text { Total } \\
\text { Commonwealth } \\
\text { grants } \\
\text { (£m.) } \\
(1)\end{array}$ & $\begin{array}{c}\text { Revenues } \\
\text { of States } \\
\text { excluding } \\
\text { grants } \\
\text { (fm.) } \\
(2)\end{array}$ & $\begin{array}{l}\text { Grants as \% } \\
\text { of States' } \\
\text { revenues } \\
\text { (excluding } \\
\text { grants) } \\
(3)\end{array}$ & $\begin{array}{c}\text { Commonwealth's } \\
\text { direct taxation } \\
\text { per head } \\
\text { (4) }\end{array}$ & $\begin{array}{c}\text { States' } \\
\text { taxation } \\
\text { per head } \\
\text { (excluding } \\
\text { Lottery Tax) } \\
\text { (5) }\end{array}$ \\
\hline 1901-02 & 7.364 & 20.834 & 35.30 & - & $\mathfrak{f 0 . 7 3 8}$ \\
\hline 1908-09 & 7.930 & 26.527 & 29.89 & - & $£ 0.854$ \\
\hline $1918 \cdot 19$ & 6.454 & 51.779 & 12.46 & $£ 2.946$ & $£ 2.350$ \\
\hline $1921-22$ & - & - & - & $£ 4$ (peak) & £3.254 \\
\hline $1928-29$ & 11.080 & 107.80 & 10.28 & $£ 2.400$ & L5.067 \\
\hline $1938-39$ & 20.287 & 104.607 & 19.39 & $£ 2.208$ & $£ 7.238$ \\
\hline
\end{tabular}

Sources: col. (1) from Commonwealth Year Book, no. 4, p. 821; C.F.B., 'Subsidy to the States' to 1926-27 in successive issues and subsequently from Grants Commission, Fifth Report (1938), appendix 24, Sixth Report (1939), appendix 23, Twentieth Report (1953), appendix 17; and Commonwealth Payments to or for the States 1963-64 (Canberra, 1964), appendixes 8, 10, 19. See also table 7.2.

col. (2) Total State revenues less col. (1); total revenue is from Commonwealth Year Book, no. 2, p. 820; C.F.B., no. 8, table 23; no. 12, table 35; no. 23, table 39 , no. 37 , table 52 .

cols. (4) and (5) from Commonwealth Grants Commission Seventh Report (1940) appendixes 20 and 25; Third Report (1936), appendix 39.

of customs and excise, but it was not burdened with the massive responsibilities of the States for providing services. In these developments the power of the Commonwealth grew at the expense of the States. The Loan Council remained formally in the position it had at the time of the Premiers' Plan but it and the Commonwealth had derived certain definite power and greater prestige from the outcome of the Garnishee Case. Still greater authority accrued to each during the 1930 s as a result of the negotiations with the banks and to the Commonwealth as a result of the allocation of the loan program. 
Table 11.2

Financial Agreement-Loan Council allocations to the States 1932-33 to 1966-67 $\left(£^{\prime} 000\right)$

\begin{tabular}{|c|c|c|c|c|c|c|c|}
\hline Year & N.S.W. & Vic. & Qld & S.A. & W.A. & Tas. & $\begin{array}{c}\text { AlI } \\
\text { States }\end{array}$ \\
\hline $1932-33$ & 5,124 & 1,602 & 1,347 & 1,180 & 1,918 & 173 & 11,344 \\
\hline $1939-34$ & 9,272 & 4,147 & 2,689 & 1,995 & 3,556 & 339 & 21,998 \\
\hline 1934-35 & 12,150 & 1,926 & 2,216 & 1,344 & 2,674 & 440 & 20,750 \\
\hline $1935-36$ & 8,564 & 2,911 & 3,125 & 1,542 & 2,071 & 723 & 18,936 \\
\hline $1936-37$ & 5,421 & 2,397 & 3,237 & 1,594 & 2,944 & 791 & 16,384 \\
\hline $1937-38$ & 5,063 & 2,178 & 2,285 & 1,152 & 1,431 & 736 & 12,843 \\
\hline $1938-39$ & 6,952 & 3,034 & 2,178 & 1,712 & 1,863 & 747 & 16,486 \\
\hline $1939-40$ & 8,477 & 3,337 & 2,741 & 2,421 & 2,027 & 979 & 19,982 \\
\hline $1940-41$ & 5,011 & 1,657 & 2,020 & 1,052 & 1,365 & 1,118 & 12,224 \\
\hline $1941-42$ & 1,408 & 195 & 738 & - & 627 & 408 & 3,376 \\
\hline $1942-43$ & - & 350 & 918 & 200 & 431 & 230 & 2,129 \\
\hline $1943-44$ & 105 & 239 & 857 & 500 & 458 & 419 & 2,578 \\
\hline $1944-45$ & - & 1,924 & 872 & 500 & 553 & 540 & 4,389 \\
\hline $1945-46$ & 2,525 & 3,482 & 1,275 & 1,250 & 883 & 1,446 & 10,861 \\
\hline $1946-47$ & 17,596 & 8,802 & 4,006 & 4,557 & 3,737 & 1,600 & 40,298 \\
\hline $1947-48$ & 30,835 & 13,324 & 5,487 & 6,046 & 3,906 & 2,500 & 62,098 \\
\hline $1948-49$ & 22,578 & 20,363 & 7,460 & 6,520 & 5,435 & 4,347 & 66,703 \\
\hline 1949.50 & 36,067 & 21,431 & 9,111 & 9,808 & 9,183 & 6,459 & 72,059 \\
\hline $1950-51$ & 48,634 & 44,689 & 19,726 & 16,524 & 16,659 & 14,791 & $161,023^{*}$ \\
\hline $1951-52$ & 72,514 & 66,061 & 26,989 & 26,413 & 19,983 & 15,100 & $227,060 \dagger$ \\
\hline $1952-53$ & 63,278 & 51,241 & 22,261 & 21,825 & 18,515 & 13,062 & 190,182 \\
\hline $1953-54$ & 65,700 & 52,650 & 22,950 & 26,500 & 17,750 & 14,450 & 200,000 \\
\hline $1954-55$ & 58,320 & 47,385 & 19,777 & 24,458 & 17,100 & 12,960 & 180,000 \\
\hline $1955-56$ & 60,750 & $49,800 t$ & 22,000 & 26,150 & 17,900 & 13,400 & $190,000 \S$ \\
\hline $1956-57$ & 60,750 & 49,800 & 22,000 & 26,150 & $19,900 \uparrow$ & 13,400 & 192,000 \\
\hline $1957-58$ & 63,950 & 52,420 & 23,160 & 27,530 & 18,840 & 14,100 & 200,000 \\
\hline $1958-59$ & 67,090 & 54,500 & 24,560 & 29,300 & 19,760 & 14,790 & 210,000 \\
\hline $1959-60$ & 70,490 & 56,705 & 26,230 & 30,385 & 20,700 & 15,490 & 220,000 \\
\hline $1960-61$ & 73,694 & 59,105 & 27,600 & 31,767 & 21,640 & 16,194 & 230,000 \\
\hline $1961-62$ & 79,301 & 63,602 & $29,70 \mathrm{tr}$ & 34,184 & 23,287 & 17,426 & 247,500 \\
\hline $1962-63$ & 81,704 & 65,530 & 30,600 & 35,220 & 28,992 & 17,954 & $255,000^{*}$ \\
\hline 1963-64 & 86,510 & 69,385 & 34,400 & 37,292 & 25,403 & 19,010 & 272,000 \\
\hline $1964-65$ & 92,285 & 73,977 & 36,676 & 39,760 & 27,084 & 20,268 & 290,000 \\
\hline $1965-66$ & 96,210 & 77,166 & 38,256 & 41,474 & 28,251 & 21,141 & 302,500 \\
\hline $1966-67$ & 102,510 & 82,270 & 40,785 & 44,215 & 30,120 & 22,540 & 322,500 \\
\hline
\end{tabular}

* Excludes $\{3,360,000$ which was not used for advances to the States for housing until 1951-52.

+ Includes carry-over payment from $1950-51$ of $£ 3,360,000$.

$\ddagger$ Includes $£ 2,000,000$ in respect of finance for the Olympic Village.

$\S$ Excludes $£ 3,200,000$ allocated to the Commonwealth for emergency wheat storage.

If Includes special allocation of $£ 2,000,000$.

** Excludes $£ 5,000,000$ which was used by the Commonwealth to finance advances for housing in 1963-64.

Source: C.P.D., 15 August 1963, 231-6; and Commonwealth Payments to or for the States $1968-69,67-8$. 
Table 11.3

Gentlemen's Agreement-Loan Council allocations, 1936-37 to 1966-67 $\left(\mathfrak{f}^{\prime} 000\right)$

\begin{tabular}{|c|c|c|c|c|c|c|c|}
\hline Year & N.S.W. & Vic. & Qld & S.A. & W.A. & Tas. & $\begin{array}{c}\text { All } \\
\text { States }\end{array}$ \\
\hline $1936-37$ & 6,375 & 505 & 1,027 & - & 350 & - & 8,257 \\
\hline $1937-38$ & 2,838 & 360 & 1,560 & 150 & - & - & 4,908 \\
\hline 1938-39 & 4,550 & 1,392 & 990 & - & - & 313 & 7,245 \\
\hline $1939-40$ & 4,650 & 1,900 & 860 & - & 一 & 44 & 7,454 \\
\hline $1940-41$ & 3,920 & 1,077 & 680 & - & - & - & 5,677 . \\
\hline $1941-42$ & 2,285 & 585 & 240 & - & - & 18 & 3,128 \\
\hline $1942-43$ & 800 & - & - & - & - & - & 800 \\
\hline 1943-44 & 300 & 250 & 160 & - & - & 14 & 724 \\
\hline $1944-45$ & 223 & 1,000 & 279 & - & - & - & 1,502 \\
\hline $1945-46$ & 2,265 & - & 591 & 9,000 & - & - & 11,856 \\
\hline $1946-47$ & 4,442 & 2,608 & 3,676 & 1,500 & - & 254 & 12,480 \\
\hline $1947-48$ & 9,085 & 5,856 & 4,140 & 89 & 435 & 301 & 19,906 \\
\hline $1948-49$ & 12,672 & 9,997 & 5,684 & 120 & 545 & 715 & 29,733 \\
\hline $1949-50$ & 16,727 & 22,947 & 8,292 & 83 & 619 & 931 & 49,599 \\
\hline $1950-5 \mathrm{l}$ & 20,795 & 37,850 & 8,836 & 154 & 608 & 1,139 & 69,382 \\
\hline $1951-52$ & 20,575 & 32,959 & 11,632 & 1,794 & 745 & 1,810 & 69,515 \\
\hline $1952-53$ & 26,900 & 41,202 & 14,647 & 5,252 & 4,401 & 5,848 & 98,250 \\
\hline 1953-54 & 21,915 & 29,911 & 18,110 & 2,718 & 3,210 & 3,010 & 78,874 \\
\hline 1954-55 & 24,278 & 33,924 & 16,117 & 1,853 & 4,454 & 3,147 & 83,773 \\
\hline $1955-56$ & 22,091 & 28,556 & 13,139 & 2,133 & 3,530 & 2,056 & 71,505 \\
\hline $1956-57$ & 22,670 & 35,005 & 15,719 & 3,532 & $3,66 \mathrm{I}$ & 2,241 & 82,828 \\
\hline $1957-58$ & 26,923 & 35,511 & 18,603 & 3,694 & 4,291 & 3,119 & 92,141 \\
\hline $1958-59$ & 29,570 & 36,655 & 20,370 & 4,589 & 3,685 & 2,957 & 97,826 \\
\hline $1959 \cdot 60$ & 31,620 & 37,493 & 21,630 & 4,956 & 4,441 & 3,521 & 103,661 \\
\hline $1960-61$ & 31,883 & 38,734 & 21,847 & 5,261 & 4,619 & 3,462 & 105,806 \\
\hline $1961-62$ & 42,830 & 45,056 & 26,910 & 6,677 & 5,720 & 4,345 & 131,538 \\
\hline 1962-63 & 42,479 & 47,308 & 30,084 & 7,134 & 6,291 & 4,523 & 137,819 \\
\hline $1963-64$ & 47,137 & 49,064 & 32,155 & 7,692 & 7,575 & 4,841 & 148,464 \\
\hline $1964-65$ & 49,529 & 49,505 & 31,608 & 8,068 & 8,871 & 4,926 & 152,508 \\
\hline $1965-66$ & 51,297 & 49,114 & 33,011 & 8,509 & 9,422 & 4,871 & 156,222 \\
\hline $1966-67$ & 55,805 & 53,948 & 35,305 & 9,376 & 10,014 & 5,931 & 179,377 \\
\hline
\end{tabular}

Source: As for table 11.2. Formal publication of local and semi-government loan programs began with the Gentlemen's Agreement of May 1936 (chap. 12). 
Table 11.4

Financial Agreement

index of Loan Council allocations per capita to the States, 1932-33 to 1965-66 (average per capita of six States $=100$ )

\begin{tabular}{|c|c|c|c|c|c|c|}
\hline Year & N.S.W. & Vic. & Qld & S.A. & W.A. & Tas. \\
\hline 1932-33 & 115.12 & 51.16 & 83.14 & 118.60 & 255.23 & 44.19 \\
\hline $1933-34$ & 107.25 & 68.58 & 85.50 & 103.63 & 243.50 & 44.71 \\
\hline $1934-35$ & 148.71 & 39.87 & 74.52 & 74.19 & 194.19 & 61.94 \\
\hline $1935-36$ & 114.59 & 56.23 & 114.23 & 93.59 & 163.70 & 111.39 \\
\hline $1936-37$ & 83.82 & 53.94 & 136.51 & 112.45 & 268.46 & 141.08 \\
\hline $1937-38$ & 100.00 & 62.57 & 122.46 & 104.28 & 165.78 & 166.84 \\
\hline 1938-39 & 106.72 & 68.07 & 90.76 & 121.01 & 167.65 & 131.93 \\
\hline $1939-40$ & 107.34 & 61.89 & 94.06 & 141.26 & 150.00 & 142.66 \\
\hline $1940-41$ & 104.05 & 49.71 & 112.72 & 101.73 & 166.47 & 268.21 \\
\hline $1941-42$ & 106.38 & 21.28 & 151.06 & - & 280.85 & 361.70 \\
\hline $1942-43$ & - & 60.00 & 293.33 & 110.00 & 300.00 & 316.67 \\
\hline $1943-44$ & 11.11 & 33.33 & 225.00 & 225.00 & 266.67 & 477.78 \\
\hline $1944-45$ & - & 160.00 & 136.67 & 133.33 & 190.00 & 365.00 \\
\hline $1945-46$ & 58.50 & 117.69 & 80.27 & 134.69 & 122.45 & 393.20 \\
\hline $1946-47$ & 110.41 & 80.30 & 67.84 & 132.34 & 139.78 & 116.73 \\
\hline $1947-48$ & 125.86 & 78.92 & 60.29 & 113.24 & 94.00 & 117.40 \\
\hline $1948-49$ & 86.26 & 112.00 & 76.14 & 113.27 & 121.19 & 189.52 \\
\hline $1949-50$ & 99.65 & 85.65 & 67.57 & 122.70 & 146.52 & 204.96 \\
\hline $1950-51$ & 77.07 & 102.21 & 83.84 & 117.44 & 149.97 & 267.21 \\
\hline 1951-52 & 81.83 & 106.92 & 81.38 & 132.90 & 126.62 & 192.67 \\
\hline $1952-53$ & 95.92 & 98.72 & 79.98 & 130.03 & 138.48 & 197.03 \\
\hline 1953-54 & 85.44 & 96.19 & 78.13 & 149.23 & 124.52 & 206.99 \\
\hline $1954-55$ & 84.68 & 95.78 & 74.79 & 152.03 & 132.55 & 207.99 \\
\hline $1955-56$ & 84.01 & 95.03 & 78.79 & 152.85 & 130.86 & 205.46 \\
\hline $1956-57$ & 83.56 & 93.63 & 77.89 & 149.90 & 144.23 & 203.50 \\
\hline $1957-58$ & 84.56 & 94.43 & 78.85 & 150.39 & 131.41 & 205.57 \\
\hline 1958-59 & 84.66 & 99.27 & 79.67 & 151.86 & 131.72 & 205.32 \\
\hline $1959-60$ & 85.14 & 92.22 & 81.38 & 149.25 & 132.35 & 206.44 \\
\hline $1960-61$ & 85.23 & 91.55 & 82.27 & 148.77 & 132.92 & 207.35 \\
\hline 1961-62 & 85.42 & 91.57 & 82.12 & 148.62 & 131.16 & 210.05 \\
\hline $1962-63$ & 85.50 & 91.56 & 82.37 & 148.43 & 129.85 & 210.92 \\
\hline 1963-64 & 85.25 & 90.74 & 86.68 & 146.46 & 127.81 & 210.63 \\
\hline $1964-65$ & 85.54 & 90.61 & 86.61 & 145.18 & 127.33 & 212.52 \\
\hline $1965-66$ & 85.78 & 90.67 & 86.49 & 143.87 & 126.63 & 214.67 \\
\hline
\end{tabular}

Sources: as for table 11.2. Calculations based on population figures in the 1966 Census and official estimates in inter-censal years. 
Table 11.5

Gentlemen's Agreement

index of Loan Council allocations per capita, 1936-37 to 1965-66 (average per capita of six States $=100$ )

\begin{tabular}{|c|c|c|c|c|c|c|}
\hline Year & N.S.W. & Vic. & Qld. & S.A. & W.A. & Tas. \\
\hline $1936-37$ & 195.08 & 22.13 & 85.25 & - & 63.11 & - \\
\hline $1937-38$ & 145.83 & 26.39 & 218.06 & 34.72 & - & - \\
\hline 1938-39 & 158.10 & 70.48 & 93.33 & - & - & 125.71 \\
\hline $1939-40$ & 157.01 & 94.39 & 78.50 & $\cdots$ & - & 16.82 \\
\hline $1940-41$ & 174.07 & 69.14 & 81.48 & - & - & - \\
\hline $1941-42$ & 184.09 & 68.18 & 52.27 & - & - & 18.18 \\
\hline $1942-43$ & 254.55 & - & - & - & - & - \\
\hline $1943-44$ & 100.00 & 130.00 & 150.00 & - & 一 & 60.00 \\
\hline $1944-45$ & 38.10 & 238.10 & 123.81 & - & - & - \\
\hline $1945-46$ & 48.12 & - & 34.38 & 891.25 & - & - \\
\hline $1946-47$ & 89.82 & 76.65 & 200.60 & 140.12 & - & 59.88 \\
\hline $1947-48$ & 115.65 & 108.02 & 141.60 & 5.34 & 32.44 & 43.89 \\
\hline $1948-49$ & 108.62 & 123.24 & 130.09 & 4.70 & 27.15 & 69.97 \\
\hline $1949-50$ & 85.95 & 170.44 & 114.22 & 1.94 & 18.42 & 54.93 \\
\hline $1950-51$ & 76.43 & 200.83 & 87.14 & 2.50 & 12.74 & 47.74 \\
\hline $195 I-52$ & 75.73 & 174.02 & 114.39 & 29.39 & 15.37 & 75.37 \\
\hline $1952-53$ & 70.65 & 153.58 & 101.77 & 60.57 & 63.66 & 170.65 \\
\hline 1953.54 & 72.28 & 138.50 & 156.94 & 38.83 & 57.13 & 109.32 \\
\hline $1954-55$ & 75.73 & 147.25 & 130.96 & 24.70 & 74.11 & 108.41 \\
\hline $1955-56$ & 81.22 & 144.69 & 125.00 & 33.16 & 68.52 & 83.81 \\
\hline $1956-57$ & 72.31 & 152.52 & 129.06 & 46.91 & 61.56 & 78.95 \\
\hline $1957-58$ & 77.21 & 138.87 & 137.39 & 43.80 & 64.92 & 98.74 \\
\hline 1958-59 & 80.10 & 134.65 & 141.82 & 51.01 & 52.73 & 88.08 \\
\hline $1959-60$ & 81.07 & 129.39 & 142.43 & 51.68 & 60.24 & 99.56 \\
\hline 1960-61 & 80.17 & 130.46 & 141.62 & 53.56 & 61.70 & 96.39 \\
\hline $1961-62$ & 86.78 & 122.07 & 140.00 & 54.63 & 60.63 & 98.56 \\
\hline 1962-63 & 82.25 & 122.30 & 149.82 & 55.62 & 62.98 & 98.33 \\
\hline $1963-64$ & 85.09 & 117.56 & 148.45 & 55.34 & 69.85 & 98.27 \\
\hline 1964-65 & 87.33 & 115.30 & 141.93 & 56.03 & 79.29 & 98.21 \\
\hline $1965-66$ & 88.55 & 111.74 & 144.51 & 57.16 & 81.76 & 95.78 \\
\hline
\end{tabular}

Sources: as for table 11.4. 
Table 11.6

Gentlemen's and Financial Agreements

index of Total Loan Council allocations per capita, 1936-37 to 1965-66 (average per capita of six States $=100$ )

\begin{tabular}{|c|c|c|c|c|c|c|}
\hline Year & N.S.W. & Vic. & Qld & S.A. & W.A. & Tas. \\
\hline $1936-37$ & 121.21 & 43.25 & 119.28 & 74.66 & 199.45 & 93.66 \\
\hline $1937-38$ & 112.74 & 52.90 & 149.03 & 84.94 & I 19.69 & 120.46 \\
\hline 1938-39 & 122.74 & 68.80 & 91.55 & 83.97 & 116.33 & 129.74 \\
\hline $1939-40$ & 120.87 & 70.74 & 89.82 & 102.80 & 109.16 & 108.40 \\
\hline $1940-41$ & 125.98 & 56.30 & 103.15 & 69.29 & 113.39 & 182.68 \\
\hline $1941-42$ & 143.96 & 43.96 & 103.30 & - & 145.05 & 195.60 \\
\hline $1942-43$ & 68.29 & 43.90 & 214.63 & 80.49 & 219.51 & 231.71 \\
\hline $1943-44$ & 30.43 & 54.35 & 208.70 & 176.09 & 208.70 & 384.78 \\
\hline $1944-45$ & 10.00 & 182.50 & 135.00 & 100.00 & 142.50 & 273.75 \\
\hline $1945-46$ & 53.09 & 56.35 & 56.03 & 528.99 & 58.63 & 188.27 \\
\hline $1946-47$ & 105.53 & 79.43 & 99.29 & 134.18 & 106.67 & 103.12 \\
\hline $1947-48$ & 123.38 & 85.99 & 80.06 & 87.01 & 79.13 & 99.54 \\
\hline $1948-49$ & 93.08 & 115.54 & 92.75 & 79.79 & 92.27 & 152.66 \\
\hline $1949-50$ & 94.86 & 115.32 & 83.89 & 80.44 & 101.70 & 152.46 \\
\hline $1950-51$ & 76.90 & 131.99 & 84.86 & 82.86 & 108.64 & 201.18 \\
\hline $1951-52$ & 80.45 & 122.70 & 89.15 & 108.64 & 100.54 & 165.17 \\
\hline $1952-53$ & 80.72 & 117.41 & 87.44 & 106.36 & 113.02 & 188.04 \\
\hline $1953-54$ & 91.24 & 108.19 & 100.29 & 118.04 & 105.49 & 179.45 \\
\hline $1954-55$ & 81.80 & 112.13 & 92.63 & 111.58 & 113.98 & 176.35 \\
\hline $1955-56$ & 83.24 & 108.60 & 91.46 & 120.12 & 113.82 & 172.16 \\
\hline $1956-57$ & 80.14 & 111.38 & 93.31 & 118.86 & 119.31 & 165.97 \\
\hline $1957-58$ & 82.27 & 108.49 & 97.35 & 116.80 & 110.47 & 171.89 \\
\hline $1958-59$ & 83.21 & 106.42 & 99.39 & 119.81 & 106.61 & 168.06 \\
\hline $1959-60$ & 83.84 & 104.15 & 100.93 & 118.00 & 109.26 & 172.21 \\
\hline $1960-61$ & 83.64 & 103.82 & 100.97 & 118.77 & 110.47 & 172.40 \\
\hline $1961-62$ & 85.89 & 102.15 & 102.21 & 116.00 & 106.69 & 171.36 \\
\hline $1962-63$ & 84.36 & 102.34 & 106.02 & 115.89 & 106.41 & 171.41 \\
\hline 1963-64 & 85.19 & 100.21 & 108.49 & 114.29 & 107.35 & 170.96 \\
\hline $1964-65$ & 86.16 & 99.13 & 105.68 & 114.47 & 110.79 & 173.16 \\
\hline $1965-66$ & 86.72 & 97.85 & 106.25 & 114.43 & 111.36 & 174.17 \\
\hline
\end{tabular}

Sources: as for table 11.4. 


\section{Allocation of the Loan Program, 1929 to the War}

The Financial Agreement permitted a unanimously agreed division of the loan program and it perpetuated what was the practice of the voluntary Loan Council. At the 1927 discussions of the draft Agreement, Lang, Premier of New South Wales, and P. Collier, Premier of Western Australia, were reluctant to commit their States to it. Lang was particularly reluctant but, to persuade him, the allocation formula in subclause 3(10) was added to cope with the division of loans, should a unanimous decision not be reached. The difficulties associated with the use of the formula suggest that the Prime Minister and the Premiers who signed the Agreement, of whom Lang was not one but Collier was, and the Parliaments which ratified it, did not contemplate that the formula would be used much, if at all. In effect, it was a stand-by arrangement in case of insoluble deadlock and its deficiencies have, it will be shown below, helped to ensure that the formula has not been used.

One of Lang's purposes in having some kind of formula inserted in 1927 was to ensure that works in progress would not be affected by the re-entry of his own State, the sixth, into the Loan Council. Thus the division of loan programs, using the formula, would in principle be according to decisions on his and other States' net loan expenditure over the past five years; it would not be according to decisions made by the voluntary Council when New South Wales had not been a member.

Using the net loan expenditure of the States and the Commonwealth's works expenditure from Loan Fund, as recorded in the Commonwealth's official Finance Bulletin, as a guide to the expenditure which would be used to apply the formula in the event of disagreement, the shares of the members in 1926-27 and 1927-28 provide a clue to the bargaining which must have gone on at the 1927 discussions of the draft agreement. The Agreement was signed in December 1927 and the statistics of 1927-28 reveal that New South Wales's share of net loan expenditure in the preceding five years rose from $24 \cdot 7$ per cent to an average of $26 \cdot 1$ per cent in 1926-27 
and 1927-28. The Commonwealth's also rose-from 18.9 per cent to $19 \cdot 6$ per cent, which probably explains its share of one-fifth under the formula.

It was appreciated that States that had been extravagant in the past stood to gain but no way out of the difficulty could be seen. It was considered that compulsory contributions to sinking funds would act as a deterrent to excessive future borrowing. ${ }^{1}$ Although the depression years, which followed immediately after the Financial Agreement was validated, revealed starkly how important debt service was as an item in the States' budgets, the deterring effect of compulsory sinking funds was probably small at the time the Agreement was arranged.

It was appreciated in the discussions of the draft Agreement that the formula was unsatisfactory, and serious consideration was given to a formula based upon increases in population, in production, and in land alienation or land settlement for the preceding five years. Increases in land alienation or settlement were put in to balance population and production which would favour the two big, industrialised eastern States. 'We came to the conclusion that such a formula would be very desirable; but that it was not practicable, as it would be difficult to make people understand it.'2

\section{Allocation in practice}

The depression years imposed considerable strains upon the State governments to explain to their electorates their inability to obtain more loan money to provide work for the unemployed.

In 1933, there were the proposals for even closer control by the Loan Council of semi-governmental borrowing, ${ }^{3}$ each State being concerned about others' activities to increase in this way their shares of the loanable funds available; in June of the same year, W. Forgan Smith, Labor Premier and Treasurer of Queensland, began saying that few people understood the implications of the Financial Agreement, and he complained that under it, the Loan Council was an extra-constitutional authority not responsible to any one Parliament, and yet its decisions were binding upon the various governments and no one Parliament could alter them-this helped him to explain by implication why he could not get more loan money; ${ }^{4}$ and in November the Loan Council agreed that the next meeting in February 1934 should be concurrent with the Premiers' Conference on the Constitution to inquire whether constitutional amendment would enable the States to achieve complete financial independence. ${ }^{5}$ This was another tactic to divert public attention from the main problem-unemployment. In the meantime, the New South Wales Premier (B. S. B. Stevens) proposed at

1 C.P.D., 14 December 1927, 3185 (Bruce).

2 Ibid.

3 Argus, 7 November 1933, 9.

4 D. B. Copland and C. V. Janes (eds.), Cross Currents in Australian Finance (a book of documents) (Sydney, 1936), 9.

5 Argus, 7 November 1933, 9. 
the February Loan Council meeting a statutory authority to undertake works for the unemployed and the Council authorised borrowing of $f 2 \mathrm{~m}$. at times and on conditions approved by the Loan Council. ${ }^{6}$ It was a means of increasing New South Wales's share of the loanable funds and the Acting Premier of Victoria (R. G. Menzies) publicly criticised the decision because it would prejudice the Commonwealth in obtaining loans if it should want to borrow, and the money would not be raised for the authority's own purposes but would be distributed to other semi-governmental and local authorities to spend..$^{7}$ Commonwealth ministers defended the action of the Council as one which would be supervised closely according to the Gentlemen's Agreement. ${ }^{8}$ Sir Edward Mitchell cleared the confusion by stating, it is submitted correctly, that under the Financial Agreement the State authority would have to issue Commonwealth securities and the loans raised would have to be counted as part of New South Wales's share of the loan program. ${ }^{9}$ New South Wales withdrew the proposal and the Loan Council rescinded its decision in June $1934 .^{10}$

The formula for the allocation of the loan program first became a contentious issue in public at the May 1935 Loan Council meeting. ${ }^{11}$ In the words of the Commonwealth Treasury: 'It so happens that Victoria has been most moderate in its loan requirements over the last five years and that the policy of the present Victorian Government entails asking for considerably more than double the loan funds for 1935-36 as compared with 1934-35.' ${ }^{2}$ When the estimates of the loan requirements of the various governments for $1935-36$ were added up, they amounted to $£ 33 \cdot 145 \mathrm{~m}$. for works and $£ 5.92 \mathrm{~m}$. for deficits, a total of $£ 39.065 \mathrm{~m}$. The Council agreed, after three days of protracted discussion and on the adamant advice of the Board of the central bank, that the program should be reduced to $£ 26.05 \mathrm{~m} .{ }^{13}$ The immediate trouble arose, therefore, from the increased requirements of the members, particularly Victoria, and the decision to cut the program. The difficulties were made greater by a deeper, long-term problem: the bias in favour of New South Wales in the allocation of loans in the preceding five depression years.

The Loan Council's discussion reached the point where it appeared that the formula would have to be applied, and it raised the particular question

6 S.M.H., 28 February 1934, 7.

7 Argus, 1 March 1934, 11.

8 Ibid.; also 3 March 1934, 23.

9 Argus, 5 March 1934, 9, and Mitchell, A Supplement to What Every Australian Ought to Know, Addenda (Melbourne, 1933).

10 Argus, 21 Junc 1934, 9.

11 S.M.H., 1 June 1935,15 , reporting a statement by the Premier, B. S. B. Stevens.

12 Report by the Commonwealth Treasury quoted in Copland and Janes (eds.), Cross Currents, 4-5.

13 Ibid., 6, 8, 11, 12, 40,4l; that was the program agreed at that time, the beginning of the financial year. Subsequently, the agreed program for 1935-36 became $£ 31.5 \mathrm{~m}$. (table 15.2) 
whether loans for budget deficits were part of 'net loan expenditure' in applying the formula.

Legal advice from the Commonwealth Solicitor-General, Mr Knowles, was obtained, and he expressed the opinion that the amount of loan raisings for meeting revenue deficits must be included as part of the States' total loan expenditure in determining the amount upon which the allocation to each State would be based. ${ }^{14}$

This advice was accepted at the time and it meant that the greater the deficits which had been incurred, or the more, relative to each other, that governments had spent loan funds in the past either on budget deficits or works, the more they would receive under the application of the formula in the 1935-36 program. The significance of this from Victoria's point of view was that as a direct result of the depression policies, New South Wales stood to gain nearly half the total of the loan program allocated to the States if a calculation based on a generally agreed interpretation of the formula was used (table 12.1, col. 2). The actual course of events at the meeting from the primary cause of the difficulties to the final outcome can be understood from table 12.1.

The States had borrowed heavily in Australia from the central bank on the security of treasury bills from 1929-30 to 1934-35 to meet budget deficits and works programs. The full amount was $\$ 53 \mathrm{~m}$. but the final settlement arranged by the 1944 amendments to the Financial Agreement was $f 46 \mathrm{~m}$, the remainder being paid off by the States from reserves at the time. The distribution of the $£ 46 \mathrm{~m}$. was weighted most heavily in favour of New South Wales which owed $£ 28.1 \mathrm{~m}$. or 61 per cent. ${ }^{15}$ This biased the shares of the 1935-36 program according to the formula heavily in favour of New South Wales ( 46.9 per cent) as shown in col. 2. This might be compared with the five years to 1927-28 when New South Wales's share of the States' net loan expenditure was 29.2 per cent and that was, at that time, an advantageous outcome of the Agreement discussions.

The Loan Council was therefore obliged to make every effort to reach agreement on some reasonable basis of allocation, which it did, Victoria taking a lead in these negotiations. The States' total programs, excluding the Commonwealth, were reduced from $£ 25.44 \mathrm{~m}$. (col. 3) to $£ 20 \cdot 30 \mathrm{~m}$. (col. 4) but ironically the share of New South Wales rose: it had proposed an amount which gave it 35.4 per cent of the States' proposed program, but it received 39.4 per cent of the amount actually agreed, which was

14 V.P.D., 4 June 1935, 475 (A. A. Dunstan, Premier and Treasurer) and statements by other Premiers reported in Copland and Janes (cds.), Cross Currents, 6, 8.

15 New South Wales's official share of Australian short-term debt in June 1935 was 63 per cent of the total of $£ 45.1 \mathrm{~m}$.; Victoria's was 11 per cent and so on. These proportions are almost identical with those in the Financial Agreement. See C.F.B., no. 28, table 65. 
Table 12.1

Allocation of the loan program, May 1935

each State's percentage share

\begin{tabular}{|c|c|c|c|c|c|c|}
\hline \multirow[b]{2}{*}{ Government } & \multirow[b]{2}{*}{$\begin{array}{c}\text { Depression } \\
\text { deficits } \\
\text { (1) }\end{array}$} & \multicolumn{3}{|c|}{ 1935-36 program } & \multirow[b]{2}{*}{$\begin{array}{c}\text { Population } \\
\text { of States } \\
(5)\end{array}$} & \multirow{2}{*}{$\begin{array}{c}\text { Index of } \\
\text { per capita } \\
\text { allocation } \\
\text { of actual } \\
\text { loans raised } \\
\text { (6) }\end{array}$} \\
\hline & & $\begin{array}{c}\text { F.A. } \\
\text { formula } \\
\text { (2) }\end{array}$ & $\begin{array}{c}\begin{array}{c}\text { First } \\
\text { proposed }\end{array} \\
(3)\end{array}$ & $\begin{array}{c}\text { Actually } \\
\text { agreed } \\
(4)\end{array}$ & & \\
\hline N.S.W. & 61.0 & 46.87 & 35.4 & 39.41 & 39.38 & 114.59 \\
\hline Vic. & 9.3 & 15.59 & 21.6 & 19.71 & 27.44 & 56.23 \\
\hline Qld & 4.9 & 14.00 & 15.4 & 14.78 & 14.37 & 114.23 \\
\hline S.A. & 11.3 & 10.11 & 9.4 & 10.34 & 8.74 & 93.59 \\
\hline W.A. & 12.5 & 11.50 & 11.4 & 12.81 & 6.64 & 163.70 \\
\hline Tas. & 1.0 & 2.93 & 6.8 & 2.95 & 3.43 & 111.39 \\
\hline States' total & 100.0 & 100.00 & 100.0 & 100.00 & 100.00 & 100.00 \\
\hline $\begin{array}{l}\text { States' amount } \\
\text { Commonwealth }\end{array}$ & $\stackrel{146.018 \mathrm{~m} .}{\text { _ }}$ & $\begin{array}{c}£ 19.08 \mathrm{~m} . \\
+6.00 \mathrm{~m} .\end{array}$ & $\begin{array}{l}£ 25.44 \mathrm{~m} . \\
+7.50 \mathrm{~m} .\end{array}$ & $\begin{array}{l}f 20.30 \mathrm{~m} . \\
+5.75 \mathrm{~m} .\end{array}$ & & $\begin{array}{l}£ 18.94 \mathrm{~m} . \\
+0.99 \mathrm{~m} .\end{array}$ \\
\hline Total of progra & & $£ 26.08 \mathrm{~m}$. & $£ 32.94 \mathrm{~m}$. & $£ 26.05 \mathrm{~m}$. & & $£ 19.93 \mathrm{~m}$. \\
\hline
\end{tabular}

Sources: col. (1) Financial Agreement 1927-1944, subclauses 12(11)(b) and (c), and Chapter 7. col. (2) V.P.D., 4 June 1935, 475.

cols. (3) and (4) Copland and Janes (eds.), Cross Currents, 8.

col. (5) Commonwealth Demography Bulletin.

col. (6) Table 11.4; average of 6 States $=100.00$ and the relevant year is 1935-36.

almost identical with its share of the population (col. 5). Victoria received a lesser share of the amount actually agreed (19.7 per cent) than of the first proposal (21.6 per cent), but Victoria still did better than it would have under the formula, although its share (19.7 per cent) was well below its proportion of the population (27.44 per cent). Of the other smaller States, Tasmania fared worst, its share being 2.95 per cent of the agreed program, which was less than its share of the population and less than half of its share of the program first proposed.

The key to understanding the negotiations would seem to be that all States except New South Wales received more than they would have under the formula. Victoria received much more $(4 \cdot 1$ per cent) and the remainder a small marginal increment in their share. The improvement still left Tasmania as well as Victoria with less than their share on a population basis.

Looking at these movements in terms of money, New South Wales's agreed share fell less (£lm.) than Victoria's $(£ 1.5 \mathrm{~m}$.) below the program first proposed. However, Victoria gained almost $£ 1 \mathrm{~m}$. more than it would have by the formula and New South Wales $£ 1 \cdot 16 \mathrm{~m}$. less, and all the other States 
were in Victoria's position, ${ }^{16}$ which made the outcome satisfactory to their representatives for the purpose of reporting back to their cabinets, Parliaments and people. ${ }^{17}$

The real test of the relative advantage of the distribution is the amount received per head, reduced in table 12.1 to an index which has as a base of 100 the average per capita to all the States (col. 6). This shows ex post how the loans actually raised in 1935-36 were allocated. Victoria's claims relative to New South Wales would seem to be justified, as Victoria received per capita less than half that of New South Wales, yet each were relatively advanced industrial and rural States. The fundamental explanation of the trend in the sharing probably lay in the relative unemployment in the States. In June 1935, 22.7 per cent of trade unionists were unemployed in New South Wales compared with but 15 per cent in Victoria. That gave the New South Wales Premier strong bargaining power. South Australia, with 18.9 per cent, was second only to New South Wales, but it had recourse to the Grants Commission for some relief, but that was in respect of revenue, not loan capital. However, as Western Australia was also a claimant State with 13.9 per cent unemployed, South Australia's low share was probably attributable to weak bargaining.

The marginal adjustments which were effected were in the right direction if the official per capita shares of the actual loan raisings for the States in 1934-35 are compared with 1935-36 (table 12.2). As the nature of governmental works programs is such that, when reductions have to be made, large absolute adjustments are politically embarrassing compared with

Table 12.2

Shares of actual loan raisings allocated to the States, $1934-35$ and 1935-36

\begin{tabular}{lccccc}
\hline \multirow{2}{*}{ Government } & \multicolumn{2}{c}{$1934-35$} & & \multicolumn{2}{c}{$1935-36$} \\
\cline { 2 - 3 } \cline { 6 - 7 } & $\begin{array}{c}\text { Amount } \\
\text { ¿m. }\end{array}$ & Per capita & & $\begin{array}{c}\text { Amount } \\
\text { £m. }\end{array}$ & Per capita \\
\hline New South Wales & 12.15 & 148.1 & & 8.56 & 114.6 \\
Victoria & 1.93 & 33.9 & & 2.91 & 56.2 \\
Queensland & 2.22 & 74.5 & & 3.13 & 114.2 \\
South Australia & 1.34 & 74.2 & & 1.54 & 93.6 \\
Western Australia & 2.67 & 194.2 & & 2.07 & 163.7 \\
Tasmania & 0.44 & 61.9 & & 0.72 & 111.4 \\
\hline Total & 20.75 & $100.0^{*}$ & & 18.94 & $100.0^{*}$ \\
\hline
\end{tabular}

* Average of six States $=100.0$

Source: Table 11.4.

16 Statistics in Copland and Janes (eds.), Cross Currents, 8.

17 V.P.D., 4 June 1935, 476; and Mercury, Hobart, 5 July 1935, quoted in Copland and Janes (eds.), Cross Currents, 9-11. 
marginal changes, the cut in New South Wales's actual share was ultimately greater than could be fairly described as marginal-from $£ 12.15 \mathrm{~m}$. in 1934.35 to $\$ 8.56 \mathrm{~m}$. in $1935-36$, or a reduction per capita from an index of 148.11 to 114.59 (table 12.2); but it was marginal relative to the New South Wales share of $£ 9 \cdot 27 \mathrm{~m}$. two years before in 1933-34, following which it had received the inordinately large amount of $£ 12.15 \mathrm{~m}$. in 1934-35.

Some further comments might be made on this particular episode. There was a basic difference of opinion about treating revenue deficits as loan expenditure for the purpose of the formula. The Premier and Treasurer of Queensland, W. Forgan Smith, obtained the opinions of two Counsel, both of which were 'to the effect' that revenue deficits were not loan expenditure within the meaning of the Financial Agreement. He announced this in his budget speech in October 1935, some months after the May meeting of the Loan Council. ${ }^{18}$ It contradicted the Commonwealth SolicitorGeneral's advice to the May meeting and the issue was not cleared up until 1944. This illustrated one of a number of reasons why the formula had never been used.

The Commonwealth's role was significant on the main issue-sharing. It proposed for itself a program of $£ 7.5 \mathrm{~m}$., agreed to a reduction to $£ 5 \cdot 75 \mathrm{~m}$. compared with $£ 6 \mathrm{~m}$. which it would have received by the formula, and actually received $£ 0.99 \mathrm{~m}$. ( 4.9 per cent) from loan raisings. This was typical of the Commonwealth's position throughout the 1930s when the most it was allocated in any one year from actual loan raisings was $54.34 \mathrm{~m}$. in 1934-35 or $17 \frac{1}{2}$ per cent; in all but two other years between 1932-33 and $1939-40$ (inclusive) it received less than $£ 2 \mathrm{~m}$., and its share was about one-eighth or less. Apart from 1934-35, its share only rose above about one-seventh from 1940-41, when the pressures of the war began to be felt, and it was less than a sixteenth in three years (table 15.2). At the May 1935 Council meeting, careful examination of the budgetary position of the States led the Commonwealth to propose a grant of $£ 0.5 \mathrm{~m}$., provided they reduced their budget deficits by an equivalent amount (thus reducing States' deficits by $f 1 \mathrm{~m}$.). ${ }^{10}$ The proposal was accepted and the grant was distributed on a population basis to the distinct advantage of Victoria. It was an example of marginal action by the Commonwealth which enabled the States' representatives to report back to their cabinets and Parliaments with more than had been expected or they were strictly entitled to. This tactic was used to achieve the Financial Agreement and is one of the most extensively used in the Commonwealth's armoury.

The loser at this meeting was New South Wales, which had the position of greatest strength-its representative could have insisted on the use of the formula. In the circumstances, B. S. B. Stevens, Premier and Treasurer, had to be able to report back to cabinet, Parliament and people in a manner

18 Copland and Janes (eds.), Cross Currents, 6, quoted from Q.P.D., 8 October 1935.

19 V.P.D., 4 June 1935, 476. 
which was acceptable to them. He took the opportunity to make a statement which demonstrated the State's magnanimous attitude and its concern for the welfare of the ather States and the spirit of the Financial Agreement. In fact, the Premier's statement echoed views, particularly a degree of concern for smaller States, which New South Wales representatives had expressed at the Convention Debates. It followed upon what was undoubtedly a meeting in which there had been bitter controversy as members contemplated the implications of the Solicitor-General's opinion on the meaning of the formula. ${ }^{20}$

It had been a unique meeting of the Loan Council said Mr Stevens. For the first time since the passage of the Financial Agreement and the formation of the Loan Council, the question of the application of what was known as the 'formula' had aroused serious consideration.

... the allocation, in accordance with the Financial Agreement, would have resulted in serious anomalies. The Commonwealth, for example, would have had its share cut down by $£ 1,500,000$, and Queensland by about $£ 1,000,000$. Tasmania's quota would have been increased greatly over its actual expenditure last year, and Victoria would have shown very little increase. . . the adoption of the formula would have operated very unfairly to some of the Governments and would probably have had an adverse effect on the subscriptions to the loan about to be floated, and it would certainly not have been in accordance with the spirit of the Financial Agreement.

Mr Stevens said that, by reason of its previous revenue and loan budgets, New South Wales was in a position to dominate the whole of the public works policy of the various Governments had it so desired, but he had preferred to look at the matter from the broad national viewpoint. Throughout the whole of the discussions he had taken the view that his duty as a member of the Loan Council was not only to watch the interests of his own State, but to help the other Governments. ${ }^{21}$

This examination of some of the issues and ploys at one Loan Council meeting at which allocation was a major issue, indicates the complexity of meetings and it poses the problem of dealing in detail with each meeting which has been held (89 are officially listed up to June 1966 (table 8.6)). It is proposed therefore to indicate the main points of those which were more important and about which reliable facts are known to show why changes occured in trends, or to illustrate the consistency of methods and attitudes adopted in the Loan Council.

The evidence of the May 1935 meeting and the outcome of the loans floated indicated that the Commonwealth acted as a buffer by reserving its share but taking only a small portion in order to ensure that the States 
received the agreed sum, or close to it. It became clear that it was 'difficult to conceive any formula that would be agreed to by all Governments in advance and that would meet all eventualities fairly, and that would contain effective safeguards against over borrowing by any one or more States'. ${ }^{22}$ By then, the formula was an incentive to unanimous agreement. The meeting illlustrated also that a lot could be achieved, in allocating the loan program, by marginal adjustments that enabled a measure of justice to be done, such marginal adjustments permitting a majority of members to report back that the outcome was fairer than it had been or was expected to be. The concept of marginal adjustments is important because it keeps to a minimum the loss of face by the loser(s). To help meet these purposes, the Commonwealth could make from its relatively great resources an unconditional or conditional grant that eased the unfair burden which some were carrying, and reduced the losses by others in a manner which, while marginal once again, was important politically when each member made his report. ${ }^{23}$

In January 1938 the question of local and semi-governmental borrowings and their effect on the allocation of loanable funds between the States became a major public issue, although it had been a subject of discussion before. There was little public discussion of these borrowings at the time of the Gentlemen's Agreement of May 1936, when local and semi-government borrowing became part of the Loan Council's published program, and when the various past resolutions of the Council were consolidated into one set of rules. Although the official statistics of the allocation between the States of loans by these authorities began in 1936-37, ${ }^{24}$ and there had been recognition of their importance as early as 1925, there was no serious controversy in connection with their programs until 1938-39. Prior to 1938, the public discussion of the Agreement formula in 1935 had been all that those States, worried about allocation, had needed for political purposes. However, in 1938 the borrowing by other authorities was used for the purpose of publicity as a means of either gaining a bigger share of loans or explaining a failure to do so.

The Melbourne press gave considerable space to the announcement by the Premier of New South Wales that his government proposed to grant autonomous powers to the Newcastle and Hunter District Water Board in the interests of efficient administration. Stevens made it clear that the borrowing power of this and other independent authorities and statutory corporations had been and would continue to be subjected to the strict limits imposed by the recognition of the Loan Council as the body through

22 Report of the Commonwealth Treasury on the May 1935 Loan Council Meeting in Copland and Janes (eds.), Cross Currents, 4.

23 See C.P.D., 30 August 1956, 82 (Budget Speech) for another example favouring Western Australia alone.

24 Table 11.3 . 
which all public borrowing for major works should be conducted'. ${ }^{25}$ Commonwealth and Victorian Ministers refused to comment, which was understandable, as Stevens's statement was impeccable. But at the next Loan Council meeting in April 1938 the States were informed by the Commonwealth that it wished to raise loans for defence purposes which, it believed, would mean cutting the amount available for their civil programs. ${ }^{26}$ The disappointed smaller States turned their attention to the disproportionately large local and semi-governmental programs of New South Wales as the means of explaining away their reduced programs, clear-cut criticism emanating from the Premiers of South Australia (R. L. Butler), Western Australia (J. C. Willcock) and the Treasurer of Tasmania (E. Dwyer-Gray). ${ }^{27}$ The Commonwealth Treasurer (R. G. Casey) was reported to have agreed with the criticism of the representatives of the three smaller States: 'Mr. Casey pointed out that if Governments persisted with proposals that had been rejected by the Loan Council the "gentlemen's agreement" would probably break down.'28

The record of 'New Money Loan Raisings' from the public by the local and semi-governmental authorities up to 1935-36, and the official allocation of these authorities' requirements by the Loan Council subsequently, demonstrated the need to readjust authorities' disproportionate loan raisings, if possible, by means of the allocations of the other loan program under the Financial Agreement. To illustrate, the following observations can be made using table 12.3. In the 1930s, New South Wales dominated loan raisings by independent authorities as it had dominated the loans

Table 12.3

Local and semi-governmental authorities new money loan raisings, 1930-31 to 1937-38 (Em.)

\begin{tabular}{lccccccc}
\hline Year & N.S.W. & Vic. & Qld & S.A. & W.A. & Tas. & Total \\
\hline $1930-31$ & 0.80 & 1.02 & - & - & 0.02 & 0.03 & 1.88 \\
$1931-32$ & 0.31 & 0.87 & 0.05 & 0.07 & 0.01 & 0.07 & 1.38 \\
$1932-33$ & 3.18 & 0.04 & 0.12 & - & 0.08 & 0.06 & 3.48 \\
$1993-34$ & 3.14 & 0.03 & 0.12 & 0.07 & 0.12 & 0.02 & 3.50 \\
$1934-35$ & 1.48 & 0.62 & 1.44 & 0.05 & 0.14 & 0.03 & 3.77 \\
$1935-36$ & 3.26 & 0.04 & 1.54 & 0.04 & 0.07 & 0.04 & 4.99 \\
$1936-87$ & 6.38 & 0.50 & 1.03 & - & 0.35 & - & 8.26 \\
$1937-38$ & 2.84 & 0.36 & 1.56 & 0.15 & - & - & 4.91 \\
\hline
\end{tabular}

Sources: $1930-31$ to $1935-36$, C.F.B., no. 29 , table 72 ; 1936-37 to $1987-38$, table 11.3 .

25 Argus, 4 January 1938, 3.

26 Argus, 23 April 1938, I.

27 Argus, 25 April 1938, 3.

28 Argus, 26 April 1938. 
raised for State governments' budget deficits and works programs; but by 1934-35 Queensland had developed a satisfactory borrowing policy through its authorities relative to all States except New South Wales. Except in the early years, Victoria lagged in this class of borrowing but the three claimant States were raising negligible sums and were therefore much worse off than Victoria.

Looking, therefore, at the per capita statistics of total Loan Council allocations from the time official figures of local and semi-government programs became available in 1936-37, Western Australia, Tasmania and Queensland attained, overall, a relatively better share between 1936-97 and 1940-41; South Australia lagged badly, especially relative to the other two claimant States; and Victoria slightly improved its position in 1938-39, no doubt because of its dissent to a cut in the program which was decided by majority vote at the April 1938 Loan Council meeting, ${ }^{29}$ and was able to sustain the improvement in 1939-40; none the less, Victoria lagged very much behind New South Wales with which it is reasonable to compare it (table 12.4).

This, then, was the position before the war intervened, the basic determinants being New South Wales's ability to obtain a very large share of the loan programs in the depression years, presumbly because its unemployment levels were persistently above the national average and also, the ability of some members to persuade the Loan Council, once the depression was over, that the programs of their States should be financed by relatively larger shares of loans. This would involve, it would seem, not only the inheritance of a larger than average share from earlier years,

Table 12.4

Total Loan Council allocations per capita, 1936-37 to 1940-41 (average per capita of the six States $=100$ )

\begin{tabular}{lrrrrr}
\hline & $1936-37$ & $1937-38$ & $1938-39$ & $1939-40$ & $1940-41$ \\
\hline New South Wales & 121.2 & 112.7 & 122.7 & 120.9 & 126.0 \\
Victoria & 48.3 & 52.9 & 68.8 & 70.7 & 56.3 \\
Queensland & 119.3 & 149.0 & 91.6 & 89.8 & 103.2 \\
South Australia & 74.7 & 84.9 & 84.0 & 102.8 & 69.3 \\
Western Australia & 199.5 & 119.7 & 116.3 & 109.2 & 113.4 \\
Tasmania & 93.7 & 120.5 & 129.7 & 108.4 & 182.7 \\
\hline Average of six States & 100.0 & 100.0 & 100.0 & 100.0 & 100.0
\end{tabular}

Total program under Financial and Gentlemen's Agreements (fm.)

$\begin{array}{lllll}24.64 & 17.75 & 23.75 & 27.44 & 17.90\end{array}$

Source: Tables 11.2, 11.3 and 11.6.

29 Argus, 23 April 1938, 3. 
but persuasive arguments about the growth of the States' economies, the profitability of private enterprise and the need for public services, both to service private enterprises and for the personal needs of the public (tramways, bus and power services are good examples of the latter). Tables 12.3 and 12.4 indicate that, relative to other States, Queensland had a balanced mixture of State and local and semi-governmental authority programs, but Western Australia and Tasmania show clearly that it was not necessary to have large local and semi-governmental authority loan programs to acquire a total per capita allocation consistently above the average for the six States.

It has been noted that meeting the criteria of the Grants Commission could leave a favourable impression where an unfavourable one had been created in past expenditure of loan moneys. The salutary effect of the Grants Commission's policy began in 1938 but it seems not to have resulted in a marked change in the trends of the claimant States' shares of total loan allocations. Nor, it has been shown, was imbalance in the allocation of the total loan program corrected by financial assistance grants under s.96.

\section{Summary of allocations}

Some broad conclusions emerged from the allocation of loan raisings in the 1930s. The States looked at loans in a realistic manner by aggregating the loan program under the Financial Agreement with the local and semigovernmental borrowings under the Gentlemen's Agreement. Of all these loan raisings, a disproportionate per capita share was allocated to New South Wales relative to all States and particularly relative to Victoria as between the non-claimant States; and a larger per capita share was allocated to Western Australia and Tasmania relative to South Australia as between the claimant States. Section 96 grants did not offset to any appreciable extent the differences in loan allocations. Victoria fared worst and South Australia was second from the bottom of the table.

The allocation formula in the Financial Agreement was found to be unsatisfactory for practical purposes, but it was none the less an incentive to reach unanimous agreement. This was no mean achievement in view of New South Wales's disproportionately big share of all loans raised in the depression years. Large or rapid changes in the allocation of the loan program were normally impracticable after the downturn to the depression because of the dislocating impact on the States adversely affected. It was found that marginal adjustments, often by making some of the Commonwealth's share available to the States, enabled a measure of justice to be done, or to appear to be done, and enabled members to report back to their governments and electorates that this was so, with a minimum loss of face to the loser(s). In addition, the Commonwealth supplemented the allocation to the States of some or most of its share of the loan program with occasional, marginal revenue grants under s.96.

This action of the Commonwealth, and the difficulty associated with 
using the allocation formula, did much to bring unity to Loan Council meetings and to Premiers' Conferences after the serious divisions from 1930 to 1932. The Commonwealth's generosity was not a hard discipline in view of its lower taxation rates and better financial position compared with the States. Even so, the Commonwealth acquired greater stature and authority from its financial strength. The allocations of loans and grants were a part, but by no means the whole, of a pattern of growth of Commonwealth power in the $1930 \mathrm{~s}$ at the expense of the States and the Loan Council.

It is perhaps important to add that there was no tendency for usurpation of State responsibility by the Commonwealth, but there was a change in the balance of power. The change in the 1930s was to a more definite form of co-operative federalism in which the Commonwealth's position grew stronger. In that growth, the Loan Council was an indispensable agent as it fulfilled its statutory obligation to meet and to allocate the loan program. 


\section{Overseas Borrowing, 1932 to the War}

Whatever one might think of its wisdom and quality, the advice of Sir Otto Niemeyer to the Loan Council in 1930 was essentially in character with that of banker to client, and the British monetary authorities' advice to the Prime Minister (J. H. Scullin) in London in the second half of 1930 that budgets should be balanced before further loans could be considered was undoubtedly in the same vein. According to Giblin, the first time the Australian authorities rejected the advice of Montagu Norman was in January 1933, when a shipment of gold was sent to London to build up reserves. Norman thought it might adversely affect confidence in Australia's exchange rate. ${ }^{1}$

In addition to advice, London was, in the 1930s, a source of short-term sterling loans to sterling area countries, which were carefully rationed by the monetary authorities. In August 1932 the Bank of England agreed to lend the Australian central bank £3m. for 'window dressing' until September, and in July 1936 a nine months' loan of $£ 5 \mathrm{~m}$. was arranged between Montagu Norman and Sir Claude Reading, Chairman of the central bank's Board, but it was never drawn upon because export prices improved. ${ }^{2}$ The United Kingdom, as banker for the sterling area was, at least in principle, lender of last resort to the central banks of member governments in the 1930s. While the relationship led to the provision of short-term accommodation of international currency (sterling), it was not fruitful in generating a renewed flow of long-term loans to the Loan Council.

Under the stress of the deepening world depression and the necessity to defend sterling, the British government established more firmly in 1930 its informal control over new foreign issues, a part of its economic policy which has persisted ever since. ${ }^{3}$ The Loan Council and member governments had experienced the full weight of this control in 1930. In June 1932 the

1 Giblin, Central Bank, 134-5.

2 Ibid., 143, 238-9.

3 Kahn, Great Britain, 188. 
Chancellor of the Exchequer made the first public appeal for a complete cessation of new foreign issues while the $£ 2,085 \mathrm{~m}$. 5 per cent war loan conversions were undertaken. That was a conversion of the British public debt on the Australian model. The request to cease lending was complied with in respect of domestic and all overseas lending; it continued until September but was relaxed in October to allow domestic and Empire borrowers to enter the market for both new issues and conversions. ${ }^{4}$

This conjunction of events was a very important, if unexpected, turning point in the Loan Council's London operations. As a result of the conversion, the British bond rate fell from 4.5 per cent to 3.5 per cent. This established a fortuitous 0.5 per cent margin below what was to be the Australian conversion rate. The yields on Australian government securities in London fell sympathetically from 5 per cent in August to close to 4 per cent late in October. By coincidence, a New South Wales loan matured in this same month and the Loan Council was able immediately to make use of the relaxation of controls and the lower London interest rate to start a long series of conversion operations, approved by the Chancellor in the first instance as 'an exceptional measure'. ${ }^{5}$ The conversions were all to be at or below the 4 per cent to which the Australian bond rate had been reduced and this saved the Loan Council from an agonising reappraisal of the local rate, which would have been under pressure to rise had the British rate been fixed higher than 3.5 per cent and the Australian rate on the London market had risen above 4 per cent.

These London conversion operations were aided by the presence in Britain by late 1932 of a fund of goodwill towards Australia and its economic plight, helped undoubtedly by the return of the Lyons non-Labor government, the Commonwealth's success in the Garnishee Case, and Bruce's appointment to London as Resident Minister; he left after the Lang affair, and discharged the function of High Commissioner when Sir Granville Ryrie's term expired in June. Bruce's duties included the management of the many conversion operations and the raising and renewal of shortterm loans from the London capital market for as long as possible before scarce London funds were drawn upon to meet commitments, particularly to the London and Westminster Bank. ${ }^{6}$ Commenting upon the first conversion loan, The Times summed up the prevailing opinion thus:

The issue enables the city and the investing public to show their appreciation of the sacrifices which the taxpayers of Australia have made during the past three years to keep faith with their British creditors in incredibly difficult circumstances. Few who have no direct knowledge of Australian conditions can realise how difficult the circumstances have 
been, or how painful have been, and still are, the sacrifices required to meet them. The fall in the prices of Australian commodities and the depreciation in the exchange have more than doubled the real burden of the debts which have been contracted in easier times. By increasing taxation, cutting down all public expenditure to the bone, reducing internal interest rates, lowering wages and salaries all round and drastically restricting imports, Australia has managed to meet in full her obligations to her oversea creditors.

It is now the business of those creditors not only to show their appreciation, but also to help her to carry on the unequal struggle, by cooperating whole-heartedly in her efforts to reduce the burden of her oversea debt by well-judged conversion operations. By so doing they help not only Australia, but themselves as well, for in these difficult times a wise creditor will make it as easy as possible for his debtors to meet their obligations...?

J. M. Keynes had earlier expressed similar views. ${ }^{8}$

There was enlightened self-interest in The Times' view as the comment ended with the reminder that the sooner normal conditions were restored to Australia and the other primary producing dominions, the sooner they would be able to resume normal purchases of British goods and reduce unemployment. The success of the conversion was regarded as being almost as important for Britain as for Australia.

The Loan Council in subsequent years watched the progress of the conversion operations with the greatest interest, the significant development being that the British war loan conversion had reduced the effective rate of interest in London by over 1 per cent. The era of so-called cheap money had begun. ${ }^{9}$ Five Australian loans totalling $£ s t g 75 \cdot 85 \mathrm{~m}$. fell due in 1933, and the Chancellor authorised the conversion of the early ones as 'an exceptional measure' once again..$^{10}$ Bruce reported that Australia had been permitted to approach the market 'while all other Dominions were debarred'.11 However, other dominions were soon allowed to follow Australia's policy, and late in 1933 a $£ 5 \mathrm{~m}$. New Zealand conversion was subscribed ten-fold and a $£ 13 \mathrm{~m}$. South African conversion was oversubscribed in five minutes. Aus. tralia's conversion had also been oversubscribed.12

The regulation of the London capital market between October 1932 and July 1934 required Empire borrowers, both Government and private, to convert old and raise new issues in London with the approval of the

7 The Times, 4 October 1932, quoted in A.I.B.R. (1932), 958.

8 Shann and Copland (eds.), Price Structure, 84-5, article by Keynes written on 25 May 1932.

9 D. S. Lees, 'Public Departments and Cheap Money', Economica, February 1955.

10 A.I.B.R. (1933), 575 and Commonwealth Grants Commission, Fifth Report (1938), 159.

11 A.I.B.R. (1934), 292, reporting Bruce's speech in Melbourne. Bruce had returned for a brief visit.

12 A.I.B.R. (1933), 902. 
Treasury. In July 1934 the embargo was further relaxed to allow sterling area and other foreign countries to raise new loans provided they agreed to use the proceeds of London loans to benefit British industry and provided their general economic development increased British exports. It has been noted that loans were also permitted for the purpose of acquiring or adding to reserves. The British government continued to maintain stringent control over the capital market through the Treasury and the Bank of England. In April 1936, the Foreign Transactions (Advisory) Committee of experts was appointed to share the control with Treasury and Bank officers. No new policy was developed, but the existing practices were formalised into an arrangement whereby the committee's body of experts was available to advise officials. The primary object of the arrangement was to protect Britain's exchange rate, but the committee gave special consideration to sterling area countries. ${ }^{13}$ The period 1931-38 was one in which new capital issues remained low, the annual average, excluding conversions and refunding issues, being $£ 33 \mathrm{~m}$. compared with $£ 117 \mathrm{~m}$. in the years 1924-30. Empire issues declined by about 60 per cent and other foreign issues declined by over 90 per cent between the two periods. With the recovery of world commodity prices and gold exports, the overseas borrowers' balances of payments improved, and the dominions particularly began to redeem as well as to convert their debt. ${ }^{14}$ Australia borrowed very little new money but it played a dominant role in the conversion operations. Table 13.1 shows that between October 1932 and June 1936 Australia converted $£ 199 \mathrm{~m}$. of Commonwealth and State securities, representing about 80 per

Table 13.1

London refunding and conversion issues for overseas borrowers, 1932-36 (£stgm.)

\begin{tabular}{lrrrrrr}
\hline & 1932 & 1933 & 1934 & 1935 & 1936 & Total \\
\hline Dominion governments & 12.1 & 89.8 & 53.2 & 43.7 & 41.0 & 239.8 \\
Other governments & 6.0 & 26.1 & 12.1 & 14.3 & - & 58.5 \\
Local authorities & 0.3 & 1.7 & 0.3 & - & 0.3 & 2.5 \\
Industrial & 6.0 & 12.0 & 3.4 & 4.2 & 1.9 & 27.5 \\
\hline Total & 24.4 & 129.6 & 68.9 & 62.2 & 43.2 & 328.3 \\
Australian governments & 12.3 & 75.9 & 36.2 & 35.9 & 38.2 & 198.5 \\
\hline
\end{tabular}

Sources: Australian operations from successive Commonwealth Auditor-General's Reports 1931-32 to 1936-37, c. par.13; other statistics from R.I.I.A., International Investment, 315, which used the Bank of England's Statistical Summary.

13 R.I.I.A., International Investment, 78-80, and Kahn, Great Britain, 188.

14 Appendix F of Kahn's Book. Australian operations from successive Commonwealth Auditor-General's Reports, 1931-32 to 1936-37, c. para. 13; other statistics from R.I.I.A., International Investment, 315, which used the Bank of England's Statistical Summary. 
cent of dominion government conversions and about 60 per cent of all conversions.

Australia's advantage was that of the $f$ stg $2,600 \mathrm{~m}$. United Kingdom company securities and public utility and government bonds and debentures listed on the London stock exchange during the 1930s, an extremely small proportion was open to conversion and Australia was the only overseas borrower to reap any considerable benefit from the low interest rates there..$^{15}$

The Grants Commission calculated that to June 1937 the interest burden fell by £stg $3 \cdot 293 \mathrm{~m}$. or $£ A 4 \cdot 129 \mathrm{~m}$. as a direct result of London conversions, with considerable advantages to budgets and the balance of payments. The States' share was the greater, being £A3.273m. The Australian debt conversion of 1931 whereby, as part of the Premiers' Plan, the contracted rate on Australian-held debt was reduced by 22.5 per cent, resulted in a greater internal saving of $£ 7 \cdot 230 \mathrm{~m}$. As only $£ 4 \cdot 1 \mathrm{~m}$. of this was relief for the States, they benefited in this short period almost as much from the London conversions as the Australian. ${ }^{16}$ The London conversions continued throughout the era of cheap money which lasted until 1951.

Apart from the many conversion operations there was a little new borrowing in London by the Loan Council in the 1930s. Between 1929-30 and the outbreak of World War II the Commonwealth raised three new long-term loans in London apart from the conversions. One for $5 \mathrm{stg} 7 \mathrm{~m}$. in May 1938 included $£ 5 \mathrm{~m}$. for the redemption of treasury bills held by the Australian central bank in London. It added to the central bank's foreign exchange reserves and to the Commonwealth's foreign indebtedness. Sinking Fund moneys were used to prepare the market for the issue, but even so, two-thirds were left with the underwriters. The remaining $£ 2 \mathrm{~m}$. of the loan was for defence purposes, as also was the other large one of $£$ stg6m. in June 1939, and these were outside the Loan Council's responsibility. A third small loan of $f$ stg0.266m. was raised in April 1937 for Western Australia to purchase a coastal vessel; it had to be repaid half-yearly between 1937 and $1947 . .^{17}$

It is reasonable to conclude that the conversion operations were regarded by the United Kingdom authorities as adequate access to the London market for the Loan Council in the 1930s. Although little could be done to raise new money, the successful conversion operations were a considerable achievement by the successive non-Labor Federal governments, acting as the agent of the Loan Council. The Council reaped the harvest of a lower London interest burden early in the era of cheap money, which the Council and the Premiers' Conference had pioneered with the conversion of the Australian-owned public debt in 1931, the British authorities following Australia's example in 1932.

15 R.I.I.A., International Investment, 313-16.

16 Commonwealth Grants Commission, Fifth Report (1938), 159.

17 C.PP., The Budget, 'V Public Debt'; Giblin, Central Bank, 239-41. 
The Australian operations on the New York market were much less significant than those in London, and they can be summarised briefly. In 1931-32 the proportion of United States' borrowing in the total of London and New York debt (in Australian currency) was about onethirteenth. ${ }^{18}$ Thus in the Loan Council, London conditions naturally dominated foreign borrowing policy. Conversions by foreign and colonial borrowers in the United States between 1931 and 1935 amounted to $\$ 210 \mathrm{~m}$., of which four-fifths were Canadian. Australia had no debt falling due until August 1946; Canada enjoyed Australia's London advantages there during the 1930s. ${ }^{19}$ The Council's policy between $1927-28$ and the war (in fact, until 1949-50) seems to have been to let the face value of the New York debt of the Commonwealth and the States gradually fall at an annual average of a few million dollars each year, by using the National Debt Sinking Fund and some of the central bank's foreign exchange reserves. ${ }^{20}$ In 1946 the Loan Council was able to begin conversion operations in New York and enjoy the benefits of the era of cheap money in that market.

\section{Contrasts in overseas borrowing experience}

The broad movements in the Loan Council's overseas borrowing in the 1920 s and the 1930s provided some striking contrasts between the two decades (table 13.2 and table 8.1). The governmental borrowing referred to was largely that decided by the Loan Council, as new defence loans in Australia ended in 1919-20 and the last in Britain before 1938 was $£ 8 \mathrm{~m}$. in 1920-21. After 1920-21, changes in the war debt were small but could be significant in contexts other than that now to be discussed. An example was the effect of war loan conversion operations on the bond rate in the 1920s.

In the decade to $1928-29$, the total capital inflow averaged about $£ 35 \mathrm{~m}$. a year; of this governments accounted for about $£ 22.5 \mathrm{~m}$. or two-thirds, and private inflow made up the rest. In contrast, from the Premiers' Plan onwards, that is from 1931-32 to 1938-39, total capital inflow averaged only about $£ 8 \mathrm{~m}$. a year and there was an annual outflow on government account averaging $£ I \mathrm{~m}$; private inflow was therefore about $£ 9 \mathrm{~m}$. annually, or roughly three-quarters of its average in the $1920 \mathrm{~s}$ and it accounted for the whole of the positive movement of the 1930s compared with only one-third of inflow in the 1920 s.

The decline in the Loan Council's borrowing abroad in the 1930s was not matched by the increase in domestic loan raisings. Australian-held government debt increased between 1921-22 and 1928-29 inclusive by an average annual amount of just over $£ 9 \mathrm{~m}$. a year; between 1931-32 and 1938-39 inclusive, the average annual increase was $f 16 \mathrm{~m}$. This rise of $£ 7 \mathrm{~m}$.

18 Information supplied by the Commonwealth Treasury.

18 R.I.I.A., International Investment, 313-16.

20 National Debt Commission, Annual Reports and Giblin, Central Bank, 393. 


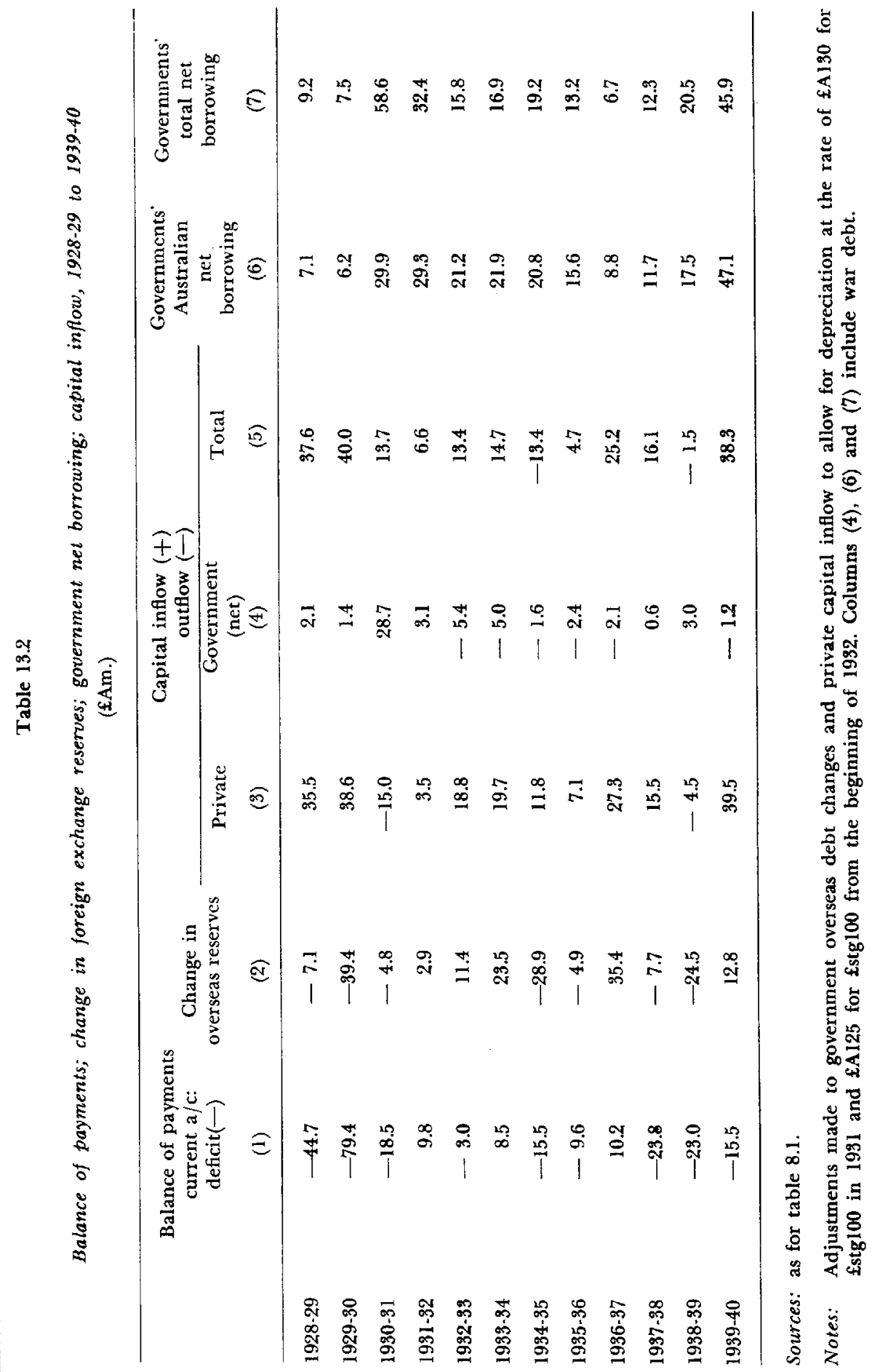


annually between the two decades was small compared with the fall of over $£ 22 \mathrm{~m}$. in government’s overseas borrowing.

One result of the decline in overseas borrowing by the Council was that in the 1930s there was a fundamental shift in the member governments' policies on works. The Commonwealth and State governments' gross domestic capital formation in the four years to 1928-29 averaged over $£ 58 \mathrm{~m}$, but in the three years to $1938-39$ that expenditure fell to an average of just under $436 \mathrm{~m}$. a year: ${ }^{21}$ the decline in works expenditure at relatively normal levels of economic activity about matched the decline in overseas borrowing by the seven governments. In contrast, the expenditure on capital formation by the private sector steadily rose in the 1930 s and by 1937-38 and 1938-99 it was slightly higher than in the 1920s; that was not a surprising result in view of the continuation of private capital inflow in the 1930s at only a slightly lower level than in the $1920 \mathrm{~s}$.

The decline in total capital inflow of about $£ 26 \mathrm{~m}$. a year between the 1920 s and the 1930 s was about 3 per cent of the gross national product at the end of the 1930s. By then, the percentage of unemployment was about the same as in the 1920 s and the economy was at what was regarded in pre-war years as the 'normal' level of activity. This decline in the country's dependence upon capital inflow supports the author's estimate that the average propensity to import fell by about 3 per cent between the last few years of the 1920s and the last few years of the 1930s and that that decline was a direct result of the fundamental policy changes introduced in 1930 and 1931. Further evidence to support the view that valuable import replacement occurred in the $1930 \mathrm{~s}$ was that the deficit on current account in the balance of payments averaged over $\$ 45 \mathrm{~m}$. a year between 1925-26 and 1928-29 inclusive; in the three years ending in 1939-40 it was only $£ 24.3 \mathrm{~m}$. or about half the deficit of the later $1920 \mathrm{~s}$.

A general interpretation of these broad movements is that the economy's dependence upon imports by the end of the 1930s had declined by about the average annual amount of government borrowing overseas in the 1920s. It signified that a major readjustment had occurred in the Australian economy and it was a very considerable aid to general economic policy in the later 1930s when all governments, the Loan Council and the banks were striving to maintain a high level of economic activity. 


\section{Realignments of Power over Economic Policy, 1932 to the War}

In the formulation of the actual Premiers' Plan of June 1931 the Loan Council's role in monetary and fiscal policy was a supporting one, but it became more central from the start of Lyons's long term in office early in 1932. After his government had succeeded in the Garnishee Case and Lang Labor was replaced in New South Wales, there was a long period of relative political stability. Although tensions between banks, particularly the central bank, the Commonwealth government and the Loan Council continued as they exercised power over economic policy, relations improved or were so transformed that, by 1938, fundamental changes had occurred which were of a very different character from the alignments in 1929-1931 in that area of power.

The Loan Council spearheaded some of the adjustments of the later 1930s. In essence, these amounted to the transfer of the initiative and therefore a transfer of power over general economic policy formation away from the banks so that a new balance was achieved. This occurred without significant legislation. The Loan Council was probably the main vehicle of co-operation between governments but it did not itself acquire more power; what it had was adequate for the task. In the adjustments that occurred, the Commonwealth, as agent of the Loan Council but acting for itself when it could, gradually acquired greater authority but it received repeated and indispensable aid from the States in the Loan Council. The practical outcome was a change from the situation in the 1920 s in which the banks, and to a lesser extent the Council, between them managed what little national economic policy there was to the situation in 1938 in which the central government and the central bank explicitly announced a modest Keynesian type of economic policy independent of the private banks.

The changes that occurred in the structure of power in the later 1930s were partly made practicable by the monumental policy measures introduced 
consciously and, in some cases, without any initiatives by the Scullin government in 1930 and 1931. The dimensions of these measures were breathtaking if one contemplates such measures in current, peacetime circumstances. Some were taken independently of governments, without the Commonwealth and the States either being able or obliged by legislative responsibility to act. These were the fall in wages by automatic cost of living adjustments by 10 per cent and a further cut of 10 per cent by the independent Arbitration Court; and depreciation by the private banks of the exchange rate by 25 per cent. These fundamental adjustments had been made by early 1931 and, in the long term, improved the terms of trade and the competitive position of the Australian manufacturer and primary producer. In addition, there were the conscious policy steps: the direct, central control of gold and the voluntary rationing of foreign exchange, each for the purpose of protecting the foreign exchange reserves; there were the quantitative restrictions and higher tariffs on imports, all designed to improve the balance of payments and some directed to assisting long-term import replacement; then there were the drastic deflationary cuts in loans by the Loan Council and in expenditure by the Commonwealth and the States which supplemented the other measures to ensure that imports were kept down to levels that foreign exchange reserves and current exchange earnings could pay for; and finally there was the reduction of the bond rate to 4 per cent, a low level which aided private investment, including that for import replacement, and which was not raised above 4 per cent for over two decades. These measures were, in toto, a strong mixture of short and long-term correctives and they were accepted at the time as being so; the end of overseas borrowing, or the sop of conversions only, drove home the long-term nature of the problem only too well by the beginning of 1932 .

From 1932 onwards the main problem in managing the economy was to assess from year to year whether a basic improvement had occurred in the balance of payments as a result of the fundamental measures introduced in the Scullin government's term in office and as a result of any improve. ment in export income; if there was an improvement, then the level of economic activity and employment could be raised, if necessary, by expanding government works expenditure. The fact that Australia's imports as a proportion of the gross national product were materially less at the end of the 1930s compared with the later 1920 s was an appreciable aid to economic expansion.

The main developments which indicated that there was a transfer of power over this area of decision-making were these. First, the Council resisted the central bank's persistent efforts to have governments continue to pursue narrow or orthodox fiscal policy, mainly by resisting the bank's determination to have the treasury bills issued in the two years of Labor rule converted to long-term securities paid for out of current loan sub- 
scriptions; that would have been deflationary. The Commonwealth also resisted the central bank's demands that Commonwealth surpluses be used not to make s.96 grants to the States, but for the purpose of redeeming treasury bills; that also would have been deflationary. The groundswell for a royal commission on money and banking proved irresistible and indicated clearly a powerful movement for reform of monetary management. The banks, especially the central bank, were therefore put on the defensive in negotiations with the Loan Council about the amount of government expenditure. The banks' position weakened further when the central bank's policy on fundamental issues diverged from and conflicted with the private banks'. The central bank's isolation ended with the appointment of the Secretary to the Treasury as Governor early in 1938 and the central bank's proposal for what was definitely a broader Keynesian policy later that year.

The argument of this chapter will therefore reveal that much of the way had been prepared late in the 1930s for the changes which were ultimately introduced in the banking regulations and legislation of the war and post-war years; it will suggest that the country was ready by the outbreak of war in 1939 for a new balance of power in economic policy formation which was more in tune with that which Theodore and Scullin had conceived in their defeated legislation of 1931. In the preparation of the way, the Loan Council performed the indispensable function of being directly involved in the negotiations and of acting out the secondary role to which its limited powers restricted it.

\section{Divided power over an unstable economy}

In the late 1920s the net gold and foreign exchange reserves of the Australian banking system were about $£ 100 \mathrm{~m}$. By the June quarter of 1931 they had fallen to the minimum that was regarded as necessary for confidence in, and the practical working of, the banking system- $\$ 45 \mathrm{~m}$. The reserves rose to the pre-depression level in the March quarter of 1934 but fell to $\$ 49 \mathrm{~m}$., danger level, in the following year and remained low for five quarters. They were back to the satisfactory level of between $£ 90 \mathrm{~m}$. and $£ 100 \mathrm{~m}$. in 1937, but fell again to the dangerously low level of $£ 52 \mathrm{~m}$. in the September quarter of 1939. ${ }^{x}$

These rapid fluctuations in the reserves were due largely to oscillations in commodity prices and to private capital outflow in two years, and they often made policy obsolete almost as soon as it was decided. While there was general agreement that short-run monetary and fiscal policy should be directed to dampening down the effects of the fluctuations on the level of economic activity, there were great differences in the interpretation of theory for practical policy. This was especially so in times of a shortage of reserves. Expansion when reserves were adequate was relatively more

1 S. J. Butlin, A. R. Hall and R. C. White, Australian Banking and Monetary Statistics 1817-1945 published by Reserve Bank as Occasional Paper No. 4A (Sydney, 1971), 451. 
easily managed. ${ }^{2}$ An example of the quickness of changes in thinking about policy was recorded by Giblin. Late in 1931 and early in 1932 the central bank considered that the gold and foreign exchange reserves were rising to a level at which it was reasonable to consider appreciating to nearer parity with sterling. By April 1932 the reserves were running down because of falling export prices. The issue then became one of considering further depreciation. $^{3}$

The difficulties created by such rapid economic changes were compounded by the fact that as in the past, the control of monetary and fiscal policy was divided between the central bank, the private trading banks, the Commonwealth government, the six State governments and, after 1927, the Loan Council. The procedures hammered out in 1930 and 1931 continued to be followed. The several governments meeting in the Loan Council submitted agreed loan programs to the central bank and discussed with it the amount of finance that would be required by the issue of treasury bills for works and to meet budget deficits. The central bank's position continued to be that of independent arbiter in these matters, open to persuasion but completely free of ministerial control; the Council could vote itself a large loan program but the central bank could underwrite a smaller one. The private trading banks retained control of their foreign exchange reserves except the amount they had agreed to make available under the Mobilization Agreement to pay the overseas interest on the public debt and any exchange they voluntarily sold to the central bank. The banks expressed the view in 1936 that to give the control of all London funds to governments was unnecessary because the private banks had managed the foreign exchange reserves for a century with notable success. To pass full control to governments could invite 'a glorious inflation'." Credit control was also firmly retained by the private banks; central control would have required the assent of the banks to borrow from the central bank or to lodge deposits with it. In evidence to the Royal Commission on money and banking in 1936, the private trading banks made it clear that they would not voluntarily submit to having their credit policy controlled by the central bank. Power over bank interest rates was also effectively retained by the private banks. ${ }^{5}$ But the central bank had acquired some responsibilities. In addition to the Mobilization Agreement and to central control of gold, one other major change had occurred in the first two years of the depression. In December 1931, the central bank had, by agreement with the private banks, assumed control of the exchange rate, which required it henceforth to buy the surplus foreign exchange of the

2 Giblin, Central Bank, 144, 215-16.

3 Ibid., 138-9.

4 Ibid., 187, 189, 228. This is considered again in chap. 15.

5 Ibid., 221-2. 
banks and the public and thus create reserves separate from those held by the private banks. ${ }^{6}$

The Loan Council's main responsibility in the discussions on economic policy was that it made decisions about the bond rate and the amount of the budget deficits and the works program; if the works program could not be financed with loans raised on the open market because the supply of loanable funds was inadequate, then the Council was obliged to obtain advances from the central bank on the security of government obligations. That was crucial throughout the $1930 \mathrm{~s}$, more so at the beginning and at the end of the decade, because the Australian market was the only source of loans for the works programs. In contrast, in the 1920 s and earlier decades works had been financed with considerable overseas loans as well.

The division of power over economic policy and the sheer size of the problem facing the country in 1932 made it evident early in Lyons's term as Prime Minister that there should be no serious discord in relations with the States if governments were to be effective in negotiations with the other groups forming economic policy. A further incentive to unity was that co-operation was an aid to each government's political survival.

\section{Strength and unity in the Loan Council}

Much of the unity achieved from 1932 onwards was due to the tactical and conciliatory moves by the Commonwealth in its relations with the States. These efforts were aided by fortuitous events and one further effect was that the Commonwealth strengthened its position in the power structure. One reason why the Commonwealth gradually grew in stature was a simple machinery matter: the Commonwealth was the agent of the Council in loan arrangements and its representative was chairman. The Commonwealth was therefore to the fore as a Loan Council representative in the much publicised negotiations with the central bank.

In addition, the Commonwealth consciously pursued a policy of keeping the peace between itself and the States. The Commonwealth succeeded in the Garnishee Case and this resulted in Lang's dismissal from office. His absence from meetings of the Loan Council and Premiers' Conferences was an aid to unity. The Commonwealth appointed the Grants Commission in 1933 and used s.96 with increasing freedom; the Commonwealth challenged the States in 1934 to improve on this arrangement of financial relations between itself and the States. Passing the initiative to the States put the responsibility in their court and prevented the kind of acrimonious discussion of the problem that had occurred in the 1920s. The Commonwealth also frequently forwent some of its share of loans raised when they were less than the agreed loan program, or advanced some of its share to the States to silence complaints from them.

6 Holder, R. F., Bank of New South Wales History 1817 to 1970 (2 vols.) (Sydney, 1971), vol. 2, 715-19; Commonwealth Year Book, no. 29, 962. 
In addition to these manoeuvres and the Commonwealth's persuasive fiscal inducements, fortuitous events contributed to unity in the Council. At the April 1932 Premiers' Conference, Lang was present and adopted a militant attitude, rejecting the Premiers' Plan to which he had reluctantly consented ten months earlier and demanding a forced reduction of the interest on the external debt; he finally walked out of the Conference. The Victorian Labor government was faced with imminent elections and it also weakened on the Plan at the conference. The two most powerful States therefore created a situation which made constructive collaboration between governments impossible. ${ }^{7}$ Yet when the Premiers met again two months later in June, the Labor governments in New South Wales and Victoria had been replaced by non-Labor governments of a much more co-operative kind and these remained in power in those States until midway through the war. Equally important, B. S. B. Stevens, the new Premier of New South Wales, and W. Forgan-Smith who became Labor Premier of Queensland at the same time as the changes to non-Labor occurred in the two larger States, were rational and able negotiators who brought strong and persuasive advocacy to the governmental side. The Loan Council benefited from these changes of personalities and could be expected to pursue reasonable policies and shrewd tactics in its relations with the banks.

In May 1936 the Gentlemen's Agreement was concluded to give the Loan Council wider power over governmental loan raising to ensure a more just distribution of loans. The control was of an informal kind over the terms and amount of all semi-government and local government borrowing programs. Thenceforth this borrowing was voluntarily considered by the Loan Council as part of the total loan program. Several amendments of the Gentlemen's Agreement as the result of experience were reported in 1939.8

But relations between member governments of the Loan Council were not always sweetly reasoned accord: that would be unrealistic. The Gentlemen's Agreement and the 1939 amendments to it were not enough to quieten misgivings about the allocation of the program that were strongly stated by A. A. Dunstan, the Victorian Premier. ${ }^{9}$ The smaller States also expressed concern about what they claimed was their disadvantageous position relative to the larger States which had more semi-governmental authorities. ${ }^{10}$

The Loan Council meetings in 1933 and early 1934 revealed considerable disquiet amongst the States which was only partially appeased by 5.96 grants and the establishment of the Grants Commission in May 1933, and by the allocation to the States of part of the Commonwealth's share of

7 Giblin, Central Bank, 161-2.

8 Argus, 23 June 1939, 2; 8 July 1939, 3; 15 July 1939, 14; V.P.D., 20 August 1939, 984.

9 Argus, 17 July 1937, 13; 23 June 1939, 2.

10 Argus, 25 April 1938, 3. 
the loan program. The Commonwealth had surpluses while the States had great and persistent deficits and serious unemployment to contend with. That led the States to seek ways of easing their problems, or at least to seem to be making practical proposals to satisfy the electorate's inquiries, frustrations, and bitterness as the depression continued.

In this mood, Victoria, early in 1934, complained that its conversions in London were low on the list of priorities and it was not therefore receiving the benefits of lower interest charges; Lyons replied that the Loan Council had decided that loans bearing the highest rates of interest should be dealt with first without regard to individual States. ${ }^{11}$ The South Australian Premier (R. L. Butler) joined in the controversy with figures alleging that Victoria had benefited most from all internal and external conversions thus far, but had been low on the list only in recent London conversions. ${ }^{12}$ This particular controversy soon ended.

Yet dissent was relatively unimportant from mid-1932 onwards and the unity and strength of the Loan Council grew as the decade passed. The Commonwealth developed into a stronger unit of government acting for itself in the disposition of its financial assistance and as leader and agent of the Loan Council in negotiations with the banks.

\section{Division and weakness amongst the banks}

In the debates with the Scullin government in 1930 and 1931, the unity and determination of the central bank and the private trading banks had enabled them to take the initiative in policy formation in the crisis. Once the general economic policies of those years were hammered out and passed through Parliaments, the basic issue was to govern the rate of recovery from the depression so that it was within the limits imposed by the current balance of payments and the level of foreign exchange reserves. Accurate statistics of the level of reserves were withheld by the private trading banks from the Commonwealth government until their publication in mid-1937 by the Royal Commission on banking, and policy up to that time was decided without full knowledge of the main facts being available to Ministers. Commonwealth Ministers and, no doubt, the Loan Council received partial information prior to that year but the principle upon which the banks rested their refusal to disclose was that 'This was dangerous and heady information for the public'-it could lead to runaway inflation. ${ }^{13}$ The spectre of resort to the printing press as in European countries in the 1920s haunted the banks and they clung to their independence and their power.

But respect for and the unity and the power of the banks eroded steadily from 1932 onwards. It was a perceptible change caused more than anything

11 Argus, 8 January 1934, 8; 9 January 1934, 7.

12 Argus, 12 January 1934, 7.

13 Giblin, Central Bank, 187, 189, 256-8. 
else by their arrogation of economic policy formation to themselves in 1930-31 and by the severity of the depression-new ideas were more acceptable. Theodore's reasoned arguments and Scullin's sincerity had sown seeds in the community and they grew with the passage of time. The weakening grip of the banks gave the Commonwealth and the Loan Council their opportunity to exercise more influence on policy. The evidence for this assertion becomes clear as the negotiations between 1932 and 1939 are recounted.

At the start of his term in office, Lyons was Treasurer as well as Prime Minister; he held both portfolios until 1935, using a succession of Assistant Treasurers until R. G. Casey's appointment as Treasurer in October that year. The Loan Council met in January 1932 and Gibson addressed the letter to Lyons informing him that the central bank's policy remained unchanged. At that early stage, Lyons found the central bank to be as adamant as it had been toward the Labor government in refusing to increase the amount of finance on the security of treasury bills above the amount agreed in the Premiers' Plan. ${ }^{14}$

Despite the warning, the works program agreed with the central bank for 1931-32 raised treasury bills outstanding by $£ 23.5 \mathrm{~m}$.; admittedly much of this had been committed by the negotiations with the bank in the formulation of the Premiers' Plan in 1931 but a small additional sum was added. In April 1932 Lyons presented to a joint meeting of the Premiers' Conference and the Loan Council the proposals of the Wallace Bruce Committee which had been appointed at the January meeting to prepare a report and advise on the economic situation. One recommendation was that $110 \mathrm{~m}$. should be raised for works, half from the Commonwealth's resources and the remainder from the issue of treasury bills to the central bank. The public works were to be kept to those productively useful. The scheme was adopted; it was successfully negotiated with the central bank, put into operation in the following months and the result was an increase of nearly $13 \mathrm{~m}$. in the amount of treasury bill finance. ${ }^{15}$ That was a cautious step towards conscious economic expansion when the depression was probably at its worst.

At the June 1932 meeting of the Council the advent of Stevens and Forgan Smith was notable; they spoke forcefully for more expansionary policies when confronted with further stern letters from the central bank which demanded that the budget deficits for 1932-33 of $f 12.6 \mathrm{~m}$. agreed in the Premiers' Plan should be reduced to $£ 6-7 \mathrm{~m}$. (an arbitrary half-way mark between $£ 12 \mathrm{~m}$. in 1931-32 and budget equilibrium in 1933-34 according to the Plan). The Commonwealth's resolution that the Premiers' Plan be affirmed was amended to express the governments' intention 'to conduct public policy with a view to reviving industry so as to restore normal 
employment'. The debate with the central bank Board on this occasion began in Canberra and was adjourned to Sydney on 1 July 1932; the Loan Council formally met again on 8 July to affirm the outcome of the discussions with the bank: that was treasury bill finance in 1932-33 for deficits of $£ 9 \mathrm{~m}$., a compromise halfway between the two limits of $£ 12.6 \mathrm{~m}$. and $£ 6.7 \mathrm{~m}$. In addition, there was an ordinary works program of $£ 7 \mathrm{~m}$. and a further $£ 7 \mathrm{~m}$. of special expenditure to provide work for the unemployed to replace the unemployment benefits for which there was no productive return; these were part of the Premiers' Plan. ${ }^{16}$ It would be fair to judge the outcome of this meeting between the Council and the central bank as being evenly divided but with the Council displaying stiffening resistance to the bank.

In October 1932 the Loan Council engaged in protracted discussions with representatives of the private and central banks regarding the first new Australian cash loan since 1930 . The central bank suggested a $\$ 20 \mathrm{~m}$. loan at 4 per cent on condition that $£ 12 \mathrm{~m}$. was used to fund treasury bills. Sir Robert Gibson insisted that a funding loan should take precedence over a 'national recovery loan' but was opposed by some private bank representatives. ${ }^{17}$ The final decision was that an $£ 8 \mathrm{~m}$. loan at 3.75 per cent should be floated on 7 November; the Loan Council is reported to have insisted on 3.75 per cent, which was probably a compromise between the central bank's 4 per cent and publicised demands for 3.5 per cent by Stevens, Premier of New South Wales. ${ }^{18}$ Stevens had the support of the Bank of New South Wales and of most economists. ${ }^{19}$ It was agreed that the loan should be half for works and half for funding treasury bills, but in the event, only $£ 3 \mathrm{~m}$. was subscribed by the public, and the rest was subscribed by the underwriting banks which substituted long-term securities for $£ 4 \mathrm{~m}$. of treasury bills, according to the purpose of the loan. The Loan Council emerged from this meeting aware that the central bank and private banks were no longer firmly united and that it could hope to amend the central bank's proposals with a good deal of success. The central bank was possibly right about the best rate of interest to offer to raise money at that time4 per cent or a rate much closer to that parameter may have resulted in larger subscriptions as it was the yield on bond sales on the open market. ${ }^{20}$

The anxiety of the central bank to be rid of treasury bills led Gibson soon after to make a presumptuous move. Late in December 1932 he began trying to persuade the Commonwealth to use its surpluses to redeem treasury bills, but in the ensuing months Lyons fended the bank off and

16 Ibid., 162-3; Schedvin, Depression, 320-1; Shann and Copland (eds.), Price Structure, 18, 108; S.M.H. and Age, 8 and 9 July 1932.

17 S.M.H., 27 October 1932, 7; Argus, 29 October 1932, 23; Schedvin, Depression, 330-1. 18 Argus, 29 October 1932, 23; S.M.H., 5 November 1932, 14; Giblin, Central Bank, 163,175 .

19 R. G. Casey in Copland and Janes (eds.), Cross Currents, 317-18,

20 Reserve Bank, Statistical Bulletin; see also chap. 15. 
the surpluses were used to make grants to the States. Lyons was obliged, as Theodore had been on another issue the previous year, to inform Gibson that the central bank had no right to expect to be consulted on the use of the Commonwealth's surpluses; if the government had done so it would have been a surrender of its responsibility for a vital area of policy. As a compromise, Lyons agreed to inform the bank about the policy after action had been taken, adding that the policy would be to stimulate the economy. ${ }^{21}$ This weak tactic of the bank strengthened the hand of the Commonwealth in relations with the bank and the States.

Intensive discussions occurred about treasury bill finance at the next meeting of the Loan Council in February 1933 between the representatives of the Board of the central bank, its Chairman and Governor, and the Prime Minister and Senator Massey Greene who was chairing the Loan Council. ${ }^{22}$ It was notable that the trading banks were not brought directly into these discussions, but it was reported that their views were known to the Council. ${ }^{23}$ F. D. Healy, Acting Chairman of the Associated Banks of Victoria, issued a statement that it was for governments to make policies and his was among the first of a steady stream of such statements as the banks endeavoured to direct attention away from the powerful position they occupied. The demands for the Royal Commission on banking were starting to have their effect and indicated a fundamental change in the electorate's conceptions about where responsibility for economic policy should be. ${ }^{24}$ Another possible reason. for leaving the private banks out of the meeting was the evidence of their own disunity and disagreement on policy with the central bank and the Loan Council. ${ }^{25}$

If at this meeting the private banks showed signs of weakening their direct pressure on the Council, the central bank did not. The Loan Council

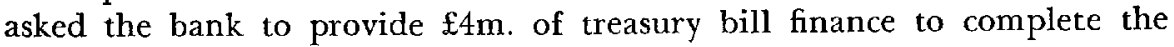
1932-33 public works program. The bank responded that it would accept only long-term debentures on the conditions that the Council undertook in the next eighteen months to float loans when the Board so advised and devoted at least half the proceeds to funding treasury billsi The Loan Council resisted these encroachments upon its freedom of action and the intensive discussion led to an agreement which was, on balance, a tactical win for the Council. The Council agreed to try to raise on the market

21 Giblin, Central Bank, 163; Schedvin, Depression, 322-3.

22 Giblin, Central Bank, 164-6; Argus, 4 February 1933, 21; 5 February, 7; S.M.H., 6 February, 9.

23 Argus, 7 February 1933, 4; A.I.B.R. (1933), 107-8.

24 Ibid.; Herald (Melbourne), 6 February 1933; Holder, Bank of New South Wales, 793; in 1935 there were reports that the central bank had issued a statement that the members of its Board 'know no politics'. Argus, 29 May 1935, 7.

25 Holder, Bank of New South Wales, 718, 734-5, 743, 791, 794 inter alia. Giblin, Central Bank, 186 inter alia; the disagreements with the central bank had been about the exchange rate, reducing bank lending rates, funding treasury bills and the allocation of treasury bills between the private banks. 
loans recommended by the bank and, after a first call of $£ 12 \mathrm{~m}$. for works out of the 1933-34 loan program, the remainder would be used to redeem treasury bills; but there was a condition that the funding loans should not prejudice future loans necessary for public works. That condition let the Council out of the agreement if it chose to strain the provision. Compromise studded other parts of that particular arrangement with the central bank but in fact the unsuccessful earlier loan of October 1932 to which the underwriting banks had subscribed more than one-half the proceeds 'was the first and last funding loan which reduced the volume of Bills outstanding. The funding loans which followed did no more than fund the bills drawn to meet the current deficits of the year and so avoid any increase in Bills outstanding' ${ }^{26}$ Governmental short-term debt remained steady or fell slightly thenceforth and there was no new deficit finance until 1938-39. This appeared to be a considerable victory for the central bank as there was no addition to the bills outstanding even in 1933-34, the last year of the Premiers' Plan when, instead of budget equilibrium, there were deficits of $£ 5.7 \mathrm{~m}$. or $£ 7 \mathrm{~m}$. in the States. What in fact occurred was that these deficits were largely financed by long-term loans and this policy was followed on a much smaller scale in 1934-35. By 1935-36 the States' deficits of $£ 2 \cdot 6 \mathrm{~m}$. were more than matched by the Commonwealth's surplus of $£ 3.6 \mathrm{~m}$. The secret of the ability of the governments to fend for themselves after the November 1932 loan was the greater flow of private loan money that was then subscribed to new issues until the middle of $1935,{ }^{27}$ together with assistance from the Commonwealth to the States from its surpluses and its share of the annual loan programs.

The elimination by the end of 1932 of the need for long-term credit from the banks on the security of treasury bills increased the independence of the Council and reduced the banks' power. This situation was not evident immediately but within a year or so, by early 1934, the central bank had changed its tactics. Instead of pressing so hard for the conversion of old treasury bills to long-term bonds, the central bank directed more of its attention between early 1934 and February 1936 to starting an open market in treasury bills to facilitate its control of liquidity in the hands of the public and the trading banks. The funding of old bills therefore became part of a general proposal for the open market for treasury bills. The public was to be asked to subscribe directly for bills. The central bank pushed this policy alone; the trading banks wished to keep treasury bills because they could be redeemed within three months or discounted at short notice by the central bank and were therefore as good as cash and yet better because they earned interest; some trading banks also regarded the policy as deflationary at a time when they were liquid and advised economic expansion; member governments of the Loan Council accepted

26 Giblin, Central Bank, 163.

27 Ibid., 174, 184; Holder, Bank of New South Wales, 792; see also chap. 15. 
the argument that the funding would be deflationary and also opposed funding the old bills because the rate of interest on bonds was higher and the Sinking Fund charges, at penalty rates on loans to meet budget deficits, would have to be paid. ${ }^{28}$ Therefore, in the process of advocating the open bill market, the central bank isolated itself even more from the trading banks and was to reveal rather starkly as late as 1936 the gulf between itself and the Loan Council. Even though the proposed open market for bills was put to the Council repeatedly and either shelved or rejected from early in 1934 onwards, the central bank went ahead with the policy on 28 February 1936. It offered $£ 1 \mathrm{~m}$. treasury bills to the public at 1.75 per cent, which was better than the 1.5 per cent offered on fixed deposits with the trading banks. Although the central bank was reported to have consulted the private banks, they were concerned lest they lose their fixed deposits and the Bank of New South Wales, followed by the Bank of Adelaide, immediately countered the central bank's move-they raised their deposit rates to 2 per cent and the subscriptions to the new issue of treasury bills were but $£ 315,000$. The Board accepted defeat and the next official attempt to act in the short-term market was in 1959. In its review of the episode, the Royal Commission concluded that a misunderstanding arose out of the central bank's discussions with the trading banks. ${ }^{29}$ But there were more important matters of principle involved.

There had been a Loan Council meeting in early February, but there is no public record that it was to discuss the central bank's definite intention to establish a bill market later that month. The Prime Minister stated in Parliament that the Commonwealth was informed of the step the day before the issue was made, barely giving time for the members of the Loan Council to be informed; presumably they rubber-stamped the terms and conditions if not the policy, and Lyons stated specifically that it was entirely a matter for the Board and not one upon which the Commonwealth should express an opinion unless the Board asked for it. ${ }^{30}$ Lyons exposed his own reluctance to go too far in criticising what he believed should be an independent central bank but he could also be taken to have washed his hands of the bank's action. The events showed very clearly the depth of the gulf at that time between the bank on the one hand and the Commonwealth and the Loan Council on the other.

Giblin commented that a further effect was a serious disagreement between the central bank and the private banks on interest rates. The central bank had kept its three-months fixed deposit rate at 1 per cent whereas the other banks had offered 1.5 per cent. Immediately after the treasury bill

28 S.M.H., 24 May 1935, 15; Copland and Janes (eds.), Cross Currents, 350 et seq.; Giblin, Central Bank, 166-9; Holder, Bank of New South Wales, 795, 810-12: 'In his private correspondence Davidson imputed the most sinister deflationary motives to the Commonwealth Bank Board'; see also chap. 15.

29 R.C.M.B., 64-5; Giblin, Central Bank, 167-73.

30 C.P.D., 11 March 1935, 25. 
fiasco the central bank sought to induce the other banks to reduce their rates to the same level as itself but the proposal was rejected and the rate on three-months deposits was raised to 2 per cent, mainly under pressure from the Bank of New South Wales. ${ }^{31}$

\section{Realignments of power}

It would seem that the main issue early in 1936 was not whether there should be an open bill market nor where the leadership in interest rates should lie but whether the private banks should be subject to central bank control. ${ }^{32}$ In a very real sense this may have been a turning point in Australian monetary history as the central bank was then in the position of needing new alignments-away from the private banks and more towards the other two monetary authorities, the Commonwealth and the Loan Council. There were other movements afoot that hastened this realignment and further eroded the traditional position of the banks in the structure of power.

In the policy speeches for the general elections in September 1994, both Labor and the Country Party stood for a Royal Commission into the banking, monetary and exchange system. Although Lyons attacked the various monetary reforms of Labor and Douglas Credit, and alleged that the banks were in danger of political interference, he was obliged during the campaign to promise a Royal Commission on banking if the newly elected Parliament demanded it. ${ }^{33}$ The Commonwealth in 1935 appointed the Royal Commission and its public hearings, which began in January 1936, were reported fully in the press; the banking system was therefore under even closer public scrutiny from 1936 onwards. The Royal Commission completed its Report in July 1937 and it was tabled in the Senate in August. The only recommendation that directly affected the Loan Council was that there should be permanent machinery which would enable the Council, the central bank and all government treasury departments to maintain close contact with one another-a function already provided by the Commonwealth Treasury. But the Report commented that public borrowing 'may affect the monetary and banking system. It is essential materially, therefore, that the Commonwealth (central) Bank should have close and cordial relations with the Loan Council as well as with the Commonwealth Government' ${ }^{34}$ The Commission also recommended that the central bank should hold the surplus foreign exchange reserves of the private banks and that the level of total reserves should be published; that the private banks should be obliged to keep deposits with the central bank up to any percentage approved by the Treasurer, a forerunner of 
special accounts and special reserve deposits; and there were other measures of control, most of which required legislation. By delaying tactics in conferences with the Treasurer and the central bank, and by effective publicity that played on the fear of some sections of the public that ministerial control of monetary policy was dangerous, an issue on which Lyons and his ministers were sensitive, the private banks were successful in persuading Lyons's government not to take profound legislative action. Even so, the vigour of the Bank of New South Wales's campaign against greater government control of the private banks induced Lyons early in 1938 to warn its manager, Davidson, privately that unless the banks curtailed their campaign, 'the Government might be obliged to introduce a bill to demonstrate that it was not being run by the banks'. ${ }^{35}$ Lyons's death in April 1939 was another reason for postponement until full implementation of the recommendations and other related measures under the defence power after the outbreak of war.

But it was a logical outcome of the changes in the structure of power that occurred from late 1932 onwards and of the publicity given to the Royal Commission and the revolutionary nature of its recommendations that closer ties should be developed as quickly as possible after the Commission's Report between the Loan Council, the Commonwealth and the central bank. That action would be a major preliminary move towards greater control of the private banks and a step was taken within six months of the tabling of the Royal Commission's Report. Sir Harry Sheehan, who had been secretary of the Loan Council from its first meetings in 1923 until July 1932 and who was Secretary of the Treasury from 1932, became Governor of the central bank in February 1938 and brought with him closer and more confidential relations between the three monetary authorities. ${ }^{36}$

This was given a practical test late in 1938, about the time that the first large $\$ 72 \cdot 6 \mathrm{~m}$. conversion of the 1931 compulsory conversion operation fell due. The preparations for the December operation were like those for about the same amount of war debt that fell due in 1925; governments, the Loan Council, the central bank, the private banks, the life assurance companies and other financial institutions were all in the discussions on terms, conditions and sharing the underwriting. One cause of fear was that the holders of these particular bonds were regarded as those people most likely to want cash instead of converting. There was also a strong undercurrent of anxiety about the balance of payments: the export price index fell by 20 per cent in 1938-39 and the foreign exchange reserves fell swiftly

35 Holder, Bank of New South Wales, 826-31. ‘. . it was a guerrilla struggle on the fringes of government and business'; R.C.M.B., 206, 228, 230-1; Giblin, Central Bank, 231-7.

36 Giblin, Central Bank, 122, 259, 261. S. G. McFarlane, assistant secretary in the Treasury, succeeded Sheehan as secretary of the Loan Council. 
quarter by quarter throughout the year to a dangerously low level of about $£ 52 \mathrm{~m}$. in the June quarter of $1939 .{ }^{37}$

The central bank understood the danger and pressed governments to conduct a public works policy to counter the imminent recession. It collaborated closely with governments and the Loan Council to ensure that approved loans were filled in addition to the large conversion in December 1938. In that month, Sir Claude Reading, Chairman of the bank's Board, made an explicit, well publicised statement that the central bank would do all in its power to mitigate any deflationary consequences of the fall in export income. The bank engaged in other Keynesian policies on a broad front. It began effective open market operations, increasing its bond holdings by $£ 3 \mathrm{~m}$. in 1938 and by $£ 12 \mathrm{~m}$. in 1939 , ensuring, inter alia, that the banking system and the public had adequate funds; it took the step of announcing its willingness, if necessary, to subscribe $£ 6 \mathrm{~m}$. to the unconverted portion of the conversion and converted its own holdings; and it joined deficit finance of $£ 4 \mathrm{~m}$. on the security of treasury bills in $1938-39$ to these other policies in attempts to maintain income and employment in the face of the disastrous slump in export income and a cessation of private capital inflow'. In response to these efforts of the bank, the Commonwealth Treasury began to seek the central bank's advice on other matters than raising loans and discounting treasury bills. ${ }^{38}$

In summary, the relations between the governmental monetary authorities in 1938-39 were a far cry from the wilderness of relations between them and the alignments with the private financial institutions in 1930 and 1931. As in those earlier years, when it prepared the way for the government authorities possessing greater constitutional power to prepare the Premiers' Plan, so in the years 1932 to 1938 the Loan Council was a vital agency in getting more control of general economic policy into the hands of the Commonwealth and its authority, the central bank. The Loan Council was by no means entirely responsible for this: the thinking of Theodore and Scullin was a light on the hill; the political pressures for reform of monetary policy resulted in the Royal Commission which confirmed the validity of the Labor leaders' attempted legislation; and the effect of Keynesian economics was profound, especially when the central bank adopted Keynesian policies in 1938. But at the same time, in the machinery of government in the 1930s, the Loan Council was a constitutionally established and powerful force for more co-operative federalism in economic policy formation and its record was commendable in years of extreme difficulty. Not the least of the Council's achievements was its

37 Ibid., 251, 292; Reserve Bank, Occasional Paper No. 4, 451.

38 Giblin, Central Bank, 250-5, 261; Argus, 17 December 1938, 1, 6. The anti-cyclical policies of the official monetary authorities in 1938-39 had the fervent support of Davidson whose bank felt the liquidity shortage keenly in the first half of that year. Holder, Bank of New South Wales, 831-3. 
ability to seek and to assess the quality of advice from academics, banks and officials. Credit for this would seem to be attributable fairly evenly between Lyons and his Assistant Treasurers, and those other powerful personalities amongst the State Premiers who exercised tactical skill and practical judgment of a high order on many occasions.

In the long period, the success of the Loan Council in aiding the Commonwealth to acquire more effective control over general economic policy was itself the beginning of the end of the Council's own quite strong hand in this vital area. When combined with the decline in the significance to the States of overseas borrowing and of the payments to them under the Financial Agreement, the general position of the Loan Council at the end of the 1930s was that it was becoming a diminishing force in the nation's affairs both in the formation of general economic policy and in the hopes for a co-ordinate federal system. 
When Davidson, the general manager of the Bank of New South Wales, said in 1936 that the private banks had managed the economy satisfactorily for a hundred years, he had in mind a definite logic of events. When the level of the private banks' foreign exchange reserves fell seriously, the banks first raised interest rates on fixed deposits and sometimes on overdrafts to slow the economy down. Later, and it could be as long as a year and then only if it was necessary, the banks restricted advances or called in overdrafts to reduce the level of economic activity and curtail imports further. The reason for the delay of up to a year before restricting bank credit was simply that the next season might see an improvement in primary production and export income; or export prices might rise; or capital inflow might increase; the net effect of all these possibilities might then be an increase in foreign exchange reserves to safe levels so that the step of restricting bank credit was not necessary. Consistent with this view, Davidson in November 1929 advocated to the central bank a rise of 1 per cent in interest rates as a remedy for the falls that had by then occurred of about 30 per cent in foreign exchange reserves and about 20 per cent in export prices. The central bank replied that devaluation was the appropriate policy, but the private banks went ahead and raised interest on fixed deposits by up to 0.5 per cent in January 1930.1

Until the central bank supported a Keynesian policy late in 1938, Davidson was certain that the central bank had not learnt the fundamental lessons of the private banks' experience-it could look only six months ahead. ${ }^{2}$ Giblin corroborated this view, finding that there was the greatest divergence of opinion and uncertainty within the central bank Board about

1 Holder, Bank of New South Wales, 664. 'This was the classic policy for a policy of financial disequilibrium'; Giblin, Central Bank, 73-4; Roland Wilson, 'Australian Monetary Policy Reviewed', 210.

2 Holder, Bank of New South Wales, 828, 832. 
what to do and about the timing of policy. ${ }^{3}$ The central bank had, in effect, to begin learning to fulfil its role as a central bank in the most difficult period for decades and certainly in its own lifetime, experiencing during the depression and the remainder of the 1930s three separate occasions in which the foreign exchange reserves fell to their practical minimum.

\section{The Bond Rate}

The analysis of the bond rate in the 1930 s is essentially that of the discussions and decisions jointly taken by the Loan Council and the central bank. Except in extraordinary circumstances, like the conversion in 1938, the private banks seem to have left it to the central bank to voice the banking view on the new issues rate because they were not deeply interested in the bond rate. Their holdings of bonds appear to have been small ${ }^{4}$ but, more importantly, their method of exercising control of the economy was through the overdraft rate and the fixed deposit rates, which directly affected a much wider variety of people and private enterprises. It was a quick and more certain method whereas the bond market was narrow and was, therefore, a slow and more unwieldy device with which to control expenditure and expectations. But an advantage of the narrowness of the bond market was that it enabled simple open market operations to keep the bond yield at a desired level.

The members of the Loan Council, on the other hand, had their traditional, vital interest in the bond rate-they paid the interest bill, which was an incentive to keep the interest rate low; they wished to raise as much money as they could to spend on works and that was an incentive to raise the rate; and the Commonwealth was concerned to avoid sharp upward movements in the rate so that sellers of existing bonds before maturity date would not suffer capital loss. By 1932, these tensions were resolved by one overriding influence: that the interest rate on new issues and conversions should not exceed the parameter of 4 per cent to which much of Australian-held debt had been reduced by the Premiers' Plan. To have paid more than 4 per cent on a new issue within at least a decade of the 1931 mass conversion, except in the most exceptional circumstances, would have been regarded as a breach of faith and would have been an extremely difficult policy to have accepted, especially by the Commonwealth in whose name all Australian-held debt was then held. The Commonwealth ministers would have had to face the prospect of disillusioned bondholders who, if they sold before maturity date, suffered capital loss. Governments feared the loss of votes, especially those of the many small subscribers. The Commonwealth's voice was supported strongly by the central bank, which stood firmly throughout the 1930 s for low interest rates for additional reasons, some of which were shared by the Council. The bank feared

3 Central Bank, 189.

4 Ibid., 180; Reserve Bank, Occasional Paper No. 4A, 549. 
that interest rates at too high a level would retard the recovery of private investment; that a high rate would attract greater subscriptions to loans and lead to excessive government expenditure; and that lower rates were part of the commitments in the Premiers' Plan..$^{5}$

The Council and the central bank had to wait nearly a year and a half after the Premiers' Plan before yields on bonds on the open market fell to 4 per cent. From 5.25 per cent or close to it between January and July 1929, yields had risen steadily to a peak of 7.56 per cent in June 1931 when the Plan was fashioned. Once the conversion operation under the Plan had been completed, yields on the 4 per cent bonds fell to between 4.6 per cent and 5.03 per cent; they reached their highest level after the Premiers' Plan, 5.03 per cent, in May 1932, at the same time as the Garnishee Case reached its climax. ${ }^{6}$ After Lang was dismissed from office in May, yields fell steadily towards the 4 per cent nominal rate on the converted internal debt until, in November 1932, they were 3.97 per cent on the open market and were below 4 per cent for the first time since 1912. The era of cheap money had arrived and new issues at low interest rates had become a practical proposition for the Loan Council.

The Australian borrowing prospects were fortuitously enhanced further by the British government's decision in July 1932 to undertake its $£ 2,085 \mathrm{~m}$.

Fig. 1 Security yields, London and Australia, 1935 to 1939 Source: Reserve Bank of Australia.

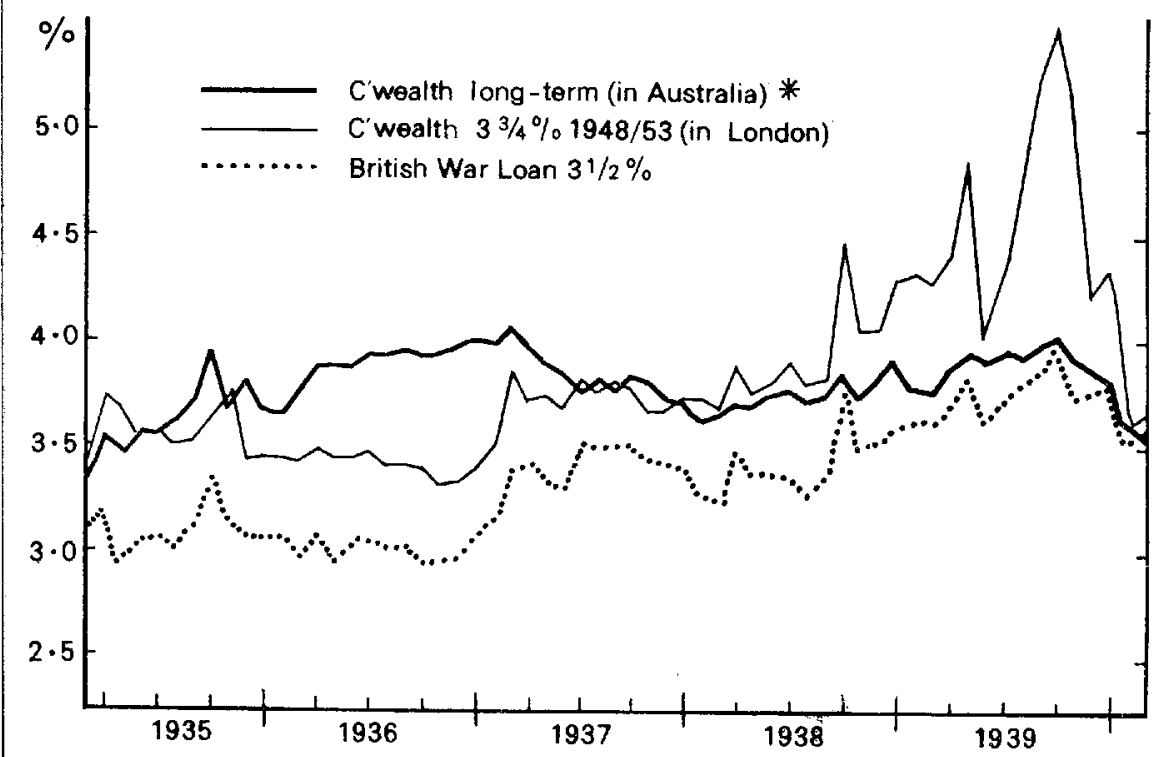

* 1936 and after, weighted average of all securities maturing in Australia after ten years. Before 1936 all 4 per cent securities excluding 1938.

5 Giblin, Central Bank, 184, 245 inter alia; S.M.H., I1 May 1933, 11.

6 All references to yields from the Reserve Bank's Statistical Bulletin; for details of actual loans floated see Giblin, Central Bank, 175. 
conversion operation, as Australia had successfully done. The British bond rate was reduced to 3.5 per cent and this created a satisfactory differential of 0.5 per cent between it and the Australian rate. In this pre-war period of free movement of capital between the two countries, the Loan Council had the advantage of a higher rate in Australia to encourage capital inflow, and equally important, to encourage Australian funds to remain at home (fig. 1). Between them, the departure of Lang and the advantageous differential with London seem to have enabled a start to be made to tapping the Australian market at roughly half-yearly intervals. From 1932 until the outbreak of the war, the most that was paid on a new issue was an effective rate of 3.97 per cent. Yields on the open market rose above 4 per cent in only three months of the period. But there were wider fluctuations in the bond rate than in the later 1920s when the Loan Council was firmly managing government borrowing. The rate on new issues between 1932 and the war fell to a minimum of 3.02 per cent, the sharpest rise between loans being 0.4 per cent and the greatest fall was 0.6 per cent.

Bond yields moved in a cyclical manner between 1932 and 1939 and the effective rate on new issues also moved on a cyclical course. In very general terms, while the economy was depressed, the rate reached its lowest level and remained low for a longer period, but when the economy was more buoyant later in the decade the rate fell less and tended to recover more quickly. The movements support the broad conclusion that as loanable funds became available in 1933 and 1934, holders of savings showed a greater preference for bonds than for other forms of investment, including equities. But as the economic recovery and industrial expansion got under way, bonds became less popular and, from the beginning of 1935, their yields rose and stayed higher. The actual movements of yields on the open market were:

\section{2-36 cycle}

bond yields fell steadily from 5.03 per cent on the eve of Lang's dismissal in May 1932 to 3.02 per cent two and a half years later in November 1934, when a new issue was floated at that effective rate, yields on market sales being 3.25 per cent at the time;

yields rose from 3.02 per cent in November 1934 to 4.07 per cent on the open market at the peak in February 1937, an upswing that lasted two and a quarter years; the highest rate paid on a new issue was 3.97 per cent in November 1936;

\section{7-39 cycle}

yields on the open market then fell for a year to 3.57 per cent in January 1938, a more moderate movement both in yields and in the length of the downturn than in the previous cycle; the new issues rate fell much less, to a minimum of $3 \cdot 73$ per cent two months earlier;

an upward movement then lasted for a year and a half during which 
yields rose to 4 per cent or slightly more on the eve of the outbreak of war in September 1939, the highest effective rate on new issues being 3.96 in May 1939.

Evidence that the economy was very liquid and that holders of cash preferred bonds to investing elsewhere in 1933 and 1934 showed up clearly in the subscriptions to public loans in those two years. Once the Loan Council and the bank had adjusted their thinking after the failure of the November 1932 loan at 3.75 per cent, they agreed on a bond rate closer to the yield on bonds on the open market; the Council found that it could, for two years, close loans long before they had run the full period it was intended that they should be open. The loan in May 1933 was heavily oversubscribed; in April yields on the open market had been 3.79 per cent and the Council was unusually cautious in proposing to raise $£ 5 \mathrm{~m}$. at 3.75 per cent in twenty-nine days, as it closed the loan after nine days with $18.46 \mathrm{~m}$. subscribed. One reason for the caution was that the loan was not underwritten; it was the only loan not underwritten in the 1930s. In November 1933, a $£ 10 \mathrm{~m}$. loan was closed in two days fully subscribed; in June 1934 the $£ 12 \mathrm{~m}$. Ioan was closed in three days, oversubscriptions not accepted totalling $£ 10.5 \mathrm{~m}$.; and in November 1934 a $£ 15 \mathrm{~m}$. loan at the very low rate of 3.02 per cent was closed after a week, even though it had been planned to keep it open for a fortnight. ${ }^{7}$

The abundant liquidity throughout 1933 and 1934 was largely due to the improvement in two current influences, capital inflow and higher export prices (up 27 per cent in 1933-34) and the effectiveness of the longterm deflationary and other policies of 1930 and 1931: it showed up in the foreign exchange reserves which rose to over $£ 90 \mathrm{~m}$. in the March and June quarters of $1934 .{ }^{8}$ As might be expected, there were definite signs of economic recovery in 1933-34: compared with the previous year the percentage of trade unionists unemployed fell about 5 percentage points (from 27.5 per cent), gross private investment rose $£ 8.4 \mathrm{~m}$. (or 28 per cent) and the value of exports f.o.b. rose $f 16 \mathrm{~m}$. (or about 16 per cent), but there was as yet no appreciable increase in gross investment by the Commonwealth and the States, and only a small increase by local authorities.9 The private sector was therefore spending the loanable funds it attracted and largely generating the recovery whereas the member governments of the Loan Council were using loans not only for works but to meet revenue deficits and, it will be seen, were accumulating reserves of loan money. By 1934-35 the economic upswing from the depression had advanced further and it was aided in that year by the increase of one-third in investment by the Commonwealth and the States. In the Loan Council's

7 Giblin, Central Bank, 182, table B.

8 Table 13.2; Reserve Bank, Occasional Paper No. 4A, 451; and C.B.G.S., Balance of Payments No. 3, 93.

9 Ibid., and Butlin, Australian Domestic Product, 17. 
and the bank's deliberations on the bond rate, a major turning point was the sharp rise in market yields that began early in 1935 (or the middle of 1934-35). By the loan of June 1935, yields on the open market had hardened to about 3.6 per cent, but the decision was taken to try to raise $£ 12.5 \mathrm{~m}$. at 3.42 per cent; the outcome was that the loan was open for the full fifteen days intended and the underwriters had to find $£ 1.675 \mathrm{~m}$. This sharp reversal to a shortage of loanable funds for the Council's new issues in the first half of 1935 had a number of causes, some of which were: too low a rate on the new issue compared with open market yields; a large fall of a third in foreign exchange reserves by the June quarter to $£ 62 \mathrm{~m}$., due mainly to a fall of 15 per cent in export prices and a big outflow of private capital as Australian yields in London rose for a short period above the local rate (fig. 1) and as speculators, who had expected an appreciation of the Australian exchange rate, repatriated their funds; there was also a sharp increase in the demand for savings as private investment increased by one-third over 1933-94-it had been encouraged by the low interest rates and the more buoyant conditions of the previous year. It was notable that as liquidity and the reserves position tightened in 1935, the Bank of New South Wales sold some bonds and contemplated raising the usual interest rates but refrained from that restraining action because it did not wish to dampen the economy while it was still struggling to recover. Giblin found from comprehensive statistical analysis that 'deliberate central bank operations were relatively small, and somewhat inconsistent, so that no definite policy is indicated by them' ${ }^{10}$ Evidence of the central bank's lack of appreciation of the issues at stake in 1935 was its pressure on the Council throughout 1935 to fund treasury bills to obtain bonds for the purpose of better controlling bank liquidity if the need arose. Giblin summed up the Loan Council's reaction thus: 'Its response to the plea of preparing for the next depression must have stressed the advisability of first getting out of the existing one'.11 The private banks' policy was more logical and deliberate; their holdings of bonds were fairly steady until after the June loan, that is up to the end of the June quarter 1935; but in the subsequent six quarters, their holdings in Australia of government and municipal securities fell steadily, from $£ 22 \cdot 7 \mathrm{~m}$. in June 1935 to $£ 14 \cdot 1 \mathrm{~m}$. in December 1936 - down by $£ 8.6 \mathrm{~m}$., which appreciably increased their liquidity but depressed bond prices, added to the upward pressure on bond yields and, in general, made it harder for the Council to float loans. ${ }^{12}$

10 Giblin, Central Bank, 183, 176, 181; and Holder, Bank of New South Wales, 806-9. Davidson, on the other hand, urged open market operations by the central bank to keep liquidity in the banking system high and to sustain the recovery. Overdraft and fixed deposit rates did not change in 1935. Reserve Bank, Occasional Paper No. 4A, 494.

11 Central Bank, 171-2.

12 Reserve Bank, Occasional Paper No. 4A, 549. 
The difficulties of the banks, and the shortage of funds in the bond market, until the end of 1936 were due fundamentally to the persistent low level of the foreign exchange reserves throughout the whole of 1935 and 1936-in the September quarter of 1936 they were at the depressed level of $\$ 52 \mathrm{~m}$. or one-half the desirable amount. Under the influence of the tighter liquidity in the economy, the trading banks were obliged in the end to take restraining action and they raised fixed deposit and overdraft rates twice in 1936, after they had fallen steadily since the beginning of 1930; even so, their advances increased. Yields on the open market reached 4.07 per cent in February 1937, and the interest rate on the new issues, peaking at 3.97 per cent on the November 1936 loan, was close to the parameter for that rate. Both the loans of 1936 were undersubscribed and up to $£ 2 \mathrm{~m}$. on each was met by the underwriters; that was, at that time, a substantial increase in credit as the banks were net sellers of bonds. ${ }^{13}$ If relief had not come in the form of an improvement in the foreign exchange reserves, the economy would have faced a crisis at the end of 1936. In the circumstances the trading banks pursued a rational policy that varied a little in 1935 from traditional logic in that they did not then raise their interest rates, but which had the effect in 1935 of raising the bond rate: their own interest rates were raised in 1936. The depressing effect of their actions on the economy was intentionally kept to a minimum; their advances rose in 1936 and by underwriting loan programs, they helped to keep governments' capital expenditure on its upward trend in 1935 and 1936.

While the trading banks' policy was understandable and consistent, there was a basic contradiction in the central bank's desire for low interest rates and the reduction of liquidity; it could not expect to have both. It might have pressed the Loan Council to raise the rate on new issues faster, even though the Council may have wanted to spend all of the increased loan money which might have flowed in; a compromise whereby loans over a certain amount were used to fund the central bank's holdings of bills would have been one way out. There appears to have been a breakdown in understanding and in the theoretical basis of policy between the Loan Council, which wanted the best of both worlds in the form of cheap money and a steady or rising flow of loan subscriptions, and the central bank, which argued and acted equally illogically. For example, in September 1935 the central bank bought $£ 1.5 \mathrm{~m}$. of securities on the market to keep the yield at the level it considered desirable and it advanced $£ 2 \mathrm{~m}$. to several banks. At least the two acts were consistent with its policy of low interest rates, but they could not, at the same time, be consistent with its concern about restraint on the economy. It naturally suited the Loan Council to align itself with the 'wait and see' part of the trading 
banks' policy and Stevens, the Premier of New South Wales, was a strong advocate of the line in public. ${ }^{14}$

Conditions improved in 1937. The rise in export prices late in 1936 brought them back temporarily to 1928-29 levels and showed up in a balance of payments surplus in 1936-37. There was also a considerable increase in private capital inflow and by the June quarter of 1937 the foreign exchange reserves reached $£ 93 \mathrm{~m}$., their highest quarterly level since 1929. Although the balance of payments was in deficit in the next year, $1937-38$, as a result of a big increase in imports of $£ 24 \mathrm{~m}$. (up 23 per cent), capital inflow continued to be high and the foreign exchange reserves remained at a satisfactory level. But in 1938-39 a balance of payments deficit, caused by a fall in export prices partly relieved by a fall in imports, and the reversal of capital movements to a small outflow, due possibly to the higher yields on Australian securities in London (fig. 1), together reduced foreign exchange reserves to seriously low levels by the June and September quarters of 1939. The pressure on the balance of payments was in part due to the expansion of the economy in the three years to mid-1939, during which employment and economic activity were at what were then accepted as satisfactory levels. Annual private investment rose nearly 40 per cent between 1935-36 and 1938-39 and was higher than in the late 1920s; annual Commonwealth, State and local government capital expenditure increased by over 25 per cent but remained well below the 1920 s rate of outlay. ${ }^{15}$

Table 15.1

Effective yields on new issues and open market sales of long-term bonds with 10 or more years to maturity

(\%)

\begin{tabular}{ccc}
\hline Date of new issue & $\begin{array}{c}\text { Effective yield on } \\
\text { new issue }\end{array}$ & $\begin{array}{c}\text { Open market yields } \\
\text { in same month }\end{array}$ \\
\hline 11.6 .35 & 3.42 & 3.62 \\
26.11 .35 & 3.77 & 3.83 \\
2.6 .36 & 3.88 & 3.96 \\
26.11 .36 & 3.97 & 4.01 \\
27.4 .37 & 3.95 & 3.91 \\
30.11 .37 & 3.78 & 3.69 \\
19.5 .38 & 3.79 & 3.72 \\
9.11 .38 & 3.88 & 3.83 \\
9.2 .39 & 3.88 & 3.79 \\
30.5 .39 & 3.96 & 3.93 \\
\hline
\end{tabular}

Sources: Giblin, Central Bank, 175, and Reserve Bank, Statistical Bulletin.

14 Giblin, Central Bank, 173; in addition, see the statements of trading bank representatives and B.S.B. Stevens, conveniently assembled in Copland and Janes (eds.), Cross Currents, 284-6, 350 et seq.

15 Table 13.2; and Butlin, Australian Domestic Product, 17. 
Just as in 1936 a crisis threatened, so in 1938-39 there were difficulties: a depression seemed to be imminent.

The demand for loanable funds for private purposes during these three pre-war years obliged the Loan Council to keep the rate on new issues high and from the peak of 3.97 per cent for the November 1936 loan the rate on new issues did not fall below 3.78 per cent (November 1937) and it rose thenceforth. Although yields on the open market fell after the big influx of foreign exchange in 1936-37 and by January 1938 were down to 3.57 per cent, the Council was unable to take advantage of the lower market rate to float a new issue at any time below 3.75 per cent. From 1935 onwards, the subscriptions to loans were increasingly hard to obtain and not only were loans left open for the full period intended but underwriters and the Commonwealth Savings Bank subscribed heavily, particularly in 1936 and 1938-39.16 Table I5.1 indicates that the Council in 1937 and after always chose a new issue rate above the yield on open market sales to attract subscriptions to new issues.

It seems that in 1938 and 1939, the third period of adversity in a decade, the central bank found its feet as an institution of the monetary authorities and was more able to take a lead in banking and monetary policy; this was acknowledged by the private banks with a good measure of relief. ${ }^{17}$

In 1937, when foreign exchange reserves and liquidity were high, the central bank had, in an effort to reduce the liquidity, engaged in open market operations in the last half of the year. In 1938 export prices fell and by the middle of 1938 the bank had reversed the open market operations, bought bonds and encouraged the Commonwealth Savings Bank to subscribe $£ 3.3 \mathrm{~m}$. to the May 1938 loan to ensure that the loan was filled. During the rest of that year, the central bank bought bonds at the rate of about $£ 2 \mathrm{~m}$. a month. The broad policy of the bank had been discussed with the private banks in July and August 1938 and was set out in a formal letter from the central bank after the discussions. A further basic purpose of the meetings and the expansionary monetary policy was to ensure that the large conversion of $£ 69 \mathrm{~m}$. due to open on 9 November at less than 4 per cent was a success. Another purpose was to ensure that Keynesian anti-cyclical action prevented any decline in the economy. The export price index had declined continuously in 1937-38 and 1938-39 from its very high level in 1936-37 and drought reduced export income in 1938. The central bank's policies suggested that it had come round to the private banks' 'wait and see' policy when the first signs of adversity showed up in 1937-38 as, even though export income was down, foreign exchange reserves in the June quarter of 1938 were at the satisfactory level of $£ 85 \mathrm{~m}$.,

16 Giblin, Central Bank, 175.

17 Holder, Bank of New South Wales, 838-9 '. . . financial leadership had moved into the hands of the Commonwealth Bank' i.e. the central bank. 
being sustained by large capital inflow and a fall in imports as a direct result of intentionally discriminatory credit policy. ${ }^{18}$

Although the private banks welcomed the expansionary operations of the central bank at that early stage of economic difficulty, they were aware that it had ulterior motives as its discussions with the private banks in July and August 1938 had included an offer from the central bank to make advances to the private banks if they needed them-it had hopes of getting the banks accustomed to deposits from the central bank and so giving it some new power of control over trading bank policy' ${ }^{19}$

The war saved the country from what appeared to be an imminent economic crisis. The general effect of the central bank's activities from 1938 onwards was that it acquired the power that goes with good economic management and it was pursuing a fiscal and an interest rate policy that suited the Loan Council admirably. It posed the question whether loan raisings at the interest rate chosen by the Council in its discussions with the bank resulted in adequate funds becoming available for works expenditure.

\section{Borrowing}

The broad movements in the borrowing programs of the Council have already been hinted at: adequate funds subscribed to loans up to the end of 1934 and an ever present possibility of oversubscriptions, followed in later years by difficulties in obtaining loan money and the need for the underwriters to subscribe to at least five of the last ten loans before the war.

The deliberations of the Council and the recommendations to it by the central bank did not therefore result in accurate estimates of the amount that could be raised at the chosen interest rate for a new issue. This should not be taken as a critical comment because the response to a chosen rate of interest on a new issue is extremely difficult to estimate at the best of times; when climbing out of a disastrous depression as in 1932, it posed the acutest problems. Analysis conducted with all the benefits of hindsight needs to be sympathetic to the problems of the policy makers who make their judgments looking ahead into the unknown.

As the Council and the central bank representatives faced each other at Loan Council meetings, the central bank's representatives regarded themselves as independent custodians of the currency which was in danger of the great potential forces of inflation, presumably on the lines of the European countries in the 1920s. 'The state of production and employment was not its particular concern; its first duty was to the currency.' ${ }^{20}$ The

18 Ibid., 833; Giblin, Central Bank, 247. Holder found the Bank of New South Wales to be dissatisfied with the liaison between the central bank and the other banks in the last half of 1938 when the conversion operation was planned against the background of falling foreign exchange reserves.

19 Giblin, Central Bank, 247 (italics added); Holder, Bank of New South Wales, 831.

20 Giblin, Central Bank, 188. 
Council, on the other hand, was deeply concerned about the level of economic activity because that was of the greatest political moment to its members, who were leaders of governments trying to retain political power. The tension between the two sides was created on the bank's side by the fear of resort by the governments to the use of the printing press to create currency on the security of unlimited amounts of treasury bills or other government securities; and fears of the Council that the bank would not allow expansion to go as far as it could. The actual process of inflation implied in the bank's position could have begun with excessive government expenditure creating demand for more goods than could be produced locally or imported and paid for out of current foreign exchange receipts and reserves. The exchange rate, which was also part of the central bank's responsibility for the currency by 1932 , would thus be endangered if excess demand spilled over into much higher imports; if the exchange rate declined and, as a result, the prices of imports increased, that rise in prices and the automatic adjustments to wages by the Arbitration Court as the cost of living rose, would set in motion the inflationary spiral. ${ }^{21}$ The bank therefore examined closely each successive loan program and proposals from the Council for finance for revenue deficits. The danger signals to all concerned should have been pressure on the exchange rate after a serious decline in the foreign exchange reserves. Imperfect knowledge of the reserves position made the discussions technically unsatisfactory-hit and miss affairs by modern standards. There was, in fact, a case for the private trading banks being more strongly represented than they were while they alone had most of the knowledge available about the exchange position and therefore how far the economy could expand. In the event, the inbuilt experience and the knowledge of the private banks, skilfully applied in 1935 and 1936 with the indirect support of the Loan Council, provided the managerial hand until the central bank began to play an equally sound part from 1938 onwards. The private banks' views were frequently made known to the central bank, but they became more the backroom adviser than they had been, especially in 1929-31.22 The changing power structure had relegated them to that role by early 1933 .

The effect of choosing the interest rate on a new issue and inviting subscriptions was that the Council had to accept the sums that the public subscribed without ever being certain that the loan would be filled. In the conditions of great uncertainty that were characteristic of the 1930s, underwriting was essential to ensure that a known sum would be available to the Council for allocation to member governments. Political necessity demanded that they know what loan funds to include in their budgets.

21 Giblin records that "Neither Sir Robert Gibson nor his successor ever publicly explained in precise terms just where the danger lay, and it appears to have been taken for axiomatic in the recorded proceedings of the Board'. Central Bank, 188.

22 Holder, Bank of New South Wales, 710-11. 
A further incentive to have loans underwritten was that if a loan failed, it indicated to the public that it had been floated at too low an interest rate and it put pressure on the Loan Council to raise the rate, a step that was anathema to it because it looked bad politically and because it raised the interest bill. A loan undersubscribed but quietly underwritten without the publicity that it had in effect failed reduced but did not eliminate entirely the strain on the Council to raise the rate on the next loan. The Council's need for underwriting was a significant part of the central bank's strength in the negotiations about the size of the loan program.23

In the bargaining with the central bank about the amount of the loan program that should be underwritten, the bank appears to have kept its part of agreements made whereas the Loan Council, made up of adept politicians skilled in tactics, manoeuvred hard at times to avoid commitments. The bank was put on the defensive by complaints to the press that the Council was subject to 'their masters' voice' - for example, when a very large loan program had been agreed to by the Council but rejected or was being considered critically by the bank. These ploys put pressure on the bank to underwrite a program in excess of what it considered, rightly or wrongly, the level of the foreign exchange reserves and the prospects for the balance of payments warranted. ${ }^{24}$ At one stage the bank reacted with a letter to the Loan Council, in January 1937, suggesting that it raise loans without the bank's advice or underwriting assistance; this elicited from Lyons a request for the service to continue and in 1938 R. G. Casey, the Commonwealth Treasurer, publicly defended the bank which, by then, was pursuing expansionary policies. ${ }^{25}$

This review of the loan programs in the years 1932-33 to 1938-39 has been anticipated in much of the earlier analysis and little more remains to be done than to tie a number of loose ends rogether, using table 15.2 which sets out the approved loan program, the actual loan raisings after all expenses were paid, the net loan expenditure, the cash balances available to the Commonwealth and the States at the end of each year and, after certain disbursements, the cash balances brought forward to the next year. ${ }^{26}$

The broad trends and features of the loan programs were these. In five of the seven pre-war years, the Council voted itself a loan program in excess of what became by the end of each financial year the underwritten

23 See Giblin, Central Bank, 177-9 for a full description of the underwriting arrangements in the 1930s.

24 S.M.H., 12 June 1933, 9; Argus, 13 June 1933, 9; Giblin, Central Bank, 179; Argus, 29 May 1935, 7; 5 June 1935, 7; S.M.H., 1 June 1935, 16; 8 November 1935, 18; Argus, 7 November 1936, 20; S.M.H., 9 November 1936, 8.

25 Giblin, Central Bank, 179; Argus, 23 April 1938, 3; 25 April 1938, 3.

26 This information, provided by the Commonwealth Treasury, complements and corrects the total proceeds column of the table in Giblin's Central Bank, 175; Giblin's 'total proceeds' of each loan are the face value of securities issued and do not allow for discounts and expenses. 


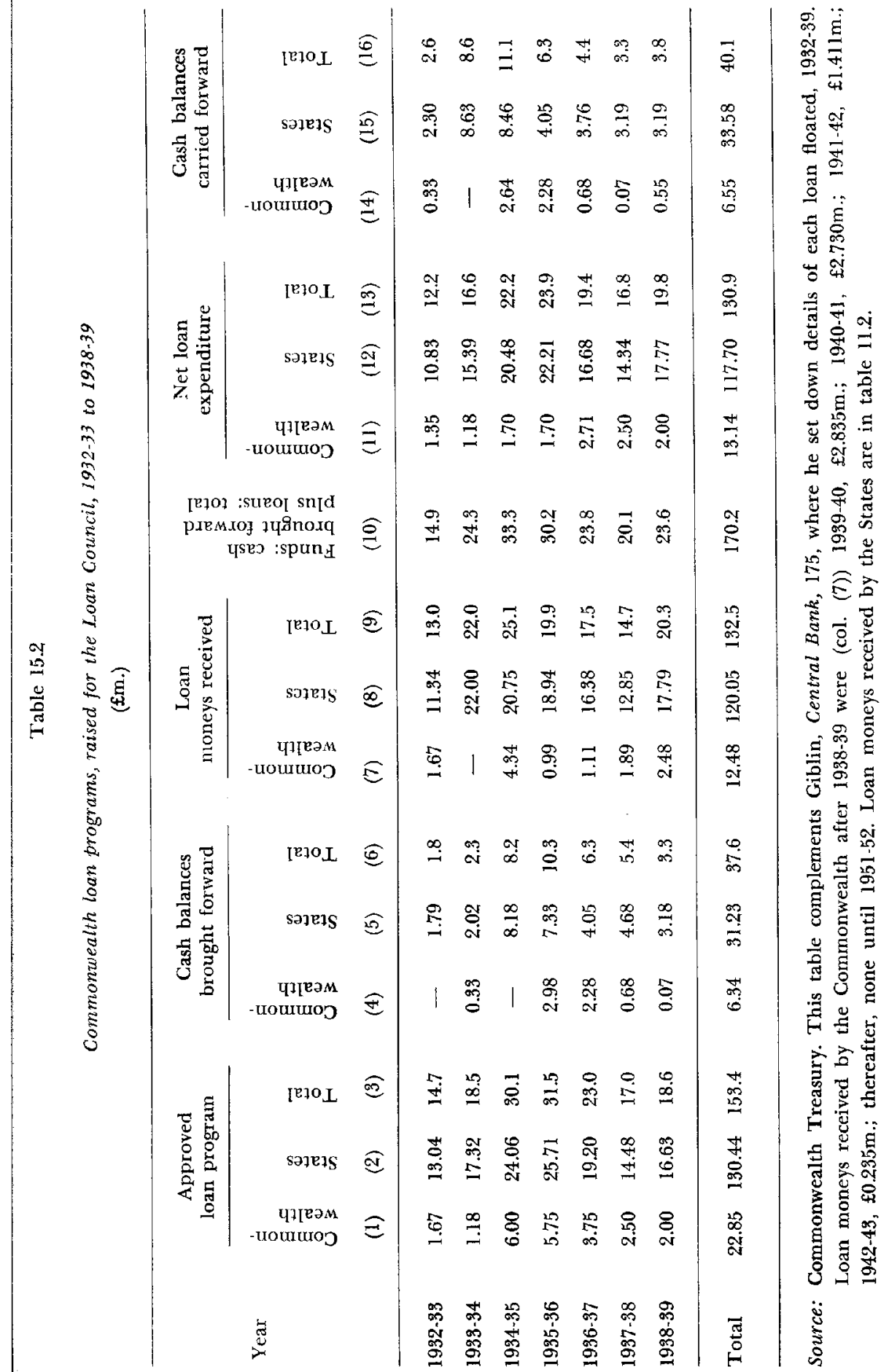


program. In those five years, the central bank was put in the position that it could be accused of dictating the size of the program to the Council but this tactic by Council members, using the press as the medium, was not employed as frequently as the five years gave members the opportunity. 'The reason for this was that the States' program of works expenditure could not rise as quickly as the flow of loan subscriptions and the governments always finished the financial year with large cash balances (col. 16) to disburse for other purposes or which they brought forward (col. 6); that was especially so in $1933-34(£ 8 \cdot 6 \mathrm{~m}$. unspent), $1934-35(£ 11 \cdot 1 \mathrm{~m}$.$) and$ $1935.36(£ 6.3 \mathrm{~m}$.). Of the $£ 26 \mathrm{~m}$. of loan money not spent on works in those three years, $£ 20.9 \mathrm{~m}$. was brought forward for expenditure including $£ 10.3 \mathrm{~m}$. in 1935-36, when the economy was in danger of faltering. The Commonwealth and the States were therefore always in a position to draw upon reserves to maintain and expand their capital expenditure if other determinants of the gross national product declined;27 as it turned out, that did not happen, but it seemed dangerously close late in 1936 and in mid-1939.

The Council depended upon the Australian capital market for its loan raisings and there was a most gratifying increase from $£ 9 \mathrm{~m}$. annually in the 1920 s to nearly $£ 19 \mathrm{~m}$. a year in the seven pre-war years, or $£ 16.7 \mathrm{~m}$. annually if the amount subscribed by the underwriters is deducted. In 1933-34 and 1934-35, the two years in which the bond rate fell to the low level of 3.02 per cent and there was an embarrassment of oversubscriptions, the average amount raised after deducting the underwriters' subscription was $£ 22.7 \mathrm{~m}$. In the following four years the annual average net of underwriters' contributions was down to $£ 16.3 \mathrm{~m}$. The flow of loanable funds to the Loan Council's issues declined by about $£ 6 \mathrm{~m}$. a year as the economy recovered in the last half of the 1930s.

The Loan Council and the central bank agreed early that there should be no acceptance of subscriptions above the underwritten loans floatedthis decision appears to have been taken after the May 1933 loan, when $£ 5 \mathrm{~m}$. was sought and $£ 8.46 \mathrm{~m}$. was subscribed and accepted. In the following two years, the Council was able to fill each flotation easily and the State governments accumulated their considerable reserves of loan funds for works. The central bank closed loans as soon as its officers were satisfied that subscriptions were just over the amount sought. ${ }^{28}$ It is interesting to reflect whether this agreement with the central bank would have come under strain had cash balances brought forward (col. 6, table 15.2) been drained. There was no danger of that until 1938-39, but by then the central bank had begun Keynesian policies; in that year it financed $£ 4 \mathrm{~m}$. of treasury bill finance to assist States, especially New South Wales.

A good deal of flexibility was built into the Loan Council's approved

27 Giblin found this to be so but did not provide evidence; Central Bank, $165 \mathrm{n}$.

28 Ibid., 177. 
program which, over the seven pre-war years, was some $£ 21 \mathrm{~m}$. higher (col. 3) than the underwritten program (col. 9). The brunt of the difference between the much publicised approved programs and the actual loans underwritten and raised was borne by the Commonwealth-its part was half the deficiency $(£ 10.4 \mathrm{~m}$.) and all the States shared the other half. This was a good example of the Commonwealth exercising its greater financial strength. It suited the Council to publicise a big program for political reasons and to encourage confidence and it was aided in this by the fact that the press was not clear about the difference between that agreed program and the smaller underwritten program; the bigger program was usually given the main publicity, together with mention that the central bank had agreed to underwrite loans. ${ }^{29}$

Gross domestic capital formation in the 1920 s by the Commonwealth and the States averaged $£ 54.7 \mathrm{~m}$. a year, but the net increase in their debt for works and other purposes was $£ 38.5 \mathrm{~m}$., or just over two-thirds. In the last seven pre-war years of the 1930s the annual average of the gross domestic capital formation of the Commonwealth and the States was $£ 29.8 \mathrm{~m}$. and the net increase in their debt was $119 \mathrm{~m}$. a year, again about two-thirds. Taxation and other sources of finance appeared to be used in about the same proportions in the 1920s and in the 1930s (one-third). The annual amount for capital expenditure found from sources other than net loans was $£ 16 \mathrm{~m}$. in the 1920 s but less than $£ 11 \mathrm{~m}$. in the later $1930 \mathrm{~s} .{ }^{30}$ One possible explanation of the difference is that there may have been a need to use some taxation from 1933 onwards, not for current works but to reimburse trust funds and other accounts and sources that were tapped in 1928-29 and 1929-30 to keep government expenditure as high as possible when revenue and loans declined. The cash deficiencies of revenue and loan funds up to the end of 1932-33 were of the order of $£ 50 \mathrm{~m}$., that is, in addition to the short-term loans from the banks on the security of treasury bills and debentures that totalled a further $\$ 87 \mathrm{~m}$. (table 8.4 ). All told, finance for works remained appreciably greater in the $1920 \mathrm{~s}$ than in the later $1930 \mathrm{~s}$, mainly because of overseas loans. Structural changes, therefore, occurred between the two decades which suggest that in the 1930s governments were under less pressure to provide capital works than they had been in the 1920s. One significant factor was that the rate of population increase was extremely high in the 1920s and much lower in the 1930s: estimates indicate that the population increase in absolute numbers was, in the 1930 s, about half that in the 1920s.

The basis of wartime finance

From May 1938 the prospect of war and the state of London funds led

29 See n.24.

30 Butlin, Australian Domestic Product, 17 and C.F.B., no. 31, table 61 provided the statistics of investment expenditure and net loans raised from which the above estimates were made. 
the Commonwealth to raise defence loans, two in London, and one of $£ 4 \mathrm{~m}$. in Australia in October 19198. War was declared in September 1939. Defence preparations gradually affected the Council and culminated, in February 1941, in a long resolution that the States would adhere strictly to the reduced program of works to which the Council had agreed in May and August 1940, on the recommendation of the newly appointed Coordinator-General of Works, ${ }^{31}$ but with an additional margin of loan money which the Council decided the States should have to spend on works as they wished without subjecting the projects to the Co-ordinatorGeneral. ${ }^{32}$

The Council found it necessary to appoint the Co-ordinator-General of Works to perform the important function of umpiring priorities in public works, although in status he was always a federal public servant who worked closely with State officials in the presentation of reports to the Council for its decisions. His authority stemmed from the collaboration with the States and from his expert knowledge; it was also a matter of personality. Sir Harry Brown was the first appointee in 1940 and in that year the Loan Council asked for his advice on the loan program with a view to keeping it down to a level harmonious with the requirements of war. In effect, the States were prepared to have their projects scrutinised and to accept Brown's recommendations. He did not try to force the pace, ${ }^{33}$ yet between 1939-40 and 1942-43 the total annual loan program for the States and their authorities fell from $£ 27.5 \mathrm{~m}$. to $£ 3 \mathrm{~m}$. and did not rise above $£ 6 \mathrm{~m}$. until the war ended. (In 1945-46, the first post-war year, it quadrupled to $£ 22.7 \mathrm{~m}$.) As the loan program and the availability of resources grew in the post-war years, so the power and usefulness to the Council of the Co-ordinator diminished. His appointment was basically a political device to have an independent authority to point to when inquiries and complaints were made about reductions and postponements of works. The position depended upon the Council's decision and was in no sense a legally binding function under the Financial Agreement; in fact, the Agreement was so drawn that such a function should not be a statutory requirement.

The war years and the return of Labor to power in the Commonwealth Parliament witnessed a vital change in Loan Council methods of approach to the loan program and the start of a new era in its relations with the central bank. In February 1942 the Loan Council agreed that the ordinary loan programs of the State governments should be financed by means of advances made by the Commonwealth government. The procedure adopted

31 Argus, 28-29 May and 13 August 1940.

32 Argus, 1 February 1941, 5.

33 Giblin, Central Bank, 292; C.P.D., 21 November 1940, 82 (A. W. Fadden, Budget Speech); E. R. Walker, The Australian Economy in War and Reconstruction (New York, 1947), 95. Walker records that in August 1941 the Commonwealth did force the pace and only two States agreed to cut the loan program by more than Brown had proposed. The Commonwealth used its casting vote to carry the day. 
was for advances to be made by the Commonwealth to the State governments from funds provided to the Commonwealth by the central bank on the security of treasury bills. The advances were funded at the end of each financial year by the issue to the central bank of long-term securities which had the same interest rates and date of maturity as the latest war loan issued prior to that date. The debt so funded was apportioned between the governments according to their shares of the program. The States paid treasury bill interest rates until the temporary borrowing was funded, when the rate became the long-term bond rate. ${ }^{34}$

This was the start of the practice in the post-war period in which the Loan Council's program was financed by the conscious decision of the Commonwealth as to its amount from its own and its authorities' resources as well as the capital market. ${ }^{35}$ The sources are the Commonwealth's revenue, the Commonwealth's trust funds and the central bank as the source of credit. The Commonwealth began in 1951-52 openly to subscribe to the loan program which the States needed, without resort directly to the central bank.

The return of Labor to office for the first time after the humiliation of the depression years, together with the experience of total war, was probably necessary to make it generally practicable to develop more explicitly than had been achieved in 1938-39 this integration of central banking and government finance which had become, in Giblin's words, 'a necessary condition for even the possibility of effective monetary control' ${ }^{36}$

34 T.P.P. Annual Report of the Auditor-General of Tasmania, 1941-42, 3 et seq.

35 See also R. G. Menzies, C.P.D., 7 September 1960, 890: 'Instead of asking simply "How much can be borrowed?" we have tried to work out a reasonable figure which would give reasonable prospects to the States of carrying out their works programmes.'

36 Giblin, Central Bank, 142. 
The strong wartime impulse to establish a New Order resulted in a sustained demand for full employment in the post-war years. Memories of the Loan Council's central part in national economic policy formation in the 1930s remained clear and it was important that it should not contribute to but instead should offset any serious changes in the determinants of effective demand in the post-war period.

For the Loan Council, the basic issue which emerged from the experience of the multiplier in the 1930s was whether there would be any serious fluctuations in the amount of loans that would be subscribed from private sources; and, if so, would they be so great as to make it essential for the Commonwealth (and the States if they could) to perform a supplementary equilibrating function?

Subscriptions to loans can come from two sources: firstly from the governments and agencies of governments represented on the Loan Council and, secondly, from independent and largely private sources, including international organisations. If fluctuations in private subscriptions are wide, the main objective of supplementary action by the Commonwealth (or the States) would be to reduce their amplitude and make the loan program a known, predictable amount to assist in the achievement of economic stability. Close, relatively amicable co-operation between the Loan Council and the central bank in the late 1930s was a step towards that goal. Then, in February 1942, the Commonwealth had decided that it own financial resources should be used, explicitly and as a matter of policy, to attain the same end. Uniform Tax greatly enhanced the Commonwealth's ability to do this, a matter that is discussed in the next chapter.

Loan subscriptions are not the sole source of uncertainty in this context, nor the sole disequilibrating factor. When a State government receives its share of the loan program, either as a lump sum or at a regular, known (monthly) rate, it is not bound to spend it at a certain rate. State loan funds can be accumulated and spent at a rate which is decided by each member individually and alone (except for minor amounts committed jointly with the Commonwealth or another State). Hence for the purpose 
of measuring the effect of fluctuations in the loan program on the level of economic activity, the critical factor is loan expenditure. State governments will take action which might or might not be an aid to stability-they can spend steadily or they can spend at a fluctuating rate which does not offset but worsens instability caused by fluctuations in other sources of effective demand.

The Commonwealth has not the power to exercise direct control over the States' rate or direction of loan expenditure, but it might choose to act indirectly. The Commonwealth needs to know that the States will spend their loan moneys at a predictable rate and when the incidence of unemployment varies, to spend it in a way which ensures that areas suffering relatively more severe unemployment are assisted. Should there be any resistance by the States to spending in areas of excessive unemployment or if States have inadequate funds to spend on employment creating works to absorb all of the unemployed, then the Commonwealth has the power to make grants under s.96 that are conditional upon the unemployment being reduced by the expenditure of the grants. They would probably be revenue or capital grants and would therefore be formally outside the Loan Council's responsibility unless a State raised it as a problem in the discussion of the allocation of loan programs; in fact, these issues are discussed at Loan Council meetings. The whole process would apply in reverse when demand is excessive and the Commonwealth underwrites a smaller increase, if any, in the loan program.

There have been two important periods in which the instability in the amount of the loan program showed beyond doubt that supplementary action by the Commonwealth was essential and continues to be potentially so. The first occurred in the economic depression of the 1930s, immediately after the Financial Agreement was validated. The second followed twenty years later in the $1950 \mathrm{~s}$, when the era of post-war reconstruction had ended, and relative normalcy had returned to the Australian capital market.

The early post-war years were a period of excessive demand due to the postponement during the war of many private as well as government developmental and maintenance works. ${ }^{1}$ The level of accumulated savings was high because people had less opportunity to spend during the war when controls drastically curtailed private investment and consumption, and war loan appeals were prosecuted vigorously. After the war, both the rate of savings and the requirements of the Commonwealth for loan moneys were reduced. On balance, the net effect was that throughout the 1940 s, war loan conversions were floated satisfactorily at $3 \cdot 125$ per cent, and cash loans for the loan program were usually oversubscribed at that interest rate. There was also a large inflow of funds from overseas between 1948-49

1 E.R. Walker, quoted in D. B. Copland and R. H. Barback (eds.), The Conflict of Expansion and Stability (a book of documents) (Melbourne, 1957), 165. 
and 1950-51 and some of this undoubtedly was used to subscribe to Commonwealth loans. ${ }^{2}$ It was not until $1951-52$ that loan programs were seriously undersubscribed.

\section{Imperfect Commonwealth control of loans}

A basic lesson of the early 1930s was that a fluctuating loan program can affect government expenditure and depress the expectations of persons making decisions to invest in capital equipment and stocks. At that time, the fall in export income contributed as well to the decline in effective demand and expectations. In table 16.1, the fluctuations in loan raisings from private sources in the 1950 s provide definite evidence of the need that the Commonwealth, in exercising its responsibility for the level of economic activity, should control the amount of the loan program decided in the Loan Council so that it is a known, predictable amount. (The Commonwealth's assistance becomes greater if, instead of the loan program,

Table 16.1

Financing the loan program, 1951-52 to 1964-65

(fm.)

\begin{tabular}{lcccccc}
\hline Year & $\begin{array}{c}\text { Loan } \\
\text { Council's } \\
\text { program }\end{array}$ & $\begin{array}{c}\text { Loan } \\
\text { raisings }\end{array}$ & $\begin{array}{c}\text { Common- } \\
\text { wealth } \\
\text { assistance }\end{array}$ & $\begin{array}{c}\text { Gross } \\
\text { national } \\
\text { product }\end{array}$ & $\begin{array}{c}\text { Commonwealth assistance } \\
\text { as percentage of }\end{array}$ \\
\hline $1951-52$ & 227.1 & 74.2 & 152.9 & 3,658 & 4.2 & G.N.P. \\
Program \\
$1952-53$
\end{tabular}

Sources: Commonwealth Payments to or for the States 1968-69 (Canberra), p. 55; and C.B.C.S., Australian National Accounts.

Note: The Commonwealth's assistance includes in the years $1951-52$ to 1957-58 the counterpart funds of overseas loans by the Commonwealth. It is not known how much of the loan raisings were subscribed by the central bank or any other Commonwealth agency. If they did subscribe, it increases the amount of Commonwealth assistance. It was agreed that in 1962-63 and 1963-64, f32m. and $£ 20.195 \mathrm{~m}$. of the total amounts raised by the Commonwealth should be used for redemptions, otherwise the amount subscribed would have exceeded the program agreed for works and housing.

2 A. W. Fadden, Treasurer, C.P.D., 30 October 1951, 1277 et seq. 
the net increase in debt, or the loan program less redemptions is considered. Normally, the Sinking Fund provides money needed for redemptions.)

Between 1951-52 and 1964-65, the proportion of the loan program to which the Commonwealth subscribed from its own resources to keep it on a steady and, generally speaking, upward trend varied from 0 per cent to 4 per cent of the gross national product. In two successive years, 1951-52 and 1952-53, the Commonwealth's assistance was 4 per cent and 3 per cent respectively, and in all but two of the ten years between 1951-52 and 1960-61, it was over 1 per cent. In the author's view, sums equal to or exceeding 1 per cent of the gross national product are large enough to be economically and politically significant.

The Commonwealth's assistance was over one-third of the program in seven of the ten years from 1951-52 onwards. It is singularly important that in 1951-52, when the Commonwealth contributed 67 per cent or over $£ 150 \mathrm{~m}$. of the program, and 4 per cent of the gross national product, exports

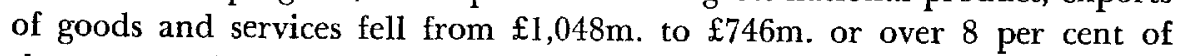
the gross national product. The deficiency of loan raising, and the fall in exports together totalled over 12 per cent of the gross national product, ${ }^{3}$ which was a parallel with the years 1929-30. In 1951-52 and 1952-53 unemployment rose slightly, the monthly average of the number receiving unemployment benefits rising from 10,246 in $1949-50$ to a peak of 29,984 in 1952-53 (about 1 per cent of the workforce). ${ }^{4}$ Although exports recovered in 1952-53, the success of the Commonwealth's policy of maintaining demand and confidence when export income fell and loan raisings were inadequate for the loan program, is strikingly apparent from the small change in employment. Throughout the period the balance of payments was protected by quantitative restrictions on imports. These controls were not lifted until 1959-60 and assisted greatly in the Commonwealth's task of economic management.

On several occasions the change in the rate of loan raisings from private sources has been over 1 per cent of the gross national product. Between 1952-53 and 1953-54, it rose over 1.5 per cent and the same occurred in 1958-59 and 1961-62. Between 1958-59 and 1960-61, loan raisings fell $265 \mathrm{~m}$., about 1 per cent of the gross national product, and if the States' works programs had been dependent largely on loan market subscriptions, they would undoubtedly have faltered in 1960-61.

By setting a predictable limit to the loan program, the Commonwealth offset variations in private subscriptions which, in isolation, would have been in some years very expansionary in their effect and in others deflationary. The programs for local and semi-governmental authorities were also appropriately controlled by the Loan Council, which set an upper

3 C.B.C.S., National Income and Expenditure 1953-54 (Canberra, 1954), 10.

4C.B.C.S., Monthly Bulletin of Employment Statistics, March 1953, no. 256, 24. The number on benefits did not exceed 29,984 again until 1960-61. 
limit to the amount and the terms of their borrowing; these programs did not fluctuate but were a known, predictable amount.

The Commonwealth's conscious intervention is a vital stabilising influence which the States have found attractive in that they have obtained not only a known predictable amount, but very often more than the loans supplied on the open market for the program of civil purposes according to the Financial Agreement. This was so even when, in 1952-53 and 1954-55, the guaranteed loan program was reduced below the previous year's as part of the Commonwealth's control of aggregate demand.

The major part of the Commonwealth's assistance was derived from general revenue sources. The shortfall, whenever it occurred, was met mainly through special loans taken up by the Commonwealth at the end of each financial year on terms and conditions similar to those offered on the public loans raised during the year. ${ }^{5}$ The States pay interest on that part of the Commonwealth's subscriptions which is financed from current revenue for which the Commonwealth pays no interest, but incurs the political disfavour arising from levying the taxation to subscribe to the loans. The States derive a further benefit which is hard to measure but none the less real-if the rate of interest were raised to a level high enough to ensure that the loan raisings from private sources were adequate without Commonwealth intervention, then the States would have to pay the higher rate on the whole of the program. They thus get a certain program at lower cost and the best of both worlds when, as is usually the case, private loan subscriptions are low and the Commonwealth subscribes as underwriter.

When the loan market subscriptions exceed the amount of the programs which the Commonwealth desires, the Council faces the prospect that the Commonwealth will take and use part or all of its one-fifth share for its own purposes instead of lending that share back to the States under the Housing Agreement; this could be done, were the Council not to conform unanimously to the Commonwealth's will on what to do with excess subscriptions. The Commonwealth might wish that excessive subscriptions be carried over as advance subscriptions to the next year's program or be used for redemptions, as in 1962-63 and $1963-64 .^{6}$ Formally, the Council decides the course to take.

This analysis of the effect on demand of the loan program has been undertaken without considering whether the Council might regulate the rate of interest on new issues for its programs in order to free itself from the Commonwealth's controlling influence. This is considered in chap. 19 on monetary policy in the post-war years. What has emerged from the

5 Commonwealth Payments to or for the States 1964-65, 37. The matter of central bank subscriptions to new issues is considered in the notes to table 16.1; and C.P.D., 30 September 1959, 1628 (Prime Minister).

6 See source and note to table 16.1 . 
preceding analysis is that it became necessary for the Commonwealth to exercise part of its control of effective demand through the loan program because, on the terms and conditions decided by the Council, private subscriptions have often been inadequate and there have been serious fluctuations in the amounts subscribed from private sources.

\section{Government borrowing and capital expenditure}

The total loan program contributed a varying proportion of the finance for governmental capital formation, that is, including local and semigovernmental loans and capital expenditure, in the post-war years. Table 16.2 has been constructed by using Professor Butlin's series for the pre-war years and the official estimates since the war. ${ }^{7}$ The statistics indicate broadly that the total loan raisings amounted to a significant proportion of total capital expenditure by public authorities. It will be recalled that governments and authorities are obliged to present to the Loan Council only the programs which they propose to finance from loans. Other financial resources need not be disclosed unless a one-year or longer obligation, or paper security, is issued to the lender; part of the explanation of the use of revenue for capital expenditure is that the Commonwealth finances its works program from revenue and that Commonwealth grants have been made to the States for roads throughout the life of the Loan Council and for other capital works purposes to an increasing extent since the war.

From 1932-33, when the Loan Council could commence again to raise long-term loans, until the end of the 1930 s loans were roughly 40 per cent of total public capital expenditure and about 3 per cent of the gross national product, ranging between 2.2 per cent and 4 per cent. After the war, the Australian National Accounts statistics indicate that the Loan Council's allocations were a higher proportion of total public capital expenditure in the early $1950 \mathrm{~s}$ (about two-thirds) than later, when they settled down lower to about one-half; and it was close to 5 per cent of the gross national product in the decade after 1954-55; before that it ranged between 4.3 and 8.2 per cent of the gross national product. There was, if these statistics are an accurate guide, a small structural change in the sources of finance for capital expenditure between the $1930 \mathrm{~s}$ and the later post-war years.

\footnotetext{
7 The statistics of the 1930 s and the post-war decades are not comparable, because from 1948-49 onwards the figures include not only expenditure on new assets, but changes in the value of stocks, small payments to the capital of international organisations, advances to persons through public financial enterprises for the purchase of homes and for land settlement and development and, in general, all capital transactions of public trading enterprises. From 1951-52, the counterpart funds of the Commonwealth's foreign loans used for subscriptions to the States' loans have been counted but once (chap. 18). The comparison between the $1930 \mathrm{~s}$ and the post-war years has been made in broad aggregates because Professor Butlin estimated Commonwealth, States and local authority capital expenditure in the 1930s, but the official National Income Estimates provided figures of Commonwealth, and combined State and semi- and local government capital expenditure, in the post-war years.
} 


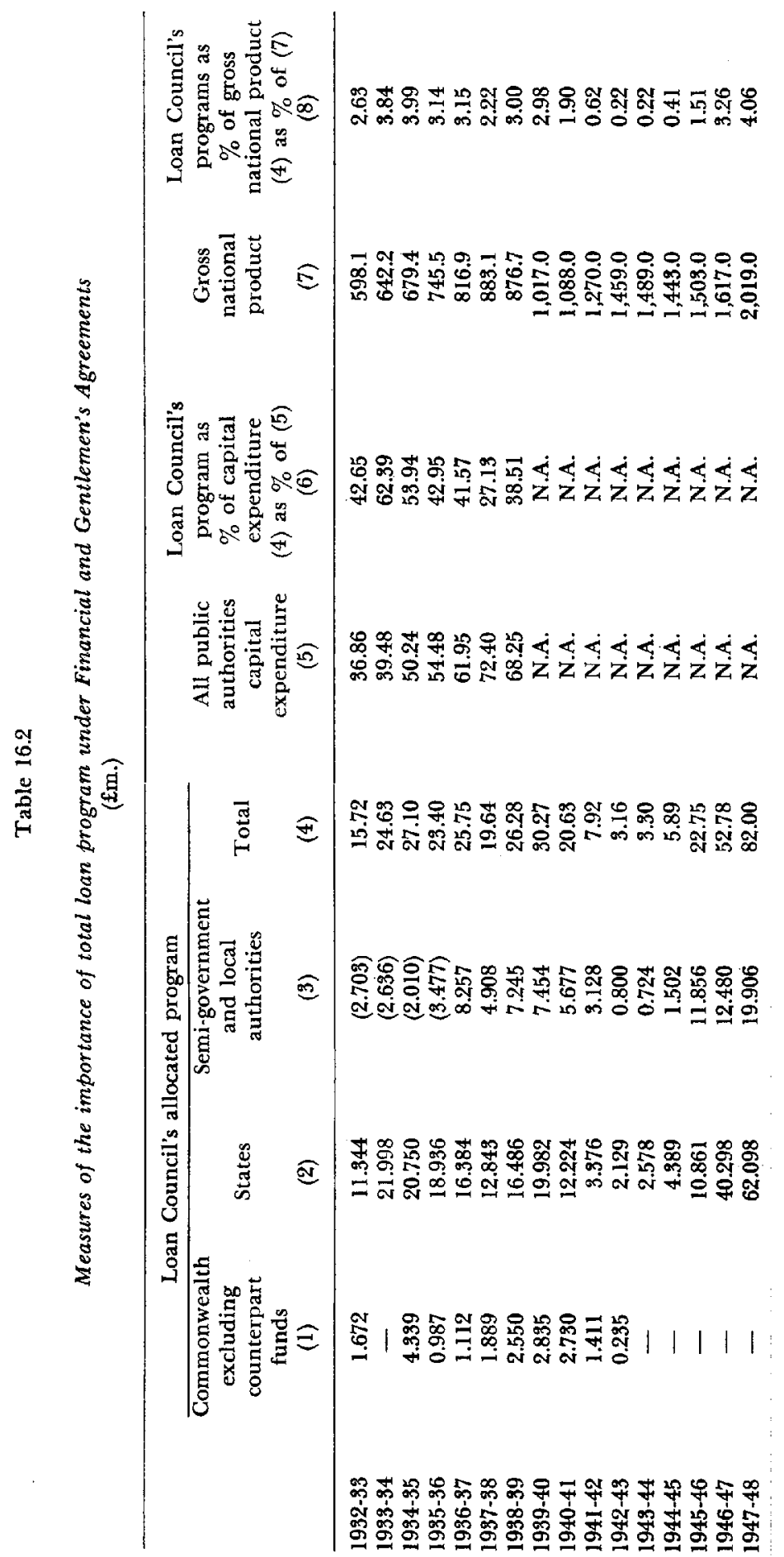




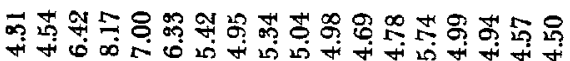

000000000000000000

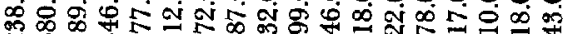
ô on a

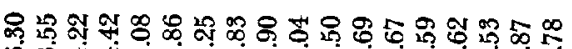

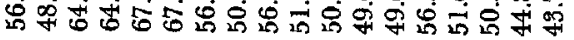

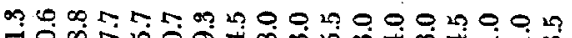

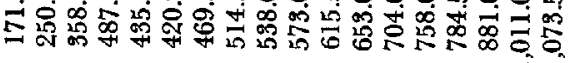

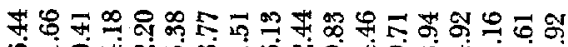

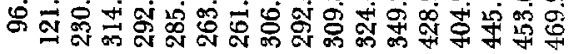

m 앙

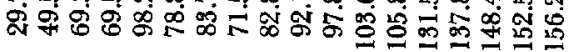

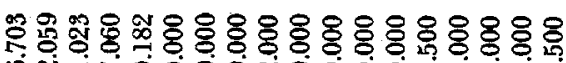
ษ

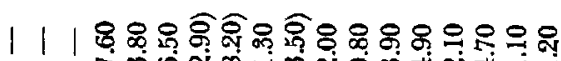

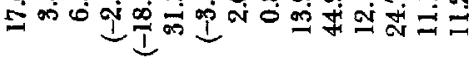

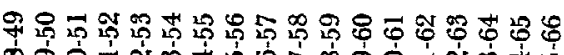

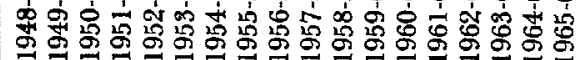


More importantly, the Commonwealth's tentative control of the size of total government capital expenditure was restricted at the most to about half that expenditure by the mid-1960s. The States and their authorities were therefore free to vary capital expenditure that directly accounted for 2 to 3 per cent of the gross national product. Should the need for the Commonwealth to underwrite programs disappear, then the Commonwealth's power to exercise a controlling influence over loans for general management of the economy could be much smaller; in other words, the proportion of the gross national product freely managed by the States would be even greater.

There emerged in the post-war period a clear but impermanent realignment of power over the size of the loan program in favour of the Commonwealth. This shift of power was desirable because the Commonwealth's difficult task of maintaining general economic stability was made easier when it could control that part of States' expenditure on capital goods that was financed from the loan program. The control depended entirely upon the amount of loan money available for Commonwealth issues on the market; if that was less than four-fifths of the amount required by the States for their own needs, then the effect of underwriting and the threat of the withdrawal of the Commonwealth's one-fifth share were significant sanctions which the Commonwealth could exercise.

But over the long period, the strains exerted upon the Australian economy by the high rate of post-war immigration since 1950 could be expected to relax, particularly if the rate of immigration slackened appreciably. It would then be conceivable for the loan market to supply much more finance at a reasonable interest rate and the history of that market suggests that it could increase the size of the practical loan program quickly, and well in excess of 1 per cent of the gross national product. Such movements in that determinant of the level of economic activity would be a serious matter for the Commonwealth in its management of the economy. In those circumstances, it would seem reasonable to expect the Commonwealth's control to be directed to variations in revenue and capital grants under the financial assistance power to counterbalance any loss of control that could be exercised in the Loan Council.

\section{Allocating loans-post-war fluctuations}

A discussion of the role of the loan program in economic management would be incomplete without analysing the allocation of the loan program between the States. Politically, the sharing of the loan program is very important to the States who depend upon it for the finance of a large part of their capital investment. In the early post-war period, allocations differed greatly from those in the 1950s and the 1960s; and the allocations in the post-war decades differed markedly from the allocation in the 1930s. 
The Loan Council's role in wartime was insignificant in its impact upon the economy; the National Works Council assumed the important function. Between 1941-42 and 1944-45 inclusive, the total of loans allocated under the Financial and Gentlemen's Agreements for civil works averaged $£ 4.7 \mathrm{~m}$. annually compared with about $£ 22 \mathrm{~m}$. a year in the last three pre-war years. After the war, the total program jumped from $\$ 22.7 \mathrm{~m}$. in the first post-war year to $£ 52.8 \mathrm{~m}$. and then to $£ 82 \mathrm{~m}$. in successive years, these annual increases continuing at an extraordinary rate until the program reached $£ 296 \mathrm{~m}$. in $1951-52$. The greatest increase, $£ 89 \mathrm{~m}$. and 3.5 per cent of the gross national product, was in 1949-50, midway through which the Labor government went out of office. ${ }^{8}$ The amounts of wartime loan programs and revenue surpluses retained in reserves were insignificant compared with the loan programs of the post-war era of rapidly increasing demand and rising costs. The central bank's proposals during the war to siphon off State revenue surpluses by funding treasury bills were made insignificant by the size of the post-war programs.

Extraordinarily inconsistent movements in shares of programs occurred as between the States in the early post-war years. In 1945-46 South Australia received nearly half the allocation $(£ 10 \cdot 25 \mathrm{~m}$.) or over five times the average amount per capita for all States. Most of this very large share $(£ 9 \mathrm{~m}$.) went to semi-government authorities, mainly for housing. South Australia's per capita index dropped to about 80 in 1948-50 and rose to 108 in 1951-52, taking the average per capita allocation to the six States as 100 . The index of Tasmania's per capita allocation from the total program fell from 188 in $1945-46$ to 99 in $1947-48$ and rose to 201 by $1950-51$. The New South Wales index rose from 105 in $1946-47$ to 123 in the following year and then fell away to 77 by $1950-51 .^{9}$ Relative stability of shares per capita in the total program was not achieved until about 1951-52, by when post-war shortages and excessive demand had largely ended.

Definite reasons for the sharp fluctuations in the shares of loan programs up to 1950-51 remain obscure, but there is some evidence of causes. There were years in the later 1940s when some States and their local and semigovernment authorities were unable to spend all of the loan money allocated to them. ${ }^{10}$ There were therefore surpluses of loan allocations carried forward that reduced the need for new loan money in some years. This was largely due to the shortages of supplies of many kinds, and the Loan Council co-operated with the Commonwealth in dealing with the situation. Soon after the war, the Commonwealth Treasurer, in a reference to the excessive demand being experienced, said:

8 C.P.D., 15 August 1963, 231-2 and Commonwealth Payments to or for the States for all loan figures mentioned unless otherwise footnoted.

9 Table 11.6.

10 C.P.D., 9 June 1948, 1806 (J. B. Chifley, Prime Minister and Treasurer). 
The Commonwealth Government in co-operation with the State Governments through the Loan Council, is seeking methods by which to achieve an appropriate balance in the demands made upon our total physical resources by private expenditure on the one hand and public expenditures, particularly works expenditures, on the other hand. ${ }^{11}$

The abundance of finance in the hands of the States for works purposes was augmented by the arrangements made in 1945 for financing housing under the new Commonwealth and State Housing Agreement. The procedure from 1945 was that the States nominated a certain sum for housing from the loan program under the Financial Agreement which the Commonwealth had agreed to underwrite. That nominated sum became the Commonwealth's share of the program which it then advanced to the States under s.96 for their use according to the terms of the Housing Agreement. The advances were at a rate of interest, were repayable and were therefore loans made under the financial assistance power. The annual loan program became known as the Works and Housing Programme, of which the States therefore received directly and indirectly the whole amount. It is of incidental interest that the loans for housing rarely rose above one-fifth of the loan program and were allocated by the States in different shares from the loans for works. The shortage of housing was one of the acutest problems after the war and New South Wales and Victoria allocated virtually all of their shares of the Works and Housing Programme (under the Financial Agreement) to housing in 1945-46 and smaller but still considerable shares as late as 1949-50. South Australia did not become a party to the Housing Agreement until 1953-54, but in 1945-46 it allocated $£ 9 \mathrm{~m}$. to local and semi-governmental authorities, largely for housing, and $£ 1.25 \mathrm{~m}$. for other works; in the subsequent five years to 1950-51, South Australia allocated only $£ 1.95 \mathrm{~m}$. to local and semi-governmental borrowing.

It is also possible that the Co-ordinator-General of Works was influential in persuading members that delays in starting certain works to avoid excess demand would not result in any diminution of opportunity to do so in the following or later years when commencements would be more appropriate to national priorities. ${ }^{12}$ That could have influenced members to vary their shares of the program from year to year.

There was no public discussion before 1951-52 indicating dissatisfaction with the fluctuating allocations decided by the Council. Basically, the liquid assets in the hands of the public and its willingness to subscribe fully to loan programs decided by the Council at 3.125 per cent meant that members had to worry not about whether there would be adequate finance, but whether they would be able to spend the loans received. Opulence seemed

11 C.P.D., 14 November 1946, 246 (J. B. Chifley).

$12 \mathrm{He}$ had been persuasive to this end and in reducing States' works programs early in the war. 
to relax the tensions associated with the allocation of the loan program and member governments felt freer to let their shares fluctuate far more than in the 1930s or in later decades.

\section{Allocating loans-stability with injustice?}

The ready availability of money to subscribe to loan programs came to an end in 1951 and the rate of interest began to rise. ${ }^{13}$ In $1951-52$ there was such an enormous shortfall between the loan program agreed and the actual loan raisings that the Commonwealth subscribed about two-thirds $\left(£ 152 \cdot 9 \mathrm{~m}\right.$.) from its own resources. ${ }^{14}$

The advent of the shortage of loan money for the States' works and housing program led immediately to public discussion and complaints about the allocation of the loan program between the States. The issues at the May 1935 meeting were repeated at the August 1951 meeting: problems developed when the States' proposed program ( $\{300 \mathrm{~m}$.) had to be cut drastically (to $£ 223.7 \mathrm{~m}$.) and the question of using the formula was raised again.

Some sections of public opinion in Victoria, but not the Victorian government, were dissatisfied with Victoria's share of the loan program. In reply to a Parliamentary question on the matter, the Prime Minister revealed that the reduction of the loan program had been decided by a vote of the Council in which there was a majority of four States to two for the resolution, Victoria voting for it. Had the program been divided according to the formula, Victoria would have received 'what some of us thought to be an unduly small share'. Consultation led some States to accept less than that which would have been their share under the formula, with the result that Victoria was eventually allocated some millions more than the formula would have accorded it. A final significant comment on this meeting was that 'As the Commonwealth was not taking any share of the $\{225,000,000$, we took no part in the consultation at which the allocation was made'.15 Undoubtedly, State officials worked together without Commonwealth officials being present, and the States' representatives on the Council presented an agreed proposal for allocation to the Commonwealth's representative.

On the outcome of the 1951-52 meetings, two further observations can be made. Firstly, the Commonwealth did not use the powerful bargaining position it had in this, the first year of its heavy underwriting subscriptions to influence openly the allocation of the program. It may have done so privately with a particular State or States; the fact that four States voted with the Commonwealth to reduce the program suggests that it did and

13 See chap. 19.

14 The loan program referred to is that under the Financial Agreement. The requirements of authorities under the Gentlemen's Agreement were met by the public.

15 C.P.D., 10 October 1951, 463-4 (R. G. Menzies, Prime Minister). 
indicates their realistic and co-operative approach to what was the start of a new and most significant era in loan programming. The incentive to State co-operation was their need to know, and to be able to publicise, for budget purposes, a definite underwritten program, which in this particular year was over $f 60 \mathrm{~m}$. (about 27.5 per cent) higher than the previous year, and amounted to 1.6 of the gross national product.

Secondly, in the allocation of Financial Agreement programs (on works and housing) plus the local and semi-governmental programs under the Gentlemen's Agreement, the per capita share of Victoria, Western Australia and Tasmania fell in 1951-52 (table 11.6). Comparing 1951-52 with the previous five years, however, Victorians appeared to be concerned, consciously or without knowing it, to hold a recently won greatly improved position relative to New South Wales, and so were Western Australia and Tasmania, and, to a lesser extent, South Australia. Queensland was not affected much one way or the other. It was extraordinary that, per capita, Victoria received in 1951-52 half as much again per head as New South Wales, a third as much again as Queensland and a fifth as much again as Western Australia. In the previous year, it was even better off.

The year 1951-52 was, in the economy generally, a turning point, marking the end of the post-war period of shortages, imports rising by 40 per cent as overseas supplies became available. ${ }^{16}$ From then until the early 1960s, more definite and relatively constant trends emerged in the allocation of the total loan program.

New South Wales's and Victoria's relative positions were reversed when compared with the 1930s, but the extremes were not as wide. Thus, in only one year between 1951-52 and 1963-64 did the New South Wales index rise above 86 and it averaged $83 \frac{1}{2}$; there was, if anything, a slight upward trend from about 80 to about 85 . New South Wales was a model of consistency. Victoria's index fluctuated about 112 for the first six years of the 1950s, and subsequently diminished by small marginal amounts to about 100 in the two financial years 1963-64 and 1964-65. As between New South Wales and Victoria, there was a gradual coming together, with the difference narrowing from over 30 per cent of the average for all States to about half that amount over the period. By 1965-66 the difference had narrowed to about 10 per cent of the average. The gap in the late $1930 \mathrm{~s}$ was, on the other hand, about 80 per cent in 1936-37 and 50 per cent in 1939-40, in New South Wales's favour. ${ }^{17}$

Victoria's gradual diminution in its relative per capita share of the amount received after $1950-51(132 \cdot 0)$ to a position where, in the mid-

16 Imports rose from $£ 862 \mathrm{~m}$. in $1950-51$ to $£ 1,219 \mathrm{~m}$, in $1951-52$ and did not exceed the latter figure again in the 1950 s, during which quantitative restrictions were applied to imports. Statistics from Australian National Accounts, National Income and Expenditure, 1948-49 to $1963-64,22$.

17 Statistics from table 11.6 
1960 s, it received about the average of all six States, was accompanied by small steady gains to Queensland, which improved its position in a similarly gradual upward movement-from about 90 at the beginning of the $1950 \mathrm{~s}$ to about 106 in 1964-65. Queensland began to receive the average of all six States, notwithstanding its enormous potential resources, only in the late 1950 s $(1958-60)$.

Broadly speaking, South Australia (at about 115) and Tasmania (at about 170) held their positions, although if there is a trend, both lost small, marginal parts of their shares in the 1960s. Their contribution was negligible compared with Victoria's. Western Australia's position was not unlike the other two smaller States, except that the marginal movements around a fairly steady average (of about 105-110) were greater in the early 1950s; Western Australia lost nothing to other States relatively between 1957-58 and the mid-1960s.

Victoria, therefore, lost most and South Australia a small amount of the ground up to 1965-66, Queensland and New South Wales gaining it. The loss by Victoria about measured Queensland's gain, while South Australia and New South Wales roughly offset each other.

The broad conclusions which might be drawn from these observations are fairly clear. Firstly, the long-term trends had reversed themselves as between New South Wales and Victoria and, to a not much lesser extent, South Australia, which received a small per capita share in the 1930 s and had the worst unemployment of any State. Secondly, the three claimant States had, in the decade up to the mid-1960s, received more per capita than the two larger States, which should have enabled the three to develop their resources at a rate which diminished, or prevented a widening of, the gap between relative taxable capacities. If this did not occur, then it poses the profound question whether there should be a movement of population to the more profitable resources of the other States. This is almost entirely an academic question and yet it is clearly an obvious conclusion to draw. ${ }^{18}$

The high rate of post-war immigration imposed great strains upon the available supply of loanable funds in Australia from 1950. Periods when there was an excess of loan money available for Commonwealth loans, as in the early post-war years, were rare. The rigidity of the Financial Agreement made rapid adjustment difficult and posed serious problems for a State which regarded itself as being held back because it was receiving an inadequate share of the loan program. The political problems of a

18 The Grants Commission in its Third Report (1936) said that the excess population should move' (p. 139). There has been a drift of population, especially from Tasmania and from rural areas elsewhere to the bigger urban centres. The simple reason why it is not practical to encourage movement by direct government action is that the smaller States have an equal number of Senate seats and enough House of Representatives seats to oblige political parties to develop the smaller States and rural areas, notwithstanding that it may be uneconomic. 
State in that position seem to be soluble in the Loan Council only by co-operation between the parties, probably through slow marginal adjustments. The Treasurer of Queensland put it thus:

I have been scratching my finger nails down to the roots to try and slightly improve our position against the other States ... By strong arm tactics we did induce the Council to agree to a review ...

The device of the Loan Council which is entrenched into our constitution protects the States who have the superior share; it would never be taken from them without their consent and they will not give it. They all say to me in the corner: 'You are getting a rough deal', but when it comes to the table and it involves their surrendering a half million for us, they will not give. . . I have seen an absence of the real Australian spirit when it comes to those parts of the discussion, when it comes to selfishness, that no man can lose face-he cannot bear the political repercussions if he went back with less money. If I were in the 'plus' position I might be just as difficult, just as human. ${ }^{19}$

There was well-informed public controversy on the trends of the allocation of the loan program, the main points of which can be briefly reviewed. Just before the June 1963 meeting of the Loan Council the Acting Premier of New South Wales, J. B. Renshaw, indicated publicly in strong terms that his State had had enough of the current disparity between New South Wales and Victoria. 'There appears to have been discrimination against New South Wales and Queensland.' ${ }^{20}$ He referred to the allocations of the 1950s and his mention of Queensland, which received less per capita than Victoria in every year from $1947-48$ to $1960-61$, was again characteristic of New South Wales's historic attitude to the federation.

The Acting Premier was supported by W. C. Wentworth, a New South Wales federal Member of Parliament who presented the facts of the situation with considerable skill. He had some background of Loan Council meetings and procedures, having attended as a New South Wales Treasury official from 1934 to 1936 . He said that New South Wales would have received $\$ 500 \mathrm{~m}$. more in the past 14 years if it had obtained the same amount per capita as Victoria. He was quoted as saying that 'the difference of $\$ 167.9$ a head between the Victorian and New South Wales loan allocations in these years is made up of $£ 31.3$ under the financial agreement of 1927 and the much larger sum of $£ 136.6$ under a so-called "gentlemen's agreement" of May 1936.21 His main conclusion was that any government that was treated persistently unfairly under the Gentlemen's Agreement had

19 T. A. Hiley, 'Federal-State and Local Government Finance', Local Government in Queensland, February 1962, 20.

20 Daily Telegraph, Sydney, 17 June 1963, 3; see also S.M.H., 15 June 1963 and Canberra Times, 12 June 1963.

21 S.M.H., 15 June 1963. 
the power and in fact a duty to withdraw from it. 'Lack of money for semi-government and local government works had held back development in New South Wales. Such things as roads, water supplies and sewerage have suffered. The lack of capital funds has resulted in higher ratings and charges.'22

The Acting Premier responded to the federal Member's support with an expression of regret that other New South Wales federal Members had not taken up their State's cause. ${ }^{23}$ At no time was the matter of justice over the long period of the 1930 s and the 1950 s referred to. The decision of the Loan Council on the 1963-64 total allocation per capita resulted in both New South Wales and Victoria receiving more than the previous year, Victoria's $£ 1.08$ being slightly less than the $£ 1.89$ per head increase for New South Wales. ${ }^{24}$

Wentworth raised the issue again in the Commonwealth Parliament. The essence of his argument, based upon valuable statistical material from the Commonwealth Treasury, was as follows.

1. At meetings of the Loan Council, and the Premiers' Conferences where general revenue grants are made under s.96, 'New South Wales has been consistently and unjustly worsted by the astuter representatives of other States, particularly Victoria'. He did not pursue the s.96 aspect very far, but the joining of loans and revenue grants was valid and important.

2. He had 'no complaint' that Western Australia, South Australia and Queensland, 'which have large areas and sparse populations' should receive more per capita than New South Wales, but Victoria, 'a small and concentrated State', was a different proposition.

3. Had New South Wales received the same per capita total loan allocation as Victoria between $1948-49$ and 1963-64, the additional amount that New South Wales would have had was $£ 465.5 \mathrm{~m} .{ }^{25}$ This provided the sound statistical calculation, at current prices, to support his earlier statements to the press. He added that 'The New South Wales Government has been a party to every one of these decisions, because every one of them was unanimous'. ${ }^{26} \mathrm{He}$ considered that the solution was a change of government in New South Wales (it had been Labor for 22 years) and stronger pressure by the New South Wales representative for an increase in New South Wales's share at the expense of Victoria.

22 Ibid.

23 Ibid.

24 Commonwealth Payments to or for the States, 1967-68, 65.

25 From W. C. Wentworth's statistics, C.P.D., 15 August 1963, 238, table 5B; the statistics upon which the estimates were based were provided by the Commonwealth Treasury and have been used to compile tables 11.2 to 11.6 .

26 Ibid., 239. 
The outcome of the considerable intellectual and political argument presented by New South Wales parliamentarians was that New South Wales improved its position relative to Victoria again in 1964-65 and 1965-66. In the latter year the relative per capita position of the States was New South Wales 86.7; Victoria 97.9; Queensland 106.3; South Australia 114.4; Western Australia 111.4; and Tasmania 174.2, the average of the six States being 100: Victorians were still receiving over 11 per cent more per head than New South Wales.

The power of New South Wales to use the veto and demand the application of the formula was far less significant in the $1960 \mathrm{~s}$ than it was in 1935 when B. S. B. Stevens, the Premier of New South Wales, was confronted with similar arguments by the Premier of Victoria. That was because it was under the Gentlemen's Agreement, which is not subject to veto and a formula, or any form of compulsion, that the major difference developed. On the one hand, under the Financial Agreement, Victoria received at the most $£ 2.8$ per head more than New South Wales in any year over the period after 1952-53. On the other hand, under the Gentlemen's Agreement, Victoria received at the beginning of the period twice as much per head as New South Wales (from 1949-50 to 1956-57) and it gradually fell to half as much again in 1962-63 and about one-third more from then to 1965-66. The amount of this difference per head between the two States under the Gentlemen's Agreement was as high as $£ 10$ in $1950-51$, fell to $£ 5$ in $1962-63$ and then to $£ 3$ in 1965-66, after which the difference rose again.

The disparity between New South Wales and Victoria under the Gentlemen's Agreement was only one reason for the persistently smaller per capita allocation to New South Wales. The long-term nature of the differences, particularly under the Financial Agreement, suggests that the New South Wales government and its authorities wished to avoid going into debt as deeply as Victoria to finance development. The only qualification to this would be if labour and materials costs in New South Wales were persistently less and that was most unlikely. The quality of the public utilities and services in New South Wales was therefore poorer than in Victoria and it remained so because, it will be seen, the relative gains to New South Wales by s.96 grants from the Commonwealth did not correct the differences in total loan allocations. 


\section{The Consequences of Uniform Taxation}

The fundamental purpose of the Financial Agreement of 1927 had been to separate the fiscal policies of the Commonwealth and the States. It was intended to create what was largely a co-ordinate system of federal finance. The general objective was achieved briefly; it was short-lived because it depended upon the taxable capacity, that is, the average personal income and wealth of the individual, being the same in each State. In fact, there had been no progress towards that desirable situation since federation and the smaller, less wealthy States became dependent upon gradually increasing, flexible assistance from the Commonwealth. By 1939 and especially during the depression years when their deficits were large, all States had accepted financial assistance for a variety of purposes and that had whittled down the effectiveness of the fiscal adjustment in the Financial Agreement. When Uniform Taxation was introduced in 1942, it completed the process: it gave the Commonwealth command of the whole of income taxation and so increased the States' dependence upon general revenue and specific purpose grants from the Commonwealth that the adjustment in the 1927 Agreement was reduced to negligible proportions. The amortisation of debt by the National Debt Commission and the functions of the Loan Council became the significant remaining parts of the 1927 Agreement, not the fiscal adjustment then made.

The importance of the Loan Council rested on its borrowing and interest rate powers and the analysis of borrowing in the post-war years revealed that, in that part of fiscal policy, the Commonwealth acquired, by its use of underwriting and its disposition of its share of the loan program, a large measure but by no means total or permanent control of the amount of governmental capital expenditure in the States. That control was made easier by the very big increase in revenue that the Commonwealth acquired when it successfully imposed Uniform Taxation; the Commonwealth then had more funds to use for underwriting and for grants for capital expenditure under the financial assistance power. 
The decision to introduce a uniform federal income tax to replace the existing system of six State taxes and Commonwealth taxation was political, but it depended for its continuity upon judicial decisions on the joint use of s.96, the financial assistance power, and s.51(ii), the Commonwealth's taxation power. The High Court's decisions to validate the wartime introduction of Uniform Taxation depended upon precedents and there was, after the Roads Case of 1926, a further decision in 1939, in Moran's Case, that enabled the Commonwealth to achieve indirectly a purpose that it was not empowered to carry out directly under the Constitution in taxation and grants matters. ${ }^{1}$ In Moran's Case a scheme of taxation and grants Acts by which the Commonwealth raised excise duties at a uniform rate but paid an amount equal to that raised in Tasmania to the Tasmanian government, which paid it to the original taxpayers, was held valid by the Privy Council, notwithstanding prohibitions against discrimination in ss.51(ii) and 99. The Board of the Privy Council issued a warning that the courts might, in some circumstances, invalidate 'legislative schemes' to get around the Constitution, even when embodied in a number of separate Acts. ${ }^{2}$ It is generally agreed that the Court would not be able to conclude whether or not a scheme was genuine without considering questions of government policy, ${ }^{3}$ and a compromise would seem to be Professor Sawer's view that the Commonwealth can go far towards securing the equality of the burden of taxation. ${ }^{4}$

By its decision in Moran's Case, 1939, to uphold the validity of the Commonwealth's action, the High Court added to those which followed from the Roads Case of 1926 (chap. 6) a fifth circumstance in which s.96 may be exercised, namely: (5) the Commonwealth can impose terms and conditions requiring a particular State to pay over the Commonwealth's assistance to a class of persons in or connected with the State.

The preceding judgments provided the basis for that in the First Uniform Tax Case of 1942. The drive to have one uniform taxing authority arose from the need for a simple, effective and relatively just wartime taxing machine to help finance the war. ${ }^{5}$ It soon became apparent that World War II had created fiscal problems. To finance its greatly increased wartime expenditure and to reduce the private demand for goods and services, it was necessary for the Commonwealth to increase to the maximum its revenue from all sources. The incidence of State income taxes, which were then levied concurrently with Commonwealth income tax, differed widely

1 W. R. Moran, Pty. Ltd. v. Deputy Federal Commissioner of Taxation (N.S.W.) (1940), 63 C.L.R., 338.

2 Sawer (ed.), Federalism, 271.

3 Latham, CJ. in First Uniform Tax Case (1942), 65 C.L.R., 428, and Wynes, Powers, 55.

4 Sawer, Cases, 134.

5 Unless otherwise footnoted, the facts on post-war developments are from successive issues of the Treasurer's Budget White Paper, Commonwealth Payments to or for the States. 
between States and, since the Commonwealth is forbidden by $\mathrm{s} .5 \mathrm{l}$ (ii) to discriminate between States in the imposition of taxes, its rates were in practice limited by the scope available for additional tax in that State with the highest rate of tax at each income level. This meant that in other States there were large untapped sources of income tax revenue. ${ }^{6}$

This problem was the subject of discussion between the Commonwealth and State governments on a number of occasions during the early war years, but agreement could not be reached on a mutually acceptable solution, ${ }^{7}$ even though by 1942 all federal political parties had agreed in principle that one uniform Commonwealth income tax was essential to finance the war.

The original conception can probably be attributed to Professor $\mathrm{R}$. C. Mills, who had advocated as early as 1928 that the problems of dual taxation and different taxing systems could be overcome by handing income and inheritance taxes over to the Commonwealth 'on the understanding that payments should be made to the States to compensate for the resulting loss of revenue' ${ }^{8}$ The first serious wartime proposal was by A. W. Fadden, non-Labor Treasurer, in the Budget Speech of November 1940, and he proposed a scheme to the Premiers in February and June 1941, which was somewhat different from the final one adopted. ${ }^{9}$

In February 1942 the Labor government appointed a Committee, consisting of Professor R. C. Mills, Chairman of the Grants Commission, J. H. Scullin, Labor M.P., and E. S. Spooner, non-Labor M.P., to consider the question of the Commonwealth becoming the sole income taxing authority for the duration of the war and the making of grants to the States in the event of their retirement from the income tax field. ${ }^{10}$ The Committee

6 In 1940-41 the Grants Commission found that severity of all taxation ranged from 68 in Victoria to 121 in Queensland, the average for all States being 100 . The incidence of income tax ranged from about $£ 6.15$ per head in Queensland to $£ 3.5$ in Victoria and $£ 3.4$ in Tasmania. In South Australia, the non-Labor government was cspecially severe on incomes up to $\mathfrak{1 4 0 0}$ and the Queensland Labor government was the reverse. See Commonwealth Grants Commission Ninth Report (1942), 76, and K. H. Bailey, 'The Uniform Tax Plan', Economic Recard, vol. XX, no. 39, December 1944, 172.

7 C.P.D., 15 May 1942, 1285 et seq.

8 R. C. Mills, 'The Financial Relations of the Commonwealth and the States', Economic Record, vol. 4, May 1928, 14.

9 C.P.D., 3-4 July 1941, 902 et seq.

10 E. S. Spooner subsequently revealed his experience of State taxation when he had been the non-Labor Minister assisting the Colonial Treasurer of New South Wales:

I believed it would be possible to have State and Federal Income Tax working side by side and for the States and the Federal Government to levy their own taxes. In the first year of my service in the Government of New South Wales, of which I was a member, I set up an expert committee. It worked for two years and prepared a new State Income $\operatorname{Tax}$ Act in co-operation with other States, and then in conjunction with the Commonwealth. The resultant Act of 1936 was as uniform as it was possible to beperhaps about 85 per cent.

In 1941 one of the first achievements of Mr McKell's Government was to reverse the position and put the law in a worse position than it was before 1936. There went the result of our work. 
presented its report in March 1942 and, as might be expected, recommended that for the duration of the war and one year afterwards the Commonwealth should be the sole authority to impose income taxes; it suggested that uniform taxation should operate from 1 July 1942 and that the States should be compensated on retiring from the field of income tax.

In May 1942 the Treasurer, J. B. Chifley, introduced legislation into the Commonwealth Parliament that implemented, with minor amendments, the recommendations of the Committee. It removed the anomaly where, under two taxing authorities, some income earners were being taxed more than 20s. in the $£$; it avoided the situation where, if the Commonwealth taxed heavily concurrently with the States, low incomes would be hit unbearably hard in some States, and high incomes in others; and it rid the taxpayer of a system of twenty-six different State and Commonwealth taxes on incomes that required different income tax returns, different methods of determining taxable income and different concessional allowances. ${ }^{11}$ Administratively, 'differing rates of Commonwealth and State taxation form a maddening maze of figures which must be studied whenever the preparation of a budget calls for additional Commonwealth revenue'.12 The legislation provided for uniform income tax to begin on 1 July 1942.

The plan was put into four separate Acts, mainly to comply with the provisions of the Constitution regarding the form of taxation measures. ${ }^{13}$ By virtue of s.55, a law imposing taxation must deal only with the imposition of taxation, and machinery measures must therefore be passed as separate Acts. These Acts were:

(a) the Income Tax Act 1942, or rates Act, which imposed a progressive income tax on every taxpayer in Australia on a completely uniform basis, irrespective of his State, at rates so high that it was virtually impossible for the States to raise any income tax; the States had imposed rates which varied between States in respect of both personal and company income tax;

(b) the State Grants (Income Tax Reimbursement) Act 1942, which empowered grants by the Commonwealth to the States of amounts respectively equal to the income tax revenue lost by them, but on the condition that they did not impose any income taxes during the relevant year;

(c) the Income $\operatorname{Tax}$ (Assessment) Act 1942, which gave an absolute

One of the main difficulties has always been that the States cannot agree among themselves on a uniform policy and I see no solution of the problem except along the lines of a centralised and uniform collection of taxation.

Comments recorded in F. A. Bland (ed.), Changing the Constitution (Sydney, 1950), 67-8.

11 C.P.D., 20 March 1946, 428 (J. B. Chifley).

12 C.P.D., 15 May 1942, 1286 et seq. (2nd Reading Speech).

13 South Australia v. The Commonwealth (Uniform Tax Case) (1942), 65 C.L.R., 373 et seq. 
priority in payment of Commonwealth income tax over State income tax for the duration of the war and one year thereafter;

(d) the Income Tax (Wartime Arrangements) Act 1942, which authorised the Commonwealth to take over the staffs, premises and records of the State Taxation offices for the war period.

Four States challenged the Plan. A majority of the Court upheld the Arrangements $A c t$ as a valid exercise of the wartime defence power, but it is clear that if the States established income taxation departments in peacetime, the Commonwealth could not then take over their staffs and equipment. ${ }^{14}$ That step was therefore only transiently valid.

The other essential components of the plan were upheld by the majority on grounds having no relation to the wartime defence power. The rates of tax Act that imposed such high tax rates that it became virtually impossible for the States to tax was held valid under the taxing power, s.51(ii); and the Assessment Act giving the Commonwealth priority over the States in tax payments was upheld as being clearly within the taxing power of s.51(ii) and incidental to s.109 which provides that Commonwealth law prevails over State law; and the Grants Act was upheld under s.96 with only Starke J. dissenting. The whole Court, including Starke J., rejected the States' arguments that in substance the Acts, taken together, amounted to a denial of the rights of the States' taxing powers. Latham CJ. said that the Parliament either had power to pass an Act or it had not; if it had the power, the enactment of other valid legislation could not affect it, while other invalid legislation could not affect it because invalid legislation could have no effect at all.15 The judgment was consistent with that in Moran's Case, in that separate powers used in combination can accomplish a policy that would not be possible when a power stood alone. It was possible to achieve indirectly a purpose which was impossible directly. ${ }^{16}$

The elimination of State income taxation was accomplished in 1942 by the combination of the taxation power, the grants power and the wartime defence power. The last power, upholding the physical seizure of the State offices, was a powerful factor in ensuring that the States ceased imposing income taxation forthwith. However, once the single Commonwealth tax was furmly established, the other relevant powers, which were permanent, and the measures authorised by them, ensured that the scheme retained momentum in the post-war period.

Between 1942, when it was launched, and the mid-1960s, the history of Uniform Tax can be looked at briefly in three stages. The first was the war period, between 1 July 1942 and March 1946, during which war conditions dominated policy. Then followed the long period of thirteen years during which the basic question of finding a politically acceptable

14 Sawer, Cases, 109.

15 Wynes, Powers, 52; (1942) 65 C.L.R., 411.

16 K. H. Bailey, 'Uniform Tax Plan', 185, and 25 A.L.J., 328. 
alternative to Uniform Tax was explored. The search was fruitless and the meeting between the Commonwealth and the States in June 1959 may have been historic in that there was unanimous acceptance of the principle of uniform taxation. That introduced the third period.

Regarding the first, under the wartime scheme the Commonwealth was the sole income taxing authority for the period of the war and one year thereafter, and by way of compensation, the States were paid constant tax reimbursement grants (provided they did not impose taxes on income) based on their average income tax collections in the years 1939-40 and 1940-41.17

The second period began when, at a Premiers' Conference in January 1946, the States were informed by the Labor Prime Minister and Treasurer, J. B. Chifley, that the Commonwealth government proposed to continue uniform income tax indefinitely in the post-war period. The basic political issue which led the Conference to accept this course was 'the maddening maze'. 'From the point of view of the taxpayer, the abandonment of uniform taxation is unthinkable.'18 The Conference worked out a new reimbursement formula, which was incorporated in the States Grants (Tax Reimbursement) Act 1946. The grants continued to be on the condition that the States refrained from levying income tax. It was decided that the total tax reimbursement grants in both $1946-47$ and 1947.48 should be $£ 40 \mathrm{~m}$. and that the aggregate grant in subsequent years should be determined by means of a formula by which this base amount would be increased in accordance with variations in population and half of the percentage increase in average wages per employed person.

The basic practical difficulty of finding a satisfactory formula became clear once the carry-over of wartime incentives to be united disappeared. As a result of discussions with the States during the next two years, the grant for $1947-48$ was increased to $£ 45 \mathrm{~m}$. and the formula embodied in the 1946 Act was amended. Beginning in 1948-49, the aggregate grant payable was determined by varying the sum of $£ 45 \mathrm{~m}$. in accordance with a formula which took account not only of variations in the total population of the States, but also the full instead of half the percentage increase in the level of average wages per person employed in Australia as a whole. It was to be significant that it was found early that a permanently satis-

17 However, the Commonwealth safeguarded itself from criticism by using the Grants Commission as arbiter. If any State considered that tax reimbursement grants were insufficient, application could be made for an inquiry in the usual way by the Grants Commission. In its Tenth Report, the Commission said that it would report to the Commonwealth Treasurer 'whether it is just that an additional amount of financial assistance should be payable to that State'. These payments were to be in addition to normal special grants recommended by the Commission and some additional payments were made to claimant States in 1945-46 and 1946-47 See Grants Commission 10th Report (1943), 87; and Commonwealth Payments to or for the States.

18 C.P.D., 20 March 1946, 428 (J. B. Chifley). 
factory formula was impossible to find. There was an exact parallel with the Founders' problems.

The States Grants (Tax Reimbursement) Act 1946 had also included a schedule determining the distribution of the aggregate grants in 1946-47 and 1947-48. It provided that in each of the years 1948-49 to $1956-57$ inclusive, a percentage of the grant should be distributed according to this schedule, the remainder to be distributed in proportion to the populations of the States (adjusted for density and for numbers of children between 5 and 15 years of age). The percentage to be divided according to the schedule was 90 per cent in 1948-49, 80 per cent in 1949-50, down to 10 per cent in 1956-57 and nothing in 1957-58. Thus the whole of the tax reimbursement grants in 1957-58 and 1958-59 would be distributed in proportion to the States' adjusted populations. It is notable that the distribution schedule meant a gradual return to what Giblin regarded as the satisfactory automatic adjustment of uniform Commonwealth tax and equal per capita payments to the States.

In all but two years from the end of the war until 1958-59 the aggregate of grants made under the agreed formula was supplemented with additional amounts called Supplementary Grants, the amounts of which were determined arbitrarily by the Commonwealth. In 1951-52 the supplementary grant was no less than 0.9 per cent of the gross national product, a significant sum in itself for a marginal adjustment. The supplementary grants were often distributed in proportions that differed from those of the formula grant. In allocating the supplementary grants, the Commonwealth was influenced in the discussions at Premiers' Conferences by the shortterm needs of the respective States and their individual bargaining power at the conference table. ${ }^{19}$

In the decade between 1948-49 and 1958-59 the States bargained with the Commonwealth in the glaring publicity of successive Premiers' Conferences, which were open to the press and public. It was to be expected that some States would be dissatisfied with the aggregate and the distribution of grants, and in October 1952 Victoria took out a writ in the High Court challenging the validity of the uniform tax legislation, but this challenge was not pursued.

In July 1952 the Commonwealth had informed the States at a Premiers' Conference that it was willing to discuss with them the possibility of the resumption of State income tax. The Conference called for a report that was subsequently prepared by Commonwealth and State treasury officers on the technical problems involved and presented to a Premiers' Conference held in February 1953.

At that Conference, Commonwealth and State treasury officers were asked

19 Supplementary Grants were as much as 39 per cent of formula grants in 1951-52, and as small as 10 per cent in $1955-56$. 
to prepare a further report as a basis for discussion at a Premiers' Conference on the extent to which the Commonwealth might vacate the income tax field. This report was received at a Conference held in August 1953, together with a review of the special problems facing Queensland, a nonclaimant State, in the event of the return of taxing powers. No agreement could be arrived at between the Commonwealth and the States on the extent to which the income tax field should be vacated by the Commonwealth. The basic issues were the same as those of the $1920 \mathrm{~s}$ and the $1930 \mathrm{~s}$ and can be understood in their more recent context from table 17.1.

Table 17.1

Commonwealth tax reimbursement and supplementary grants, 1952-53 (Em.)

\begin{tabular}{lccccc}
\hline & $\begin{array}{c}\text { Actual } \\
\text { allocation } \\
1952-53^{*}\end{array}$ & $\begin{array}{c}\text { Compensation } \\
\text { principle } \\
\text { (1946-47 } \\
\text { basis) }\end{array}$ & $\begin{array}{c}\text { Population } \\
\text { principle } \\
(1957-58 \\
\text { basis) }\end{array}$ & $\begin{array}{c}\text { Derivation principle } \\
\text { (individuals } \\
\text { only) }\end{array}$ & $\begin{array}{c}\text { Residence } \\
\text { (individuals and } \\
\text { companies) }\end{array}$ \\
\hline N.S.W. & $(1)$ & $(2)$ & $(3)$ & 5 ) \\
Vic. & 54.0 & 55.6 & 52.4 & 51.1 & 53.0 \\
Qld & 32.4 & 29.9 & 34.8 & 41.6 & 41.3 \\
S.A. & 21.7 & 22.3 & 21.1 & 14.3 & 14.7 \\
W.A. & 11.6 & 11.7 & 11.5 & 13.1 & 12.2 \\
Tas. & 10.8 & 11.4 & 10.3 & 12.0 & 10.3 \\
\hline Total & 4.5 & 4.1 & 4.8 & 3.0 & 3.5 \\
\hline
\end{tabular}

* Excludes deductions for State tax arrears, $10.9 \mathrm{~m}$. extra assistance to Victoria, and special (Commission) and other grants.

$\dagger$ Report by Treasury Officers: Resumption of Income Tax by the States (Canberra, 1953), 32.

$\ddagger$ Ibid., 33 .

Source: W. Prest, 'The Economics of Federal-State Finance' in $\mathrm{H}$. W. Arndt and M. W. Corden (eds.), The Australian Economy (Melbourne, 1963), 242; and $\dagger$ above.

Column (1) shows the actual allocation of tax reimbursement and supplementary grants in 1952-53, based half on each State's proportion of tax proceeds prior to uniform tax and half on 'adjusted population' according to the 1946 formula. ${ }^{20}$ Column (2) shows the allocation which would have resulted from applying as a basis the tax proceeds prior to Uniform Tax.

20 The half arose from the simple fact that 1952-53 was half way through the 10-year period of the allocation formula. The formula for adjusted population in the States

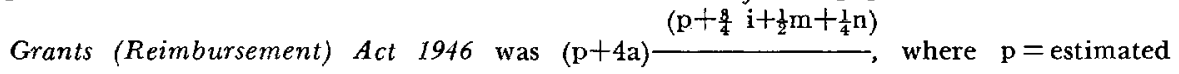
$p$

population of a State at beginning of the year; $a=$ children aged $5-15$ inclusive; $i=$ persons living in areas with a density of under 1 person per square mile; $m=$ persons living in areas with a density of $1-2$ persons per square mile; and $n=$ density of $2-3$ persons. 
Column (3) shows the allocation which would have resulted from applying the 'adjusted population' basis exclusively, or the 1957-58 adjustment. As it worked itself out, the formula was gradually benefiting Victoria and Tasmania at the expense of the other States.

Columns (4) and (5) show the revenue which each State would have raised if the Commonwealth had reduced its own income tax collection by $£ 135 \mathrm{~m}$. and if the States levied taxation at rates which made the combined Commonwealth and State rates equal to those actually applied by the Commonwealth. Column (4) indicates what each State would have derived from individuals resident within its borders, and column (5) indicates what would have been derived from individuals and companies whose incomes originated within its borders (but who were not necessarily residents). These two columns show one further reason why States would not agree to a return of taxing powers; on a residence (individuals only) basis, New South Wales, Queensland and Tasmania lost, with only Tasmania of the three having recourse to the Grants Commission for compensation. Queensland lost so heavily that it would have had to be accorded special treatment similar to a claimant State. On the origin basis, Western Australia also lost but, like Tasmania, it could have recourse to the Grants Commission. Again, Queensland would have lost so considerably as to make the return of taxing powers to the States almost a political impossibility. ${ }^{21}$

The transfers from Victoria (mainly to Queensland) were, very likely, one reason why, in December 1955, the Victorian government took out a new writ in the High Court challenging the validity of the uniform tax legislation. In particular, Victoria disputed

(a) the power of the Commonwealth to make, in the Grants Act, tax reimbursement grants conditional upon the States not levying income tax; and

(b) the Commonwealth's power to provide in the Assessment Act an absolute priority for payment of Commonwealth income tax over income taxes levied by the States.

In November 1956 the New South Wales government intervened to support Victoria's challenge. ${ }^{22}$

The case could be heard because New South Wales had not been a party to the 1942 litigation; also, the scheme was originally introduced in the critical days of the Pacific War, and although most of the reasoning had no connection with the defence power, some drafting changes accompanied the political decision in 1946 to continue the scheme, ${ }^{23}$ so that as a matter of legal form the legislation now attacked was not that held valid in 1942.

21 W. Prest, 'The Economics of Federal-State Finance' in $H$. W. Arndt and M. W. Corden (eds.) The Australian Economy (Melbourne, 1963), 241-2.

22 In addition to Commonwealth Payments to or for the States, see also Wyncs, Powers, 235.

23 Sawer, 'The Second Uniform Tax Case', 31 A.L.J., 347. 
After a thorough examination, the whole Court affirmed the validity of the Grants Act but a majority held that that part of the priority provision in the Assessment Act that prohibited a taxpayer from paying any State income tax before payment in full of federal tax could not be justified under the taxation power.

There remained to the Commonwealth, therefore, the power to impose very high Commonwealth taxes and the power to make grants to the States on the condition that the States did not impose income tax, the latter being affirmed by all members of the Court, who recognised that to overrule the 1942 decision or even to distinguish it must involve a grave judicial responsibility. ${ }^{24}$

The effect of the judgments in both Uniform Tax cases was to add two further sets of circumstances to the list to which s. 96 applies. They are:

(6) the Commonwealth may impose the condition that a State refrain from exercising a constitutional power, namely its right to tax in this case;

(7) the Commonwealth can create the necessity for the assistance by its own act, in this case by imposing taxes so high that the State became very dependent on the Commonwealth.

The Court was well aware of the enormous implications of the wider interpretation of s.96, especially when allied with the interpretation of the taxing power, s.51(ii). The Chief Justice in 1942 had said:

It is perhaps not out of place to point out that the scheme which the Commonwealth has applied to income tax of imposing rates so high as practically to exclude State taxation could be applied to other taxes so as to make the States almost completely dependent, financially and therefore generally, upon the Commonwealth. If the Commonwealth Parliament, in a grants Act, simply provided for the payment of moneys to States, without attaching any conditions whatever, none of the legislation could be challenged by any of the arguments submitted to the Court in these cases. The amount of the grants could be determined in fact by the satisfaction of the Commonwealth with the policies, legislative or other, of the respective States, no reference being made to such matters in any Commonwealth statute. Thus, if the Commonwealth Parliament were prepared to pass such legislation, all State powers would be controlled by the Commonwealth-a result which would mean the end of the political independence of the States. Such a result cannot be prevented by any legal decision. The determination of the propriety of any such policy must rest with the Commonwealth Parliament and ultimately with the people. The remedy for alleged abuse of power or for the use of power to promote what are thought to be improper objects is to be found in the political arena and not in the Courts. ${ }^{25}$ 
The decision of the Court in the Second Uniform Tax Case confirmed this view. However, a State cannot be coerced, it can only be induced ${ }^{26}$ by conditions which do not remove voluntary State action. ${ }^{27}$ A State enjoys an equal right to access to taxable income if it chooses to refuse the grants and impose a tax on income already taxed by the Commonwealth. ${ }^{28}$ Thus the condition that a State abstain from taxation in order to receive a grant was not an interference with an essential State function.

The decision set at rest any doubts that might have remained as to the meaning and scope of s.96-its permanency, the absence of any express or implied limitation upon the terms or conditions which may be imposed and the validity of discrimination as between States, provided a State retains the right voluntarily to accept or reject terms and conditions. ${ }^{29}$

Basic political and financial considerations and not legal doctrine have, in fact, made uniform tax durable. It would be very embarrassing for any one State to add its income taxation to the existing high uniform Commonwealth rates, and because of s.51(ii) the Commonwealth could not vary the rate of its tax for a particular State willing to forgo reimbursement grants; only the unanimous agreement of the six States, followed by an arrangement with the Commonwealth, can bring about a smooth resumption of State taxation. ${ }^{30}$ 'A combination of legal, political and economic factors makes it almost impossible for a willing Commonwealth to abandon the Uniform Tax Scheme... The six States together could by a joint ultimatum compel an unwilling Commonwealth to abandon the present scheme, and this is so irrespective of the constitutional law of the matter.' ${ }^{31}$

The High Court's decision in the Second Uniform Tax Case did not result in a defeatist attitude by the States. Dissatisfaction with uniform tax led Victoria and Queensland to apply in October 1958 for special (Commission) grants. The New South Wales government reacted strongly to this move by Victoria. Its Labor Premier, J. J. Cahill, expressed his disapproval by saying at the next Premiers' Conference in March 1959 that if a State like Victoria with its large population and higher economic development became a claimant State, it would be the end of State government and the Commonwealth should take over. ${ }^{32}$

At the June 1959 Premiers' Conference the Commonwealth made it clear that it considered that the system of special (Commission) grants

26 (1957) 99 C.L.R., 605, 610.

27 Ibid., 630, 656, 642-3.

28 Ibid., 613 et seq.

29 Wynes, Powers, 477.

30 Sawer, Cases, 109.

31 Sawer, 'Judicial Decisions Affecting Public Administration, 1956-8', Public Administration, vol. XVII, no. 2, June 1958, 97-8.

32 Proceedings of Conference of Commonwealth and State Ministers, March 1959, 31. This Conference was, in effect, a preliminary discussion precedent to the next Conference in June when major decisions were taken. 
should be continued. At the same time, the Commonwealth expressed the view that the machinery which had been developed over the years by the Grants Commission would become unworkable if as many as five States were to seek special grants. It was, in fact, a denial of the very basis for having the Commission.

The Commonwealth suggested that the States might be regarded henceforth as falling into three categories. At one extreme were the two wealthier States of New South Wales and Victoria, which should not participate in any arrangements for special (Commission) grants, and at the other extreme were Western Australia and Tasmania, which for the time being might be regarded as having a continuing need for special grants. In an intermediate category were the States of Queensland and South Australia; the Commonwealth considered that, while these two States ought not to be denied the right of access to the Grants Commission, the per capita tax reimbursement grant ${ }^{33}$ to them should be increased sufficiently to enable them, unless exceptional circumstances arose, to avoid applying for special (Commission) grants.

The main point was that the Commonwealth wanted to change the general revenue grants from being almost equal per capita to all States, as the States' taxation had been prior to 1942, and make them dissimilar, the less wealthy States receiving more per head than the others. This general approach to the problem was accepted by the States and, in agreeing to the new revenue grants arrangements, the Premiers of Queensland and South Australia each gave an undertaking that his State would not exercise the right of applying for special (Commission) grants in future unless special or unexpected circumstances endangered its budgetary position. The new revenue grants arrangement, which took the place of 'Tax Reimbursement Grants', were to become known as 'Financial Assistance Grants', a change of name which emphasised that the grants were not based on what the States' taxation had been prior to 1942, but on a new formula with the accent on inequality.

The agreement was on an arbitrary basis, reached in accord with the long-established concept of the Commonwealth acting as 'the great negotiator' from its strong financial position. The allocation was in accord with, but favoured the less wealthy States even more than, the former automatic adjustment of uniform Commonwealth tax and equal (or nearly equal) per capita payments to the States. The need for flexibility to enable adaptation to changing conditions remained as strong as ever. Arrangements were not made on a permanent basis, but remained subject to reconsideration and revision to take account of new developments. That has been so since the 1959 Conference.

33 Table 17.2 shows that up to $1958-59$ these grants were roughly equal per capita to all six States. 
The change in per capita payments of revenue grants to the States when the tax reimbursement grants formula was superseded by the financial assistance grants formula is strikingly illustrated by the change between payments in the years up to 1958.59 and the years after (table 17.2).

Table 17.2

Tax reimbursement and financial assistance grants per capita, 1944-45 to $1962-63$ (א)

\begin{tabular}{lrrrrrrr}
\hline Year & N.S.W. & Vic. & Qld & S.A. & W.A. & Tas. & \multicolumn{1}{c}{$\begin{array}{c}\text { Average } \\
\text { six States }\end{array}$} \\
\hline $1944-45$ & 5.14 & 3.20 & 5.35 & 3.70 & 5.25 & 3.57 & 4.46 \\
$1946-47$ & 5.44 & 4.30 & 5.98 & 5.36 & 6.74 & 4.77 & 5.27 \\
$1951-52$ & 10.35 & 8.84 & 11.43 & 10.16 & 11.84 & 9.40 & 10.15 \\
$1958-59$ & 17.39 & 19.66 & 19.05 & 17.80 & 19.34 & 18.14 & 18.47 \\
$1959-60$ & 22.00 & 21.27 & 25.13 & 29.65 & 35.11 & 31.24 & 24.21 \\
$1962-63$ & 25.73 & 25.19 & 29.36 & 34.81 & 40.87 & 36.75 & 28.41 \\
$1964-65$ & 27.73 & 27.20 & 31.51 & 37.52 & 44.28 & 39.21 & 30.61 \\
\hline
\end{tabular}

Source: Grants under the formula from Commonwealth Year Book. The grants exclude Supplementary Grants. They also exclude special (Commission) grants to Western Australia, South Australia, and Tasmania. The information is also in Common. wealth Payments to or for the States.

Whereas under the tax reimbursement grants formula the payments to each State were relatively close to the average for the six States until 1958-59, the change agreed in 1959 resulted in greater per capita payments to the four less wealthy States, compared with New South Wales and Victoria. In addition to greater amounts under the new formula, the two remaining claimant States, Tasmania and Western Australia, continued in the mid-1960s, when this review concludes, to receive grants as recommended by the Grants Commission, that resulted in greater per capita revenue grants than were received by the two intermediate nonclaimant States, Queensland and South Australia.

In addition to formula-based, general revenue grants and Commission grants, there were also grants of a capital and revenue nature to the States for specific purposes, such as roads, universities, natural disasters, railway standardisation, agxicultural extension services and northern development projects. These grants far outgrew in importance special (Commission) grants and payments under the Financial Agreement between the 1930s and the post-war years. The broad position is evident from table 17.3. Before the war, specific purpose grants ( 45 per cent of the total) were about equal in importance with payments under the Financial Agreement. By the mid1960 s they had become nearly eight times greater than payments under the Financial Agreement and also special (Commission) grants.

Broadly, the overall relationship of the Commonwealth to the States 
Table 17.3

Commonwealth payments to or for the States, $1938-39$ to $1964-65$

\begin{tabular}{|c|c|c|c|c|c|c|c|c|}
\hline & \multicolumn{2}{|c|}{ 1938-39 } & \multicolumn{2}{|c|}{$1942-43$} & \multicolumn{2}{|c|}{$1958-59$} & \multicolumn{2}{|c|}{$1964-65$} \\
\hline & $£ \mathrm{~m}$. & $\%$ & $\mathrm{fm}$. & $\%$ & $£ \mathrm{~m}$. & $\%$ & $\mathrm{fm}$. & $\%$ \\
\hline \multicolumn{9}{|l|}{ Grants (s.96) } \\
\hline General revenue* & - & - & 34.06 & 65.3 & 205.00 & 69.1 & 340.67 & 68.9 \\
\hline Specific purpose $†$ & $9.21 \ddagger$ & 45.3 & $6.75 \S$ & 12.9 & 57.97 & 19.5 & 121.88 & 24.7 \\
\hline Special (Commission) & 2.02 & 10.0 & 2.18 & 4.2 & 20.75 & 7.0 & 15.86 & 3.2 \\
\hline \multicolumn{9}{|l|}{ Payments (s.105A) } \\
\hline Financial Agreement & 9.06 & 44.7 & 9.17 & 17.6 & 12.97 & 4.4 & 15.91 & 3.2 \\
\hline Total & 20.29 & 100.0 & 52.16 & 100.0 & 296.69 & 100.0 & 494.32 & 100.0 \\
\hline
\end{tabular}

- Tax reimbursement + supplementary grants, 1942-43 to 1958-59.

$\dagger$ Revenue and capital grants for specific purposes, excluding the Financial Agreement and Special (Commission) Grants.

$\ddagger$ Commonwealth Payments and Commonwealth Grants Commission, Twentieth Report (1953), Appendix 17.

\& Commonwealth Grants Commission, Eleventh Report (1944), 126.

Source: Commonwealth Payments to or for the States (Government Printer, Canberra), unless otherwise noted above.

changed so that the proportion of Commonwealth payments of all kinds to the States in their revenue, including Commonwealth payments but excluding business undertakings, rose from about 23 per cent in 1938-39 to about 57 per cent in $1963-64 .^{34}$

While the 1959 arrangements reduced from 7 per cent in $1958-59$ to 2.5 per cent in 1959-60 (compared with 10 per cent before the war) the proportion of special (Commission) grants in the total, their function continued to be to complete the work begun by other transfers and ensure for claimant States equality of government services as between the States.

The effect of Uniform Tax on the adjustment to financial relations incorporated in the 1927 Financial Agreement was even more dramatic. Between 1938-39 and 1964-65, all payments to the States grew nearly twentyfive times, but payments under the Financial Agreement less than doubled. The share of Agreement payments in the total has fallen during the period from 45 per cent to about 3 per cent. The trend had been downward, but less markedly, prior to uniform taxation.

Uniform taxation therefore accelerated a major shift of power to the Commonwealth. It was achieved by political and judicial decisions, not by constitutional amendment; and it was achieved without powerful resistance

34 Only rough estimates can be made because official national income estimates do not separate State revenues from those of local and semi-government authorities. The assessment above is based on information in Commonwealth Year Book no. 32 of 1939, 882-3 and table 17.3; Commonwealth Year Book no. 51 of 1965, 931-2; and Commonwealth Payments to or for the States 1964-65, table 35. 
from any quarter, except Victoria, to the concept of the Commonwealth raising large sums for the States to spend. The States were the main losers in the transfer of power. The guarantees to them for the first ten years of federation under the Braddon clause of s.87, and after 1927 by the Financial Agreement under s.105A, were replaced in principle and in effect by negotiations for grants under s.96. Once its constitutional validity had been determined, the change was perpetuated by at least two necessities-the management of the war economy, and the willingness of the people to accept it in peacetime, both as an aid to less complex taxation returns and as the means by which the Commonwealth could manage the economy better than had been experienced before the war. The Loan Council also lost power to the Commonwealth as a result of the Commonwealth's very great acquisition of revenue resources; the Commonwealth was then able easily to exercise the vital underwriting function discussed in chap. 16. The loss of power to the States was offset by what was, in principle, a doubtful advantage-the States were no longer responsible for raising the revenue advanced by the Commonwealth but which was spent to the political advantage of their respective governments. The fact that there was no effective outcry against this in the post-war years as in the 1920 s suggests that reducing the cost of government, rather than the principle of obliging governments to raise the money they spent, was the main issue in the 1920s.

Other interesting changes occurred with Uniform Taxation. Up to its innovation in 1941-42, the Commonwealth's payments to or for the States were always less than three-quarters of the customs and excise revenue and less than the interest on the States' public debts. After Uniform Taxation, the Commonwealth's payments were very much in excess of the interest on the States' debt; and from 1943-44 the payments exceeded three-quarters of the tariff revenue and were to remain in excess in all but the three immediate post-war years. ${ }^{35} \mathrm{Had}$ the States always been entitled to threequarters of the customs and excise revenue, their direct taxation would have been lower and uniform taxation by the Commonwealth would have been a much less significant loss. This hypothetical situation opens up, therefore, possibilities for speculation but the observations have no practical significance; they merely indicate when that lingering part of the history of federal-State relations appeared to close.

The advent of Uniform Taxation transformed federal financial relations to the point where the adjustments and payments arising out of the Financial Agreement became insignificant. The Commonwealth's assumption of liability for all debt incurred for and on behalf of the States and

35 Statistics from C.F.B. and Commonwealth Grants Commission, Twenty-sixth Report (1959), 115 and 119. If payments to primary producers are excluded from Commonwealth payments, then the payments to or for the States did not begin to exceed three-quarters of the customs and excise revenue until 1950-51. A decisive change then occurred in the first year in office of R. G. Menzies's non-Labor government. 
the States' payments to the National Debt Commission continued as important responsibilities arising out of the Financial Agreement but as a fiscal adjustment, the effect of fulfilling the intention of s.105 (and the hopes for it, a co-ordinate system) were dwarfed by the movement in the opposite direction - much greater Commonwealth control over revenue and over its disbursement to the States. After 1942, the importance of the Agreement in policy formation lay in the creation of the Loan Council with its powers over borrowing, interest rates and the allocation of loans.

The total loan program and grants under 5.96

It was notable in the 1930 s that grants under s.96 to Victoria did not offset the appreciably greater share of loan programs received by New South Wales. Did grants to New South Wales offset the advantages Victoria derived from loan allocations after 1947-48?

The distribution of the specific purpose and general revenue grants in the first two decades after the war was such that while all States enjoyed a growing absolute amount and the distribution greatly favoured the four smaller States, between New South Wales and Victoria there was relatively little difference. ${ }^{36}$ As between New South Wales and Victoria, from 1951-52 to 1963-64 the specific purpose grants per capita grew at about the same rate and by the same amounts. Throughout the early part of this period New South Wales enjoyed an advantage over Victoria of, at most, $£ 0.81$ per capita, but it lost it in 1959-60. On the other hand, the total loan allocations favoured Victoria by at least $£ 5$ and it was often nearer $£ 10$ per capita, and even higher. Hence s.96 grants for specific purposes did not help New South Wales in this period any more than they had helped Victoria in its pre-war years of disadvantage.

The four less wealthy States received a greater allocation per capita of specific purpose grants than New South Wales and Victoria, just as they had received a greater amount of loans per capita. ${ }^{37}$ The relative position of each of the four States was as follows.

Queensland. In the 1950s and the early 1960s, Queensland's loan allocations gradually grew from about 10 per cent under to 5 per cent over the average for all States, or from about $£ 5$ per capita below to about $£ 3$ above. In the allocation of specific purpose grants, Queensland received in the 1950s two-fifths more per capita and in the early 1960s it grew to twice as much as Victoria's and New South Wales's or an advantage of $115 \mathrm{per}$ capita in 1962-63.

36 Tables 11.2 to 11.6 and 17.5, and Commonwealth Payments to and for the States 1969-70,68, for statistics used in this and next paragraph.

37 The allocation of loans per capita as between the four States will be related to the average for the six States because Victoria received so much more than New South Wales in the post-war years. The allocation of grants will be related to New South Wales and Victoria which received about the same amount of specific purpose grants per capita. 
South Australia. In the 1950 s and the early 1960s, South Australia received loan money about 15 to 20 per cent above the average for the six States, or $£ 5$ to $£ 7$ per capita more, and its specific purpose grants were $£ 3$ to $£ 4$ per capita more than Victoria's and New South Wales's.

Western Australia. Over the same period, Western Australia received a share of total loans about 5 to 10 per cent per capita above the average, or about $£ 2$ to $£ 5$ per capita more. However, it received a much greater proportion per head of specific purpose grants-it was about $£ 5$ at the beginning of the 1950 s and $£ 10$ in $1960-61$, rising to $£ 20$ per capita more than New South Wales and Victoria in 1963-64.

Tasmania. The greater advantage received by Western Australia in the allocation of specific purpose grants was matched by Tasmania in the allocation of loans. Its receipts of loans per capita were some 70 per cent above the average in the 1950 s and $1960 \mathrm{~s}$, or $£ 20$ to $£ 30$ per capita. Its receipts of specific purpose grants were only about $£ 4$ per capita more than New South Wales's and Victoria's.

If all grants to the States are taken, that is, specific purpose plus general revenue grants including special (Commission) grants, a slightly different statistical result emerges, but in principle it is not unlike the pattern for specific purpose grants. The main point of difference is that Tasmania and Western Australia each received much more than Queensland and South Australia, which in turn were well ahead of the two wealthier States. ${ }^{38}$ New South Wales received more than Victoria until the late 1950s, when the two States began to converge, receiving about the same total grant per capita. New South Wales began to receive more again in the mid1960s. The periods in which New South Wales was favoured with greater grants did not offset significantly its relative deficiency in loan allocations.

Summarising the complicated details in preceding paragraphs, it may be said that, at the most, total grants per capita to New South Wales were $£ 2 \cdot 36$ (1953-54) greater than to Victoria, compared with Victoria's advantage per capita in total loan allocations of, at the least, $£ 5.3$ (1953-54) and as much as $£ 14.4$ (1950-51). W. C. Wentworth's main point regarding the post-war distribution of total loan money was not affected appreciably by the allocation of grants as between the two larger States.

Of the movements in the relative positions of the other four States, Western Australia's greater per capita share of grants roughly offset Tasmania's greater per capita share of loans and Queensland has emerged in the 1960 s as the new beneficiary of a greater per capita share of loans and grants, roughly on a par with South Australia, as might be expected in view of Queensland's less developed industrial condition, great potential, sparsely

38 Table 17.5. In 1962-63 the four smaller, less developed States received total payments greater than New South Wales and Victoria (about $£ 34$ each) of the following order per capita: Queensland £13; South Australia £15; Western Australia £40; Tasmania £33. 
Table 17.4

Index of the tax-paying capacity of the States, 1914-15 to $1941-42$

(average per capita of six States $=100$ )

\begin{tabular}{|c|c|c|c|c|c|c|}
\hline $\begin{array}{l}\text { Year in which } \\
\text { income earned }\end{array}$ & N.S.W. & Vic. & Qld & S.A. & W.A. & Tas. \\
\hline $1914-15$ & 112 & 85 & 130 & 64 & 107 & 58 \\
\hline $1915-16$ & 96 & 112 & 99 & 87 & 137 & 73 \\
\hline $1916-17$ & 111 & 87 & 115 & 82 & 121 & 45 \\
\hline $1917-18$ & 112 & 80 & 122 & 86 & 125 & 40 \\
\hline 1918.19 & 112 & 106 & 79 & 84 & 95 & 61 \\
\hline $1919-20$ & 104 & 108 & 84 & 114 & 80 & 62 \\
\hline $1920-21$ & 95 & 118 & 85 & 110 & 93 & 69 \\
\hline $1921-22$ & 103 & 122 & 68 & 99 & 87 & 45 \\
\hline $1922-23$ & 95 & 119 & 88 & 99 & 91 & 70 \\
\hline $1923-24$ & 95 & 129 & 59 & 122 & 75 & 72 \\
\hline Average for 10 years & 103 & 107 & 93 & 95 & 101 & 60 \\
\hline Average last 3 years & 98 & 124 & 72 & 107 & 84 & 62 \\
\hline \multicolumn{7}{|l|}{ Assessment year } \\
\hline $1925-26$ & 110 & 106 & 87 & 89 & 93 & 51 \\
\hline $1926-27$ & 121 & 105 & 73 & 85 & 64 & 39 \\
\hline $1927-28$ & 110 & 120 & 73 & 82 & 67 & 45 \\
\hline $1928-29$ & 115 & 116 & 70 & 84 & 81 & 54 \\
\hline $1929-30$ & 125 & 101 & 60 & 70 & 100 & 51 \\
\hline 1931-32 & 108 & 113 & 79 & 77 & 92 & 66 \\
\hline $1932-33$ & 104 & 116 & 99 & 77 & 83 & 69 \\
\hline $1933-34$ & 106 & 110 & 97 & 74 & 83 & 67 \\
\hline $1934-35$ & 108 & 104 & 99 & 80 & 89 & 65 \\
\hline $1935-36$ & 120 & 117 & 108 & 88 & 100 & 67 \\
\hline $1936-37$ & 117 & 117 & 94 & 88 & 99 & 85 \\
\hline $1937-38$ & 123 & 122 & 92 & 91 & 89 & 83 \\
\hline $1938-39$ & 119 & 120 & 96 & 93 & 97 & 75 \\
\hline $1939-40$ & 119 & 120 & 98 & 88 & 98 & 77 \\
\hline $1940-41$ & 118 & 125 & 99 & 87 & 91 & 80 \\
\hline $1941-42$ & 125.2 & 138.7 & 89.1 & 86.2 & 83.8 & 77 \\
\hline \multicolumn{7}{|c|}{$\begin{array}{c}\text { Index of personal income per capita, } 1948-49 \text { to } 1965.66 \\
\text { (average per capita of six States }=100 \text { ) }\end{array}$} \\
\hline $1948-49$ & 101.3 & 106.0 & 94.8 & 99.0 & 94.6 & 77.3 \\
\hline $1949-50$ & 100.9 & 106.4 & 93.1 & 98.2 & 95.8 & 80.0 \\
\hline $1953 \cdot 54$ & 101.7 & 106.3 & 91.2 & 98.3 & 95.0 & 85.2 \\
\hline $1959-60$ & 103.7 & 107.6 & 90.3 & 92.8 & 85.6 & 87.7 \\
\hline $1961-62$ & 104.6 & 106.8 & 88.9 & 92.0 & 88.1 & 88.7 \\
\hline 1963-64 & 104.0 & 106.4 & 92.7 & 93.3 & 85.5 & 85.5 \\
\hline $1964-65$ & 104.8 & 107.2 & 90.2 & 92.9 & 83.4 & 86.2 \\
\hline $1965-66$ & 102.6 & 107.7 & 90.5 & 91.2 & 93.3 & 87.4 \\
\hline
\end{tabular}

Sources: 1914-15 to 1923-24: The Case for T'asmania, presented by the Hon. J. A. Lyons, M.H.A., Premier and Treasurer, 1926, to Sir Nicholas Lockyer, C.B.E., I.S.O., Special Representative appointed to inquire into the Financial Position of Tasmania.

1925-26 to 1931-32: Grants Commission, First Report (1933), 100.

1932-33 to 1941-42: Successive Reports of Grants Commission using the Combined Index.

1948-49 to 1964-65: C.B.C.S., Australian National Accounts 1948-49 to 1966-67, table 33. N.S.W. includes A.C.T, and S.A. includes N.T. 
Table 17.5

Index of

Commonwealth payments to or for the States per capita (average per capita of six States $=100.00$ )

\begin{tabular}{|c|c|c|c|c|c|c|}
\hline Year & N.S.W. & Vic. & Qld & S.A. & W.A. & Tas. \\
\hline \multicolumn{7}{|c|}{ General revenue grants } \\
\hline $1951-52$ & 94.04 & 83.04 & 99.65 & 129.10 & 159.72 & 108.08 \\
\hline 1958-59 & 89.33 & 86.90 & 96.26 & 116.80 & 169.17 & 150.88 \\
\hline $1959-60$ & 87.71 & 85.80 & 98.20 & 124.40 & 161.14 & 166.00 \\
\hline $1961-62$ & 87.22 & 85.78 & 98.66 & 117.85 & 166.57 & 176.15 \\
\hline $1964-65$ & 86.95 & 85.56 & 97.11 & 116.06 & 167.53 & 187.22 \\
\hline $1965-66$ & 86.05 & 85.37 & 97.00 & 113.54 & 173.93 & 191.66 \\
\hline \multicolumn{7}{|c|}{ Specific purpose grants } \\
\hline $1951-52$ & 77.15 & 86.43 & 112.47 & 144.50 & 192.87 & $\mathrm{I} 12.37$ \\
\hline $1952-53$ & 79.16 & 76.88 & 113.76 & 156.14 & 194.33 & 122.13 \\
\hline $1953-54$ & 82.44 & 75.74 & 112.02 & 134.63 & 199.01 & 129.40 \\
\hline $1954-55$ & 87.04 & 70.44 & 114.82 & 126.06 & 208.42 & 124.69 \\
\hline $1955-56$ & 86.44 & 72.02 & 113.32 & 119.32 & 215.73 & 124.64 \\
\hline $1956-57$ & 83.95 & 71.09 & 119.30 & 124.13 & 213.00 & 126.77 \\
\hline $1957-58$ & 81.42 & 73.29 & 116.01 & 127.56 & 219.70 & 129.11 \\
\hline $1958-59$ & 81.96 & 77.19 & 115.52 & 114.94 & 211.62 & 140.89 \\
\hline $1959-60$ & 79.83 & 87.46 & 105.63 & 114.98 & 205.96 & 139.06 \\
\hline $1960-61$ & 78.41 & 91.98 & 106.20 & 105.49 & 207.57 & 139.21 \\
\hline $1961-62$ & 78.58 & 84.36 & 127.79 & 102.78 & 200.87 & 126.05 \\
\hline $1962-63$ & 75.49 & 73.54 & 143.50 & 112.41 & 217.94 & 116.54 \\
\hline $1963-64$ & 74.50 & 67.74 & 148.94 & 113.43 & 231.03 & 120.20 \\
\hline $1964-65$ & 81.24 & 69.75 & 120.95 & 119.57 & 230.41 & 131.62 \\
\hline $1965-66$ & 90.25 & 61.61 & 119.38 & 110.54 & 232.45 & 125.38 \\
\hline \multicolumn{7}{|c|}{ Additional assistance grants } \\
\hline $1957-58$ & 105.83 & 76.70 & 153.40 & 80.58 & 88.35 & 83.50 \\
\hline $1961-62$ & 59.47 & 64.21 & 228.42 & 104.21 & 92.11 & 295.26 \\
\hline $1962-68$ & 70.86 & 76.07 & 166.26 & 123.01 & 107.67 & 260.43 \\
\hline $1963-64$ & 85.79 & 91.26 & 82.24 & 147.54 & 128.69 & 212.02 \\
\hline \multicolumn{7}{|c|}{ Total payments } \\
\hline $1951-52$ & 90.49 & 83.75 & 102.33 & 132.32 & 169.00 & 108.97 \\
\hline $1952-53$ & 89.36 & 79.51 & 100.79 & 138.24 & 180.31 & 116.48 \\
\hline $1953-54$ & 90.76 & 80.03 & 101.36 & 131.61 & 148.62 & 117.59 \\
\hline $1954-55$ & 92,61 & 80.90 & 104.03 & 110.52 & 174.65 & 134.16 \\
\hline $1955-56$ & 90.65 & 79.40 & 99.50 & 121.33 & 178.39 & 150.78 \\
\hline $1956-57$ & 88.23 & 82.86 & 101.50 & 123.20 & 176.39 & 140.33 \\
\hline 1957.58 & 87.84 & 69.51 & 101.90 & 121.68 & 177.73 & 139.77 \\
\hline $1958-59$ & 87.61 & 84.61 & 100.90 & 116.39 & 179.36 & 148.53 \\
\hline $1959-60$ & 85.86 & 86.19 & 99.96 & 122.18 & 171.66 & 159.66 \\
\hline $1960-61$ & 85.63 & 87.51 & 100.15 & 115.69 & 173.92 & 164.50 \\
\hline $1961-62$ & 84.50 & 84.92 & 108.69 & 113.97 & 172.83 & 167.24 \\
\hline $1962-63$ & 83.82 & 82.52 & 112.59 & I 17.14 & 174.79 & 163.53 \\
\hline $1963-64$ & 84.39 & 81.78 & 110.30 & 118.08 & 177.37 & 163.39 \\
\hline $1964-65$ & 85.35 & 81.15 & 103.74 & 117.04 & 185.03 & 171.69 \\
\hline $1965-66$ & 87.27 & 78.41 & 103.54 & 112.65 & 191.04 & 172.25 \\
\hline
\end{tabular}

Source: Commonwealth Payments to or for the States, 1966-67 and 1968-69. 
dispersed population and relatively low share of all forms of loans and both capital and revenue grants in the past. ${ }^{39}$

Loans, grants and the States' relative taxable capacity

One test of whether greater per capita allotments of loan money and s.96 grants to the four smaller States are leading to what the Founders had expected-more nearly equal if not equal taxable capacity-can be measured roughly from available statistics of personal income per capita in each State. From table 17.4 it is reasonable to conclude that Tasmania had, in the $1960 \mathrm{~s}$, begun to reveal evidence of response to the greater share of loans and grants it received, and that the need for Queensland to receive the increasing share it had since 1961-62 is clear because it was less well off than all States except Tasmania until the mid-1950s. The relative decline in income per capita of Western Australia until 1965-66, and of South Australia, is notable despite the larger payments to them. It is also notable that, regardless of New South Wales's smaller share of loans relative to Victoria's in the 1950s, New South Wales's personal income per head has risen closer to the level of Victoria's.

These results are only indicative of probable trends. Other factors, such as the average wealth of people in a State, have not been taken into account, and if they were, this would probably widen the disparity between the two larger and the four smaller States. ${ }^{40}$

The results point to the need for a wider study of the wealth and of the value added in each State, but they suggest, on the basis of Tasmania, that in the long run, a State can improve its economic standards generally from

Table 17.6

Inequalities among the States, 1964

\begin{tabular}{|c|c|c|c|c|c|c|}
\hline & N.S.W. & Vic. & Qld & S.A. & W.A. & Tas. \\
\hline Persons per sq. mile, 1964 & 13.3 & 35.6 & 2.4 & 2.7 & 0.8 & 13.9 \\
\hline \multicolumn{7}{|l|}{ Proportion of population $(\%)$ : } \\
\hline Factory employees, 1963-64 & 11.9 & 13.4 & 7.0 & 10.9 & 7.1 & 8.7 \\
\hline \multirow[t]{3}{*}{ Census 1961: metropolitan } & 55.7 & 65.2 & 40.9 & 60.7 & 57.0 & 33.1 \\
\hline & 29.4 & 19.6 & 35.4 & 18.3 & 17.1 & 37.8 \\
\hline & 14.6 & 15.0 & 23.6 & 20.6 & 25.5 & 29.4 \\
\hline All school children, 1964 & 20.4 & 21.3 & 21.5 & 22.8 & 22.8 & 24.4 \\
\hline State school children, 1964 & 15.4 & 15.6 & 16.5 & 19.1 & 17.4 & 19.4 \\
\hline \multicolumn{7}{|l|}{ Accumulated net loan expenditure } \\
\hline per capita, June $1964(\mathfrak{f})$ & 293 & 277 & 287 & 466 & 442 & 640 \\
\hline \multicolumn{7}{|l|}{ Net debt charges per capita, } \\
\hline $1963-64(f)$ & 6.8 & 10.7 & 11.5 & 13.8 & 14.0 & 13.8 \\
\hline
\end{tabular}

Source: see n.40.

39 The statistics most revealing regarding this conclusion are in tables 11.6 and 17.5.

40 Prest, 'Federal-State Financial Relations' in Economic Papers of the Economic Society of Australia and New Zealand, N.S.W. and Vic. Branch, no. 20 of October 1965, 28. 
a greater share per capita of loans through the Loan Council and of grants per capita from the Commonwealth.

However, the growth towards greater equality of taxable capacity will be slow and it could be reversed; while they exist, disparities will make necessary the equalising grants and shares of loans to the four less wealthy States for several reasons. Using the information in table 17.6, which is largely geographic and demographic in character, it can be argued to this end that ${ }^{41}$

1. the relatively large rural populations of Tasmania, Western Australia and Queensland may adversly affect taxable capacity because average rural income may be low; and State revenue was less by concessions granted to agriculture through, for example, State land tax and motor tax;

2. the relatively high proportion of children in Tasmania, Western Australia and South Australia directly imposed a heavier burden on these States for education and family welfare services not provided by the Commonwealth;

3. unit costs of State services may be higher in Queensland, South Australia and Western Australia where they have to be spread over sparsely settled populations. The cost to Tasmania may be higher than to New South Wales which has the same population density because New South Wales's population was eleven times as large and its administrative overheads could therefore be spread over a correspondingly larger number of persons. The greater proportion of persons in rural areas in the four smaller States supported this argument. The low density of population in South Australia probably offset to a considerable extent that State's high proportion of factory employees and metropolitan population.

One most notable feature of the allocation of the total loan program was the much higher shares received by what were, until 1959, the three claimant States, and Queensland from the early 1960s, all of which had either or both a low density of population and a high proportion of rural population. In order to develop agriculture and industry in these States, their governments had to embark on relatively heavy capital expenditure on transport, power, water supply, roads and similar services and disproportionately larger expenditure may be necessary on housing, schools and hospitals where population increased in rural areas.

The effect of this was to add a fourth reason why the less wealthy States suffered disparity in their relative taxable capacity:

4. the accumulated net loan expenditure in South Australia and Western Australia in 1964 was about 60 per cent higher and in Tasmania it was about 125 per cent higher than in the other three eastern States. 
Average net debt charges were also higher, ${ }^{42}$ although except for New South Wales, which can make its railways pay, the disparities in net debt charges were less marked (table 17.6) because the additional borrowing was spent in enterprises from which debt charges have been recovered.

The general conclusions which emerge from the analysis may be briefly stated.

The disparities in taxable capacities between New South Wales and Victoria on the one hand and the less wealthy States on the other, led to greater grants per capita from the Commonwealth to the four less wealthy States. Three of the four, in the early post-war years, received a greater per capita share of loans, and Queensland also began to do so later. The taxable capacity of Tasmania increased relatively in the early 1960 s but the disparities between all States remained wide and there was no assurance that the amplitude of disparities would continue to lessen.

One effect of the allocation of grants and loans was to ensure equal standards of public services. Another was that rapid development took place in the four less wealthy States as well as in New South Wales and Victoria. The grants, especially those recommended by the Grants Commission until 1959, and in addition, general financial assistance grants since 1959, helped the less wealthy States to meet their higher per capita interest and sinking fund payments, resulting directly from the greater share of loans they received to aid their development.

Fundamentally, the need for transfers of revenue raised by the Commonwealth from the more wealthy to the less wealthy States remained as important politically in the 1960 s as in the early decades of the federation for which the Founders provided in ss.87, 94 and 96. Likewise, the need for greater per capita shares of loans, as well as grants, to the less wealthy States remained as politically strong in the 1960s, an era of as sustained development and high employment as the 1920s when the Financial Agreement was made on the basis of greater shares of loans per capita to South Australia and Western Australia (but not at the time to Tasmania).

The Loan Council, when allocating the total loan program under the Financial and the Gentlemen's Agreements, was cognisant of the strong political pressures and made decisions that met the needs of federal political parties as well as those in the smaller States. The State that gave most in the post-war deals was New South Wales, a characteristic of the State since federation; in the 1930s it had been Victoria but it shook off that role as much as it could in the post-war period up to the mid-1960s.

It is sometimes useful to recall that the rise of federal political parties and the need to have a majority in both federal Houses has been one of 
the major political developments of the federation. The political imperative that pressed most heavily upon federal political parties was, and continues to be, their need to win a majority of seats in both Houses of Parliament. Senate seats became of greater importance in this fundamental context because in aggregate the smaller States together had, and continue to have, greater representation than the two larger, more wealthy States. As some revenue and loan moneys raised are tranferred from the richer to the poorer States, some loss of political favour in the two wealthier States has been more than counterbalanced by the gains in seats won, especially Senate seats, in the four smaller States.

By and large, federal political parties expressed the important sentiment or fundamental belief of the people that a fair deal, or equality of treatment, should be handed out to all in the federation. That, it was noted, was written into the Constitution itself in the sections relating to the disposition of surplus Commonwealth revenue and, by implication, its financial assistance grants. It was, in fact, an expectation of the Founders, expressing the will of the great majority of the people at that time and, in the author's view, it is the people's continuing aspiration; for apart from changes in the Constitution relating to the debt provisions, the only other significant changes have been of a social welfare kind-the granting to the Commonwealth of the power over social services and over Aborigines, to assist the most needy groups in the country. In these broad developments the Loan Council played out a sympathetic and consistent role, but at a greater cost to the two larger States than to the others in their capital, or public works, development and in revenue transferred to the other four smaller States. 
The cessation of foreign lending to the Commonwealth on behalf of the Loan Council in 1929 and its serious effects were long remembered. Over the next twenty years, the Council raised few new loans abroad and, in fact, the emphasis was on reducing the amount of governmental indebtedness abroad. The trend in Australia's borrowing was characteristic of world conditions.

From 1929 to 1950 , long-term foreign loans outstanding and foreign portfolio assets of the United States diminished in every area except Canada and Newfoundland.... In the 1930s and the 1940s, therefore, there was no net flow of loans and portfolio investments from the United States to underdeveloped countries, but a strong reverse flow of repayments. ${ }^{1}$

The old direct channels of finance by private subscriptions to overseas flotations were replaced in part by new, government sponsored international organisations, including the International Bank for Reconstruction and Development and the Export-Import Bank that channelled private investments lodged with them into loans to governments seeking finance from abroad.

In the early post-war years there was no need for the Loan Council to consider borrowing abroad, as the Australian market fully subscribed to all flotations. There was also adequate sterling in the foreign exchange reserves but a shortage of hard currencies; the policy was to refrain from increasing the overseas public debt and to reduce it as the foreign exchange reserves permitted. This was an understandable objective. For members of the Labor Party, the events of 1929131 had been traumatic, and after Labor took office in October 1941, the transformation in the Commonwealth's

1 Felipe Pazos, 'The Role of International Movements of Private Capital in Promoting Development' in J. H. Adler (ed.), Capital Movements (New York, 1967), 191-3. 
policy towards overseas debt influenced the Loan Council's decisions until the end of 1949, when the Labor Party lost the elections.

Thenceforth, there was a new era of overseas borrowing that was very different from the past in a number of respects. The Council permitted the Commonwealth to negotiate hard currency loans from 1950 onwards as a result of major improvements that occurred in the proportion of overseas debt interest to the foreign exchange reserves and export income. Much of this borrowing was for hard currencies to purchase essential North American equipment for development projects and to buy aircraft for domestic and overseas airlines, and there is evidence that it was timed to stabilise the foreign exchange reserves when they showed signs of moving downwards in the 1950s and early 1960s.

\section{Labor reduces the overseas debt, $1941-49$}

During the years of recovery from the depression, the total short and longterm sterling debt in London remained almost constant-from June 1933 there was a rise of but $£ 6 \mathrm{~m}$. to the all-time high of $£$ stg $478 \mathrm{~m}$. in June $1941 .{ }^{2}$ From that figure it fell during the Labor government's term in office to fstg $386.5 \mathrm{~m}$, or by nearly 20 per cent in eight years. On the other hand, the New York debt fell by only 16 per cent, from $\$ U . S .233 \cdot 6 \mathrm{~m}$., in the much longer period of twenty-two years between 1927-28 and 1949-50; it was a gradual fall, on average a few million dollars each year, accomplished by the use of the National Debt Sinking Fund and some foreign exchange reserves. ${ }^{3}$ The Loan Council's attention was, therefore, concentrated on London, where most of the debt and interest had been contracted, interest due at the end of June 1941 being $£$ A23.4m. in London and only $£$ A $3.2 \mathrm{~m}$. in New York. ${ }^{4}$ At that time, the $£ A 26 \cdot 6 \mathrm{~m}$. of overseas debt interest was about one-quarter of the desirable or normal level of the foreign exchange reserves, a very high proportion indeed.

Basic Labor policy, explicitly spelled out in ministerial statements, was to reduce governments' overseas debt and the proportion of debt interest in foreign exchange earnings as much as the foreign exchange reserves would permit. For example, in his Budget Speech for 1943-44, J. B. Chifley reported that the $£ 12 \mathrm{~m}$. defence loan of 1940 was being repaid as exchange reserves permitted, and that its repayment and the operations from the National Debt Sinking Fund had reduced London debt by $£ 9 \mathrm{~m}$. since the outbreak of the war. ${ }^{5}$ In his Budget Speech two years later, he reported

2 There had been a slight fall until 1940 when a $£ 12 \mathrm{~m}$. defence loan was arranged with the United Kingdom government to assist with war finance. This loan was not a matter for the Loan Council.

3 National Debt Commission successive Annual Reports and Giblin, Central Bank, 333.

4 Unless otherwise footnoted, all loan information has been obtained from successive C.P.P.'s., 'The Budget: V Public Debt and Government Securities on Issue'; and National Debt Commission, Annual Reports.

5 C.P.D., 29 September 1943, 158. 
that high foreign exchange reserves had enabled the central bank to provide Estg57m. for London redemptions for which it received Commonwealth securities. ${ }^{6}$ In fact, by the end of 1946 London debt had fallen by that amount plus another 1 stg $13 \mathrm{~m}$. by the use of the Sinking Fund. Not all London debt falling due was redeemed. About $£ 90 \mathrm{~m}$. was converted by the end of the war and some conversions were difficult. ${ }^{7}$

The Loan Council was a willing party to the policy because the Commonwealth and the States shared the redemptions roughly in proportion to their respective shares of the total London debt and each reaped the benefit of the decline in interest; between June 1941 and June 1949, the Commonwealth's annual interest due on all overseas debt fell by $£ A 1.9 \mathrm{~m}$. and the States' fell by $£ A 6.9 \mathrm{~m}$., the total annual interest liability declining from $£ 26 \cdot 6 \mathrm{~m}$. to $£ 17 \cdot 8 \mathrm{~m}$.

The ability of the Commonwealth to reduce the London-held debt on behalf of the Loan Council increased as the war progressed. A number of factors contributed. Export income was well maintained during the war and imports of non-essentials were severely restricted. There were large imports of war supplies but a considerable part of these was made available under Lease Lend and Mutual Aid programs. Reciprocal Aid extended to the U.S. Forces reduced the dollar inflow, but the cash expenditure of American troops in Australia resulted in the net accrual of U.S. dollars. The outcome was that considerable sums in dollars were converted to sterling and held as London funds. ${ }^{8}$

The Loan Council was unable to raise new cash loans in London until 1958. London lending was strictly controlled; in principle, the United Kingdom's policies of the 1930s carried over into its war and post-war legislation controlling foreign capital issues.

The one significant development in New York debt up to 1949 occurred soon after the war ended when, between August 1946 and June 1947, $\$ 128 \mathrm{~m}$. of 4.5 and 5 per cent New York debt was converted by raising five redemption loans. Paying in each case an effective rate of interest of less than 3.75 per cent, the Loan Council reaped the harvest of saving concurrent with the era of cheap money before it ended three years later. After 1950-51, Australia's debt in United States dollars rose rapidly as a result of New York and International Bank loans.

\section{Foreign loans after 1950-principles}

The beginning of the 1950 s was a turning point in the Loan Council's foreign borrowing policy. The main events were, firstly, the return of the non-Labor federal government late in 1949 under R. G. Menzies as Prime

6 C.P.D., 7 September 1945, 5217, and Giblin, Central Bank, 334.

7 Giblin, Central Bank, 332.

8 C.P.D., 19 September 1947, 106 (Budget Speech); Giblin, Central Bank, 332 gives an interesting account of procedures and problems associated with one conversion in 1942. 
Minister and, secondly, the acceptance, as a long-term trend, of the remarkable improvement in, and consistently high level of export earnings and foreign exchange reserves. The improvement in the reserves position in the late 1940 s was quite dramatic. In 1947 , the reserves were about $£ 240 \mathrm{~m}$. but had only increased by the same percentage above the safe or normal level of $£ 100 \mathrm{~m}$. in the pre-war years as the import price index had increased. In other words, the value of the reserves at constant (import) prices was the same in 1947 as the safe pre-war level. But in 1948, the reserves were close to $£ 400 \mathrm{~m}$, and in 1949 they exceeded $£ 500 \mathrm{~m}$. and had risen by nearly twice as much as the pre-war (1936-39) import price index. ${ }^{9}$ That was abundance indeed. The reserves, scarce dollars particularly, were protected by a long period of post-war dollar import restrictions, and restrictions on imports from other areas from 1952, which did not end until 1959-60. The net result was that by 1949 the proportions of governmental fixed interest to both the receipts from exports of goods and services and the foreign exchange reserves fell to a perfectly safe level and were held there.

Table 18.1

Commonwealth and State governments' interest payable abroad as percentage of exports and foreign exchange reserves, 1930-1965

\begin{tabular}{|c|c|c|c|c|c|}
\hline 30 June & $\begin{array}{l}\text { Interest } \\
\text { liability } \\
\text { (fm.) } \\
\text { (1) }\end{array}$ & $\begin{array}{l}\text { Exports of goods } \\
\text { and services } \\
(£ \mathrm{~m} .) \\
(2)\end{array}$ & $\begin{array}{c}\text { Foreign exchange } \\
\text { reserves } \\
\text { (£m.) } \\
(3)\end{array}$ & $\begin{array}{c}\text { Interest as } \\
\% \text { of exports } \\
\text { (4) }\end{array}$ & $\begin{array}{c}\text { Interest as } \\
\text { \% of reserves } \\
\text { (5) }\end{array}$ \\
\hline 1930 & 27.60 & 108 & 58.3 & 25.5 & 47.3 \\
\hline 1959 & 25.84 & 157 & 60.7 & 16.5 & 42.6 \\
\hline 1949 & 17.82 & 579 & 446.6 & 3.1 & 4.0 \\
\hline 1959 & 25.93 & 943 & 516.4 & 2.8 & 5.0 \\
\hline 1962 & 30.65 & 1,216 & 561.2 & 2.5 & 5.3 \\
\hline 1965 & 34.68 & 1,581 & 677.2 & 2.2 & 5.2 \\
\hline
\end{tabular}

Sources: (1) C.P.P., The Budget 1961-62 and 1968-69, 'IV Government Securities on Issue'.

(2) C.B.C.S., Balance of Payments 1928-29 to 1951-52, no. 3, 98; and issues of National Income and Expenditure.

(3) Giblin, Central Bank, 356; D. G. Badger, 'Australia's Foreign Exchange', Economic Record, vol. XXXI, no. 60, May 1955, 31; Reserve Bank of Australia, Statistical Bulletin.

Note: The interest liability includes that on war debt held abroad and has been converted by the Treasury to Australian currency at the rates of exchange ruling on the dates indicated.

The improvement had been noted by the Labor government, but it came rather late for action other than to lessen the urgency it felt about the redemption of London debt. A dollar loan was hinted at in the 1949

9 C.B.C.S., Balance of Payments 1928-29 to $1951-52$ No. 3, 93, and D. G. Badger, 'Australia's Foreign Exchange', Economic Record, vol. XXXI, no. 60, May 1955, 31. 
Budget Speech whereas nine months earlier Chifley had rejected such a policy outright-it would have increased overseas debt. ${ }^{10}$

The new federal government was undoubtedly influenced by the fall in the proportion of interest on overseas government debt to export receipts and to exchange reserves. Table 18.1 shows that between June 1939 and June 1949, the proportion of interest to export receipts fell from about a sixth (its size in the late 1920s also) to about 3 per cent and remained close to that very low, safe figure. The proportion of interest to official foreign exchange reserves fell from a frightening two-fifths in one immediate pre-war year to 4 per cent in 1949. The total absolute amount of governmental interest liability abroad did not rise above the 1929-30 figure until 1959-60 - three decades later, after falling to as low as $£ 17.6 \mathrm{~m}$. in $1950-51$.

Viewed in isolation from private capital inflow and its service cost, increased overseas borrowing by governments, in other words, created no danger from the early 1950s. (The relationship between government and private borrowing is taken up at the end of this chapter.) After two decades in which the Loan Council watched with anxious eyes the ratio of governmental overseas fixed interest to foreign exchange reserves and the ratio of governmental overseas fixed interest to export income it was, by 1950, practicable to look ahead on the basis of other general principles as guides to policy. For example, the view of the Commonwealth Treasury was that

The full balance of payments benefit arising from the inflow of investment must be gauged by the extent to which the return on that investment (to the overseas investor) is matched, directly or indirectly, by a resulting increase in exports or a reduction in imports. In the shortrun, of course, the inflow may itself be of assistance to the balance of payments but, in looking to the long-term implications of overseas investment in Australia, this stop-gap view of the matter has to be set aside. ${ }^{11}$

The Labor government's policy had been designed primarily to reduce overseas interest payments abroad; the new policy allowed for an increase in capital inflow and therefore interest payments abroad, but hoped that the effect of the foreign investment, private or through the governments, would improve the balance of payments by the amount of earnings on the investment payable overseas.

The Committee of Economic Enquiry, on the other hand, concluded that 'Provided that the trade balance improves sufficiently, whether directly attributable to overseas investment or not, debt servicing will cause no difficulty'. ${ }^{12}$ It emphasised that improving terms of trade may enable

10 C.P.D., 7 December 1948, 4052, and 7 September 1949, 22-3 (Budget Speech).

11 Commonwealth Treasury, Supplement to the Treasury Information Bulletin, The Balance of Payments, February 1966, 28.

12 Report of the Committee of Economic Enquiry (Melbourne, 1965), para. J.73. 
overseas debt to be serviced easily, and vice versa, irrespective of the contribution investment made to export expansion or import replacement.

The difference between the non-Labor government's and the Committee of Economic Enquiry's views is reconcilable in a practical manner which would explain, in principle, the decision of the Loan Council to embark upon a new era of borrowing abroad. It is safe to assume that part of member governments' loan expenditure is directed to general economic development which directly or indirectly helps to improve the balance of payments in the long period; if some public expenditure was on social capital that worsened the long-term balance of payments position, then governments could argue that the loans for those welfare purposes were raised locally but that overseas borrowing was directed to development works that were expected to reduce the dependence of the economy on foreign exchange receipts. This principle was given considerable practical application from 1950 onwards when loans were negotiated abroad, particularly from the I.B.R.D. It was combined with the argument that although Australia had plenty of soft currency reserves, it was short of hard currency. The attraction of I.B.R.D. loans was that they were in dollars, at the time the scarce international currency. Australia earned fewer dollars than it spent and, in most years, drew on the sterling area's pool; the dollars were needed to obtain certain essential capital equipment and plant obtainable only in the United States and Canada.

The Prime Minister (R. G. Menzies) conducted the negotiations with the President of the I.B.R.D. and agreed to standard conditions (required of all borrowers) to obtain a number of loans totalling $£ 141.8 \mathrm{~m}$. by the end of 1956. The significant feature of the conditions was that they required investment of the funds in useful projects. That could be taken to include an improvement in the balance of payments. To that end, I.B.R.D. officials were to visit Australia to gain direct knowledge of the economic situation and the need for the loans; there should be a continuing exchange of information between the Bank and the Australian government; and notably, an arrangement whereby schedules of dollar payments for goods imported against dollar import licences were to be submitted to I.B.R.D. from time to time by the Australian authorities as the basis for periodical drawings by the Commonwealth authorities against the loan and to support the Australian claim that the expenditure was for 'development purposes'. In the general case presented to the I.B.R.D., the smallness of the ratio of governmental interest payments abroad to export earnings and the low ratio of governmental foreign debt to the gross national product (15 per cent) were also mentioned.13 In 1955 the case for loans in Switzerland and Canada was supported by the argument that they would assist with internal development, by implication on a sound basis that would not adversely 
affect the balance of payments. An additional reason given was that foreign exchange reserves would be supplemented, the Swiss franc and Canadian dollar being among the world's strongest currencies. ${ }^{14}$

In principle, loans might also be raised abroad if the effective interest rate was less than in Australia; but if the need for hard currencies was so great that the Commonwealth wished to raise a loan at a higher interest rate than in Australia, then tensions could develop in the Loan Council. The States, who paid the interest bill on loans for the works and housing program, could be expected to protest. For example, the Premier of South Australia, Sir Thomas Playford, was reported as saying in 1960:

At a time such as the present we should not be mortgaging our country by public overseas borrowing. . . . This is what happened in the 1920s and was largely responsible for the depression. . . . Although Australia has borrowed as favourably as most other borrowers and perhaps better than some, the costs were well above those for internal loans. In other words, we are paying the highest rates of interest for the least desirable loans. ${ }^{15}$

The Commonwealth found a way out of this problem by the device of counterpart funds. It made the proceeds of more expensive overseas loans available to the States at the lower internal bond rate. Alternatively, it could use its powerful bargaining position, for example, while it was underwriting loan programs, to counter the States by insisting that they take all or part of more expensive foreign loans. A 'reasonable' rate of interest on overseas loans was a matter for bargaining within the Council as well as with the lenders abroad.

One lesson of the 1920s was that there was danger in obtaining most of governments' overseas capital from one market; spreading the borrowing over a variety of markets would spread the risk. The Loan Council acted on this principle and borrowed in a number of new markets after 1950, although this became less important with the fall in the ratios of debt interest to export income and government borrowing to export income.

But no one, or a combination, of principles could avoid the unpalatable fact that private lenders in overseas capital markets are not reliable sources of loans. There was, therefore, the need for an international lender of last resort to governments and central banks, sufficiently strong in international currency to enable the effects of sharp changes in the rate of lending by one country to another to be avoided. Loans from international organisations might be better applied and more reliable than from national markets, but even this depended upon the resources of the organisations. Up to 1966 , there was none which was not limited by the conventions upon which

14 C.P.D., 20 April 1955, 55-6 and 26 October 1955, 1902-4.

15 Adelaide Advertiser, 12 May 1960, 3; report of radio broadcast by Sir Thomas Playford. 
the international currency arrangements were based, and these could only be changed either by the provision of a new I.M.F. currency to supplement (or replace) national reserve currencies and gold, or, alternatively, by a big rise in the price of gold. In 1967, steps were taken to enable the I.M.F. to perform ultimately the role of issuing bank to governments.

\section{Patterns of foreign borrowing since 1950}

The Loan Council authorised loans from six independent sources between 1951-52 and 1961-62. By 1965-66 the pattern and number of loans was as in table 18.2. There was a considerable gap in the amount borrowed between the three small sources and the larger lending markets, which is not surprising in view of the relative size of their populations and economic resources.

Table 18.2

Pattern of new raisings, $1951-52$ to $1965-66$

\begin{tabular}{lccc}
\hline \multicolumn{1}{c}{ Source } & $\begin{array}{c}\text { Number } \\
\text { of loans }\end{array}$ & $\begin{array}{c}\text { Total } \\
\text { borrowed } \\
(\mathrm{fm} .)\end{array}$ & $\begin{array}{c}\text { Percentage } \\
\text { of total }\end{array}$ \\
\hline 1.B.R.D. & 7 & 186.5 & 36.0 \\
New York & 24 & 220.7 & 42.6 \\
London & 4 & 66.7 & 12.9 \\
Switzerland & 4 & 24.5 & 4.7 \\
Canada & 2 & 14.5 & 2.8 \\
Netherlands & 1 & 4.9 & 1.0 \\
\hline Total & 42 & 517.8 & 100.0 \\
\hline
\end{tabular}

Source: Table 18.5 .

Of the forty-two new flotations, only four were raised before 1955, all from the I.B.R.D., which met needs when they were most urgent. By March 1955, Australia had arranged from the Bank loans totalling $£$ A115m., over one-fifth of all new cash loans abroad between mid-1950 and mid-1966. Loans were arranged annually in New York after 1956 but borrowing from other sources was sporadic.

Between 1950 and 1966, 36 per cent of new loans were raised from the I.B.R.D., 43 per cent from New York and 13 per cent from London. New York therefore usurped London's pre-eminent position as the source of new loans from private capital markets. The Commonwealth sought and received permission from the British authorities to raise on behalf of the Loan Council its first new loan (£stg15m.) in London in October 1958, and it was followed by a second in February 1960 (£stg12m.), and two 
others in 1963 (totalling $£$ stg26.3m.). These reversed the trend in sterling debt which had fallen by $£$ stg68m. from $£$ stg $386.5 \mathrm{~m}$. in June 1949 to £stg $318.4 \mathrm{~m}$. by June 1958. Although this was a fall of nearly 20 per cent, it was accompanied from 1950 by the big increase in Loan Council borrowing from other overseas sources, mainly the dollar area. Between 1950-51 and 1965-66, the government securities on issue overseas rose by two-fifths, from $£ A 533 \mathrm{~m}$. to $£ A 752 \mathrm{~m}$, or by $£ A 219 \mathrm{~m}$., and the overseas debt was increased to pay a part of but not all interest due, as in the 1920s. The annual interest liability doubled, rising from $£ A 17 \cdot 6 \mathrm{~m}$. to $£ 34.6 \mathrm{~m}$. and the total of these interest payments over the sixteen year period was approximately $£ 414 \mathrm{~m}$., so that the net borrowing of $£ 219 \mathrm{~m}$. was only about one-half the interest paid; interest was paid from revenue as well as from foreign loans. One reason why the interest bill grew much faster than the net debt was that conversions of loans in London and New York were from the low rates of the era of cheap money to the higher rates that prevailed after 1951, the reverse of the period 1932-50.

\section{Foreign loans in the loan program}

Between July 1950 and June 1966, the total of new cash borrowing abroad (as distinct from conversions) was $£ \mathrm{~A} 518 \mathrm{~m}$. Of this sum, $£ 367.4 \mathrm{~m}$. was used to finance the approved loan program for the States. The balance, $f 150 \cdot 3 \mathrm{~m}$., was applied directly to Commonwealth purposes, mainly the purchase of aircraft for Qantas and national airlines. Commonwealth securities were issued for all of the loans and they were approved by the Council.18

Not all of the $£ 367.4 \mathrm{~m}$. used to finance the States' works and housing was raised in the first instance for the States. The first five International Bank loans and the first two Swiss and the first Canadian loans (totalling $£ 160 \mathrm{~m}$.) were negotiated for the Commonwealth's loan program as an additional borrowing authority over and above the States' programs, but the Commonwealth applied $£ 139.7 \mathrm{~m}$. of the loans, by means of counterpart funds in Australian currency, to subscribe to the States' programs in its underwriting capacity. ${ }^{17}$ The point of this was that, generally speaking, early in the 1950 s the Commonwealth was regarded, by the I.B.R.D. especially, as a more reliable spender of the scarce hard currencies, and the Council was obliged to authorise foreign loans for the Commonwealth's purposes; later loans could be raised for the States' works and housing

16 Table 18.5. However, two States borrowed overseas in the name of the State-South Australia borrowed $13.9 \mathrm{~m}$. in 1952 for the Radium Hill Project and Western Australia

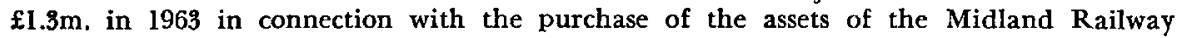
Company of Western Australia. See also C.P.D., 1 December 1950, 3522 (I.B.R.D. loan); 20 April 1955, 55-6 (Swiss loan); 26 October 1955, 1902-4 (Canadian loan); 20 March 1957, 44 (Qantas loan), and so on.

17 Information from the Treasury in a personal letter dated 9 September 1964. Later, Canadian and Swiss loans were borrowed for States' works and housing programs. See table 18.5 . 
programs. The $£ 139.7 \mathrm{~m}$. was applied as counterpart funds, or the equivalent at the Australian interest rate, from 1951-52 to 1957-58; then counterpart funds ceased and from 1955-56, first a few millions but from 1957-58 much more overseas borrowing was raised for and applied directly to the States' program-in total $£ 227 \cdot 7 \mathrm{~m} .{ }^{18}$ After $1955-56$, loans overseas were usually at a rate above the internal bond rate. ${ }^{19}$ The States took a share of these, but under protest such as Sir Thomas Playford's, indicating that the Commonwealth's superior bargaining power prevailed.

In aggregate (table 18.3), the States loan programs between 1951-52 and 1965-66 were $\{3,402 \cdot 9 \mathrm{~m}$.; of this, the Commonwealth's assistance from its own part of the overseas program was 4 per cent. The overseas program was 14 per cent of the combined Commonwealth's and States' programs (and, of course, a much smaller proportion of their total capital expenditure). The 14 per cent in the 1950s and 1960s can be compared with the 1920s when the States' and the Commonwealth's overseas borrowing program was about 60 per cent of net loan expenditure. ${ }^{20}$

Table 18.3

Overseas loans, $1951-52$ to $1965-66$

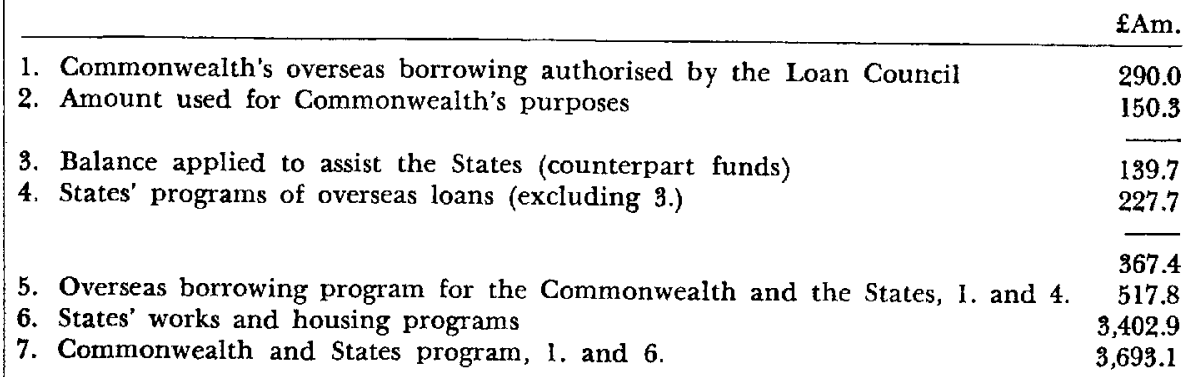

Sources: Table 18.5, and Commonwealth Payments to or for the States.

Government and private capital inflow-relationships

In the post-war years the Commonwealth encouraged private overseas investment in Australian enterprises. Remittances of profits and dividends, although subject to exchange control, were unrestricted and the policy towards repatriation of capital was liberal. The non-Labor government expressed a preference for overseas investment that was likely to help in the balanced development of Australia's resources and which brought with

18 Table 18.5 .

19 Table 18.6; J. C. Pomroy, 'Some Aspects of Commonwealth Borrowing Overseas 1950-51 to 1961-62' (M. Com. thesis, A.N.U., 1969).

20 C.F.B., for example no. 22, table 21 for net loan expenditure and no. 30, table 61, for net increase in all overseas debt of which war debt was small. 
it the skill and 'know-how' needed to complete successfully the project in which investment was made. It indicated that Australian participation in ownership and management was desirable, but no rules were made. ${ }^{21}$ The policy was a logical extension into the private sector of the optimistic belief that there had been a long-term improvement in the balance of payments from 1950 onwards.

Of total capital inflow, that for private purposes was far greater than government borrowing. Between 1948-49 and 1963-64, overseas investment in public authority securities accounted for only about 8 per cent of the total net identified capital inflow. Its highest point was in 1962-63 when, at $£ 42 \mathrm{~m}$., it amounted to but 16 per cent of the total. ${ }^{22}$ Net Australian public borrowing overseas was almost entirely for the Loan Council's programs - there were few new loans abroad by semi-government and local authorities, their total debt abroad being less than 2 per cent of all public debt owing. ${ }^{23}$

While the proportion of government borrowing was, in the aggregate, very small, its contribution to changes in the flow of overseas investment and its influence on the balance of payments was markedly greater. ${ }^{24}$ In the years when exports decreased sharply (1951-52, 1953-54, 1954-55 and 1957-58), or when imports increased steeply (1950-51, 1951-52 and 1962-63), capital inflow increased, often by a large amount. Of these years, changes in governmental borrowing as a proportion of the total change was 90 per cent in 1950-51, 70 per cent in 1951-52, a negative influence in 1953-54, 30 per cent in 1954-55, 100 per cent in 1957-58 and 33 per cent in 1962-63.25 The influence of the Loan Council's decisions to borrow abroad, particularly from the I.B.R.D. in the early 1950s, was clearly of some significance.

The importance of the relationship that the statistics suggest should not be overestimated. The stabilising effect, due to the relatively small changes in the absolute level of total capital inflow, resulted mainly from the tendency for private capital inflow to lag by about one year behind domestic fluctuations, so that private inflow, which might have been expected to change drastically, instead remained high in a balance of payments crisis and fell after the crisis had passed. The increase in imports and the concurrent increase in private capital inflow is partly explainable by leads and lags in the payment for imports in intercompany accounts. ${ }^{26}$ Overall, the Loan Council's policies to which the Commonwealth contributed the main drive and the important administrative arrangements, and built-in, fortuitous changes in private capital inflow, eased the general balance

21 Commonwealth Treasury, Overseas Investment in Australia (Canberra, 1962).

22 Committee of Economic Enquiry, para. J.20-1 and table J.22.

23 Ibid., para. J.10. There were two small loans in 1955 and one in 1964.

24 It was often intended to strengthen foreign exchange reserves. See, for example, the Treasurer's comments in C.P.D., 8 March 1966, 37.

25 Committee of Economic Enquiry, table J.22.

26 Ibid, para. J.58. 
of payments difficulties that developed in 1951-52, 1953-54, 1954-55, 1957-58 and 1962-63.27

The income payable overseas on foreign-held debt, which had been the cause of so much anxiety, changed its composition and as might be expected, the private sector became more significant than the government. After the war, government interest liability was an insignificant proportion of exports of goods and services, falling from the high pre-war ratios to but $3 \cdot 1$ per cent in 1948-49 and 2.2 per cent in 1964-65. On the other hand, after 1948-49, the ratio of private income payable overseas to exports of goods and services rose from 6.9 per cent to an average of over 10 per cent in the early 1960s (table 18.4).

Under the successive non-Labor governments' liberal policy towards capital inflow, government interest payable overseas doubled and private income payable quadrupled by the mid-1960s, but there was such an improvement in export income that the proportion of total income payable abroad in exports rose only by one-third. Even so, the great inflow of foreign investment in the two post-war decades had so increased the demands made upon export receipts by interest, dividends, and profits payable abroad that unless there was an offsetting long-term improvement in the terms of trade or an adequate decline in imports as a result of import replacement, the country was, in theory, borrowing to meet the interest and profits paid abroad. It is probable that, between the quinquennia centring on $1950-51$ and 1965-66 the increase in interest and

Table 18.4

Government and private income payable abroad as a percentage of exports of goods and services, $1949-1965$

(Em.)

\begin{tabular}{lcccccc}
\hline 30 June & $\begin{array}{c}\text { Government } \\
\text { interest } \\
\text { liability } \\
(1)\end{array}$ & $\begin{array}{c}\text { Net } \\
\text { private } \\
\text { income } \\
(2)\end{array}$ & $\begin{array}{c}\text { Exports of } \\
\text { goods and } \\
\text { services } \\
(3)\end{array}$ & $\begin{array}{c}\text { Government } \\
\text { interest as } \\
\text { of exports } \\
(1):(3)\end{array}$ & $\begin{array}{c}\text { Net private } \\
\text { income as \% } \\
\text { of exports } \\
(2):(3)\end{array}$ & $\begin{array}{c}\text { Total } \\
\text { income of exports }\end{array}$ \\
\hline 1949 & 17.8 & 40 & 579 & 3.1 & 6.9 & 10.0 \\
1959 & 25.9 & 127 & 943 & 2.8 & 13.5 & 16.3 \\
1962 & 30.6 & 108 & 1,216 & 2.5 & 8.9 & 11.4 \\
1963 & 33.6 & 142 & 1,226 & 2.8 & 11.6 & 14.4 \\
1964 & 34.5 & 150 & 1,554 & 2.2 & 10.2 & 12.4 \\
1965 & 34.7 & 143 & 1,581 & 2.2 & 9.1 & 11.3
\end{tabular}

Sources: (1) and (3) as for table 18.1, n. (1).

(2) Australian National Accounts, National Income and Expenditure, 1948-49 to $1967-68$. This column includes 'undistributed income accruing to overseas residents' and is made up of debits less credits.

27 The Committee of Economic Enquiry's conclusion that there was no evidence of a causal relationship does not accord with the facts about the Loan Council's policies-see para. J.66 for the Committee's comments. 
profits paid abroad was broadly offset by the decline of about one percentage point in the average propensity to import. On the broad principles upon which Loan Council and private borrowing abroad had been encouraged, national development, financed in part by that borrowing, had helped to pay for the rising interest dividends and profits paid abroad.

\section{Assessment}

When the Labor Party gained power again in the federal Parliament in 1941 , it showed very clearly that it had learned the lessons of the 1930s. As foreign exchange became more abundantly available as a result of wartime and post-war conditions the Loan Council was persuaded to use surplus reserves to redeem London debt to reduce the proportion of government interest in export earnings and the foreign exchange reserves. That was a realistic policy, supported by the States because they shared the saving in interest and understood that greater economic stability would follow. In the process, the Commonwealth acquired greater stature and influence because it had control of the foreign exchange reserves and it applied them to the advantage of all member governments of the Loan Council.

As export receipts and foreign exchange reserves grew as a result of Australia's post-war economic development, world conditions and inflationary increases in primary product and other prices in the last few years of the 1940s, government interest payable overseas was reduced to negligible proportions of export receipts and the foreign exchange reserves. A new era of overseas borrowing became possible and was embarked upon steadily by the Menzies non-Labor governments from 1950 onwards. The Commonwealth's authority and power increased early in this development because some foreign loans, particularly from the I.B.R.D., could be negotiated only for the Commonwealth's purposes; the Commonwealth made the funds so obtained available to the States by counterpart funding-it subscribed to Australian loans at Australian interest rates as underwriter, using the proceeds of loans abroad. As time passed, it became possible to borrow overseas for the States' works and housing programs and the Loan Council was therefore less dependent upon the Commonwealth's authority and negotiating power in overseas markets. Even so, its agent, the Commonwealth, retained very considerable authority because of its obligatory negotiating role.

'The Council showed that it had learned other lessons from governments' overseas borrowing history. It diversified its borrowing in hard currency countries as widely as possible and, in the process, America replaced London as the most important source of loans to governments. The Council was obliged in the case of some loans, particularly from I.B.R.D., earnestly to apply the proceeds of loans to sound national development that would not impose strains upon the balance of payments. There were indications by 
the end of the second decade after the war that the government had reduced its share of the burden of invisible payments and that there had been no marked increase in the burden of private plus government borrowing in the balance of payments. ${ }^{28}$ There was further evidence that the timing of overseas borrowing by the Council, on the advice of the Commonwealth, assisted in a fairly marginal manner in keeping the foreign exchange reserves higher than they otherwise would have been on a number of occasions when balance of payments difficulties developed.

The Loan Council borrowed abroad a much smaller proportion of finance for works expenditure in the two post-war decades than in the 1920s. That also was an aid to economic stability. While there is evidence of prudence by the Loan Council, the difficulty, in a capital starved world, of "raising government loans at acceptable rates of interest was also a significant deterrent to large-scale governmental borrowing abroad. That higher cost had encouraged the States, who paid the interest, to press for moderate overseas borrowing.

In substance the Loan Council's overseas borrowing policies in the first two post-war decades aided the Commonwealth in its efforts to achieve internal and external economic balance and revealed that the Council was flexible in taking advantage of changes in local and overseas conditions. In pursuing its overseas borrowing policies, it was dependent upon the Commonwealth as agent and negotiator and, in the early years, as the authority in control of, and able to make available, supplies of foreign exchange. In the process, the Commonwealth acquired greater authority which it could exercise in the decision-making processes of the Council.

28 Table 18.4 and the earlier comments on the small fall in the average propensity to import. 


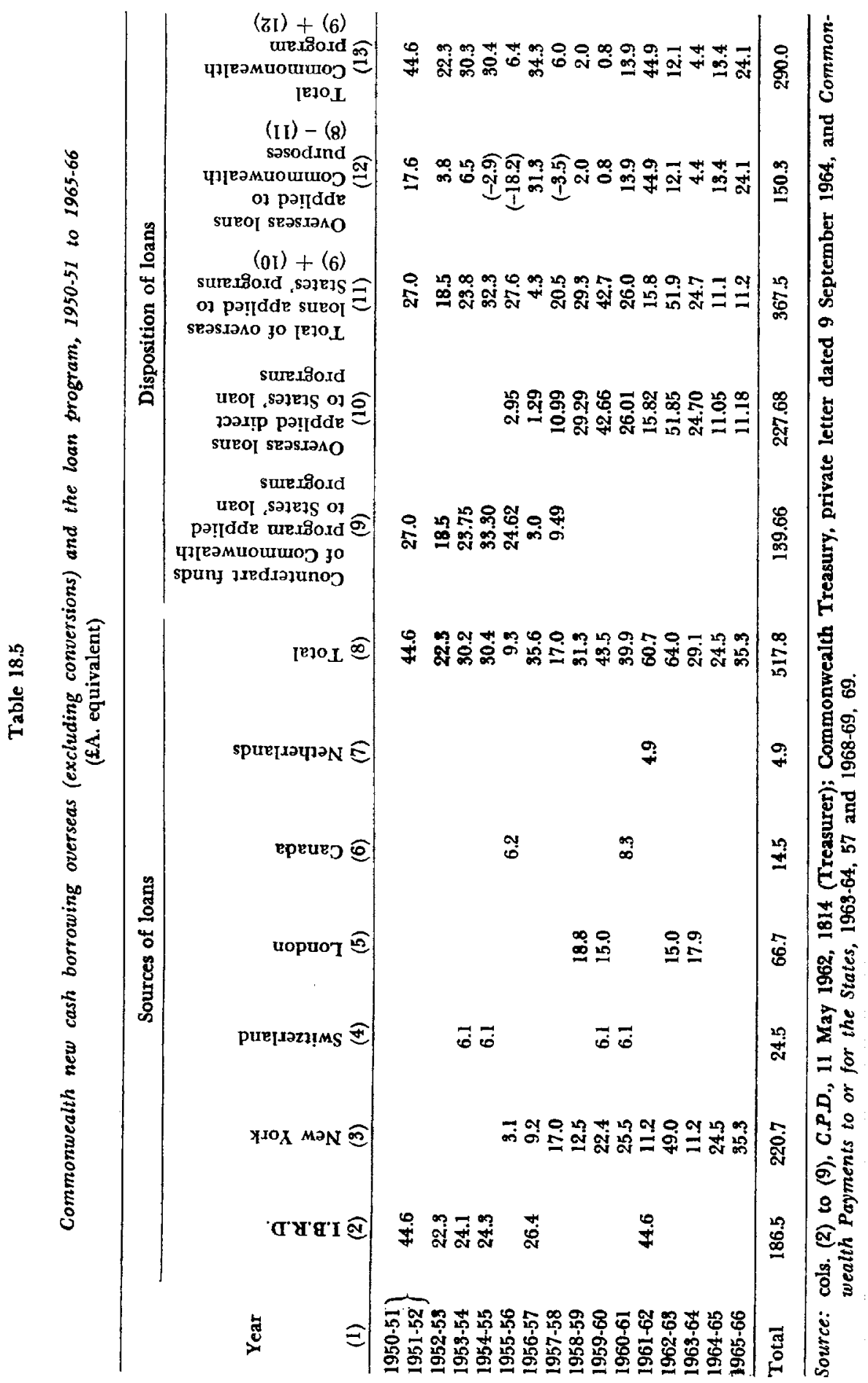




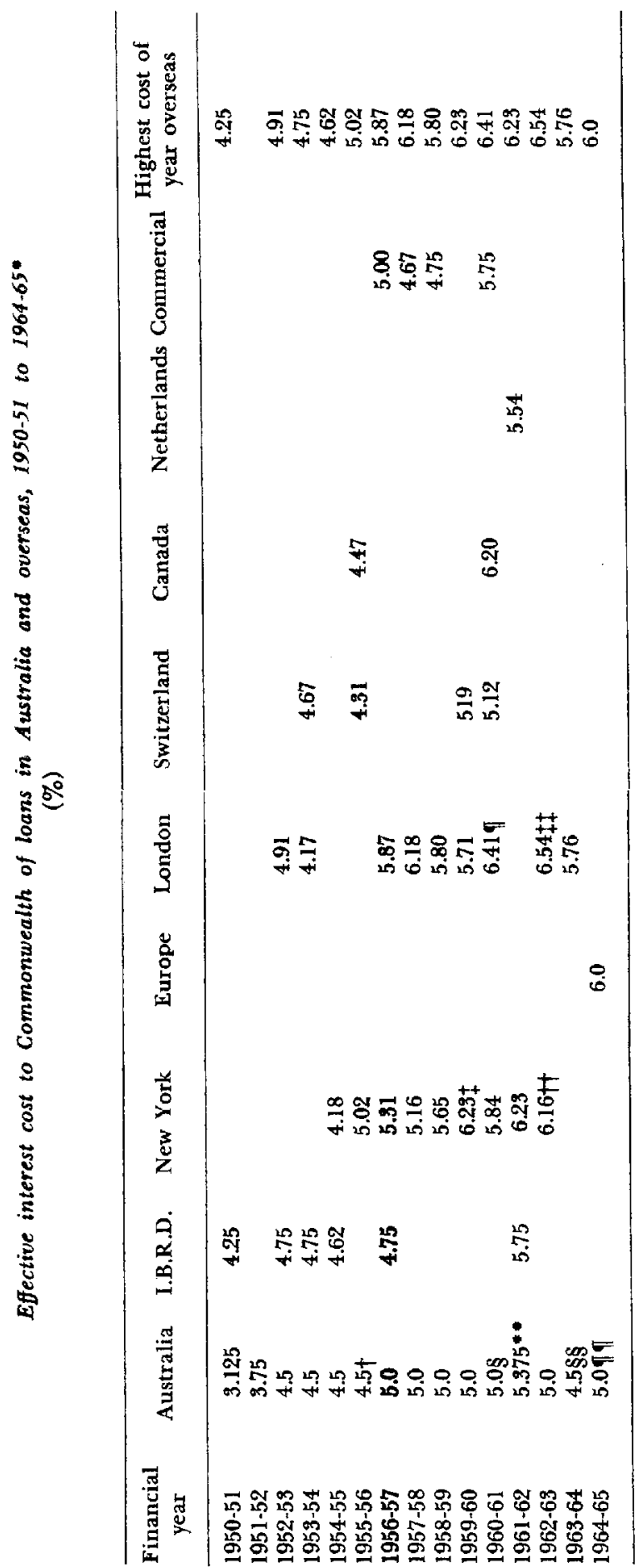

苑

递

$\dot{\Phi}$

돌

i 용

苛

忿 $\equiv$

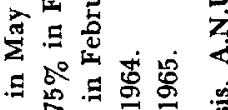

ㅇํ

๑ $9 \sum \frac{\mathrm{a}}{4}$

매

ส

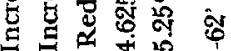

$+\cos : \cos 8$

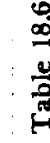

政 
The voluntary Loan Council came into being in 1923 because competitive borrowing in the local market forced the rate of interest above what it was considered governments, as first-class borrowers, should pay. This matter became such a central article of policy that the primary purpose of the Loan Council, as set down in the 1927 Financial Agreement, was to fix the rate of interest at the level which member governments considered they should pay on a gilt edged security. Having fixed the price, they then accepted the amount subscribed by the public at that rate. Underwriting, or floating loans below the amounts it was certain would be available from the market, were the only ways to ensure that a loan program would be subscribed.

By the end of the 1930s the Loan Council, the Commonwealth government, the central bank and the private trading banks were acting in concert to stabilise the economy at a time of serious decline in export income and the foreign exchange reserves. The use of the bond rate as a means to maintain internal and external balance was of minor importance as Keynesian economic policies of deficit finance and promises of expansionary action were pursued; the economic situation was ultimately saved by the sharp rise in capital inflow in the first year of the war, 1939-40, and by a better trade balance.

Major changes then occurred in the functions and the relative importance of the institutions of the monetary and fiscal authorities. Strong action was taken during the war under the defence power to integrate monetary and fiscal policies in a manner suited to total war. This was carried over into the post-war years and the record of post-war developments that concerned the Loan Council-borrowing for and underwriting the works program, Uniform Taxation and overseas borrowing-revealed that to maintain steady economic growth in the private and government sectors and internal and external balance, the Australian economy was managed in a much more sophisticated manner after the war than during the preceding two decades of the Loan Council's life.

The Council continued to be an institution of the monetary authorities 
with sovereign power over the bond rate on new issues but it was obliged to relate its decisions on that instrument of monetary policy to the whole range of policy measures used by the Commonwealth and its authority, the central bank. It was a logical outcome of the relatively small part played by the bond rate that, in the sphere of general monetary policy, a further shift of power to the Commonwealth should occur in the first two post-war decades.

In respect of the size of the loan program, the deliberations of the Council led to a considerable shift of power to the Commonwealth government that was in no sense permanent. It continued only while the Commonwealth was obliged to underwrite the loan program. In monetary policy, the shift of power to the Commonwealth was more definite. Even so, it will be shown that until 1960 the States were effective in achieving their objective in respect of the bond rate-that was to keep it as low as possible for as long as possible. This objective was one that also suited the Commonwealth but only in some respects. Thereafter, there was a more flexible rate to help the Commonwealth and the central bank to control the more sophisticated capital market that had developed in Australia.

From the early 1960s, the States seemed to be less interested in the costs of new borrowing-these they could recoup by successful demands for greater general revenue grants. The importance of the Loan Council's influence on the bond rate diminished simultaneously. It is important to add that Council's voice was not extinguished: this could not be while the Council retained supra-parliamentary authority over borrowing and the bond rate on new issues. The more subtle question was whether the Commonwealth, as a member of the Loan Council, used its powerful financial and voting position to influence the State members on bond rate and other borrowing policies.

An inflexible bond rate for two decades: $1940-60$

The most significant feature of the bond rate in the twenty years up to the end of 1960 was its steadiness for long periods. War loans and post-war borrowing for the civil works program were at 3.25 per cent for over six years-from April 1940 to the end of 1946; then the rate on new issues fell to 3.125 per cent for four years, until early in 1951 . The rate then began to rise: it increased to 4.5 per cent at the end of a brief fifteen months period (during which an unsuccessful attempt was made to hold it at 3.75 per cent for most of 1951) and the rate remained at 4.5 per cent for nearly four years until early in 1956; it could then no longer be kept at that level and it rose to 5 per cent. The rate was steady at 5 per cent for nearly five years until November 1960 when it rose briefly to 5.4 per cent and then began to fluctuate within fairly narrow limits-between 4.5 per cent and 5.25 per cent for over four years. The first half of the 1960s was a period of relative flexibility in the bond rate after twenty years of steadiness and it 


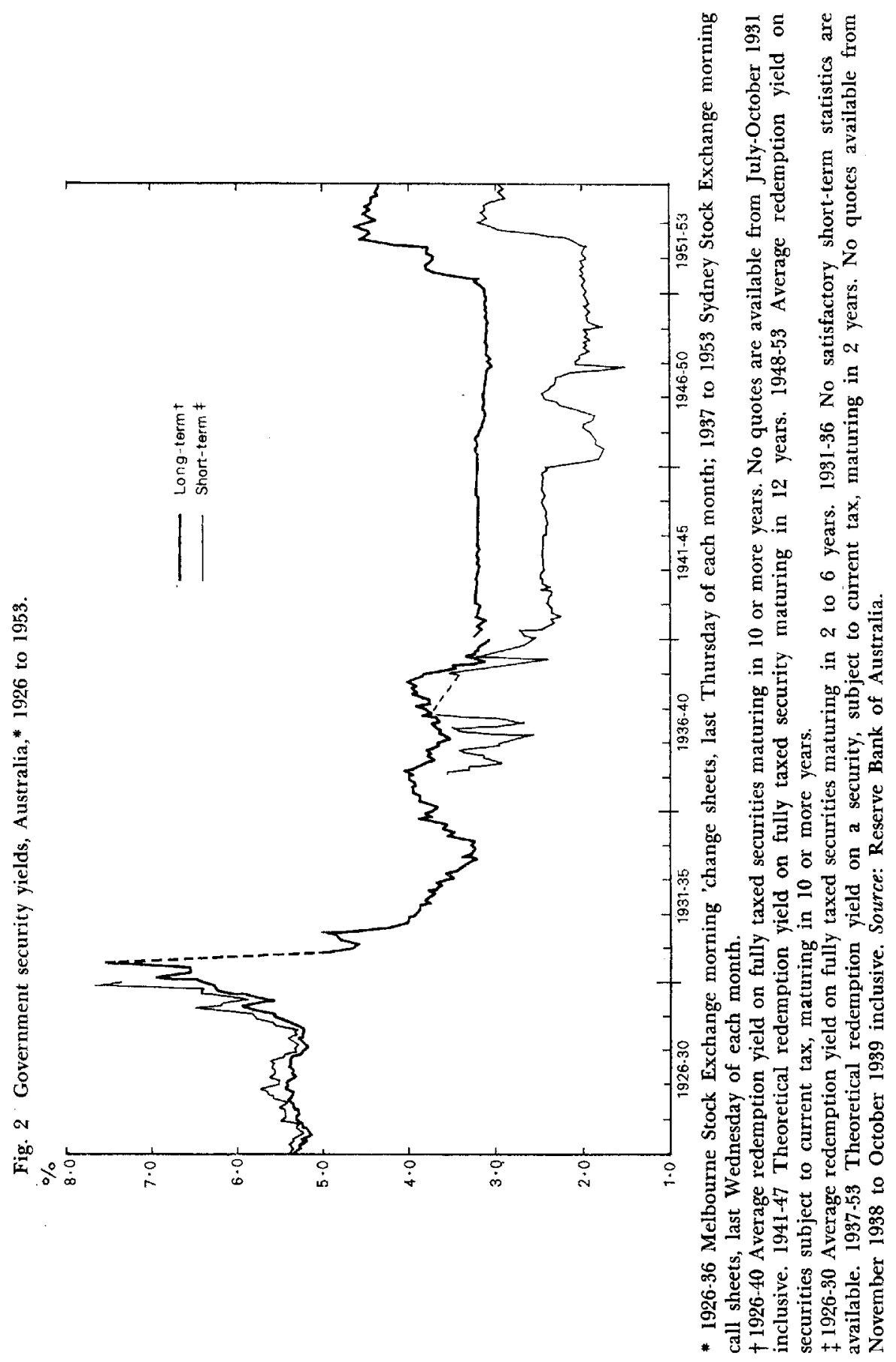


indicated that a significant change had occurred in the Loan Council's policy (table 19.1 and figs 2 and 3 ).

The end of the 1950s was therefore the end of an era-since 1925, or for three and a half decades, the Loan Council and the Commonwealth and its authorities had, for years on end, held the bond rate constant or relatively so except in the later 1930 s when it was not permitted to rise above the limit of 4 per cent. That had been achieved in the narrow bond market by the central bank's buying and selling operations on the open market both on and off the stock exchange, and by the Commonwealth Treasury's buying operations on the exchanges on behalf of the National Debt Commission, using the resources of the Sinking Fund. The policy objective of keeping the bond rate below 4 per cent in the 1930s had been aided by the fact that from 1932 to the war, the central bank had independently concluded that the bond rate should be held at less than 4 per cent, as had the Loan Council. That was a fortunate coincidence that had kept that much less the tensions between the bank and the Council up to the outbreak of the war.

In the post-war years, the central bank became very definitely an instrument of the Commonwealth. The relationship of the central (Commonwealth) bank to the Commonwealth government has been clearly defined in the High Court by Dixon $\mathrm{J}$.

The attributes of the Commonwealth Bank as an agency of the Federal Government, though unusual, are clear enough. If it is to be compendiously described, it is an organized service of government given a separate legal personality, in virtue of which it owns property, incurs duties and obligations and enjoys rights, set up as the banking and monetary authority of the country and charged with the functions of currency control, central banking, exchange control and ordinary general banking, together with some super added responsibilities of providing financial aid to production and industry, and placed under the administrative direction and authority of its chief officer, to whom is given a greater degree of independence than the permanent head of a department, but who is bound ultimately to carry out the policy prescribed by his responsible Minister. ${ }^{1}$

Latham C.J. also had said that the Commonwealth Parliament is the final authority for central bank policy: 'It is within the power of the Commonwealth Parliament to give directions to, or to provide for directions being given, the Commonwealth Bank as to the manner in which it is to exercise its function'?

In matters relating to the bond rate, the central bank was, in law, obliged

1 Bank Nationalization Case (1948), 76 C.L.R., 362.

2 Melbourne Corporation v. The Commonwealth (1949), 74 C.L.R., 48. 


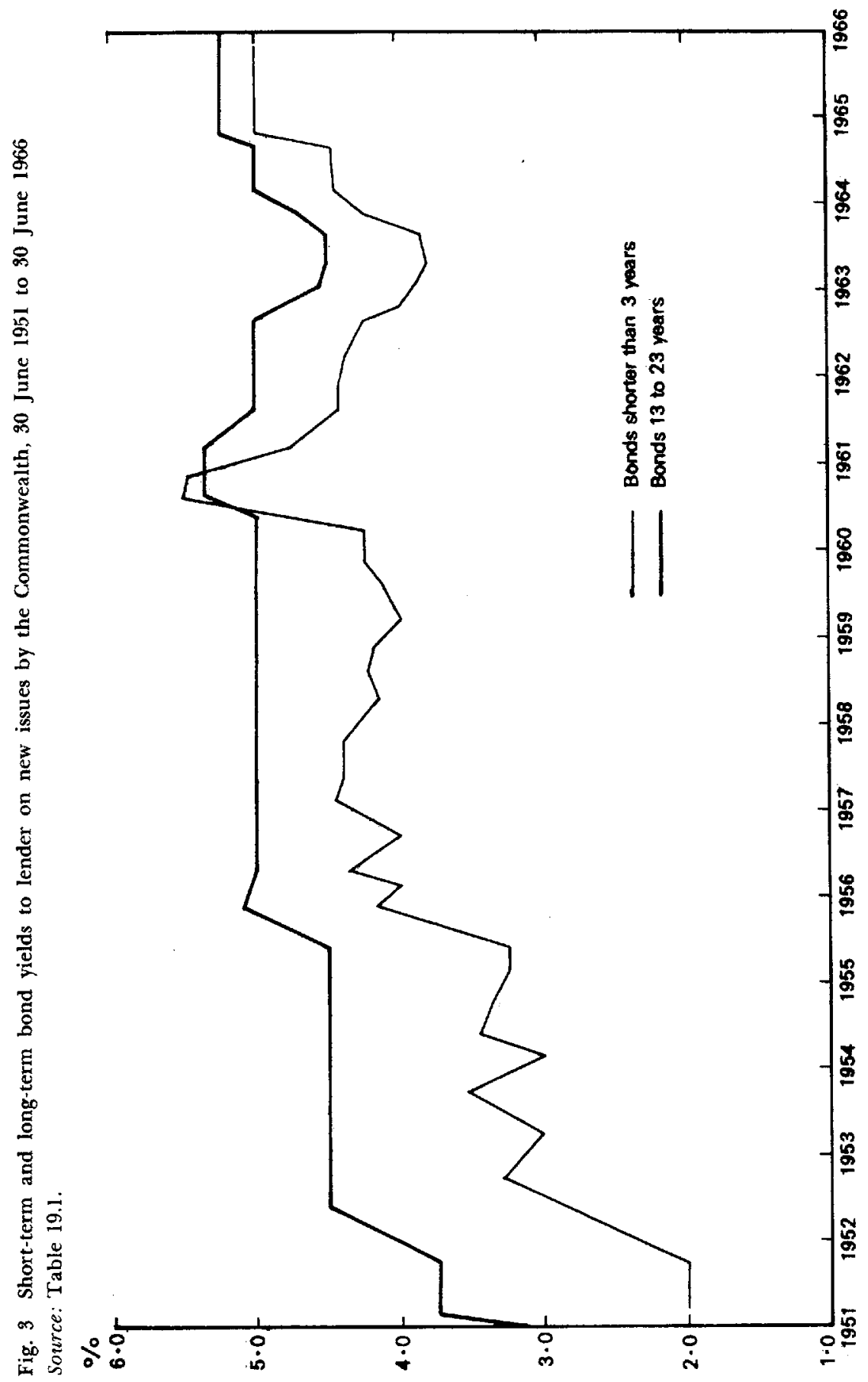




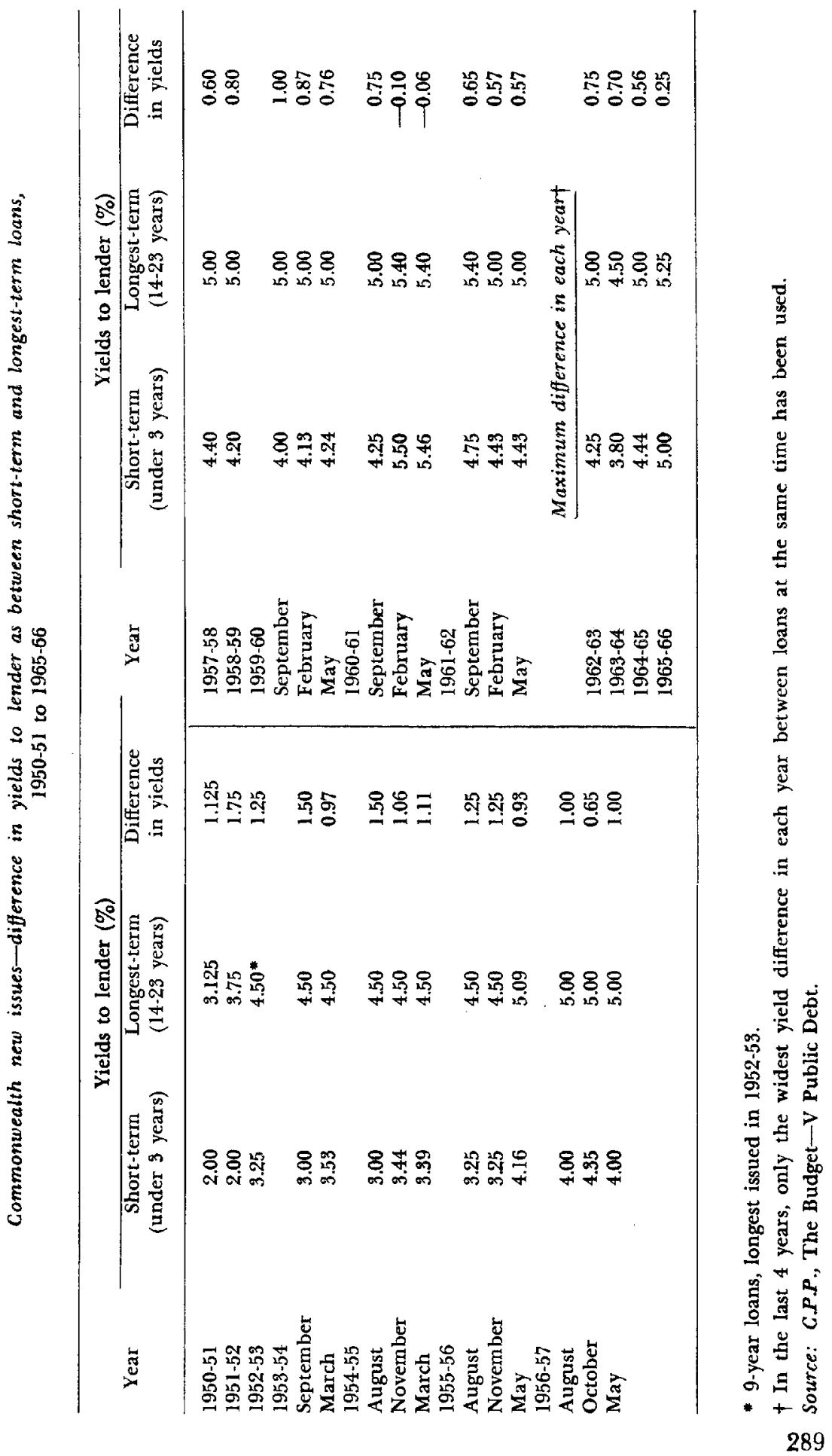


to conform to the sovereign authority of the Council, which used the Commonwealth and therefore the bank as its agent. 'Thus the approval of the Loan Council must be obtained if the Commonwealth judges it necessary to push bond sales for the purposes of monetary policy. This means contacting each State and explaining the position. The amount to be issued must be settled, as well as the issue price. Neither of these matters can be decided by the Commonwealth alone.' 3 The central bank is therefore obliged to look over its shoulder constantly (towards the Loan Council) in its market operations to be sure that the current bond yield is close to the rate on new issues during the last loan and close to what the Council is likely to decide upon for the next issue. Sharp changes in bond yields that might influence the market situation for the next issue would require a persuasive case to be presented to the Council to obtain, in effect, its consent to equally sharp changes in the rate on new issues. It is practicable for the States to have, and they in fact do acquire, a sound knowledge of monetary conditions through their State banks and authorities and by employing expert officials. What the Commonwealth has is a greater practical knowledge of the bond market as a direct result of the operations of its authorities in it. This gives the Commonwealth a persuasive and authoritative voice but up to the 1960 s it had to carry the States with it when the bigger changes in bond yields and the new issues rate occurred. Officials and ministers must work within the limits imposed by the Constitution and the Financial Agreement.

The central bank is not alone in operations on the open market for bonds. The Treasury's Sinking Fund operations are a further constraint upon the bank to co-operate with the Treasury to ensure that the two lots of dealings are in unison. The Treasury, by operating through different brokers and using a different system than that of the bank is in a position in its purchasing operations to exercise some influence on day-to-day yields. ${ }^{4}$ There could be, in effect, competition and tension between the two authorities; in fact they co-operate closely by telephone daily.

There were powerful economic and political influences upon the member governments to resist upward movements in the bond rate in the post-war years. States, which received all the proceeds of the loan program, raised sufficient funds at current rates prior to 1950 because there were plenty of loanable funds. From 1950 onwards, they were relieved of the need to raise the local rate because the Commonwealth's ability and willingness to underwrite loans offset the shortage of loanable funds at current rates.

The States' purpose was to some extent coincident with the Commonwealth's once the post-war surplus of loanable funds came to an end and

3 P. J. Rose, Australian Securities Markets (Melbourne, 1969), 154.

4 Ibid., chap. 10, particularly pp. 151 et seq., for the method of operation by the bank and the Treasury. Rose suggests that 'this institutional arrangement is continued because political circumstances make it difficult to establish a more efficient system' (p. 152). 
the bond rate began to rise above the $3 \cdot 125$ to 3.25 per cent that had been the level between the end of 1940 and the beginning of 1951. The reason for this was that as the bond rate moved upwards at each long step from 1951 onwards, the Commonwealth suffered the politically adverse effects of unfavourable comment by the many small investors in low yielding war loans who faced the prospect of capital loss if they sold before maturity. Institutional investors can avoid losses by buying a range of securities with varying maturity dates appropriate to their needs, but this assumes that bonds at the maturity dates required are available, which might not always be so. In 1958 and 1959, the Commonwealth took steps (considered later in this chapter) to lessen the significance of fear of capital loss, to increase the volume of securities available and to broaden the range of maturity dates to some extent: (1) it introduced, with the Loan Council's consent, Special Bonds to ease the problems of small investors; (2) it arranged for the central bank to support the official short-term market dealers by acting as lender of last resort on bonds with less than three years to maturity; (3) and it issued short-term treasury bills and notes to widen the range of institutional investor's' portfolios and to increase the supply of securities available on the market.

On balance, up to 1960 , the common political interests of both the Commonwealth and the States were probably best served in periods of internal economic balance if the bond rate was both low and steady. But the Commonwealth was on the horns of a dilemma in that, when conditions changed in the capital market and economic balance was threatened, a fluctuating rate was potentially a useful policy measure-a rise in the rate to ease inflationary pressure or a fall to encourage demand, depending on the economic conditions at the time. It was not, therefore, always practicable for the Commonwealth to have the best of both worlds, that is a low rate simultaneously with a restrictive monetary policy as a weapon of general economic policy. When other measures were used to keep the economy in balance, very few of these policies concerned the Loan Council -one was to authorise Commonwealth borrowing abroad to augment the foreign exchange reserves, especially, it would seem, in years when the reserves fell. Another, the size of the loan program, was determined by the Commonwealth, as underwriter, from 1951-52.

The period between the war and 1960 was, then, one of rising interest rates in which the bond rate was rather insignificant as a policy measureit reacted to situations rather than being a means of anticipating and avoiding economic difficulties before they developed. The general tendency for the Loan Council to be tardy in changing the bond rate created a mild tension between the Council and the central bank but the bank showed that it understood and accepted the Council's sovereignty over this instrument of policy. It is of considerable interest that, after nearly a decade of acrimony and disunity in the 1930s, the central bank exercised 
great care in the post-war period in lamenting, but gently, that its management of post-war monetary policy was hindered because the Council would not permit a more flexible bond rate. This attitude of the bank was no doubt encouraged also by the subordination of the central bank to Commonwealth ministerial control in the 1945 banking legislation.

The interesting question about the bond rate in the first fifteen years after the war, that is, prior to the beginning of a more flexible rate after 1960, is why it rose in 1951-52, 1955-56 and in 1960-61. After the rise in 1960-61 the main question became whether the greater flexibility was a useful aid to the management of the economy or whether even greater freedom of action was needed by the two Commonwealth authorities that operated on the market.

The first post-war rise in the bond rate: $1951-52$

The most important variable in the Australian economy in the post-war years continued to be the very substantial fluctuations that occurred in the balance of payments. The importance of this unpredictable factor in

Table 19.2

Economic indicators, $1928-31$ and $1950-53$

\begin{tabular}{|c|c|c|c|c|c|}
\hline \multirow[b]{2}{*}{$\begin{array}{l}\text { End of } \\
\text { June }\end{array}$} & \multirow[b]{2}{*}{$\begin{array}{c}\text { Export price } \\
\text { index } \\
\text { (excl. gold) } \\
\text { (June 1936-39 } \\
=100 \text { ) } \\
\text { (1) }\end{array}$} & \multirow[b]{2}{*}{$\begin{array}{c}\text { Inter- } \\
\text { national } \\
\text { reserves } \\
\text { (fAm.) } \\
(2) \\
\end{array}$} & \multicolumn{3}{|c|}{ Major trading banks } \\
\hline & & & $\begin{array}{l}\text { Liquid assets } \\
\text { plus govt. } \\
\text { securities } \\
\text { (fAm.) } \\
\text { (3) }\end{array}$ & $\begin{array}{c}\text { Special } \\
\text { accounts } \\
\text { (fAm.) } \\
(4) \\
\end{array}$ & $\begin{array}{c}\text { Cash, treasury } \\
\text { bills and } \\
\text { London funds } \\
(\mathfrak{f A m} .) \\
(5)\end{array}$ \\
\hline 1928 & 129 & 104.9 & 127.1 & - & 93.3 \\
\hline 1929 & 120 & 97.7 & 110.6 & - & 79.6 \\
\hline 1929 (Dec.) & 98 & 60.6 & 76.3 & 一 & 53.2 \\
\hline 1930 & 73 & 58.3 & 84.7 & - & 60.4 \\
\hline 1981 & 72 & 53.5 & 99.7 & - & 80.5 \\
\hline & $\begin{array}{c}\text { Base } \\
(1952-53=100)\end{array}$ & & & & $(3)+(4)$ \\
\hline 1950 & 79 & 629.5 & 209.4 & 437.0 & 646.4 \\
\hline 1951 & 137 & 803.7 & 230.9 & 556.4 & 787.3 \\
\hline 1952 & 97 & $\$ 72.5$ & 218.0 & 256.4 & 474.4 \\
\hline 1953 & 100 & 561.2 & 348.0 & 333.0 & 681.0 \\
\hline
\end{tabular}

Sources:

1928-31, col. 1 Commonwealth Year Book, no. 33 of 1940, 797.

col. 2 As in table 8.1(2).

col. 3,5 R.G.M.B., 296, cols. 19 and 23 , and 310 , col. 5 .

1950-53, col. 1 Reserve Bank of Australia, Statistical Bulletin Economic Supplement, November 1961, 12.

cols.2-5 Governor of the Commonwealth Bank of Australia, Memorandum of Evidence, Committee on the Working of the Monetary System (H.M.S.O. 1960), vol. 1, 246. 
influencing both the liquidity of the public, mainly their deposits with the banking system, and hence the liquidity of the private trading banks, can be seen from table 19.2, showing two periods of serious fluctuations during the life of the Loan Council-from 1928 to 1931 and from 1950 to 1953; the main indicators are the export price index, the level of international reserves, the private trading banks' holdings of liquid assets plus government securities, and the trading banks' Special Accounts in the latter period. The Special Accounts were introduced as a wartime measure and carried over into post-war policy. They are the trading banks' assets, but they are frozen by statute as soon as they are called up by the central bank, and cannot be regarded as cash for the purpose of the bank's advances policy. They were re-named Special Reserve Deposits in banking legislation in 1959. The change in the level of the export price index and the level of reserves is in very sharp contrast to the inelastic demand for imports throughout the period. 5

The worst effect of the big changes in the aggregates in the table is that they are transmitted to demand, directly through the expenditure of exporters when export income changes and through investment in stocks and to a lesser extent, consumption, if the change in bank liquidity is transmitted to borrowers. Another important consequence can be the effect upon expectations about the rate of profit, leading to changes in private investment expenditure. The transmission of these primary changes as the multiplier takes effect has automatic secondary effects which depend upon the value of the multiplier for their size. The conclusion of the statistical analysis in chap. 8 was that the effect of changes of well over 40 per cent in export prices, international reserves and the banks' liquid assets in the period 1928-30, together with the cessation of foreign lending, was a major factor contributing to the depression.

Fluctuations of similar magnitudes in the early 1950s led to hardly a ripple on employment levels, even though 'There was a clear danger that this set-back could have deteriorated into a recession'. "The main reason why the economy did not slip down into a major depression in 1951-52 was that it was not then in fundamental disequilibrium as it had been in the late 1920s. Another reason was better economic management, including the stabilisation of the States' total loan program at a predictable figure, which eliminated that possible variable element from the calculations of the Commonwealth in a period of great uncertainty. That part of the States' expenditure which was financed from revenue grants by the Commonwealth also grew at a steady rate and it was, also, an important stabilising influence on demand. While the Loan Council was at the centre

5 R. S. Gilbert, 'Structural Trends in Australian Imports', Economic Record, vol. XXXV, no. 70, April 1959, 130-2.

6 H. C. Coombs, 'The Development of Monetary Policy in Australia', in Other People's Money (Canberra, 1971), 19. 
of the discussions of these matters so was the Premiers' Conference at which the general revenue grants were discussed. However, in respect of both, the strong hand was played by the Commonwealth because it alone had the financial resources required in the crisis to keep the States' expenditure steady.

The movements in the aggregates were so great that the bond rate was not a significant means to control the situation. Adequate open market operations designed to reduce or increase the cash holdings of the public by hundreds of millions of pounds were impracticable in a market where the total non-government holdings of the public (excluding government savings banks) were about $£ 1,350 \mathrm{~m}$. in these years, ${ }^{7}$ and there was a relatively small volume of securities available for open market operations. For example, the liquid assets, government securities and special accounts held by the private banks fluctuated between $£ 787.3 \mathrm{~m}$. and $£ 474.4 \mathrm{~m}$. between 1950-51 and 1951-52. What little information from official sources is available about open market operations suggests that the central bank felt able to allow its net holdings of securities to change by about $\$ 120 \mathrm{~m}$. in $1951-52$ and $£ 125 \mathrm{~m}$. in 1952-53.8 Successive Annual Reports of the Reserve Bank indicate that the greatest net change over the ten years to 1963-64 was a fall of $£ 68 \mathrm{~m}$. in $1961-62 .^{9}$

In the circumstances, a greater rise in interest rates early in 1950-51 may have helped to damp down the excess demand from high export income in that year, but the effect of such a policy can only be a matter of guesswork. In fact, the long-term rate of interest rose from $3 \cdot 125$ per cent to 4.5 per cent between February 1951 and June 1952 despite efforts by the central bank to meet the demand for cash and keep the rate down; ${ }^{10}$ the rise in the interest rate was coupled with the more certain procedure whereby the central bank released trading banks' excess liquid assets from Special Accounts when the liquid assets of the banks were rapidly reduced by depositors to spend abroad on imports.

The Special Accounts procedure had its origin in emergency wartime controls, although for monetary policy it was clearly one of the main lessons of the 1930s. Despite some modifications, the essentials of the system remain and, in principle, must do so while major external shocks to the economy cannot be neutralised by interest rate policy, open market operations and fiscal policies. On the occasion of the first major rise in the bond

7 Reserve Bank of Australia, Statistical Bulletin Financial Supplement, September $1960,26$.

8 Coombs, 'Development of Monetary Policy', 23.

9 Report, 1963, 21.

10 Before February 1951, not only the authorities, but the recipients of the proceeds of the boom in wool prices at the outbreak of the Korean War and non-resident owners of speculative balances in Australia bought bonds in larger quantities from institutional sellers and kept the bond rate low; see H. W. Arndt, 'The Postwar Bond Market', Economic Record, vol, XXX, no. 59, November 1954, 263-9. 
rate in the post-war period, the usefulness of the rate of interest was dwarfed by the magnitude of other economic variables and the need for other policies; the Loan Council's importance in general economic formation was likewise diminished.

\section{The non-bank financial intermediaries show their strength: $1955-56$}

There was, however, a growing weakness associated with the use of Special Accounts as the means to control the money supply. They are restricted to banks and the Commonwealth's power through the central bank's control of bank interest rates, the money supply and credit is therefore directly related only to banks. Throughout the post-war years, the financial intermediaries not defined as banks in the sense that banking is used in the Constitution grew in importance. The development diminished the effectiveness of the Commonwealth's monetary policy and was to pose eventually a major challenge to the Loan Council's policy of keeping the bond rate fixed for long periods.

The Commonwealth's power in respect of banking and financial institutions rests on $\mathrm{s.5l}$ (xiii) and $(\mathrm{xx})$. These are:

s.51 The Parliament shall, subject to this Constitution, have power to make laws for the peace, order, and good government of the Commonwealth with respect to:-

(xiii) Banking, other than State banking; also State banking extending beyond the limits of the State concerned, the incorporation of banks, and the issue of paper money:

(xx) Foreign corporations, and trading or financial corporations formed within the limits of the Commonwealth.

The financial corporations' power in $5.51(\mathrm{xx})$ had been the subject of much difference of judicial opinion and its meaning and effect have never been determined with any precision. The consensus of judicial opinion until Strickland v. Rocla Concrete Pipes Ltd in 1971 suggested that its meaning was fairly narrow; the power was unsuccessfully relied upon in support of bank nationalisation and it then seemed doubtful whether it could be used as an effective instrument of national economic policy.11 The Concrete Pipes Case opened the way for the exercise of a wider control over financial intermediaries than had been possible.

In practical terms, the banking power granted by 5.51 (xiii) included, with the exception of State banking, authority in respect of bank credit and advances policies, the creation of a central bank and the equipping of it with central banking powers. It included power to control interest rates on bank deposits and advances. But there was, in the first two and a half post-war decades, a deficiency. 'A power to control bank deposit interest rates by keeping them relatively low could be defeated by a bidding

11 (1971) C.L.R.; Report from the Joint Committee on Constitutional Review, chap. 16. 
up for deposits at fancy rates of interest by the non-banking bodies. ${ }^{12} \mathrm{Up}$ to 1971 , therefore, the private non-banking bodies, or financial intermediaries, whose activities may affect monetary policy, could only be directly regulated by the States; the Commonwealth had, at the most; indirect control over them until such time as the banking power was defined more widely or the financial corporations power was defined more clearly, even though the Commonwealth was charged with the responsibility for central banking and general monetary policy.

The Constitution allotted to the Commonwealth a power over banking at a time when the banks were the dominant source of credit, and even up to the last five years before the 1939-45 war, bank credit accounted for about 56 per cent of all credit supplied. ${ }^{13}$ However, after 1900, and especially since World War II, there was a striking development in the institutional framework of the financial system. Specialised institutions emerged which narrowed the field occupied by the traditional banking structure. The domestic capital market developed, with issuing houses, stronger underwriters and stock exchanges making possible the wider participation of the public in the direct provision of capital. One result was an increase in the velocity of circulation of money.

Ever since 1946 there has been a persistent downward trend in the money supply expressed as a percentage of the gross national product and since 1955 this percentage has been appreciably below the pre-war level. Expressed in general terms this has meant that the banking system has been becoming a less significant element in the financing of the economy. ${ }^{14}$

The statistical evidence leaves no doubt about the decline in the share of bank finance and therefore of Commonwealth control of finance flows. Between the periods 1934-39 and 1953-58, new issues on the stock exchange rose from 18 to 36 per cent of all finance raised and hire-purchase finance rose from 2 per cent to 16 per cent of total credit. ${ }^{15}$ In the five years to June 1958, the proportion of total credit provided by the trading banks had declined to about one-quarter and if corporate savings, which increased in importance relative to external finance, are included, the contribution of trading bank credit to the grand total of finance was but 10 per cent, and it would be smaller still if data on self-finance by unincorporated businesses and owner-builders were available. ${ }^{16}$ 'It is evident that these

12 R. G. Menzies, 'Problems of Management in a Federation', Inaugural John Storey Memorial Lecture (University of Melbourne, 1962).

$13 \mathrm{H}$. W. Arndt, The Australian Trading Banks (2nd ed., Melbourne, 1960), 122.

14 H. C. Coombs, 'Conditions of Monetary Policy in Australia', in Other People's Money, (Canberra, 1971), 40.

15 Joint Committee on Constitutional Review 1959, para. 1062, referring to Professor Arndt's evidence.

16 Arndt, Trading Banks, 122-3. 
developments have drastically reduced the Commonwealth's control of credit through the banking power.' 17

Other developments within the banking system itself reduced the effectiveness of the Commonwealth's banking power. Some State governments had undertaken commercial banking with rural and industrial banks; and trading banks purchased controlling interests in major hire-purchase companies, undertook various agency services and entered into trust development.

The effects of the growth of credit facilities from non-bank sources first became overt in 1955-56. A conjunction of domestic inflation and a serious balance of payments deficit created a situation in which non-bank financial intermediaries showed their strength and attempted to counter the authorities' use of calls to Special Accounts to control the excessive demand for money. The cause of domestic inflation was a rise in consumption and private investment. Between June 1953 and June 1955, domestic expenditure rose by $£ 1,000 \mathrm{~m}$. or 27 per cent. At the same time export prices and receipts fell, but imports rose extraordinarily, and in 1954-55 the deficit on current account was $£ 258 \mathrm{~m}$, , or one-third of exports and 45 per cent of international reserves at the beginning of the year. In 1955-56 the same pressures continued and 'by the end of 1955, a tense and complex situation had arisen' ${ }^{18}$

The economic problem was worsened by the structural change in the money market. To curb the rise in consumption expenditure on durable consumer goods, the central bank in July 1955 asked the trading banks not to grant additional advances for the expansion of hire purchase. Up to then, hire purchase companies had relied heavily on bank overdrafts as a source of finance, nearly 30 per cent of their funds being drawn from that source as late as 1953-54. ${ }^{19}$ Increasingly from then on, hire purchase companies changed from the banks to the short-term money market for loans. In the three years succeeding 1954-55, the issue of debentures and notes by the hire purchase companies trebled. In 1955-56, the total amount of this kind of security issued by all listed Australian companies almost doubled compared with 1954-55, while new issues of ordinary and preference shares fell slightly (table 19.3). In the strong competition for investable funds, some borrowers, especially hire purchase companies, had raised their rates to attract money from such sources as fixed deposits and savings bank deposits. Subscriptions to the Commonwealth's loans for the annual loan program fell and the Commonwealth's underwriting assistance rose from $£ 49.5 \mathrm{~m}$. in $1954-55$ to $£ 88.3 \mathrm{~m}$. in $1955-56$. The market for government securities also came under strong pressure as holders of bonds sold them

17 Joint Committee on Constitutional Review 1959, para. 1063. $7-9$.

18 Commonwealth Treasury, 1957 and Beyond: an Economic Survey (Canberra, 1957),

19 Coombs, 'Conditions of Monetary Policy', 40. 
Table 19.3

New Capital raisings by Australian listed companies, 1952-53 to 1965-66 (£m.)

\begin{tabular}{rccccc}
\hline Year & $\begin{array}{c}\text { Share capital } \\
\text { (ord. and } \\
\text { pref.) }\end{array}$ & $\begin{array}{c}\text { Debentures, } \\
\text { loans, notes } \\
\text { and deposits }\end{array}$ & Year & $\begin{array}{c}\text { Share capital } \\
\text { (ord. and } \\
\text { pref.) }\end{array}$ & $\begin{array}{c}\text { Debentures, } \\
\text { loans, notes } \\
\text { and deposits }\end{array}$ \\
\hline $1952-53$ & 26.5 & $11.9 *$ & $1959-60$ & 48.0 & 200.4 \\
$1953-54$ & 42.6 & $28.3^{*}$ & $1960-61$ & 98.4 & 120.4 \\
$1954-55$ & 59.7 & 27.6 & $1961-62$ & 76.2 & 99.6 \\
$1955-56$ & 59.2 & 52.8 & $1962-63$ & 52.4 & 114.8 \\
$1956-57$ & 43.7 & 51.7 & $1963-64$ & 63.2 & 81.1 \\
$1957-58$ & 35.3 & 81.6 & $1964-65$ & 73.8 & 84.9 \\
$1958-59$ & 48.8 & 142.0 & $1965-66$ & 87.6 & 74.1 \\
\hline
\end{tabular}

* Estimate

Sources: Coombs, Mills Memorial Lecture 1958, 36; Reserve Bank, Statistical Bulletin, October 1966, 87 and Financial Supplement, September 1963, 49.

to obtain cash to invest in the debentures, notes and deposits which offered a more attractive rate of interest. Very considerable market support was required if the 4.5 per cent bond rate was to be held. This would have been expansionary and would also have compromised the deflationary credit policy. In March 1956, market support was withdrawn sufficiently for the long-term yield to rise to 5.33 per cent by June, after which the authorities succeeded in getting it down to the steady long-term level of 5 per cent. ${ }^{20}$

The decision to let the bond yield rise was accompanied by disinflationary taxation measures in a supplementary budget in March 1956. Later, the immigration program for $1956-57$ was reduced. The action was also an instance of wider action than open market operations and movements in the bond rate being necessary to recover economic balance. Commonwealth Ministers admitted that the bond rate had been held down by abnormal purchases of securities by the central bank: the impracticability of having a budget deficit and of supporting the bond market on the one hand, and applying credit restrictions at the same time on the other was explicitly recognised by Commonwealth Ministers. ${ }^{21}$ The Loan Council was no doubt persuaded by the Commonwealth's advocacy on the point, in that the rise in yields to 5 per cent was, in practical terms, essential and irreversible at the time. Commonwealth Ministers also appreciated that the growth of the short-term securities market had reached proportions requiring action to enable better control of it. The problem to be tackled was the 'bidding up for deposits at fancy rates of interest by the non-banking bodies'.

20 Commonwealth Treasury, 1957 and Beyond, 7-9; Coombs, 'Conditions of Monetary Policy', 40.

21 C.P.D., 8 March 1956, 641, and 14 March 1956, 792-3. 
The end of the era of the fixed bond rate: 1960-61

Once the March 1956 measures had taken effect, long-term yields on Commonwealth securities remained close to 5 per cent until October 1960 (for $4 \frac{1}{2}$ years) as one result of the central bank's operations in the market. The range of variation was narrow, being from 4.87 to 5.05 per cent. ${ }^{22}$ This appearance of a return to the conditions which had preceded the events of $1955-56$ is deceptive. For the Loan Council was confronted by continuous pressure on its short-term bond rate; thenceforth the differential between the short and long rates was considerably less than it had been. From about 1.25 percentage points up to November 1955 the differential had to be reduced for the May 1956 loans to less than 1 percentage point and it was as much as 1 percentage point again for only three loans during the next ten years (table 19.1 and fig. 2). There was therefore a steeper, long-term, upward movement in the short-term relative to the long-term rate between the early and the later 1950s.

The mainspring of this was the even more intense activities of the nonbank financial intermediaries. By June 1960, annual new capital raised by debentures, notes and deposits had quadrupled (£200.4m.) compared with their already very high level in $1955-56(£ 52 \cdot 8 \mathrm{~m}$.); whereas ordinary and preference share issues contributed, in each year of this period, less than the amount at the beginning (table 19.3).

The central bank pointed the way to the need for changes. The Governor stated in April 1958 that the bank needed to have an institutional structure within which to engage in effective open market operations to control the liquidity in the non-bank sector of the securities markets. The bank placed considerable emphasis upon the need for flexible interest rates, a proposal that had specific implications for and was no doubt intended to influence all member governments of the Loan Council. ${ }^{23}$ The emphasis on flexible interest rates and open market operations was well placed at the time because, as the years passed, it became evident that the use of the banking power over a handful of trading banks and, had it been legally possible for the Commonwealth, over a few hire purchase companies, was a simple matter relative to the large number of finance companies that was beginning to emerge in the Australian markets. By 1964, it had become evident that the proliferation of financial enterprises made direct controls administratively well-nigh impossible and the central bank admitted it.

There is so wide a range of people and institutions who provide credit in various forms that attempts at rationing credit by administrative act would involve great difficulties and would, moreover, be likely to stimu-

22 Table 19.4

23 Coombs, 'Conditions of Monetary Policy', 32; and at p. 42: 'The Central Bank will continue to be handicapped in its open market policies until institutional developments in the Government security market reduce dependence on the Central Bank and until we become educated to accept changes in interest rates more readily.' 
late further financial innovations and organization of affairs by the community in ways which would be less subject to interference from the authorities. ${ }^{24}$

The official acceptance of the need for open market operations on an adequate scale and flexible interest rates posed several problems. The first was to safeguard small investors against capital loss in the event of a rise in rates. The second was to strengthen the central bank's direct links with the money market to enable it to engage in adequate open market operations and to exercise a controlling influence on the supply of money held outside of the trading banks.

On the first matter, it was accepted that the small investor would not be happy about rises in the bond rate, no matter how temporary nor how essential the measure was for general management of the economy. Steps were taken in October 1958 to assist the small investor who wished to convert his bonds before maturity date without capital loss. The Loan Council approved the issue of Special Bonds up to a limit of $£ 5,000$ per investor, which could be redeemed at full face value after the first interest date, provided one month's notice was given. The limit was raised to $\mathfrak{f 1 0 , 0 0 0}$ in February 1960. This tap was subsequently used by the public a great deal- $\$ 30.2 \mathrm{~m}$. were taken up in $1958-59$ during which they were available for nine months only; $£ 21.8 \mathrm{~m}$. in 1959-60; about $£ 16 \mathrm{~m}$. in each of the next two years; $£ 43 \mathrm{~m}$. in $1962-63$ and $£ 30.8 \mathrm{~m}$. in the following year. The Commonwealth's problems with the small investor also diminished as war loans at 3.25 per cent and the post-war loans at 3.125 per cent were redeemed or converted to loans at much higher rates. With the advent of Special Bonds, other government securities became concentrated as time passed in the hands of enterprises and institutions who accept that prices of securities do fluctuate. ${ }^{25}$

It was therefore a logical next step that the central bank's proposed widening of the institutional structure should take the form of an officially supported short-term securities market that would enable the bank to use open market operations more effectively to control liquidity. When the official short market was established in February 1959 there was in Australia no well organised and officially recognised body of dealers in short-term Commonwealth securities. The main characteristic of the money market was the small volume of business normally transacted relative to the great changes in money supply which could suddenly occur and disrupt the market. As late as 1958, the Governor of the central bank stated that 'In

$24 \mathrm{~J}$. G. Phillips, 'Recent Developments in Monetary Policy in Australia', E. S. and A. Bank Research Lecture 1964 (University of Queensland Press), 20; R. F. Henderson, 'Monetary Policy in Australia', Economic Record, vol. XXXVII, no. 79, September 1961; he also argued strongly for the use of varying sales taxes on goods bought under hire purchase to check excessive expansion.

25 Phillips, E. S. and A. Bank Lecture 1964, 20. 
the Government security market, regular purchases by the Central Bank and the National Debt Commission are necessary to ensure that a reasonable market is kept alive.' 26 He added that the yield on government securities was generally regarded as the basic rate in the general market structure of Australian interest rates and that rates of interest on Commonwealth government loans were determined by the Australian Loan Council.

The process of broadening the market was naturally a slow one but it was well founded in practices that had developed privately in the decade prior to the officially backed market's birth. ${ }^{27}$ When the market was given official support in early 1959, the dealers made it known that the supply of suitable securities for their portfolios was inadequate; they urged that the maturities of Commonwealth securities be more evenly spaced throughout the year and that short-term treasury bills be sold in the open market. ${ }^{28}$ In November 1959 the Loan Council authorised the issue of seasonal treasury notes fortnightly, with a currency of 91 days and at a discount which gave them a yield close to the current short-term money market rate. In 1960 they were issued on a daily basis. It was a shortcoming of the seasonal treasury notes that they had to be redeemed in the financial year of issue, which meant that no notes could be issued in the April-June quarter. In addition, the Commonwealth's high liquidity in the first few months of the year added a further two months to the number in which the notes were not available. ${ }^{29}$ These limitations were not removed until July 1962, when the seasonal treasury notes were replaced by treasury notes, which were available on tap daily.

The monetary authorities' extension of the range of securities and maturity dates, especially over shorter periods, was supplemented with action to provide other incentives to investors and to facilitate dealings. One example was that stock exchange brokerage rates, which used to be high for small parcels, were reduced to make the charges less onerous for these transactions, for changes from one security to another and for trans-

26 Governor of the Commonwealth Bank of Australia, Memoranda of Evidence, Committee on the Working of the Monetary System (London, 1960), vol. 1, 246.

27 There is a growing authoritative literature on the origins and the working of the official and other securities markets. The most detailed study is Rose, Securities Markets. Others include H. R. Longmuir, 'The Short Term Money Market in Australia' in Jobson's Digest Year Book 1962 (Sydney, 1962); H. W. Arndt and C. P. Harris, The Australian Trading Banks (3rd ed., Melbourne, 1965); Reserve Bank of Australia, The Short Term Money Market in Australia (Sydney, April 1963 and July 1966); Reserve Bank, successive Annual Reports; and M. R. Hill, 'Commonwealth Bond Market', Economic Society of Australia and New Zealand, New South Wales Branch, Monograph no. 306 (cyclostyled, August 1969).

28 Arndt and Harris, Trading Banks, 100.

29 Ibid., 93. The reason for not issuing in the last quarter was based on the meaning of borrowing for temporary purposes in the Financial Agreement. The authorities were at first probably uncertain whether the Agreement clause 6(7) enabled the life of a short-term security to extend beyond the end of a financial year. 
actions in very short-term securities..$^{30}$ The result of all these steps was that in addition to the official money market dealers, a number of other firms were willing to hold a portfolio of short and medium dated Commonwealth securities financed by short-term deposits received from the public. Greatly increased competition developed between the operating firms. ${ }^{31}$

The central bank was also concerned to devise a technique which would make its quantitative control of banks' advances policies more exact, and it set out to build up its consultative relationship with the banks so that they willingly conformed to its wishes. ${ }^{32}$ Over the decade between 1956 and 1966, this was achieved. ${ }^{33}$

The central bank's desire for greater flexibility of interest rates and for appropriate institutional developments to control non-bank liquidity were expected to take a number of years to achieve. In the meantime, changes in the bond rate were made only in response to exceptionally strong market pressures by the non-bank financial intermediaries. ${ }^{34}$

It was notable that these decisions on monetary policy and institutions had involved the Loan Council quite deeply, but it was obviously dependent upon the advice and recommendations of the Commonwealth. The new arrangements were put to a severe test soon after they were launched in a financial boom and collapse in 1960-61. The experience of this particular financial year gave rise to relatively more flexible interest rates on new issues. The distinctive feature of 1960 for monetary policy was that the operations of the non-bank financial intermediaries had been building up to the point where they had by then added a new dimension to the supply of liquidity. In the boom conditions of that year there was an unprecedentedly excessive demand for money substitutes bearing high interest rates. 'In essence what was happening was that the community's demand for liquid assets was being largely satisfied by the rapid expansion of issues of money substitutes by the non-bank intermediaries, the community being willing to accept these issues in lieu of money and conventional liquids. The process was cumulative. ${ }^{35}$ The new issues at high rates of interest induced people to draw money out of bank deposits and many used a larger proportion of their permitted overdrafts in unwonted fashion. The finance so obtained increased the velocity of circulation, the money being used, in particular, to finance the purchase of durable consumer goods and real estate. The prices of real estate were dangerously inflated by unhealthy speculation. ${ }^{36}$

30 Phillips, E. S. and A. Bank Lecture 1964, 20.

$31 \mathrm{P}$. J. Rose, 'Recent Developments in the Australian Money Markets', Bankers' Magazine, October 1965, 211.

32 Coombs, 'Conditions of Monetary Policy', 42.

33 Arndt and Harris, Trading Banks, 200-8.

34 Phillips, E. S. and A. Bank Lecturer 1964, 6.

35 Ibid., 12.

36 Henderson, 'Monetary Policy in Australia'; Commonwealth Treasury, The Australian Economy 1961 (Canberra, 1961), 12. 
In November 1960 the Commonwealth took very strong fiscal measures as well as making calls to Special Reserve Deposits to curb the boom. These included the use of the tax power against almost all non-bank financial intermediaries who, from November 1960 until June 1961, were not permitted to charge net additions to interest paid on capital as a deductible expense in calculating taxable income. ${ }^{37}$ Sales tax was increased until February on some of the goods (private vehicles) financed by hire purchase companies. The insurance power was used to oblige life offices and pension funds to reverse the trend of investing a diminishing proportion of their assets in public authority securities. ${ }^{38}$ The February 1961 loan on behalf of the Council was at 5.375 per cent, compared with 5 per cent on the preceding loan.

From February 1961 the market yield on bonds and the new issues rate was allowed to fluctuate far more than in any previous post-war period. ${ }^{39}$ It was a direct result of the new institutional arrangements of 1958 and 1959. The strain on the bond rate was lessened from April 1962 by the use of the maximum overdraft rate as a signal to the banks and to the public regarding the need for monetary restraint or expansion. 'Variations thus have implications in Australia which are somewhat similar to variations in "Bank Rate" in a number of other countries.'40 In 1964 the central bank initiated a rise in interest rates to forestall increases in the rate of turnover of money. ${ }^{11}$ The overdraft rate rose from $6 \frac{1}{2}$ per cent to 7 per cent in April. In May, the yields on new issues were higher than on the October and February loans. ${ }^{42}$

But these developments did not mean that effective control had been achieved. The Commonwealth's monetary measures were restricted to bank overdraft rates, the yield on bonds in day-to-day operations in the market, the bond rate at the time of a loan, open market operations, changes in Special Reserve Deposits and consultation with and co-operation by the trading banks and some financial institutions. There was no direct control of the money supply held by non-bank financial intermediaries, only indirect action being practicable through open market operations and as lender of last resort to official dealers. There was the possibility that practicable changes in short-term yields by the central bank as lender of last resort, or in its open market operations, would not counter the demand for money and money substitutes to the extent required in periods of even moderately

37 C.P.D., 15 November 1960, 2856 (Treasurer). The tax measure did not apply to banks, approved pastoral finance companies, approved short-term money market dealers, building societies, and some small companies which borrowed up to $£ 10,000$ or were coming onto the market for the first time.

38 Treasury, Australian Economy 1961, 13, 15.

39 Tables 19.1 and 19.4 .

40 Reserve Bank of Australia (published by the Bank, 1966), 22.

41 Reserve Bank of Australia, Annual Report 1964, 16. According to some, this was the first time such an initiative had been taken. Arndt and Harris, Trading Banks, 207.

42 The short-term rate rose by 0.41 per cent and mediums and longs by 0.2 per cent. 
excessive or deficient demand. Expectations of capital gains (or losses) could so change investors' choices that the movements in interest rates and yields would be insignificant in their calculations. A good deal depended on whether appropriate action could be taken, as in 1964 , to forestall movements in securities' prices before the snowballing speculative process began. ${ }^{43}$

In pursuing these policies, a tension could exist between what may now be taken as the Commonwealth's growing desire for flexible and therefore rising rates at certain times, and the Loan Council's, meaning primarily the States', desire for low interest rates. For the Commonwealth uses revenue for its works purposes, whereas the States, who depend upon the loan program for much essential finance, have no incentive to agree to raise the bond rate to attract loans, particularly while the Commonwealth underwrites the program. It was considered that as late as 1964

this relationship between loan raisings and the works programmes of the States clearly limits the extent to which debt management operations can be geared to support monetary policy objectives. The primary object of loan raisings is to finance the works programmes, the effects on the liquidity situation in the economy being more or less incidental. ${ }^{44}$

It was a matter for the future to see whether the States would accept an even more flexible interest rate policy.

\section{Prospects}

By the mid-1960s the Loan Council was prepared to permit more frequent changes in interest rates on new issues. This change was probably attributable in part at least to the proposals of the central bank and academic and professional observers that flexible interest would assist the authorities in controlling the financial intermediaries if they bid for money when the purpose of the authorities was a restrictive monetary policy. But are the instruments of policy adequate with the sanctioning, let us say, of an upper limit to the new issues rate below which the Commonwealth and its authorities can operate, using yields as but one of the Commonwealth's armoury of economic policy measures?

In the formation of policy, the Loan Council is a statutory forum which has the power to make decisions about the terms and conditions of the regular governmental borrowing. The Commonwealth and the States between them have the power to legislate with respect to all financial institutions but there were considerable structural changes in the post-war years that increased the significance of the States because financial intermediaries became more important sources of finance for all purposes than the banks in the ill-defined sense that banking is used in the Constitution. The Loan Council therefore had an opportunity to be an instrument of

43 Phillips, E. S. and A. Bank Lecture 1964, $21-2$.

44 Ibid., 19. 
co-operation between the Commonwealth and the States on uniform legislation and policy. It did so in the late 1950s in the moves towards a flexible bond rate and it could do so again should the need arise to add to existing techniques. Steps taken in the early 1960s to achieve uniform companies and hire purchase legislation were in no sense intended to regulate the non-banking financial intermediaries to the requirements of monetary policy, but these first steps towards uniformity were of major practical importance if further legislative action were contemplated. Up to the mid-1960s the Council (in effect the States) had given the Commonwealth the authority to take steps it was deemed were necessary to deal indirectly with the proliferating non-bank intermediaries. But if the States ceased giving the Commonwealth the authority it needed in the Loan Council to frame a satisfactory monetary policy, what constitutional changes or tactical means would aid the Commonwealth?

Constitutional change was recommended by the Joint Committee on Constitutional Review-specifically that the Commonwealth should have vested in it effective control of capital issues, excluding the use of profits and reserves; and power to make laws with respect to hire purchase and other agreements or transactions entered into in connection with the sale, purchase, hire or encumbrance of goods which involve the making of periodical payments or involve the deferment of payment of a debt. It added a third recommendation that the Commonwealth Parliament should have power, concurrently with the States, to make laws with respect to rates of interest and other charges payable in connection with loans obtained upon the mortgage or other security of land. ${ }^{45}$ The fact that the proposals emanated from a Joint Committee of all political parties suggests that, in due course, the support of all parties for such proposals at a referendum may make the result more successful than is usually the case in Australia.

Alternatively, constitutional impediments might be overcome by the High Court's wider interpretation of 'banking' or of 'financial corporations' to encompass the financial intermediaries and to include the acceptance of deposits and the giving of credit, in addition to the provision of a service by operations through the use of cheques. Almost all forms of cash deposits and lending on credit have at base the same person to person relationship of trust and the provision of adequate security between borrower and lender, although methods of operation may be different and do change.

If constitutional reform were necessary but not practicable, if wider interpretations of the banking and the financial corporations powers were not handed down, and the Loan Council chose not to recommend to executives uniform legislative arrangements to enable the Commonwealth to manage the liquidity of the economy more exactly in conjunction with existing techniques, the Commonwealth has the power under s.96 and in 
the Financial Agreement to attempt to persuade the States indirectly to conform on the matter. This would be a difficult political step and one to be taken in the foreseeable future only as a last resort. If the Commonwealth refrained from exercising its powers under s.96 and in the Financial Agreement, then the joint use of the tax and banking powers might be tried, if necessary, with the accompanying risk that the High Court might decide that the Commonwealth cannot exercise control of what are now the non-bank financial intermediaries.

A further alternative would be for the Commonwealth to take over all State debt under ss.105 and 105A and to persuade the States to allow the Commonwealth to borrow for itself alone. The proceeds plus additional sums could be advanced under s.96 to the States for capital purposes on terms attractive to them. There could be a notional interest rate so that the return on States' works programs would have that element of cost to meet and with which to test their efficiency relative to capital expenditure by private enterprises. One significant effect of this policy could be that the Commonwealth would then have full responsibility for and control of the bond rate to use it as freely as it wished in monetary policy. Such a step would be within the Constitution and in accord with the fundamental long-term aspirations of the Australian people that, where practicable, the financial problems of the federation be solved by a transfer of responsibility over the States' debts. The policy of taking over part or all States debts, their amortisation, and the interest due on them would have to be worked out in the general context of revenue payments to the States. It would be part of a larger arrangement of which one benefit to the Commonwealth would be unfettered control of bond rate policy. 
Table 19.4

Government long-term security yields, Australia, 1926-1971

Year Jan. Feb. Mar. Apr. May June July Aug. Sep. Oct. Nov. Dec.

1926-40: average redemption yield on fully taxed securities maturing in 10 or more years

\begin{tabular}{|c|c|c|c|c|c|c|c|c|c|c|c|c|}
\hline 1926 & 5.33 & 5.28 & 5.28 & 5.23 & 5.27 & 5.25 & 5.17 & 5.20 & 5.25 & 5.26 & 5.33 & 5.34 \\
\hline 1927 & 5.33 & 5.30 & 5.32 & 5.37 & 5.37 & 5.41 & 5.42 & 5.38 & 5.35 & 5.45 & 5.46 & 5.43 \\
\hline 1928 & 5.45 & 5.41 & 5.35 & 5.39 & 5.39 & 5.42 & 5.40 & 5.40 & 5.39 & 5.38 & 5.28 & 5.26 \\
\hline 1929 & 5.21 & 5.25 & 5.29 & 5.30 & 5.25 & 5.23 & 5.24 & 5.32 & 5.39 & 5.50 & 5.60 & 5.57 \\
\hline 1980 & 5.72 & 5.93 & 5.98 & 5.94 & 5.66 & 5.81 & 6.02 & 6.12 & 6.27 & 6.28 & 6.35 & 6.51 \\
\hline 1931 & 7.00 & 6.87 & 6.57 & 6.58 & 7.01 & 7.56 & n.a. & n.a. & n.a. & n.a. & 4.90 & 4.68 \\
\hline 1932 & 4.63 & 4.79 & 4.82 & 4.87 & 5.03 & 4.70 & 4.31 & 4.15 & 4.04 & 4.03 & 3.97 & 3.92 \\
\hline 1983 & 3.90 & 3.88 & 3.88 & 3.79 & 3.82 & 3.79 & 3.75 & 3.78 & 3.69 & 3.65 & 3.70 & 3.61 \\
\hline 1934 & 3.54 & 3.58 & 3.54 & 3.45 & 3.40 & 3.39 & 3.26 & 3.42 & 3.29 & 3.27 & 3.25 & 3.90 \\
\hline 1935 & 3.29 & 3.45 & 3.57 & 3.52 & 3.62 & 3.62 & 3.60 & 3.77 & 3.90 & 3.78 & 3.83 & 3.74 \\
\hline 1936 & 3.68 & 3.81 & 3.90 & 3.90 & 3.91 & 3.96 & 3.96 & 3.98 & 3.95 & 3.96 & 4.01 & 4.02 \\
\hline 1937 & 3.99 & 4.07 & 3.98 & 3.91 & 3.85 & 3.75 & 3.80 & 3.76 & 3.82 & 3.77 & 3.69 & 3.68 \\
\hline 1938 & 3.57 & 3.62 & 3.67 & 3.65 & 3.72 & 3.74 & 3.69 & 3.72 & 3.86 & 3.76 & 3.83 & 3.93 \\
\hline 1939 & 3.79 & 3.79 & 3.88 & 3.97 & 3.93 & 3.97 & 3.94 & 4.00 & 4.04 & 3.96 & 3.88 & 3.83 \\
\hline 1940 & 3.61 & 3.50 & 3.52 & 3.20 & 3.30 & 3.28 & 3.26 & 3.25 & 3.22 & 3.21 & 3.11 & 3.09 \\
\hline
\end{tabular}

1941-Jan. 1948: theoretical redemption yield on a fully taxed security maturing in 12 years

$\begin{array}{lllllllllllll}1941 & 3.26 & 3.25 & 3.20 & 3.25 & 3.25 & 3.16 & 3.24 & 3.23 & 3.23 & 3.23 & 3.21 & 3.25 \\ 1942 & 3.25 & 3.25 & 3.25 & 3.25 & 3.24 & 3.24 & 3.24 & 3.25 & 3.25 & 3.23 & 3.23 & 3.23 \\ 1943 & 3.22 & 3.24 & 3.23 & 3.24 & 3.24 & 3.24 & 3.23 & 3.23 & 3.23 & 3.23 & 3.24 & 3.24 \\ 1944 & 3.24 & 3.24 & 3.24 & 3.24 & 3.24 & 3.24 & 3.24 & 3.24 & 3.24 & 3.24 & 3.24 & 3.24 \\ 1945 & 3.24 & 3.25 & 3.25 & 3.25 & 3.25 & 3.25 & 3.25 & 3.25 & 3.25 & 3.24 & 3.24 & 3.25 \\ 1946 & 3.24 & 3.24 & 3.24 & 3.24 & 3.25 & 3.25 & 3.24 & 3.25 & 3.25 & 3.25 & 3.23 & 3.21 \\ 1947 & 3.20 & 3.18 & 3.18 & 3.16 & 3.15 & 3.15 & 3.16 & 3.18 & 3.17 & 3.17 & 3.17 & 3.17 \\ 1948 & 3.27 & & & & & & & & & & & \end{array}$

Feb. 1948-June 1959: average redemption yield on securities subject to current tax maturing in 10 or more years

\begin{tabular}{llllllllllllll}
1948 & & 3.15 & 3.15 & 3.15 & 3.14 & 3.15 & 3.15 & 3.15 & 3.13 & 3.12 & 3.07 & 3.13 \\
1949 & 3.09 & 3.14 & 3.13 & 3.12 & 3.13 & 3.13 & 3.14 & 3.13 & 3.14 & 3.13 & 3.13 & 3.12 \\
1950 & 3.12 & 3.12 & 3.13 & 3.14 & 3.13 & 3.15 & 3.14 & 3.15 & 3.15 & 3.13 & 3.14 & 3.17 \\
1951 & 3.15 & 3.21 & 3.27 & 3.28 & 3.24 & 3.51 & 3.73 & 3.82 & 3.83 & 3.80 & 3.76 & 3.75 \\
1952 & 3.82 & 3.82 & 3.81 & 4.19 & 4.43 & 4.62 & 4.51 & 4.49 & 4.61 & 4.68 & 4.62 & 4.53 \\
1953 & 4.46 & 4.53 & 4.57 & 4.51 & 4.54 & 4.48 & 4.47 & 4.47 & 4.42 & 4.43 & 4.42 & 4.40 \\
1954 & 4.40 & 4.40 & 4.47 & 4.46 & 4.47 & 4.44 & 4.47 & 4.49 & 4.48 & 4.49 & 4.50 & 4.52 \\
1955 & 4.49 & 4.49 & 4.53 & 4.53 & 4.49 & 4.53 & 4.53 & 4.51 & 4.51 & 4.53 & 4.52 & 4.53 \\
1956 & 4.54 & 4.57 & 5.12 & 5.18 & 5.19 & 5.34 & 5.15 & 5.05 & 5.04 & 5.05 & 5.07 & 5.09 \\
1957 & 5.04 & 5.05 & 5.03 & 5.06 & 5.05 & 5.04 & 5.02 & 5.00 & 4.98 & 5.00 & 5.00 & 5.00 \\
1958 & 5.01 & 5.01 & 4.98 & 4.96 & 4.96 & 4.95 & 4.96 & 4.97 & 4.97 & 4.98 & 4.96 & 4.93 \\
1959 & 4.96 & 4.95 & 4.89 & 4.92 & 4.95 & 4.89 & & & & & & \\
\hline
\end{tabular}


The Australian Loan Council

Year Jan. Feb. Mar. Apr. May June July Aug. Sep. Oct. Nov. Dec.

July 1959-1971: theoretical yield on 10-year bond (subject to tax rebate)

$\begin{array}{lllllllllllll}1959 & & & & & & & 4.86 & 4.83 & 4.83 & 4.83 & 4.82 & 4.83 \\ 1960 & 4.84 & 4.86 & 4.88 & 4.88 & 4.87 & 4.88 & 4.93 & 4.94 & 4.91 & 4.96 & 5.14 & 5.34 \\ 1961 & 5.43 & 5.38 & 5.42 & 5.41 & 5.43 & 5.38 & 5.32 & 5.28 & 5.28 & 4.99 & 4.89 & 4.88 \\ 1962 & 4.82 & 4.83 & 4.86 & 4.83 & 4.82 & 4.81 & 4.77 & 4.79 & 4.80 & 4.77 & 4.71 & 4.72 \\ 1963 & 4.71 & 4.69 & 4.66 & 4.52 & 4.44 & 4.37 & 4.39 & 4.34 & 4.31 & 4.29 & 4.26 & 4.29 \\ 1964 & 4.29 & 4.29 & 4.32 & 4.44 & 4.54 & 4.58 & 4.72 & 4.77 & 4.74 & 4.74 & 4.76 & 4.76 \\ 1965 & 4.77 & 4.78 & 5.12 & 5.15 & 5.15 & 5.15 & 5.16 & 5.16 & 5.15 & 5.15 & 5.15 & 5.15 \\ 1966 & 5.15 & 5.15 & 5.15 & 5.15 & 5.16 & 5.17 & 5.18 & 5.17 & 5.17 & 5.17 & 5.09 & 5.02 \\ 1967 & 5.01 & 5.02 & 5.02 & 5.03 & 5.04 & 5.03 & 5.02 & 5.01 & 5.01 & 5.03 & 5.02 & 5.10 \\ 1968 & 5.11 & 5.11 & 5.10 & 5.12 & 5.11 & 5.11 & 5.11 & 5.11 & 5.12 & 5.13 & 4.89 & 4.91 \\ 1969 & 4.92 & 4.92 & 4.93 & 4.95 & 5.10 & 5.35 & 5.53 & 5.55 & 5.59 & 5.63 & 5.66 & 5.64 \\ 1970 & 5.65 & 5.67 & \mathbf{6 . 0 0} & 6.52 & 6.55 & 6.52 & 6.52 & 6.52 & 6.49 & 6.43 & 6.38 & 6.41 \\ 1971 & 6.42 & 6.42 & 6.42 & 6.40 & 6.40 & 6.40 & 6.40 & 6.40 & 6.38 & 6.18 & & \end{array}$

July 1959-1971: theoretical yield on 20-year bond (subject to tax rebate)

$\begin{array}{lllllllllllll}1959 & & & & & & & 4.98 & 4.98 & 5.01 & 5.01 & 5.01 & 5.01 \\ 1960 & 5.01 & 5.01 & 5.01 & 5.01 & 5.01 & 5.01 & 5.02 & 5.01 & 5.01 & 5.02 & 5.22 & 5.26 \\ 1961 & 5.32 & 5.37 & 5.38 & 5.38 & 5.38 & 5.38 & 5.38 & 5.39 & 5.38 & 5.22 & 5.04 & 5.03 \\ 1962 & 5.00 & 5.00 & 5.01 & 5.01 & 5.00 & 4.95 & 5.00 & 5.00 & 5.01 & 4.99 & 4.97 & 5.00 \\ 1963 & 5.01 & 5.01 & 4.97 & 4.70 & 4.62 & 4.57 & 4.57 & 4.54 & 4.52 & 4.51 & 4.51 & 4.51 \\ 1964 & 4.51 & 4.51 & 4.52 & 4.68 & 4.72 & 4.75 & 4.98 & 5.00 & 5.01 & 5.01 & 5.01 & 5.01 \\ 1965 & 5.01 & 5.02 & 5.25 & 5.26 & 5.25 & 5.25 & 5.26 & 5.25 & 5.26 & 5.26 & 5.25 & 5.25 \\ 1966 & 5.25 & 5.25 & 5.25 & 5.25 & 5.25 & 5.25 & 5.25 & 5.25 & 5.25 & 5.25 & 5.25 & 5.25 \\ 1967 & 5.25 & 5.25 & 5.25 & 5.25 & 5.25 & 5.25 & 5.25 & 5.25 & 5.25 & 5.25 & 5.25 & 5.25 \\ 1968 & 5.25 & 5.25 & 5.25 & 5.25 & 5.25 & 5.25 & 5.25 & 5.25 & 5.25 & 5.25 & 5.02 & 5.03 \\ 1969 & 5.04 & 5.04 & 5.04 & 5.05 & 5.14 & 5.48 & 5.56 & 5.63 & 5.66 & 5.66 & 5.67 & 5.72 \\ 1970 & 5.73 & 5.70 & 6.20 & 6.60 & 6.60 & 6.60 & 6.54 & 6.55 & 6.55 & 6.50 & 6.47 & 6.49 \\ 1971 & 6.49 & 6.49 & 6.47 & 6.40 & 6.40 & 6.41 & 6.40 & 6.40 & 6.38 & 6.25 & & \end{array}$

Source: Reserve Bank of Australia Research Department.

Note: While undue significance should not be attached to small movements in yields, the series is believed to be a reasonable measure of major shifts in the level of yields. 
Since the Constitution was approved by the people, it has become generally accepted that central governments have a responsibility for the state of the economy. The development of economic understanding has made the influences determining the level of employment and the internal and external value of the currency so much clearer that governments can plan effective action to maintain a high level of employment and a stable currency.

After the harrowing experience of the depression years, it became the recognised and accepted task of the Commonwealth and not the States to play the major role in determining the stability and the rate of growth of the economy. The Joint Committee on Constitutional Review, composed of members of all federal political parties, agreed that summarily expressed aggregate expenditure should be-

(a) sufficient to maintain full employment;

(b) not so great as to involve-

(i) balance of payments difficulties;

(ii) cost increases relative to international competitors; or

(iii) rising prices;

(c) balanced as to give a healthy relationship between the various interdependent sectors of the economy. 1

It is, therefore, necessary that the Commonwealth Parliament should be able to exercise a stimulating or restraining influence on the magnitude of expenditure in the Australian economy. ${ }^{2}$

In a federation the difficulties in achieving these ends are much greater than in a unitary state, and in his review of the situation up to 1950, Giblin concluded that 'Some more coordinated system of expenditure of Commonwealth, States and local governments must be developed before any complete control of monetary policy is possible in Australia'. ${ }^{3}$

1 Report, para. 1031.

2 Ibid., para. 1066.

3 Giblin, Central Bank, 226. It might be emphasised that a co-ordinated system is close to being the direct opposite of a co-ordinate system. 
One vital constructive purpose of the Loan Council is that it is a co-ordinating authority which ended competitive governmental borrowing, with respect to both the costs and the amount. Broadly, the Loan Council decides the bond rate and short-term rates on governments' conversions and new borrowing for civil purposes, and it decides the amount, source, and allocation of long-term borrowing requiring the issue of securities. But what of the Commonwealth and the States; and in particular can the Commonwealth, with its currently much greater responsibility for general economic policy, directly or indirectly influence the Council's decisions? To answer this question, it is perhaps desirable to state briefly but clearly the division of constitutional power over specific parts of economic policy.

The Commonwealth is responsible for central banking policy and the control of enterprises engaged in the business of banking; it controls the exchange rate and foreign exchange reserves; and it manages the issue of currency, which it can use as public moneys for any purpose without Loan Council approval, provided securities are not given for the moneys and no charges are made. Securities for a defence loan from the bank or other sources do not require Loan Council approval. The Commonwealth has exclusive power over imports and exports, and customs and excise revenue. In the 1950s, this revenue, together with income tax, which the Commonwealth alone levied, amounted to about 70 per cent of tax revenue from all sources, Commonwealth and State. In respect of wages and incomes policy, the Commonwealth is confined substantially to setting up independent, unfettered authorities to settle by conciliation and arbitration disputes extending beyond the limits of one State. These authorities or courts decide national wages policy.

When it taxes, the Commonwealth must do so uniformly, which may to some extent reduce the flexibility of its fiscal policy. The Commonwealth might, through the financial corporations power or the joint use of the tax and banking powers, attempt to control the non-bank financial intermediaries as if they were banks, but this is an uncertain use of powers which remains to be tested in the High Court. The Commonwealth can garnishee a State's revenues in the event of default in its commitments under the Financial Agreement, but this power is relatively unimportant as a means of carrying out general policy.

The States share concurrently with the Commonwealth the power to impose all forms of taxation except customs and excise though they have de facto lost the ability to impose income tax. Each State, like the Commonwealth, has the power to use for all purposes its public moneys without intervention by the Commonwealth except in the event of default under s.105A. The States can borrow money from certain sources within their respective territories for long-term, civil purposes and they are accountable to the Loan Council only with respect to the costs, unless securities are issued in which case they become part of the loan program. The States 
can conduct State banking within their own territories free from any Commonwealth controls, and are free to bank and arrange overdrafts where they wish, being subject only to the Loan Council with respect to the costs of overdrafts. The States have had authority over non-banking financial institutions that deal in money but are not defined as banking in the sense in which that word is used in the Constitution; for a brief period the Commonwealth took direct action through the use of the tax power, but this did not, and could not, give the Commonwealth the wide scope it requires to regulate non-bank intermediaries as if they were banks. The Commonwealth has refrained from attempting to act indirectly through the States, not only because it would be difficult but because it has managed that sector by open market operations. The States retain the power over industrial disputes, including wages and incomes, confined to their own territory, and most of land settlement, urban affairs and transport, which are the major areas of economic development. ${ }^{4}$ Their ability to finance development from loans was made subject to the Loan Council in the 1927 Agreement, and their freedom of action has been limited by the Commonwealth's ability to induce them to vacate the income tax field under the joint use of ss.51(ii) and 96 whereby the Commonwealth achieved indirectly what it could not do directly; and it is clear from the dictum of Latham CJ. that the Commonwealth can control the level and composition of States' and semi-governmental expenditure by conditional and unconditional grants, and pass legislation whereby 'all State powers could be controlled by the Commonwealth'. The Commonwealth has, however, exercised great care not to leave any impression that it has such a purpose in view. ${ }^{5}$

In answer to the question whether the Commonwealth can, as it has with the States, achieve indirectly in the Loan Council what it is not directly empowered to do, the answer is, briefly, that it can. The decisions that the Commonwealth needs to influence are the bond rate on conversions and new issues for long-term, civil purposes; the amount and possibly the allocation of the loan program at home and abroad for the States and their authorities; and the cost and amount of governmental borrowing for temporary purposes by way of overdraft or fixed or other deposit. The Commonwealth has the following means at its disposal.

In all decisions but those relating to the use by a State of its own securities to borrow abroad, and the allocation of the loan program, the Commonwealth needs only a majority vote to achieve its purposes, which means the votes of two of the six States. The Council meets in camera, and there is always opportunity for bargaining and persuasion outside the meeting as well as within it whereby a sufficient number if not all of the States conform to the Commonwealth's wishes in return for grants under s.96,

\footnotetext{
4 Examples of exceptions are interstate and overseas airlines, the Commonwealth's rail-
} ways and the Commonwealth's responsibility for the Northern Territory.

5 Menzies, Storey Memorial Lecture. 
or some other arrangement, such as the timing and direction of the Commonwealth's own development expenditure, which benefit States affected. Deals can be quietly made; such political arrangements are understandable, practicable and effective. They are also necessary, and s.96 is important once again for the purpose.

One important area for negotiation is the size of the loan program. The Loan Council decides the rate of interest and the other conditions of borrowing. Having decided the price, it is not possible to be sure what the private sector of the market will supply. The only certain thing is the uncertainty of the outcome. But the States desire for political and administrative purposes to know what their share of a certain, known loan program will be and tend to look to the Commonwealth for assurances which the Commonwealth's knowledge and power to influence the market enable it to give; ${ }^{B}$ the Commonwealth may also be willing to subscribe to the balance of an agreed program from its own resources if the loan market does not meet it, so providing not only assurance but a guarantee.

The Commonwealth derived advantage from doing this. It kept the level of State and semi-governmental civil works expenditure at a known predictable level; that assisted greatly in ensuring that fiscal policy prevented fluctuations which it would be impossible for monetary policy to correct. It therefore met the kind of co-ordinating purpose Giblin envisaged. To this end, the Commonwealth has, since 1951-52, openly agreed to a loan program in excess of what can be expected from the market on the understanding that the State governments would fulfil certain conditions designed to promote governmental loan raisings in each year, including the placing of a firm ceiling on borrowing by semi-governmental and local authorities. For its part the Commonwealth undertook to make available the Australian currency equivalent of any new money loans it might be able to raise overseas for general purposes; to leave to the States for housing and works purposes the whole of the proceeds of public loan raisings in Australia; to make monthly payments to the States; and to refinance maturing loans not converted, the last of which the Commonwealth would do from the Sinking Fund or from its own resources subject to the States indemnifying the Commonwealth on an agreed basis. ${ }^{7}$

Should the loan market meet the program decided by the Council so that 'special loan assistance' is not required from the Commonwealth, as in 1962-63 and 1963-64, then the Commonwealth has, in addition to the power to make deals with s.96 grants, the power not to agree to the distribution of the program, as decided by the States, and to demand a one-fifth share of the program, or less, according to the formula. The Commonwealth

6 Through the central bank, the National Debt Commission and defence loans.

7 See successive Budget Speeches since 1951-52, Statement relating to Loan Transactions; Budget Speech, 1955-56, 12, and Commonwealth Payments to or for the States 1962-63 (Canberra, 1962), 33. 
could in practical political terms demand a much smaller proportion than its fifth, the margin being large enough just to dislocate States' works programs and to persuade sufficient States to conform to the Commonwealth's wishes about the bond rate and any other conditions it desired. It was notable that from the inception of the Commonwealth and State Housing Agreement in 1945, under which the Commonwealth permitted the States to nominate a certain proportion of the loan programs for housing, which then became the Commonwealth's formal share of the program, and which it subsequently made available to the States as a 5.96 grant under the Housing Agreement, the proportion of the Commonwealth's share did not exceed 21.75 per cent of the loan program, and it was above 20 per cent in only three years between 1947.48 and 1965-66.8 There was therefore in the loan program after $1947-48$ a small margin which the Commonwealth could claim out of its 20 per cent share according to the formula, without disrupting completely the procedure for determining the amount for housing under the Housing Agreement. This may have been intended, certainly after 1946-47.9 Even so, the use of the allocation power by the Commonwealth remains an uncertain means of control because of the possibility of heavy private subscriptions to the loan program, particularly if there were large movements of international capital or if the rate of net immigration declined sharply for several consecutive years. The results could be an embarrassment of riches for the States which the Commonwealth would have to live with or treat as an occasion to cut or reduce the rate of increase of assistance under $\mathrm{s} .96$ for revenue or capital purposes.

The further division of economic powers in the Financial Agreement was, therefore, in principle, no constitutional barrier to the Commonwealth achieving its purposes for fiscal and monetary policy. 'It has in practice further enhanced the financial supremacy of the Commonwealth.'10

None the less, administratively and politically the use of the Commonwealth's strong bargaining position presents difficulties and it might be as well to end this review of the Constitution on a practical and sobering note. In the opinion of Dixon J:

It may be conceded that the Financial Agreement under s.105A of the Constitution and the adoption of the system of uniform taxation of incomes place the finances of the States in a very different position from that which they occupied when the Commonwealth was first established. . .

8 Commonwealth Payments to or for the States 1965-66 (Canberra, 1965), 70.

9 'Conference of Commonwealth and State Ministers, 22-23 June 1955', 6, where the Prime Minister, R. G. Menzies, said, 'In brief, the amount to be made available . . for housing ought to be subject to limits ... we must ourselves be in a position to determine the size of our liabilities'.

10 K. H. Bailey, 'Fifty Years of the Australian Constitution', 25 A.L.J. 1951, 324. 
Section 105A cuts across the Constitution and, as has been construed in this Court, imposes upon the States absolute liabilities to the Commonwealth enforceable against the revenues of the States. Extensions of constitutional power or supremacy may explain, but they do not justify, further extensions. ${ }^{11}$

The pace of change to further extensions within the Constitution will be slow while federation continues to suit most Australians and the State Parliaments and authorities continue to administer competently and to indicate clearly that they understand the needs of their own areas and people. ${ }^{12}$ As 'the great negotiator', the Commonwealth will not hasten changes. The great financial power of the Commonwealth will be exercised, therefore, in such a way as to permit the States to discharge their constitutional duties, but in the belief that excessive emphasis upon purely local rights while the Commonwealth continues Uniform Tax merely reveals unawareness of the great changes which Australian federation has sustained and which the people seem to have accepted.13

In this broad context an important role will continue for the Loan Council and for the Premiers' Conferences, each being a highly significant instrument of co-operative federalism. The main difference between them is that while it exists legally, the Loan Council is bound by statutory requirements to meet and decide certain vital matters. It is notable that those matters are explicitly defined and small in number whereas the Premiers' Conference can range over the whole field of policy and is bound by no legal restraints or obligations whatsoever. The two together have what may be a satisfactory kind of balance for co-operative management of the federation.

A study of the origin and life of the Loan Council must none the less be the record of the rise and then the decline in importance of this institution in the federation. Until the depression revealed the great need for a strong central government able to manage the economy in a manner which prevented serious economic fluctuations, the Loan Council enjoyed a few brief years as the central, federal economic policy-forming institution. The relationship of the Loan Council as handmaiden to the Premiers' Conference which drew up the Premiers' Plan of June 1931 is analogous to the modern relationship between the Loan Council and the Commonwealth government.

The analysis has been undertaken with the legal basis of the separation of powers clearly in view. The importance of this is that it has clarified the particular avenues of economic policy which the members of the Loan

11 Dixon J., Melbourne Corporation v. The Commonwealth (1947), 74 C.L.R., 84-5.

12 Menzies, Storey Memorial Lecture; C.P.D., 7 September 1960, 887-8.

13 R. G. Menzies, 'The Challenge to Federalism', Melbourne University Law Review, vol, 3, 1961-62, 14 . 
Council can insist that it shall decide; and it clarifies also how far the Commonwealth can go in achieving indirectly what it has not the power to do directly under the Constitution and the Financial Agreement. The Commonwealth is in a position to persuade or oblige the States to reach decisions that are in step with the many other parts of the Commonwealth's general economic policy.

It is important to emphasise that the techniques of persuasion and co-operation through consultation are the dominant methods used, and that these methods are as relevant in modern conditions as they were to the advocates of this modus operandi at the Convention Debates. Behind this is the fact that 'it is the Australian Nation which is sovereign'; ${ }^{14}$ the people agreed to unite and in so doing they agreed to limit the powers of the States to which they belonged, because they were aware that, at the same time, they were citizens of both the State and the Commonwealth.

It transpired, however, that because the States gave up their independent control of their borrowing and interest rate policy to the Loan Council, and because the Commonwealth can directly or indirectly persuade or oblige the Council to reach decisions it desires, the Financial Agreement has enhanced the power of the Commonwealth in monetary and fiscal policy. Further, while it was intended that the Financial Agreement should knit the federation more closely together in that the members are obliged to co-operate in the spheres of policy for which the Council makes decisions, to the extent that the Commonwealth can directly and indirectly influence those decisions, it has been an unintended centripetal development in the federation. But then it can be argued that Keynesian economics sounded the knell of federal theory.

In any event, the fact that the working of the Financial Agreement has been different from what was intended when it was conceived in the pre-Keynesian era does not mean that it has not been an acceptable development-the advantages which have flowed from it have been considerable, primarily in the maintenance of a steady but growing loan program, often by subscriptions by the Commonwealth government or its authorities, including the central bank; fluctuations in government expenditure as a direct result of variations in private subscriptions to the Loan Council's programs have been avoided as part of Keynesian economic policy since 1938.

Not the least important influence on the acceptance of the new arrangement is that, during the $1950 \mathrm{~s}$ and in the early $1960 \mathrm{~s}$, the States received a certain, predictable amount of loan money for their works programs which was more than the uncertain and smaller amount of private subscriptions. Just as in 1927 when the Financial Agreement was framed, the States stood to gain financially and politically from the new arrangement, so under the

14 Ibid., 5. 
post-war procedures that have altered the practical effects of the Agreement, the States have derived the financial and political advantages from larger sums to spend than the private subscriptions to the loan program provided.

The strength of the Commonwealth's position was greatly enhanced by the validity of Uniform Tax in peacetime. It gave the Commonwealth huge resources from which to draw and great power over the States, which suddenly became dependent upon the Commonwealth for about half their revenue, excluding business undertakings. The importance of this is manifold, but for the Loan Council there is a special implication. This is that, as by the nature of government expenditure only marginal adjustments are usually desired, so major changes between States in the allocation of the loan program are difficult to make, and this rigidity has made flexible adjustments necessary in some other way in respect of moneys for capital purposes in the States. This the Commonwealth has steadily been doing since the 1950s to an increasingly important degree by means of specific purpose grants, particularly those for capital purposes, which have been a means of offsetting inflexibility in the Loan Council's decisions. Although these developments in the use of s.96 grants for specific capital purposes are outside the compass of what is strictly the Financial Agreement, they are none the less intimately related to the Loan Council in that its failure to be flexible obliged the Commonwealth to take steps under s.96 to perform a function which, in the sphere of capital expenditure by the States, is analogous to the function which the Grants Commission performed on the revenue side of claimant States' accounting and expenditure on services. The general revenue or financial assistance grants since 1959 and specific purpose grants for revenue purposes have also reduced the role of the Grants Commission materially.

The development of greater dependence upon the Commonwealth increased the centripetal movement and there was up to the mid-1960s little public demand for a reversal, except in Victoria with respect to Uniform Taxation. ${ }^{15}$ Nevertheless, the predominant wish of the people is that the States should continue in their traditional role of administering the expenditure of revenue and loan moneys. The fact that the Commonwealth now provides about one-half of States' revenues and exercises considerable control over the Council's decisions about the size of the loan program for capital works purposes has not eliminated but has merely qualified the utility of the States to the electorate. But it will be an uneasy alliance while so much revenue is raised by one government for others to spend.

This great political factor in the situation will fashion the course that the Loan Council will follow in the future. There are several possible 
developments which could lead to a regeneration of its importance. One would be a change from making what are traditionally small marginal adjustments in the allocation of the loan program to a position which meets the need to make bigger changes quickly. This seems unlikely, and the Commonwealth can be expected to achieve these ends by taking over State responsibilities such as their debt and by general and specific purpose grants under s.96. This issue is important because the decisions about the allocation of loans for capital development determine the course of an important part of the nation's growth.

The Loan Council could also become more significant if it were to make recommendations through its members to their respective Executives about the problem of controlling the non-banking financial intermediaries so that they conform to a national monetary policy which is in accord with the Commonwealth's general control of the economy. In this rapidly developing sphere of economic policy, there is analogy between the conditions in 1923 and present problems, except that the modern situation is more complex. It is an area of policy which will be explored with care and it seems very unlikely that the Commonwealth will seek the co-operation of the States if it can achieve its ends by direct means through its existing powers, apart from the use of $\mathrm{s.96}$, which it could be expected to use as a last resort, perhaps after trying and failing in some measure of voluntary co-operation with the States. That is a matter for the future and then only after it has been proven beyond all doubt that there is a need for strong Commonwealth intervention.

In the search for a simple note upon which to end, it is perhaps timely to refer back to Knox and his original conception of what the Loan Council might be. There is a permanency and deep perception in his view that the authority which was established should be primarily of an advisory character. This is a function which cannot be taken from the Loan Council while it exists, whether it be until 1980 or, it is submitted, until 53 years after the last new loan is floated by the Commonwealth for and on behalf of the States.

If the Loan Council ceases to exist in 1980, the problems created by the return to independent borrowing by the States will be settled in the context of relations between the Commonwealth and the States at that time. It is reasonable to expect, from the trend in federal-State financial relations, that the Commonwealth's position will have been strengthened by further evolution of the popular expectation, evident since the 1930s, that the Commonwealth rather than a supra-federal authority should manage the nation's general economic policy. 


\section{Selected Bibliography}

Official Reports and Files

Canadian Royal Commission on Provincial Relations, Report of Proceedings, 1937.

The Case of the People of Western Australia to withdraw from the Commonwealth, Perth, 1934.

The Case for Union-A Reply, Canberra, 1934.

The Commonwealth Bank in the Second World War, Sydney, 1947.

The Central Bank's Annual Reports ('Commonwealth Bank' until January 1960, and 'Reserve Bank' since then).

Committee on the Working of the Monetary System, London, 1960.

Commonwealth Grants Commission Annual Reports, Canberra, annually since 1933.

Commonwealth Payments to and for the States, issued by the Commonwealth Treasury, Canberra, annually since the 1961-62 Budget.

Files of the Commonwealth Government, Commonwealth Archives, Canberra.

Files of the New South Wales Treasury, Mitchell Library, Sydney.

Hansard of Commonwealth and Six State Parliaments.

Official Records of the Debates of the Australasian Federal Conventions: First Session (Sydney, 1891)

(Adelaide, 1897)

Second Session (Sydney, 1897)

Third Session (Melbourne, 1898).

Official Record of the Proceedings and Debates of the Australasian Federation Conference, Melbourne, 1890.

Overseas Investment in Australia, issued by the Commonwealth Treasury, 1960.

Proceedings of the Australasian Federal Convention (with Papers Ordered to be Printed), Adelaide, 1897.

Parliamentary Papers, Journals and Proceedings of the Parliaments of the Commonwealth, and the Six States, 1901 to date. 
Premiers' and Ministers' Conferences, Reports of Proceedings in Parliamentary Papers and Proceedings.

Report of the British Economic Mission, Canberra, 1929; also in Commonwealth Parliamentary Papers, 1929.

Report of the Committee of Economic Enquiry (Commonwealth of Australia, May 1965). Appointed by the Prime Minister in February 1963, to report to the Commonwealth Government.

Report from the Joint Committee on Constitutional Review, Canberra, 1959.

Report of the Royal Commission on the Finances of South Australia as Affected by Federation, Adelaide, 1929.

Report by Treasury Officers: Resumption of Income Tax by the States, Canberra, 1953.

Royal Commission on the Constitution of the Commonwealth, 1927-8.

Minutes of Evidence (Canberra, 1927)

Report (Canberra, 1928).

Royal Commission to Inquire into The Monetary and Banking Systems in Australia.

Report (Canberra, 1937)

Minutes of Evidence (2 vols.) (Canberra, 1936).

The Australian Economy, Annual Survey issued by the Commonwealth Treasury since 1956.

The Australian Tariff, An Economic Enquiry, Melbourne, 1929. Report of an informal Committee set up by the Rt Hon. S. M. Bruce, Prime Minister of Australia, in 1927.

The books of documents published by Copland and Janes, Shann and Copland, in the 1930s contain copies of many important letters and cables from official files. The newspapers and Hansard did likewise at the time.

Official Periodical Reports, Publications and Statistical Bulletins

Annual Reports of Auditors-General of Commonwealth and the States.

Balance of Payments and Bulletin of Overseas Investment in Australia (C.B.C.S.).

Central Bank's Statistical Bulletin (monthly), including Financial Supplements, and Occasional Paper No. 4A.

Commonwealth Demography Bulletin (C.B.C.S.).

Commonwealth Finance Bulletins (C.B.C.S.).

Commonwealth Law Reports (C.L.R.).

Commonwealth and States Acts.

Monthly Review of Business Statistics (C.B.C.S.).

National Debt Commission Annual Reports.

National Income and Expenditure (Australian National Accounts), annually. Official Year Book of the Commonwealth of Australia (C.B.C.S.) (short title,

Commonwealth Year Book). 
Official Year Books of the Six States.

Treasury Information Bulletins and Supplements.

Newspapers

Advertiser, Adelaide.

Adelaide Register.

Age, Melbourne.

Argus, Melbourne.

Australasian Insurance and Banking Record (monthly).

Daily Telegraph, Sydney.

The Economist, London.

Herald, Melbourne.

Mercury, Hobart.

The Times, London.

\section{Periodical Literature and Published Lectures}

Adarkar, B. P., 'Federal Finance in Australia', Economic Record, vol. XIII, no. 22, June 1936.

Arndt, H. W., 'The Postwar Bond Market', Economic Record, vol. XXX, no. 59, November 1954.

Atkin, J. 'Official Regulation of British Overseas Investment, 1914-1931', Economic History Review, 2nd Series, vol. XXIII, no. 2, August 1970.

Badger, D. G., 'Australia's Foreign Exchange', Economic Record, vol. XXXI, no. 60, May 1955.

Bailey, K. H., 'The Working of the Constitution Since Federation', in G. V. Portus (ed.), Studies in the Australian Constitution, Sydney, 1933.

- 'The Uniform Tax Case', Economic Record, vol. XX, no. 39, December 1944 .

Bambrick, Susan, 'Indexes of Average Prices of Australian Imports from the United Kingdom, 1919-20 to 1927-28', Australian Economic Papers, vol. 6, no. 9, December 1967.

Bruce, S. M., 'The Financial and Economic Position of Australia', Joseph Fisher Lecture in Commerce, Adelaide, 1927.

Brown, H. P., 'Composition of Personal Income', Economic Record, vol. XXV, no. 48, June 1949.

- 'Giblin and the Grants Commission' in Copland, D.B. (ed.), GiblinThe Scholar and The Man, Melbourne, 1960.

Butlin, N. G., 'Some Structural Features of Australian Capital Formation, 1861 to 1938/39', Economic Record, vol. XXXV, no. 72, December 1959.

- 'Some Perspectives of Australian Economic Development, 1890-1965', in Forster, C. (ed.), Australian Economic Development in the Twentieth Century, London, 1970. 
Butlin, S. J., 'The Problem of Federal Finance', Economic Record, vol. XXX, no. 54, May 1954.

Canaway, A. P., 'Section 105A of the Commonwealth Constitution', 12 A.L.J., 1939.

Colebatch, Hal, 'Australian Credit as Viewed from London', Economic Record, vol. 3, no. 5, November 1927.

Copland, D. B., 'An Economic Survey of Australia', Annals of the American Academy of Political and Social Science, November 1931.

Cowper, N., 'The Financial Agreements', in G. V. Portus (ed.), Studies in the Australian Constitution, Sydney, 1937.

- 'The First Financial Agreement', Economic Record, vol. VIII, no. 15, December 1932.

Davidson, A. C., 'Australia's Share in International Recovery', The Joseph Fisher Lecture in Commerce, Adelaide, 1932.

Davis, S. R., 'A Vital Constitutional Compromise', University of Western Australia Annual Law Review, vol. 1, no. 1, December 1948.

- 'A Unique Federal Institution', University of Western Australia Annual Law Review, vol. II, no. 2, December 1952.

Dyason, E. C., 'The Australian Public Debt', Economic Record, vol. III, no. 5, November 1927.

Fisher, A. G. B., 'Crisis and Readjustment', Journal of Political Economy, December 1934.

Fitzgerald, T. M., Review of J. T. Lang's The Great Bust, in Nation, 5 May 1962.

Giblin, L. F., 'Federation and Finance', Economic Record, vol. II, no. 3, November 1926.

- 'Australie Agonistes', Australian Quarterly, no 8, December 1930.

- 'Financial Aspects of the Constitution' in A.I.P.S., Federation in Australia, Melbourne, 1949.

Gilbert, R. S., 'Structural Trends in Australian Imports', Economic Record, vol. XXXV, no. 70, April 1959.

- 'World Payments and the I.M.F.', The Banker, September 1961.

- 'London Financial Intermediaries and Australian Overseas Borrowing 1900-1929', Australian Economic History Review, vol. XI, no. 1, March 1970.

The Governor of the Commonwealth Bank of Australia, Memoranda of Evidence, Committee on the Working of the Monetary System, vol. I, London, 1960.

Hart, P. R., 'Lyons: Labor Minister-Leader of the U.A.P.' in R. Cooksey (ed.), The Great Depression in Australia, Canberra, 1970.

Henderson, R. F., 'Monetary Policy in Australia, 1960-61', Economic Record, vol. 37, no. 79, September 1961 .

Herbert, C. H., 'A Loan Council for Canada', Canadian Journal of Economics and Political Science, vol. 2, no. 3, August 1936. 
Hiley, T. A., 'Federal, State and Local Government Finance', Local Government in Queensland, February 1962.

Keating, M., 'Australian Work Force and Employment, 1910-11 to 1960-61', Australian Economic History Review, vol. VII, no. 2, September 1967.

La Nauze, J. A., 'Alfred Deakin and the Morning Post', Historical Studies, vol. 6, no. 24, May 1955.

- 'Who Were the Fathers?' Historical Studies, vol. 13, no. 51, October 1968.

Laski, H. J., 'The Obsolescence of Federalism', New Republic, 3 May 1939.

Lees, D. S., 'Public Departments and Cheap Money', Economica, February 1955.

McLean, I. W., 'The Australian Balance of Payments on Current Account, 1901 to 1964-65', Australian Economic Papers, vol. VII, no. 10, June 1968.

Martin, A. W., 'Economic Influences in the "New Federation Movement" ', in Eastwood, J. J. and Smith, F. B. (eds.), Historical Studies-Selected Articles, Melbourne, 1964.

May, R. J., 'The Commonwealth Grants Commission', Public Administration, vol. XXI, no. 3, September 1962.

Melville, L. G., 'Report of the British Economic Mission', Australian Quarterly, no. 1, March 1929.

Menzies, R. G., 'Problems of Management in a Federation', Inaugural John Storey Memorial Lecture, University of Melbourne, 1962.

- 'The Challenge to Federalism', Melbourne University Law Review, vol. 3, 1961-2.

Mills, R. C., 'The Financial Relations of the Commonwealth and the States', Economic Record, vol. IV, no. 6, May 1928.

- 'Australian Loan Policy' in Campbell, P., Mills, R. C., and Portus, G. V. (eds.), Studies in Australian Affairs, Melbourne, 1930.

Phillips, J. G., 'Recent Developments in Monetary Policy in Australia', The E. S. \& A. Bank Lecture, University of Queensland, 1964.

Prest, W., 'The Economics of Federal-State Relations' in Arndt, H. W. and Corden, W. M. (eds.), The Australian Economy, 1956-62, Melbourne, 1963.

- 'Federal-State Financial Relations' in Economic Papers of the Economic Society of Australia and New Zealand, New South Wales and Victorian Branches, no. 20 of October 1965.

- 'Federalism in Australia: the Role of the Commonwealth Grants Commission', Journal of Commonwealth Political Studies, vol. V, 1967.

Raws, Lennon, 'Australian Loan Expenditure', Economic Record, vol. IV, no. 7, November 1928.

Robertson, J. R., 'Scullin as Prime Minister: Seven Critical Decisions' in Cooksey, R. (ed.), The Great Depression in Australia, Canberra, 1970. 
Rose, P. J., 'Recent Developments in the Australian Money Markets', Banker's Magazine, October 1965.

Sawer, G., 'The Second Uniform Tax Case', 31 A.L.J., September 1957.

- 'Judicial Decisions Affecting Public Administration, 1956-58', Public Administration, vol. XVII, no. 2, June 1958.

- 'The Commonwealth and the States', Current Affairs Bulletin, 11 January 1971.

Watt, E. D., 'Secession in Western Australia', University Studies in Western Australian History, vol. III, no. 2, October 1958.

Wilson, R., 'Australian Monetary Policy Reviewed', Economic Record, vol. VII, no. 13, November 1931.

Wright, D. I., 'The Politics of Federal Finance: the First Decade', Historical Studies, vol. 13, no. 52, 1969 .

\section{Symposia of Articles and Lectures}

Adler, J. H. (ed.), Capital Movements, New York, 1967.

Arndt, H. W. and Corden, W. M. (eds.), The Australian Economy, A Volume of Readings, Melbourne, 1963.

Bland, F. A. (ed.), Changing the Constitution, Sydney, 1950.

Campbell, D. A. S. (ed.), Postwar Reconstruction in Australia, Sydney, 1944. Campbell, Persia, Mills, R. C. and Portus, G. V. (eds.), Studies in Australian Affairs, Sydney, 1930.

Cambridge History of the British Empire, vol. VII, part 1, Cambridge, 1939. Cooksey, R. (ed.), The Great Depression in Australia, Canberra, 1970.

Copland, D. B. (ed.), Giblin-The Scholar and the Man, Melbourne, 1960. Davis, S. R., (ed.), The Government of the Australian States, Melbourne, 1960.

Duncan, W. G. K. (ed.), Trends in A ustralian Politics, Sydney, 1935.

Eastwood, J. J. and Smith, F. B., Historical Studies-Selected Articles, Melbourne, 1964.

Else-Mitchell, R. (ed.), Essays on the Australian Constitution, Sydney, 1952. Federalism in Australia. Papers read at 15th A.I.P.S. Summer School, Melbourne, 1949.

Forster, C. (ed.), Australian Economic Development in the Twentieth Century, London, 1970.

Paton, G. W. (ed.), The Commonwealth of Australia, London, 1952.

Portus, G. V. (ed.), Studies in the Australian Constitution, Sydney, 1933. Sawer, G. (ed.), Federalism, Melbourne, 1952.

\section{Books and Theses}

Arndt, H. W., The Australian Trading Banks (2nd ed.), Melbourne, 1960. - and Harris, C. P., The Australian Trading Banks (3rd ed.), Melbourne, 1965.

Barnard, M., A History of Australia, Sydney, 1962. 
Benham, F. C., The Prosperity of Australia: An Economic Analysis, London, 1928.

Birch, A. H., Federalism, Finance and Social Legislation, Oxford, 1955.

Brigden, J. B., Escape to Prosperity, Melbourne, 1930.

Britain-An Official Handbook, 1954, London, 1954.

Butlin, N. G., Investment in Australian Economic Development 1861-1900, Cambridge, 1964.

- Australian Domestic Product, Investment and Foreign Borrowing, 1861-1938/39, Cambridge, 1962.

Butlin, S. J., War Economy 1939-1942, Canberra, 1955.

- Hall, A. R. and White, R. C., Australian Banking and Monetary Statistics 1817-1945, published by Reserve Bank as Occasional Paper no. 4A, Sydney, 1971.

Campbell, W. J., Australian State Public Finance, Sydney, 1954.

Canaway, A. P., The Failure of Federalism in Australia, London, 1930.

Clark, A. Inglis, A ustralian Constitutional Law (2nd ed.), Melbourne, 1905.

Clark, Colin and Crawford, J. G., The National Income of Australia, Sydney, London, 1938.

Cockburn, J. A., Australian Federation, London, 1901.

Cooke, S. R. and Davenport, E. H., Australian Finance, Dedicated to the Imperial Conference 1926, London, 1926.

Coombs, H. C., 'The Development of Monetary Policy in Australia' and 'Conditions of Monetary Policy in Australia' in Other People's Money, Canberra, 1971.

Copland, D. B., Australia in the World Crisis 1929-1933, Cambridge, 1934.

- and Barback R. H. (eds.), The Conflict of Expansion and Stability (a book of documents), Melbourne, 1957.

- and Janes, C. V. (eds.), Cross Currents in Australian Finance (a book of documents), Sydney, 1936.

Cramp, K. R., The State and Federal Constitutions of Australia, Sydney, 1914.

Crisp, L. F., The Australian Federal Labor Party 1901-1951, London, 1955.

- Ben Chifley, Melbourne, 1961.

- The Parliamentary Government of the Commonwealth of Australia (3rd ed.), Adelaide, 1961.

Coghlan, T. A., A Statistical Account of the Seven Colonies of Australasia, 1899-1900, Sydney, 1900.

Deakin, Alfred, The Federal Story (2nd ed.), Melbourne, 1964.

Denning, Warren, Caucus Crisis, Sydney, 1937.

Eggleston, F. W., Reflections of an Australian Liberal, Melbourne, 1953. Ellis, U. R., A History of the Australian Country Party, Melbourne, 1963.

Encel, S., Cabinet Government in Australia, Melbourne, 1962.

Evatt, H. V., The King and His Dominion Governors, London, 1936. 
Fitzhardinge, L. F., William Morris Hughes, A Political Biography, Sydney, 1964.

Fitzpatrick, B., The Australian People 1788-1945, Melbourne, 1946.

Forster, Colin, Industrial Development in Australia 1920-1930, Canberra, 1964.

Garnett, A. C., Freedom and Planning in Australia, Wisconsin, 1949.

Giblin, L. F., The Growth of a Central Bank, Melbourne, 1951.

Gilbert, R. S., The Australian Loan Council 1923-1929, M. A. thesis, 1958, University of Adelaide.

Gollan, R., Radical and Working Class Politics, Melbourne, 1960.

- The Commonwealth Bank of Australia-Origins and Early History, Canberra, 1968.

Greenwood, G., The Future of Australian Federalism, Melbourne, 1946. Haig, B., Measurements and Explanation of Inventory Changes in the Australian Economy, M. Com. thesis, University of Melbourne.

Hicks, U. K., The Finance of British Government 1920-1936, Oxford, 1938.

Hill, M. R., Commonwealth Bond Market, Economic Society of Australia and New Zealand, N.S.W. Branch, Monograph no. 309.

Holder, R. F., Bank of New South Wales History 1817 to 1970 (2 vols.), Sydney, 1971.

Hunter, J. S. A., Interest Rates in Australia 1931-1956, M. Com. thesis, 1958, University of Melbourne.

Jauncey, L. C., Australia's Government Bank, London, 1933.

Kahn, A. E., Great Britain in the World Economy, New York, 1946.

Lamberton, D. McL., Security Prices and Yields 1875-1955, Sydney, 1960.

La Nauze, J. A., Political Economy in Australia, Melbourne, 1949.

- Alfred Deakin, A Biography (2 vols.), Melbourne, 1965.

- Federated Australia-Selections from letters to the Morning Post 1900-1910 by Alfred Deakin, Melbourne, 1968.

Lang, J. T., The Great Bust, The Depression of the Thirties, Sydney, 1962. League of Nations, International Currency Experience [n.p.], 1944.

Longmuir, H. R., 'The Short Term Money Market in Australia', Jobson's Digest Year Book 1962, Sydney, 1963.

McFarlane, Bruce, Professor Irvine's Economics in Australian Labor History, Canberra, 1966.

Mackay, A. L. G., The Australian Banking and Credit System, London, 1931.

Maclaurin, W. R., Economic Planning in Australia 1929-1936, London, 1937.

Maxwell, James A., Commonwealth-State Financial Relations in Australia, Melbourne, 1967.

May, R. J., Federation and Financial Inequalities in Australia, M. Econ. thesis, University of Sydney, 1964. 
Menzies, R. G., Central Power in the Australian Commonwealth, London, 1967.

Miller, J. D. B., Australian Government and Politics (2nd ed.), London, 1959.

Mills, R. C. and Benham, F. G., Money Banking and Foreign Exchange, Sydney, 1925.

Mitchell, E. F., What Every Australian Ought to Know, Melbourne, 1931.

- A Supplement to What Every Australian Ought to Know, Melbourne, 1933.

- A Supplement to What Every Australian Ought to Know, Addenda, Melbourne, 1933.

Moore, W. Harrison, The Constitution of the Commonwealth of Australia (2nd ed.), Melbourne, 1910.

Nicholas, H. S., The Australian Constitution (2nd ed.), Sydney, 1952.

Overacker, L., The Australian Party System, Yale, New Haven, 1952.

Page, Earle, Truant Surgeon, Sydney, 1963.

Plumptre, A. F. W., Central Banking in the British Dominions, Toronto, 1940.

Pomroy, J., Aspects of Commonwealth Borrowings Overseas 1950-51 to 1961-62, M.Com. thesis, A.N.U., 1966.

Quick, J. and Garran, R. R., The Annotated Constitution of the Commonwealth, Sydney, 1901.

Ratchford, B. U., Public Expenditures in Australia, Durham, N. C., 1959.

Robinson, W. S., If I Remember Rightly, Melbourne, 1967.

Rose, P. J., Australian Securities Markets, Melbourne, 1969.

Royal Institute of International Affairs, The Problem of International Investment, London, 1937.

- Survey of British Commonwealth Affairs, vol. II, London, 1940.

Sawer, G., Australian Federal Politics and Law 1901-1929, Melbourne, 1956.

- Australian Federal Politics and Law 1929-1949, Melbourne, 1963.

- Cases on the Constitution of the Commonwealth of Australia (3rd ed.), Sydney, 1964.

Schedvin, C. B., A ustralia and the Great Depression, Sydney, 1970.

Shann, E. O. G., The Boom of 1890-and Now (2nd ed.), Sydney, 1927.

- An Economic History of Australia, Cambridge, 1930.

- and Copland, D. B. (eds.), The Crisis in Australian Finance (a book of documents), Sydney, 1931.

- The Battle of the Plans (a book of documents), Sydney, 1931.

- The Australian Price Structure 1932 (a book of documents), Sydney, 1933.

Smith, A. N., Thirty Years: The Commonwealth of Australia, 1901-1931, Melbourne, 1933.

Sutcliffe, J. T., The National Dividend, Melbourne, 1926.

Sweetman, E., Australian Constitutional Development, Melbourne, 1925. 
Teare, H. E., Australian Banking, Currency and Exchange, Sydney, 1926.

Tew, Brian, International Monetary Co-operation 1945-60 (5th ed.), London, 1960.

Thomas, Brinley, Migration and Economic Growth, Cambridge, 1954.

Triffin, R., Gold and the Dollar Crisis, New Haven, 1960.

Turner, H. G., The First Decade of the Australian Commonwealth, Melbourne, 1911.

United Nations, International Capital Movements During the Inter-war Period, New York, 1949.

Walker, E. R., Australia in the World Depression, London, 1933.

- The Australian Economy in War and Reconstruction, New York, 1947.

Warner, K. O., Problems of Australian Federalism, Washington, 1933.

Wheare, K. C., Federal Government (4th ed.), London, 1963.

Whyte, W. F., William Morris Hughes, Sydney, 1957.

Wildowsky, A. and Carboch, D., Studies in Australian Politics, Melbourne, 1958.

Wilson, R., Capital Imports and the Terms of Trade, Melbourne, 1931.

Wise, B. R., The Making of the Australian Commonwealth (2nd ed.), London, 1913.

Wood, G. L., Borrowing and Business in Australia, London, 1930.

Wynes, W. Anstey, Legislative, Executive and Judicial Powers in Australia (3rd ed.), Adelaide, 1962. 


\section{Index}

Aborigines, 4, 267

Advisers to governments, $56-8,62,66,76$, $81,86,99,122,161,210,221,317$

Allocation, financial assistance, 23-5, 27-9, $41,166-8,185-6,250-67$

Allocation, loans, $81,86,88,91,166-86,199$, $232,236-44,260-7,311-13,316-17$; bias, 177; formula, $88,174-8,180-2,185-6,244$, 312-13

Amendments of Constitution, see Referendum

America, see United States

Anstey, F. E., 127, 127n., 133, 139

Approved dealers, see Borrowing, official short-term market

Arbitration Court, see Wages

Argentine, 113

Arndt, H. W., 296n.

ARU Case, see Cases

Associated Banks of Victoria, see Banks, private

Atkin, J., 116n.

Auditor(s)-General, 147-9, 155

Balance of payments: Australia, 91, 102-8, $113,120-3,138,196,201,208-9,211,215$, 218-19, 231, 240, 268-74, 278-81, 284, 292-4, 297, 310; United Kingdom, 110-12

Bank, Central, 7, 8, 56, 64, 100, 108, 109, $128-9,135,139-44,149-53,187,192,194-8$, 202, 206-13, 216-17, 219-24, 227-8, 230n., 237, 270, 274, 287-306, 310, 315; Board, $121,127,131,136,138,141-2,151,153$, 176-7, 197-8, 203-4, 206, 206n., 208, 211; bond holdings, 217, 219, 294; Governor, 299-300; legally defined, 288-9; open market operations, 64-5, 216, 219, 288, 290, 294, 298-305, 311; special accounts, special reserve deposits, 208, 293-5, 297, 303; see also Gibson, $\mathbf{R}$.

Bank credit, see Borrowing, temporary and treasury bills

Bank of England, 108, 115-16, 116n., 127, $129,140,187,190$

Banks, private: Australian, 7, 56-7, 61, 64n., $66,101 n ., 106,108,118,121,126-9,132-43$, 
$150,160,168,194-8,201-12,216-21,292-305$, 310; London, 101n., 107-8, 115, 129, 188; associated banks, 57, 207; Bank of Adelaide, 206; Bank of New South Wales, 203, 206, 208, 216, 220; bond holdings, 212, 216-17; economic control (principles), 211-12, 217, 219; London and Westminster, see Westminster Bank

Barton, E., 15, 18, 18n., 20, 21, 24n.

Bavin, T. R., 82n., 85n.

Bond rate, yields, see Interest rates

Book-keeping system, 14, 22-4, 27-9, 38; see also Customs and excise revenue

Borrowing, 3, 10, 18, 41-7, 50-68, 81-3, 86, $88,96,98,102-6,117-19,122-3,141,176-94$, $210,225,228-36,245,268-85,291 \mathrm{ff} ., 306$, 310-17; counterpart funds, $274,276-7,280$; official short-term market, 291, 298-301, 304-5, 317; overseas (Canada), 273, 276, (I.B.R.D.) 268, 270, 273, 275-8, 280, (London) 45-7, 50, 53, 67, 79-83, 99-123, 131, 149-50, 187-94, 196, 201, 225, 270, 275, (Netherlands) 275, (New York) 81, $101,109-10,129,192,194,225,270-2,275$, (Switzerland) 273, 276; special loans, 232, 310; special bonds, 291, 300; State, 88, 112 , 310; temporary, $86,107,115,117$, 129, 132-6, 141-3, 205, 225-7, 301, 301n., 311; treasury bills (1929-35) 10In., 115-19, $129,133-7,141-50,177,196-206,225-7$, (1938-39) 209, 224, (1959-60) 291, 301-2, (funding) 203-5, 216-17, 227, 237, (market) 205-6, 216, 291, 301-2; loan programs, Australia (1928-33) 107, 109, 111, 115, $117-19,126-8,141-3,150-1,202-4,215$, 222-5, (1933-36) 176-83, 205, 215-16, 222-4, (1936-37) 182-4, 209, 219, 222-4, (war years) 184, 225-7, 237, (1946-51) 229, 237-8, 290, (1951-) 228-36, 290-308; local and semi-governmental, see Local and semi-governmental borrowing; Tax free, see Taxation

Braddon Clause, see Constitution, s.87

Braddon, E. N. C., 15, 20-1

Bray, J. C., 15

Brazil, 113

British Economic Mission, 80, 113-14, 130

British Empire Loans, London, 79-80, 188-9; see also Capital markets

British Government, see United Kingdom

British War Debt Conversion, 116n., 188-9

Bruce, S. M., 51, 54, 59, 63, 69, 74-80, 88n., $99,102,113,154,188,189 \mathrm{n}$.

Brown, H., 226, 226n.
Building construction, $67,105,145,238$; see also Commonwealth and State Housing Agreement

Butler, R. L., 183, 201

Butlin, N. G., 102, 103n., 233, 233n.

Cabinet, 78, 108, 131, 136, 138, 179-80; see also Ministers

Cahill, J. J., 255

Cain, N., 108n., 118n.

Canada, 112, 192, 268

Capital expenditure, see Investment

Capital issues, 305

Capital markets: Australia, 54-68, 102, 225, 227-31, 238-41, 284, 291, 295-306, 315, 317; London, 79-83, 102-17, 187, 189-90, 201, 270, 275; New York, 81, 101, 109-10, 192, 270, 275; see also Advisers to governments; Borrowing; British Empire Loans; Debts and debt Interest; Interest rates

Capital movements, see Foreign exchange, movements

Cases on Constitution: A.R.U. Case (1930), 156; Concrete Pipes Case (1971), 295, 310; Engineers' Case (1920), 48; First Uniform Tax Case (1942), 246, 254; Garnishee Case (1932), 153-61, 168, 188, 195, 199, 213, 310, 313-14; Moran's Case (1940), 246; Roads Case (1926), 71-2, 246; Second Uniform Tax Case (1957), 253-5; Surplus Revenue Case (1908), 39

Casey, R. G., 147, 183, 202, 203n., 222

Cessation of foreign loans, 101-18, 188, 268; see also Borrowing

Chancellor of the Exchequer, see United Kingdom authorities

'Chariot wheels', 32, 39

Cheap money, see Interest rates, cheap money

Chifley, J. B., 237n., 248, 248n., 250, 250n., 272

Civil war, 158

Claimant States, see Grants Commission

Clarke, E., 114n.

Coercion, 78-9, 95-100

Collier, P., 86, 174

Collins, J. R., 47

Committee of Economic Enquiry, 272-3, $279 n$.

Committees, see Officials' committee; Joint committee

Commonwealth and State Housing Agreement, 232, 238, 313 
Commonwealth Bank, see Bank, Central

Commonwealth Savings Bank, 219

Compulsory conversions, 17-19

Concrete Pipes Case, see Cases

Constitution, 1, 4, 10-30, 35, 41-4, 48, 69, $76-8,87-90,126,131,140,142,154-61,165$, $175,209,242,246,248-9,253-5,259,267$, 287-90; division of powers, 89-92, 304-14; Sections (51(ii) taxation) 76, 246, 249, 254-5, (51(vi) defence) 249, 253-5, (51(xiii) banking) $288,295-7,305,310-11,(51(x x)$ financial corporations) 295, (51(xxiii A) social services) 90, (s.55 tax bills) 248 , (s.81 consolidated revenue fund) 38 , (s.87 guarantee of customs revenue) $3,6,10$, $19-29,33,35-44,89,259,266$, (s.88 uniform tariff) 27, (s.89 payments to States before uniform tariff) 27, 38, (s.90 customs) 27, (s.92 free trade) 27, (s.93 five years after uniform tariff) 24,38 , (s.94 surplus revenue) $23-4,38-9,266$, (s.95 Western Australian customs revenue) 28, (s.96 financial assistance) $6,10,22,25-9,39,43,49,71$, $197,199,229,238,244,246,253-5,259$, 266, 306, 311-12, 316-17, (s.105 State debts) $3-5,17-19,29-30,33,37-9,43,69,79,81$, $87,89-90,260,306$, (s.105A financial agreements) $4,6,87,89-90,133,153-61,259$, $306,310,314$, (s.109 inconsistency of laws) 249, (s.128 Constitution alteration) 159-60; see also Cases; Referendum

Constitution Alteration (Finance) Act 1909 , 42

Constitution Alteration (State Debts) Act 1909,42

Convention debates, $8,10-30,33,41,82,182$, 315; see also Founders

Conversions, see Borrowing; Debt and debt interest; Compulsory conversions

Cook, J., 40n., 80

Cooke, S. R., 79-80, 113-15, 130

Co-operative federalism, $4,7,9,53,86,100$, $186,195,199-200,209,240,305,311,314-16$

Co-ordinate federal system, 1-17, 28-31, 33-4, $37,41 n ., 43,69,73,75,83,88,91-5,166$, $210,245,309 n ., 315$

Co-ordinated borrowing, see Borrowing;

Debt and debt interest

Co-ordinator-General of Works, 151, 226, 238

Copland, D. B., 143

Counterpart funds, see Borrowing

Counter sales of bonds, 57, 82, 117, 117n.

Country Party, 52, 52n., 69, 71, 207
Cowper, N., 140n., 158

CSIRO, 114

Customs and excise duties and revenue, 3 , $10-17,19-29,32-3,36,38-41,48-9,67,70$, $72,75-7,89,92,103,122,126,128,162$, $168,196,259,310$

Davenport, E. H., 79-80, 113-15, 130

Davidson, A. C., 134, 143-4, 206n., 208, 211 , 216

Dealers, see Borrowing, official short-term market

Deakin, Alfred, 11, 13-16, 21n., 23, 25-6, 29 , $31-4,36-7,40,40 n ., 42-3,49,102$

Debts and debt interest: Australia, 3, 8-19, $22-3,29,31,34-53,68-70,78-84,89-93,99$, 132, $145,153-60,192,225,245,259-60$, 265-6, 275-7, 306; conversion (Australia 1931) $137,141,144-7,188,191$, (overseas) $51,82,101,104,106-7,112,137,149-50$, 188-92, 198, 268-77, 279-81; repudiation proposals, 113, 131, 138; war debt, 53, 64, 115-16, 118, 192; see also Constitution, s.105, s.105A

Default, 113, 131, 138, 153-61, 310; see also Cases, Garnishee Case

Defence loans, $47,51,57,62,64,66-7,88$, 91, 183, 191-2, 225-6; see also Borrowing

Defence power, see Constitution, s.51(vi)

Deficit finance, see Borrowing, temporary and treasury bills

Depression (1930s), 4-7, 117-23, 126-52, 195-9, $201-5,211,228,309,314$

Development, see Economic growth; Economic policy

Development and Migration Commission, 80,114

Dibbs, G. R., 14n., 15, 17 n.

Dickson, J. R., 15, 21, 26

Disequilibrium, see Economic disequilibrium

Disunity, 35, 82, 100, 139-41, 143, 152, 161, $165,201-6,211-12,220-1,253-5,288,291$, 317

Dixon, O., 71, 156, 254n., 287, 313

Dollars, see Foreign exchange; Borrowing

Douglas Credit, 207

Downer, J. W., 15, 20, 24, 24n.

Drummond, I., 116n.

Duckham, A., 114n.

Duffy, G., 156

Dunstan, A. A., 177n., 200

Dw yer-Gray, E, 183

Dyason, E. C., 98, 114 
Economic disequilibrium (long-term), 67-8, $81,98,102-6,113,121,194,196,229$, $268-73,293$

Economic growth, 47, 49-51, 61, 67, 86, 91, $103,113-14,196,202,205,218-19,222$, $228-35,273,276-80,284,309,317$

Economic policy: general, 5, 7-9, 29-30, 56-8, $60,62,65,67-8,81,88,90-2,102,106,108$, $113,121-3,126,128-45,152,194-9,201$, 209-12, 217, 219-20, 225-33, 236-8, 259-60, $270-81, \quad 284, \quad 291-5,298, \quad 302-17$; war (1939-45) 246-8, 259, 269-70

Elections, 21, 26, 32, 34, 42, 52, 75, 77, 126, 200,207

Electorate, 75, 78-9, 83, 142

Engineers' Case, see Cases

Equality of sacrifice (1931), see Debts and debt interest

Estate duty, see Taxation

F.vatt, H. V., 156, 157n.

Exchange rate, see Foreign exchange, rate

Export-Import Bank, 268

Exports, see Balance of payments

Ex-servicemen, 49, 103

Fadden, A. W., 147, 230n., 247

Farm income, see Rural producers

Federal Aid Roads Act 1926, see Statutes

Federal imbalance, 72, 83, 87, 95, 162, 165-6, 256; see also Power, realignment

Federal principle, see Co-ordinate federal system; Co-operative federalism

Fenton, J. E., I15n., 127, 127n., 132-3

Fiduciary note issue, $139-40$

Finance companies, see Financial corporations

Finance Council, see Loan Council

Financial Agreement, 1927, 3-10, 16, 18, 43, $45,66,68-70,83-101,133,135,137,147-50$, $152-61,167,176-7,185,210,238,245$, $257-60,284,290,301,304,306,310,313$, 315-17; enforcement, 5, 153-61, 310; financial assistance to States, 83-4, 92-100 257-9; legal liability to bondholder, 154; penalty for deficits, 91, 129, 147-9; permanency, 8,89 , 317; rigidity, 241, 316; unconstitutional borrowing, 176-7, see also Loan Council; Debts; National Debt Sinking Fund; Interest rates

Financial assistance to States: general revenue, 5, 6, 9, 23, 25-9, 31, 36-7, 42-5, 49, $69-70,73-83,92-100,153,165-7,180,182$, 185-6, 197, 201, 204-5, 229, 244, 247-67, $293-4,305-6,312-13,316-17$; formulae,
250-7; redistributive effects, 24, 76, 251, 256, 258, 266, 316; specific purposes, 70-3, $79,83-4,92-100,165-7,233,257-60,316$; see also Guarantees to States; Grants Commission; Allocation

Financial corporations, 56-8, 62, 64, 66, 102 , 144, 208-9, 291, 294n., 295-306, 310-11, 317

Financial Settlement, 1910, 40-3

First Uniform Tax Case (1942), see Cases

Fisher, A., 32, 40, 40n., 46, 48, 49n., 102

Floating debt, see Borrowing, temporary and treasury bills

Foreign exchange: reserves, 56, 64, 100, 102, $106,111,113,120-3,127,129,134-41,152$, 192, 196-201, 208-12, 215-25, 268-75, 278-81, 291-3, 310; control 129, 132, 137, 152, 196, 198, 207, 268ff., 310; movements, 67, $97,102-3,108,108 \mathrm{n} ., 110,187,192-4$, $197-8,211,215,218-19,229-30,269,271-2$, $277-8,284,291,313$; rate, 106, 121-3, 134, 137, 196-8, 211, 221, 310; rationing, $121-2,196$

Foreign investment, see Borrowing; Foreign exchange; Investment

Foreign Transactions (Advisory) Committee (U.K.), 190

Formulac, see Allocation, loans; Financial assistance

Forrest, J., 15, 17, 20, 25, 25n., 29, 33, 34, $36-7,37 \mathrm{n} ., 40-1,46,49$

Founders, 1-3, 9-31, 43, 68-73, 79, 95, 142, $251,266-7$

France, 110

Fraser, S., 14n., 15, 19n., 25n.

Free trade, 11, 27; see also Constitution, s.92

Fusion Party, 40, 40n., 42

\section{Grrnishee Case, see Cases}

Garran, R. R., 25, 28, 39

Gentlemen's Agreement, see Local and serni-governmental borrowing

Giblin, L. F., 29n., 64, 71-3, 121, 127n., 131, 131n., 135n., 136, 143, 151, 161-9, 187, 198, 206, 211, 216, 216n., 221n., 222n., 224n., $227,309,312$

Gibson, R., 121, 127, 191, 191n., 133-41, $151,153,202-3,221 n$.

Glynn, P. M., 19

Gold, 47, 56, 126-7, 138, 149, 187, 196, 198; see also Foreign exchange

Government services, 2, 11, 122, 168, 265, 273

Governor, State, 158-9 


\section{Governor-General, 163}

Grants Commission, 6, 29, 73-5, 79, 83, 92-6, $145,161-7,185,191,199,200,241,247$, 247n., 250n., 253, 256-8, 261, 266, 316

Grants to States, see Financial assistance; Grants Commission; Constitution, s.96; Allocation

'Great negotiator', 9, 18, 28-31, 43, 79, 256, 281,314

Gregory, T., 130-1

Griffith, S. W., 15, 16, 24

Guarantees to States, 3, 10, 17, 19-31, 34-41, $82,89,100,259,266,312$

Haig, B., 118, 118n., 120n.

Hall, A. R., 108n.

Hancock, W. K., 113n.

Harper, R., 37n.

Harvey, E., I15-16

Henderson, R. F., 300n.

Henry, J., 15, 25

Higgins, H. B., 15

High Commissioner, London, 80, 188

High Court, 5, 6, 8, 39, 48, 63, 71, 154-61, 246, 253-5, 287, 305-6, 310; see also Cases; Constitution

Hire purchase companies, see Financial corporations

Hirst, H., 114n.

Holder, F. W., 13, 15-21, 24-5

Holder, R. F., 220n.

House of Representatives, see Parliament

Housing, see Building construction; Commonwealth and State Housing Agreement

Hughes, W. M., 45, 45n., 49, 51, 102

Imbalance in federation, see Federal imbalance; Taxable capacity; Grants Commission

I.M.F., 275

Immigration, $7,48-50,80,102-3,236,241$, 313; see also Development and Migration Commission

Imperial conferences, 37, 49, 79, 80, 113, 131

Incomes, 121; see also Rural producers; Taxable capacity

Import, average propensity, 121-2, 194, 196, 279-81

Import restrictions, 121-2, 137, 196, 273

Imports, see Balance of payments

Imports, elasticity, 122-3

Inequalities, see Federal imbalance; Grants Commission; Taxable capacity
Inflation, .134-6, 198, 201, 221, 221n., 238, $280,297,302$

Innovations, 49, 67, 103

Instability, see Economic disequilibrium; Economic policy

Insurance companies, 65-6, 144, 208

Interest on debt, see Debts and debt interest

Interest rates: general, 5, 10, 19, 47-51, 56-8, $91,109,128,137,143-6,152,188,198-9$, 203, 211-19, 222, 232, 238-9, 245, 284-308, 310 ; bond yields and new issues rate, 57 , 213-19, 284, 290, 297-304; cheap money, $147,188-9,212-13,270,285,287$; flexible rates, see Long-term rate (1950-65) (below); London, 62, 107, 109, 123, 147, $188,201,214$; other overseas, 270, 274; long-term rate $(1920 \mathrm{~s}) 56-68,81-2,85$, 145-6, (1930s) 141, 145, 196, 203, 212-21, (1940s) 229, 238, 284-5, 290-1, (1950-65) 239, 285-308; short-term rate, 206, 291, 299

International Bank, see Borrowing, I.B.R.D. International liquidity, 123, 187, 274-5

International Monetary Fund, see I.M.F.

Investment: Australian private, 50, 67, 104, $113,118,128,143-5,196,212-15,218,230$, 293; foreign private, 103, 274, 277-81; Australian governments, 50, 113, 215, 218, 225, 233-6

Irvine, Prof., 127n., 137

Irvine, W. H., $34 n$.

Isaacs, I., 131

Joint committees: constitutional review, 305,309 ; public accounts, 162

Keynes, J. M., 79, 79n., 113, 189,

Keynesian policies, 7, 68, 91, 137, 195, 197, 209, 211, 219, 224, 315; see also Economic Policy

Kindersley, R., $110 \mathrm{n}$.

Kingston, C. C., 15-16, 18, 26

Knox, W., 35-6, 317

Labor Party, 5, 31-3, 36, 40-3, 46-9, 52-3, $67,77-8,82,85-6,113,122,126-8,130$, $132,136,139,141,143,150-2,175,196$, 200-2, 207, 209, 226-7, 237, 243, 247, 247n., 268-9, 271-2, 280

La Nauze, J. A., 14n.

Land settlement, 50, 103, 113, 311

Land tax, see Taxation 
Lang, J. T., 5, 60n., 67, 82, 85, 85n., 86, 113 , 133, 136; Lang Plan, 138, 139, 143-4, 150, $152,159,174,188,195,199-200,214$

Latham, J. G., 143-4, 249, 254, 287, 311

Lease Lend and Mutual Aid, 270

Legislation, uniform, 305

Lender of last resort: Australia, 291, 303; international, 123; London, 116, 187

Liquidity, see International liquidity; foreign exchange; Sterling area

Loanable funds, $2,7,50,64,176,199,215$, $219,224,236,239,241,290$

Loans, see Borrowing; Allocation; Defence loans

Loan Council, Voluntary, 45-68, 69, 75, $79-87,99,101,104,284$

Loan Council, Statutory, 4-11, 17, 30-1, 35-7. $41,56-7,67,69,70,81-109,112,115-18$, $123,128-54,158-61,164,174-245,259-60$, 265-317; general powers, 87-92, 112, 118 , $126,130,134-7,166-8,174,284-5,287-91$, $310,314-15$; Commonwealth as agent of, $88,199,273,276,280-1,290$; supraparliamentary power, $90-1,156-9,175,285$, 317; limitations, 91, 137, 284-5, 314; permanency, $8,89,317$; procedures, 53-5, 112; membership, 54, 160; chairman, 54, 88 , 204, (absence from meetings) 136; voting, $88,239,285,311$; confidentiality, 53-5; loan defined, 88; short-term and long-term defined, 88, 129, 134; loan program, 88, 284; excess subscriptions, 232; allocation of program, see Allocation, formula; Temporary borrowing, see Borrowing, temporary and treasury bills

Loans to States from Commonwealth taxation, see Borrowing, Special Loans

Local and semi-governmental borrowing, 60 , $65,82,86,113,128,128 \mathrm{n} ., 166,176,182-5$, 200, 231-2, 236-8, 243-4, 266, 311-12

London and Westminster Bank, see Westminster Bank

London Funds, see Foreign exchange, reserves

Long-term loans, see Borrowing; Loan Council

Lyne, W. J., 15-16, 33, 37, 37n.

Lyons, J. A., 7, 72, 86, 127, 132-3, 136, 137n., 139, 144, 147, 152-4, 161-3, 165n., $188,195,201-8,222$

McFarlane, S. G., 208n.

McKell, W., 247

McMillan, W., 15, 17-18, 24n., 29
Mc'Tiernan, E. A., 157

Main Roads Development Act 1923, 70n., 71

Massey Greene, Senator, 204

Meeting dates, 54, 124-5

Melville, L. G., 143

Menzies, R. G., 8, 147, 165-6, 176, 227n., 239n., 259n., 270, 273, 280, 313n.

Mills, R. C., 98,247

Minister(s), 33, 45n., 78, 108-9, 116, 130-4, $136,138-9,146,179-80,183,188,198,201$, 206, 212, 287, 290, 292, 298

Mitchell, E. F., 89n., 133, 150, 159, 176

Mobilization Agreement, 129, 132, 198

Monetary authorities: Australian, 5, 57, 91, $134-5,138-9,142,153,197-9,207-12,219-22$, $225-8,259-60,284,287,290-2,295,301$, 303-17; British, 101, 115-16

Monetary policy, 56-68, 91, 134, 136, 138-43, 152, 198-9, 207-11, 219-27, 232, 284-311,

317; see also Borrowing; Interest rates

Moran's Case, see Cases

Moratorium, 1931, 118

Multiplier effect, 118, 120, 132, 228, 293

Mungana Case, see Theodore

National Debt Commission, 90, 245, 288, 301

National Debt Sinking Fund, 63-5, 81, 89, $92,96,98-101,145,147-50,192,231$, 269-70, 288, 290

National Works Council, 151, 237

Nationalist Party, 46n., 52, 69

Netherlands, 110

New South Wales, 13, 15, 17, 18, 20, 23n., $24,26,36,37 \mathrm{n} ., 41-2,51,53-4,60,66-7$, $70,76,81-2,85-7,93,99,107,113,128$, $131,133,136-9,149-50,154,161,166$, $174-86,188,195,200,203,206,237-8$, 240-4, 247n., 253-66

New York, 110, 129; see also Borrowing, New York

New Zealand, 112, 114, 189

Niemeyer, O. E., 47n., 115-16, 129, 131-4, 187

Nivison and Co., 99, 109, 112; see also Advisers to governments

Non-Labor parties, 41, 53, 75, 77, 128, 136 , $147,152-4,191,200,242-3,259 \mathrm{n} ., 279-80$

Norman, Montagu, 115, 127, 187

Note issue, 56; see also Monetary policy

Official short-term market, see Borrowing Officials' committees, 137-8, 143, 146, 150-1, 251-2

O'Malley, K., 37n. 
Open market operations, see Central Bank Overdrafts, see Borrowing, temporary and treasury bills

Overseas capital movements, see Foreign Exchange

Page, Earle, 52, 54, 59, 63, 74-6, 78, 82n., 96 Parkes, H., 8n., 15

Parliament, 20, 35-6, 38, 40-2, 76-8, 85, 87, $90,100-1,107,127,130,136,139,141-3$, $145,150,155-60,163,175,179-80,201$, 206-7, 226, 239, 24ln., 248, 254, 280, 288, 305,309

Payments to States, see Financial assistance Pearce, G. F., 144

Pensions, see Social services

Plans, see Premiers' Plan; Lang; Theodore; Economic policy

Playford, T., 274, 274n., 277

Policy, economic, see Economic policy

Political influence, 45, 52, 55, 70, 73-83, 87, $98-100,102,127,130-47,152-4,161,175$, $182,195,199-201,204,207,209,212,221$, $225-7,236,24 \ln ., 242,246,250,253-5$, 266-9, 290-1, 312-16

Political parties, see Country Party; Fusion Party; Labor Party; Nationalist Party; Non-Labor parties; Tariff Reform Party; United Australia Party

Population, 49-50, 67, 72, 75n., 92, 96, 102, $162,225,236,241,241 \mathrm{n} ., 250-3,255,265$; see also Immigration

Power, realignment, 1-9, 87, 126, 152, 161, $166,168,186,195-210,221,236,239,258-60$, 274, 280-1, 284-5, 288, 294-7, 303-6, 313-16; see also Federal imbalance

Powers, constitutional, see Constitution

Premier(s), 14-15, 21-2, 26, 32, 34-6, 41, 46, $54,67,72,77-8,82,85-6 ; 115 n ., 122,133$, $138-40,143,145,147,151,160,174-83$, 200-3, 242-4, 247, 255

Premiers' Conferences, 20-2, 25, 34-41, 45-6, $5 \ln ., 53-4,74-8,85,106,126,130-4,137-41$, $144,146,161,165,186,191,199-202$, 250-2, 255, 255n, 294, 314

Premiers' Plan, 7, 137, 141-52, 191-2, 195, 200, 202-5, 209, 212-13, 314

Price control, 122

Price levels and price indexes, 58-9, 61, 208, 271, 293

Primary producers, see Rural producers

Prime Minister, 7, 8, 32-3, 35-7, 40, 46, 52, 54, 78-80, 99, 113, 115n., 122, 128, 132, 147,148 n., 153, 163, 174, 187, 202, 204,
206, 232n., 237n., 239, 239n., 250, 250n., $270,273,313 \mathrm{n}$.

Prime Minister's Department, 163

Privy Council, 157, 246

Protectionists; 11, 19, 75, 77

Public criticism of policy, 52, 77, 81, 97, $114,239,242,255$; see also Public Works

Public works: criticism, 52, 77, 81, 97, 164, 304; policy, $16,47,67,70,82,90,103$, $106,122,126,135,194,202,225-6,238$, 265, 304

Pump priming expenditure, 68, 202, 209; see also Economic policy

\section{Qantas, 276}

Quantitative restrictions, see Import restrictions

Queensland, 13, 15, 21, 26, 36, 42, 46, 53, $57,63,70,72,93,101$ n., 108-9, 130, 138, $150, \quad 174-86,200,240-4,247 \mathrm{n} ., 252-3$, 255-66

Quick, J., 25

Railway unification, 70-1

Rationing, 122

Reading, C., 187, 209

Redistributive effects of taxation, see financial assistance

Referendum, 2, 8, 21, 26, 40, 42-8, 85, 87, $90,98,159-60$

Regional development, 91

Reid, G. H., 15, 17n., 21, 24n., 26, 31n., 33, 41, 4ln.

Renshaw, J. B., 242

Rentiers, 146

Repudiation, see Dcbts and debt interest

Reserve Bank, see Bank, Central

Rich, G. E., 156

Roads Case, see Cases

Roads grants, see Financial assistance

Robinson, W. S., 1]5, 117

Rose, P. J., 290n.

Royal Commissions, 73, 130, 136, 161, 197-8, 201, 204, 206-9

Rural producers, income, 121, 126, 130, 146, 151,265

Ryrie, G., 188

Sawer, G., 77n., 154, 246

Scullin, J: H., 113, 115, 117, 127, 130-3, $136-40,143-4,150,152,162,187,196$, 201-2, 209, 247

Second Uniform Tax Case, see Cases 
Semi-government, see Local and semigovernment

Senate, 20, 36, 127-8, 136, 139-40, 163, 207, $241 n$., 267

Services, government, see Government services

Severity of taxation, see Taxation

Shann, E. O. G., 98, 102, 114, 143

Sheehan, H., 208

Short-term debt, see Borrowing, temporary and treasury bills

Sinking Fund, see National Debt Sinking Fund

Smith, W. Forgan, 175, 180, 200, 202

Social services, $4,31,38,42,90,132,139$, 144,267

Solicitor-General, 177, 180

South Africa, 112, 114, 189

South Australia, 6, 11n., 13, 15, 56, 70-1, 93, 104, 108, 138n., 139, 150, 161-2, 164n., 166, 174-86, 201, 237-8, 240-4, 247n., 255-66, $274,276 \mathrm{n}$.

Sovereign States, see Co-ordinate federal system

Special Bonds, see Borrowing

Special Grants and Special (later Commission) Grants, see Grants Commission

Special Loans, see Borrowing

Specific Purpose Grants, see Financial assistance

Spender, P. C., 147

Spooner, E. S., 247 n.

Starke, H., 249

State borrowing, see Borrowing, State

State rights, see Co-ordinate federal system

Statutes: Commonwealth Bank Act, 140; Conciliation and Arbitration Act, 73; Financial Agreements Enforcement Acts (1, 2, 3,4) (1932), 154-61; Financial Agreement Validation Act (1929), 87; Federal Aid Roads Act (1926), 70n., 71; Grafton to South Brisbane Railway Act (1924), 71n.; Income Tax Act (1942), 248-9, 254; Income Tax (Assessment) Act (1942), 248-9, 254; Income Tax (Wartime Arrangements) Act (1942), 249; Main Road Development Act (1923), 70n., 71; Navigation Act (1921), 72, 114, 162; States Grants (Income Tax Reimbursement) Act (1942), 248-51, 253-4; Statute of Westminster, 131; Surplus Revenue Act (1908), 38-9; Surplus Revenue Act (1910), 28, 43, 98

Sterling area, 187; see also Foreign exchange
Stevens, B. S. B., 109n., 112n., 115n., 128, 130n., 175, 176n., 180-1, 200, 218, 218n., 244

Supplementary grants, see Financial assistance, uniform tax

Supraparliamentary power, see Loan Council, Statutory

Surplus revenue, 3, 12, 23, 27-9, 34, 38-9, 43, 90; see also Constitution, s.94; Cases; Statutes

Tariff, see Customs and excise duties and Revenue

Tariff Board, 72, 161

Tariff Reform Party, 40n.

Tasmania, $6,11 \mathrm{n}, 13,15,20,25,54,56$, $71,73-4,76,86,93,101 n ., 108,127 n ., 138$, $147-50,154,162-4,166,174-86,237,239-44$. 246-7, 253, 255-66

Tax reimbursement grants, see Financial assistance

Taxable capacity, 2, 3n., 5, 9, 12-15, 23-5, $43,71-3,76,83,92,95,165,241,245$, 264-6

Taxation, 'maddening maze', 248, 250

Taxation, severity, 72, 247n., 250

Taxation, used for loans to States, see Borrowing, Special Loans

Taxation: Commonwealth and State income, 6, 11, 12-15, 34, 48, 69-72, 75, 77, $83,96,99,100,106,135,144,162-3,165$, $167,186,225,245,249$ ff., 310 ; uniform income, $6,7,9,72,75-6,92,95,161,166-7$. 228, 245-60, 310, 313-16; estate duties, 77; land tax, 48, 77; indirect taxation, 77; tax free loans, 51, 63, 82; see also Customs and excise

Temporary borrowing, see Borrowing, tem. porary

Terms of trade, 104, 121; see also Balance of payments

Theodore, E. G., 53, 109, 115, 127-44, 147, 150, 150n., 202, 204, 209; Theodore Plan, 137

Three Year Plan, see Premiers' Plan

Trade, see Balance of payments; Terms of trade

Transferred properties, 41,89

Treasurer(s), 13, 15, 19, 20, 33-4, 37, 46; 51-4, 57, 57n., 64, 72, 75, 78, 104, 109, $115 \mathrm{n} ., 128-9,136-8,146-7,155,175,177 \mathrm{n}$., $180,183,202,207-8,210,222,222 n ., 237$, $242,247,250,250$ n., 278 
Treasury(ies), 38, 47, 47n., 75, 115n., 116n., 130, 151, 163, 176, 182n., 197, 208-9, 222n., 242-3, 27 ln., 272, 276n., 288, 290

Treasury bills and notes, see Borrowing

Trust Funds, 28, 36, 118-19, 225

Turner, G., 15, 26, 33-7

Underwriting, 57, 198-9, 215, 217, 219-33, $236,240,245,259,274,284-5,290-1,297$. 312, 315; see also Nivison and Co.; Central Bank

Unemployment, 67, 120-1, 126, 132, 137, 162, $175,179,184,188-9,194,201-3,215$, $228-9,231$

Uniform taxation, see Taxation

United Australia Party (U.A.P.), 143

United Kingdon authorities, 46-7, 50, 80-1, $101,110,113,115-16,122-3,133,187-92$, 213, 269n., 275; see also Borrowing, London

United States, 110, 268, 270, 280; see also Borrowing, New York

Urban development, 311; see also Public Works; Loan Council, General powers

Victoria, 11n., 13, 15, 34, 42, 53-4, 71, 93, $96,104,107,138-9,149-50,154,165-6$, 174-86, 200-1, 238-44, 247n., 253, 255-66, 316

Voting, see Allocation, loans, Loan Council

Wages, 73, 121, 123, 126, 132, 137, 139, 144, $146,162,196,221,250,310-11$

Walker, E. R., 226n., 229n.

Wallace Bruce Committee, 202

War casualties, 111

War debt, see Borrowing; Debts and debt interest; British War Debt Conversion

Watson, J. C., 32

Wealth, see Taxable capacity

Wentworth, W. C., 242-3, 261

Western Australia, 6, 11 n., 13, 15, 23-8, 41, $43,53,56,63,69-74,86,93,107,138,150$, 164-6, 174-86, 239-41, 253, 255-66, 276n.

Westminster Bank, 101n., 108, 115, 129, 149-50, 188

Wheare, K. C., 3

Willcock, J. C., 183

Wilson, Roland, 64n.

Wise, B. R., 15, $25 \mathrm{n}$.

Yields, see Interest rates 
R. S. Gilbert is a graduate of the University of Adelaide and holds a Doctorate from Oxford University. He has had extensive experience as an economist and administrator in the Commonwealth Public Scrvice, mainly in the Prime Minister's Department where his duties included attendance at Premiers' Conferences. He is now an economic adviser in the Department of Environment in London.

Text set in 10/12 Linotype Baskerville and printed on $85 \mathrm{gsm}$ Burnie Machine Finish by Riall Print Pty Ltd, Melbourne 